University of Louisville

ThinkIR: The University of Louisville's Institutional Repository

Electronic Theses and Dissertations

$12-2012$

\title{
The impact of Edward Perry Warren on the study and collections of Greek and Roman antiquities in American academia.
}

James Murley 1947-

University of Louisville

Follow this and additional works at: https://ir.library.louisville.edu/etd

\section{Recommended Citation}

Murley, James 1947-, "The impact of Edward Perry Warren on the study and collections of Greek and Roman antiquities in American academia." (2012). Electronic Theses and Dissertations. Paper 1028. https://doi.org/10.18297/etd/1028

This Doctoral Dissertation is brought to you for free and open access by ThinkIR: The University of Louisville's Institutional Repository. It has been accepted for inclusion in Electronic Theses and Dissertations by an authorized administrator of ThinkIR: The University of Louisville's Institutional Repository. This title appears here courtesy of the author, who has retained all other copyrights. For more information, please contact thinkir@louisville.edu. 


\title{
THE IMPACT OF EDWARD PERRY WARREN
}

ON THE STUDY AND COLLECTIONS OF GREEK AND ROMAN ANTIQUITIES

IN AMERICAN ACADEMIA

\author{
By \\ James Murley \\ B.A., Bellarmine University, 1969 \\ M.A., Duke University, 1971 \\ M.A., University of Louisville, 2001
}

\author{
A Dissertation \\ Submitted to the Faculty of the \\ College of Arts and Sciences of the University of Louisville \\ in Partial Fulfillment of the Requirements \\ for the Degree of \\ Doctor of Philosophy \\ Department of Art History \\ University of Louisville \\ Louisville, Kentucky
}

December 2012 
THE IMPACT OF EDWARD PERRY WARREN

ON THE STUDY AND COLLECTIONS OF GREEK AND ROMAN ANTIQUITIES IN AMERICAN ACADEMIA

\title{
By
}

\author{
James Murley \\ B.A., Bellarmine University, 1969 \\ M.A., Duke University, 1971 \\ M.A., University of Louisville, 2001
}

A Dissertation Approved on

October 26, 2012

by the following Dissertation Committee:

Stephanie Maloney, Dissertation Director

\begin{tabular}{c} 
Christopher Fulton \\
\hline Thomas Mackey
\end{tabular}

Peter Morrin 


\section{DEDICATION}

This dissertation is dedicated to my spouse

Marilyn Borders-Murley.

With infinite patience, she gave me unqualified and loving support in this undertaking. 


\section{ACKNOWLEDGEMENTS}

Above all, I would like to thank my mentor, Dr. Stephanie Maloney, for her guidance and encouragement. I am grateful to Dr. Christopher Fulton, and Professor Peter Morrin, for serving as readers. Dr. Thomas Mackey has my gratitude for his unwavering patience and support. The instruction and inspiration of my professors at the University of Louisville have proven invaluable as have the resources and staff of the Ekstrom and Margaret M. Bridwell Art Libraries. I am also thankful for the support and patience of the administration, faculty, and students at Elizabethtown Community and Technical College. The Peden Fund of the Central Kentucky Educational Foundation and the Don Payton Graduate Award in Art History from the Hite Institute of Fine Arts funded my research. 


\begin{abstract}
THE IMPACT OF EDWARD PERRY WARREN

ON THE STUDY AND COLLECTIONS OF GREEK AND ROMAN ANTIQUITIES

IN AMERICAN ACADEMIA
\end{abstract}

James Murley

November 8, 2012

This dissertation assesses the influence of Edward Perry Warren (18601928) on the development of collegiate collections of Greek and Roman art and the rise of art history and archaeology in elite academic institutions in the United States. It employs archival research to explore Warren's motivations for acquiring thousands of antiquities which he sold or gave to the Museum of Fine Arts, Boston and six collegiate museums and study collections. Organized into six chapters, this multidisciplinary dissertation describes Warren's roles at these institutions. It highlights antiquities that have figured prominently in scholarship and that demonstrate the range and variety of his collecting tastes.

In the first three chapters, the dissertation places Warren's collecting in light of its social, economic, intellectual, and cultural backdrop and considers how Warren both reflects and diverges from his family's values. It also weighs how Warren's sexuality impacted his collecting tastes and resulted in the establishment of his antiquities emporium in Lewes, England. It chronicles his partnership with John Marshall, Edward 
Robinson, and John Davidson Beazley and ascertains what is known about his relationships with those who established the classical collections at Harvard, Bowdoin, the University of Pennsylvania, Bryn Mawr, the University of Chicago, and the Rhode Island School of Design.

Chapters 4, 5, and 6 function as a selective catalogue of Warren's antiquities, organized by medium. Chapter 4 is devoted to a discussion of how the Greek vases and other ceramic antiquities he obtained for American collections have been pivotal in developing the American scholarship on these objects. Chapter 5 considers the impact of Warren's collecting on Greek numismatics as well as on ancient gems, jewelry, ivory, and glass. Chapter 6 features bronze and stone antiquities that illustrate his connoisseurial acumen.

This dissertation argues that the collecting of Edward Perry Warren is essential to understanding the rise of art history and archaeology as academic disciplines in the United States. Antiquities that he obtained for American collections continue to figure prominently in the scholarship and exhibitions focusing on Greek and Roman material culture and social history. 
TABLE OF CONTENTS

PAGE

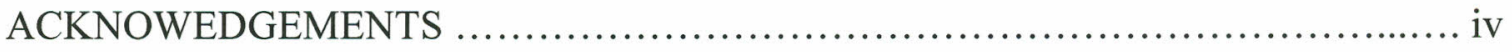

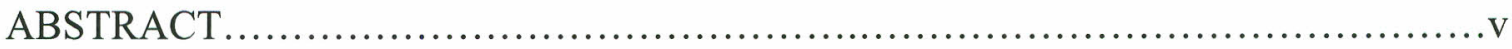

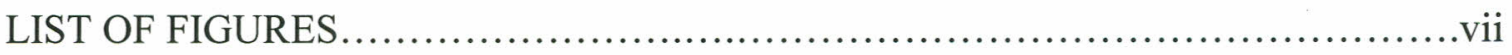

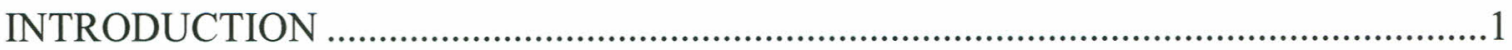

CHAPTER 1: WARREN AND THE GILDED AGE .........................................................24

CHAPTER 2: THE INTELLECTUAL CLIMATE FOR WARREN'S COLLECTING ..63

CHAPTER 3: WARREN AND AMERICAN COLLEGIATE COLLECTIONS............120

CHAPTER 4: CERAMIC ANTIQUITIES FROM WARREN IN AMERICAN

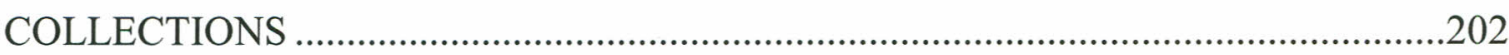

CHAPTER 5: WARREN ANTIQUITIES IN PRECIOUS MATERIALS IN AMERICAN

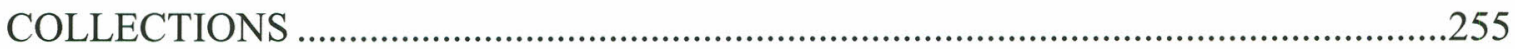

CHAPTER 6: WARREN'S BRONZE AND STONE SCULPTURES IN AMERICAN

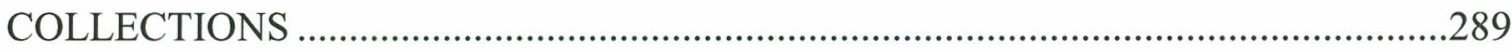

CONCLUSION

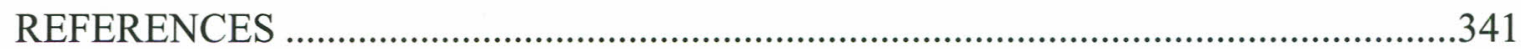

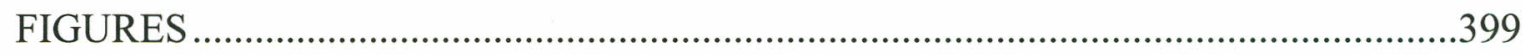

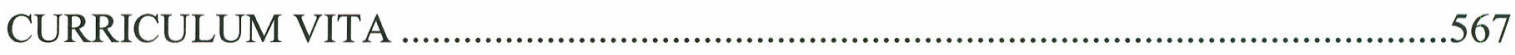




\section{LIST OF FIGURES}

FIGURE

PAGE

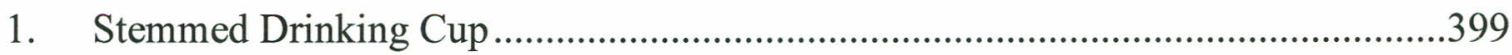

2. Ned Warren and John Marshall at Lewes House .................................................400

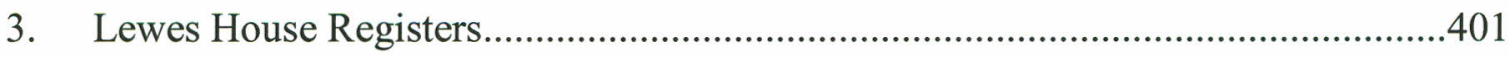

4. Interior of the Warren Home: 67 Mount Vernon Street .....................................402

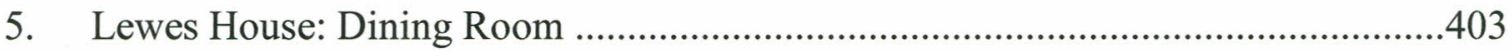

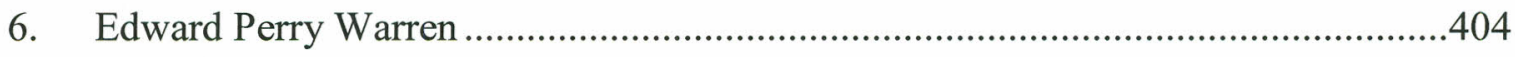

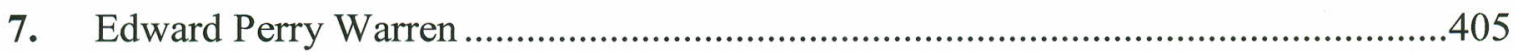

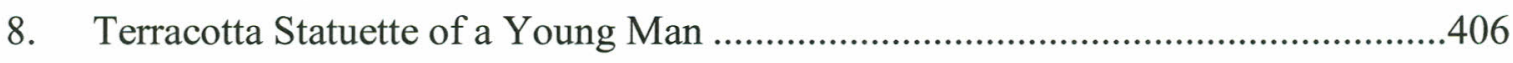

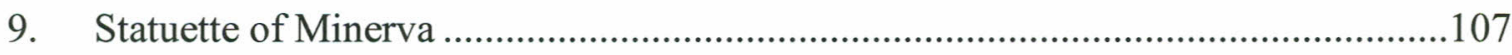

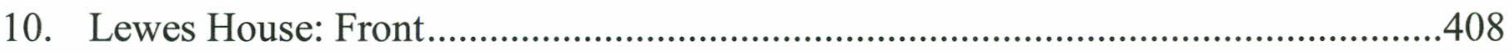

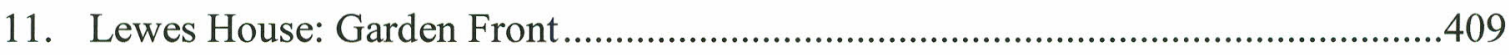

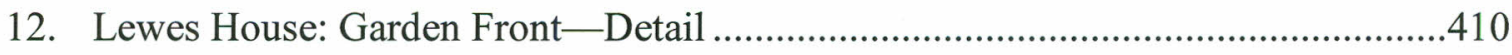

13. Lewes House: Garden with Plinth ..................................................................411

14. Lewes House — water color by Roger Fry .........................................................412

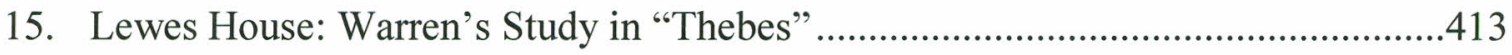

16. Edward Perry Warren and John Marshall .....................................................414

17. Edward Perry Warren, John Marshall, and unidentified man ..............................415

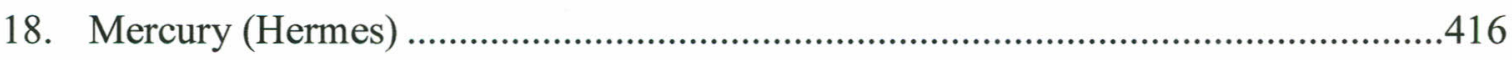

19. Mercury (Hermes) and Mercury (Hermes) at Lewes House .................................417 
20. Mercury (Hermes) at Lewes House.......................................................................418

21. Mercury (Hermes) at Lewes House.......................................................................419

22. The Cast Gallery in the Museum of Fine Arts, Boston ...........................................420

23. Attic Red-figure Amphora Attributed to the Berlin Painter .......................................421

24. Attic-Red Figure Kylix attributed to the Foundry Painter.........................................422

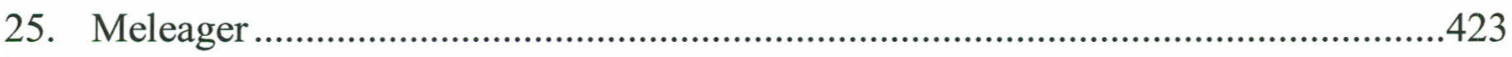

26. Mercury (Hermes) and Meleager .........................................................................424

27. Colossal Head of a Giant or Barbarian: Present Mount .............................................425

28. Colossal Head of a Giant or Barbarian: Earlier Mounts...........................................426

29. Rotunda of the Walker Art Building, Bowdoin College, before 1937 ....................427

30. Attic Red-figure Pelike Attributed to the Dinos Painter ..........................................428

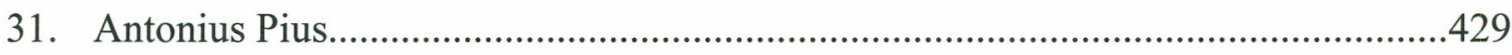

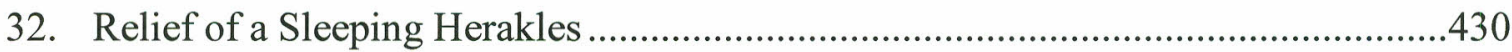

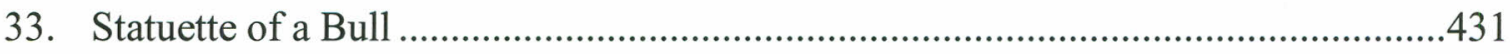

34. Tanagra Comic Figure on a Donkey ………………..............................................432

35. Dwarf Carrying a Kid on His Shoulders ..................................................................433

36. Terracotta Jointed Female Doll Holding Rattles ......................................................434

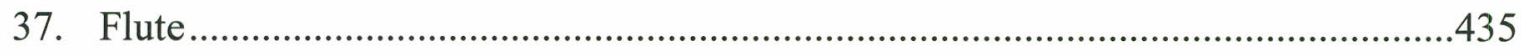

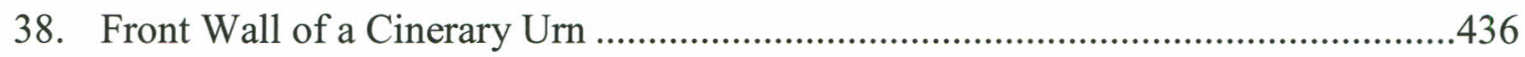

39. Female Statuette: Aphrodite and Lewes House Registers.......................................437

40. Table Support Fragment (?): Dionysus/Bacchus.......................................................438 
41. Portrait of a Middle-Aged Woman.....

42. Red-figure Plate Attributed to the Bryn Mawr Painter ..........................................440

43. Red-Figure Kylix Fragments Attributed to the Euaion Painter..............................441

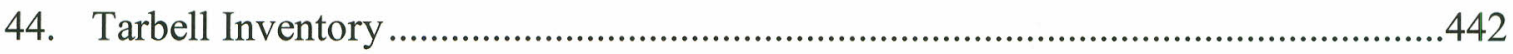

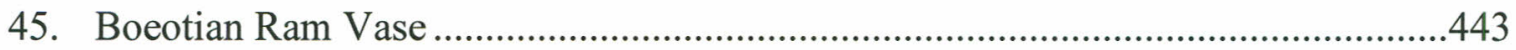

46. Attic Black-figure Amphora Attributed to Near the Painter N .............................444

47. Attic Black-figure Pelike Attributed to the Eucharides Painter ..............................445

48. Attic Black-figure Loutrophoros Amphora .........................................................446

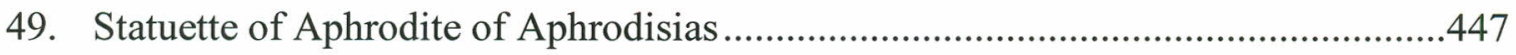

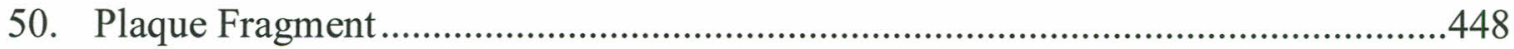

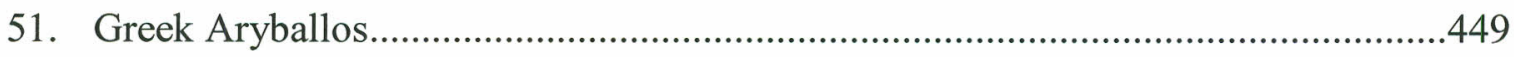

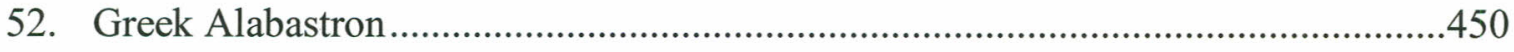

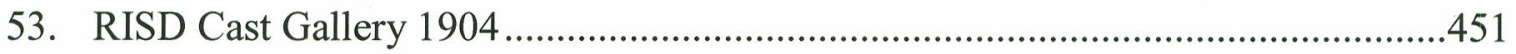

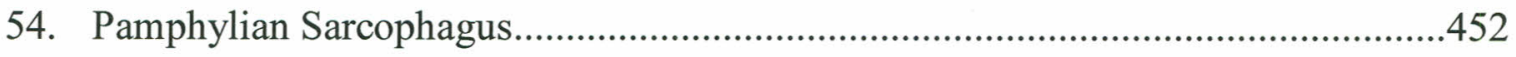

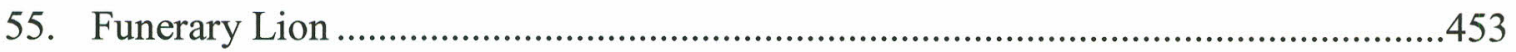

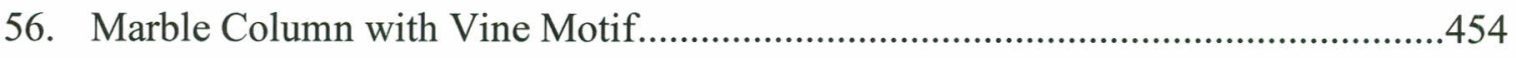

57. Attic Black-figure Amphora Signed by the Potter Nikosthenes ............................455

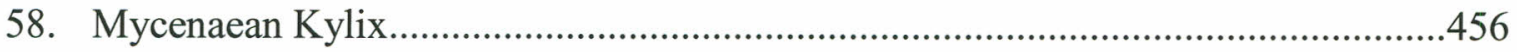

59. Attic Geometric Vase in the Form of a Pomegranate...........................................457

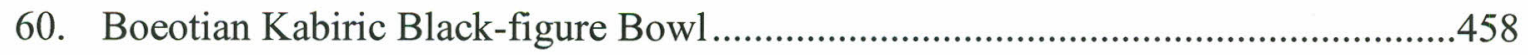

61. Attic Red-figure Krater Attributed to the Pan Painter...........................................459 
62. Attic Red-figure Lekythos Attributed to the Pan Painter .460

63. Attic Red-figure Nolan Amphora Attributed to the Pan Painter .461

64. Attic Red-figure Nolan Amphora and Beazley's Drawing .462

65. Attic Red-figure Lekythos Attributed to the Bowdoin Painter .463

66. Attic Red-figure Kylix Attributed to the Bowdoin Eye Painter .464

67. Attic Red-figure Amphora Attributed to the Providence Painter..... .465

68. Lantern Slide: Attic Red-figure Amphora Attributed to the Pan Painter 466

69. Attic Bilingual Amphora Attributed to the Andokides and Lysippides Painters ....467

70. Attic Bilingual Amphora: Details .468

71. Attic Bilingual Amphora Attributed to the Andokides and Lysippides Painters ....469

72. Attic White-ground Lekythos Attributed to Near the Painter of Munich 2335 ......470

73. Attic White-ground Lekythos Attributed to the Bedlam Workshop 471

74. Attic White-ground Lekythos Attributed to the Achilles Painter 472

75. Attic White-ground and Coral-red Kylix Attributed to Sotades as Potter 473

76. Attic White-ground and Coral-red Kylix and Drawing of Forged Tondo. 474

77. Paestan Red-figure Amphora Attributed to the Boston Orestes Painter 475

78. Apulian Red-figure Volute Krater Attributed to the Varrese Painter. 476

79. Apulian Red-figure Oenochoe

80. Attic Red-figure Cup in the Shape of a Donkey's Head 478

81. Attic Red-Figure Oenochoe Attributed to Group L: The Providence Group .479

82. Attic White-ground Libation Bowl Signed by Sotades as Potter .480 
83. Attic Black-figure Aryballos

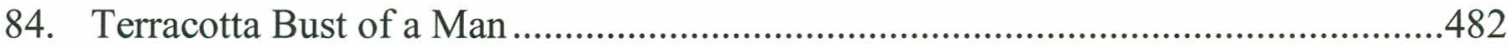

85. Terracotta Boeotian Bell-shaped Figurine..............................................................483

86. Standing Idol with Birdlike Head .......................................................................484

87. Terracotta Statuette of Eros Wearing the Lion Skin of Herakles ..............................485

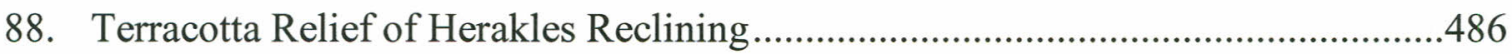

89. Terracotta Figurines of Girls Playing Knucklebones ...............................................487

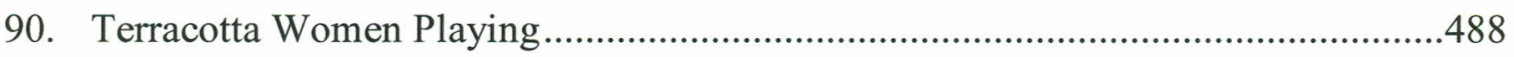

91. Terracotta Statuette of an Old Man Offering Grapes to a Girl................................489

92. Terracotta Figurine of a Woman Cooking, Watched by a Girl .................................490

93. Terracotta Standing Women (Tanagra type) ............................................................491

94. Terracotta Statuette of Aphrodite or a Muse Leaning on a Pillar...............................492

95. Terracotta Relief Depicting a Palaistra Scene ………………………………..........493

96. Terracotta Relief Depicting a Palaistra Scene ……………………………............494

97. Impression of a Terracotta Fragment of an Arretine Bowl: Youth and Boar........495

98. Impression of a Terracotta Fragment of an Arretine Bowl: Hunter on Horseback .496

99. Terracotta Fragment for an Arretine Bowl: Youth Attacking a Lion .......................497

100. Italo-Megarian Relief Ware Signed by Caius Popilius ..............................................498

101. Terracotta Mold Fragments for an Arretine Bowl...................................................499

102. Fragmentary Terracotta Bowl: Cupid on a Column between Couples in Coitus ....500 
103. Silver Tetradrachms of Athens .501

104. Gold Stater for the Kingdom of Macedonia Struck Under Philip II 502

105. Silver Stater for the Kingdom of Macedonia Struck Under Philip II........................503

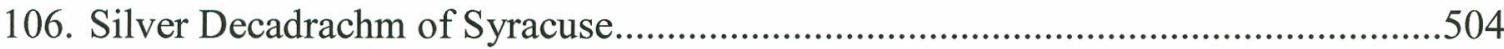

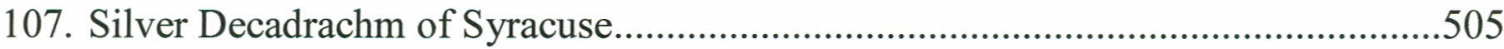

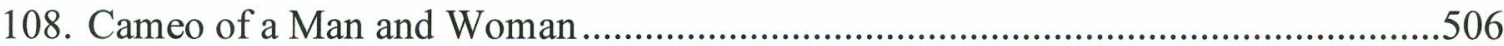

109. Oval Intaglio with Winged Victory Signed by Dioskourides ..................................507

110. Cameo with Wedding of Cupid and Psyche Signed by Tryphon ..............................508

111. Cameo with Livia Holding a Bust of Augustus (?) ....................................................509

112. Intaglio with Octavian (?) as Neptune .................................................................

113. Scarab with a Satyr Tuning a Lyre Signed by Onesimos ..........................................511

114. Scaraboid Gem with a Nude Youth and a Horse Signed by Epimenes....................512

115. Oval Gem with the Head of Sirus Signed by Epimenes............................................513

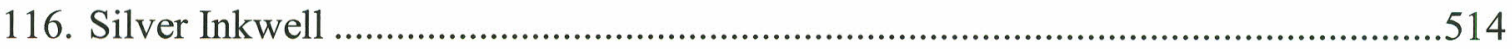

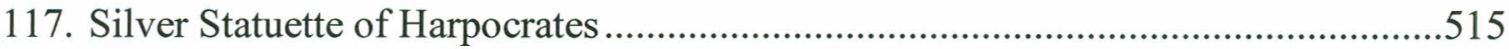

118. Electrum Plaques: A Bee Woman and Centaurs Holding Rabbits..........................516

119. Earring with Nike Driving a Two-horse Chariot......................................................517

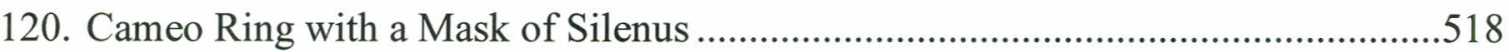


121. Pair of Etruscan Earrings

122. Vine-trellis Diadem .520

123. Necklace with Pendant Eros 521

124. Ring with Aphrodite Taking-up Arms Signed by Gelon. 522

125. Ivory Phallus on Two Legs. 523

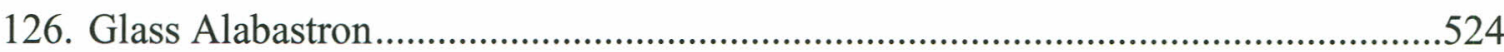

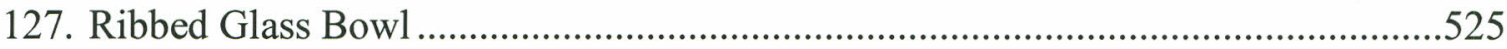

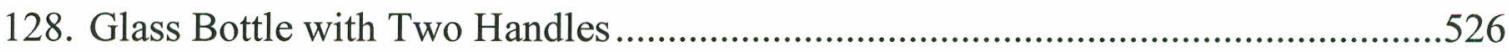

129. Cameo Glass Plaque with Priestess Figure ……………………………...............527

130. Cameo Glass Plaque with Herakles and the Keryneian Stag ...................................528

131. Mirror Stand with Aphrodite and Erotes .................................................................529

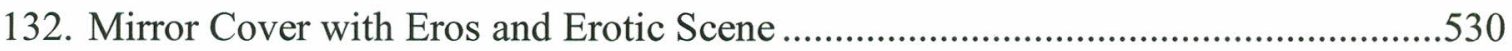

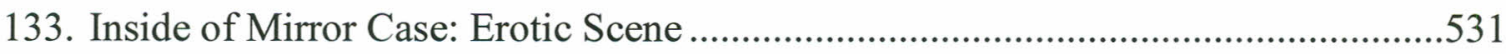

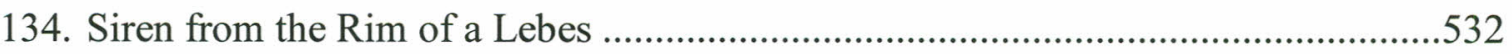

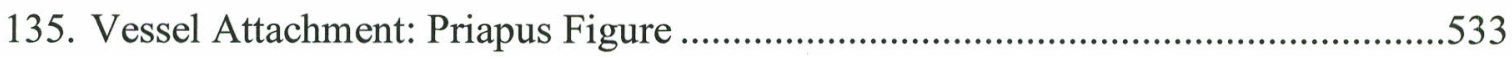

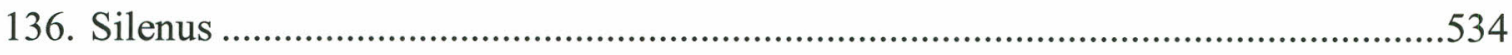

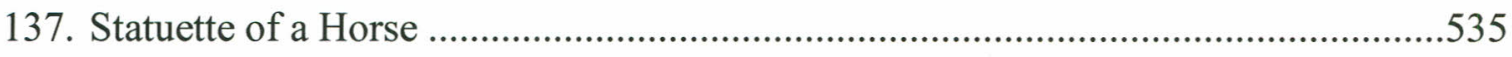

138. Statuette of a Deer Nursing her Fawn ................................................................536 
139. Statuette: Mantiklos "Apollo"

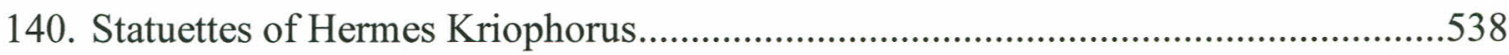

141. Man in a Cloak …………………………………..........................................539

142. Head of a Goddess or Queen ..............................................................................540

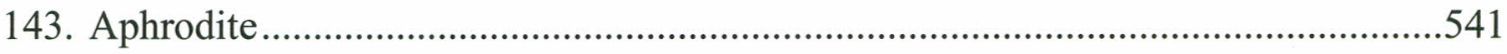

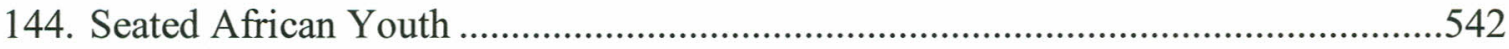

145. Lantern Slide: Marble Column with Vine Motif......................................................543

146. Architectural Panel with Griffin .........................................................................544

147. Relief of Mithras Slaying the Bull...................................................................545

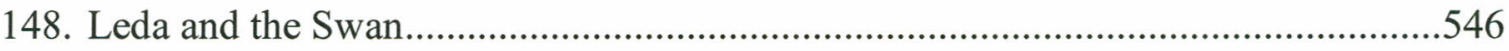

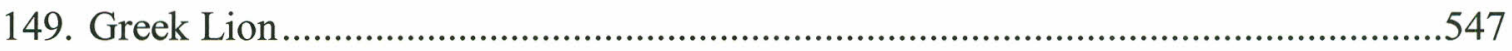

150. Greek Lion in the MFA Classical Gallery .............................................................548

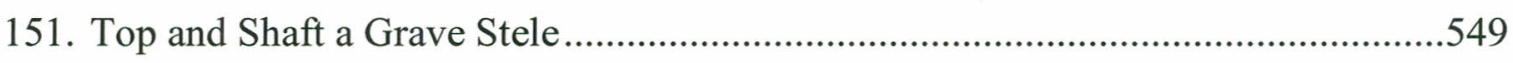

152. Top and Shaft a Grave Stele at "Thymbra Farm” ..................................................550

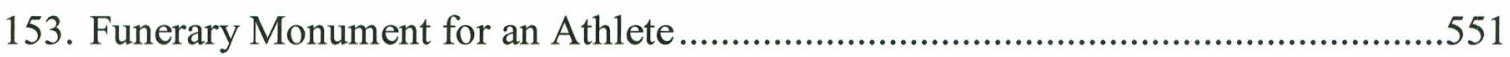

154. Fragments of Funerary Monument for an Athlete and Proposed Reconstruction...552

155. Fragmentary Oil Flask (Lekythos) Serving as a Grave Monument .........................553

156. Funerary Monument of Aththaia, Daughter of Malchos ............................................554 
157. Funerary Relief of Petronia Hedone and her Son, Lucius Petronius Philemon .......555

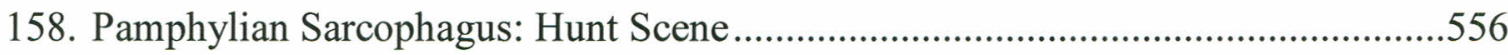

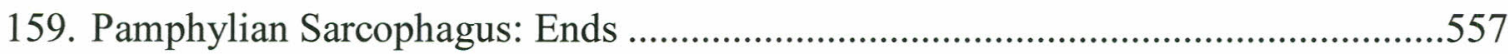

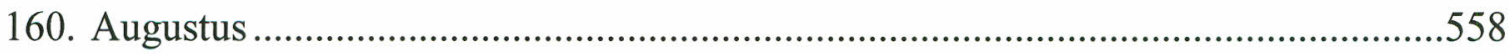

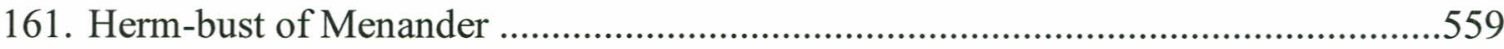

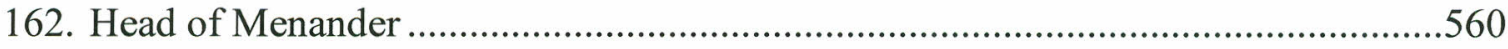

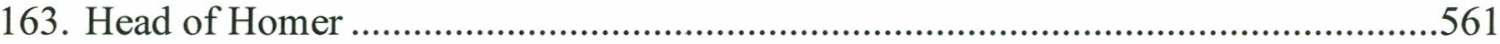

164. Aphrodite ("The Bartlett Head") and Head of a Goddess ("The Chios Head")......562

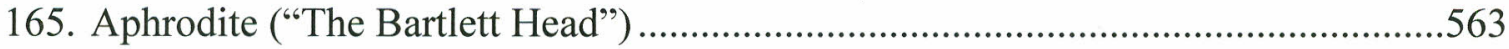

166. Head of a Goddess ("The Chios Head")..................................................................564

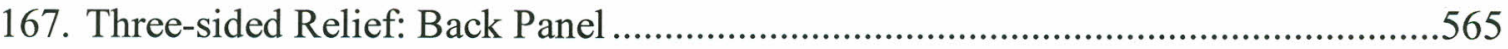

168. Three-Sided Relief: Side Panels 


\section{INTRODUCTION}

"The Impact of Edward Perry Warren on the Study and Collections of Greek and Roman Art in American Academia" examines a pivotal figure in the growth of collegiate collections and the development of scholarship in the United States. Warren was one of the first Americans to advocate that genuine antiquities, rather than plaster casts, were the appropriate means of understanding Greek and Roman art and culture. In the analysis of Warren's varied roles in forming the collections at the Museum of Fine Arts, Boston (MFA) and elite educational institutions in the United States at the turn of the twentieth century, this dissertation provides a new vantage point to observe how art history and archaeology became alternatives to the Latin and Greek philology that dominated American universities. In addition, its argument that Warren's sexuality was a primary motivation for his antiquities collecting contributes to the rapidly growing scholarship in gender studies. The multidisciplinary research utilizes information from a wide array of sources, particularly archival material, in the United States and Great Britain and advances the scholarship in art history and other disciplines.

\section{Organization of the Dissertation}

The dissertation is organized into an introduction, six chapters, and a conclusion. After reviewing the scholarship on Edward Perry Warren, the introduction discusses the various biographical sources for his life and describes the methodology for the research. Chapter 1 offers an overview of the late nineteenth-century social and economic 
backdrop, especially in the rise of philanthropy. It considers the Warren family in the context of the Gilded Age and provides a biography of Warren as a framework for understanding his numerous collecting ventures and the overlapping and layered relationships in his life. Chapter 2 describes Warren's intellectual milieu: an overview of antiquities collecting, the establishment of American museums, and the domination of classical philology in colleges and universities in late nineteenth-century. Next it considers how Warren's interest in Greek and Roman art was fostered at Harvard, then under the influence of Charles Eliot Norton, and at Oxford, where archaeology and ancient art were developing as alternatives to philological study. Chapter 2 also considers the link between Warren's sexuality and his antiquities enterprise via the first objects he acquired for the MFA. It chronicles the establishment of Lewes House in England and his services to the MFA, focusing on Warren's partnerships with John Marshall, Edward Robinson, and John Davidson Beazley. Chapter 3 explains Warren's varied roles in the establishment of six collegiate collections in the United States: Harvard University, Bowdoin College, the University of Pennsylvania, Bryn Mawr College, the University of Chicago, and Rhode Island School of Design. It describes what is known about his relationship with key individuals and the extent to which Warren's antiquities affected the study of ancient art at each institution.

Chapters 4,5 , and 6 serve as a selective catalogue of Warren antiquities in American collections, highlighting antiquities to illustrate the quality and diversity of the objects Warren sent to the United States as well as their significance in scholarship. ${ }^{1}$ Warren and his Lewes House assistants handled thousands of Greek and Roman

\footnotetext{
${ }^{1}$ Note all dates for art discussed refer to B.C.E. unless I use C.E. or where confusion may occur.
} 
antiquities of all types — vases and fragments; terracotta figurines, plaques, and moldmade vessels; coins; gems and seals; a variety of gold, silver, electrum, glass, and ivory objects; vessels and statuettes in bronze; sarcophagi and cinerary urns, sculpture and architectural fragments in stone - that eventually entered civic and academic museums in the United States. Like most collectors of his era, Warren gravitated toward Greek and Greek-inspired works. However, as Beazley observed, Warren was "not content with the facile formula 'Greek and good, Roman bad"', and knew that "much that was truly Greek lived on in the Roman period." 2 The goal of the last three chapters is not to provide a complete catalogue of Warren antiquities in American collections, but rather to demonstrate the breadth and quality of his "sendings" and the role his antiquities have played in scholarship and museum exhibitions.

Organized by medium, Chapters 4, 5, and 6 are further subdivided by the function of the object, and in some cases by dating, origin, workshop, and decorative technique or production method. Chapter 4 discusses ceramics from Warren subdivided into Greek vases, terracotta figurines, mold-made reliefs, and pottery. The number of Greek vases warrants further division according to technique - that is, black-figure, red-figure, whiteground, and plastic. Chapter 5 follows with a treatment of smaller antiquities in precious materials: coins, gems, jewelry, ivory, and glass. Chapter 6 focuses on Warren's contributions in bronze and stone to American collections. It highlights ancient bronzes, with functional objects treated first and then sculpture. Antiquities in stone-chiefly

\footnotetext{
${ }^{2}$ Burdett and Goddard 1941 334. Paul Zanker, one of the foremost scholars on Roman art, emphasizes the Roman reliance on "Greek forms" in a recent book: see Zanker 2010, 1-46.
} 
marble - organized into categories of architectural elements, funerary objects, and sculpture complete this select catalogue.

The conclusion summarizes Warren's impact on the study of Greek and Roman art and proposes how this dissertation may lead to further research. Photographs of Warren and the antiquities he acquired for collections in the United States are referenced within the text and included after the bibliography.

\section{State of the Research}

Over the last twenty years, scholarly attention has focused on antiquities collecting and the reception of Greek and Roman art, primarily in England. ${ }^{3}$ In addition, recent popular and academic publications have addressed the controversies about the acquisition of antiquities by prestigious museums in the United States and the question of national ownership of such objects. ${ }^{4}$ Such publicity and the widespread recognition of the importance of context in understanding Greek and Roman art have created a heightened awareness of provenance - that is, the findspot or archaeological contextand of the history of ownership. Warren's work on behalf of American museums does not figure prominently in recent discussions about antiquities acquisition because his collecting took place before national or international laws imposed strict regulation on the exportation of such objects. ${ }^{5}$ Thus, few of the previously cited works mention Warren

\footnotetext{
3 Jenkins 1992; Jenkins and Sloan 1996; Edwards 1999; Kurtz 2000; and Coltman 2009.

${ }^{4}$ Watson and Todeschini 2006; Hamilakis 2007; Miles 2008; and Silver 2009.

5 The exception is in Thomas Hoving's book on forgeries in which Warren is discussed in regard to the "Boston Throne." Hoving 1996, 256-74.
} 
and, if they do, it is in an aside or a footnote to more recent collectors and issues. ${ }^{6}$ Some scholarship on collecting includes Warren briefly in regard to broader issues such as the history of collecting or a specific archaeological site. ${ }^{7}$

Warren is best known through his most famous possession, a Roman silver cup (Figure 1) dated to the early first century C.E. and decorated with explicit depictions of homoerotic activity, now in the collection of British Museum. The "Warren Cup," as it is called, is the subject of a British Museum monograph as well as articles by American scholars John R. Clarke and John Pollini in the Art Bulletin. ${ }^{8}$ In fact, my first acquaintance with Warren stems from a graduate seminar on new approaches to the study of Greek and Roman art in which the Clarke and Pollini articles were assigned readings. Other than as the owner of the silver cup identified with his name, Warren does not figure prominently in discussions of Greek and Roman art. He is identified as the donor or previous owner of certain antiquities in exhibition catalogues, collection handbooks, and the catalogues of the Corpus Vasorum Antiquorum (CVA) because he was the source or donor for many ancient works that entered the Museum of Fine Arts, Boston (MFA) and six collegiate collections. ${ }^{9}$ However, such references to Warren are often brief and easily overlooked. He receives the most attention in the accounts of the founding of the MFA

\footnotetext{
${ }^{6}$ For example, Watson and Todeschini who allot Warren two sentences and inaccurately describe him as "settling in Rome," 44.

7 See, for example, Rouet 2001, 35-6, and Nørskov 2002, 69-71, 97-8, 148, 206, 300, who discuss Warren as one of the first antiquities agents to acquire Greek vases for American collections; Hartswick 2004, 12130, who treats Warren in relation to the discovery of the Ludovisi and Boston "thrones"; and Boardman 2009a, 19, who makes reference to Warren as a connoisseur of ancient gemstones. For Warren in relation to the development of "museum tradition" in the United States, see Dyson 1998, 136-42, who views Warren as a proponent of "the cult of the original object [that] came to dominate museum ideology," 136. ${ }^{8}$ Clarke 1993; Pollini 1999. For the most comprehensive treatment of the Warren Cup, see Williams $2006 b$.

${ }^{9}$ For the Corpus Vasorum Antiquorum project, see Rouet 124-37.
} 
and the Bowdoin College Museum of Art (BCMA). ${ }^{10}$ Recent handbooks for the collections at the Museum of Art, Rhode Island School of Design (RISD) and the Smart Museum of Art, University of Chicago, acknowledge his role in forming the classical collections of these institutions. ${ }^{11}$

Warren funded the publication of two catalogues to document his personal collections of coins and gems. In 1906, a numismatic specialist in Berlin, Kurt Ludwig Regling, compiled Die griechischen Münzen der Sammlung Warren. ${ }^{12}$ Only a few copies of this two volume work survive. ${ }^{13}$ In 1920 Warren commissioned his long-time collaborator and well-known Oxford scholar, John Davidson Beazley, to write a catalogue for his impressive collection of ancient gems and seals entitled The Lewes House Collection Ancient Gems. ${ }^{14}$ The British classicist, John Boardman, revised and republished this catalogue in $2002 .^{15}$

In 2003 Iain Jeremy Stewart submitted a thesis, "Putting the Pieces Together: The Collecting Practices of Edward Perry Warren (1860-1928) and the Museum of Fine Arts, Boston" as one of the requirements for an MA in art history at Concordia University, Montreal, Quebec. ${ }^{16}$ Stewart explores collecting as a general concept, with the goal of viewing Warren's collecting practices in the social and cultural context of late nineteenth-

\footnotetext{
${ }^{10}$ For the MFA, see Whitehall 1970a. For Bowdoin, see Herbert 1964, 4-10, and Higginbotham and Westley 2005, 19-23.

${ }^{11}$ For RISD, see Michie 2008b, 18-24, and Barrett and Martinez 2008a, 392-44. For the University of Chicago, see Nielsen 1998, 1-8.

${ }_{12}$ Regling 1906. Research for this dissertation has revealed little information about Kurt Regling (18761935).

${ }^{13}$ A copy in the George J. Mitchell Department of Special Collections \& Archives, Bowdoin College Library is likely a gift from Warren.

${ }^{14}$ Burdett and Goddard, 361-63.

15 Boardman and Beazley 2002.

${ }^{16}$ Stewart 2003.
} 
and early twentieth-century Boston, especially in the development of the Museum of Fine Arts. He discusses four sculptures and a group of gems, once owned by Warren, now in the MFA collection. However, Stewart's thesis does not address the collector's relationship with American museums other than the MFA and the Metropolitan Museum of Art, New York, nor does it describe the quantity, quality, and variety of antiquities that arrived in this country through Warren's efforts. Stewart does not discuss Warren's homosexuality, a key issue in his collecting and work as an antiquities agent, as I will contend.

The only biography devoted solely to Warren is Osbert Burdett's and E. H. Goddard's Edward Perry Warren:The Biography of a Connoisseur (1941), a pastiche of autobiographical fragments, Warren's letters, and recollections of those who knew him, published thirteen years after his death. Two books treat Warren and his family and the network of men he recruited to assist in his collecting enterprises. Martin Green's The Mount Vernon Street Warrens: A Boston Story, 1860-1910 (1989) describes the knotty relationships in the family. ${ }^{17}$ David Sox's Bachelors of Art: Edward Perry Warren \& the Lewes House Brotherhood (1991) examines Warren and the young men he recruited to live and work in the exclusively male community he established in East Sussex, England. ${ }^{18}$ Neither of these books, it should be noted, focuses exclusively on Edward

\footnotetext{
${ }^{17}$ Green 1989. For Martin B. Green (1927-2010), a Professor of English at Tufts University, who published thirty-seven books on a wide variety of topics, see "A Guide to the Martin Green Papers, 19602000." Tufts University Digital Collections and Archives. 2004. http://hdl.handle.net/10427/14683 (June 7).

${ }^{18}$ David Sox, an American who now resides primarily in England, has written about forgeries in relics and art. His best known book is Unmasking the Forger: The Dossena Deception (1987). Sox explains that he became aware of Warren and the Lewes House group in researching Alceo Dossena. Sox 1991, ix. Sox also wrote a pamphlet about Warren and his contemporaries in Lewes for the Lewes District Council. Sox 2006.
} 
Perry Warren. Both works treat "Ned"—as Warren was called by his friends and family — as the center of a tangled web of familial and homosocial bonds. Green and Sox relied heavily on the account of Warren's life in Burdett and Goddard, a work which both Green and Sox found rambling, vague, and often incoherent. The Burdett and Goddard book is discussed more extensively below.

Recent reference works provide overviews of Warren's career. William Calder contributed an entry to An Encyclopedia of Classical Archaeology (1996) while David Sox contributed an account of Warren's life to the Oxford Dictionary of National Biography (2005). ${ }^{19}$ Both essays are accurate biographical sketches of the collector. Over the last decade, scholarship in gender studies has also touched on Warren. The British historian, A. L. Rowse, included Warren in Homosexuals in History: A Study of Ambivalence in Society, Literature and the Arts (1997). Beginning his chronology of homosexuals with the Renaissance, Rowse devotes three and a half pages to Warren in the fifth chapter entitled "A Handful of Americans." Unfortunately, Rowse's treatment of Warren contains glaring factual errors and unsubstantiated assertions. ${ }^{20}$ Art historian Whitney Davis briefly considers Warren's antiquities in an article on five collections of homoerotic art from 1750-1920. The Warren Cup is the only specific object from Warren discussed and then only briefly. ${ }^{21}$ Davis does not provide a complete portrait of Warren or describe the extent of his collecting. Recent scholarship on masculinity has begun to notice Edward Perry Warren. In Material and Visual Cultures Beyond Male Bonding,

\footnotetext{
${ }^{19}$ Calder 1996; Sox 2005.

${ }^{20}$ Rowse 1977, 309-13. Rowse gives Warren's dates as (1860-1936 rather than 1860-1828) and makes questionable observations: for example, he states that John Marshall suggested that Warren go into archaeology.

${ }^{21}$ Davis 2001.
} 
1870-1914 (2008), art historian John Potvin briefly refers to the relationship of Ned Warren and John Marshall and includes a photograph of the pair (Figure 2). ${ }^{22}$ Potvin has done work on Warren as part of his ongoing research on domestic space and "same-sex and queer men and their collections" in Great Britain. ${ }^{23}$ His scholarship on how the material culture reveals otherwise undocumented intimacy among men during the late nineteenth century has informed my thinking about Warren. In 2011, the Museum of Fine Arts, Boston organized an exhibition, "Aphrodite and the Gods of Love," with half of the one hundred and sixty antiquities from Warren. ${ }^{24}$ The MFA Curator acknowledged Warren's pivotal role in establising that world-renowned collection and confirmed assertions made in this dissertation:

Warren, a dealer, collector, and philosopher, had perspicacious insights into the meaning and function of erotic works in ancient society. Most specifically, he acquired works that revealed the Greek taste for homoerotic subjects. His passion for Greek art expressed his personal proclivities and a lifestyle shaped around Greek aesthetics and male companionship.... [he obtained] oddities for the times in which they were collected, but today offer unique insights into ancient life. ${ }^{25}$

This survey of how Edward Perry Warren has figured in recent scholarship illustrates the timeliness of this dissertation. My research documents the number, variety, and impact of the antiquities he collected and distributed to American collections. Furthermore, it suggests that the motivation behind Warren's "sendings," as he called them, was multivalent. In my survey of Warren antiquities in prominent classical collections in the United States, the dissertation fills a lacuna in scholarship on the history of collecting and the historiography of art history.

\footnotetext{
${ }^{22}$ Potvin 2008.

${ }^{23}$ John Potvin, e-mail message, 8 October 2010, to author.

${ }^{24}$ Christine Kondoleon, e-mail message, 13 July 2011, to the author.

${ }^{25}$ Kondoleon 2011, 14-15.
} 


\section{Biographies of Warren}

The most important—yet most flawed—biography is Edward Perry Warren: The Biography of a Connoisseur published by E. H. Goddard in 1941, thirteen years after Warren's death. This source requires a thorough discussion because it provides the most comprehensive information about Warren yet provokes questions that are best addressed prior to reading this dissertation. To begin with, it is not clear who in fact wrote the biography and why E. H. Goddard delayed publishing this book until thirteen years after Warren's death. A great deal of the confusion may be traced to Warren's naming three British literary executors without stipulating each man's role in the project and a deadline for completion. In his will, he left his "private and personal papers wherever they may be, including any writings or literary papers or letters and ... all manuscript papers and documents relating to [his] purchase or collection of antiquities and works of art" to Osbert Burdett, E. H. Goddard, and Charles Reginald Schiller Harris for the "preparation of a biography” providing $£ 100$ per year to each as compensation. ${ }^{26}$ According to Goddard in the preface, Burdett's goal was to complete the task within ten years, implying that Burdett was in charge of the project. ${ }^{27}$ Goddard explains that Burdett's

\footnotetext{
${ }^{26}$ See "Will of Edward Perry Warren (November 23, 1928)." A typed copy of this document with "FHG's copy" handwritten on the cover is in the Lewes House Archives, Lewes District Council, Lewes, East Sussex. "F. H G." is Frank Herbert Gearing, Warren's secretary and accountant at Lewes House. Gearing's widow gave material and documents connected to Warren, including the will, to the Lewes District Council.

${ }^{27}$ In Warren's will, Osbert Burdett (1885-1936) is identified as "of Harrow-on-the Hill," a district just northwest of London. It also designated him as one of the guardians and trustees for Warren's adopted son, Travis, and bequeathed him an additional £800. Osbert Burdett was a prolific writer, producing at least twelve books. He wrote five book-length biographies of British authors, artists, and politicians. He was interested in the late nineteenth-century British aesthetes such as Aubrey Beardsley, Walter Pater, and Oscar Wilde, an affinity he shared with Warren, perhaps prompting Warren to name him as a literary executor. Burdett's extensive publications may have distracted him from completing the Warren biography. Research for this dissertation has not yielded any correspondence or any other information
} 
death in 1936 and "other difficulties" caused delay in publishing the work. ${ }^{28}$ C. R. S. Harris, the third literary executor named in Warren's will, is not mentioned in Goddard's preface nor does he appear anywhere in the book. ${ }^{29}$ Furthermore, other than the preface, it is not apparent what was written by Burdett and what was contributed by Goddard.

The Burdett-Goddard biography of Warren is organized into eighteen chapters. The first three contain Warren's memoirs of his childhood and early education, as well as his reminiscences about Harvard and Oxford. The authors do not indicate when Warren penned the recollections incorporated into their manuscript. However, based on the similarity of topics and phrasing in his letters to Susan Wilbur Jones, his younger cousin, one can conjecture that Ned wrote these recollections in 1910-20. Fourteen of the fifteen following chapters are made up of Warren's letters. For many letters, Burdett and Goddard include the dates as well as salutations and closings. Sometimes letters to Warren from John Marshall were used. It is not clear if individual letters are completely or partially replicated because none of the original letters have survived to permit such an

about the relationship between Burdett and Warren. Nonetheless, the fact that Burdett was named one of the guardians for Warren's adopted son suggests that Warren valued and trusted him.

${ }^{28}$ E. H. Goddard (1896-1983) is described as “of Corpus Christi College, Oxford” in Warren's will. Warren bequeathed an additional £1,500 to Goddard stipulating that, if Goddard was deceased at the time of Warren's death, the sum should be distributed equally to Goddard's wife and his surviving children. According to the Biographical Register at Corpus Christi, Goddard was born Edgar Henry Gropius but changed his surname in 1920. He held a scholarship at Corpus where he studied from 1915-20 earning both a B.A. and M.A. He served briefly during the First World War until an injury required his discharge. Goddard, who married in 1920 and had two daughters, taught at several public schools before becoming Head Master of Haberdashers' Aske's School in London, where he retired after twenty-nine years. Goddard also co-authored Latin textbooks. As in the case of Burdett, research for this dissertation has not revealed information about the relationship between Goddard and Warren. Goddard may have lived at Lewes House or been connected to one of the young men there. Warren may have known him via his frequent visits to Oxford and his friendships at Corpus Christi College. The biographical information about E. H. Goddard comes from the biographical register at Corpus. E-mail message, Julian Reid, Archivist at Corpus Christi and Merton Colleges, 29 March 2010, to the author.

${ }^{29}$ C. R. S. Harris (1896-1979) of All Souls College, Oxford, wrote Duns Scotus (1927) and The Heart and the Vascular System in Ancient Greek Medicine, from Alcmaeon to Galen (1973). Harris is not in the Oxford Dictionary of National Biography. 
analysis. ${ }^{30}$ Burdett and Goddard placed the tribute, "Warren as Collector," contributed

by J. D. Beazley as the sixteenth chapter of the biography. Two additional chapters, again compilations of letters and third person narratives, follow Beazley's essay. ${ }^{31}$ Five appendices end the biography. ${ }^{32}$ Burdett and Goddard's biography contains photographs of Warren, Marshall, the interior of Lewes House, and "some of Warren's choicest" antiquities in the MFA Boston. ${ }^{33}$

The highly wrought language, convoluted sentence structure, sudden shifts in point of view and disjointed organization of the excerpts from Warren's letters often make the biography confusing and difficult to understand. ${ }^{34}$ In the preface, Goddard claims that the "lack of cohesion" in this work was the result of "collaborators and handymen." He asserts that Warren had expressed a desire to confine the memoir to

\footnotetext{
${ }^{30}$ Research for this dissertation has not located any of the letters in Burdett and Goddard. They are not in the Warren-Marshall papers in the Sackler Library of the Ashmolean Museum, Oxford, nor are they in the Lewes House Archives, Lewes, East Sussex. Warren apparently kept letters from John Marshall among copies of his own correspondence.

31 These final chapters are "Oxford and Warren" and "Epilogue."

${ }^{32}$ Appendix I is "The Warren Family" based on a tribute to S.D. Warren from Westbrook, Maine, published at the time of his death (see Samuel Dennis Warren (September 13, 1817--May 11, 1888): A

Tribute from the People of Cumberland Mills 1888) and the memoir of Susan Clarke Warren written by Cornelia Warren (see Warren 1908). Copies of both Cornelia Warren's book and the S. D. Warren tribute are in the Lewes House Archives. Warren 1908. Appendix II is "Letter from H. A .Thomas to the President of Corpus." The letter is dated November 28, 1912, Lewes. Harry Asa Thomas was one of Warren's assistants who inherited Lewes House and most of its contents. Appendix III is "'In Memoriam' Edward Perry Warren and John Marshall" by Ludwig Curtius, originally published in Mitteilungen des Deutschen Archaologischen Instituts (44), 1929. Ludwig Curtius (1874-1954) was Director of the German Archaeological Institute from 1928 until 1938. Appendix IV is “ The Bowdoin Collection,” Warren's essay on the antiquities he gave to Bowdoin. Appendix V is Warren's sketch of Lionel Johnson, the poet and literary scholar that Warren contributed anonymously to Oscar Burdett's The Beardsley Period (1925). Johnson struggled with his religious beliefs (he converted to Roman Catholicism) and repressed homosexuality. For Lionel Johnson, see Thornton 2007. The five appendices add to the sense of disjointedness in the Burdett and Goddard biography. Ending the book with Lionel Johnson seems abrupt.

${ }^{33}$ The preface credits L. D. Caskey, Director of the Classical Department of the MFA Boston, for the photographs. Burdett and Goddard vii. Photographs of twenty-one antiquities in the MFA are scattered through the biography.

${ }^{34}$ For an example of an abrupt shift from first to third person point of view, see Burdett and Goddard 8 .
} 
"statements of fact" and exclude "gossip" and "opinions." "35 Goddard's meaning, here, is not clear. Perhaps he was aware of the incoherence in the biography and anticipated criticism for what appears to be slip-shod work. Thus, his allusion to Warren's directives may be his excuse for the lack of cohesion in the book. A more recent Warren biographer, Martin Green, attributes the muddled ambiguity in the Burdett-Goddard text to "sleepy-headedness" in Warren's literary executors and to a "panic or paralysis of discretion" over the possibility that readers of the biography would "guess that Warren was homosexual. ${ }^{36}$

The other two sources for Warren's life are Martin Green's The Mount Vernon Street Warrens (1989), a history of the Warren family, and David Sox's Bachelors of Art (1991), an account of Warren and four of the men he recruited to work in his antiquities enterprises. Both Green and Sox use Burdett and Goddard extensively and cite sources, especially in Oxford, that are now lost or cannot be accessed. Both conducted interviews with now deceased individuals who knew Warren. ${ }^{37}$ Martin Green focuses on the distinctly American aspects of Warren's life and career while David Sox gives more attention to the British side of Warren's activities. Overall, Green presents Warren more negatively than Sox does.

Both Green and Sox attempt to clarify the confusion inherent in the tangled relationships, concurrent projects, and shifting preoccupations in Ned Warren's life;

${ }^{35}$ Burdett and Goddard vii.

${ }^{36}$ Green 1989, xiii.

${ }^{37}$ Sox and Green also acquired miscellaneous documents connected with Warren. Martin Green died in 2009. Unfortunately, I was unable to meet with David Sox. Dr. Dyfri Williams of the British Museum offered to introduce me to David Sox. However, Dr. Williams was teaching in South Africa during my research visit to England (May 2009). E-mail messages from Dyfri Williams, 28 October 2009, 29 October 2009, and 3 March 2009, to the author. 
however, they employ different organizational strategies. In The Mount Vernon Street Warrens, Green presents members of the family in distinct narrative strands that are threaded through his biography of the family, beginning with the parents Samuel Dennis Warren (1817-88) and Susan Cornelia Clarke Warren (1825-1901) and ending with Ned's death (1928). Sox, on the other hand, arranges Bachelors of Art into seven sections with the first three devoted to Ned Warren and one section accorded to four members of Ned's community at Lewes: John Marshall, John Fothergill, Matthew Stewart Pritchard, and Harold Woodbury Parsons. Most scholarship treating Warren relies on both Green and Sox.$^{38}$

In 2009, Michael Matthew Kaylor and Mark Robert Miner produced a privately printed annotated edition of Warren's Defence of Uranian Love (1928). Kaylor's introductory biographical essay argues that Warren's pedophilia constituted the prime motivation for his interest in Greek culture as well as his recruitment of young men and boys to his estate in Lewes. ${ }^{39}$ My research has not confirmed this assertion about Warren. Miner's commentary focuses on Warren's use of classical texts in his Defence..$^{40}$ The reissue and annotation of the Defence is additional testimony for interest in Edward Perry Warren and provides access to Warren's book.

\footnotetext{
${ }^{38}$ Green and Sox are used in the most recent sketch of Warren's life in the new edition of A Defence Warren, Kaylor and Miner 2009, xvii-cxxii.

${ }^{39}$ Warren, Kaylor and Miner xvii-cxii. Kaylor edited Warren's text and wrote the introduction. Miner provided translations and audio files of the numerous quotations Warren took from Greek and Latin texts. William Armstrong Percy III, who wrote a foreward for this edition, expresses the hope that the new edition of $A$ Defence of Uranian Love "will have an impact, one so dearly needed in this age of the demonized paederast." Warren, Kaylor and Miner xv.

${ }^{40}$ Warren, Kaylor and Miner 313-26.
} 


\section{Methodology}

The sources consulted for this dissertation include correspondence and records in archives. The Burdett-Goddard biography preserves many of Warren's letters; therefore, much of that volume may be considered a primary resource. In addition, research in fourteen archives in the United States and England generated significant information for this dissertation. Museum and university archives constituted the chief resources in the United States.

Boston and Cambridge, Massachusetts, offer rich sources for inquiry into Warren's collecting. The MFA Museum Archives contains Directors' Reports and the Directors' Correspondence files from 1884-1928 relevant to Warren. ${ }^{41}$ I was not permitted to examine the original materials in the curatorial files; however, according to the MFA staff, what is known about the history of antiquities in the MFA collection can be accessed through the provenance field in the Collection Database on the museum's website. $^{42}$ At Harvard, two archives proved immensely valuable in my research. The curatorial files of the Department of Ancient and Byzantine Art and Numismatics of the Harvard Museums contain materials documenting the vases and a marble head Warren

\footnotetext{
${ }^{41}$ The MFA did not permit me to examine the original documents; however, I was able to skim the microfilm reels of the letters and to copy pertinent sections of the bound Directors' Reports in the Archives. On my return from Boston, I accessed the Directors' Correspondence from 1894-1928 via microfilm in the Archives of American Art. The MFA Archives staff advised me that Walter Whitehall's history of the MFA contains much of what is known about the relationship between the Museum and Warren, a fact that my reading of the Directors' Correspondence and Reports confirmed. See Whitehall (chiefly Volume 1). Maureen Melton, MFA Director Library and Archives and Museum Historian, provided guidance in my search. Paul McAlpine, the MFA Library and Archives, helped me access information about Warren and his antiquities in the MFA.

${ }^{42}$ E-mail message Mary B. Comstock, Cornelius and Emily Vermeule Curator and Keeper of Coins, Greek and Roman Art, Museum of Fine Art, 20 May 2008, to the author. Thus, this dissertation cites the MFA Collection database for provenance information for Warren objects in that museum. In the early stages of my research, Dr. Comstock provided me with a bibliography of sources on Warren.
} 
gave to the Fogg Museum. The curatorial staff removed all Warren antiquities from storage to permit my close inspection and graciously responded to my follow-up questions. ${ }^{43}$ Research in the Harvard University Archives in Pusey Library allowed me to better understand Warren's undergraduate academic experience. By examining the class rosters from 1879-83, I determined the courses in which Warren enrolled, including two classes with Charles Eliot Norton. The course catalogues from Warren's era have helped me chart the development of art history and archaeology at Harvard. In addition, the Alumni Files for Warren and his brothers preserved in the Pusey Library clarified my understanding of how their activities and careers were viewed at their alma mater.

My discoveries at three distinguished American academic institutions-Bowdoin College, the University of Pennsylvania (Penn), Rhode Island School of Design (RISD) - were especially important. Warren's best-known connection with an American academic institution is with Bowdoin College. The Bowdoin College Museum of Art provided a list of the over five hundred Warren gifts, a useful tool in my research. ${ }^{44}$ In the Curator's Office, I found correspondence not only from Warren but also from his friend and associate, J. D. Beazley, the noted Oxford scholar. ${ }^{45}$ The George J. Mitchell Department of Special Collections \& Archives of the Bowdoin College Library houses

\footnotetext{
${ }^{43}$ Karen A. Manning, Department of Ancient and Byzantine Art and Numismatics of the Harvard Museums, was a continual source of guidance on Warren's gifts to the Fogg Museum.

${ }^{44}$ On my two research visits to the Bowdoin College Museum of Art, Diana K. Tuite and Kate Herlihy were immensely helpful. John Anderson served as a gracious and thoughtful facilitator. John Cross, Secretary of Development and College Relations at Bowdoin, assisted me in acquiring more information about the faculty and museum personnel connected with Warren antiquities.

${ }^{45}$ Beazley corresponded with G. Roger Edwards (1915-2009), a Bowdoin graduate then serving as an assistant curator for the college museum. After earning his Ph. D. at Johns Hopkins, Edwards became a Greek vase specialist and served as archaeologist and curator at the University of Pennsylvania for 30 years. I had the privilege of interviewing Dr. Edwards, then 94 and living in retirement as curator emeritus, in Haverford, PA, in March, 2009.
} 
Reports to the President 1894-1930 and a sheaf of letters from Warren to his cousin Susan Wilbur Jones ("Susie"). ${ }^{46}$ Later, I located additional correspondence between Warren and Susie and her husband in the Llewellyn Jones Papers in Yale Collection of American Literature, Beinecke Rare Book and Manuscript Library. ${ }^{47}$ At the Penn Museum of Archaeology and Anthropology, six of the seven marble sculptures acquired through Warren are on permanent display in the Greek and Roman galleries. ${ }^{48}$ The Museum Archives at the University of Pennsylvania contains Warren correspondence, chiefly with Sarah Yorke Stevenson, the first Curator of the Mediterranean Section, and George Byron Gordon, the Museum Director. With Penn's long and distinguished role in American classical archaeology, its Museum Archives serves as a valuable resource for information about the first American scholars in Greek and Roman art. ${ }^{49}$ Research at RISD also proved crucial to my understanding Warren's impact on American scholarship in art history. Most of the significant antiquities entering RISD's impressive classical collection before 1928 came through Warren. The RISD curators, faculty, archives and library staff supported my research, giving me access to object files as well to the Warren antiquities. ${ }^{50}$ Lantern slides I discovered in the Visual Resource Center indicate that

\footnotetext{
${ }^{46}$ Bowdoin recently acquired these letters through an estate sale; thus, they are a new source for information about Warren. For a biography of Susan Wilbur Jones (1893-1968), see Smith and Burns 2006. "Susan Wilbur Jones, b. 1893." http://drs.library.yale.edu (5 February 2010). Daniel S. Hope and Caroline Moseley, George J. Mitchell Department of Special Collections and Archives of Bowdoin College, provided access to correspondence and other documents.

${ }^{47}$ The Beinecke Library provided photocopies of the Warren correspondence. Although these documents do not touch on Warren's collecting, they provide glimpses into his values, intellectual interests, and temperament.

${ }^{48}$ Chrisso Boulis, Registrar, and Lynn Makowsky, Keeper of Collections for the Mediterranean Section, provided access to the sculpture obtained through Warren and the curatorial records at Penn.

${ }^{49}$ Alessandro (Alex) Pezzati, Archivist at the Penn Museum of Archaeology and Anthropology Archives, provided invaluable assistance throughout my research.

${ }^{50}$ Dr. Gina Borromeo, Curator of Ancient Art, has been a constant source of information and encouragement. Her assistant Dr. Lisa Anderson served as my guide in examining the Warren antiquities at
} 
images of Warren antiquities were used in the first art history classes offered at RISD and nearby Brown University. The RISD Archives was especially significant because it preserves almost thirty years of correspondence between Warren and Eliza Metcalf Radeke, one of the founders of the RISD Museum.

My research reveals that Warren's contacts with Bryn Mawr College and the University of Chicago were tangential. Antiquities entered the collections at both institutions through his acquaintance with professors who taught archaeology courses, but my research has not found evidence that he visited either institution. In 1901 Joseph Clark Hoppin, the first American authority on Greek vases and an avid collector who taught archaeology at the newly established Bryn Mawr College, purchased an assortment of ancient ceramics from Warren-chiefly vase fragments but also some complete Greek vases and Hellenistic and Roman bowls - to build a study collection. ${ }^{51}$ My search in the M. Carey Thomas Presidential Papers and the early college catalogues preserved in the Special Collections of Bryn Mawr Library revealed no information about the circumstances of the purchase. The Collections Files contains Hoppin's annotated inventory of the Warren ceramics but no correspondence between Warren and Hoppin. In 1902 Warren gave approximately eighty antiquities to Frank Tarbell, a professor of Greek who taught the first archaeology courses at the University of Chicago. These

RISD. Dr.Maureen C. O'Brien, RISD Curator of Painting and Sculpture, provided assistance and encouragement. Dr. Baruch Kirschenbaum, Professor Emeritus of Art History, and Dr. Marta Bustillo, Visual Resources Librarian, helped in my quest to determine the pedagogical impact of Warren antiquities at RISD. Douglas Doe and Andrew Martinez of the RISD Archives gave me access to important documents and resources.

${ }^{51}$ Dr. Ann Ashmead, who co-authored catalogues of the RISD and Bryn Mawr Greek vases, was a resource for Greek vase scholarship. Sarah Hafner and Barbara Grubb served as gracious hosts for my visit to the Bryn Mawr teaching collection. Dr. Alice Donohue provided valuable guidance and advice. 
objects, chiefly vases and shards but also some statuettes, remained in the collections of the Classics Department until the opening of the David and Alfred Smart Museum of Art, where most are now kept in storage. The only record of the Warren antiquities is a handwritten “Tarbell Inventory,” identifying Warren's gifts, sometimes with notes about iconography or findspot. ${ }^{52}$ Investigations in Special Collections of the Regenstein Library produced little information about Tarbell and nothing about his relationship with Warren. $^{53}$

Viewing Warren antiquities in the MFA and the five collegiate collections complemented my archival research in the United States. The curators at the academic institutions allowed me to see objects in storage. ${ }^{54}$ To acquire a sense of context for my research, I also explored the Beacon Hill neighborhood in which the Warren family home still stands and toured Westbrook, Maine, to visit buildings and institutions connected with the Warren family and its paper mill. ${ }^{55}$ With the assistance of the Westbrook Historical Society, I visited Fewacres, Warren's summer house, which now serves as a real estate agency. ${ }^{56}$

My research in Oxford and Lewes where Warren lived for much of his adult life helped me understand the collector and his antiquities enterprise from a different

\footnotetext{
${ }^{52}$ Dr. Richard A. Born, Senior Curator, and Natasha Derrickson, Associate Registrar, made my visit to the Smart Museum of Art possible.

${ }_{53}$ Julia Gardner, Reference \& Instruction Librarian at the University of Chicago, assisted me in this search.

${ }^{54}$ I have examined all the Warren antiquities in the Harvard, Penn, Chicago, and Bryn Mawr collections.

${ }^{55}$ According to the curatorial staff at the nearby Nichols House Museum, the façade is all that remains of the Warren home on Mount Vernon Street. In Westbrook, the Warren family is still held in high regard. The Westbrook Historical Society maintains a small museum and archive which document the impact of the Warren Paper Company in the mill town from 1870-1970.

${ }^{56}$ Vaun Born, Donna Conley, Jan Usher of the Westbrook Historical Society proved invaluable to my understanding of the various Warren family members and their legacies in relation to the Warren Mills and Westbrook.
} 
perspective. I examined the Warren Cup, now prominently displayed next to the Portland Vase in the British Museum. Unfortunately, the Ashmolean Museum was closed for renovation, preventing me from viewing Warren's gifts to its collection. My research at the Beazley Archives proved disappointing because all materials connected with Warren were misplaced when the Archives moved into new facilities. ${ }^{57}$ The Archivist at Sackler allowed me to examine several boxes of unlabeled papers belonging to John Marshall, Warren's friend and antiquities collaborator; but few of these documents proved relevant to my research. ${ }^{58}$ In the Corpus Christi Archives, I examined Warren correspondence and college records. ${ }^{59}$

My visit to Lewes was especially rewarding. Warren's house has been remodeled and some of the outbuildings have been torn down. However, the Lewes District Council has preserved much of the mansion and the garden as they were in Warren's time. The Lewes House Archives contains collecting records, photographs and newspaper clippings, copies of Warren's books, remnants of Warren's personal library, and assorted memorabilia connected with Warren and his staff of assistants and servants. ${ }^{60}$ My most significant discovery was five ledgers, bound into three volumes, recording 2,705

\footnotetext{
${ }^{57}$ Dr. Donna Kurtz, Beazley Archivist, informed me that notebooks connected with his collecting could not be located after the Beazley Archives moved from the Cast Gallery of the Ashmolean Museum to Ioannou School on St Giles, adjacent to the museum.

${ }_{58}$ According to Dr. Dyfri Williams, "the material in the Ashmolean is not of much use," but I felt compelled to look at these papers to be sure. E-mail message Dyfri Williams, 28 October 2008, to the author. Dr. Graham Piddock, Librarian in Charge \& Archaeology Subject Consultant at the Sackler, gave me access to the Warren and Marshall Papers.

${ }^{59}$ Julian Reid, the Corpus Archivist, was most helpful on my visit and in follow-up inquiries about Warren's circle of friends at Corpus.

${ }^{60}$ Ann Spike, then Chairman's Secretary, provided work space, answered questions, and shared information. She has continued to assist me since my visit.
} 
antiquities that passed through Warren's emporium in Lewes (Figure 3). ${ }^{61}$ According to

Anne Spike of the Lewes District Council, only one other scholar has inspected what I

call the Lewes House Registers. ${ }^{62}$ The findspots are often given, usually a general

location - "the Troad," "Caria," "Constantinople," or "Rome," for example—and, in

some cases, the Lewes House staff member who acquired the object, often "J.M." (John

Marshall) but also "M.S. P.” (Matthew Stewart Pritchard). Most significant to my

research were the notations about where antiquities were sent, in the form of a

handwritten note or the impression from a rubber stamp in red or blue. The most

frequent destination, of course, is the MFA Boston ("Presented to BMFA August 1896"

or "M. F. A. Feb 1903" or "M. F. A. 1897"), but one also finds "given to Leipzig," "sold

to St. Louis Dec 1896," "sold to JM 1907 [probably John Marshall for the Metropolitan

Museum of Art]," "Given to [Bernard] Berenson 1902," or "Given to [Auguste] Rodin

February 16 1905." Since the focus of this dissertation is collegiate collections in the

United States, I was especially interested in objects from Lewes House that went to

${ }^{61}$ The sections of each original ledger are indicated by the slight differences in size of the pages and the colors of the marbleized edges. According to a note following the index of the first ledger, the records began January 31,1894 , but no indication is given as to when they ended. The last ledger has only thirty entries with the rest of the pages blank. The first two ledgers of the registers begin with indices of categories that indicate the type of object and medium and-for vases - the shape and/or decorative style. The entries are usually in black ink, but sometimes in pencil or with red underlining. Distinct changes in handwriting and format suggest that various individuals compiled the records. Some types of information included are standard. Each entry begins with a number, sometimes preceded with abbreviations-for example, "TC" for terracotta figurines or "RF" for red-figure vases. A title or description follows such as "Two Handled Pelike, Return of a Warrior, Reverse Three Figures." Measurements are given, usually in centimeters, often with a notation on the objects condition- "unbroken" or "under the right jaw is a ding . . . is filled with plaster." For most entries, a source is included and occasionally the price paid for the object is added - "Martinetti 80 lire," for example. Some entries provide the commissions paid or an observation such as “70 £ too high.” Usually iconography is described, sometimes with a reference to a book or catalogue. Drawings are incorporated into some of the entries.

${ }^{62}$ Dyfri Williams of the British Museum examined the Lewes House Registers in an unsuccessful search for information about the "Warren Cup." He recommended that I consult the Lewes House Registers for my research. E-mail message from Dyfri Williams, 28 October 2008, to the author. Dr. Williams has been very helpful in my research through e-mail communications. His research on collecting has proven crucial to this dissertation. 
Bowdoin ("Bowdoin 1915" or "Brunswick"); Bryn Mawr ("Hoppin bought" and "Hoppin Brought July 1901"); Penn (“Mrs. Stevenson 1901”); RISD ("sent to Providence October 1900" or more typically, "Providence"); and the University of Chicago ("Given to Tarbell 1901"). ${ }^{63}$ As will be discussed in Chapter 3, descriptions of antiquities in the Lewes House Registers confirm information already in correspondence and records in American museum archives. In some situations, the Lewes House Registers filled in gaps in the knowledge about Greek and Roman objects in American collections and verified that previously undocumented antiquities unequivocally came from Warren's collecting emporium at Lewes.

Understanding the context for Edward Perry Warren's collecting and its connection to how the art of ancient Greece and Rome came to be studied in the United States demands familiarity with important cultural and intellectual developments in the late nineteenth and early twentieth century United States and Great Britain. It also requires understanding what can be determined about Warren's relationships with those who played key roles in establishing the classical collections and the programs of study at the six American academic institutions receiving antiquities from Warren. Thus, the bibliography for this dissertation includes scholarship on a range of overlapping topics: the Gilded Age and the surge of philanthropy; the establishment of civic and collegiate museums in the United States; the inclusion of material culture in the study of Greece and Rome at leading universities, chiefly at Harvard and Oxford; and gender studies,

${ }^{63}$ I did not find any reference to Harvard in the Lewes House Registers. 
especially in regard to homosexuality and the concepts of masculinity in the United States and Great Britain during Warren's era. 


\section{CHAPTER 1}

\section{WARREN AND THE GILDED AGE}

Assessing the impact of Edward Perry Warren's collecting of antiquities on American museums and academic institutions requires understanding late nineteenthcentury culture in the United States. Chapter I offers an overview of the period in the United States that has become known as the Gilded Age. It also charts the Warren family's rapid rise to elite intellectual, cultural, and social circles and explores how members of the Warren family fulfilled or deviated from the expectations of Brahmin Boston. The chapter closes with a biography of "Ned," as he was called by his family and close friends, to serve as a chronological framework for the rest of the dissertation.

\section{The Gilded Age}

Extending approximately from 1865 until the end of the nineteenthcentury, a spurt of affluence launched the Gilded Age. ${ }^{64}$ After surviving the agony of the Civil War, the industrial North and Midwest rebounded with a surge of prosperity and optimism. Historian Samuel Eliot Morrison described the country as "in the midst of the

\footnotetext{
${ }^{64}$ The term "Gilded Age," borrowed from the title of Mark Twain and Charles Dudley Warner's 1873 satirical novel, suggests that post-Civil War prosperity disguised social, political, and economic distress and unrest in the United States. The following period - roughly 1890-1920 - is traditionally known as the Progressive Era because efforts for reform marked the later decades. Some scholars object to this dichotomy and seek to emphasize the continuities. For such an approach, see Edwards 2006, 4-7.
} 
most roaring, spectacular material development that he had ever known." ${ }^{65}$ The last three decades of the nineteenth century produced marvels that Americans celebrated with great enthusiasm. In 1876, for example, almost ten million people visited the Centennial Exposition in Philadelphia featuring the Corliss engine, a machine that George Pullman employed to produce his famous railroad sleeping cars. ${ }^{66}$ In 1883 , after fourteen years of construction, the Brooklyn Bridge was unveiled as the world's longest suspension bridge, a feat commemorated with fireworks and processions. ${ }^{\mathbf{6 7}}$ The World's Columbia Exposition, held in Chicago in 1893 , brought the century to a close with bravura. ${ }^{68}$ This complex of grandiose neoclassical buildings attracted millions of tourists to celebrate what historian Ruth Crocker has called a proclamation of "national unity, material progress, and technological innovation.",69

The new technology and the increase in wealth in the United States during the Gilded Age promoted the conviction that those who worked hard and took risks had limitless opportunities for prosperity. Ample proof for such a belief could be found in the popular rags-to-riches novels of the era. ${ }^{70}$ However, this optimism could be justified by reality as well as by fiction. For example, Andrew Carnegie (1835-1919), employed at

\footnotetext{
${ }^{65}$ Morrison 1936, 18-19.

${ }^{66}$ The Centennial Exposition also promoted an interest in high quality production, art education, and aesthetics, inspiring the foundation of the Rhode Island School of Design, discussed in Chapter 3. For the 1876 Centennial Exhibit, see Giberti 2002 and Rydell 1984, 9-37.

${ }^{67}$ McCullough 1972, 322.

${ }^{68}$ Rydell 38-71. Rydell emphasizes the sociological significance and intellectual context of the Columbian Exposition of 1893. As discussed in Chapter 4, the Columbia Exposition had an impact on departmental collections at the University of Chicago.

${ }^{69}$ Crocker 2007, 211.

${ }^{70}$ The archetype, of course, is Horatio Alger's Ragged Dick serialized in 1867 and published as a popular novel in 1868. See Klein and Kantor 1976, 233; Crocker 214-15.
} 
the age of thirteen as a bobbin-boy in a Pittsburg textile mill, became the wealthiest man in the world. ${ }^{71}$

Success in manufacturing, fuel production, and transportation ventures in the United States created a new upper class that indulged itself in opulent housing, furnishings, and dress; in the acquisition of art; and in travel to European cultural centers. ${ }^{72}$ Carnegie, who built a four-story, sixty-four room mansion on Fifth Avenue in New York City, is the paradigm of the Gilded Age success story, but certainly others existed, such as John D. Rockefeller, J. Pierpont Morgan, Henry Clay Frick, and Leland Stanford. ${ }^{73}$ Their lavish life styles were made possible through the profits generated by those who toiled in horrendous working conditions for low wages. In the late 1890s, the average steel worker, for example, sweated twelve hours each day, seven days a week, to earn ten dollars or less per week. ${ }^{74}$ Workers had few rights or benefits, and the factory owners resisted efforts at unionization. ${ }^{75}$ In 1892 in Homestead, Pennsylvania, a full scale battle raged between the pro-union workers and their supporters and the Pinkerton Detective Agency agents hired by Andrew Carnegie and Henry Frick. ${ }^{76}$

\footnotetext{
${ }^{71}$ Nasaw 2006, 567-92; Standiford 2005, xiii-xiv.

${ }^{72}$ Laurie and Foner 1989, 131-2. For Henry Marquand's mansion, see Kisluk-Grosheide 1994.

${ }^{73}$ For a description and the history of the Carnegie's mansion, now the Cooper-Hewitt, National Design Museum, see Dolkart 2002 . Rockefeller, Morgan, Frick, and Stanford are significant because these industrialists or their families were founders or patrons of important museums in the United States.

${ }^{74}$ For the skewed distribution of wealth and the difference in life styles between the owners and the workers, see Laurie and Foner 127-32.

${ }^{75}$ Warren Mills, as will be discussed later in this chapter, was more benevolent than many companies. The Warren Mills provided company housing for its workers in Westbrook. The Warren family helped build a church, swimming pool, and library for the town. The chief patrons of the Rhode Island School of Design, the Metcalf family, controlled the Wanskuck Company, the woolen mills in Providence, which also built housing for its workers.

${ }^{76}$ Demarest 1992; Krause 1992.
} 
The term "Gilded Age," one should remember, was coined by contemporary critics for "an era when political and business worlds, so fair and prosperous on the surface, were downright ugly and corrupt underneath." ${ }^{, 77}$ Motivated by guilt, generosity or both, the new millionaires invested much of their wealth in museums, libraries, concert halls, and colleges and universities. ${ }^{78}$ Carnegie used his fortune to create the Carnegie Institute of Technology in Pittsburgh, to build almost three thousand libraries across the country, and to erect a splendid concert hall in New York City. Rockefeller of Standard Oil established the University of Chicago, and railroad mogul Stanford employed his wealth to create an Ivy-league college on the West Coast to memorialize his only son. ${ }^{79}$ Banker J. Pierpont Morgan bestowed rare decorative arts on New York's Metropolitan Museum of Art, and manufacturer Henry Clay Frick bequeathed his Fifth Avenue mansion filled with masterpieces of European art to edify his fellow citizens. ${ }^{80}$ Thus, despite the barbs of Samuel Clemons, William Dean Howells, and Edward Bellamy, "when it comes to 'high culture,' the fortunes of Gilded Age millionaires made it all possible." 81 As Andrew Carnegie quipped, "without wealth there can be no Maecenas.. ${ }^{\$ 2}$ The great American cultural institutions-- the libraries,

\footnotetext{
${ }^{77}$ Crocker 229.

${ }^{78}$ For an overview, see Klein and Kantor 263-64. For the impact of the Gilded Age industrialists on masterpiece paintings in museums in the United States, see Saltzman 2008.

${ }^{79}$ For the Stanford family, Leland Stanford Junior University, and the history of the University's museum, see Osborne, Turner and Mozley 1986 ; Johnston 2003. The Cantor Art Center, as the museum at Stanford University is now named, owes its beginning to the ancient glass acquired by Leland Stanford, Jr. in Rome. ${ }^{80}$ For the impact of J. Pierpont Morgan and Henry Frick on museums in the United States, see Saltzman .

${ }^{81}$ Crocker, 213. For Twain, see Twain and Warner 1996. For Howells, Howells and Cook 1982. For Bellamy, Samuels 1984; Bellamy and Tichi 1986.

${ }^{82}$ Carnegie 1969, 2. Ironically, Carnegie, who criticized university education grounded in the classics, here makes an allusion to Gaius Cilnius Maecenas, the famous patron of the arts, who was a friend and confidante of the emperor Augustus.
} 
symphonies, universities, and museums - were elitist in origin and reflected, for the most part, both the tastes and prejudices of the class that created them. ${ }^{83}$

Although on a less grandiose scale than Andrew Carnegie or the Rockefeller dynasty, the Warren family fits the Gilded Age stereotype in its rise to wealth and prominence in late nineteenth-century New England as well as in its contributions to the cultural and educational endeavors in Boston and Westbrook, Maine. The antiquities enterprise of Ned Warren represented a diversion from the family's entrepreneurial roots, but his service and donations to the MFA and American collegiate collections were in keeping with Gilded Age philanthropy. At the same time, his expatriate lifestyle and his acknowledgment of his sexual identity challenged Brahmin Boston. However, as shown in the biographical sketches that follow, Ned's values and interests reflected those of his family.

\section{Samuel Denis Warren (1817-88)}

The father of Edward Perry Warren followed the Gilded Age "rags to riches" blueprint. "S. D." Warren, as he was called to distinguish him from his eldest son "Sam," was the eleventh of fourteen children of a mother who ran a family store. ${ }^{84}$ His father

\footnotetext{
${ }^{83}$ Miller 1970. For an overview of the scholarship on culture and philanthropy in the Gilded Age, see DiMaggio 1982a, 30-35; DiMaggio 1982b, 303-22; McCarthy 1985.

${ }^{84}$ The Warren names can be confusing. First of all, the family recycled names. "Sam," whose full given name was Samuel Denis, had a son also named Samuel Denis. The Warren's only daughter was named Cornelia after her mother, Susan Cornelia Warren, and Warren cousins were also named Susan and Cornelia. No designations such as "Senior" and "Junior" or "I" and "II" were used for the Warren males. This dissertation calls Ned's siblings "Sam" and "Cornelia" and the parents "Mr. Warren" or "S. D." and "Mrs. Warren" or "Susan Warren." For Edward Perry Warren, the appropriate name requires some explanation. Most contemporaries called him "Ned" or "Ned Warren," a practice that I follow when discussing him in relation to his family and friends. He signed his name as "E. P. Warren." He never used "Edward Warren" or "Edward P. Warren." The use of "Edward P. Warren" suggests a lack of knowledge about Edward Perry Warren (1860-1928). Such a designation also is imprecise because "Edward P.
} 
plied a peddler's route extending from Massachusetts to North Carolina and sometimes as far as the West Indies, selling shoes for field workers and slaves.

Despite his humble origins, S. D. Warren managed to complete his secondary education and, in 1832, went to work as an office boy at Grant \& Danielle, a Boston firm that sold paper and paper mill supplies. ${ }^{85}$ Within six years, he became a junior partner, and by his thirtieth birthday, he married "up" to Susan Cornelia Clarke (1825-1901), the daughter of a Phillips Academy and Williams College educated Congregationalist minister. S. D. Warren's genius was his recognition that impressive profits could be gained from using Maine timber for paper production. ${ }^{86}$ In 1854 , he bought the Congin Paper Mill in Westbrook, Maine, changing its name to Cumberland Mills and, with additional takeovers in 1871 , to the S. D. Warren and Company. By 1880 , the Warren enterprise in Westbrook had become the world's largest paper mill and the source of a sizeable family fortune. ${ }^{87}$

With S. D. Warren's acquisition of the mill, Westbrook became a "company town" in which he treated his workers more kindly than many Gilded Age industrialists. In the first year of his owning the company, Warren began providing housing for his workers and was particular about these buildings. Andrew Jackson Downing's The Architecture of Country Houses (1850) provided the inspiration for some

Warren" was used by a contemporary British architect and archaeologist, Edward P[rioleau] Warren (18561937).

${ }^{85}$ Usher 2004.

${ }^{86}$ E. P. Warren's description of his father's trade was "Papa was a paper-maker." Burdett and Goddard 4.

${ }^{87}$ For papermaking, see "A Brief History of Papermaking in Maine." http://www.pulpandpaper.org/history_of_papermaking.shtml (17 June 2009). In 1967 the Warren Mills merged with Scott Paper Company. Sappi, Ltd, a South African based company, purchased the Westbrook mill in 1994. For a history of the S. D. Warren Company, see Usher 2004. 
of the dwellings. ${ }^{88}$ In addition, Warren Mills commissioned John Calvin Stevens, Maine's leading architect, to design cottages in the Queen Anne and Shingle Styles. By S. D. Warren's death in 1888, his company had built four hundred houses in Westbrook with several thousand people living in them. ${ }^{89}$ The National Register of Historic Places lists surviving cottages built for the Warren employees on Brown Street in Westbrook. These structures serve as testimony to S. D. Warren's enlightened sensibilities. Besides offering one of the country's first employee pension plans, the Warren Mills pioneered an eight-hour work day. ${ }^{90}$ In deliberate efforts to elevate Westbrook above the level of a “mill town,” S. D. Warren built and supported a school for his workers' children; contributed to the construction of the Congregational Church; and established a library. ${ }^{91}$ The Warren name persists in Westbrook in the Warren Memorial Library, WestbrookWarren Congregational Church, Warren Little League Complex, and Cornelia Warren Memorial Trail. ${ }^{92}$ S. D. Warren died in 1888 when Ned was studying in Oxford.

${ }^{88}$ By 1870, sixty-six homes had been built; by 1888, more than two hundred. Weigle 2000, $\mathrm{x}$.

${ }^{89}$ Green 1989, 5.

${ }^{90}$ Pension plans were offered in 1892 and an eight-hour work day inaugurated in 1901. Usher .

${ }^{91}$ S. D. Warren donated $\$ 5,000$ and the land for the original church building. He also installed rose windows imported from Italy. After the original church structure was demolished in 1979, the windows were installed in the present Westbrook-Warren church building."Warren Congregational Church, Westbrook, ca. 1950." http://www.mainememory.net (17 September 2008).

92 One historian labels such benevolence as "tainted philanthropy." Krause 351. Others dub it "industrial paternalism." See, for example, Shackel and Paulus 2006, 831. For a history of the library in Westbrook, see "Our Library's History," in Rowe 1952. This document describes E. P. Warren's role as a trustee of the library, calling him "a college professor." The Maine Historical Society archives contain an 1882 lantern slide of the first library. "Warren Memorial Library, Westbrook, 1943."

http://www.mainememory.net (17 September 2008) The Warren Memorial Library closed in May 2009 after the Warren Memorial Foundation suffered severe losses in the stock market. "Westbrook's Warren Memorial Library Will Close." WMTV 2009. http://www.wmtw.com/news/18874655/detail.html (18 June 2009). Ned owned marble portrait busts of his parents in the neoclassical style popular during the late nineteenth century, now in the Warren Memorial Library in Westbrook. Jan Usher, a member of the Westbrook Historical Society, reported that these busts will remain in the Warren Memorial Library until the trustees of the Warren Memorial Foundation determine the fate of the building. E-mail Jan Usher, 19 June 2009, to the author. Ned left the marble busts of his father and mother to his brother Fiske, who apparently gave them to the Warren Memorial Library. The Will of Edward Perry Warren (November 23, 


\section{Susan Cornelia Clarke Warren (1825-1901)}

Susan Warren, S. D's widow, was a leading force in the family's philanthropic activities in Westbrook; her will established a permanent foundation in her husband's name to support educational and artistic activities in the mill town. ${ }^{93}$ S. D. and Susan Warren and their daughter Cornelia are still held in high esteem in Westbrook and neighboring communities. ${ }^{94}$ The father of Susan Clarke Warren immersed himself in recalling Puritan days, judging by the titles of the journal he edited, The New England Puritan, and his best known book, Orthodox Congregationalism and the Sects. ${ }^{95}$ On the other hand, his daughter embraced Gilded Age values in her preoccupation with the Warren homes and their furnishings.

Susan Warren devoted herself to planning and overseeing the construction of Cedar Hill, the family's first home, situated on an almost one hundred and fifty acre plot near Waltham outside Boston. ${ }^{96}$ Linked by enormous mahogany doors set on silver hinges, the eighteen rooms of Cedar Hill contained sixteen fireplaces. Broad porches commanded views of the countryside. ${ }^{97}$ She furnished the house with china, glass, textiles, and furniture that she had purchased in Europe. Her taste in paintings ranged

1928) in Lewes House Archives, Lewes District Council, describes the busts as "in America." They likely were at Fewacres, Ned's home outside Westbrook.

${ }^{93}$ For a recent tribute, see Weigle, in which Susan Cornelia Warren's chapter (pp. 7-9) is subtitled "Warren Family Matriarch \& Fine Arts Collector."

${ }^{94}$ For an example of Westbrook's reverential attitude toward the Warrens, see A Presence in the Community: The Warren Family Legacy in which chapter one is dedicated to Samuel Dennis Warren and subtitled "Visionary Leader, Benevolent Employer." Weigle 1-6.

${ }^{95}$ Warren's autobiographical fragment in Burdett and Goddard begins with a recollection of his grandfather praying for an awakening from the Holy Spirit. See Burdett and Goddard 1.

${ }^{96}$ Later, the building was called "The Mansion House" with the estate known as "Cedar Hill."

${ }^{97}$ For photographs, see Prescott 1958. The Girl Scouts acquired the estate in 1923. The Warren mansion was torn down in 1951. Now called Camp Cedar Hill, the property is used for camping and volunteer meetings and serves as a nature center. A Girl Scout Museum is also located on the grounds. 
from Théodore Rousseau and Charles-François Daubigny of the Barbizon School to nineteenth-century Spanish artists. ${ }^{98}$ The Waltham estate became the Warren summer home after the family bought a home on Boston's Beacon Hill.

In 1863 the Warrens purchased a house designed by the prominent Boston architect George Minot Dexter for the Amory family at 67 Mount Vernon Street in Beacon Hill, the most prestigious neighborhood in the city. ${ }^{99}$ Later, they bought the home behind the Amory residence, a building facing Pickney Street that runs parallel to Mount Vernon Street, and then joined the two houses into a single structure. ${ }^{100}$ The acquisition of the Beacon Hill property marked the family's entry into Boston society. In fact, Susan Warren vied with Isabella Stewart Gardner, one of the most well known collectors in Boston, for masterpieces that were then entering European art markets. ${ }^{101}$

Ned described his family as living in eclectic opulence, typical of the Gilded Age nouveau riche. Visitors entered the ground floor of 67 Mount Vernon into a reception room "used only to receive short calls." At the back was an octagonal breakfast room

\footnotetext{
${ }^{98}$ The Spanish painters were Eduardo Zamacois y Zabala and Mariano José María Bernardo Fortuny y Marsal.

${ }^{99}$ McIntyre 1975, 27-46. McIntyre describes many of the elegant houses on Mount Vernon Street but does not refer to 67 Mount Vernon or the Warrens. The house at 67 Mount Vernon Street still stands, but its interior has been remodeled, according to the historian at the Nichols House Museum, 55 Mount Vernon Street. Bill Pear, e-mail message to the author, 1 July 2009. For domestic architecture on Beacon Hill, see Moore and Weesner 1992.

${ }^{100}$ According to a guide to Beacon Hill, the name Warren on a metal plate still marks what was likely the service entrance of 34 Pickney Street. McIntyre 85.

${ }^{101}$ In 1896 the connoisseur Bernard Berenson, a friend of Ned Warren, proposed that Susan Warren purchase Titian's The Rape of Europa, one of the first Italian masterpieces to enter a collection in the United States. Saltzman 75-80. Saltzman suggests that the offer was Berenson's ploy to elicit a bigger price for the painting. Now one of the best-known works in the Isabella Stewart Gardner Museum in Boston, this erotically charged painting does not seem in keeping with Susan Warren's tastes.
} 
decorated in "the Pompeian style." The china closet, kitchen, a dining room for servants, and laundry room occupied the rest of this floor. ${ }^{102}$

Upstairs and over the front entrance was the "little parlor" outfitted with ebony furniture inlaid with ivory in the "Venetian" fashion. Here also were the drawing room and a big hall, the latter originally serving as a reception foyer but subsequently transformed into a dining room. Warren described the jumble of styles in his family's home with unmitigated disdain (Figure 4). ${ }^{103}$ The paneled walls contained oval portraits of Louis XV's ladies of court and Watteau-like courtship scenes hung on the paneled walls, and "Oriental" vases and embroideries decorated the French furniture. The black walnut dining room "in some French style" had a sideboard "sustained" by griffins. ${ }^{104}$ Over this cabinet was a mirror flanked with ground-glass gas-globes, one held by a halflength Roman and the other by a Gaul. This floor also contained two libraries. The cornice, mantle, and wall paper in the front library, said Warren, were unpleasantly dark. The "Walter Scott" furniture was upholstered in dark velvet. Books, such "as should be in every gentleman's library," chiefly the complementary copies from the publishers for whom the family company furnished paper, filled the shelves. The back library served as "a retreat" for the father, S. D. Warren. ${ }^{105}$

\footnotetext{
${ }^{102}$ Burdett and Goddard 4-5.

${ }^{103}$ For ostentatious décor produced in the United States, see "Consumption and Design," in Venable 1995, 123-202. Venable provides photographs of the sumptuous silver inspired by art historical studies and archaeology, as well as the art and design of the Near East, India, Russia, and Japan. Ned Warren's taste was for the more restrained neoclassical silver, as can be verified in the photographs of the sale catalogues preserved in the Lewes House Archives, Lewes District Council, Lewes, East Sussex.

${ }^{104}$ Burdett and Goddard 4-5.

${ }^{105}$ Burdett and Goddard 4-5.
} 
Another indication of the Warrens' status was the family's association with the Museum of Fine Arts. ${ }^{106}$ The Warrens participated in a subscription drive to purchase a series of William Blake watercolors. ${ }^{107}$ An avid collector of fine porcelain, Susan Warren gave a Chinese jar to the MFA in 1876; in the following year her husband donated a Millet painting. ${ }^{108}$ She bequeathed funds to add significant nineteenth-century paintings to the MFA collection. ${ }^{109}$ Moreover, S. D. Warren served as a Museum trustee for the last five years of his life (1883-88). ${ }^{110}$ S. D. and Susan Warren's contributions to the Museum of Fine Arts were very much in keeping with Gilded Age philanthropy and mark the beginning of their family's long and intimate involvement with this important Boston cultural institution.

Although the Warrens were not among the "first" families of Boston, their wealth and their Beacon Hill address gave the Warren children opportunities to associate with the elite in Boston society. The Warrens became well known and influential; however, as discussed below, some of the Warren siblings — particularly Ned—challenged Boston conventions. ${ }^{111}$

\footnotetext{
${ }^{106}$ For the MFA in the context of the Gilded Age, see Harris 1962.

${ }^{107}$ Whitehall 86-7.

${ }^{108}$ Whitehall 87. The MFA credits S.D. Warren for the Millet oil painting (77.249). See "Young Shepherdess about 1870-73, Jean-François Millet, French, 1814-1875" in Museum of Fine Arts "The MFA Collections." http://www.mfa.org (accessed10 April 2009).

${ }^{109}$ According to Whitehall, these works included the Barbizon School artist Jules Dupré's On the Cliff; the neoclassicist Jean Lèon Gérôme's L'Eminence Grise,; the popular British Thomas Lawrence's portraits of Lord and Lady Lyndhurst; and the Welsh landscapist Richard Wilson's Tivoli and the Roman Campagna. Whitehall 190-1. Susan Warren's gifts of the paintings by Gérôme (03.605) and Wilson (03.606) remain in the Museum's collection. See Museum of Fine Arts "MFA Collections. http://www.mfa.org " (accessed 18 January 2010).

${ }^{110}$ Whitehall 143.

${ }^{111}$ For the "Boston elite of "Ante-Bellum Industrialism" in contrast to those in the "Era of Industrial Capitalism 1870-1950," see Jaher 1986.
} 


\section{The Warren Children}

As would be expected from their privileged upbringing, the Warren children were accomplished. They travelled abroad, mostly to Europe but also to Egypt, North Africa, and Asia, for health reasons and on buying sprees. ${ }^{112}$ The five Warrens were well educated. ${ }^{113}$ All four sons graduated from Harvard and, as was the custom among the Boston elite of the time, daughter Cornelia was educated by tutors at home. ${ }^{114}$

\section{Samuel Denis Warren II (1852-1910)}

The oldest of the Warren children, Sam, was the polar opposite of his younger brother Ned in that he seemingly fulfilled all the expectations of an upper class Boston upbringing. "Fitted for college at the Boston Latin School," he was a high achieving student and athlete who belonged to the exclusive Porcellian Club during his undergraduate years at Harvard (1871-75). ${ }^{115}$ After completing his bachelor's degree, Sam immediately entered the Harvard Law School and graduated in 1877 with honors at the top of his class, ranking second, just behind his friend, Louis Brandeis (18561941). ${ }^{116}$ Sam coauthored three articles with Brandeis for the Harvard Law Review, including “The Right to Privacy” (1890), considered one of the most famous articles

\footnotetext{
${ }^{112}$ When Ned was born in 1860, his father was on an extended stay, on medical advice, in Italy. Ned frequented spas, particularly one in Lucca. Taking "curative waters" via bathing and drinking was popular among the privileged in the late nineteenth century.

113 The second son died in infancy while the parents were in Europe.

${ }^{114}$ For women's educational opportunities, see Cordery 2007, 133-4. Women's opportunities to enter museum work and academia are discussed in Chapter 4 in regard to Penn, Bryn Mawr, and RISD.

115 See his Harvard obituary, "Warren, S. D. Harvard College, Class of 1875." 1910 in 1875 Warren, Samuel Dennis Folder, HUG 300, Harvard University Archives. For Harvard as a reflection of Boston Brahmin values, see Amory 1947, 302-11.

${ }^{116}$ For Harvard's Law School when Brandeis and Sam Warren were students, see Sutherland 1967, $162-$ 205; Urofsky 2009, 25-8.
} 
published in United States legal history. ${ }^{117}$ He and Brandeis formed a successful law firm in which Sam was an active partner until 1889, when he took over the management of the family's paper mills after his father's death. ${ }^{118}$ Sam married Mabel Bayard, from a well-known and politically prominent family in Washington, D.C., and they lived with their six children on an estate near Dedham outside Boston and associated with the scions of the Cabot and Lowell families. ${ }^{119}$ Sam Warren was a member of hospital boards and served as a trustee of the Museum of Fine Arts, and was eventually elected to the chairmanship of that distinguished institution. On his father's death in 1888, Sam left his law practice with Brandeis to run the Warren family business under the terms of the Mills Trust, which he and Brandeis devised. ${ }^{120}$

On the surface, this arrangement worked well until Susan Warren died in 1901, and Ned began challenging Sam's management of the Warren Mills and the terms of the Mills Trust. ${ }^{121}$ Over the next seven years, he continued to question whether he was receiving his fair share of the income. ${ }^{122}$ In December, 1909, the protracted dispute between the brothers culminated with Ned filing a bill of equity that resulted in a series of

\footnotetext{
${ }^{117}$ For a summary of this article and its implications, see Gajda 2008; Urofsky 98-102.

${ }^{118}$ Urofsky 48-9, 55-6, 98.

${ }^{119}$ Green 1989, 106-07. Mabel's father, Thomas Bayard (1828-98), was a three-time senator from Delaware and had served as Secretary of State in Grover Cleveland's first term and ambassador to London during Cleveland's second term.

${ }^{120}$ Urofsky 68-9. A partnership made up of Sam, his brother Fiske and a cousin, Mortimer M. Mason, ran S. D. Warren \& Co, the family firm; however, by all accounts, Sam was in charge.

${ }^{121}$ Sam claimed that Ned was the "author of all his ills." Within two years of his father's death, Ned became financially strapped due to his antiquities collecting., and employed an attorney to monitor the accounts of the Warren firm; in 1906, he asked "for hundreds of thousands of dollars, for changes in the trustees and trust ... and changes in the running of the paper mills themselves." Green 1989, 5.

${ }^{122}$ Green 1989, 5-6.
} 
almost daily hearings in January $1910 .{ }^{123}$ On February 18, 1910 Sam committed suicide with his hunting rifle in his stables at Dedham. However, the obituaries reported the cause of death as "apoplexy," and the suicide was not publically acknowledged. ${ }^{124}$ As might be expected, Ned became estranged from Sam's family. ${ }^{125}$ Unlike his younger brothers, Sam Warren embodied what some scholars have called the "Bully manhood" stereotype among men in the United States, epitomized by Theodore Roosevelt. ${ }^{126}$

\section{Henry Clarke Warren (1854-99)}

The second Warren brother, Henry, was strikingly different from the robust and extroverted Sam. Spinal injuries suffered in a carriage accident in his childhood limited his mobility. He never married, and a mysterious and silent black manservant assisted him in coping with his daily needs. ${ }^{127}$ Ned described his brother: "Though not emotional, [Henry] must have felt always that he was battling alone against

\footnotetext{
${ }^{123}$ The role of Brandeis and his lack of active involvement in Sam's defense were brought up in the 1916 United States Senate Committee Hearings on the Nomination of Brandeis to the Supreme Court. For a vindication of Brandeis in regard to the Warren Trust, see Painter 2001. Biographers differ on the dispute between Ned and Sam. Green questions Sam's handling of the Mill Trust and describes him as "an aging lion, a king of the jungle, whose jackals turn against him." According to Green, Sam's business friends blamed Brandeis "either for having failed to come to Sam's defense or for having long before set up a flawed trust." Green 1989, 12. Urofsky, on the other hand, views Sam and Brandeis as blameless and cites a 1916 letter from Cornelia Warren in defense of Brandeis. See Urofsky 450.

${ }^{124}$ Sam's family did not acknowledge his suicide. See New York Paper Trade Journal, February 24, 1910, Clipping File Harvard University Archives, HUG 300, 1875 Warren, Samuel Dennis Folder. The 1941 biography of Ned Warren reported that Sam died "according to the doctor's report from apoplexy." Burdett and Goddard 248. The 1970 Museum of Fine Arts: A Centennial History gives no details about his death. Whitehall reprints a laudatory letter from Matthew Pritchard, a protégé of Ned, who became Sam's ally at the MFA. Whitehall 211-17. For Isabella Stewart Gardner on Sam's death from a stroke, see Berenson and Hadley 1987, 367.

${ }^{125}$ See Letter of Edward Perry Warren to Susan Wilbur Jones, 23 May 1923, George J. Mitchell Department of Special Collections \& Archives, Bowdoin College Library. The fact that none of Sam's children are mentioned in Ned's will also indicates a rupture between Ned and his oldest brother's family. ${ }^{126}$ Kimmel 2006, 120-4.

${ }^{127}$ Green 1989, 56.
} 
odds." ${ }^{128}$ A skilled linguist, Henry became a protégé of philosopher George Herbert Palmer at Harvard. ${ }^{129}$ He studied Sanskrit at Harvard and, after graduation in 1879 , took up Pali, the sacred language of South India, at Johns Hopkins University. After Charles Lanman, his mentor at Johns Hopkins, joined the Harvard faculty, Henry Warren and Lanman founded the Harvard Oriental Series, to which Henry contributed two volumes, Buddhism and Buddhism in Translation. The latter has been reprinted several times since its initial publication in $1896 .{ }^{130}$ Henry Warren became one of the first authorities on Buddhism in the English-speaking world. His interest in Eastern religion can be traced to what T. J. Jackson Lears has called "a vein of deep religious longing, an unfulfilled yearning to restore infinite meaning to an increasingly finite world" in the Gilded Age. ${ }^{131}$ With typical Warren largesse, Henry funded the printing of the entire Harvard Oriental Series. Although he was never on the Harvard faculty, he settled in a house near the campus which also functioned as the office for the Harvard Oriental Institute. ${ }^{132}$ Among the Warren siblings, he was closest to Ned in interests and sympathies. According to Ned, Henry

\footnotetext{
${ }^{128}$ Edward Perry Warren in Foreward, Warren 1896, xx.

${ }^{129}$ Palmer's wife was Alice Freeman Palmer Wellesley, who became a friend of Cornelia Warren.

${ }^{130}$ Louis Brandeis donated his copy of Buddhism in Translation to the University of Louisville. Now in the Ekstrom Library, it is inscribed from Sam Warren to Louis Brandeis.

${ }^{131}$ Lears 1981, 58.

132 The building still stands at 12 Quincy Street on the Harvard campus. After Henry Warren's death, it housed the Modern Language Department, and now, as part the Barker Center at Harvard, it contains faculty offices and seminar rooms for Folklore and Mythology and Celtic Languages and Literature. See Schwartz 1959. "Warren House." http://www.thecrimson.com/article.aspx?ref=159569 (accessed 19 June 2009).
} 
... disapproved of the objects for which some of our family lived. I agreed with him in part and protested. He would not protest: 'We can do nothing; it is a storm; we must let it pass over.' 133

Harvard was the chief recipient in Henry's will; however, Henry bequeathed twenty-five thousand dollars to Ned, the sole beneficiary among the Warren siblings. ${ }^{134}$

\section{Cornelia Lyman Warren (1857-1921)}

The only Warren daughter never married and served as her widowed mother's companion. Cornelia was educated at home, tutored by George Herbert Palmer, Henry Warren's mentor and well known philosopher and scholar at Harvard. ${ }^{135}$ Her bequests still support various philanthropic efforts in Westbrook, Maine, where the family's mill was located. ${ }^{136}$ On her mother's death in 1901, Cedar Hill, the Warren's Waltham estate, became Cornelia's residence, where she became known as a leader in the development of sustainable agriculture with her innovative uses of the property. ${ }^{137}$ After her death in 1921, Cedar Hill was conferred on the Girl Scouts of America and much of the land has become part of the Waltham Land Trust. Cornelia supported the settlement house

\footnotetext{
${ }^{133}$ Written in 1927, Ned's foreward to Buddhism in Translation reveals as much about Ned as it does Henry. It begins "My brother Henry, born in 1854, fell out of a carriage when he was a mere child, and, in consequence, grew up much deformed, conspicuously humpbacked" and ends "I have been anxious that his work, of which I did not know the merit, should be published, and I am heartily glad it now appears." Ned himself died a year later.

${ }^{134}$ Green 1989,147 . The Warren family wills, which were frequently revised, provide insights into the alliances among the siblings.

${ }^{135}$ Alice Freeman and her husband George Palmer, Cornelia's tutor, actively supported women's education. Alice Freeman Palmer was a teacher at Wellesley and later the college president. For a contemporary description of the education of young women in Boston, see Dillaway 1881, 253-5.

${ }^{136}$ The Cornelia Warren Community Foundation built a public swimming pool adjacent to the Warren Memorial Library in 1947. Weigle 10, 17.

${ }^{137}$ For the history of the property, see a tribute to Cornelia Warren printed by the S.D. Warren Company with the support of the Girl Scouts of America. "Cornelia Warren and the Story of Cedar Hill." (n. d.) S. D. Warren Company. Ned called Cedar Hill "Cornelia's Temple." Edward Perry Warren to Susan Wilbur Jones, 23 May 1923, George J. Mitchell Department of Special Collections \& Archives, Bowdoin College Library.
} 
movement and served as a trustee at Wellesley College for over a decade. ${ }^{138}$ She wrote a novel, Miss Wilton (1892), and a memoir/biography, A Memorial of My Mother (1908), both self-published. ${ }^{139}$ In the dispute over the Warren family trust, Cornelia took the side of her brother Sam. Later in life, Ned regretted what he viewed as an emotional distance between himself and his only sister. ${ }^{140}$ Burdett and Goddard report that, when Cornelia died in 1921, she and Ned were "more or less reconciled," yet "not sufficiently so to make her change her will and to put him on a level with her other heirs."141 Cornelia's support of Wellesley, settlement houses, and the Girl Scouts reflects her family's noblesse oblige, as well as her efforts to further the status and independence of women.

\section{Frederick Fiske Warren (1862-1938)}

The youngest Warren son, Fiske, was marginally involved in the family firm and was known for his eccentric interests, radical causes, and elegant wife. He drove the first electric carriage in Massachusetts and, in his later life, was reputed to be a nudist. ${ }^{142} \mathrm{He}$ supported the Single Tax Movement and opposed the involvement of the United States in the Philippines. ${ }^{143}$ His wife, Gretchen Osgood, claimed descent from John Quincy

\footnotetext{
${ }^{138}$ A portrait of Cornelia by the French painter Alexandre Cabanel (1823-89) is now in the Davis Museum and Cultural Center at Wellesley College (Portrait of Miss Cornelia Lyman Warren, Trustee of Wellesley College Accession number 1929.2.) Bo K. Mompho, e-mail message, 10 August 2009, to the author. Ned apparently inherited this portrait on Cornelia's death and, according to his will, bequeathed it to Wellesley. ${ }^{139}$ For an analysis of the novel, see Green 1989, 137-39. Green views Cornelia's book, in some ways, as a roman à clef with the characters based on her friend and mentor, Alice Freeman Palmer, and her parents. A copy of A Memorial of My Mother inscribed by Cornelia to her brother Ned is in the Lewes House Archives, East Sussex.

${ }^{140}$ Edward Perry Warren to Susan Wilbur Jones, undated letter, George J. Mitchell Department of Special Collections \& Archives, Bowdoin College Library.

${ }^{141}$ Burdett and Goddard 80.

${ }^{142}$ For Fiske Warren, see Green 1989, 26-7, 149-58.

${ }^{143}$ For the history and impact of the Single Tax Movement in the context of American political reform, see Candeloro 1979. For the Spanish-American War, see Tompkins 1970, 140-60 ; Dobson 1978, 121-22; Trask 1981, 369-422.
} 
Adams. ${ }^{144}$ Fiske and Gretchen were world travelers and entertained lavishly at Tahanto, their utopian enclave, in Massachusetts. They were also collectors, particularly of Asian ceramics. A well known John Singer Sargent portrait of Gretchen and their daughter is now in the Museum of Fine Arts. ${ }^{145}$ As the last surviving sibling, Fiske served as one of the trustees for Ned's estate and received most of the Warren family portraits kept at Fewacres, Ned's home in Maine. ${ }^{146}$

Fiske shared characteristics of his older brothers. Like Sam, he married a socially prominent woman; like Ned and Henry, he developed interests and adopted causes outside the mainstream of elite Boston. Fiske also shared Ned's penchant for travel and a wide circle of friends and contacts. He gave a number of antiquities to the MFA, sometimes listed as co-donor with Ned. ${ }^{147}$

\section{Edward Perry Warren (1860-1928)}

This survey of the major periods in the life of Ned Warren serves as a chronological frame of reference for this dissertation. More details and discussion are supplied in later chapters that explore the intellectual context for his collecting as well as his role at the MFA and collegiate museums.

\footnotetext{
144 See Amory 125.

${ }^{145}$ Mrs. Fiske Warren (Gretchen Osgood) and Her Daughter Rachel (1903) (MFA 64.693).

${ }^{146}$ The Will of Edward Perry Warren (November 23, 1928), Lewes House Archives, Lewes District Council, Lewes, East Sussex.

${ }^{147}$ Antiquities with sexually explicit scenes entered the MFA as Fiske's gifts. For example, two Roman marble reliefs-Herakles engaging in intercourse with Omphale (MFA Res.08.33d) and an erotic scene with an old man and a siren (MFA Res.08.34c) — and an Attic black-figure cup with a bearded man fondling a young boy (MFA 98.292) are listed as gifts of Ned and Fiske.These works are not discussed in this dissertation.
} 


\section{Childhood and Adolescence}

Born on June 8, 1860, Edward Perry was the Warrens' fourth child. ${ }^{148}$ His father had been absent most of the pregnancy because a doctor had recommended he spend the winter in Italy to speed his recovery from a throat problem. ${ }^{149}$ In fact, S. D. did not learn that his wife was pregnant until he returned to America a little more than two weeks before Ned's birth. ${ }^{150}$ Ned attended Phillips Grammar School, a public school in his Beacon Hill neighborhood, and later, like other sons of wealthy families, went to John P. Hopkinson's school on Boylston Place in preparation for Harvard. ${ }^{151}$ Never drawn to traditional boys' activities or sports, he enjoyed collecting china and, in his adolescence, became preoccupied with sculpture as well as religious ritual and garb. ${ }^{152} \mathrm{He}$ also devoted himself to music, an interest he maintained for the rest of his life.

Ned reported always having strong preferences in his childhood about his surroundings and his dress and confessed to taking "infinite pains" in draping a valance and having a weakness for "pretty" neckties. In grammar school, Ned wore boots with tassels handed down by his sister Cornelia, earning him the nickname "Tassels" as well

\footnotetext{
${ }^{148}$ Presumably he was born at Cedar Hill, the family's newly built mansion in Waltham. S. D. and Susan Warren had six children; however, their first child, Josiah Fiske Warren (1850-1853) died of scarlet fever.

${ }^{149}$ See Burdett and Goddard 64. A doctor described S.D.'s throat as "like raw beef." It is not clear what this "throat problem" might have been. The Warrens visited spas and sought climates considered conducive to their health. Ned's letters document that he was often concerned about his health and that of his friends.

${ }^{150}$ Burdett and Goddard include a January 21, 1887 letter from Mrs. Warren to Ned, in which she explained the "strain" accompanying his birth. The doctor had advised her not to worry Mr. Warren while he was recovering in Italy, as he would likely return home prematurely. She acknowledged her concern that her husband might think Ned was not his child and admitted her relief when Ned strongly resembled his father. Burdett and Goddard 64.

${ }^{151}$ The source for information about Ned's education before Harvard is the autobiography section of Burdett and Goddard. Burdett and Goddard 7-11.

${ }^{152}$ Green 1989, 48-9.
} 
as bruises from the "rough" boys in the neighborhood. ${ }^{153}$ His aesthetic inclinations as an adult seemed a vivid contrast to those of his parents. Comparing the photographs of the ostentatious décor in the family's dining room in Boston with those of his monastic-like refectory at Lewes House suggests that he may have developed a more restrained, classically-inspired inclination as a reaction to his mother's flamboyant taste (Figures 4 and 5). However, Ned may have acquired his affinity for collecting from his mother and, in his adulthood, continued in some of their shared interests, especially in antique dinnerware and silver. He confessed that in his childhood the habit of arranging and rearranging his own small china collection in his bedroom often made him late for bedtime. $^{154}$

Ned also was fascinated with religion. Despite the Warren family's Congregational roots and the family's devotions and church attendance on Sundays, religion was a matter of individual conscience as can be verified in the unorthodoxy and lack of consistent religious commitment among the Warren siblings. ${ }^{155}$ He said that he "wandered about" in the Unitarian, Episcopal, and Anglican churches in Boston, but that

\footnotetext{
153 Burdett and Goddard 7.

${ }^{154}$ Burdett and Goddard 5. Ned and his mother shopped for china in antique shops in Boston and in England.

${ }^{155}$ A description of the family's Sunday devotions is included in a tribute to Cornelia Warren. Prescott 56. The Warrens, like many wealthy Bostonians, visited various churches and were drawn to what Ned describes as the "exalted and spiritual nobleness of Mr. Phillips Brooks." Burdett and Goddard 21. Brooks, rector of Trinity Church and famous preacher, had a long association with Harvard. He wrote the Christmas carol, O Little Town of Bethlehem. For a biography of Phillip Brooks (1835-1893), see "Brooks Phillips, 1835-1893. Papers of Phillips Brooks: An Inventory." Harvard University Archives. 2006. http://oasis.lib.harvard.edu/oasis/deliver/ hua11004 (17 April 2009). Ned said that his brother Henry was "a disbeliever." See Edward Perry Warren to Susan Wilbur Jones, 7 June 1917, George J. Mitchell Department of Special Collections \& Archives, Bowdoin College. In Warren's recollections preserved in Burdett and Goddard, he described Henry as "slipping away from dogma himself" and explained that his brother was "alarmed to find me intrenching [sic] myself more firmly behind it." Burdett and Goddard 15.
} 
the rituals, vestments, and candles were his obsessions. ${ }^{156}$ In early boyhood, he dressed himself in a nightgown and sashes to conduct services for his mother. ${ }^{157}$ In the company of a male friend called "Lucy,"158 he shopped for candle sticks in second-hand stores, composed litanies using their friends' names, and became fixated on determining the appropriate liturgical colors for the ribbons used in his priestly role-playing. ${ }^{159}$ Warren confessed to having been impressed later in his adolescence by a "bracing and severe" High Church English priest visiting Boston who preached a "manly religion."160 $\mathrm{He}$ continued to be interested in Catholicism and Anglo-Catholicism throughout his life. Part of his attraction to Oxford was John Henry Newman, and recalled later: "I was in love with High Church." He delighted in meeting bishops and cardinals and going to services in Paris and Rome conducted by high ranking prelates. ${ }^{161}$

Aside from "Lucy," Ned claimed to have no friends his own age. While other boys played cowboys and Indians, he went "anticking," as his family called it, in a toga. ${ }^{162}$ Ned confessed a fascination with the male body and recalled that, during family excursions to museums, he lingered among the nudes in sculpture and cast galleries after

\footnotetext{
156 Burdett and Goddard 15.

157 Green 43.

${ }^{158}$ David Sox assumes 'Lucy” was female. Sox's confusion about the gender of Lucy may stem from Warren's avoiding pronouns for Lucy except once where "he" is used. Warren declared, "I saw few of the boys after school hours, and even at recess, for the most part, only a rather feminine youth usually called 'Lucy." Burdett and Goddard 10. The use of quotation marks around the name also supports this interpretation. Given Burdett and Goddard's reticence to address Warren's sexual orientation, perhaps they deliberately avoided pronouns for Warren's friend.

${ }^{159}$ Burdett and Goddard 16.

${ }^{160}$ Burdett and Goddard 25. For "manliness in religion" in Great Britain and the United States, see Vance 1985.

${ }^{161}$ Edward Perry Warren to Susan Wilbur Jones, 7 June 1917, George J. Mitchell Department of Special Collections \& Archives, Bowdoin College. Cardinal John Henry Newman (1801-90) maintained a friendship and shared a home with his fellow convert Ambrose St John. The two men were buried next to one another. For Newman's homosexuality, see Hilliard 1982.

${ }^{162}$ Burdett and Goddard 364.
} 
the rest of his family went on to paintings. ${ }^{163}$ Ned reminisced about gazing at his mother's photographs of sculpture and cast catalogue and disclosed that the plaster copy of the Ludovisi Mars in the Boston Athenaeum produced "no small excitement." ${ }^{164} \mathrm{He}$ described himself as "a boy ... yearning for those things of which I had inadequate evidence ..."165

A consolation in Ned's adolescence was music, which became a life-long interest. ${ }^{166}$ Particularly influential was his German piano teacher, Ernst Perabo, whom Ned described as "kind, dark-bearded and dark-eyed." The music teacher, he recalled, possessed "an extreme and almost morbid tenderness" and would weep and share "his secrets" with his pupil. ${ }^{167}$ Perabo, maintained Ned, was "concerned with the value of true, tender, and high feeling" and taught him "far more than music."168 This last phrase, one suspects, may refer to sexual initiation. No matter what their ties, Ned and his beloved music teacher sustained a bond for at least thirty years. ${ }^{169}$

\footnotetext{
163 Burdett and Goddard 59.

${ }^{164}$ Warren describes "applying himself to Brigham's cast catalogue." Burdett and Goddard 12. He refers here to William Tufts Brigham's Cast Catalogue of Antique Sculpture; With an Introduction to the Study of Ornament Boston, 1874. Such catalogues contained depictions of male nudes, which Ned apparently found titillating. For his comment about the Ludovisi Mars, which was often found in cast galleries, see Burdett and Goddard 60.

165 Burdett and Goddard 41.

${ }^{166}$ An example of Warren's commentary on musical compositions is in Llewellyn Jones Papers. Yale Collection of American Literature, Beinecke Rare Book and Manuscript Library. Llewellyn Jones, a writer and teacher of some note, was married to Susie, one of Ned's favorite cousins. The score of a waltz that Warren composed is in the Lewes House Archives, Lewes District Council, Lewes, East Sussex.

${ }^{167}$ German-born Ernst Perabo (1845-1920) was a well-known concert pianist, teacher, and composer in Boston and highly regarded for his interpretation of Beethoven and Schubert. See Whiting 1902, 307-9. Ned recalled Perabo quoted Lincoln to him: "Show me the Church that embraces all humanity and I will join it." Burdett and Goddard 12.

${ }_{168}$ Burdett and Goddard 11.

${ }^{169}$ An undated letter from Warren described the music teacher "writing music and tinkling the motifs on the piano" at Fewacres. Burdett and Goddard 239. Among Warren's possessions now in the Lewes House Archives are two objects connected with Ernest Perabo. One is a photograph of a man at a piano, annotating a score. This man is likely Perabo. The other is a bronze medal of Perabo by the Boston
} 
Ned Warren was unabashedly honest about his attraction to other boys. He said he began to "burn" for the first time for an older youth whom he "worshipped" at a distance. ${ }^{170}$ Ned dedicated a poem to the boy he called "Antinous," after Hadrian's beautiful favorite. ${ }^{171}$ He described himself as standing in the street at night outside the boy's window in the hope of seeing "a curly head bent over his books" and rifling the classroom waste can for scraps of the boy's discarded Greek exercises. ${ }^{172} \mathrm{He}$ confessed that he treasured an autograph and photograph of "Antinous." ${ }^{173}$ Ned also wrote a poem to another boy he only knew by name and "had only seen in a window.",174

\begin{abstract}
Alienation at Harvard
When Warren attended Harvard from 1879-1883, social status was the foremost concern among most students. ${ }^{175}$ Ned recalled that his popular older brother Sam attempted to guide him into negotiating the "best set"; however, these efforts were
\end{abstract}

sculptor Roger Noble Burnham (1876-1962). Its inscription is "Johann Ernest Perabo MDCCCX (1910) Res Severa Est Verum Gaudium." The Latin quotation is from Seneca: "True joy is a serious thing."

${ }^{170}$ Burdett and Goddard 19.

${ }^{171}$ Antinous was Hadrian's young male lover, immortalized in a number of Roman sculptural portraits. For the popularity of Antinous, see Haskell and Penny 1981, 140-43. For the fascination with Antinous among Victorian homosexuals, see Waters 1995. References to Antinous, common in "Uranian" poetry of the time, were overtly homosexual. See Smith 1970. D’Arch Smith includes Edward Perry Warren, under Warren's pseudonym Arthur Lyon Raile, as a poet in the chapter “The Uranians: 1900-1930" and reproduces the photograph of Ned at around thirty years old that serves as the frontispiece in Burdett and Goddard. For the poem, see Burdett and Goddard 19.

${ }^{172}$ Warren does not provide a specific time frame or setting for this recollection. The Phillips Grammar School and the John P. Hopkinson's school are both possibilities. Given that the exercises are Greek, the Hopkinson school, which would have provided preparation for Harvard, seems the more likely setting for Warren's crush.

${ }^{173}$ Warren explained that he obtained this photograph through the intercession of the Warren's French maid who had once worked for the boy's family. The maid borrowed the photograph from which Ned had a tintype made. Ned put the autograph in an envelope to keep it clean. He then cut a hole in the envelope that he glazed with transparent paper so that he could look at the autograph. Burdett and Goddard 19.

174 Burdett and Goddard 20.

${ }^{175}$ At this time, Harvard students were ranked according to social status. This caste system established the order in chapel seating and academic processions, as well as the priority in class recitation and service at meals. The club system adopted this "official" social ranking. Until 1905, the exact order of "elections" to Harvard clubs was published in the Boston newspapers. Amory 285-87. 
unsuccessful, according to Ned, who labeled himself "a social struggler." ${ }^{176}$ He claimed he was inept at the "punches" and found himself at the "third table" at meals, populated by New Yorkers and "Westerners." ${ }^{177}$ Unlike Sam, he never participated in athletic pursuits or gained membership in the final clubs, the exclusive undergraduate social organizations that dominated Harvard life, such as the Porcellian. ${ }^{178}$ He described himself as having a "somewhat absent-minded air and slouching gait" and speculated that he must have seemed "a strange mixture of snobbishness, bad form, and refinement.",179

In his recollections of Harvard incorporated into the Burdett and Goddard biography, Warren claimed to have garnered some respect on campus for his musical abilities and aesthetic sensibilities. ${ }^{180}$ Investigation not only supports this assertion, it also suggests that Ned may not have been as much of a "social struggler" as he claimed. His obituary in the Harvard Graduates' Magazine indicates that he was in the Institute of 1770 and Delta Kappa Epsilon, fraternities established as alternatives for those rejected by the snobbish final clubs system. In fact, a Delta Kappa Epsilon medal inscribed with “E. P. Warren Class of '83” remains in the Lewes House Archives. The Harvard obituary also lists his membership in the Hasty Pudding, famous for its theatrical reviews; the O. K. Society, an exclusive literary group; and the St. Paul Society, an Episcopal

\footnotetext{
${ }^{176}$ Burdett and Goddard 27. By this time, Sam had moved up to the Law School.

${ }^{177}$ Burdett and Goddard 27. According to Amory, most Harvard students came from Boston, and their families' positions in Boston society determined their social status at Harvard. Students sat at tables based on their status; thus, Ned's table with students outside of Boston reflected negatively on his standing at Harvard.

${ }^{178}$ Burdett and Goddard 29. The Porcellian, to which Sam belonged, was one of the most exclusive Harvard organizations in the late nineteenth and early twentieth century.

${ }^{179}$ Burdett and Goddard 28

${ }^{180}$ Warren recalled "My music and my interest in beautiful things were marked ..." Burdett and Goddard
} 28. 
organization. ${ }^{181}$ Ned was recognized for his musical interests and ability in his election as Class Chorister. ${ }^{182}$ Medals in the Lewes House Archives confirm his membership in the Harvard Glee Club and the Harvard Orchestra.

Ned Warren recorded few memories of his studies at Harvard and did not name specific professors or classes at Harvard in his correspondence. Thus, what can be known about his education at Harvard must be gleaned from the Annual Returns ledgers in the Harvard Archives, containing the courses in which he enrolled each year and the numerical grade he received for each course. Latin and Greek were compulsory for all Harvard freshmen until 1886, with instruction in these languages being the primary function of preparatory schools. ${ }^{183}$ Ned admitted that he despised mathematics but loved Virgil, despite the poor background in grammar he received at the Hopkinson School. ${ }^{184}$

For Ned, most relationships were superficial, but his reading of Walt Whitman revealed a "secret or gospel" and he "most warmly ... agreed with [Whitman's] acceptance of the flesh."185 He confessed a devotion to an unnamed classmate who was preparing for the Church and, later, for Charlie Perrin, a "very attractive fellow" from

\footnotetext{
${ }^{181}$ The St. Paul Society matched his interest in Anglo-Catholicism. He created "special services" for this organization during Advent and Lent. Burdett and Goddard 38.

${ }^{182}$ Frederick Nichols, Edward Perry Warren obituary, The Harvard Graduates' Magazine, March 1929. In Warren, Edward Perry 1883 Folder, HUG 300, Harvard University Archives, Cambridge, MA.

${ }^{183}$ Morrison 1936, 36. Most universities and colleges of the Gilded Age followed Harvard's admission requirement. Winterer 2002, 101-02. The eldest Warren son Sam went to the Boston Latin School; the other brothers went to the Hopkinson School, a preparatory school for Harvard. Boston Latin, founded in 1635, is considered to be the oldest American school in continuous existence. Why only Sam, the eldest among the three Warren brothers, attended Boston Latin is not clear. The Warrens may have viewed Sam's enrollment at Boston Latin as a way of insuring his status at Harvard. Students from Hopkinson School, where Ned was enrolled, also entered Harvard. Ned's obituary in the Harvard Graduates' Magazine described him as one of eight "promising schoolmates" from Hopkinson in the class of 1883. See Frederick Nichols, Edward Perry Warren obituary, The Harvard Graduates' Magazine, March 1929. Warren, Edward Perry 1883 Folder, HUG 300, Harvard University Archives, Cambridge, MA.

${ }^{184}$ Burdett and Goddard 20.

${ }^{185}$ Burdett and Goddard 31.
} 
Kansas, whom he described as "passionate, unreasonable, uncultivated, though refined in his instincts, and very fond of music. ${ }^{186}$ Ned admitted: "Friendship with me passed very naturally into love" and that "I was not yet aware of myself." 187 He described his "only dissipations" as "the theatre, and beer and oysters after the theater at a smoky bar-room in a cellar." $" 188$

In 1881-82, his third year at Harvard, the "stress of passion" took hold of Ned. ${ }^{189}$ Shelley was "the master of his soul" — "a beloved, and yet only half-understood, Master." ${ }^{190}$ He memorized the final stanzas of Shelley's Adonais while sitting on a rock in a river. ${ }^{191}$ In the poem, an elegy to John Keats, Shelley suggested that he and Keats were misunderstood and mistreated; Ned apparently found his situation at Harvard similar. In a 1917 letter, he wrote "Shelley had accomplished for me ... transference of glory from Christianity to disbelief." ${ }^{192}$ By the time he completed his studies at Harvard in 1884, he had rejected Christianity and "passed out of the faith with pomp and

\footnotetext{
${ }^{186}$ Burdett and Goddard 33-4. Ned described Perrin as a distant relative of Robert E. Lee. His mother was from the "F.F.V's" (First Families of Virginia).

${ }^{187}$ Burdett and Goddard 48.

${ }^{188}$ Burdett and Goddard 36. The italics are in Burdett and Goddard.

${ }^{189}$ Burdett and Goddard 42.

${ }^{190}$ Burdett and Goddard 46.

${ }^{191}$ Burdett and Goddard 46. The last lines of Shelley's poem are:

The breath whose might I have invoked in song

Descends on me; my spirit's bark is driven

Far from the shore, far from the trembling throng

Whose sails were never to the tempest given;

The massy earth and sphered skies are riven!

I am borne darkly, fearfully, afar;

Whilst, burning through the inmost veil of Heaven,

The soul of Adonais, like a star,

Beacons from the abode where the Eternal are.

Shelley, Leader and O'Neill 2003, 545. The name "Adonais" is a mix of the Greek "Adonis," a beautiful but doomed youth, with the Hebrew "Adonai," which means "Lord." Such a conflation would have appealed to Ned. For commentary on Shelley's poem, see Shelley and Knerr 1984.

${ }^{192}$ Edward Perry Warren to Susan Wilbur Jones, 7 June 1917, George J. Mitchell Department of Special Collections \& Archives, Bowdoin College.
} 
rejoicing," declaring "I disbelieved and was glad." 193 Later, Ned collected first editions of Shelley and visited Shelley's grave in Rome "with tears."194

\section{Oscar Wilde's tour of America in 1882 validated Ned's acceptance of his} sexuality. The famous English aesthete's lectures and poetry readings attracted hordes of young men often attired in "languid" and "subversive" attire and holding lilies or sunflowers, the flowers that had become associated with Wilde. ${ }^{195}$ In his reminiscences to his cousin, Ned described himself as "one of the youths who wore sunflowers at [Oscar Wilde's] lecture."196 He confessed he was attracted to Wilde's “trail of conscientiousness."197

Wilde received much publicity, invariably negative, in the United States. Critics lambasted his American followers, "the gilded youth," as they were called, and cartoons caricatured them as effeminate dandies. ${ }^{198}$ Even before Wilde's widely publicized visit, social critics — all male, of course-—had begun to express fear that "manhood" was eroding in the United States. These detractors blamed the growing influence of women; their fear was "the increasing dominance of a female audience in a society where women had become the keepers of the cultural flame."199 Colleges and universities also were

\footnotetext{
${ }^{193}$ Burdett and Goddard 42-9.

${ }^{194}$ Burdett and Goddard 123. The visit was in 1889.

195 Shand-Tucci 1995, 15.

${ }^{196}$ Edward Perry Warren to Susan Wilbur Jones, 7 June 1917, George J. Mitchell Department of Special Collections \& Archives, Bowdoin College. In a postscript, Warren recollected that he had four opportunities to see Wilde: twice in Boston, once in New York, and once in Paris where he saw Wilde and his lover Alfred Douglas walking together. The relationship with Douglas resulted in the famous trial in 1895 culminating in Wilde's conviction for homosexual acts. A poem written by Douglas contains the famous characterization of homosexuality as "the love that dare not speak its name."

197 Burdett and Goddard 46.

198 Blanchard 1998, 14, 44.

199 Lears 49.
} 
suspect, for bookishness was the anathema of a virile and active life. As one professor complained: "The popular idea of a young scholar is that he should be a pale and bespectacled young man, very thin, and with a slight and interesting tendency to sentimentality and consumption.” ${ }^{200}$ Ned Warren certainly fit this stereotype.

In his biographical study of the architect Ralph Cram, Douglas Shand-Tucci connects Anglo-Catholicism with homoeroticism in late nineteenth-century Boston and asserts that Ned Warren was part of the intellectual and artistic network of homosexuals, the "Queer-Fishes," most of whom lived near Pinckney Street on Beacon Hill. ${ }^{201}$ ShandTucci argues that Warren was acquainted with Ralph Cram as well as Wilde's American publisher, F. Holland Day, whose homoerotic photographs were well known in "certain" circles. ${ }^{202}$ According to Shand-Tucci, Warren's sexual affinities are evident in his close relationship with Bernard Berenson, as well as with Joe and William Amory Gardner, the nephews of Isabella Gardner. ${ }^{203}$ Warren, in fact, travelled to Greece with William Amory Gardner and reported that they stayed together in Athens, visited Mycenae and Delphi, and stood on the nose of the Lion of Chaeronea. ${ }^{204}$ Martin Green makes an allegation similar to Shand-Tucci's, claiming that Ned belonged to a homosexual circle at Harvard composed of the art historian Bernard Berenson (1865-1959), the philosopher/novelist George Santayana (1863-1952), the collector Charles Loeser (1864-1928), and the

\footnotetext{
${ }^{200}$ William Parsons Atkinson (1820-90), a professor of history and English at MIT, in On the Right Use of Books (Boston, 1878) qtd in Veysey 1965, 13-14. As early as the 1850s ,"a visible gay subculture emerged in the nation's cities." Kimmel 68

201 "The Queer Fishes" is Shand-Tucci's term.

${ }^{202}$ Shand-Tucci 1995, 40-5, 219-24.

${ }^{203}$ Shand-Tucci 1995, 436-40. Shand-Tucci holds that Ned Warren "bridged discourses both Whitmanic and Wildean" in his study about homosexuality and Harvard, see Shand-Tucci 2003, 89. He also refers to Berenson and Beazley as Warren's "protégés." Shand-Tucci also includes a long quote from Warren's Tale of Pausanian Love as support for Warren's homosexuality but does not identify the work.

${ }^{204}$ Burdett and Goddard 61. This trip took place after Ned's second year at Oxford.
} 
essayist Logan Pearsall Smith (1865-1946). ${ }^{205}$ Warren's acquaintance with the Gardner brothers and his sponsorship of Bernard Berenson for admission to Harvard and their later travel together in Europe are documentable. ${ }^{206}$

The histories of Harvard, as a rule, ignore Edward Perry Warren and his brothers Sam, Henry, and Fisk. ${ }^{207}$ Perhaps Ned's homosexuality, Sam's suicide, Henry's reclusiveness, and Fisk's involvement in radical causes account for their absence in these accounts. Ned Warren is only noted briefly in references to Greek vases he loaned in 1895 and gave in 1927 to Harvard's Fogg Museum.

\section{Warren at Oxford}

In contrast to his minimal—and usually negative—recollections of Harvard, Ned recalled Oxford with glowing and wistful descriptions. Burdett and Goddard assert that he felt "starved imaginatively in America" and "not inclined" to enter the family business because "it would hinder his reading." ${ }^{208}$ In a letter to a favorite cousin, Ned declared that he began to be "in touch with English ways of thinking" presumably through reading Shelley, Wilde, and Swinburne, and observed that one could get instruction in America but that it lacked "the atmosphere." 209

\footnotetext{
${ }^{205}$ Green 1989, 75-6. Like Warren, Smith lived as an expatriate in England and had young male companion/secretaries. George Santayana reported that he visited Ned in Oxford. Sox 1991,103-4.

${ }^{206}$ Joe Gardner lived across the hallway from Ned in his second year at Harvard. Warren described him as "the most thorough gentleman and the most tender and conscientious in heart and life whom I have ever known." Burdett and Goddard 37.

${ }^{207}$ For example, Morrison 1930 .

${ }^{208}$ Burdett and Goddard 25.

${ }^{209}$ Edward Perry Warren to Susan Wilbur Jones, 7 June 1917, George J. Mitchell Department of Special Collections \& Archives, Bowdoin College.
} 
In the summer of 1883, the twenty-three year old American arrived in England to pursue further studies with his "appetite for culture . . stronger than ever., ${ }^{210} \mathrm{He}$ contemplated entering Cambridge; however, since "it was not the University of Shelley and Newman," he decided to apply to one of the Oxford colleges. ${ }^{211}$ Ned first inquired at Balliol, but he found the ideas at that college too modern and he disliked "the architecture of its hall. ${ }^{212} \mathrm{He}$ considered studying philosophy; however, after consultation with the famous Benjamin Jowett (1817-1893) and other renowned Oxford teachers, Warren decided on New College. ${ }^{213}$ Here, he embarked on the Literae Humaniores, "the Greats" program, "a systematic study of Greek history, literature and philosophy" intended to serve as "a ground of transcendent value alternative to Christian theology." 214 However, as Dowling points out, this curriculum functioned as "homosexual code" before homosexuality emerged "as a locus of sexual identity.",215

Ned's attraction to Oxford University is understandable, for —as described in Burdett and Goddard — it was "the vestment in which the Greek Idea had clothed itself in modern times. ${ }^{.216}$ In contrast to Harvard where he felt alienated, Oxford seemed to welcome the expatriate from Boston. He recalled with fondness the banks of the Cherwell

\footnotetext{
${ }^{210}$ Burdett and Goddard 51.

${ }^{211}$ Burdett and Goddard incorporate Warren's recollection of meeting Newman, who inscribed a book for Ned at this interview. Burdett and Goddard 92-99.

${ }^{212}$ Burdett and Goddard 51.

${ }^{213}$ Warren said that Jowett and "the compulsory Literae Humaniores did me the greatest service." Burdett and Goddard 52. For Jowett, see Jenkyns 1980, 414-32; Hinchliff and Prest. 2004 (24 January 2009). The other Oxford advisors were Thomas Case (1844-1925) and Arthur Sidgwick (1840-1920). Case and Warren correspondence is in the Archives of Corpus Christi College in Oxford. They were in agreement about keeping Oxford exclusively male and maintaining the Greek requirement for its students. Warren made Corpus Christi bequests in his will. For Case, see Otter 2009 ( 24 January 2009) . For Sidgwick, see Howarth 2004.

${ }^{214}$ Dowling 1994 , xiii.

${ }^{215}$ Dowling 1994, xiii.

${ }^{216}$ Burdett and Goddard 376.
} 
River, commenting that seldom were women to be seen on the stretch from Christ Church to Parson's Pleasure. ${ }^{217}$ The Oxford method of teaching was based upon the weekly tutorial when the undergraduate and his tutor had "a weekly hour long meeting ... in which an essay is read and criticized, [and] conversation revolves around the subject of study, and some of the older man's wisdom and experience is supposed to alight like a mantle on his pupil. ${ }^{218}$ By Ned's matriculation at Oxford in 1883, the tutorial had become "a vehicle for the intensifying reciprocal bonds of masculine interest, affection, and obligation." ${ }^{219}$ Ned confessed that he had found "more appreciation of the beauty and charm of youth at Oxford than Harvard. ${ }^{, 220}$ Now acquainted with Plato's Phaedrus and Symposium through the Literae Humaniores, he disclosed that he had a "yearning for the renewal of Greek love.”221

Ned did not provide specific information about what he studied in Oxford and research does not reveal the names of his tutors. Rather, he recalled his first year (188384) there with romantic wistfulness. In "A Taste for Solitude," an autobiographical section in Burdett and Goddard, he described his loneliness through his poem Memoria Amorum, dating to that period. ${ }^{222} \mathrm{He}$ claimed that he was not interested in courting the Oxford intelligentsia. He reported glimpsing the elderly Robert Browning and Matthew Arnold and, stressing that his goal in Oxford was "not to see great men but to be like

\footnotetext{
${ }^{217}$ Burdett and Goddard 60. For Parson's Pleasure, the traditional bathing spot for the undergraduates and dons, Horan 2000, 122.

${ }^{218}$ Morris 1978, 46. For a discussion of Oxford pedagogy and the dons, see Engel 1983.

${ }^{219}$ Dowling 1994, 35.

${ }^{220}$ Burdett and Goddard 58.

${ }^{221}$ Burdett and Goddard 58-9. For a portrayal of homosocial Oxford, see the novel Brideshead Revisited: The Sacred and Profane Memories of Captain Charles Ryder which was adapted into a British television series and a film. Waugh 1945. Also, see the reminiscences of the transsexual Jan Morris, an Oxford graduate, World War II veteran, historian, and travel writer, Morris 102.

${ }^{222}$ Burdett and Goddard 44-5.
} 
them," he boasted that he was so intent on his own studies that he did not attempt to attend the lectures of Walter Pater, the famous art critic and essayist. ${ }^{223}$

By his second year at Oxford, Warren felt he "had come home" and had grown more confident because he "had found people who did not damn [his] ideas as incorrect, but on the contrary, found them interesting." 224 He began to receive recognition, earning "a First in Mods" - that is, the highest evaluation on the comprehensive examinations, called the Moderations or "Mods" in Oxford slang, taken at the end of the first year of study. He was selected for admission to the New College Essay Society. Ned also travelled extensively, visiting Greece with William Amory Gardner, spending a holiday in Paris, and touring Germany with his mother. ${ }^{225}$

Oxford, Ned believed, was vastly superior to Harvard. Despite his acknowledgment that what he called "immorality" — which Ned equated with heterosexual promiscuity — was present at both, he claimed Harvard students had easier and more frequent access to brothels. At Oxford, "commonplace immorality [sank] into the background." 226 Oxford men, he admitted, did use obscene language too frequently, but merely as "recognition of physical facts." 227 In contrast to the snobbery of the exclusive Harvard team sports or the debauchery of the bars in Boston, camaraderie at Oxford was available through boating and rowing on the Cherwell and the Thames, or

\footnotetext{
${ }^{223}$ Burdett and Goddard 53-4. Walter Pater (1839-94) began offering lectures on Greek sculpture at Oxford in 1879. Kurtz 2000, 234. Warren's failure to attend these lectures is surprising.

${ }^{224}$ Burdett and Goddard 53.

${ }^{225}$ Burdett and Goddard 61. William Amory Gardner was the nephew of Isabella Stewart Gardner.

${ }^{226}$ Burdett and Goddard 58.

227 Burdett and Goddard 58.
} 
sharing wine in the college rooms. ${ }^{228}$ The emphasis on Plato, the intimacy of the tutorial system, and a homosocial culture made Oxford a haven to which Ned Warren returned frequently for the rest of his life. ${ }^{229}$

\section{John Marshall and Lewes House}

After his father's death in 1888, Ned remained in England, supported by an income generated by the Warren Family Trust. It was at this time that Ned formed a relationship with a fellow Oxford student, John Marshall (1862-1928), an attachment that persisted throughout their lives. ${ }^{230}$ In 1890 Ned (Figure 6) leased Lewes House, a Georgian home in Lewes, East Sussex. There Ned established a center for collecting Greek and Roman antiquities. He recruited young men - usually from Oxford - to live, study, and work in a male community dedicated to what Warren intended to be a Hellenic-inspired lifestyle. Marshall was Ned's chief collaborator and served as his agent in Rome, which was then the hub of the antiquities trade and a convenient base for launching collecting forays to Tuscany, South Italy, and Greece. John Marshall and the other men involved in the Warren antiquities enterprise are discussed in more detail in Chapter 2.

The period from 1895-1905 was the peak of the Lewes House collecting enterprises. Ned's cadre of assistants sent hundreds of antiquities, chiefly Greek and Roman sculpture and Greek vases, to Boston's Museum of Fine Arts, Boston with Ned's

\footnotetext{
${ }^{228}$ Burdett and Goddard 58.

${ }^{229}$ Correspondence from Warren at Oxford dates as late as January 1928. Warren died in December of that year.

${ }^{230}$ For male relationships during this period, see Potvin 2008. Potvin refers to the Warren-Marshall bond and includes the Edward Reeves photograph of the pair with a St. Bernard in a window at Lewes House (Figure 2).
} 
recommendation for purchase. Through this means, some of the most famous examples of Greek and Roman art entered that museum's collection, supplanting the plaster casts that previously had filled the galleries. After Boston's extensive museum building projects prevented further acquisitions, the relationship between the MFA and Ned Warren cooled. In 1905, Edward Robinson, Boston's curator and a Warren ally, moved to the Metropolitan Museum of Art in New York. There he employed Warren's protégé, John Marshall, as his agent for purchasing antiquities, transferring the Lewes House connection to the MET. Ned continued to give and sell antiquities sporadically to the MFA until his death in 1928. Chapter 2 considers Warren's work on behalf of the MFA and Chapters 4, 5, and 6 discuss noteworthy examples of art from Warren in the MFA.

Ned Warren also sold, either directly or as a middleman, a small number of Greek and Roman objects to the University of Pennsylvania Museum of Archaeology and Anthropology, Bryn Mawr College, the Worcester Museum, and the St. Louis Museum. ${ }^{231}$ In addition to the vases he lent and eventually gave to Harvard, Ned donated a considerable number of antiquities to various academic institutions over the last thirty years of his life. In1901-02 he bestowed well over a hundred objects - chiefly terracottas and vase fragments - on Frank Tarbell, a professor of classics at the University of

\footnotetext{
${ }^{231}$ For Beazley on antiquities at Worcester and St. Louis, see Burdett and Goddard, 355. The Lewes House Registers contain the note "large Lucanian crater height $32 \mathrm{~cm}$. . . Sold to St. Louis Dec 1896." However, documentation for Warren antiquities cannot be located at either the Worcester Museum or the St. Louis. E-mail message Sidney Goldstein, The St. Louis Museum of Art, 7 July 2008, to the author; e-mail message Kate Dalton, Worcester Art Museum, 12 December 2008, to the author. Given that Warren antiquities cannot be documented through the records at these museums and neither collection is connected to an academic institution, these museums will not be discussed. Other Warren antiquities entered the Reading Museum in Pennsylvania through the liquidation sale of Fewacres, his estate outside Portland, Maine. For vases from Warren in the Reading Collection, see Oakley, Coulson and Palagia 1997, 232. Since these antiquities did not enter through Warren and the records are incomplete, neither the Reading museum nor its collection is within the scope of this dissertation.
} 
Chicago. Moreover, at various times, Ned gave vases and fragments to the Ashmolean Museum in Oxford and to the university collections at Leipzig, Bonn, and Heidelberg. ${ }^{232}$

Next to the MFA, Bowdoin College and the Rhode Island School of Design (RISD) received the largest number of Greek and Roman antiquities from Warren. Often the objects that went to Brunswick and Providence had been declined by the Boston and New York museums. In 1896, he began shipping gifts of antiquities, "sendings" as he called these personally selected assemblages, to Bowdoin's newly completed museum. In 1900 he agreed to serve as an agent and consultant for the Museum of the Rhode Island School of Design. Eliza Metcalf Radeke, whose family had helped found the school, purchased many antiquities via Warren from her own funds and recruited family members and friends to fund acquisitions for RISD. During the twenty-eight years of his relationship with RISD, Ned Warren also made gifts of Greek and Roman art and other objects to the school's museum. Warren's relationship with Harvard, Penn, Bryn Mawr, Chicago, Bowdoin and RISD is treated in Chapter 3.

Warren and John Marshall began to drift apart after 1905. Marshall's isolation in Rome and the travel required in acquiring antiquities began to wear on him as did Ned's introduction of a series of handsome young assistants at Lewes House. Marshall also objected to his friend's growing preoccupation with the disputes over the management of the Warren Trust. Added resentment arose from Ned's increasingly frequent visits to America. After 1903, most of Warren's summers were spent at Fewacres, a home he established near the family's mills in Maine. Ned also became intent on establishing a

\footnotetext{
${ }^{232}$ These antiquities and the European universities receiving them lie outside the boundaries of this dissertation.
} 
family and, in 1911, he adopted a four-year old boy, Travis. ${ }^{233}$ Marshall's response was to marry a Warren cousin, Mary Bliss. Despite Marshall's marriage and his employment as an agent for the Metropolitan Museum of Art, Ned continued to support his friend financially and still entered into occasional collecting ventures with him. Warren spent most of the First World War in residence at Corpus Christi College in Oxford, while his houses in Lewes were used as hospitals for injured soldiers. ${ }^{234}$

\section{Warren's Literary Works}

Warren wrote and published in the last twenty years of his life, often under the pseudonym Arthur Lyon Raile. He commissioned three collections of his poems that were merged into a single volume, The Wild Rose, in 1928. The title symbolizes the intimate relationship of men, which Warren considered superior to conventional heterosexual bonds. Warren's literary efforts also include an allegorical tale The Prince Who Did Not Exist (1928 and 1958); a collection of stories retold from Greek mythology, Alcmaeon, Hypermestra, Caeneos (1919); and a pamphlet, Classical and American Education (1918). ${ }^{235}$ In 1887, he wrote A Tale of Pausanian Love, a novella with

\footnotetext{
${ }^{233}$ Very little is known about Travis Warren (1907- 78), the illegitimate son of Muriel Murley, who was the daughter of a vicar in Cornwall. See Sox 1991, 98-101. Kaylor asserts that Warren's adoption of Travis constituted putting his "paederastic theories" into practice. Warren, Kaylor and Miner lxxxvii.

${ }^{234}$ Burdett and Goddard 79. In 1913 Warren bought School Hill House, which still stands next door to Lewes House, up the hill and on the other side of the Church Twitten. In undated letters, now in the Sackler Library of the Ashmolean Museum, Oxford, John Marshall made references to his concern for the injuries and illness of the soldiers. The extent of Marshall's involvement in the hospital is not clear. No other information about the use of Warren's property during the Great War is available, according to the Lewes House Archives. E-mail message, Ann Spike, Lewes House District Council, 19 January 2010, to the author.

${ }^{235}$ Alcmaeon, Hypermestra, Caeneos is very similar to Oscar Wilde's fairy story “The Young King." Green 1989, 73.
} 
numerous autobiographical elements that was published in $1927 .{ }^{236}$ "Pausanian" is an allusion to Plato's Symposium in which the character Pausanias describes a form of "higher" or more spiritual love possible only between men.

Studies in Victorian literature identify Warren as one of the "Uranians, "a group of nineteenth-century poets whose treatment of male friendship, athleticism, religious sentiments, and classical subjects had homosexual associations. ${ }^{237}$ In fact, Warren entitled his longest and last literary undertaking A Defence of Uranian Love. The friendship and love between men constitute the central themes in most of Warren's verse and prose.

During the last fifteen years of his life, Warren (Figure 7) labored on what he called his “magnum opus," A Defence of Uranian Love (1928). ${ }^{238}$ In A Defence, Warren not only acknowledges his own sexuality but champions the love between an older male (in Greek, erastēs or "the male who is in love") and a youth (in Greek, erōmenos or "the male love interest") as superior to heterosexual relationships. ${ }^{239}$ Warren organized the

\footnotetext{
${ }^{236}$ The reason for delay in the publication of A Tale of Pausanian Love until 1927 is not clear. Warren's work on his treatise, A Defence of Uranian Love, may have prompted him to publish the short novel, written forty years earlier. Burdett and Goddard consider A Tale of Pausanian Love autobiographical, with Warren and his friend and lover John Marshall as the models for the main characters, Claude Sinclair and Alfred Byngham, both Oxford students. Burdett and Goddard 86-92.

${ }^{237}$ For the origins of the term, Uranians, see Smith xix-xxiii.

${ }^{238}$ Warren began A Defence as "a relief and a recreation" after the suicide of his brother Sam in 1910, and wrote much of it during a six month stay on Taormina, Sicily in 1913, and completed the work in Oxford. Burdett and Goddard 385. Both locations seem appropriate because Taormina was a favorite haunt of European homosexuals and Oxford was a stronghold of homosocial culture and philhellenism. For Taormina, see Aldrich 1993. Kaylor also cites Warren's visits to Taormina as an indication of Warren's putting his "paederastic theories" into practice. Warren, Kaylor and Miner lxxxviii. For Oxford and homosexuality, see Dowling 1994; Ellis 2007; and Evangelista 2007.

${ }^{239}$ Many scholars have written about the convention of a relationship between youths and their mentorlovers among the Greek elite. Warren, as will be discussed later, specialized in Attic red-figure pottery, which often are decorated with depictions of the male courting rituals as well as inscriptions called kalos (literally "beautiful") referring to a youth. The Roman "Warren Cup," discussed above, graphically depicts
} 
work into three parts: "The Boy-Lover," "The Uranian Eros," and "The Heavenly

Wisdom." In his preface, Warren describes the work as made up of "loose blocks, not

built into a single whole." ${ }^{240} \mathrm{He}$ warns that "the reader will wonder where he is" because "here [is] no intelligible march of argument." The rambling tome is filled with quotations from the Bible, classical texts, and an assortment of writers, ranging from Thomas à Kempis to Tennyson and from Nietzsche to Keats, with few transitions between them. Frequently, the quotations are in French, German, and Latin, and include long passages, often in Greek. Usually Warren identifies these references only by the author; the Greek texts sometimes receive a book or line number. The Burdett-Goddard biography devotes a chapter to A Defence, but it offers little commentary and resorts to cobbling together passages from Warren's book as a means of discussing it. ${ }^{241}$ David Sox, one of Warren's more sympathetic biographers, describes A Defence as “impossibly self-indulgent, defuse . . . and sluggish." ${ }^{242}$ Few printed copies of A Defence have survived. ${ }^{243}$

sexual activity between a man and a youth. For a pioneering study of homosexuality in ancient Greece, see Dover 1989 Also, see the scholarship of David Halperin, especially, Duberman, Vicinus and Chauncey 1989; Halperin 1990; Halperin, Winkler and Zeitlin 1990. For Roman homosexuality, see Williams 2010. Some recent scholars avoid using the modern term "homosexual" for male relationships in ancient Greece. See, for example, Davidson 2007.

${ }^{240}$ A Defence is not paginated; thus, references to the sections of Warren's "magnum opus" in the above discussion are the most specific form of documentation.

${ }^{241}$ See Burdett and Goddard 300-30. The chapter is entitled "The Magnum Opus."

${ }^{242}$ Sox 1991,83

${ }^{243}$ In 2008 I purchased a scanned copy from the McCormick Library of Special Collections, Northwestern University. World Cat lists two other volumes in the United States; the only copy of A Defence of Uranian Love in the Oxford University Libraries is on microfilm in the Bodleian Library. As explained in the Introduction, Michael Matthew Kaylor and Mark Robert Miner published a privately printed and annotated edition of $A$ Defence in 2009. 
After the death of Mary Bliss Marshall in 1925, Ned and John Marshall became less estranged. ${ }^{244}$ By 1926 the collecting and cataloguing at Lewes House had ceased. When Marshall's health began to fail, Ned took charge of his care and was at his side in Rome when his friend expired on February 16, 1928. ${ }^{245}$ On December 28 of the same year, Ned himself died after abdominal surgery in London. The ashes of Ned Warren and John and Mary Marshall are buried in the same grave, marked with a marble urn in the English Cemetery at Bagni di Lucca in Tuscany. ${ }^{246}$

\footnotetext{
${ }^{244}$ I have not been successful in determining the exact day of Mary Bliss Marshall's death. Neither Sox nor Green gives the exact date. It may be inscribed on the monument marking the grave she shares with Ned and John Marshall in Bagni di Lucca, which I have not had the opportunity to visit.

${ }^{245}$ The date of Marshall's death is based on a letter that Warren wrote on February 28, 1928 to John Rowland Fothergill describing Marshall's death, reprinted in Sox 1991, 126-7. Sox used Fothergill's unpublished letters and memoirs for his book. In this letter Warren described lying beside Marshall and propping up his friend's head. Warren said Marshall went to bed early on February 15 and died at 1:05 the next morning.

${ }^{246}$ Bagni di Lucca, with its hot mineral bath spa, was a fashionable summer haven for the English, including Queen Victoria, in the late nineteenth century. See Amfitheatrof 1980, 58-61. Nineteenth-century writers - John Keats and Elizabeth Barrett Browning, for example — died and were buried in Italy. The burial of Ned and the Marshalls in Italy seems fitting.
} 


\section{CHAPTER 2}

\section{THE INTELLECTUAL CLIMATE FOR WARREN'S COLLECTING}

In the late nineteenth century, the study of classical language and literature, chiefly Latin, taught through rote dominated the curricula in American colleges and universities. Since only a few unimpressive antiquities had reached the United States by this time, plaster casts of ancient works in European collections and classically inspired modern sculptures were the principal means of studying Greek and Roman material culture. However, during Ned Warren's years at Harvard, archaeology and art history emerged as academic disciplines under the auspices of Charles Eliot Norton, one of the most prominent intellectuals in Gilded Age Boston. Unlike his fellow student, Harold Norton Fowler, Warren did not participate in activities sponsored by the newly established Archaeological Institute of America or pursue an academic career. Nonetheless, he acquired an enthusiasm for antiquities at Oxford where Percy Gardner promoted the study of classical art and archaeology.

The turning point in Ned Warren's life came in 1888, for not only did he complete his studies at Oxford, but he inherited a substantial legacy that permitted him to acquire property in England and launch his career as a collector and agent for American museums. This chapter considers the significance of the first antiquities to enter the 
MFA Boston via Warren, in 1887. It then recounts the establishment of Lewes House, the hub for his antiquities enterprise, and reconstructs what is known about this exclusively male community. Warren's relationships with three friends and cohorts were pivotal in Warren's collecting for American museums-John Marshall, his "alter ego" and partner in antiquities collecting ventures; Edward Robinson, Curator at the Museum of Fine Arts and later at the New York's Metropolitan Museum of Art; and John Davidson Beazley, the Oxford scholar who developed the attribution system for Greek vases.

\section{The Study of Greece and Rome in Nineteenth-Century American Academia}

In the United States, Latin dominated the program of study in high schools with few opportunities for students to learn Greek, and American teachers generally lacked a thorough grounding in classical philology. They also failed to inspire their students; rote memorization, drills, and recitation constituted the accepted modes of instruction in both high schools and colleges. ${ }^{247}$ The "recitation" was a forty-five to fifty minute oral response to prepared questions held five times per week. Here, the teacher sometimes corrected translations or answers, but more often not. The recitation of one day served as a review for the following day, with the expectation that it be better than the first. The students did not ask questions and never disagreed with the instructor. ${ }^{248}$ The methodology remained unchanged for decades, with students complaining that their classes were dull and distasteful. For example, James Freeman Clarke (1810-1888), a

\footnotetext{
${ }^{247}$ Reinhold 1984, 194-5.

${ }^{248}$ Veysey 37-8.
} 
friend of Ralph Waldo Emerson and an advocate of education reform, recalled his education at Harvard in the late 1820s:

No attempt was made to interest us ... We were expected to wade through Homer as though the Iliad were a bog, and it was our duty to get along at such a rate per diem. Nothing was said of the glory and grandeur, the tenderness and charm of this immortal epic. As only a few of the class recited well enough for us to learn anything from what was said, those hours were not only wasted, but put us in a condition of mental torpor. ${ }^{249}$

Colleges and universities in the United States not only lacked inspiring instruction, they were without adequate libraries and cast collections. The few Americans who ventured to Germany in the early nineteenth century for advanced degrees were astounded by the extensive libraries there that supported study in the classics, and they were impressed by cast collections that provided a comprehensive view of the development of classical sculpture. ${ }^{250}$ Just as eye-catching to the Americans was the display of antiquities in German museum collections. In Munich, for example, the sculptures from the Temple of Aphaia at Aegina had been housed in the Glyptothek since $1828 .{ }^{251}$

Neoclassical architecture and decorative arts in the late eighteenth century had whetted American taste for the Greek and Roman aesthetic. ${ }^{252}$ The new nation idealized the Roman Republic and employed Roman visual imagery - the eagle and the fasces, in particular-in its symbolism. Popular art portrayed American heroes as Romans, with

\footnotetext{
${ }^{249}$ As quoted in Winterer 34.

${ }^{250}$ For comparison of university library holdings in the United States and in Germany, see Winterer 55.

${ }^{251}$ Dyson 1998, 31.

${ }^{252}$ For an overview, see Cooper 1993.
} 
George Washington cast as the new Cincinnatus. ${ }^{253}$ Neoclassical sculptors Jean-Antoine Houdon (1741-1828) and Horatio Greenough (1805-52) depicted Washington using classical imagery. ${ }^{254}$ Ciceronian oratory influenced both political speeches and church sermons. $^{255}$

Despite the widely held veneration for classical culture, only Colonial aristocrats like Thomas Jefferson or James Bowdoin who visited England and the Continent had contact with Greek and Roman antiquities and monuments. Yet, by the mid-nineteenth century, the American academic, literary and artistic elite began to visit Europe. ${ }^{256}$ In the preface to The Marble Faun (1860), novelist Nathaniel Hawthorne described how the antiquities in Rome impressed him:

In rewriting these volumes, the Author was somewhat surprised to see the extent to which he had introduced descriptions of various Italian objects, antique, pictorial, and statuesque. Yet these things fill the mind, everywhere in Italy, and, especially in Rome, and cannot easily be kept from flowing out upon the page, when one writes freely, and with self-enjoyment. ${ }^{257}$

In the 1860s, lingering international tensions discouraged American tourism as did the political and economic stress of the Civil War. Gradually, however, the introduction of regular packet boats and then steamship service made ocean passages faster and safer. ${ }^{258}$ As in the case of the Warrens, wealthy Americans began to travel to Europe in larger numbers during the 1870 s.

\footnotetext{
253 See Wills 1984.

${ }^{254}$ For Houdon, see Poulet 2003. For Greenough, see Wright 1963.

${ }^{255}$ For the impact of classical rhetoric, see Clark and Halloran 1993.

${ }^{256}$ For Americans' experience in Italy, see Amfitheatrof ; Vance 1989; Stebbins 1992.

${ }^{257}$ Hawthorne 1889, 3. Hawthorne was an 1825 graduate of Bowdoin College. In tribute to its famous alumnus, Bowdoin acquired a cast of the "Marble Faun" for its museum.

${ }^{258}$ For the dangers and discomfort of travel to Europe, see Amfitheatrof 11-24
} 
Before the Civil War, only a few Americans obtained graduate education in Germany where a new type of course, known as the seminar, emphasized meticulous textual analysis, and where the curriculum, under the influence of J. J. Winckelmann, included material culture in the study of ancient history and philology. A fervent philhellenism began to take hold in the German universities which regarded ancient Greece as "a quasi-religious realm of the beautiful and the true." ${ }^{, 259}$ Not surprisingly, Harvard was the first academic institution in the United States to come under the influence of German scholarship and philhellenism. Edward Everett (1794-1865) was the first American to pursue graduate study in Germany. After his graduation from Harvard in 1811 and his immediate appointment as the first Eliot Professor of Greek, the Harvard Trustees sent him to study philology and archaeology at Göttingen, where he became aware of the importance of sculpture, architecture, and epigraphy as well as the latest philology. He also travelled widely and purposefully, visiting Rome, Pompeii and Paestum. He also made a tour of Greece. ${ }^{260}$ After Everett's return to Harvard where he taught Greek for five years, he developed into a popular lecturer by incorporating knowledge based on direct experience with Greek antiquities and monuments. ${ }^{261} \mathrm{He}$ translated several influential German classics texts into English and replaced the drill used in the traditional recitation methods with the lecture format he learned in Germany. ${ }^{262}$ Everett also persuaded a friend to purchase the gigantic painting, Panorama of Athens, so that students could become familiar with the topography of the ancient

\footnotetext{
${ }^{259}$ Winterer 51.

${ }^{260}$ Larrabee 1957, 28-31

${ }^{261}$ Reinhold 208-10; Dyson 1998, 20; Winterer 53,185.

262 Richard 2009, 14-15.
} 
city. ${ }^{263}$ Frustrated with the continued expectation that he serve as a "drill master," Everett resigned from the Harvard faculty in 1824 . However, he employed his oratorical skills in an active and diverse political career, interrupted by a brief return to Harvard as President (1846-49). ${ }^{264}$ Everett was so influential in his political oratory that his student, Ralph Waldo Emerson, heralded him as a new "Pericles."265

The naming of newly founded cities in the United States testifies to its growing infatuation with Greece. ${ }^{266}$ By the 1850 s, thirteen American towns were called Athens, and others, like Nashville, fancying itself the "Athens of the South," adopted Athens as a sobriquet. Since Boston had its "Pericles" in Everett, it could then claim to be America's Athens. If Boston was America's Athens, then Harvard sought to become its Academy.

\section{Antiquities Collections and Museums before Warren}

Until the establishment of civic museums in the 1870s in Boston and New York, the opportunities for viewing antiquities in America were limited. No distinctions were made between original art and reproductions. Copies of paintings, popularly called "Old Masters," and plaster casts of antique sculptures dominated the few meager collections. One of the earliest art collections belonged to John Smibert (1688-1751), a Scottish painter who worked in Boston from 1728-52. Smibert owned a single cast of the Venus

\footnotetext{
${ }^{263}$ Larrabee 41; McNeal 1995; Winterer 67; Richard 14-15. For the history of panoramas in general, see Oettermann 1997.

${ }^{264}$ Reinhold 210.

${ }^{265}$ Winterer 53. For the plaster bust of Everett (1893) in classical garb in the Boston Athenæum, see Cushing and Dearinger 2006, 276- 81.

${ }^{266}$ For "classical conditioning" expressed through the naming of towns, ships, and people, see McCarthy ; Richard 31-32.
} 
de' Medici and copies of Baroque and Renaissance paintings. ${ }^{267}$ Thomas Jefferson was a collector of Old Master paintings and an admirer of classicism. In 1771, he made a list of casts of ancient sculpture including the Apollo Belvedere, Antinous, the Venus de' Medici, and the Farnese Faun, none of which he was able to obtain. ${ }^{268}$ In $1829-30$, the American portraitist Rembrandt Peale (1778-1860) made copies of famous paintings in Rome and Florence which he then exhibited on his return to Philadelphia in $1831 .^{269}$ Other Americans purchased plaster impressions of ancient gems in Rome which they proudly displayed in their homes. ${ }^{270}$

The few antiquities reported to be in America before the mid-nineteenth century were quite modest and now are disputed or lost. For example, P.T. Barnum's American Museum in New York displayed fragments of ancient marble from Carthage and Italy as well as Etruscan terracotta burial urns, but these objects were destroyed in an 1865 fire. A marble relief of a horse reportedly from Herculaneum entered the Boston Athenaeum in 1812; however, its authenticity cannot be established. ${ }^{271}$ One ancient sculpture arrived in America in 1828. Popularly called the "Philadelphia Ceres," this late Hellenistic colossal work was given to the Pennsylvania Academy of Fine Arts (PAFA) in Philadelphia where it eventually was displayed over the front entrance of the new building. ${ }^{272}$ The

\footnotetext{
${ }^{267}$ Cooper 77. Smibert may have been the source for the Old Master paintings that were given to Bowdoin College. See Wegner 1994.

${ }^{268}$ Of the fifty paintings owned by Jefferson, forty-one either lacked attribution to a specific artist or were acknowledged as copies. The Boston Athenæum received most of these paintings in 1826. See Constable $1964,11$.

${ }^{269}$ Cooper 86.

${ }^{270}$ Cooper 82.

${ }^{271}$ The relief, now in an oval frame, supposedly had been brought from Italy in the 1790s. Cushing and Dearinger 2006, 36, 60.

${ }^{272}$ Dinsmoor 1943, 87-90. The headless statue had been purchased by an American naval captain at Megara, Greece, in 1827 and then given to the PAFA. When the present Pennsylvania Academy of Fine
} 
sculpture remained there until 1937 when it was removed for fear that fragments of the disintegrating marble might injure those below. ${ }^{273}$

Aside from these examples, the most important antiquities to reach American shores before the Civil War were Greek vases, which had been popular among elite English collectors since the early eighteenth century. For example, the wealthy Baltimore collector and patron of the arts, Robert Gilmor (1808-1863), owned several vases. A portrait now in the Baltimore Museum of Art shows the elderly Gilmor in his study with a red-figure oenochoe sitting in a kylix in the foreground of the painting. ${ }^{274}$ Another painting, the 1854 portrait of the Richard K. Haight Family, depicts at least three redfigure vases on a shelf behind the family. ${ }^{275}$ None of the Greek vases depicted in the Gilmor and Haight portraits can be traced to present collections in America. On the other hand, the whereabouts of three ancient vessels arriving in Philadelphia in the early nineteenth century can be verified. These came as gifts from Joseph Bonaparte (17681844) to American friends. After his brother's fall from power in 1815, Joseph resided near Philadelphia for almost twenty-five years. ${ }^{276}$ Another Bonaparte brother, Lucien (1775-1840), had excavated thousands of Greek vases from Etruscan graves on his estate

Arts building designed by Frank Furness (1839-1912) and George W. Hewitt (1840-1916) was constructed, this sculpture was installed with a new head over the arch of the main entrance, adding a Greek motif to the already eclectic structure. For this PAFA building, see Hain and Baker 2005. The blackened "Ceres" was destroyed by chipping it apart.

${ }^{273}$ Dinsmoor 88-9.

${ }^{274}$ BMA 1956.287 by William James Hubbard. Records from the Peale Museum in Baltimore listed that Gilmor exhibited "an Etruscan Vase . . being at least 2,700 years old." It is not clear how many vases Gilmor owned besides the two in the painting. The location of these vases is unknown, Cooper 98. Also at the Baltimore Museum of Art is a portrait done in 1823 by Thomas Sully (1783-1872), depicting a youthful Gilmor in a Romantic fashion, see Craven 1994.

${ }^{275}$ Richard K. Haight Family, c. 1848, attributed to Nicolino Calyo (1799-1884), gouache on paper. Accession number 74.97.2, Museum of the City of New York, New York. For Haight, see Cooper 62, 6667, 100-101.

${ }^{276}$ For Joseph Bonaparte who lived in the Philadelphia area from 1815-39, see Cooper 68-71. 
at Vulci, Italy. ${ }^{277}$ Both Lucien and Joseph had been elected members of the American Philosophical Society in Philadelphia, and at least three vases from Vulci were given to friends in the American Philosophical Society. One vase, now on loan to the Walters Art Gallery from a private collection, is a lidded Attic black-figure neck amphora. The other two are red-figure vases: a stamnos, attributed to the Kleophrades Painter and dated c.490, features the deeds of Herakles; and a kylix, credited to the Penthesilea Painter and dated c. 470 , is decorated with a youth pursuing a maiden in the tondo and youths and men with horses on the exterior. These two vessels are now in the University of Pennsylvania Museum of Archaeology and Anthropology. ${ }^{278}$

Modest museums with a natural history emphasis had been established in America by the late eighteenth century, but none were devoted to art. ${ }^{279}$ In 1801 the Society of the Fine Arts in New York City, later called the American Academy of Fine Arts, attempted to establish a museum and, in 1803 acquired casts of ancient statuary and copies of Old Master paintings. This short-lived organization, plagued by dissent and lack of direction, failed in its efforts to acquire a permanent building for its small and unimpressive collection. ${ }^{280}$ The Pennsylvania Academy of Fine Art (PAFA), established in Philadelphia in1805, is considered to be the first American art museum because this

\footnotetext{
${ }^{277}$ For the excavations at Vulci, where more than three thousand vases were extracted from Etruscan graves, see Nørskov 58-61, 90-92, 116.

${ }^{278}$ The red-figure vases are in the collection of the Philadelphia Museum of Art but on loan to the University of Pennsylvania Museum of Archaeology and Anthropology. For photographs and background on these vases, see Cooper 99. Also, Dinsmoor 90.

${ }^{279}$ The Charleston Museum, begun in 1773, was essentially a natural history museum. Burt 1977, 26. The same is true of the Museum of the Tammany Society, or the American Museum as it was later called, organized in New York in 1790. Miller 1966, 90. See also Dinsmoor 72.

${ }^{280}$ Miller 91-102; Burt 44-6; Cooper 79-81.
} 
institution always functioned as a museum, as well as an art school. ${ }^{281}$ The PAFA was launched through the efforts of the painter Charles Willson Peale (1741-1827), who also had established a natural history museum in Philadelphia. From its beginning, the PAFA Museum specialized in the work of American artists; Greek and Roman antiquities were never part of its collection. Nonetheless, Greek and Roman sculpture played an important role in the School's early curriculum in that plaster casts were employed to teach drawing and modeling.

Early forms of art museums also developed in the United States in connection with the athenaeum movement. ${ }^{282}$ In the late eighteenth and early nineteenth centuries, upper-class New England men organized themselves into literary and scientific associations, all with a name incorporating a variation of "athenaeum." Impressive meeting halls inspired by Greek and Roman architecture were constructed in prominent locations. Such organizations, supported by subscription membership, provided libraries and gathering places for businessmen, doctors, and educators. In essence, each athenaeum served as an elite men's club where members could read, play chess, and discuss important issues. ${ }^{283}$ Exhibition space was sometimes included in an athenaeum; in fact, two of these New England organizations acquired collections and sponsored permanent art galleries before the Civil War.

\footnotetext{
${ }^{281}$ For the early history of the PAFA, see May 2005.

${ }^{282}$ Variant spellings are "Atheneum" and "Athenæum."

${ }^{283}$ For an overview of the Athenæum's history, functions, and impact in elite American culture, see Story 1975.
} 
The most influential of these institutions was the Boston Athenæum, founded in 1807. ${ }^{284}$ From its inception, the Boston Athenæum was multi-purpose-a combination of a library, reading-room, laboratory, and art gallery. ${ }^{285}$ In 1817 , it received casts of the Laocöon and the Dying Gaul and, five years later, acquired casts of eight full-length and three small-scale plaster copies of classical sculpture. These casts were made available to aspiring young artists for study and drawing. In addition to the plaster casts, the Athenæum also received modern marble copies of ancient sculptures; two of these, the head of the Apollo Belvedere from the Vatican and a full scale Venus de' Medici from the Uffizi, both mandatory sights for any American on a Grand Tour, remain in its collection. ${ }^{286}$ Although copies of antiquities constituted most of the sculpture in the Athenæum collection, neoclassical works were also included, most notably Boston's own Horatio Greenough (1805-52), who often took up classically inspired subjects, such as Venus Victrix or The Judgment of Paris (both 1837-1840). ${ }^{287}$ A gallery, added in 1826, made the Athenæum the principal venue for art for fifty years in Boston. ${ }^{288}$ Ned Warren likely first saw casts — then considered "classical sculpture"—at the Athenæum.

\footnotetext{
${ }^{284}$ The other Athenaeum — but spelled "Atheneum" — claims to be the first "public art museum" in America. Established in 1842 in Hartford, Connecticut, the Wadsworth Atheneum is named for its founder Daniel Wadsworth (1771-1848). The Wadsworth's files and records do not contain evidence for casts in their collections. Antiquities only entered the Wadsworth Atheneum in the early twentieth century, and none of these came from Edward Perry Warren. According to the Wadsworth Atheneum Museum, a few ancient works were acquired by 1900-1905; more came as a 1917 gift from John Pierpont "Jack" Morgan, Jr. (1867-1943). E-mail Eric Zafran, Curator of European Art, 16 July 2009, to the author.

${ }^{285}$ For the early history, see Swan 1940.

${ }^{286}$ Except for a "Herculaneum horse relief," whose origin is uncertain, the Boston Athenæum did not exhibit any antiquities until 1885 when it purchased two Etruscan sarcophagi from Vulci. Swan 36-37, 58, 63.

${ }^{287}$ For American neoclassical sculptors and the Boston Athenæum, see Swan 141-6; Cushing and Dearinger 253-91.

${ }^{288}$ Burt 46-7.
} 
After the Athenæum's collection of paintings, sculptures, and casts outgrew the gallery space, a committee recommended in 1866 that a separate building be built or a separate institution for the fine arts be established in Boston. As a result, in 1870 an independent "Museum of Fine Arts" was incorporated and plans were made for constructing a facility. The new Museum of Fine Arts, Boston, used the Athenæum for exhibitions until its own building on Copley Square was opened in 1876. At that time, most of the Athenæum collection was transferred to the MFA. Today the Boston Athenæum serves primarily as a research center with an extensive library, archive, and special collections, but it still maintains a collection of fine art. ${ }^{289}$ The MFA receives further treatment later in this chapter in the discussion of Warren's collecting.

\section{Warren in the "Golden Age" at Harvard}

Ned Warren was admitted to Harvard in 1879 , during the era that has been called Harvard's “Golden Age.” Charles William Eliot (1834-1926), who has been called "the greatest man in Harvard history," had just completed the first decade of his forty year tenure as President of the University (1869-1909). ${ }^{290}$ Under Eliot, Harvard experienced astronomical growth: the number of undergraduates and professors almost doubled during the first twenty years of his presidency. ${ }^{291}$ Harvard also became more culturally diverse, with a number of Jews admitted as students. Louis Brandeis and Bernard

\footnotetext{
${ }^{289}$ The Athenæum retained Jean Antoine Houdon's busts of Washington, Franklin, and Lafayette, the John Adams portrait once owned by Thomas Jefferson, and several Gilbert Stuart and Thomas Sully portraits. It continues to acquire art. See "Special Collections." Boston Athenæum http://www.bostonathenaeum.org/collections.html (16 August 2009).

${ }^{290}$ Fleming 1986b, 79; Fleming 1986a, 63.

${ }^{291}$ The Harvard enrollment grew from 563 students in 1869 to 1270 in 1889 and then to over 2,200 in 1909 , the year he retired. The professors increased proportionately, from 45 in 1869 to 90 in 1888-89 and then to 194 by 1909. See Fleming 1986b, 70; "Statistics of Growth, 1869-1936” in Morrison 1936.
} 
Berenson, both of whom were connected to the Warren family, were among the most prominent Harvard graduates during the Eliot years. However, the most significant change during the Eliot presidency was the institution of an elective system at Harvard in 1884, an innovation that the Classics Department, as might be expected, opposed. ${ }^{292}$

When Ned Warren enrolled at Harvard, the "Prescribed Studies" for freshmen consisted of twelve credits, which included Greek and Latin, mathematics, physics, and chemistry. ${ }^{293}$ In addition, either three hours of German or French were required; Ned took German, a language he would put to use in his career as an antiquities agent and connoisseur. The only other required course was Rhetoric in the sophomore year. Students were expected to submit six "themes" as sophomores and juniors and four "forensics"- upper level writing assignments in specific subjects — during the junior and senior years. ${ }^{294}$ Eliot's elective system allowed students to choose to enroll in social sciences, history, literature, and philosophy as "Elective Studies" unless a student sought "Honors" in a particular subject. ${ }^{295}$ In that situation, the student's options were more restricted, requiring him to take approved courses in a discipline. ${ }^{296}$

Eliot's implementation of the elective system resulted in an immediate decline in the enrollment in logic, mathematics, metaphysics, and especially Greek and Latin. With

\footnotetext{
${ }^{292}$ Smyth 1930, 34. For college enrollment patterns, the changes in curricula, and the "dethroning of the classical languages" in the Gilded Age, see Winterer 100-10.

${ }^{293}$ Greek was eliminated as a prerequisite for admission and as a required course in 1886. Gardiner and Pierce 1914, 45.

${ }^{294}$ Shumway and Dionne 2002. Also, Harvard 1879-80 HUG 8500.16 Harvard University Archives.

${ }^{295}$ Sophomores were obliged to maintain twelve hours of electives, juniors fourteen, and seniors twelve. Harvard HUG 8500.16, Harvard University Archives.

${ }^{296}$ For example, a candidate for Honors in Ancient Languages had to complete at least a year of Hebrew or Sanskrit, two courses in comparative philology, and three specific Greek course sequences. Harvard HUG 8500.16, Harvard University Archives.
} 
Eliot also came changes in pedagogy. He disapproved of the "daily recitations" and so, by the time Ned Warren attended Harvard, lectures, discussions, and “'Socratic' colloquies between the teachers and the taught" were the prevailing instructional modes. ${ }^{297}$ During Ned's years at Harvard (1879-83), some of the most popular elective lecture courses were taught by President Eliot's cousin, Charles Eliot Norton, whom one of his students described as issuing "a clarion call for the young gentlemen of Harvard to save the United States from cultural and political dissolution." ${ }^{298}$ Norton had not studied in German universities nor did he have an advanced degree, unlike Ned's professor for Latin Literature, George Martin Lane (1823-97). ${ }^{299}$ Nonetheless, Norton's knowledge, which he had acquired through reading and from extended European travel, as well as his literary accomplishments and connections, prompted President Eliot to appoint his cousin as Harvard's first Professor of Fine Arts in 1873.

Norton's message in his lectures echoed the theories of John Ruskin, the English aesthete, with whom Norton had become close friends. For Norton, history was "the urgent, electrifying message that mankind, leaping across the gulf of oblivion, brought to every individual man and woman in the here and now." ${ }^{300}$ In his lectures he argued that the poetry, sculpture, painting, and architecture not only allowed his listeners to share in the labor, the failures, and the triumphs of the past but also to recognize that a nation's art was an index of its moral and spiritual state. The vulgarity and decadence of the

\footnotetext{
${ }^{297}$ Morrison 1936, 347.

${ }^{298}$ Fleming 1986b, 91. Norton began teaching in 1874.

${ }^{299}$ Lane, the Pope Professor of Latin, earned a Ph. D. from the University of Göttingen in 1853. See Morrison 1936, 38-9 and "Lane, George Martin, 1823-1897 " Harvard University Archives. http://oasis.lib.harvard.edu/oasis/deliver/ hua14004 (25 June 2009).

${ }^{300}$ Dowling 2007, 24
} 
Gilded Age were contagious: "we are corrupted by ugliness," he said. ${ }^{301}$ In his lectures, Norton stressed the moral and social significance of the arts and frequently remarked on current events and other issues. In a lecture on the art of ancient Greece, for example, he was reported to have made pointed comments about "the machine-made scarf-pins" and "watch chains with dangling appendages" worn by his students, contrasting what they wore with the simplicity of ancient adornment. ${ }^{302}$ According to Norton, Greek art could inspire Americans to question cloying notions of patriotism and blind acceptance of the status-quo:

A man who becomes thoroughly imbued with a sense of beauty of the Greek world, and the power of which it indicates, will live forever with a noble discontent inciting him to improve himself and the generation to which he belongs - a discontent which will keep him from that foolish, spread-eagle Fourth-of-July optimism which characterizes the American people in general. ${ }^{303}$

Norton was most fond of late medieval Italian art and Dante, but he always argued for the superiority of Greek art, particularly in the age of Pericles. Norton's first course, "The History of the Fine Arts and their Relations to Literature" given in 1874 was followed in the next year by his popular "The Rise and Fall of the Arts in Athens and Venice" and later, a course on Roman and Medieval Art. In the classroom, Norton "evoked the spirit of Hellas to oppose the vulgar new capitalists with their neoRenaissance mansions and neo-Roman railroad stations." 304

Norton's art history courses at Harvard proved to be enormously popular. Students swelled his famous classes for twenty-four years, attracted by his scholarly and

\footnotetext{
301 As quoted in Dowling 2007, 140.

302 Dowling 2007, 140.

303 As quoted in Dowling 2007, 192.

${ }^{304}$ Dyson 1998, 37.
} 
gentle demeanor and his aesthetic musings presented often without the benefit of illustrated textbooks and never with slides. ${ }^{305}$ Norton had a reputation for easy grades, which no doubt contributed to his popularity. ${ }^{306}$ Undergraduates were known to have escaped from his lecture hall immediately after roll was taken and reportedly mimicked what they considered to be his affected speech patterns. Nonetheless, one of his colleagues observed that "many a graduate of the last quarter of the nineteenth century recalls his attendance at Norton's lectures as an experience which opened to him a new world." 307 The wealthy patrons who indulged themselves in amateur collecting and who would come to finance the acquisition of antiquities at the new museums in Boston, New York, and Providence often "had learned the classical aesthetic from Charles Eliot Norton at Harvard." 308 The Yearly Returns indicate that Ned Warren took not only elective courses in philosophy and music but also two of Norton's courses in art history. ${ }^{309}$ During his senior year, Ned was registered for Fine Arts 4: “Art in Italy from the Conquest of Greece by the Romans to the Year 1600"; and Fine Arts 5: "Greek Art." Both courses required the ability to read German for enrollment. ${ }^{310}$

\footnotetext{
${ }^{305}$ Von Reber's History of Ancient Art that Norton used when Ned Warren was enrolled in Fine Arts 5: Greek Art was illustrated with drawings. Norton, as might be expected, did not use slides when they became available at Harvard.

${ }^{306}$ For the response of students to Norton, see Veysey 1965, 224; Samuels 1979, 32; Duffy 1996, 106-7.

${ }^{307}$ Chase 1930, 131.

${ }^{308}$ Dyson 2006, 159. For more on the influence of Norton, see Vanderbilt 1959.

${ }^{309}$ The Yearly Returns are academic ledgers, which changed frequently in organization and format in the late nineteenth century, now in the Harvard University Archives. Generally, these volumes list the Harvard students enrolled in each class - i.e. freshman, sophomore, junior, and senior-with the courses they completed and the assigned course grade. In another section of The Returns, organized according to the professor's name, the "marks" for each course were entered next to the students' names. The number and consistency of "marks" vary among the professors, and even within a specific course. The entries are sometimes illegible.

${ }^{310}$ Ned excelled in Music 2: Counterpoint and Music 4: The Instrumental Music of Haydn, Mozart, Beethoven and their Successors. The specific philosophy course could not be determined; sometimes, as in this case, the Yearly Returns do not list the professor. Information about the content of the courses
} 
Norton's influence was felt beyond the Cambridge campus. Not only was he active in the founding of the Museum of Fine Arts, he helped to establish the American School of Classical Studies in Rome which would evolve into the American Academy. The most far reaching of his efforts was the founding of the Archaeological Institute of America (AIA), an organization that would set the direction for classical archaeology in the United States. ${ }^{311}$ The AIA traces its beginnings to a meeting in 1879 of elite Bostonian intellectuals; among the most prominent and vocal, of course, was Norton. The AIA grew rapidly and by 1896 it had eleven chapters, including one in Washington State. ${ }^{312}$ Norton's zeal for the new organization is evident in a letter to his friend John Ruskin written shortly after the AIA's organizational meeting:

I have been occupied of late in getting up an archaeological Society in the hope of encouraging classical studies, Greek studies I mean; and of training some of our College-bred boys to take part in investigations in Greek regions, \& regions further east. ${ }^{313}$

Norton's friend, Oliver Wendell Holmes, described him as "the moving spirit" behind the AIA, enthusiastic about the possibility of its digging up "some gods in Greece. ${ }^{314}$ Norton, in fact, was the first President of the AIA, serving eleven years in that capacity. The early history of the AIA has been described as testimony to "the

sometimes can be gleaned from the course descriptions in corresponding Harvard College catalogues. Norton's Fine Arts 5: "Greek Art," for example, used a translation by Joseph Thacker Clarke (1856-1921) of Franz von Reber's History of Ancient Art. See Harvard 1874-84. Considered to be one of the first American field archaeologists, Clarke had studied to become an architect in Germany and had done research on how Greek temples were lighted. For Clarke's career and Assos, see Dyson 1998, 120-21. Norton wrote the preface for a revised edition of von Reber's The History of Ancient Art published in 1883. ${ }^{311}$ For the founding of the AIA, see Winterer 157-70.

${ }^{312}$ Winterer 158.

${ }^{313}$ As quoted in Dyson 1998, 39.

${ }^{314}$ As quoted in Dyson 1998, 39. 
interlocking worlds of professional scholarship, cultivated amateurism, opulent private patronage, and modern science" in Gilded Age America. ${ }^{315}$

Norton and his colleague William Watson Goodwin, Harvard Professor of Greek, were instrumental in founding the American School of Classical Studies at Athens in 1881. ${ }^{316}$ They encouraged one of their protégés, Harold North Fowler (1859-1955), to enroll as the first student there. Fowler's travel diary presents a vivid picture of the adventure involved in visiting archaeological sites around the Peloponnese in $1883 .{ }^{317}$ He earned a doctorate from the University of Bonn in 1885, and, in the same year, offered the first course in archaeology_ "The Antiquities of Athens and Olympia"—at Harvard. Fowler edited the American Journal of Archaeology from 1906-16 and later taught at Western Reserve University in Cleveland. ${ }^{318}$ With James R. Wheeler (18591918), his traveling companion on the 1883 tour and later a professor at Columbia, Fowler wrote the first archaeology textbook published in the United States, A Handbook of Greek Archaeology (1909). This landmark book featured photographs of Warren antiquities in the collections of the Museum of Fine Arts. ${ }^{319}$

\footnotetext{
${ }^{315}$ Winterer 147.

${ }^{316}$ Goodwin is significant in that he emphasized graduate studies as "professional" with "scientific and methodical investigation" as the goal rather than general, liberal education. Winterer 176-77.

317 See Murray and Runnels 2007

${ }^{318}$ Dyson 1998, 104. Western Reserve University became Case Western Reserve in 1967 when it federated with Case School of Technology.

${ }^{319}$ Fowler and Wheeler 1901. For a review of this textbook by the first professor of archaeology at the University of Chicago, see Tarbell 1910b. Although Fowler and Wheeler relied chiefly on illustrations reprinted from German publications, the MFA supplied photographs of a number of works — chiefly Greek vases but also terracotta figurines, gems, and jewelry-from its Greek and Roman galleries. Most of the antiquities in these photographs came to Boston through Ned Warren. The authors thanked Edward Robinson of the MFA, a friend and ally of Warren, for his help; however, Warren is not mentioned. Fowler and Wheeler 7-8.
} 
Research for this dissertation has not discovered any connection between Ned Warren and his contemporary, Harold Fowler. Unlike Fowler, Warren did not attend the American School of Classical Studies in Athens, nor did he pursue graduate studies or an academic career, or become involved with the newly formed AIA. Nonetheless, it seems likely that the two must have known — or, at least, known about—each other, given their overlapping years at Harvard, common interests, and circles of acquaintance. Without question, the rise of archaeology and art history as academic disciplines at Harvard and other venerable institutions in New England, as well as at the newly founded universities in the Midwest coupled with the publications and activities of the AIA, created a receptive and informed audience for the vast number and variety of antiquities that Warren would send to the United States. The fact that that first American archaeology textbook featured photographs of MFA antiquities procured by Warren reveals how inextricably linked he is to the study of Greek and Roman art in this country.

\section{Archaeology and Ancient Art at Oxford}

Ned Warren's arrival in Oxford in 1883 coincided with important shifts in the study of ancient culture there. The advent of Percy Gardner (1846-1937), one of the first British scholars devoted to Greek and Roman art has been described as the onslaught of a battle between" the pen" and the "spade," resulting in two victories: "classicizing the stone" and "aestheticizing the Classical.",320 In 1887 Gardner had been lured from Cambridge University, where he was professor of archaeology, to Oxford where he

${ }^{320}$ Stray $1968,205-12$. 
assumed the newly created Lincoln Chair. ${ }^{321}$ Initially, Gardner was faced with opposition from tutors who objected to the inclusion of archaeology as subject matter in the "Greats" curriculum at Oxford.

Gardner advocated that the study of Classics at Oxford be "widened" in two ways: first, by using the lantern slide projectors as "a necessary adjunct of all thorough studies except such as deal with things invisible"; and, second, by encouraging study under the direction of experts in museums and at archeological sites. ${ }^{322}$ Gardner expanded Oxford's relatively modest cast collection, obtained photographs of monuments and archaeological sites, and gathered the ancient marbles from the Arundel and Pomfret collections, then scattered about the University, into the Ashmolean Museum. ${ }^{323}$ In 1905 he published A Grammar of Greek Art in which he outlined the "principles" found in the "surviving monuments of ancient Hellas" and Greek painting, sculpture, and architecture. His choice of title is significant, given his battle with philologists in presenting the legacy of Greece. $^{324}$

In his long career at Oxford, Gardner taught many important figures in the history of classical archaeology, including John Davidson Beazley, Bernard Ashmole, H. R. W. Smith, A. W. Lawrence, Jocelyn Toynbee, and Leonard Woolley. Although Gardner was a numismatics expert, his scholarship was diverse. In 1880 he helped to found the Journal

\footnotetext{
${ }^{321}$ For Gardner, see Beard 1993, 1-29; Medwid 2000, 118-19; "Percy Gardner (1887-1925)" in Kurtz 2000, 255-90. Gardner's interest was focused primarily on numismatics.

322 Stray 207.

${ }^{323}$ For these sculptures, known as the Arundel and Pomfret collections, see Vickers 2006. For the complicated history of the museums and archaeological materials at Oxford, see Ovenell 1986; Kurtz 2000, 205-34; MacGregor 2001.

${ }^{324}$ In 1913 he enlarged his Grammar, re-titling it The Principles of Greek Art and retaining "The Grammar of Greek Art” for its introductory chapter. Gardner 1926.
} 
of Hellenic Studies and in 1893 wrote the first catalogue of Greek vases in the Ashmolean and a Guide to the Cast Collections. ${ }^{325}$ Since Gardner began his lecturing at Oxford in 1887, Warren well may have been in attendance. ${ }^{326}$

Gardner advanced the study and appreciation of Greek art at Oxford, and, in fact, one of his students, John Davidson Beazley, whom Gardner selected to be a Fellow at Christchurch, became the most influential scholar of Greek vase painting in the twentieth century and an ally in Warren's antiquities enterprises. ${ }^{327}$ Research reveals no documentation for any contact between Warren and Gardner. Nonetheless, despite the inability to verify Warren's interaction with Gardner, the success in promoting the study of material culture in Oxford unquestionably created an auspicious climate in which Ned Warren's interest in antiquities was nurtured.

At Oxford, Warren found not only validation for his intellectual and artistic interests in Greek culture but also a setting in which male intimacy was valued. Throughout his adulthood, he returned to Oxford for extended stays and often expressed his admiration and fondness for life there. He developed friendships with administrators and faculty at several colleges, especially Corpus Christi, and resided in that college's facilities for much of World War I. Warren left bequests to the Corpus professors and an

\footnotetext{
325 Catalogue of Greek Vases in the Ashmolean (1893); Kurtz 2000, 231.

${ }^{326}$ Gardner supposedly kept a list of students who attended his lectures, but no list could be found in the Beazley Archives.

${ }^{327}$ Beazley is discussed later in this chapter.
} 
endowment to support a lectureship. He also gave a number of antiquities to the Ashmolean Museum. ${ }^{328}$

\section{Warren's Earliest Collecting}

Ned Warren's studies at Oxford (1883-88) stimulated his interest in collecting antiquities. The galleries of the Ashmolean Museum crowded with archaeological displays, sculptures, and casts, would have attracted his notice. ${ }^{329}$ His travels, both on the Continent and to Greece (1886), had made him aware of the numerous antiquities then becoming available for purchase. In addition, Warren's return to Boston in the winter of 1887-88 must have alerted him to the interest in ancient material culture developing in the United States, as demonstrated by the activities of the newly-founded Archaeological Institute of America.

As early as 1885 while still a student at Oxford, Warren began to buy antiquities; however, little is known about these early purchases. In his tribute "Warren as Collector," Beazley reported seeing a receipt with that date for "an Etruscan vase" obtained from an Oxford dealer. ${ }^{330}$ He also stated that Warren purchased Greek coins and gold earrings in

\footnotetext{
${ }^{328}$ In addition, some of J. D. Beazley's gifts to the Ashmolean came via Warren. See Select Exhibition of Sir John and Lady Beazley's Gifts to the Ashmolean Museum 1912-1966 1967. The closing of the Ashmolean Museum for renovation prevented the author from conducting research on those antiquities in its collection connected to Warren.

${ }^{329}$ For the sculpture in the Ashmolean in the late nineteenth century, see Vickers 2006. For the casts and a detailed history of antiquities in Oxford, see Kurtz 2000. Warren presented two Attic red-figure cups to the Ashmolean in 1896; more gifts came after he met Beazley in 1911. Kurtz 2000, 270. See also Beazley 1927; Beazley, Payne and Price 1931.

${ }^{330}$ The dealer was "W. Ogden." Burdett and Goddard 332. Research for this dissertation yielded no information about Ogden. See "Dealers and Auction Houses etc up to 1945." Pitts River Museum http://history.prm.ox.ac.uk/page_73.html (10 April 2010).
} 
Paris and spent eleven thousand lire on antiquities in Rome. ${ }^{331}$ Friedrich Hauser (18591917), a German archaeologist who was active in such trade in Italy, especially Greek vases, was one of Warren's early advisors. ${ }^{332}$ Hauser and another early Warren contact, Paul Hartwig (1859-1919), were both trained archaeologists who were part of the expatriate German homosexual community in late nineteenth-century Rome. ${ }^{333}$ As will be discussed later in this chapter, the interest of Hauser and Hartwig in Greek vases, especially in their attribution, had an influence on Beazley. John Marshall, Warren's chief Lewes House collaborator, also knew them. Like Warren, both Germans were wealthy and, thus, could speculate in antiquities as well as maintain personal collections. The erotic imagery on Athenian vases may have attracted Warren, Hauser, and Hartwig. ${ }^{334}$ This theory is plausible given that Hartwig's Die griechischen Meisterschalen (1893) included red-figure vases with erotic themes and Warren collected many antiquities that may be considered "erotica.",335

\footnotetext{
${ }^{331}$ Beazley did not provide details about these antiquities except that the coins and jewelry came from "Messrs. Rollin and Feuardent." Burdett and Goddard 332. For this French firm/auction house, see "British Museum Collection Database " http://www.britishmuseum.org/research/search_the_collection_database/term_details.aspx?bioId=93014 (10 April 2010).

${ }^{332}$ Hauser is mentioned four times in Burdett and Goddard. He was considered Ned's "old friend" by 1911. Burdett and Goddard 78. He is also described as an (antiquities) "agent." Burdett and Goddard 211. John Marshall and Hauser, who both worked in Rome, were "not on speaking terms" Burdett and Goddard 254. The Burdett and Goddard text does not indicate the reason for the tension between Hauser and Marshall. It may have stemmed from a rivalry or dispute in the antiquities trade or in relationships among the expatriate homosexual community in Rome. Warren gave Leipzig vase shards, presumably because of his relationship with Hauser. The Lewes House Registers contain stamped notations "To Leipzig" with specific years, usually in the early 1900s. The CVA for the Leipzig vase collection documents gifts of pottery fragments, especially from red-figure cups, from Warren. See Pfister-Haas 2006.

${ }^{333}$ Hartwig produced some of the earliest research on Greek vases including Die griechischen Meisterschalen der Blüthezeit des strengen rothfigurigen Stiles (1893) and Die antiken Vasen von der Akropolis zu Athen (1909). Hartwig and Hauser, once fast friends, eventually became estranged. Pollak and Guldan 1994, 98.

${ }^{334}$ Nørskov 96-7.

${ }^{335}$ For Hartwig, see von Bothmer 1995, 82. The best known of Ned Warren's antiquities, the sexually explicit "Warren Cup," that is now in the British Museum, was in his possession at the time of his death.
} 
The first two antiquities that entered the MFA from Warren are interesting in that they provide insights into his motivations for sending antiquities to Boston. The 1887 report from Edward Robinson, curator of the newly founded Department of Classical Archaeology, documents the donation of two statuettes from S. D. Warren, Ned's father, who was then an MFA Trustee. ${ }^{336}$ One is a terracotta figurine of a young nude male (MFA 87.1), now identified as East Greek, Hellenistic period, which Robinson explained was "purchased by Mr. Edward P. Warren, in Athens." ${ }^{337}$ Ned probably acquired this piece (Figure 8), when he visited Greece in 1886. Robinson's report also credits S. D. Warren with a second gift, a bronze statuette of Athena (MFA 87.7) "bought in Germany." ${ }^{, 338}$ This figurine (Figure 9), now labeled as Minerva because of its identification as a Roman work dated to 100 C.E., may have been obtained through Warren's connections with the previously mentioned German archeologists/dealers.

At the threshold of Warren's career as collector and museum agent, these statuettes suggest that three convictions motivated his collecting. First of all, the bronze and terracotta figurines testify to his unwavering belief that authentic objects, regardless of size or medium, provided a direct means by which to experience the wonders of Greece and Rome, superior to the plaster versions of classical sculpture that filled most

\footnotetext{
${ }^{336}$ Why these two small sculptures entered the MFA as gifts with S. B. Warren named as donor is not clear. Ned's financial dependency on his father in 1887 may have dictated that antiquities he bought, in a sense, were owned by S. D. Warren. The objects may also have been literally Ned's gifts to his father who, in turn, chose to present them to the MFA. Without doubt, these bronze and terracotta figurines were the first antiquities to enter an American museum via Edward Perry Warren, no matter what the circumstances might have been.

${ }^{337}$ Whitehall 1970, 66-7. At the end of the nineteenth century, a number of dealers in Athens offered these terracotta figurines, with many entering the British Museum, London, and the Ashmolean Museum in Oxford. Ned Warren later gave similar terracottas to Frank Tarbell at the University of Chicago and to the Bowdoin College Art Museum. For terracotta figurines in the MFA, see Thompson 1934a. Forgeries of the terracotta figurines were common. Andrén 1986, 66-7.

${ }^{338}$ Whitehall 1970, 66-67.
} 
museum galleries at the time. Another reason to value the bronze work lay in the theory that it was a diminutive "copy" of Pheidias' colossal statue of Athena that once stood on the Acropolis ${ }^{339}$ This connoisseurial approach still persists in the study of Greek and Roman art to a certain extent. Moreover, the acquisition of the "Statuette of the Male Figure" may indicate that Warren's homosexuality influenced his collecting, in that its display of the nude male body supported his belief that the ancient "pagan" world validated his sexuality. In fact, the terracotta figurine may have expressed his defiance of Brahmin Boston conventions, serving as a declaration of his sexual nature-a "coming out," in contemporary jargon — to his family as well as to the social and cultural elite in Boston. Support for this interpretation can be found in Ned's later statement that his antiquities collecting was "a rebellion against Sam and against all to who I had objected from my youth ... it was the hatred of Boston that made me work for Boston ... The collection was my plea against that in Boston which contradicted my (pagan) love." 340

Before discussing Warren's collecting enterprises, it is necessary to describe Lewes House and some of the men who lived and worked there. His acquisition of a "country house" in Lewes in 1890 signaled Warren's resolve to recruit young men to study and work in a community based on his idealized concept of Greek "friendship."

\section{The Establishment of Lewes House}

After the completion of his degree at Oxford in 1888 and with the financial independence provided by his inheritance, Warren concentrated on two goals

\footnotetext{
${ }^{339}$ MFA Handbook (1914), 119.

${ }^{340}$ Burdett and Goddard 146-7.
} 
simultaneously: to locate "a house for bachelors and scholars" and to recruit an "alter ego" to assist in his collecting ventures. ${ }^{341}$ By 1890 , his aspiration to be surrounded by men in a "country house" with "furniture and silver and wines" had been fulfilled. He had leased Lewes House and had begun recruiting young men to form what Burdett and Goddard call his "circle." At the very center of the Lewes House circle, of course, was Ned Warren; his second in command was John Marshall, with whom he formed a lifelong bond.

Warren's tie to Marshall solidified with the discovery of an estate in the center of Lewes, near Brighton. Warren wrote Marshall that the mansion was "huge, old, and not cheap" with "only three or four sunny rooms . . . a quiet garden, a big kitchen garden, a paddock, a greenhouse, and stables ... downs accessible and green woody country ... the seaside.” 342 Warren leased the estate in 1890 and bought it in $1913 .^{343}$

The "County Town" of East Sussex, Lewes proved to be an ideal location for Ned Warren's collecting enterprise, for it is on the train line between London and Brighton. ${ }^{344}$

\footnotetext{
${ }^{341}$ For "a house for bachelors and scholars," see Burdett and Goddard 131. Burdett and Goddard claimed to have borrowed the term "alter ego" from the recollections of Arthur George Bainbridge West, Warren's first secretary. Burdett and Goddard 111.

${ }^{342}$ Burdett and Goddard 122.

${ }^{343}$ The lease was signed April 25, 1890. Burdett and Goddard 127. In May 1910 Warren obtained a lease for 21 years at $\$ 150$ per year. Rose 2007. It is not clear when the estate began to be called "Lewes House." Warren bought Lewes House on March 25, 1913 for £3,750 and also acquired two other buildings in Lewes. He owned "School Hill House," a Georgian building next door to Lewes House on High Street, separated only by the Church Twittens. Rose 2007. One of Ned's Oxford friends reported that he bought "a very beautiful house, Shelley House" in order "to preserve it." Grundy 1945, 117. "The Shelly's" is now a four-star hotel and wedding venue. According to the hotel's website, an inn called the "Vine" dating to the early sixteenth century stood on its grounds. Later a member of the family of Percy Bysshe Shelley bought the property, giving the present building its name. The hotel website does not mention Edward Perry Warren. The Shelley's. 2010. http://www.the-shelleys.co.uk/ (5 April 2010).

${ }^{344}$ Newhaven, only thirty miles away from Lewes, was a ferry ride across the Channel to Dieppe, France. Ferry service began in 1790 and rail connections in 1847 made the six hour route the shortest and most efficient route between London and Paris. Dieppe became a popular haven for artists and writers on both
} 
Situated on the River Ouse, Lewes had long served as a market town for the surrounding villages and countryside and a center for iron smelting and brewing. ${ }^{345}$ Lewes House is situated midway on the south side of High Street, the town's main artery that climbs the hill crowned with a fourteenth-century barbican and keep. A maze of alleys and twittens—as the narrow walled lanes dating to Saxon times are called—provided discreet entry to and exit from the enclosed two and half acres that contained gardens, lawns, greenhouse, and stables. Lanes at the back of the property led to the South Downs, which were ideal for galloping the Arabian stallions that Ned kept in his stables, or down to the Ouse, where his young assistants could sun on its banks or swim.

"Lewes House," as the brick Georgian house was dubbed under Warren's ownership, still stands in Lewes (Figure 10), now serving as the seat of local government, the Lewes District Council. ${ }^{346}$ References to "Bugates," as the site was once called, can be traced back to the reign of Edward III (1327-77). The present structure is reputed to have been built in the early eighteenth-century around a medieval core. ${ }^{347}$ The back part of the building (Figures 11 and 12), dated to the mid-eighteenth century, still opens to a closely clipped lawn, bordered on each side with mixed flower borders in the English style where Warren and Marshall walked arm-in-arm, their St. Bernard dogs played, and

sides of the Channel in the late nineteenth century: Oscar Wilde was a frequent visitor. See "A Taste of Dieppe." http://www.dieppe.fr/mini-sites/a-taste-of-dieppe/pages/a-long-history-107 (5 April 2010). Artists and writers of the Bloomsbury Group frequented Lewes and the surrounding area. See Sox 2006. ${ }^{345}$ For a history of Lewes with photographs, see Poole 2000. Poole includes Edward Perry Warren in her chapter "Later Lewes Landmarks," focusing on Warren's acquisition of Auguste Rodin's Kiss in 1904 and the ensuing controversies.

${ }^{346}$ Warren left the house to his last secretary, H. A. Thomas, discussed below, and the property was sold three times after Thomas acquired it. In 1945 the Chailey Rural District bought Lewes House for use as offices. After the local government was reorganized and renamed in 1974, the Lewes District Council was located in the building. Rose 2007. The citizens of Lewes usually refer to the building as the "District Council."

${ }^{347}$ Rose 2007. 
the "house tea was taken on fine summer afternoons." 348 A plinth (Figure 13), crowned by a sun-dial until only a few years ago, marks the end of the garden which once looked down toward paddocks for Arabian stallions. Photographs and paintings dating to the time of Warren's ownership record some of its features; Burdett and Goddard's description of the house and grounds suggests that much remains as it was during Warren's lifetime. ${ }^{349}$

The "stable block" to the rear of Lewes House, referred to as "Thebes" during Warren's tenure, was the center of the collecting activities. Warren had a wooden stairway installed to provide entry to the second floor, which became his private study. The walls above the oak wainscoting were then jade green and deep red linoleum covered the floor. ${ }^{350}$ Exposed timbers that Warren obtained from a remodeling at Corpus Christi College divide the hipped plaster ceiling into segments. Pairs of rosettes and heads of Erotes, apparently fragments of Roman marble sarcophagi, still serve as decorative supports for the Corpus beams (Figure 15). Patterned tiles installed during Warren's ownership cover the sill of the bay windows. ${ }^{351}$ On its ground floor are two rooms, once filled with books and "the litter of scholarship." In a connecting hallway, one can still

\footnotetext{
${ }^{348}$ Burdett and Goddard, 128.

${ }^{349}$ Edward Reeves, who made the portraits of Warren and Marshall, also photographed the interior of the house, furnishings, and grounds. When Warren's estate was sold, Reeves photographed various objects for the catalogues. Copies of these photographs and other snapshots are in the Lewes House Archives. Reeves Photography has original glass negatives. Two paintings from the Bloomsbury Group depict Lewes House and its activities. Artist and critic Roger Fry (1866-1934) painted a watercolor of Lewes House and its lawn on a 1908 visit (Figure 14). It is now displayed in Lewes House. The painting is intriguing, given Lewes House's misogynistic underpinnings, because three women are depicted. David Sox suggests that one is Helen Fry, Roger Fry's wife, and another may be Mary Bliss Marshall, Ned's cousin whom John married in 1907. Fry was well acquainted with John Marshall because both worked for the Metropolitan Museum of Art, New York. He also knew John Fothergill, another member of Warren's circle. Sox 2006.

${ }^{350}$ Burdett and Goddard 129.

${ }^{351}$ The Lewes House Council has not identified the date of the decorative tiles or their place of manufacture. The pattern suggests they may be Dutch or Flemish.
} 
view the shelves and cabinets which held ancient vases, jewelry, and the "the Will box," containing Warren's latest will. ${ }^{352}$

Warren assembled a staff of loyal servants at Lewes, some of whom were in his service for thirty years, and established connections with several local businesses. ${ }^{353} \mathrm{He}$ seemed careful to employ only those whom he could trust to be discreet about his antiquities trade as well as the habits of the young men and the eccentric American who lived and worked at Lewes. For the locals, Lewes House became a "familiar and friendly puzzle" and "their clothes, the fine Arab horses, and sometimes their behavior excited more or less humorous comment." ${ }^{354}$ Warren's antiquities enterprises, remodeling projects, and the needs of his household generated income for tradesmen and businesses in Lewes. A local carpenter, George Justice, was frequently at Lewes House, remodeling and building additions to Lewes House, repairing the antique furniture that Warren collected, and building wooden crates for shipping antiquities. ${ }^{355}$ Justice built the staircase and added the panels and the Corpus timbers in "Thebes." Warren also used the services of Edward Reeves (1824-1905), a Lewes photographer. Reeves took most of the well-known photographs of Ned Warren and John Marshall and provided the

\footnotetext{
${ }^{352}$ Burdett and Goddard 129. Warren frequently revised and updated his will.

${ }^{353}$ Warren's generosity was "quixotic" in that "those most loyal to him would think that they were taken for granted, while those who asked most appeared to be rewarded for their asking." Burdett and Goddard 142. James Shepherd, the butler, is shown at attention in one of the photographs of the Lewes House dining room. John Fothergill, one of the Lewes House circle, was present at Ned's cremation. He recalled "a little row of his [Ned's] old servants, pensioners and [a]carpenter [presumably George Justice] looking sad, silent ..." at the chapel. Fothergill 1949, 239.

${ }^{354}$ Burdett and Goddard 142. Matthew Stewart Pritchard, who is discussed below, was an avid swimmer and never wore a "costume" while swimming with the locals in the River Ouse.

${ }^{355}$ Warren left Justice a £1,000 bequest in his will. Article 12 (x). Justice had become what Burdett and Goddard called Ned's "office of works," a medieval term used for the official who supervised the royal castles and properties, and "the custodian of Warren's superfluous purchases of old furniture." Burdett and Goddard 132. After Warren's death, Justice established a furniture restoration business in Lewes.
} 
photographs for the auction catalogues, when $\mathrm{H}$. A. Thomas auctioned the contents of the house and outbuildings in 1929. George Justice's Furniture Restoration on Albion Street and Edward Reeves Photography on High Street are still located only a few blocks from Lewes House. $^{356}$

According to Burdett and Goddard, "Thebes" and the main house were provided with "substantial good things" but "there was nothing . . . that a woman, or for that matter many men, could call comfortable." 357 Warren encouraged his young assistants to exercise and provided a communal bathtub at Lewes House. ${ }^{358}$ The buildings were lighted solely by the windows and candlelight and the only pens were quills; few curtains or carpets were in the house and the oak furniture lacked cushions. Several photographs of the dining room have survived to document the furnishings: a brass chandelier with fourteen candles was suspended over a Tudor dining table flanked by antique benches. Lewes House was "cold and bleak" but "filled with artistic treasures." 359 He also collected antique furniture and silver, as indicated by the catalogues of the estate sales, both in Lewes and in Westbrook. ${ }^{360}$ At various times, Cranach's Adam and Eve, a Titian

\footnotetext{
${ }^{356}$ In May 2009, the author interviewed Colin Tompsett who worked with George Justice and, after Justice's death in 1932, bought the business. Tompsett did not know Warren, but he heard stories from those who did carpentry at Lewes House. He recalls seeing stacks of billing records and photographs from the Warren days in the back of the shop. None of these documents has survived. For George Justice, see "George Justice Furniture Restoration." http://www.georgejustice.co.uk/index.htm (16 April 2010). Edward Reeves was a watchmaker and jeweler who became interested in photography in the early 1850s. Thomas Reeves, his great-grandson, now runs the family business. The building at 159 High Street has been in continuous use for four generations. In May 2009, the author viewed portraits of Warren, Marshall, and various staff at Lewes House and photographs of antiquities among the glass negatives in storage. For Edward Reeves, see "Edward Reeves Photography." http://www.edwardreeves.com/about.html (16 April 2010).

${ }^{357}$ Burdett and Goddard 130.

${ }^{358}$ For homosexuality and public bathing in Warren's era, see Potvin 2005.

${ }^{359}$ Burdett and Goddard 134.

${ }^{360}$ Copies of the sale catalogues are in the Lewes House Archives. One of Warren's assistants, H. A. Thomas, inherited Lewes House and all of its contents-including the Warren Cup, Rodin's The Kiss, a
} 
drawing, a Filippino Lippi tondo, an ancient marble relief of a sleeping Herakles hung on the walls (Figure 5). ${ }^{361}$ Warren owned at least five Rodin sculptures, commissioning a version of The Kiss in 1900. ${ }^{362}$ Recent scholarship interprets such carefully arranged interior décor as a means of expressing homosexuality during this era. ${ }^{363}$

Warren's contemporaries offer varied commentaries on the community at Lewes House. Burdett and Goddard call it "a house for bachelors and scholars," a setting for “"the good life' [which] was to include fun and good fellowship, with horses to keep the men fit and good wine and food to complete their wellbeing." Warren is described as delighting "in minute scholarship ... the niceties of grammar," but "some of his friends were entirely indifferent to scholarship. If they were well and merry and fond of riding, he was content." ${ }^{364}$ Beginning with six members, the group expanded because Warren "delighted to take under his wing any boys or young men who, whether they were

bronze bust of Livia, Cranach 's Adam and Eve, and Filippino Lippo's Holy Family - as well as other property from Warren. For the bust of Livia, now in the Metropolitan Museum of Art, see Alexander 1953. Thomas went to Heidelberg and spent a year at Harvard (1903-04), apparently under the sponsorship of Ned Warren. According to Sox, Thomas was often at Fewacres, Maine, and Ned's "obsession" with Thomas was a source of friction between Warren and John Marshall. Sox 1991, 78-9. After Thomas married, he lived at Lewes House. Letters from Thomas and his wife Nan are in the Corpus Archives in Oxford and photographs of the couple and their children are in the Lewes House Archives. Warren appears in photographs with the Thomas children.

${ }^{361}$ In 1906 Warren gave the relief to Bowdoin College in his first "sendings." The Lucas Cranach (1526) is now in the Courtauld Institute, London; Filippino Lippi's Holy Family (1495) is in the Cleveland Museum of Art. Letters at Bowdoin and RISD indicate that Warren offered to sell the Titian drawing to patrons of these museums.

${ }^{362}$ Warren's version of The Kiss (1901-4), one of the three full-size versions made during Rodin's lifetime, is now in the Tate Modern, London. Rodin visited Lewes House and John and Mary Marshall in Rome. Burdett and Goddard mention Rodin frequently and reproduce correspondence between Warren, Marshall and Rodin. Burdett and Goddard 258-74. For the relationship between Rodin and Warren, see Sox 1991, 94-5, 111-15. For The Kiss in Lewes, see Poole 29-30. The Lewes House Registers document gifts of antiquities to Rodin. For Rodin and antiquities, see Garnier 2002. The relationship of Warren and Rodin lies beyond the scope of this dissertation.

${ }^{363}$ See, for example, Hatt 2007; Potvin 2008; Potvin 2009.

${ }^{364}$ Burdett and Goddard 142. 
promising or not, happened to cross his path." ${ }^{365}$ Burdett and Goddard describe him as “indulgent to oddities and would find a niche ... for artistically sensitive but incapable people." 366 An Oxford friend was equally acerbic: "The household included two or three rather feckless young men who had failed to make a living by professed yearnings for culture without any desire to study seriously. Warren supported them out of pure but mistaken kindness of heart." 367 H. A. L. Fisher, a visitor from Oxford, characterized Warren's community at Lewes more positively. He admired "the thoroughness and persistence with which E. P. pursued his learned quest" and described the Lewes House circle as "a small group of New College friends whom he [Warren] schooled in classical archaeology":

[Warren's] colleagues were subjected to a rigid discipline. They were ordained regular horse exercise, and rigorously sent off to bed at nine o'clock. A majordomo saw to the preparation of delicate meals, suited to scholarly digestion. Liberally financed from Warren's deep pocket the Lewes school of archaeology made notable contributions not only to Boston but also to learning in general. The names of Marshall and Pritchard, two college friends and disciples, became famous among connoisseurs ... 368

William Rothenstein, a frequent visitor to Lewes House, called it "a monkish establishment" with "an ample table and well-stocked wine-cellar." 369 He described "a secrecy [that] seemed to permeate the rooms and corridors, to exhaust the air of the house" and the relationships "often strained." 370 The commentary in Burdett and Goddard supports this assessment of Lewes House with a reference to "“chaotic

\footnotetext{
${ }^{365}$ Burdett and Goddard 131.

${ }^{366}$ Burdett and Goddard 131.

367 Grundy 18.

${ }^{368}$ Fisher 1940, 140. For Fisher, see Judge 2006; Ryan 2010.

${ }^{369}$ Rothenstein 1931, 343. Rothenstein, a friend of many important artists of the time, knew John Fothergill, who lived and worked at Lewes House. For Rothenstein's negotiating Warren's commission of The Kiss, see Rothenstein 370-3. For Rothenstein's biography, Lago 2008.

${ }^{370}$ Rothenstein 343.
} 
excitement' ... so frequent and so unnecessary" and a quip from Warren that "the Lewes kennel seems rather needlessly quarrelsome."’371

\section{The Appeal of Greek Art to Warren and Marshall}

As described in Burdett and Goddard, with the death of his father in 1888, Ned Warren set out single-mindedly to find his alter-ego. The first candidate was Arthur George Bainbridge West, who completed a BA at New College, Oxford, the same year as Ned. West was among his friends at New College and, in 1888, at Ned's suggestion, had travelled with Bernard Berenson, another friend, to Sicily. ${ }^{372}$ The following year, Warren engaged West as a "secretary" on a "trial" basis for a visit to Germany and Rome. West reported that he and Ned read Greek literature together on this trip and searched for antiquities to purchase. However, uncomfortable with the dual role of servant and companion, West returned to Oxford for an MA degree. ${ }^{373}$ Warren and West remained friends, with Ned serving as godfather to West's sons. One son, Charles Murray West, became Ned's secretary and manager at Fewacres, Warren's house in Maine. Warren left this property and its contents to Charles Murray West and his wife. ${ }^{374}$

Burdett and Goddard assert that West was "one of a long line of friends who became [Warren's] private secretaries" but do not discuss any of them except John

\footnotetext{
${ }^{371}$ Burdett and Goddard 213. Both statements are in reference to Lewes House in 1899.

${ }^{372}$ Burdett and Goddard 39.

${ }^{373}$ Burdett and Goddard 111. West was subsequently ordained and became a curate in a poor mining town in Wales. He married, went to Australia, and later became rector at St. Dunstan's-in-the-East in London. Sox 1991, 38-9. For St. Dunstan's-in-the-East, see Bradley and Pevsner 1998.

${ }^{374}$ West inherited Warren antiquities at Fewacres, at least some of which are now in the Reading Public Museum, Reading, PA. See 1997, 232. The Reading Public Museum has not yet been able to locate records of Warren's ownership. E-mails Scott A. Schweigert, 22 November 2009; 10 December 2009; and 12 December 2009, to author. Since these antiquities are not in academic collections and did not come directly from Warren, they are beyond the scope of this dissertation.
} 
Marshall (1862-1928). In this man, Warren found "a friend ... to share his fortune, his projects, and his heart.”375 Marshall, who studied at New College from 1881-85, came from a deeply religious family in Liverpool. According to a letter from Marshall reprinted in Burdett and Goddard, Marshall, with the blessing of his parents, "went up to Oxford to enter the Church." Marshall admitted to being "thoroughly religious" at that time and confessed an attraction to Anglo-Catholicism, an interest he would share with Warren. At New College, Marshall was "nervous and awkward," he said, because he did not possess the public school background of his fellows there. ${ }^{376}$ In his second year at Oxford, Marshall associated with an older Balliol student who introduced him to poetry. Shakespeare's sonnets, Marshall discovered, were more than "many bundles of rhymes": they contained "his secret," apparently a reference to his homosexuality. ${ }^{377}$

John Marshall was an excellent student, receiving Firsts in both of his examinations. ${ }^{378}$ At Warren's invitation, he spent August of 1890 with him in Keswick in the Lake District. ${ }^{379}$ Burdett and Goddard reprint over a dozen letters that document what David Sox has called "The Wooing of Marshall." These documents demonstrate the intensity of Warren's feelings for the man he was now calling "Maréchal":

\footnotetext{
${ }^{375}$ Burdett and Goddard 110.

${ }^{376}$ Burdett and Goddard 102

${ }^{377}$ Burdett and Goddard 104. Here, perhaps Marshall is referring to Sonnet 20 lines 7-8: "A man in hue, all 'hues' in his controlling/ Much steals men's eyes ...." Nineteenth-century British Uranian poets found homosexual references in Shakespeare. See Robinson 1999, 9.

${ }^{378}$ Burdett and Goddard 109. Oxford students took exams at the end of their first year and again at the completion of their studies; they were evaluated and assigned First, Second, or Third.

${ }_{379}$ Burdett and Goddard 112. Warren met Marshall in 1884; correspondence between them dates to 1887 when Warren was in "exile" in Boston. Burdett and Goddard 11-27, 32.
} 
I sometimes think of myself as a kind of express train, far off and unheard but coming quickly through the darkness, to take you away from Liverpool and your life there and set you in a warm room surrounded by books, downs, and horses. ${ }^{380}$

In another letter, Warren sent Marshall "a beautiful cloud which was blown away before it had let fall its heavy drops." ${ }^{381}$ Marshall, despite his parents' disapproval, agreed to serve as Warren's secretary and companion and wrote to Warren: "everything you say and do seems inseparable from you and my love for you." ${ }^{382}$ Early in their relationship, the men called each other by the love name, "puppy"; several photographs from the early days of Lewes House show the two men with their dogs (Figures 2 and 16). In his letters, Warren invariably addressed or referred to Marshall as "Johnny.",383

Recent scholarship on masculinity in the late nineteenth and early twentieth century views the relationship between Ned Warren and John Marshall, not in terms of its deviancy from the rigid social codes, but rather as expressions of the sublimated "desire for closeness" and an "intimacy with other men" that some men discovered and enjoyed outside conventional family units. ${ }^{384}$ Indeed, the photographs taken at Lewes House by Edward Reeves in the 1890s convey the intimacy Warren and Marshall shared, at least at the beginning of their affiliation. The two men look very much alike in that their mustaches and clothes are strikingly similar. ${ }^{385}$

\footnotetext{
${ }^{380}$ Burdett and Goddard 121.

${ }^{381}$ Burdett and Goddard 115.

${ }^{382}$ Burdett and Goddard 126

${ }^{383}$ Burdett and Goddard recount that Marshall first conveyed that he reciprocated Ned's affection by leaving flowers. Burdett and Goddard 123. A similar gesture is used in the male courting depicted in Evelyn Waugh's novel, Brideshead Revisited. Arthur Evelyn St. John Waugh (1903-1966) likely was acquainted with Warren's circle in Oxford. See Green 1976.

${ }^{384}$ Potvin 2008, 1.

${ }^{385}$ Potvin says that Marshall and Warren were "often mistaken for one another" but does not provide a source for his assertion. Potvin 2008, 119.
} 
In one of Reeves' photographs (Figure 16), Warren and Marshall lean against one another as each hugs a dog in his arms. The significance of their cuddling of "puppies" is even more apparent when one recalls that "Puppy" was the love name between the two. In another portrait, probably taken the same day as the other photograph, one of the Lewes House Saint Bernard dogs leans between the two men seated on a window sill at Lewes House (Figure 2). In this portrait, one finds more visual clues to their relationship. Potvin interprets the photograph as documenting "an aesthetic of intimacy ... a closeted one ... encoded by their outward gaze, which denies, at least on the surface, the true level of their intimacy." 386 The portrait, however, bears another reading given the men's antiquities enterprises. First of all, their identical hats not only signify their bond, they also recall the petasos, the wide brimmed sun hat worn by ancient Greek men outdoors. ${ }^{387}$ Appropriately, Ned is literally outside Lewes House, for he was the much more public face of Lewes House and controlled the sales or gifts of antiquities to the American museums, while Marshall looks outward from the darker realms of Lewes House, symbolizing the clandestine world of the antiquities trade and the esoteric domain of scholarship. ${ }^{388}$ Both Marshall and the dog gaze at Ned as if acknowledging his importance; their lines of sight have the same effect on the viewer. ${ }^{389}$

A third Reeves photograph taken before 1895 shows a bareheaded Ned on a bench holding an ancient torso at the end of the Lewes House garden (Figure 17). On his

\footnotetext{
${ }^{386}$ Potvin 2008, 119.

${ }^{387}$ For the petasos, see Johnson, Abrahams and Evans 1964, 75.

${ }^{388}$ Warren, as pointed out later in this chapter, considered John Marshall to be more scholarly than he.

${ }^{389}$ Potvin lends support for this interpretation in his assertion that "cross-class relationships were more easily disguised." Marshall, at least in the early part of his relationship with Warren, could be considered "a personal secretary." If a man "could assume the guise of a servant," he could live in "the same domicile as the master." Potvin 2008, 59.
} 
left sits an unidentified man, perhaps a workman as indicated by his rougher clothing and lack of tie. On the right is Warren's right-hand man, John Marshall, and the body language seems to echo the nature of their relationships. In the center is Warren, literally in possession of the sculpture: his face and body and the nude torso are open to the camera's lens. Marshall's body, on the other hand, is closed with his right leg twisted more tightly over his left knee as he leans toward Warren. His left hand touches Warren's arm, while Warren's right foot brushes against Marshall's right shin. At the other end of the bench apart from the pair, the third man sits stiffly with his hands in his lap. His discomfort at being photographed and in sharing the bench with the ménage of Warren, Marshall, and the nude torso is evident. The MFA acquired this sculpture (MFA 95.67) in 1895 for its Greek and Roman gallery, and it is considered one of the MFA's most important classical sculptures (Figure 18). ${ }^{390}$

Photographs of the torso taken by Edward Reeves on the lawn at Lewes House (Figures 19, 20, and 21) underscore the homoerotic appeal that Warren and Marshall found in Greek and Roman art. ${ }^{391}$ In the Reeves photographs, the torso is shown from different angles on or propped against a richly decorated cushion and draped chair. The play of light and shadow across the torso emphasizes its sensuality. The purpose of the

\footnotetext{
${ }^{390}$ The torso is identified as Hermes Psychopompos, the god in his role as conductor of souls, and reportedly came from Capua, where it may have been part of a funeral monument.Two places on the head of the torso show where small wings, an attribute of Hermes, once were attached. Scholars have speculated that it was a pendant for a sculpture of Psyche, now in Naples. Comstock and Vermeule 1976, 93. Matthew Stewart Pritchard, one of the Lewes House assistants, recalled helping Marshall and Warren move the torso around Rome in 1892 to avoid the police who were then making the first feeble attempts to regulate the exportation of antiquities. Sox 1991, 73.

${ }^{391}$ The sculpture is currently displayed in the Roman gallery of the MFA, but the marble is probably Greek (from Paros). The 1999 collection handbook calls the sculpture "Roman." MFA: A Guide to the Collection of the Museum of Fine Arts, Boston 1999, 93. The 1976 catalogue labels it as "Graeco-Roman." Comstock and Vermeule 1976, 93. The 1925 MFA catalogue of Greek and Roman sculpture attributes it to a "copyist" in the "Graeco-Roman period." Museum of Fine Arts and Caskey 1925 vi.
} 
photographs is not documentation, but rather to suggest its erotic appeal. Letters between Warren and Marshall discussing "the pelvic line" of this and other sculptures support such an interpretation. ${ }^{392}$ For example, from Rome Marshall bewailed his separation from Warren and confessed that only "the Hebungen" (literally, the "swellings") of the pubic region on such sculpture "rescue me from blank despair."393 These comments and the carefully staged photographs of the Hermes torso illustrate the "homoerotic projection of the Greek ideal" in Warren and Marshall, a trait also evident in the eighteenth-century art historian Johann Joachim Wincklemann. ${ }^{394}$ The photograph of the torso (MFA 95.67) in the 1906 and 1914 MFA Handbooks and the 1916 University Prints series for Greek and Roman Sculpture shows its right side, thus circumventing the frontal view and the "Hebungen" which fascinated Warren and Marshall. ${ }^{395}$ The homoerotic appeal of Greek art seems to have been one of the motivations behind some of Warren's selections for the MFA, especially the objects from his personal collection of "erotic art" that he gave to the Museum.

\section{Collecting at Lewes House}

Funded by the legacy from his father and with his house furnished and staffed at Lewes, Ned Warren launched his collecting campaign in 1892. Earlier, in the summer of 1891, he had sent Marshall to investigate sales in London and Germany and to visit

\footnotetext{
392 Potvin 2009. Potvin discusses how the collecting of the painter Charles Shannon (1863-1937) and illustrator Charles Ricketts (1866-1931) can be viewed as "an extension of the couple's identity . . . a queer intimacy materialized." Potvin argues that collecting reveals "the material traces of identity." 193

${ }^{393}$ Burdett and Goddard 183.

${ }^{394}$ Potts 1994, 184. Potts discusses the "very explicit homoeroticism in Winckelmann's accounts of art."

${ }^{395}$ A photograph of the torso (95.67) is in both the 1906 and 1914 MFA collection handbooks but neither provided a frontal view of Hermes.
} 
museums in Berlin, Cologne, and Frankfort. On this journey, Marshall visited Bernard Berenson, whom he already knew through Warren, and became acquainted with Edward Robinson, the American curator for whom he would acquire antiquities, first at the MFA in Boston and later at the Metropolitan in New York. ${ }^{396}$ In May 1892, Warren and Marshall purchased Greek vases at the van Branteghem sale in Paris. ${ }^{397}$ By October, of that year, Warren dispatched Marshall to Italy and, as documented in the letters, was in frequent contact with him. ${ }^{398}$

Warren was well acquainted with the antiquities market in Rome and, thus, could coach Marshall via an almost daily exchange of letters." ${ }^{\text {399 }}$ He directed Marshall to capitalize on his time in Rome to learn as much as possible about the range of antiquities he could purchase for Lewes House. Warren instructed him to visit the Villa Albani for its sculpture, Ostia for its "Roman archaeology," and the Vatican where the vases needed to be seen "thoroughly and repeatedly." 400 Furthermore, he instructed Marshall to call on Rodolfo Lanciani (1845-1929), the prominent Italian archaeologist, and Wolfgang Helbig (1839-1915), the advisor for the Danish collector Carl Jacobsen. ${ }^{401}$ Ned also suggested that Marshall contact Helbig's collaborator, Francesco Martinetti (1833-95), a Roman

\footnotetext{
${ }^{396}$ Burdett and Goddard 134-5.

397 Alphonse van Branteghem, a Belgian amateur collector of Greek vases, is discussed later in regard to several vases Warren acquired at this sale.

398 The letters are found in Chapter IX: Collecting in Full Swing," 151-72 and Chapter X: "Years of Achievement, 174-200. The Burdett and Goddard text does not include dates for the letters. Marshall later made collecting forays to Campania, the Bay of Naples, and Greece. Research for this dissertation has not yielded a chronology for these ventures. Matthew Stewart Pritchard, unquestionably the most important "field" agent in Ned's circle after Marshall, went to Greece, Turkey, and Egypt in search of antiquities. The Lewes House Registers document Pritchard's and Marshall's successes in acquiring a variety of antiquities. ${ }^{399}$ Burdett and Goddard 158. As explained earlier, Warren had begun purchasing antiquities in 1885; and, by 1887 two statuettes he had acquired entered the MFA as gifts from his father.

400 Burdett and Goddard 158.

${ }^{401}$ For Lanciani, see his AJA obituary Lanciani, Roberto 1930. Lanciani assisted the MFA and Penn in acquiring antiquities from Italy. For Helbig, Andrén 94-5; Nørskov 166-9; Dyson 43, 107-8, 148-9.
} 
"restorer" and dealer. ${ }^{402}$ Finally, Ned urged his friend to make contact with those having "private Tuscan collections in the neighborhood of Vulci and Cerveteri."403 By "private collections," Warren may have been referring to local landowners in Tuscany, but one suspects he also meant middlemen for those who were clandestinely "harvesting" Etruscan tombs. These instructions to Marshall demonstrate that Warren knew the most important collections in Rome and the network of antiquities traders and agents there.

It is not surprising that Ned Warren sent Marshall to Rome, for the city has been called an "Eldorado for antiquarians," especially in the late nineteenth century. ${ }^{404}$ The economic and political situation in late-nineteenth and early-twentieth century Italy was certainly favorable for those interested in obtaining antiquities. Many of the old landowning families whose wealth had depended on cheap labor on their estates were on the brink of insolvency, as food prices dropped with the importation of less expensive American grain and Asian rice. Thus, Italian aristocrats were forced to liquidate their collections, and rural agricultural workers turned to looting isolated Etruscan tombs as a means of livelihood. ${ }^{405}$ The "building fever" in Rome that followed national unification in 1870 also enhanced opportunities to acquire antiquities. Much of Rome was turned "literally, upside down":

Excavations for apartments, luxury buildings and commercial establishments - all of which needed roads, sewers and water-tore through layers of archaeological

\footnotetext{
402 For Martinetti, see Andrén 88-91; Dyson 149. Lanciani, Helbig, and Martinetti are among those who helped Warren and Marshall obtain the "Boston Throne," the still controversial three-part marble relief in the MFA Boston. Hartswick 119-30. The Boston Throne is discussed in Chapter 6.

${ }^{403}$ Burdett and Goddard 159.

404 Nørskov 93.

405 Nørskov 88-96.
} 
history that could barely be recorded (if at all) before its covering by modern constructions. ${ }^{406}$

Many artifacts, often in fragmented conditions, were uncovered from building sites, gardens, and vineyards. These objects were hidden from inspectors during the day so that they could be ferreted away to dealers at night. ${ }^{407}$ Rome became the center for antiquities trade and German archaeologist and dealer Ludwig Pollak (1868-1943), who lived in Rome for most of his life, recalled that each small Italian town had its "antiquarian" who gathered such objects to be sold in Rome. ${ }^{408}$ Thus, according to Count Tyszkiewicz from whom Warren purchased important antiquities, the city became "a true paradise for amateurs and agents of antiquities." ${ }^{, 409}$ Pollack described how the now demolished Piazza Montanara, near the Theater of Marcellus, was transformed into an open air antiquities market each Sunday where farmers and agents gathered to haggle with dealers, collectors, and archaeologists. ${ }^{410}$

Thus, by 1895, Warren—with Marshall's help in Rome—assembled an assortment of antiquities with the understanding that the MFA would purchase them for its collection. This sale seems to have been the result of a series of prior negotiations with Edward Robinson, the MFA curator. Robinson, it should be recalled, was well aware of antiquities then becoming available, for he had accepted the terracotta Helios and the bronze Athena from Warren in 1887 (Figures 8 and 9). Burdett and Goddard indicate that Robinson met with Warren and Marshall in Munich in 1891, apparently to discuss

\footnotetext{
${ }^{406}$ Hartswick 28.

${ }^{407}$ Nørskov 94.

${ }^{408}$ Pollak and Guldan 1994, 199.

${ }^{409}$ Count Michel Tyszkiewics in Notes et souvenirs d'un vieux collectionneur (1898) as quoted in Nørskov 95.

${ }^{410}$ Pollak and Guldan 147.
} 
antiquities for the MFA. ${ }^{411}$ By 1894, Warren and Robinson may have already reached an understanding because in a summer visit to Lewes House, Robinson drew up lists of antiquities destined for Boston and negotiated their prices. ${ }^{412}$ One hundred and sixty six antiquities were in this first of the Lewes House "sendings" to Boston.

\section{Edward Robinson and the MFA Classical Collection}

Edward A. Robinson (1858-1931) was an 1878 Harvard graduate who forsook law school to study Greek art and architecture. He was a student at the American School of Classical Studies in Athens and participated in the1881 excavations at Assos, the archaeological venture in Turkey sponsored by the newly established Archaeological Institute of America. ${ }^{413} \mathrm{He}$ followed up these experiences in Greece and Turkey with further Mediterranean travel and additional study in Germany, where he undoubtedly saw the extensive cast collections in Bonn and Berlin. After returning to the United States, he became the MFA's Curator of Classical Antiquities in 1885 and began teaching ancient art at Harvard in 1893. Eventually he devoted himself entirely to museum work, first as MFA Director (1902-05) and then as Assistant Director and Curator of Classical Antiquities (1905-10) and Director (1910-31) at the MET. ${ }^{414}$ In New York, Robinson retained his position as curator of classical antiquities until 1925 when he appointed his long-time assistant Gisela M. A. Richter (1882-1972), the first woman to hold a major position in an American museum.

\footnotetext{
${ }^{411}$ Whitehall 149.

412 Sox 1991, 51.

${ }^{413}$ For Assos, see Dyson 1998, 68-72. The MFA was a major sponsor of the excavation and received one third of the finds.

${ }^{414}$ For Edward Robinson, see Fairbanks 1931.
} 
During Robinson's twenty year tenure (1885-1905) in Boston, he was an enthusiastic proponent of its cast collection, writing a Catalogue of Casts from Greek and Roman Sculpture in 1887, a book that went through two revisions (1896 and 1900) and whose contents were adapted for catalogues and labels of cast collections at smaller museums. ${ }^{415}$ In 1887 he assembled a study collection of classical and Renaissance casts for the Slater Memorial Museum in Norwich, Connecticut, a collection that has survived and is still on view. ${ }^{416} \mathrm{He}$ also wrote an article on casts in collegiate museums. ${ }^{417}$

Despite his affinity for casts, Robinson was eager to augment the few antiquities then in the Boston collection. The AIA had contributed its share of the wide assortment of material from its first excavation project (1881-83) at Assos. ${ }^{418}$ In addition, in 1886 the MFA had recently purchased an Etruscan sarcophagus. ${ }^{419}$ By 1888 , Robinson conveyed a sense of excitement in his curator reports in proposing that the Museum acquire more antiquities:

... I hardly remind you of the value which even one first-rate specimen, if it were only a head or torso, would have for our Museum, it would fill a place which an entire collection of casts fills but imperfectly, both in attracting, interesting, and instructing the public and as an inspiration for artists and students of art . . ${ }^{420}$ Almost immediately, Robinson negotiated to acquire two groups of antiquities for the Museum. The first consisted of Roman busts, terracottas, Greek vases, Arretine pottery,

\footnotetext{
${ }^{415}$ Bowdoin and RISD used Robinson's text in the catalogues for their cast collections. Although Robinson is not credited, the same seems true of RISD's catalogue in the RISD Archives. See Robinson 1891.

${ }^{416}$ Dyson 1998, 140-1. The Slater still exists as part of the Norwich Free Academy. See "Slater Memorial Museum." Norwich Free Academy. http://www.norwichfreeacademy.com/museum/ (16 April 2009).

${ }^{417}$ Robinson 1917.

${ }^{418}$ Whitehall 64.

${ }^{419}$ MFA 86.145a-b.

${ }^{420} 1888$ Report of Curator, Department of Classical Antiquities as quoted in Whitehall 147.
} 
and Roman bronzes purchased on the "advice" of Rodolfo Lanciani. ${ }^{421}$ In 1889 he added a smaller group composed of two black-figure hydrias, marbles, and terracottas. ${ }^{422}$ Then, as a letter to the president of the MFA trustees indicates, an 1894 visit to Lewes House spurred his enthusiasm for antiquities and for Ned Warren:

His knowledge and experience as a collector have developed greatly ... he has been trying to secure only first rate things ... he has come across remarkable pieces of sculpture ... even original Greek works ... here, instead of a dealer, we have a man who is doing everything he can to help the museum, who is fixing his prices as low as he can afford to . . ${ }^{423}$

Robinson explained that Warren had already invested more than $\$ 15,000$ in Greek vases which now had to be sold to raise enough cash to respond to the market. The traffic in antiquities was so brisk, Robinson warned, that Warren would not have time to consult a committee back in America "else the impatient discoverer or owner will carry his treasure elsewhere . . ,424 Thus, in 1895 , circumstances on both sides of the Atlantic were auspicious for Lewes House antiquities to be transported to Boston.

From 1895 to1905, waves of Lewes House sendings filled the MFA galleries, crowding out the plaster cast displays. ${ }^{425}$ In 1902 Robinson's promotion to Director of the Museum strengthened his commitment to the acquisition of even more antiquities through Warren. However, both Robinson and Warren became embroiled in a dispute

\footnotetext{
${ }^{421}$ Whitehall 138.

422 Whitehall 146.

${ }^{423}$ Edward Robinson to Martin Brimmer 15 September 1894 as quoted in Whitehall 149.

${ }^{424}$ Whitehall 149.

${ }^{425}$ The MFA publications provide an indication of the shift from casts to authentic antiquities. The 1906 and 1914 handbooks devote two and a half pages to a description of the MFA casts. A Handbook of the Museum of Fine Arts, Boston 1906, 191-3; A Handbook of the Museum of Fine Arts Boston 1914, 359-61. In 1925 the MFA published a catalogue of Greek and Roman sculpture, but no mention is made of casts and the catalogue could not include all of the classical works in the collection. See Museum of Fine Arts and Caskey .
} 
with the Museum Trustees over the decision in 1902 to erect a larger museum on the Fenway. When the Trustees, under the leadership of Sam Warren, began planning a new facility, Ned Warren and Robinson objected to the plan but for different reasons. Warren argued that the priority should be on expanding the collection while quality antiquities were still available, not on constructing a new building. Robinson, for his part, insisted that casts should continue to be components of the classical collection and that they be allotted space in the new building. Robinson's efforts to guarantee the display of casts in the Fenway complex resulted in what has been called the "the Battle of the Casts," a fight he lost. As a result, in 1905 Robinson left Boston to take a curatorial post at the MFA's rival, the MET, and in 1907 he hired John Marshall as the MET's purchasing agent in Europe. ${ }^{426}$ During his twenty years of service to the Metropolitan, Marshall acquired some of the most important works of Greek and Roman art for its collection; at the same time, he was also involved in several forgeries entering the Museum. ${ }^{427}$

After 1905, Warren continued to sell and give antiquities to the MFA but on a drastically smaller scale. Even after Marshall's marriage in 1907, he and Warren continued to cooperate in antiquities ventures. Although the extent of Warren's impact on the MET has not been adequately recognized, the 2007 Metropolitan Museum's classical

\footnotetext{
${ }^{426}$ Robinson expanded the cast collection at the MET and published a guide. See Howe 1913, 252-3.

${ }^{427}$ The most well-known case of forgery at the MET was the terracotta "Etruscan" Warriors. On Marshall's recommendation in1915, curator Gisela Richter acquired two standing warriors and a colossal head of a third for the New York Museum. To his credit, Marshall was always suspicious about their authenticity and was pursuing their provenance during the last years of his life. Both Ned Warren and Harold Parsons attributed Marshall's nagging worries about the warriors as contributing to his death. See "The Most Outrageous Forgeries of All Time," in Sox 1991, 116-22. Richter delayed exhibiting the sculptures until 1933 after their validation through technical analysis and published a monograph three years later. See Richter and Binns 1937. Eventually, research revealed that the sculptures were indeed forgeries: they were removed from display in 1961. von Bothmer and Noble 1961; Andrén 69-72; Hoving 88-100.
} 
art catalogue acknowledged that Robinson and Marshall were responsible for many of the most important Greek and Roman antiquities in the collection. ${ }^{428}$ Indisputably, Robinson's confidence in Warren and Marshall resulted in the formation of the two foremost classical collections in the United States.

\section{Warren and the MFA}

From the onset of his work for the MFA, Ned Warren's goals were bold. In a nine page letter outlining his intentions and principles to the President of the MFA Trustees in 1895, Warren indicated that he firmly believed that the MFA's classical antiquities should provide learning opportunities for serious students:

My object is that the Museum should in time possess one of the finest Greek collections in the world, and so to make the study of Greek art possible in Boston. Every acquisition should be a step to that end. This collection, to be intelligible, should contain, not sculpture only, but gems, vases, coins, and good examples of all the minor arts. It does not provide exclusively for the demands of existing laymen; it rather supplies a field for thorough students, not at present as numerous as they may be later on. ${ }^{429}$

Warren was confident that the MFA could create a collection within ten or twenty

years that would "not fear comparison with European museums," but he warned that

To be successful one must be an opportunist. One must not impose a preconceived order of purchase when things come on the market so erratically.

\footnotetext{
${ }^{428}$ Due to the limitations of this dissertation, no attempt was made to examine the extent of Warren's impact on the Metropolitan Museum of Art. A search of the collection database on the MET website produces only two antiquities acquired directly from Warren: the marble portrait of the emperor Augustus (07.286.115) purchased in 1907 and the Minoan Agate Lentoid Gem (14.104.1) bought in 1914. A third piece, a bronze head of Livia (52.11.6) that was in Lewes House at Warren's death, came to the MET in early 1950s. For the bronze Livia, see Alexander. Photographs of this bronze taken by Edward Reeves for the 1929 auctions of Warren's estate are in the Lewes House Archives and the glass negatives are with Edward Reeves Photography, Lewes, East Sussex. For the recent tribute to Marshall and Robinson, see Picon 2007, 27. Warren is not included in the dedication.

${ }^{429}$ Warren to Martin Brimmer 4 September 1895, as quoted in Whitehall 151. Martin Brimmer (18291896) was a founding MFA trustee and President of the MFA for twenty-five years.
} 
Every variation from the opportunist rule implies an ultimate loss to the Museum, either in money or the importance to the collection. ${ }^{430}$

The Trustees, for their part, expressed reservations about some of Warren's proposed acquisitions. Ancient coins, for example, were a concern because they were "historically rather than artistically" interesting and might more economically be represented through reproductions. In addition, the committee objected to gems because they were "difficult to exhibit."431 However, vases were the chief source of contention with the Trustees, who were willing to accept only an "occasional purchase of a fine specimen." 432 Warren's response was a warning that

A general exclusion of vases seems ... neither practical nor desirable: not practicable, because they constitute the chief means whereby a connexion (sic) with dealers and archaeologists is opened and maintained; not desirable, since they satisfy the needs of students, the Museum must have a good sized collection. ${ }^{433}$

Eventually, the dispute between Warren and the Trustees subsided after Warren paid a visit to Charles Eliot Norton, who had been a trustee for twenty-two years. ${ }^{434}$ No record of what was said in this meeting has survived, but Warren must have been persuasive. In a July 26, 1895 letter to Martin Brimmer, the President of the Trustees, Norton effusively praised Warren and his efforts:

Could he act freely as agent for the Museum, I have no doubt that he [Ned Warren] would before long make it one of the important museums of the world . . .. The marbles which he now proposes ... will not indeed be of much interest to the general public, but they are of such a character, and of such importance in the

\footnotetext{
${ }^{430}$ Whitehall 151.

${ }^{431}$ Whitehall 151.

${ }^{432}$ Whitehall 151.

${ }^{433}$ E. P. Warren to Martin Brimmer 4 September 1895, as quoted in Whitehall 151.

${ }^{434}$ Warren and John Marshall were in Boston in the summer of 1895 and went to Ashfield in rural western Massachusetts where Norton spent his summers. For Norton and The Locusts, the $18^{\text {th }}$ century farmhouse in which the visit likely took place, see Dowling 2007. Dowling does not mention Warren in her book.
} 
history of Greek art, that the possession of them will make the Museum famous in the eyes of students of Greek art, and . . . confirm the public pride in it. ${ }^{435}$

The exact nature of the relationship settled upon by the MFA and Warren is difficult to determine. However, the upshot of these negotiations was that Warren's purchases were considered to be the Museum's property as soon as the Trustees gave their approval. The Museum was not financially liable for any objects it did not retain. ${ }^{436}$ When the expenses for these enterprises increased because of the costs entailed in maintaining Lewes House and in "the field," the arrangement was adjusted so that the MFA began paying the cost of those antiquities it accepted, plus an added $25 \%$ to cover Warren's overhead. Later the amount to cover the collecting expenses was raised to $30 \%$. Despite this increase, Warren was often left "well out of pocket," a situation that worried the Warren family, especially his older brother Sam who managed the Warren Mill Trust. $^{437}$

The MFA Trustees' qualms about Greek vases and Warren's retort that "the Museum must have a good sized collection" of them are significant in that the first shipment from Lewes House contained 59 Greek vases, well over a third of the 150

\footnotetext{
${ }^{435}$ Charles Eliot Norton to Martin Brimmer 26 July 1895, as quoted in Whitehall 152-3.

${ }^{436}$ Whitehall 148.

${ }^{437}$ Whitehall 153. Sam was appointed an MFA Boston trustee in 1892, the same year that Ned embarked on his campaign to acquire antiquities in Paris and Rome. By 1894, Ned's enthusiasm for antiquities led to a $\$ 77,000$ overdraft on his personal bank account and a dip into his capital for an additional $\$ 40,000$. As a consequence, Mrs. Warren and the siblings - especially Sam — became concerned. In 1895, a family meeting was called at Cedar Hill, which Ned attended with John Marshall. More family conferences took place with Sam and his wife Mabel; then, Mrs. Warren and Cornelia made separate visits to Lewes House. The end result was that Mrs. Warren agreed to rescue Ned with a \$25,000 loan. Ned also proposed a scheme for antiquities purchases over a five year period whereby the Warren family would put up $£ 1,000$ per year with the Museum matching the Warren contribution. Ned's proposal never materialized. Green $1989,128-9$.
} 
antiquities sent to the MFA. ${ }^{438}$ In order to discuss the significance of the vases Warren sent to the MFA, it is necessary to consider his relationship with John Davidson Beazley and how scholarship on Greek vases enhanced Warren's collecting.

\section{Warren and Beazley}

The third important collaborator in Warren's antiquities enterprise was Sir John Beazley (1885-1970), who exerted extensive influence on American scholarship in Greek art via the hundreds of ancient vases that Warren obtained for museums in the United States. Beazley's attribution of thousands of unsigned Attic vessels still serves as the system for dating vases. ${ }^{439}$

Without question, Beazley's approach to the study of Greek vases enhanced the value of the vases entering American collections via Warren. The underlying principles of Beazley's approach included the conviction that the "hands" of specific vase painters could be identified based on style, that these vase painters were as valuable to study as the better known artists of later periods, and that organizing vases according to their painters provided the best means of studying these objects. ${ }^{440}$ Beazley first employed this system for Attic red-figure pottery and then for Attic black-figure ware; and, later, other scholars extended this approach to pottery produced outside Attica. Before discussing the

\footnotetext{
${ }^{438}$ The shipment included 59 vases (mostly from the van Branteghem sale), eighty coins, ten gems, and "various objects in gold, bronze, and marble." Whitehall 149.

${ }^{439}$ For a history of the study of vase painting, see True 1987, 184-204; Cook 1997, 275-311; Oakley 2009.

${ }^{440}$ Robertson 1991, 1. Robertson is well qualified to describe the essential aspects of Beazley's methods because he served as Lincoln Professor of Classical Archaeology and Art at Oxford (from 1961 to 2004), a post Beazley held from 1925-56. Robertson adopted Beazley's methodology and helped update and enlarge Beazley's list of vase painters. See Beazley 1972. Robertson wrote a survey of Attic red-figure vases. See Robertson 1992.
} 
implications of Beazley's methodology, it is important to explore how he came to meet Warren and the nature of their relationship.

No full-length biography of Beazley has been written, with the collection of essays containing the reminiscences of his students and colleagues, Beazley and Oxford (1985) constituting the only comprehensive source of biographical information. ${ }^{441}$ The catalogue for an exhibition of Beazley's gifts to the Ashmolean Museum provides a list of his numerous publications between 1907 and $1966 .{ }^{442}$ Until the 1990s much of what was written about Beazley was panegyric; but, since then, scholars have engaged in a lively debate about his methodology. ${ }^{443}$ Although the origins of Beazley's attributive process and its role in the study of ancient painting are not the focus of this dissertation, a description of his approach serves to establish a context for Warren's and Beazley's relationship and its implications for antiquities collecting and scholarship in the United States.

In the eighteenth and nineteenth centuries, Greek vases were collectors' items valued for their aesthetic appeal. Scholars began to study them because of the depictions of mythological subjects and their relationship to Greek and Roman literature. In

\footnotetext{
${ }^{441}$ Kurtz 1985. See also Robinson 2004. Beazley's students included the twentieth-century's most distinguished scholars in Greek and Roman art, such as Bernard Ashmole (1894-1988), Dietrich von Bothmer (1819-2009), Joan Evans (1893-1977), and Humfry Payne (1902-36). Although Arthur Dale Trendall (1909-1995) was educated at Cambridge rather than Oxford, he became one of Beazley's most important disciples. Trendall followed Beazley's methods in attributing vases from workshops in South Italy. A search on the digital archive JSTOR produces over three hundred articles authored by Beazley or about his work (7 July 2010).

${ }^{442}$ Select Exhibition 1967.

${ }^{443}$ For hagiography, see Moignard 1990, 514. For the debate about Beazley's methods, see Whitley 1997 with the rebuttal Oakley 1998. For current attitudes toward Beazley's methods, see Oakley 2009, 605-6. For the structuralist approach to Greek vase scholarship that began in the 1980s, see Ferrari 2002, 1-10. For the limitations of Beazley's "shadowy figures," i.e. the specific artists he identified, see Beard 1991, 12-35.
} 
addition, scholars came to view scenes on red-figure and white-ground vases as revealing the influence of lost panel paintings by Greek artists like Polygnotos of Thasos. ${ }^{444}$ Later, in the attempts to organize the vases according to the time and place of manufacture, the inscribed names on some of the vessels led to the practice of attributing the decorations to individual hands. German scholars_ - like Wilhelm Klein, Adolf Furtwängler and Warren's friends and associates, Paul Hartwig and Friedrich Hauser-assembled lists of signatures and groups of vases around them. ${ }^{445}$

After visiting vase collections in museums across Europe, Beazley began to use the details employed by vase painters, especially the treatment of dress and anatomy, to compile lists of vase painters and attributions. Beazley's departure from the previous work of the German scholars was that he did not start with painters who left signatures. In fact, sometimes he ignored signatures, believing them misleading, and relied on careful observation to identify artists and to chart their careers. ${ }^{446}$ For those vase painters who did not sign their work, Beazley assigned names based on their favorite potter ("The Andokides Painter"); the location of a vase ("The Providence Painter"); the subject on an iconic vessel (“The Pan Painter"); a kalos name ("The Panaitios Painter”); or a characteristic element of style (“The Bowdoin Eye Painter”).

Beazley's method is often assumed to have derived from that of Giovanni Morelli (1861-1891), who attributed early Italian and Renaissance paintings. Warren's long-time friend, Bernard Berenson, adopted Morelli's approach in his scholarship and in his work

\footnotetext{
${ }^{444}$ Textbooks still present the Niobid and Phiale Painters as reflecting the innovations of Polygnotos. See, for example, Gardner and Kleiner 2010, 121-1.

${ }^{445}$ Robertson 1992, 3.

${ }^{446}$ Boardman 2001b, 128-38.
} 
as an agent and consultant for American collectors and museums seeking European paintings. Berenson, it has been suggested, may have inspired Beazley. ${ }^{447}$ Beazley’s most complete account of his methodology is a 1920 article on the Berlin Painter in which he described a "system of forms" (that is, shape, design, patterns, figures and execution). ${ }^{448}$ He copied the lines from vases, sometimes through tracings on their surfaces, sometimes transforming them laboriously into finished drawings. By drawing these details repeatedly, he taught himself to identify the "hand" of specific artists. In the case of the artist he came to call the "Berlin Painter," for example, he drew one hundred vases that he believed were decorated over a span of forty years. Beazley claimed that he could still recognize the original system in the Berlin Painter's later vases, even though the system had begun to collapse, possibly due to the artist's age or failing eye sight. Beazley's conclusion was that the system was the product of one artist whom he named after a red-figure two-handled storage vessel in Berlin. ${ }^{449}$ Beazley also made use of photographs; his wife Marie Bloomfield became an expert photographer and took hundreds of photographs, now preserved in the Beazley Archive. ${ }^{450}$

Very little is known about how Beazley met Warren and the research for this dissertation has not located documents or letters referring to specific visits by Beazley to Lewes House. According to Bernard Ashmole, a German vase specialist told Beazley that

\footnotetext{
${ }^{447}$ Rouet 59-81. However, Oakley disputes Morelli's and Berenson's influence. Oakley 2009, 606.

${ }^{448}$ Beazley 1922; "Sir John Beazley." The Beazley Archive http://www.beazley.ox.ac.uk/pottery/collection/johnbeazley.htm (7 July 2010).

${ }^{449}$ The database of the Beazley Archive contains photographs of 260 vases and fragments attributed to the Berlin Painter. Kurtz published Beazley's lecture on the Berlin painter. See Kurtz 1989b, 66-77. Kurtz also published a book reproducing Beazley's drawings of the Berlin Painter with photographs of select vases and a discussion of the Beazley's drawing style. See Kurtz and Beazley 1983.

${ }^{450}$ Ashmole 1985 For the Beazley Archive, see Kurtz Also, The Classical Art Research Centre: The Beazley Archive (website) http://www.beazley.ox.ac.uk/index.htm
} 
Warren was responsible for the name vase of the Pan Painter (10.185) entering the MFA. ${ }^{451}$ Beazley, who was especially interested in the Pan Painter, was soon introduced to Warren in Oxford, probably around 1910. ${ }^{452}$ According to Ashmole, Beazley then became acquainted with Marshall and was "able to study at leisure a whole range of newly found or newly acquired vases, sculptures, and gems" at Lewes and "enjoy the intellectual stimulus of these two fine scholars and lovers of antiquity." ${ }^{453}$ Without a doubt, Beazley possessed an encyclopedic grasp of Warren's antiquities including when and where Warren obtained antiquities and to what collections they were sent. ${ }^{454}$ Only two references in Burdett and Goddard offer insights on the relationship between Beazley and Warren. ${ }^{455}$ This biography noted Beazley as one of the visitors to Lewes during the First World War who helped revive "some of the old scholarly atmosphere."456 Beazley associated with others in Warren's circle: Harry Asa Thomas, who inherited Lewes House, and John Fothergill, whose inn near Oxford has been described as "an extension of Lewes House.”457 The Burdett and Goddard biography reprinted part of Beazley’s “striking tribute" published as Warren's obituary in the London Times, in which Beazley

\footnotetext{
451 Ashmole 1985, 61. The archaeologist was Karl Reichhold.

${ }^{452}$ Since the Pan Painter vase entered the MFA in 1910, Warren and Beazley presumably met that year or shortly thereafter. Beazley wrote a monograph on the Pan Painter in German in 1931, with the English version published after his death. See Beazley 1974.

${ }^{453}$ Ashmole 1985, 60.

${ }^{454}$ Beazley's essay "Warren as a Collector" in Burdett and Goddard and the annotated lists provided for Bowdoin and RISD are testimony to his familiarity with antiquities at Lewes House.

${ }^{455}$ The biography makes three briefer references to Beazley. Burdett and Goddard 141, 160, and 353.

${ }^{456}$ Burdett and Goddard 79. Burdett and Goddard asserted that "domesticity . . . had invaded the house on the marriage of [H. A.] Thomas and the entry of an adopted son [Travis]."

${ }^{457}$ Green 1989, 237.
} 
disclosed that he and Warren discussed the mighty oak in Pindar's Fourth Pythian Ode during their last talk together at Oxford in the summer of $1928 .^{458}$

What little is known about Beazley's youth before he settled down into his scholarly career suggests why he might have been comfortable with the Lewes House Circle and with Warren's collecting interests. Beazley learned about arts and crafts from his father, an interior decorator. Always an excellent student, he earned honors on all levels of his education. When his family moved to Brussels where his father studied glass-making in 1897, Beazley gained a base to travel on the Continent. ${ }^{459}$ After undergraduate study at Balliol College at Oxford (1903-07), he was elected Student and Tutor at Christ Church College, a post he held for seventeen years (1908-25). He travelled widely, working on his attribution studies in museums in France, Germany, and Italy. He thrived in the Philhellenic homosocial culture of Oxford: strikingly handsome and considered an accomplished poet, he was popular among the literary set at Oxford. T. E. Lawrence (1888-1935) praised his poetry, and the poet James Elrod Flecker (18841915) was his close friend. ${ }^{460}$ Four years after Flecker's death in 1915 , Beazley wed Marie Bloomfield Ezra, the widow of one of his friends from the British School at

\footnotetext{
458 The date given for the newspaper tribute is on January 7, 1929; but, only the month (January) was provided for an extended version in the Oxford Magazine. Burdett and Goddard 83-4. Charles Calhoun uses this reference to Warren as an oak in his article about Warren and Bowdoin. See Calhoun 1987.

${ }^{459}$ He claimed his obsession with Greek vases began in a museum in Brussels, where a cup by Onesimos was his "first vase-love." As qtd. in Ashmole 1985, 57. The tondo of this red-figure cup (Brussels, Musées Royaux, A889) shows a nude girl preparing her bath.

${ }^{460}$ For Flecker, Lawrence, and Beazley, see Rowse, 254. For the relationship of Flecker and Beazley, see Boardman 2001, 131; Basu 2004. For photographs of Beazley and Flecker, see Sherwood 1973.
} 
Athens. ${ }^{461}$ She learned to photograph vases and managed almost all aspects of her husband's life outside of scholarship.

John Beazley's associates are significant in that they may explain why he was drawn into the Lewes House Circle and may account for his fascination with Greek vases. The depictions of beautiful young men and the sexual activities frequently represented on the vases appealed to Warren and Marshall, and perhaps did the same for Beazley. Beazley's drawing and photographing of the images on vases and his preoccupation with the details of anatomy seem akin to Warren and Marshall's discussion of "pelvic lines" on ancient sculptures and the photographs they had taken of the Hermes torso at Lewes House. Another link with Warren may be seen in the Warren Vase which Warren apparently kept in "Thebes," his private study at Lewes House. According to Dyfri Williams, Beazley knew the Lewes House code name for the silver cup was "the Holy Grail.” Although Warren never attempted to sell it during his lifetime, he had a copy made "that passed to Beazley." 462

\section{Warren's Impact on the MFA}

Edward Perry Warren's “sendings” of antiquities transformed the MFA's classical collection: genuine objects in a variety of media and sizes filled the galleries once dominated by the plaster casts from the classical canon (Figure 22). Stone, bronze and clay sculptur, architectural reliefs and fragments, Greek vases, glass, jewelry, coins,

\footnotetext{
${ }^{461}$ For the British School at Athens, founded in 1886, see Waterhouse 1986. No references are made to Beazley.

${ }^{462}$ Williams 2006b, 26. Williams said the copy is in the Ashmolean Museum. A copy of the Warren Cup was displayed in the Common Rooms at Corpus in 1999. E-mail Ann Spike, 5 April 2011, to author.
} 
gems obtained from Warren eventually displaced the plaster casts from the galleries. ${ }^{463}$

In 1900, his brother Sam, who had become an MFA trustee, hosted a dinner to celebrate Ned's work on behalf of the Museum. At this occasion, Charles Eliot Norton expressed unqualified appreciation for Warren's efforts: "There is not now and never has been in America or in Europe a man with such capacities, will, and circumstances for collecting, and the museum must be entirely dependent upon him ...."464 The circumstances continued to be favorable for collecting and Ned supplied a large number of high quality antiquities to Boston each year between 1895 and $1905 .^{465}$ After 1895, Warren sent fewer vases in each sending - apparently in an effort to pacify the Museum Trustees — and concentrated on sculpture instead.

The absence of references to Warren in the MFA's early guides to its collections suggests uneasiness on the part of the Trustees about the Museum's relationship with Warren. For example, in the first handbook for the MFA collections almost all the objects featured in the classical art section came from Warren, but his name does not appear in the volume. ${ }^{466}$ Similarly, A Handbook of the Museum of Fine Arts (1914) highlights five works in the Classical Art collection, all of which arrived through Warren, yet he is not credited as the donor or agent. ${ }^{467}$ However, only a decade later, the

\footnotetext{
${ }^{463}$ Walter Muir Whitehall's two volume Museum of Fine Arts Boston: A Centennial History is the chief source for this transformation. Warren appears chiefly in Volume I. Whitehall includes a photograph of a gallery in the Copley Square building. Whitehall 1-245, 199.

${ }^{464}$ Whitehall 157. Although Ned Warren is not mentioned as present at the dinner, the context seems to suggest that he was there.

${ }^{465}$ The dates are from Whitehall 169.

${ }^{466}$ His brother, Samuel D. Warren, is listed as President in the general information section at the end of the handbook. See A Handbook of the Museum of Fine Arts, Boston 1906, 197.

${ }^{467}$ Warren is mentioned indirectly: a footnote at the end of the section devoted to Classical Art informs the reader that "A Catalogue of the Greenwell-Warren Collection [of Greek Coins], purchased from the Pierce Fund in 1904 has been published: Regling, Die griechischen Münzen der Sammlung Warren, Berlin, 1906.
} 
preface of the first catalogue of MFA sculpture (1925) touts the service of both Warren and Marshall. ${ }^{468}$ This expression of appreciation for Warren's work resulted from the number and variety of high-quality antiquities that Warren sent to the Museum. This tribute may have stemmed from the growing awareness among scholars-chiefly through Beazley and his disciples—of these objects in American collections. Before the range and significance of Warren objects in American museums are discussed, his role in forming the antiquities collections at six important educational institutions requires exploration.

A Handbook of the Museum of Fine Arts Boston 1914, 128. The absence of Warren's name in the 1914 handbook may have come at his request. Intermediaries and speculators may have attempted to negotiate higher prices from Warren because of his service to the MFA. Sam Warren's suicide in 1910 and Ned's homosexuality also may have prompted this anonymity.

${ }^{468}$ Museum of Fine Arts and Caskey v-vii. 


\title{
CHAPTER 3
}

\section{WARREN AND AMERICAN COLLEGIATE COLLECTIONS}

\author{
Although most of the antiquities from the Lewes House enterprise went directly to \\ the Museum of Fine Arts Boston through purchase or as gifts, Edward Perry Warren \\ donated or sold objects to other museums in the United States. He was most generous to \\ the Walker Art Museum at Bowdoin College in bestowing over five hundred Greek and \\ Roman antiquities - marble and bronze sculpture; Greek vases and fragments; Greek and \\ Roman terracotta figurines and reliefs; ancient glass, gems, jewelry, and assorted small \\ objects. Less well known gifts include sixteen Greek vases and the marble "Head of a \\ Giant" to the Fogg Museum at Harvard and over ninety small antiquities of various types \\ to Frank Tarbell, Professor of Archaeology at the University of Chicago. Warren also \\ sold antiquities to academic collections. He acquired seven impressive Greek and Roman \\ marble sculptures for the newly founded University of Pennsylvania Museum's \\ Mediterranean Section with funds provided by Lucy Wharton Drexel. At nearby Bryn \\ Mawr College, Joseph Hoppin bought thirty-one vase fragments from Lewes House to \\ establish a study collection for the American women seeking professional training in \\ archaeology and art history. Warren's role at the Rhode Island School of Design was \\ more complex, for there he served as an antiquities agent, consultant, and patron.
}


Archival research indicates that Warren was the source of at least seventy-five objects in the RISD collection and perhaps up to an additional one hundred antiquities.

Chapter 3 draws on a wide variety of sources. Histories of specific collections where they exist have been consulted, with that information supplemented and refined through research in the correspondence in the curatorial files and collegiate archives, as well as in the Lewes House Registers. Although the majority of the objects from Warren discussed in this dissertation are treated in Chapters 4-6, some of Warren's antiquities are addressed in this chapter in light of what they reveal about the collector's impact on the academic museums and how they illuminate his relationships with these distinctly different academic institutions and museums.

\section{Warren and Harvard's Fogg Museum}

Despite Warren's disparagement of Harvard, he gave sixteen Greek vases and a marble head to his alma mater's Fogg Museum. No documents explain Warren's motivation for these gifts and only minimal records corroborate their arrival. Warren does not refer to these antiquities in surviving correspondence and the sole reference to them in Burdett and Goddard appears in Beazley's essay on Warren's collecting: "He gave gifts to Harvard, his first university . ..." 469

In 1895 Harvard opened the Fogg with an exhibition of sixteen Greek vases loaned by "Edward P. Warren (A. B. 1883)." 470 This form of his name hints at the tenuous relationship between the Fogg and Ned Warren, for it is a moniker that he

\footnotetext{
${ }^{469}$ Burdett and Goddard 354.

${ }^{470}$ For histories of the Fogg Museum, see Chase 1930; Forbes 1941; Cuno 1996, 10-35; Orcutt 2006.
} 
abhorred and one that his friends, associates, and family never used. George Chase's 1930 history of the Fine Arts and the Museum at Harvard devotes only a single sentence to the 1895 exhibition. ${ }^{471}$ Few references to Warren and his loans — later gifts - appear in the Fogg Director's Reports and only briefly, if at all, in institutional and departmental histories of Harvard. The designation "Edward P. Warren" is carried over in a recent chronicle of the Fogg, in which he is described as an "antiquarian" in a reference even briefer than in Chase's account of the museum's early history. ${ }^{472}$ No notations about Warren's gifts to the Fogg are in the Lewes House Registers, and only five documents in the Harvard curatorial files refer to the Greek vases and the 1913 donation of a colossal marble head.

\section{Warren Vases at Harvard}

Two curatorial records at Harvard refer to Warren's Greek vases that made up the first Fogg exhibition. An 1895 receipt verifies that sixteen vases were received on loan from Lewes House with the notation "changed to gift 15 July 1927." On this receipt the original numbers assigned to the vases, 1633-1648, were crossed-out and replaced with new ones, 27.140-27.155, indicating that the vases were accessioned into the Harvard collection in 1927. Another document, a two-sentence typed letter to Warren in 1927

\footnotetext{
${ }^{471}$ Chase 1930, 131. George H. Chase (1874-1952) was the Hudson Professor of Archaeology at Harvard and a long time faculty member and administrator.

472 This account describes the Fogg's "reinvention" in the 1920s in relation to other leading academic museums. The lone reference to Warren is “. . . several alumni who had come under Norton's spell during their undergraduate years, among them the antiquarian Edward P. Warren and the investment banker and philanthropist James Loeb, lent their personal collections of classical antiquities to the museum for extended periods to augment the number of original works on view." Brush 2003, 22.
} 
from Edward Forbes, Director of the Fogg (1909-74), acknowledges the gift of the vases and offers thanks. ${ }^{473}$

Warren's vases are rarely mentioned in the Fogg Annual Reports of Charles Moore (Director 1896-1909) or his successor Forbes (Director 1909-1974). ${ }^{474}$ One exception is the 1897 report in which Moore argued that, although the Harvard students in archaeology, history, and fine arts had access to photographs of "works of art of all kinds," the Museum needed original examples to give the photographs "their full value" and praised the Warren vases as the "best of their kind and almost sufficient to [the museum's] needs." 475 Photographs of the galleries in the early 1900 s verify that Warren's vases were displayed in the Fogg. ${ }^{476}$ The long-serving second Director of the Fogg, Edward Forbes, makes brief reference to Warren's vases in two alphabetized lists in an Annual Report. ${ }^{477}$ No documents reveal who initiated the loan of the vases or its original terms. Beazley listed four of the vases in his 1918 publication of red-figure vases in American collections and indicated that each was "lent by E. P. Warren."478 Beazley did not provide the provenance for the vases. However, Warren had a supply of high quality vessels from his purchases at the 1892 van Branteghem sale in Paris, and so

\footnotetext{
${ }^{473}$ Edward W. Forbes to E. P. Warren, 3 August 1927, Harvard Museum Curatorial Files, Harvard University.

${ }^{474}$ For Moore, see Renn 2007. For Forbes, Whitehill 1969.

${ }^{475}$ Moore 1897, 1, 5.

${ }^{476}$ A photograph dated to 1905 or earlier shows a glass case used to display Greek vases. Brush 19. It is difficult to identify specific vases; however, given the date, most of the vases would have come from Warren. Warren's amphora (1927.48) with Theseus and Sinis is recognizable in the corner of one case. ${ }^{477}$ The 1926-27 Report of the Fogg Art Museum refers to Warren as "E. P. Warren, Class of 1883" under "Lenders of Objects" and in the next paragraph as "Edward P. Warren" among over thirty-five donors, under the subheading "Permanent Gifts and Acquisitions." Nowhere does Forbes identify Warren's loansgifts as vases. Given that the report covers 1926-27, it appears that Warren is being identified as lender in 1926 and donor in 1927. Forbes 1926.

${ }^{478}$ Beazley 1918, 38, 94, 134, 158.
} 
it seems likely that at least some of the Harvard vases may have been acquired at this famous sale. ${ }^{479}$

Given the dearth of antiquities in the Fogg in 1895, the sixteen vases from Warren certainly would have made an effective display. This group of Attic vases illustrates the variety of shapes, iconography, and decorative motifs popular in Greek vase painting in the late Archaic and Classical periods. ${ }^{480}$ Among the sixteen vases sent in 1895 , nine are decorated in the red-figure style with the remaining vessels being black-figure. One of the black-figure vases is done with the white ground technique, in which white slip was used for the background. The shapes include a plastic vase in the form of a woman's head (1927.144), a pyxis (1927.152.A-B), and a squat lekythos created for funeral ceremonies (1927.147). Pitchers, or oenochoe (1927.143 and 1927.154), and amphorae, the widebellied storage vessels with handles (1927.148 and 1927.150), also are represented in the group. The rest—a skyphos, kylikes, and cups—are drinking vessels appropriate for the symposium, the drinking party popular among elite men. Unquestionably, the iconography on the Warren vases would have created interest, for they illustrate a range of popular subjects. Visitors to the Fogg would have recognized heroes like Herakles, Theseus, and Oedipus; gods like Hermes, Triton or Dionysos; scenes with satyrs and Erotes; and depictions of daily life, for example, women at sacrifice or warriors arming. ${ }^{481}$

\footnotetext{
${ }^{479}$ Research has not located a catalogue or list for the van Branteghem sale that might verify if any of the vases at Harvard were purchased there.

${ }^{480}$ All sixteen vases were manufactured in or near Athens.

481 The iconography includes the Labors of Herakles (the Cretan Bull and the Erymanthian Boar on 1927.141); Theseus and Sinis (1927.48); Oedipus and the Sphinx (1927.151); Triton and Nereid (1927.50);
} 
As explained in Chapter 2, by the end of the nineteenth century, much scholarship on Greek vases focused on their attribution to specific artists based on inscriptions and stylistic features. Beazley assigned five of the Warren vases at Harvard to specific vase painters: two to the Athena Painter (1927.143 and 1927.154), and one vase each to the Akestorides Painter (1927.155), the Alikimachos Painter (1927.148), and the Foundry Painter (1927.149). The most notable Warren vase at Harvard is the red-figure amphora (1927.150) which Beazley attributed to the highly regarded Berlin Painter. This vessel (Figure 23) and the Foundry Painter kylix (Figure 24) have received the most scholarly attention among Warren's gifts to Harvard. ${ }^{482}$

The loaned vases from Warren created a comprehensive survey of shapes, decorative techniques, and iconography well suited to a study collection. Edward Robinson taught a course at Harvard focusing on Greek vases from 1892-1902, one of the first such courses offered in the United States. ${ }^{483}$ The Annual Reports of the Fogg reveal that the vase collection grew steadily through donations, usually one vase at a time and sometimes in the form of collections of fragments. The largest group of Greek vases

Dionysos (127.142); misbehaving satyrs (1927.145 and 1927.153); warriors in combat or arming( 1927.43 and 1927.149); combat between Hermes and a Giant (1927.154); woman at sacrifice (1927.155); women and Erotes ( 1927.147); youth, girls, and Erotes (1927.152A-B). A lip cup is decorated with lions (1927.146).

${ }^{482}$ The red-figure amphora (HM 1927.150) is discussed in the next chapter.

${ }^{483}$ Robinson was a friend of Warren and Beazley, the Curator of the Classical Collection at the Museum of Fine Arts, and Harvard alumnus (1879). As Lecturer in Classical Archaeology, Robinson had lectured on classical art at Harvard from 1893-94. Chapter 2 explained that he was one of the chief collaborators during the most prolific period of Warren's work as an antiquities agent for the Museum of Fine Arts, Boston. After Robinson was promoted to the Director of the MFA, George H. Chase (Harvard 1896) taught the Greek vase course beginning in 1902. 
arrived at the Fogg in 1925 with the bequest of fifty-six from Joseph C. Hoppin, an 1893 Harvard graduate and one of the first American scholars to specialize in Greek vases. ${ }^{484}$

Hoppin's fifty-six vases eclipsed Warren's sixteen not only in number but also in the variety of shapes and styles. The 1936 Fogg Art Museum Handbook extols Hoppin's bequest as the most important group of vases in the Harvard collection but makes no mention of Edward Perry Warren despite the fact that the Nolan amphora with Theseus and Sinis (1927.148) and the Foundry Painter kylix (1927.149)—both Warren's gifts— are featured in the publication. ${ }^{485}$

\section{Forbes, Warren and Classical Sculpture at the Fogg}

Edward W. Forbes shaped the art collection and the teaching of art history at Harvard for more than three decades because he was the foremost patron of its art collections as well as a member of the art faculty (1909-41) and Fogg Director (190944). ${ }^{486}$ In the early years of the Fogg, plaster casts were the primary means of studying and appreciating Greek and Roman sculpture, as was the custom in most museums. However, like Warren, Forbes had little use for these copies. Although he advocated the use of photographs because they revealed the texture of sculpture and argued that slides were necessary for large lecture courses, he believed that students should have ready

\footnotetext{
${ }^{484}$ Hoppin's career and his relationship with Warren are discussed in regard to Bryn Mawr later in this chapter.

${ }^{485}$ Fogg Art Museum Harvard University Handbook 1936, 16, 104.

${ }^{486}$ A member of the Fine Arts faculty (1909-41), Forbes was respected as an innovative teacher; he was well known for his "Egg and Plaster" course_ officially titled "Methods and Processes of Italian Painting" - in which students learned about artists' materials and techniques by actually painting frescoes and tempera on panel. He was responsible for developing technical analyses of Italian painting as a means of attribution and an approach to understanding the painting process. For a ten page list of the gifts from Forbes to the Fogg collections, see Forbes 1971.
} 
access to original works. ${ }^{487}$ Forbes sought to build a comprehensive collection at the Fogg, but he focused on adding "early Italian pictures, as well as Greek marble statues and other classical antiquities." ${ }^{, 48}$ As a result of his efforts, more than forty Greek, Roman, and Etruscan sculptures entered the Fogg collections during the thirty-five years of his tenure as Director, many donated by Forbes or his family and friends.

Forbes' camaraderie with archaeologist Richard Norton (1872-1919), the son of Charles Eliot Norton, spurred Forbes' interest in acquiring art for the Fogg. ${ }^{489}$ When he was Director of what was then called the "American School of Classical Studies at Rome" (1899-1909), Norton was actively engaged in the antiquities trade and is credited with establishing the study collection at the American Academy in Rome. ${ }^{490}$ In 1899 Forbes exhibited classical marbles he had purchased through Norton, the first ancient sculpture to be displayed at the Fogg, where the vases Warren had lent four years earlier in 1895 were still on exhibition. ${ }^{491}$ The most important of the sculptures acquired through Norton are the head and torso of a young god or hero (1926.48). ${ }^{492}$ Usually identified as the Greek hero Meleager and considered a copy of a lost work by the fourth-

\footnotetext{
${ }^{487}$ Forbes $1918 b, 22$.

${ }^{488}$ Forbes 1918a, 125.

${ }^{489}$ Forbes 1941, 20-21.

${ }^{490}$ For Norton's obituary, Kelsey 1919. For Norton and the collection at the American Academy in Rome, Geffcken 2001. Norton's contentious relationships with Arabs, Turks, and Italians were a concern for American collectors and agents. Bernard Berenson, Warren's friend, came to view Norton as an enemy because of the tension he created with the Italian government. Dyson 1988, 76-8, 112-4. Richard Norton was the source for many of the architectural fragments, ash urns, and sarcophagi that Isabella Stewart Gardner displayed in her villa on the Fenway in Boston. He also assisted Arthur Fairbanks in obtaining antiquities for Penn's Mediterranean section, as discussed later in this chapter.

${ }^{491}$ These included Roman sarcophagus fragments (1899.9a, b and c), dated to the late second to early third centuries C.E ., with a battle between Greeks and Amazons. Vermeule and Brauer 1990, 133; and a GrecoRoman marble Head of a Nymph or Hermaphrodite (1899.10), then identified as Aphrodite, dated to the late fourth century. Vermeule and Brauer 78.

${ }^{492}$ Found in 1895 in the ruins of a Roman villa near Civitavecchia, northwest of Rome, this sculpture was loaned in 1899 and then bequeathed to the Museum in 1926 by Forbes' sister. Vermeule and Brauer 45.
} 
century Greek sculptor Skopas of Paros, this statue (Figure 25) is the most published antiquity in the Harvard collections. ${ }^{493}$

The exhibition of Meleager (1926.48) at the Fogg in 1899 acquires added significance in view of the antiquities Warren was then sending to the MFA. Indeed, comparisons between this sculpture at the Fogg and Warren's Hermes (95.67) in the MFA would have been inevitable among visitors to the two collections (Figure 26), as would have been comparisons between the two collector/patrons. A generation separated Warren (1860-1928) and Forbes (1873-1969); however, they had similar backgrounds and interests. ${ }^{494}$ Both families were among the Boston elite, but the Forbes family had higher status than the Warrens, given that the maternal grandfather of Forbes was Ralph Waldo Emerson. Forbes, like Warren, had gone to Harvard (1895) where he studied art history with Charles Eliot Norton and, similarly, studied in Oxford (English Literature from 1900-1902). Both travelled extensively in Europe. Most importantly, both Forbes and Warren possessed the wealth for acquiring art then becoming available. The two connoisseurs were well known in Boston, and they likely had opportunities to encounter each other in Boston and in Oxford. ${ }^{495}$ However, research does not reveal correspondence or evidence of contact between Warren and Forbes except for the few terse letters in the files of the Harvard museums.

\footnotetext{
493 See Stewart 1977, 104-107, 110, 122, 144. For the current bibliography on the sculpture, see Vermeule and Brauer 45. A photograph in the Fogg dated to 1905 or earlier shows the Meleager in the entrance hall among the plaster casts. See Brush 18.

${ }^{494}$ For Forbes, see "Biographical Note: Forbes, Edward Waldo, 1873-1969." Harvard Art Museum Archives. 2008. http://oasis.lib.harvard.edu/oasis/deliver/ art00005 (4 December 2010).

${ }^{495}$ Forbes was a MFA Trustee from 1903-66.
} 
Thus, the 1913 arrival of the "Colossal Head of a Giant or Barbarian" (1913.13), the only sculpture in the Harvard collection from Warren (Figure 27), is puzzling. Three letters in the Harvard Museums files refer to this broken marble, now identified as "a splendid copy" from the late first or second century C.E. perhaps by sculptors from Aphrodisias. ${ }^{496}$ In 1912 Frank Gearing, Warren's secretary at Lewes House, wrote that he had a marble head that "Mr. Warren would like to present to the Museum," explaining that the sculpture would be "delivered free" if the Museum "would care to accept it.",497 Two replies came from Edward Forbes two days later. One to Gearing accepts the sculpture; the other, addressed to Warren, thanks him for the "generous gift." In the latter message, Forbes bewails that the Fogg was "practically without funds that it can devote to the purchase of works of classical art," but he adds it "already has enough originals to make us eager for more." ${ }^{498}$ Tellingly, Warren neither responded to Forbes nor offered more gifts of sculpture to Harvard. One wonders if he was not put off by Forbes' reference to the classical sculpture already in the Fogg, particularly Meleager (1926.48) and the other works procured through Richard Norton displayed there. In addition, one can perceive a coolness in the single sentence Forbes devotes to the Warren head in his Annual Museum Report, in which he describes a number of Greek sculptures entering the Harvard museum during the previous year: "The collection of the classical Antiquities has been enriched by a beautiful fragment of a fourth-century Greek marble head in the style of Scopas (sic), a gift of Edward P. Warren, of the Class of 1883." The

\footnotetext{
${ }^{496}$ Vermeule and Brauer 63.

${ }^{497}$ Frank Gearing to Director, Fogg Museum, 2 November 1912, Harvard Museum Curatorial Files, Harvard University.

${ }^{498}$ Edward Forbes to Frank H. Gearing, 14 November 1912; Edward Forbes to Edward P. Warren, 14 November 1912. Harvard Museum Curatorial Files, Harvard University.
} 
identification of Warren only as a Harvard graduate without reference to his work as a collector/antiquarian, his role in building the classical collections at the MFA, or the earlier loan of the Greek vases suggests tension between Warren and Forbes.

The Warren Head, indeed, lacks the elegance of the Meleager acquired by Forbes through Norton. The entire lower portion of the face is missing, prompting Harvard's authority on classical sculpture, George H. Chase, to describe it as "mutilated."

Photographs of the head in the curatorial files show that on its arrival from Warren it was set atop a distracting plaster plinth that was cut down and eventually removed (Figure 28). Now in storage, the Warren head is mounted much more appealingly on a metal rod.

Despite its mutilated condition and the awkward fashion in which it was displayed, George Chase argued in the 1917 College Art Bulletin that details of the face reflect the style of Skopas and that the hair is very similar to that of the Fogg's Meleager ${ }^{499}$ Chase's overriding message is that the recent acquisitions of original Greek sculpture in the Fogg and MFA collections are proof of the recently acquired "wealth" in American museums, which Chase complains was "habitually" underrated at that time. In his article he not only puts the Harvard sculptures into context, he praises the "wonderful growth of museums and the museum idea" then taking hold in America and urges

\footnotetext{
${ }^{499}$ Chase pointed to "the round wide-open eyes, with their strongly emphasized lids, and . . . the modeling of the forehead, with the roll of flesh over the outer corner of the eyes." Chase 1917, 113-3. This argument was based on a chain of stylistic details: the Warren Head was inspired by Skopas because the treatment of its hair is similar to that of the Fogg Meleager, which was widely accepted as having been a copy of a Skopas work. See also Chase's analysis of "Scopas" in Chase 1924
} 
teachers of art history to "make full use of original materials [that] lie ready to [their] hands." $" 500$

The gift of the "Warren head" in 1913 and the sixteen vases are the only legacies of Edward Perry Warren to his alma mater. Perhaps Warren lacked sufficient capital to give more antiquities to Harvard, a line of reasoning that is supported by Warren's persistent concerns about his financial situation and his wrangling with his brother Sam over the Warren Family Trust. However, Warren continued to give antiquities to both Bowdoin and RISD in the last two decades of his life. What seems telling is that Warren's name does not appear in Edward Forbes' extensive papers, nor do surviving Warren correspondence and the Lewes House Registers refer to the Fogg Museum or either of its first two directors, Charles Herbert Moore and Edward W. Forbes, both of whom Warren surely must have known. Perhaps this silence was due to rivalry that Warren and Marshall felt for the brash Richard Norton, who was active in the same antiquities circles in Rome and was the source of at least seven sculptures that entered the Fogg. ${ }^{501}$ Warren also may have resented Forbes, who successfully combined the roles of patron, museum director, college professor, scholar, and sportsman and received numerous awards and accolades. ${ }^{502}$ Forbes, married for almost sixty years and the father of five children, may have disapproved of Warren's homosexuality and his rejection of

\footnotetext{
${ }^{500}$ Chase 1917, 13.

${ }^{501}$ In addition, Norton's work for Isabella Stewart Gardner might have been an irritation.

${ }^{502}$ Married for 59 years with five children, Forbes was a painter and outdoorsman who enjoyed physical labor. He was fond of music and singing. He was awarded two honorary degrees from Harvard and one from the University of Pittsburgh and named Chevalier by the French Legion of Honor for his Red Cross service in the First World War. In addition to being a MFA Boston trustee for sixty-three years, Forbes served as a trustee of the Wadsworth Athenaeum and on the administrative committee of the Dumbarton Oaks Collection and Research Library of Byzantine Studies. "Biographical Note: Forbes, Edward Waldo, 1873-1969." (23 July 2009).
} 
traditional values. Or, the reverse might have been true: Warren's failure to lend more support to Harvard's museum could have been rooted in the expatriate's rejection of Brahmin Boston, especially in what he would have perceived as the pretension in Harvard establishing a museum in proximity to the MFA. Another underlying reason may be that Warren resented the status Forbes attained at Harvard, not only as a patron but also as a beloved teacher and mentor.

Whatever the reason or combination of reasons for the disconnection between Edward Perry Warren and the Fogg Museum and its directors, the seven Greek and Roman marbles Forbes presented to Harvard surpassed Warren's “mutilated head" in quality and quantity. ${ }^{503}$ More classical sculpture, of course, entered the Fogg during the directorship of Forbes, many donated through his encouragement. ${ }^{504}$ The paucity of Warren antiquities at Harvard is apparent in contrast with the over five hundred antiquities he gave to Bowdoin College in Maine.

\section{Warren and Bowdoin College}

\footnotetext{
${ }^{503}$ In addition to the three sculptures discussed earlier, Forbes bought five more major pieces, mostly through Richard Norton. Another is a colossal head of a goddess or woman (1900.4) in rosso antico, which Norton obtained from a vineyard near the Porta Salaria in 1899. Originally thought to be a Roman copy of a $5^{\text {th }}$ century work, this head is now considered to be a modern forgery. Vermeule and Brauer 169.Two impressive works entered in 1902 as gifts from Forbes. A statue of a nude athlete (1902.10) has been interpreted as a Roman copy of a work by Polykleitos dated to the Hadrianic period. Vermeule and Brauer 34-5. An equestrian figure on a votive relief (1902.5) is identified as a Hellenistic ruler. Vermeule and Brauer 58-9. In 1905, again via Norton, Forbes donated two Roman heads from a British collection. One (1905.6) is of a goddess from an acrolithic statue. Vermeule and Brauer 108. The other (1905.07), an architectural fragment, is the head of a Captive Barbarian Queen. Called the "Ponsonby Head," this work dated to the Trajanic/Hadrianic period.Vermeule and Brauer 107. Forbes also gave an inscribed Attic Grave Stele (1905.8) dated ca. 325. Vermeule and Brauer 41.

${ }^{504}$ For example, Paul J. Sachs donated the capital of a Roman pilaster (1926.31.2). The Norton family gave more than 25 small sculptures and fragments in 1922 and 1924 that had been collected by Charles Eliot and Richard Norton.
} 
From its foundation, Bowdoin College attracted patrons who provided a variety of gifts to enrich its curriculum and inspire its students. Its collection is recognized as one of the first in American academia. The evolution of Bowdoin's museum and the manner of the display is, in fact, a window on the changing tastes in American academia in the late nineteenth and early twentieth century. The relationship between Warren and the College is chronicled through correspondence in Bowdoin's curatorial files and the George J. Mitchell Department of Special Collections \& Archives, museum records, and in the Reports of President. In recognition of his generosity, Bowdoin awarded him an honorary degree in 1926 and acknowledges him in its museum catalogues and other publications. ${ }^{505}$

Bowdoin College was established in 1794 in Brunswick, a lumber and industrial center in southeastern Maine, through a charter signed by Massachusetts Governor Samuel Adams. ${ }^{506}$ Bowdoin owes the origins of its museum to James Bowdoin III (1752-1811), the College's benefactor, who named the institution after his father. ${ }^{507}$ James Bowdoin III bequeathed books and scientific materials to Bowdoin that reveal the sophistication of the college's patron. The two thousand volumes and over a hundred "bundles" of pamphlets he left to the college library more than tripled its holdings,

\footnotetext{
${ }^{505}$ See particularly, Calhoun 1987.

${ }^{506}$ Maine, called the "District" because it was a separate admiralty district during the Revolutionary War, became a state in 1820. Bowdoin College's first building, called "Massachusetts Hall," still stands on the edge of the present campus. For the early history of the college, Hatch 1927, 1-22.

${ }^{507}$ The men of the Bowdoin family were all named James Bowdoin. Historians now refer to these James Bowdoins as I, II, and III to distinguish them. James Bowdoin I (1676-1747) was reputed to have been the richest New Englander of his day; his son James Bowdoin II (1726-1790), a member of the Massachusetts Constitutional Convention and the state's second governor, was a prominent figure in Colonial America; his only son, James Bowdoin III (1752-1811), was the early patron of the College and named it in honor of his father. For a history of the Bowdoins, Kershaw 1976.
} 
making Bowdoin's the third largest library among the colleges in New England. ${ }^{508}$ A keen interest in "natural philosophy" among the Bowdoins also resulted in their bequests of scientific instruments and collections of specimens to the new college. ${ }^{509}$ In his extended visits to Europe, James Bowdoin III acquired an impressive collection of drawings and paintings which he also left to the college bearing his family's name, the first documented gift of art made to any American college or university. ${ }^{510}$ Like the books and scientific materials, these works of art were displays of elite status and were intended to refine the tastes of its students. Housed in the "philosophy chamber" of Massachusetts Hall, the College's first building, the art collection increased rapidly, with the arrival of a plaster bust of Benjamin Franklin, purportedly Jean-Antoine Houdon's own work, as well as casts of ancient sculptures. ${ }^{511}$ By 1850 , concerns arose about the need to clean and preserve the paintings as well as to house them in a designated gallery.

Bowdoin's fourth president, Leonard Woods (1813-1878), addressed the needs of the College's expanding art collection by insisting that an art gallery be included in a new

\footnotetext{
${ }^{508}$ Harvard had 9,000 books, Yale a little over 1,500 and Brown a little less than 1,500 volumes. Carpenter 1994, 85. Worthy of note is the Histoire de l'art chez les anciens, a French translation of Winckelmann's influential work which Bowdoin had shipped from Paris in 1809. For a photograph of the Winckelmann volume at Bowdoin, see Carpenter 114.

${ }^{509}$ Bowdoin's father conducted a wide range of scientific investigations, was one of the founders of the American Academy of Arts and Sciences, and was elected to the Royal Society in London. James Bowdoin III was particularly interested in geology, obtaining all the books on mineralogy available at that time. While in Paris, he also purchased collections of minerals and crystal models, all of which were left for the students' use at Bowdoin. Hussey 1994. For a celestial globe, an orrery, and an air pump from the Bowdoins, see photograph numbers 49-53 in Kershaw .

${ }^{510}$ Dimond 2008, 6. He gave drawings by Pieter Brueghel the Elder, Karel van Mander, Sebastiano Ricci, and Giulio Romano to the college. Burke 1981, 147-93; Becker 1985, x-xx. Although most of Bowdoin's paintings were copies of European masters, he also presented paintings by noted Colonial and Federal portraitists Robert Feke (ca. 1707-ca. 1752) and Gilbert Stuart (1755-1828). Wegner 141-2. James III purchased the majority of the copies "after the Masters" on the Continent; however, some may have been produced in the Boston studio of the Scottish immigrant painter John Smibert. Dimond 6-7.

${ }^{511}$ Kershaw 107; Burke 17.
} 
chapel designed by Richard Upjohn. ${ }^{512}$ With a thousand dollar donation from a wealthy cousin,Dionysus Theophilus Wheeler Walker (1813-1878), President Woods provided a permanent home for the college art collection on the chapel's second floor behind the organ, dedicated as the Sophia Walker Gallery in 1855 to honor Walker's mother. Convinced by his own visits to Oxford, Paris, and Rome that art could powerfully affect education, Woods also commissioned figural murals on Old and New Testament themes for the walls of the new chapel. ${ }^{513}$ The first antiquities arrived at Bowdoin in 1860: five large Assyrian reliefs from Ashurnazirpal II's palace at Nimrud given by Henri B. Haskell, a graduate of Bowdoin and a medical missionary in Mosul. ${ }^{514}$ These alabaster murals joined the school's paintings and casts in the Sophia Walker Gallery. Thus, by the 1890s, an impressive and varied assortment of art works greeted Bowdoin students attending college religious services. The crowded condition in the Sophia Walker Gallery eventually inspired efforts to fund a building devoted to housing the college's collection.

Again, the Walker family came to Bowdoin's aid. In 1891 sisters Mary Sophia Walker (1839-1904) and Harriet Sarah Walker (1844-1898) commissioned the Walker Art Building, in memory of Theophilus Wheeler Walker, their uncle and guardian, the long-time supporter of Bowdoin. ${ }^{515}$ Designed by McKim, Mead, \& White, one of country's leading architectural firms, this Beaux-Arts structure with its Pantheon-inspired rotunda still houses the Bowdoin art collection. The decorative programs on the exterior and interior of the Walker Art Building were intended to greet the visitor with a

\footnotetext{
${ }^{512}$ For the Upjohn Chapel, Miller 1994, 187; Sprague 2007, 218.

${ }^{513}$ For the murals, see Wegner 151-154.

${ }^{514}$ For Bowdoin's Assyrian reliefs, Porter 1989.

${ }^{515}$ For the Theophilus Walker and the Walker sisters, see Miller 187-215; Sprague 1994.
} 
celebration of western civilization's arts and letters. Bronze copies of the lions from the Loggia dei Lanzi in Florence still flank each side of the entrance, with statues of Demosthenes and Sophocles positioned on the right and left. Busts of Hermes, Dionysos, and Homer are installed in niches on the façade. ${ }^{516}$ The central rotunda, then called the Sculpture Hall, crowned with allegorical murals depicting Athens, Rome, Florence, and Venice served to display the College's collection of plaster casts of famous antique sculptures. ${ }^{517}$ As early as the 1880 s, patrons of Bowdoin had begun to purchase full-scale plaster copies of famous Greek and Roman sculptures. Photographs reveal that the Augustus of Prima Porta, the Artemis of Versailles, the Laocöon, and the Venus de Milo were the first objects visitors would have seen on entering the rotunda of the Walker Art Museum (Figure 29). These casts remained an integral part of the display until the 1930s. ${ }^{518}$ Ironically, while the plaster casts were featured in the grand setting of the Sculpture Hall, the five Assyrian reliefs - the authentic antiquities given to Bowdoin thirty years earlier — were banished to the basement of the new building. ${ }^{519}$

The Walker sisters not only provided an elegant setting for the College's assortment of portraits, drawings, old Master copies, plaster casts, and ethnological

\footnotetext{
${ }^{516}$ Anderson 1998, 43-8; Wegner 158.

${ }^{517}$ For the allegories of Athens, Rome, Florence, and Venice commissioned from Elihu Vedder (18361923), John La Farge (1835-1910), Abbot Hanson Thayer (1849-1921), and Kenyon Cox (1856-1919) respectively, see West 1972; Miller 1994, 197-201.

${ }_{518}$ As documented in the Reports of the Director of the Museum of Fine Arts found in the Reports of the President of Bowdoin College, the last cast acquired was a bust of the Apollo Belvedere on July 28, 1922. Andrews 1923, 65. The $4^{\text {th }}$ edition of the Bowdoin College Museum of Art catalogue, published in 1930, lists ten "classical sculptures" in the Sculpture Hall, three bronze reproductions, and twenty-four casts of famous Greek and Roman works. Andrews 1930. Around 1937, with the approval of Bowdoin College President C. M. Stills and Museum Director Henry Andrews, the new assistant director Phillip C. Beam began to remove the casts, which by that time had become very soiled and unattractive. The casts were lent to various preparatory schools in Maine. By the 1950s all mention of the casts had been removed from the Museum catalogues. Wegner 159. In October 2009, the author saw a plaster cast of the Venus di Milo, perhaps the only survivor of the college cast collection, in a drawing studio in the Visual Arts Center.

${ }^{519}$ Hatch 456.
} 
objects, they augmented the collection with gifts, often selected with the guidance of Martin Brimmer (1829-1896), the first president of the MFA Boston Trustees. ${ }^{520}$

Although their tastes were chiefly for paintings from the Barbizon School or watercolors by John LaFarge and Winslow Homer, they also donated over forty Greek and Roman antiquities, chiefly glass and pottery. ${ }^{521}$ Among these antiquities was an Attic red-figure pelike (1895.2), now attributed to the Dinos Painter and dated c. 425-420 (Figure 30), which the Walkers obtained from Edward Perry Warren in $1895 .{ }^{522}$

The Walker sisters likely knew about Warren through his work on behalf of the MFA. Martin Brimmer (1829-1896), the first president of the MFA Boston Trustees who served as an advisor to the Walkers in their patronage of Bowdoin, may have referred them to Warren, who at that time was beginning his collecting on behalf of the MFA. Another Warren collaborator, the MFA's curator Edward Robinson, supplied remarks on the Dinos Painter vase comparing it to Parthenon frieze, a commentary later incorporated into early museum catalogues at the College. ${ }^{523}$ As was his custom in his dealings with those purchasing antiquities, Warren sent along his own gift to Bowdoin, a silver coin from Syracuse (1895.1). This tetradrachm, dated c. 317-10, marks the beginning of an

\footnotetext{
${ }^{520}$ See the first catalogue for the Bowdoin Museum, Johnson 1895, 10.

${ }^{521}$ Report of the President of Bowdoin College 1893-4, 14; Miller 201-7; Herbert 1960b, 5.

${ }^{522}$ A letter M. Sophia Walker to Professor Johnson 23 February 1895 and commentary "Description by Edward Robinson of the Boston Art Museum of the Greek Vase presented to the Walker Art Building, Bowdoin College by the Misses Walker," 26 January 1895, George J. Mitchell Dept. of Special Collections \& Archives, Bowdoin College Library. Robinson ends his description with "It was purchased for the Misses Walker by Edward Perry Warren, in 1894, from a private collection in England, into whose possessions it came from Greece in 1893, and was said to have been found at Thebes."

${ }_{523}$ Andrews 1930, 38.
} 
over thirty year relationship between Warren and the Bowdoin College Art Museum, as the Walker Art Museum is now known. ${ }^{524}$

\section{The Warren Collection of Classical Art at Bowdoin}

Warren likely became aware of Bowdoin because of its proximity to Westbrook, where the Warren Mill was located, and through the Walker family. In addition, George Warren Hammond (1833-1908), a Warren cousin and employee at Warren Mills, was an avid collector of Egyptian antiquities who sent an array of gifts to Bowdoin in 1897 with "the hope and expectation that they will be the nucleus that will induce others to send their collections. ${ }^{, 525}$ Warren probably also knew Dana Estes (1840-1909), a prominent Boston publisher and collector who gave ancient glass, Cypriot pottery and terracottas, and Egyptian funerary objects to Bowdoin. ${ }^{526}$

Warren's relationship with Bowdoin blossomed in 1906, the same year in which he established a summer residence at Fewacres near the family's mill in Westbrook, only an afternoon train ride from Brunswick. In a letter addressed to the "Professor of Fine Arts, Walker Art Museum" in the fall of 1906, Warren introduced himself as the nephew

\footnotetext{
${ }^{524}$ Warren and ancient coins are discussed in Chapter 4. A red-figure stemless Cup 1901.1 in the Bowdoin College Art Museum is listed as a gift from E. P. Warren in some records. According to the donor file, Kevin Herbert suggested that it came from Warren. A card says that this object, with a label with the number 20, was received from "the Cleveland Cabinet on 12 September 1901." In the mid-nineteenth century, the Bowdoin Collection was sometimes called "the Cleveland Cabinet" because collections of minerals and art were housed in the top floor of Massachusetts Hall renovated in honor of Bowdoin Professor Parker Cleveland. Hussey 132-33.

${ }_{525}$ Herbert 1964, 3. For Hammond, Warren 1912, 233-5; Green 1989, 20-21, 216; Higginbotham and Westley 19. In 1900 Bowdoin bestowed an honorary degree on Hammond, who was the cousin of Ned's father and the husband of Ned's maternal aunt.

${ }^{526}$ Dana Estes1898, 9. Bowdoin awarded Estes an honorary degree in 1898. The Estes firm specialized in luxury books often printed on special paper from the Warren Mills.
} 
of George Hammond and offered three pieces of sculpture to the museum. ${ }^{527}$ One was the alabaster head of John the Baptist (1906.3), now attributed to a northern Italian workshop and dated c. $1500 .{ }^{528}$ The other two sculptures were ancient marbles. One-a "good portrait" head of Antoninus Pius (1906.1) dated to c. 138-40 CE - he described as "well preserved," for its marble surface still had "the original gloss" (Figure 31). The other, the Hellenistic relief of a sleeping Herakles with children stealing his club and wine (1906.2), he noted as being "somewhat corroded" (Figure 32). ${ }^{529}$ In this letter, Warren included the provenience for his gifts: he bought the Antoninus Pius and John the Baptist heads in Rome and suspected that the latter may have been made in Milan. The Herakles relief came from a wall in Florence, but he confessed he could not identify the workmanship as either Roman or Alexandrian. The Herakles relief had been at Lewes House because a Reeves photograph shows it hanging on the wall of the dining room there (Figure 5). The circumstances of its arrival in the United States are not clear. Warren may have brought it to Fewacres to serve as a decorative element as it once did at Lewes House.

Correspondence with curators at the University of Pennsylvania preserved in the Penn Archives reveals that he had offered to sell the Antoninus Pius portrait to Penn in 1902. In any case, the trio of sculptures - the Herakles relief, Antoninus Pius portrait, and head of John the Baptist — far surpasses any set of gifts Warren gave to other academic

\footnotetext{
${ }^{527}$ Warren's letter to Johnson does not refer to a fourth sculpture that he gave to Bowdoin in 1906, the gypsum head of Assunasirpal II of Assyria (1906.4) dated to 900-850. Why this object was not mentioned in the initial letter is not clear; the museum records only indicate that the relief is a gift from Warren. There is no additional information about how and why Warren acquired the panel fragment. One assumes that he desired to augment five Assyrian reliefs acquired in 1850. For a discussion of its significance and where it was placed in the Northwest Palace at Nimrud, see Porter 13.

${ }^{528}$ Burke 37. Warren later gave Bowdoin another medieval sculpture, the limestone Head of a King (1915.100), French and dated 1220-1230. Burke 49-51.

${ }^{529}$ Edward Perry Warren to Professor of Fine Arts, 22 September 1906, Edward Perry Warren Donor file, Bowdoin College Art Museum.
} 
collections and demonstrates his keen interest in Bowdoin. The head of Antoninus Pius (1906.1) is discussed in Chapter 4 in the context of other Warren sculptures.

In 1906 Warren invited Bowdoin professor Henry Johnson (1855-1918), who also served as the Director of the Museum, to see three sculptures at Fewacres, which he advised could be reached "by trolley from Portland." In a postscript, Warren added "If you prefer not to undertake the journey, I would send them to you."530 Johnson recognized the value of Warren's gifts and his patronage in a 1907 Report of the Curator of Art Collections announcing that "the present year has seen the bestowal of the most valuable single gift of works of art received since the Walker bequest, namely, the classical and later sculpture given by the distinguished critic of classical fine art, Mr. Edward P. Warren, a donor not personally associated with the college." 531 In the same document, Johnson lamented the lack of funds at Bowdoin for "any systematic instruction in the history of art," a complaint that he repeated frequently during his thirty years as Curator. ${ }^{532}$

Warren shipped the sculptures to Brunswick because in another letter he apologized for "confusion" in packing which resulted in a crack in the marble Herakles relief. He offered the consolation that a crack is better than the "disintegration of the surface" or going to "ruin" in the wall (presumably in Florence) where he had obtained it. Now, he said, at least the relief would be "safely housed." Furthermore, in expressing his approval of Bowdoin's new building, Warren advised that he might see some "chances"

\footnotetext{
${ }^{530}$ Edward Perry Warren to Professor of Fine Arts, 22 September 1906, Edward Perry Warren Donor file, Bowdoin College Art Museum.

531 Johnson 1907, 59.

${ }^{532}$ For Henry Johnson, see Hatch 173-4; Beam 1991, 4.
} 
for more bequests. He admitted that his "own interest is for museums where people have quiet, rather than centres (sic) of population." 533

Warren's enthusiasm for Bowdoin quickly grew. In 1908 he provided "notes as full as [he] could make them" on the sculptures given in 1906 and began providing lists of objects he intended for Bowdoin, assembling the "sendings" from what remained from antiquities purchased in lots for the MFA Boston. ${ }^{534}$ Although he confessed that the antiquities he gave to Bowdoin were not "the first pick," he confided that the MFA "did not have all that was good." ${ }^{535}$ By 1913 he committed himself to continue to give objects to Bowdoin "to whatever effort my overtaxed and recalcitrant finances will allow." $" 536 \mathrm{He}$ admitted that he was selecting antiquities for Bowdoin without consulting Johnson beforehand but assured him what was not wanted at Bowdoin simply could be returned to Fewacres. Warren declared that his "sendings" consisted "wholly of gifts," emphasizing that he would cover all expenses for shipping. Moreover, he confided that he had requested that Beazley compile a list of antiquities designated for Bowdoin, sorting vase fragments and supplying attribution ("assignment of the vases to their authors") in a form that could be employed as labels in the Museum. ${ }^{537}$ Three such inventories by Beazley under the headings List I, List II, and List III are in the Curator's Reports to the President of Bowdoin for 1923 and 1925.

\footnotetext{
${ }^{533}$ Edward Perry Warren to Henry Johnson, 12 November 1906, Edward Perry Warren Donor File, Bowdoin College Art Museum. Other letters from Warren to Johnson in this file are henceforth shortened to EPW to HJ, date, BCMA.

${ }^{534}$ EPW to HJ, 29 February 1908, BCMA.

${ }^{535} \mathrm{EPW}$ to HJ, 30 October 1912, BCMA.

${ }^{536} \mathrm{EPW}$ to HJ, no day September 1913, BCMA.

${ }^{537}$ EPW to HJ, no day September 1913, BCMA. Beazley created similar lists for RISD.
} 
Over the next quarter century, the freewheeling transfer of antiquities from Lewes House to Bowdoin, sometimes directly from England but often by way of Fewacres or Boston, was not without mishaps and mistakes. Letters at Bowdoin document three incidents. One, a crack in the marble Herakles relief (1906.2) during transit to Bowdoin, has already been described. Another instance of damage is documented in a letter from Warren to an assistant curator in which he apologized for breaking "your" Faliscan vase. ${ }^{538}$ The third "mishap" was mistakenly sending Bowdoin a South Italian red-figure "jug," intended for Boston. Frank Gearing, a Warren assistant at Lewes House in charge of shipments, apologized to Johnson: "Being indecent, it should have never been included in your consignment." ${ }^{539}$ This vase is likely the Apulian red-figure oenochoe (MFA 13.93) discussed in Chapter 4.

As the "sendings" from Lewes House to Bowdoin continued, the relationship between Warren and the curators at Bowdoin—first, Johnson and later his successor Henry Andrews (1821- 1939)—deepened. ${ }^{540}$ A 1913 exhibition of Warren's gifts to Bowdoin, presumably part of the permanent display in the Walker Museum, "much pleased" Warren. He wrote to Johnson that the antiquities made "a better effect than I hoped [they] would make. ${ }^{.541}$ In another letter, Warren adopted a confidential tone with

\footnotetext{
${ }^{538}$ Edward Perry Warren to Anna Smith, 19 October 1927, BCMA.

${ }^{539}$ F. H. Gearing to Henry Johnson, 16 December 1912, BCMA. Research has not identified such a vase at the MFA; it may have been one of the "Phylax" vases thought to depict scenes from a type of farce popular in South Italy and Sicily during the fourth century BCE. The typical costume of the actors on such vases was padded tights with a large false phallus.

${ }^{540}$ Directors of Bowdoin College Museum during this period were Henry Johnson (1881-1918), interim Charles T. Burnett (1918-1920), and Henry Andrews (1921-1939).

${ }^{541}$ EPW to HJ, no day September 1913, BCMA. Research has not located any further references to such an exhibition.
} 
Johnson, explaining first that he was sending coins and closing with the comment that he had "some things to tell you in your ear."

Warren confided that he knew that Johnson has a "hard" task in managing the Museum: "since your building cannot contain and conceal the rubbish that is likely to be poured into it by 'generous donors.' It needs to be more exclusive than a bigger museum."543 In 1915 Warren disclosed that he was becoming "more systematic," with the goal of creating "a good little illustrative collection of antiquities, small things that would help a student without making much show, no expensive specimens" as an "apparatus" that would "develop quietly." Stressing that he was "not fond of archaeology without a knowledge of Greek and Latin," he expressed a hope that funds might be raised to sponsor "a scholarship in classics and archaeology." Whether he envisioned that the scholarship would have sponsored a young man's enrollment at Bowdoin or, as was becoming a practice at other colleges and universities in the United States, funded an opportunity for a Bowdoin student to attend the newly established programs at the American School of Classical Studies in Athens, is not clear. ${ }^{544}$

\footnotetext{
${ }^{542}$ F. H. Gearing to Henry Johnson, 16 December 1912, BCMA. A gift of 18 Greek coins (1914.6.11916.6.19) were accessioned in 1914; however, research has not revealed what Warren referred to as "things to tell you in your ear."

${ }^{543}$ EPW to HJ, no day September 1913, BCMA. Examples of what Warren may have meant by "rubbish" can be found in lists of acquisitions in the Reports of the Director of the Museum of Fine Arts. For example, "an old stone axe from the Southwestern United States, blood-stained and presumably used in sacrifices" Andrews 1926, 45 . Note: with Andrews the title of the Bowdoin professor in charge of the museum changed from "Curator of the Art Collections" to "Director of the Museum of Fine Arts." To prevent confusing with the Museum of Fine Arts, Boston, only the civic museum in Boston is referred to as the MFA in this dissertation.

${ }^{544}$ Edward Perry Warren to Miss Curtis, 19 December 1915, BCMA .
} 
Johnson, for his part, continued to heap praise on Warren. In 1916 he announced that Warren had "made extensive and valuable additions to his previous gifts." 545 Since Bowdoin had "no fund for the purchase of such objects," he expressed relief that "such a distinguished expert of international reputation ... should be interested in the expanding, liberal work of Bowdoin College." Johnson also reported that courses in the art history and the Greek and Latin departments made "immediate use of this original material" and acknowledged that Bowdoin was "indebted to the generosity and professional help of the gentleman who has seen our need and acted practically in contributing to meet it.",546

When Henry Andrews (1821- 1939) succeeded Johnson as Director of the Art Collections, Warren's relationship with Bowdoin continued. ${ }^{547}$ Andrews expanded the offering in art history which he taught with the textbooks and lantern slides then becoming available. ${ }^{548}$ Warren's antiquities at Bowdoin began to be referred to as the "Warren Collection of Classical Art" and annotated lists arrived from Lewes, with remarks from "Prof. J. D. Beazley" suitable for labels or for inclusion in a catalogue. ${ }^{549}$ For a bronze Greek statuette (1923.49), Beazley added the comment, “A bronze figure of a youth naked above the waist, with a garment from waist to ankle. He originally carried

\footnotetext{
${ }_{545}^{545}$ Bowdoin accessioned 10 pieces from Warren in 1915.

546 Johnson 1916, 73.

${ }^{547}$ Andrews, who succeeded Johnson in 1921, graduated from Bowdoin in 1894 and taught English at MIT before taking the position as Director of the Art Museum. Andrews, like Johnson, had trained himself in art by traveling in Europe and extensive reading. For Andrews, see Beam , 4, 11-13.

${ }^{548}$ In the first annual report he described how the smaller lecture room in the basement of the Museum had been outfitted to allow two lantern slides to be displayed side-by-side so that comparison could be made. Andrews 1920-21, 47. A lantern slide in the George J. Mitchell Dept. of Special Collections \& Archives of the Bowdoin College Library shows the arrangement of the room. The textbook Andrews used, Apollo: An Illustrated Manual of the History of Art Throughout the Ages, contains photographs of Warren antiquities in the MFA. Reinach 1935, 52, 81.

549 These inventories are titled List I, II, and III. Lists I and II came to Bowdoin in 1923 with the much longer III (with 90 entries) arriving in 1925. These lists might reflect Warren's intent to liquidate what antiquities remained in Lewes in the 1920s when he spent more summers at Fewacres and concentrated on completing the Defence of Uranian Love.
} 
a burden on a pole from his shoulder." He described a Greek votive (1923.109) as "a small bronze bull inscribed Sacred to Kabeiros," observing "No doubt, one of a pair harnessed to a cart or plow, whence the plural in the inscription, Greek work of the $5^{\text {th }}$ century, B. C.” (Figure 33). ${ }^{550}$ Sometimes, Beazley gave an evaluation and proposed a date, as with a Hellenistic gold cable bracelet (1923.35): “Great work of about the $3^{\text {rd }}$ century." Other times, he offered comparanda such as, for a bronze protome (1923.16): “A bronze griffin's head, hollow cast from a cauldron. A complete cauldron, decorated with such heads is figured in Olympia 4, Page 115 Missing, parts of the ears and pompom on the forehead, Greek work of about 600 B.C." ${ }^{551}$ In 1924 Warren and Charles Murray West, his secretary in residence at Fewacres, spent almost a week at Bowdoin unpacking and arranging antiquities in the Boyd Gallery of the college museum. Warren also supplied a copy of the two-volume catalogue of his coin collection Die Griechishen Münzen der Sammlung Warren (1906) for the Museum's reference library. ${ }^{552}$

Although Warren often expressed the wish that his gifts and efforts on behalf of Bowdoin remain "quiet," in 1926 he proposed that Beazley write a catalogue for the antiquities he had given to Bowdoin. Warren reassured Andrews about the expense and labor involved: the collection was not "ambitious" (i.e. not large) and he would cover the printing cost, arguing that doing so in England would be cheaper. Warren contended that publishing his collection would make the interest in it "more lively" and would prompt

\footnotetext{
${ }^{550}$ The bronze votive (BCMA 1923.109) is discussed in Chapter 4.

551 Andrews 1924, 53. One object in List I is simply identified as a "bronze forgery," 54.

552 Andrews 1924, 54. The Die Griechishen Münzen der Sammlung Warren (1906), now in the George J. Mitchell Dept. of Special Collections \& Archives of the Bowdoin College Library, is probably this gift; however, no inscriptions in the volumes verify this speculation.
} 
others to contribute to its expansion. He requested that photographs be sent to Beazley so that the British scholar could compose entries. ${ }^{553}$

Warren wrote an introduction to the catalogue: a seven page typed manuscript with the title "Preface by E. P. Warren" in the Donor Files of the Bowdoin Art Museum. Beazley sent a copy of Warren's preface to Bowdoin in 1941, but it is not clear if the undated document now in the Donor Files arrived at Bowdoin in its present form or is a copy of the version Beazley sent. ${ }^{554}$ This essay was incorporated as an appendix entitled “The Bowdoin Collection” in Burdett and Goddard's biography published the same year. ${ }^{555}$ Warren began with an admonition to readers to "lay aside seriousness and resign [themselves] to enjoyment." Fittingly, the first antiquity mentioned is a terracotta figurine of a comic rider on a braying donkey (1923.10), dated to 525-500. He describes the figure (Figure 34) as a "silenus . . laughing his fill . . f found in a grave at Tanagra" and citing it as evidence that "the Greeks and their lofty god [s] . . were not always cold and classical." He then directed the visitor to terracotta grotesques (Figure 35) he had given to Bowdoin: "a bearded dwarf carrying a ram" (certainly1915.51); big eared man" (likely 1913.53); and “an aegipan who carries a baby” (perhaps 1923.12). From these grotesques, Warren shifted to an assertion that the "exalted style" of Greek sculpture can only be viewed through Roman copies or on the depictions on vases. After calling attention to the head of Antoninus Pius (1906.1) (Figure 31), which he stressed as "said

\footnotetext{
${ }^{553}$ Edward Perry Warren to Professor Andrews, 1 November 1926, BCAM. This letter is unusual in that it is typed rather than handwritten on Lewes House letterhead.

554 J. D. Beazley to G. Roger Edwards, 15 July 1940, BCMA. Edwards, Assistant Curator from 1939-41, is discussed later in this chapter. The document has handwritten corrections, but it is not clear if Warren, Beazley, Edwards or someone else made the annotations.

${ }^{555}$ Burdett and Goddard 414-19.
} 
to be the best portrait of that emperor," he praised the "grace" of various terracotta

figurines and scenes on vases at Bowdoin and argued that a Greek doll (1913.28) and a

Roman flute (1928.2) provided opportunities to catch glimpses of ancient everyday life

(Figures 36 and 37). He concluded with what he calls "the playful" in a reference to

Herakles "in his cups" (marble relief 1906.2, Figure 32) and the wish "that Bowdoin

could obtain more and more antiquities, pieces that need less explanation to be enjoyed."

Numbers in parentheses that follow his references to the object seem to correspond to

those on the labels in the galleries, suggesting that the preface corresponded to Warren's

arrangement of his antiquities that Andrews described in $1924 .^{556}$

\section{Warren's Antiquities at Bowdoin after 1928}

With Warren's death in December 1928, the work on the proposed catalogue for the Warren Collection seems to have come to a standstill. ${ }^{557}$ In 1933 Andrews reported:

"Mr. Warren [had] requested Mr. J. D. Beazley to prepare a definite catalogue of the collecting," adding "it is hoped [it] may eventually be received." ${ }^{, 558}$ With Warren's death, the impetus as well as the financial backing for the proposed catalogue vanished, and his gifts garnered less attention at Bowdoin. In fact, Warren's name appears only twice in

\footnotetext{
${ }_{556}^{55}$ Andrews 1924, 54.

${ }^{557}$ In 1931 Andrews declared that a catalogue of the "Edward Perry Warren Collection" was "in preparation." Andrews 1931, 60. An earlier Report stated that "G. B. Webber of Brunswick" already had photographed many antiquities. Andrews 1928, 46. Webber owned a photography business in Brunswick. A handwritten list in the files of the Museum with the heading "Photographs wanted by Mr. Warren 192728 " indicates that photographs of thirty antiquities may have been sent to Beazley. On the list is the notation: "Sent to Professor J. D. Beazley, The Judge's Lodging, St. Giles, Oxford." It is not clear exactly how many objects were photographed: a second page in the same hand is in the BCMA file, but the numbering system does not match and there are cross-outs and added objects. All objects are antiquities still at Bowdoin but not all are Warren objects. Some are labeled the "Dana Estes Collection." This list may indicate that the catalogue was meant to include all antiquities at Bowdoin. Research at the Beazley Archives and Lewes House did not locate any of these photographs.

${ }^{558}$ Andrews 1933, 57.
} 
the 1930 Bowdoin College Museum catalogue, Descriptive Catalogue of Paintings, Sculpture, and Drawings. ${ }^{559}$ British archaeologist Stanley Casson (1889-1944), a visiting Professor at Bowdoin in 1933-34, produced a sixteen page catalogue entitled "Catalogue of Marbles, Gems, Bronzes and Coins of the Warren Collection of Greek and Roman Antiquities." ${ }^{560}$ However, he did not include the vases and terracottas from Warren, despite Henry Andrews' statement in the preface asserting that these objects were "the most important possessions of the museum." 561

When G. Roger Edwards (1915-2009), a 1935 Bowdoin graduate, became assistant curator in 1939 , he was charged with developing a systematic catalogue of the collections and contacted Beazley about the catalogue for the classical collection Warren had proposed ten years earlier. ${ }^{562}$ He also explained that Bowdoin lacked complete information on many of the Warren objects and asked if Beazley could provide lists or

\footnotetext{
${ }^{559}$ Andrews 1931. In the introduction, the "Edward Perry Warren Classical Collection" is included in the list of seven recent bequests. In the catalogue, Warren is merely acknowledged as the donor of nine classical sculptures in the Sculpture Hall.

${ }^{560}$ Casson was in residence at Bowdoin through funds from Frank Gifford Tallman, who received a honorary Master of Arts from Bowdoin (29 June 1935), but no records at Bowdoin indicate what Casson's duties at Bowdoin were. Casson, who was educated at Oxford, attended the British School in Athens, excavated in Macedonia, Thrace, and Constantinople, and wrote Technique of Early Greek Sculpture (1930). He was killed in combat during the Second World War. For Casson, see General Catalogue of Bowdoin College and the Medical School of Maine: A Biographical Record of Alumni and Officers 17941950 1950, 22; Medwid 55-56; Boardman 1985, 52. Casson may have arrived at Bowdoin through his connections to Beazley, with whom he wrote an Oxford CVA. See Beazley, Payne and Price ${ }^{561}$ Casson 1934. The entries are numbered, suggesting that they match those on museum labels, and are inconsistent in length and content. The first refers to a plaster cast of the Faun attributed to Praxiteles in the Capitoline Museum which was not a Warren gift.

${ }^{562}$ Beam 1991, 19. After graduating from Bowdoin, Edwards earned an MA from Johns Hopkins (1937) and a Ph. D. in Classical Archaeology from the University of Pennsylvania (1939). For Edwards, see his obituary. Albersmeier 2009 (10 December 2010). I had the privilege of discussing Warren, Beazley, and the Bowdoin collection with Dr. Edwards in February 2009.
} 
records from Lewes House to assist in his efforts to update the museum records, offering to supply photographs of the Bowdoin antiquities. ${ }^{563}$

Beazley's apologetic reply arrived five months later. First, he put the matter of writing a catalogue for the Warren Collection to rest. He had "always wanted to write the catalogue," but felt he needed to see the collection to do so and so had "put off the work in the hope of visiting America." ${ }^{564}$ Now, he "must renounce the plan." Any records that he had used for his chapter, "Warren as Collector," for the Warren biography, he explained, already had been returned to E. H. Goddard, Warren's literary executor. ${ }^{565}$ Beazley, nevertheless, agreed to copy and send any notes he had made about "the Bowdoin things." In addition, he agreed to look at photographs of the Bowdoin antiquities Edwards offered to provide. ${ }^{566}$

Letters in the Bowdoin College Art Museum suggest that a working relationship developed between the Oxford scholar and the young assistant curator. In response to Beazley's refusal to write a catalogue, Edwards proposed a "modest affair" for gallery use that might "fill the breach." ${ }^{567}$ Beazley assisted with information he compiled based on photographs Edwards provided. ${ }^{568}$ Unfortunately, the gallery guide Edwards proposed never materialized and none of the descriptions Beazley supplied have survived.

Correspondence from 1940-41 indicates that the Oxford scholar and young American

\footnotetext{
${ }^{563}$ G. Roger Edwards to J. D. Beazley 5 December 1939 in BCMA.

${ }^{564}$ According to Dr. Edwards, Beazley never visited Bowdoin.

${ }^{565}$ Edward Perry Warren: The Biography of a Connoisseur was not published until 1941.

${ }^{566}$ G. Roger Edwards to J. D. Beazley, 24 May 1942, BCMA. Edwards' lists—all titled "Photographs sent to Professor Beazley" and dated 4 December1940, 24 January 1941, and 3 February 3, 1941 —are in the BCMA.

${ }^{567}$ G. Roger Edwards to J. D. Beazley 13 June 1940, BCMA.

${ }^{568}$ G. Roger Edwards to J. D. Beazley to G. Roger Edwards 5 December 1940, BCMA.
} 
curator exchanged information about antiquities at Bowdoin until Edwards was drafted into the Army. 569

The status of Warren antiquities at Bowdoin resurged when Kevin Herbert, who had recently earned his Ph. D. from Harvard, joined the Classics Department in $1955 .{ }^{570}$ Besides Greek and Roman art, Herbert's research interests included epigraphy, numismatics, philology, historical fiction, and pedagogy. ${ }^{571}$ In his seven years on the Bowdoin faculty, five of his nine publications were on Warren antiquities. He contributed two articles to the American Journal of Archaeology, one on the Roman cinerary urn (1927.2O) (Figure 38) and the other on the Greek and Latin inscriptions at Bowdoin. ${ }^{572}$ In 1959 he published twenty terracotta figurines in the collection in the Classical Journal, an article that he expanded into a small illustrated catalogue, Terracotta Figurines in the Walker Art Building (1960). ${ }^{573}$ This catalogue and a comprehensive handbook for the ancient art at Bowdoin in 1964 not only brought greater attention to the Warren gifts, but they also suggest that the Bowdoin students were then experiencing "the magic sense of contact with the ancient world that is felt upon close examination," as Warren intended. $^{574}$

\footnotetext{
${ }^{569}$ In my conversation with Edwards, he disclosed that he never met Beazley. Edwards served until 1945.

${ }^{570}$ Kevin Herbert, who earned an A.M .(1948) and Ph. D. (1954) from Harvard, was an instructor at Bowdoin in 1955-56 and an assistant professor there from 1956-62. He became a professor at Washington University, St. Louis, in 1962 retiring in 1992 as Professor Emeritus. The author was unable to contact Dr. Herbert.

${ }^{571}$ He published the coin collection at Washington University ( Herbert 1996) and the inscriptions in the Brooklyn Museum (Herbert 1972) and wrote about Advance Placement Courses in Latin (Herbert 1973). For his philology, see Herbert 1957. Herbert also reviewed for the AJA, AJP,CW, and $C J$.

${ }^{572}$ Herbert 1960a; Herbert 1962. The Roman cinerarium (1927.2O) is discussed in Chapter 6.

${ }^{573}$ Herbert 1959; Herbert 1960b.

${ }^{574}$ Herbert 1960b, 10.
} 
Terracotta Figurines in the Walker Art Building is interesting in that Herbert published a number of the antiquities that Warren discussed in the "preface" Beazley sent in $1941 .{ }^{575}$ Herbert organized the catalogue into two sections: a history of the classical collections, in which he discussed Warren extensively; and a second part composed of an introduction to classical terracotta statuettes followed by entries for each of the twenty in the Bowdoin collection. ${ }^{576}$ Some of Herbert's information about Warren is inaccurate: for example, he stated that illness forced Warren to leave Harvard without graduating and he did not identify Warren's A. M. from Oxford as honorary. In a footnote he recommended Burdett and Goddard's biography to those interested in learning more about Warren and rather hyperbolically observed that "Warren was cut from the same cloth as Henry Adam Adams and Henry James . . possessed all the best qualities of that world which unhappily came to an end in August, 1914."

In his concluding remarks in the introductory section of Terracotta Figurines in the Walker Art Building, Herbert evaluated the status of the antiquities in the Bowdoin collection at that time. He lamented that the lack of exhibition space for classical art had relegated fourteen of the twenty terracottas in his catalogue to storage. In observing that the classical collection's strength was not in the number of exceptional pieces but rather in its "range and variety," he advocated better "arrangement, lighting, and description" and recommended that the classical art have its own gallery. ${ }^{578} \mathrm{He}$ announced that majors

\footnotetext{
${ }^{575}$ Herbert called the document Warren's "evaluation of the Bowdoin Collection that bears his name." Herbert 1960b, 9. He footnoted it as from Burdett and Goddard. Herbert 1960b, 21.

${ }^{576}$ The second part is a reprint of the article published in the Classical Journal. An error crept into the catalogue: the entries for Figures 5 and 6 were exchanged.

${ }^{577}$ Herbert 160b, 21.

${ }^{578}$ Herbert 1960b, 10.
} 
in the Classics Department had begun to study the inscriptions and terracottas, presumably under his direction; and he planned to do the same for the sculptures, coins, and vases.

Herbert's major contribution in promoting the Warren antiquities at Bowdoin was Ancient Art in Bowdoin College: A Descriptive Catalogue of the Warren and Other Collections which he completed in 1961 but did not publish until 1964 after he joined the Washington University faculty. In the preface, he explained that this volume was "something more than a catalogue in the usual sense" because it had three audiences: the scholar, for whom it would serve as "a catalogue raisonné, with objects mainly arranged by culture and type, in chronological sequence, and with technical data and references appended to each item"; the Bowdoin undergraduate, who could employ it as "a text with references" to the College collection; and the gallery visitor whose "understanding and enjoyment" might be enhanced. ${ }^{579}$ Herbert's catalogue remains the most comprehensive guide to the classical collection at Bowdoin. ${ }^{580}$

The more than five hundred Warren gifts to Bowdoin have contributed to the prominence of the College's ancient art collection, which The Burlington Magazine called "one of the most extensive compilations ... in a North American college museum."581 In 2005 Warren antiquities were featured in "Ars Antiqua: Treasures from the Ancient Mediterranean World at Bowdoin College." Spotlighting Warren gifts, such

\footnotetext{
${ }^{579}$ Herbert 1964, vi.

${ }^{580}$ See Bowdoin College Museum of Art 1977, 62. Prominent British and American classical scholars positively reviewed it. Cook 1965; Hill 1965.

${ }^{581}$ Bowdoin College Museum of Art , 62. This comment appeared in a review of "The Bowdoin College Museum of Art: The Ancient Collection” exhibition (October 21, 1977-January 8, 1978) of five hundred antiquities.
} 
as Roman dice and tesserae, Greek coins, fragments of cameo glass, and tiny silver statuettes, as well as the vases and marbles, the thematically-organized exhibition illustrated the range and variety of his generosity to Bowdoin. ${ }^{582}$

Bowdoin students still have direct contact with Greek and Roman material culture via the Warren antiquities as Herbert advocated in the1960s. ${ }^{583}$ They come to know Warren antiquities intimately, as they design and mount exhibitions as class projects. ${ }^{584}$ Professors schedule class meetings in a specially designed classroom in the museum so that their students can experience "the magic sense of contact with the ancient world.",585 Thus, as Beazley predicted in his eulogy for his friend and collaborator, "a coin, a vase, statuette ... speak of Greece in the heart of Maine ... [to] the student whose spirit would require them."

\section{Warren and the University of Pennsylvania}

Among the approximately 30,000 objects in the Mediterranean Section of the University of Pennsylvania Museum of Archaeology and Anthropology, only seven entered through Edward Perry Warren. Correspondence in the Museum Archives reveals that Warren served as consultant and middle-man for the acquisition of Greek and Roman

\footnotetext{
${ }^{582}$ The Ars Antiqua exhibition, however, was not exclusively devoted to objects from Warren. Most of the photographs of Bowdoin objects in this dissertation are from this catalogue.

${ }^{583}$ Herbert promoted the use of slides and films to teach Greek and Roman culture. See Herbert 1971. He also was interested in historical fiction and poetry inspired by the ancient world. See his reviews, Herbert 1958, Herbert 1960c.

${ }^{584}$ Exhibitions developed by Bowdoin students in 2009-2010 were "Sex and Scandal in the Ancient World" and "Urban Development, Urban Space: Archaeology of the Campus Martius."

${ }^{585}$ Herbert 1960b, 10. On October 14, 2009, the author observed Dr. Ryan Ricciardi challenge the students in her archaeology class to speculate about the use and function of Greek vases she had chosen from the collection for their inspection. Most of the eleven ancient vessels came from Warren. The first floor of the renovated Bowdoin College Art Museum contains the Zuckert Classroom, designated for close experience with works in the College collection.

${ }^{586}$ Beazley as quoted in Kline 2005, 11.
} 
sculpture through an arrangement with Sara Yorke Stevenson (1847-1921), the first curator of the Mediterranean section, and George Byron Gordon, the Museum Director (1910-27). Penn's Classical Sculpture catalogue identifies Warren as the source for these marbles and acknowledges him as one of the collectors and dealers through whom the Museum purchased important works in its collection. ${ }^{587}$ In fact, the catalogue features one of the Warren sculptures, the portrait head of a middle-aged Roman woman (MS 49190), on its frontispiece. Six of the seven Warren marbles are in the permanent displays in the galleries.

Penn, as the institution is commonly called, traces its origins to the vision of Benjamin Franklin in 1749. ${ }^{588}$ Despite Franklin's hope for a more practical approach to education for the business and governing class rather than of clergymen, Penn-like most American colleges and universities_-emphasized Greek and Latin literature and languages in its curriculum. Interest in ancient material culture can be traced to 1887 , when the University agreed to fund an expedition to Nippur, the Sumerian site between the Tigris and Euphrates Rivers, and to establish a museum to accommodate the finds. ${ }^{589}$ In 1889, Penn dedicated a room in College Hall as the Museum of American Archaeology to house the excavated materials. Beginning in 1891, a Board of Managers, composed of university personnel and community volunteers, governed the Department

\footnotetext{
${ }^{587}$ Romano 2006, ix-xi.

${ }^{588}$ The date for Penn's founding is controversial. Thomas and Brownlee 1999, 23-37, 139-41.

${ }^{589}$ Penn has a long history of excavations in Iraq. Archaeological work continued intermittently at Nippur until 1900 and later in 1948-52. Penn in cooperation with the British Museum sponsored excavations at Ur from 1922-34 under the direction of C. Leonard Woolley. For the excavations at Ur and the objects from "the Royal Tombs," see The World of Ur 1998 Expedition 40 (2).
} 
of Archaeology and Paleontology and the museum. William N. Bates, Professor of Greek, offered the first course in classical archaeology in $1896 .{ }^{590}$

Penn erected a dedicated building for archaeological and ethnological materials in 1899 , organizing the museum under three departments, each with its own curator: the Babylonian Section; the Egyptian and Mediterranean Section; and the American, African, Pacific, and Far East Section. ${ }^{591}$ The Philadelphia elite, such as Lucy Wharton Drexel, Phoebe A. Hearst, and John Wanamaker, served on the Museum Board and financed the purchase of many of the significant early antiquities before the First World War. ${ }^{592}$ Sara Yorke Stevenson (1847-1921), Secretary of the Museum, proved the catalyst for the Museum's growth, when she became Curator of the Egyptian and Mediterranean Section in 1894. She initiated major purchases that served as the foundation of Penn's impressive Egyptian collection through her friendship with the British archaeologist Flinders Petrie. ${ }^{593}$ Stevenson was the president of the Pennsylvania chapter of the Archaeological Institute of America and founded the American Exploration Society, which supported the excavations at Gournia by Harriet Boyd Hawes (1871-1945), one of the first woman professional field archaeologists. Although she never attended college, Stevenson became

\footnotetext{
${ }^{590}$ The title for this course, offered as an elective to juniors and seniors in the Greek Department, was "Greek Archaeology, Lectures and Conferences, Architecture, Sculpture, Terra-cottas, Vase Painting." Hiss and Fansler 1934, 2. William Nicholson Bates (1867-1949), an early leader in the AIA, edited the AJA from 1920 to 1923. Donahue 1958, 15-18.

${ }^{591}$ The museum was then named "the Free Museum of Art and Science," but by 1903 it was unofficially referred to as "The University Museum," a designation that became official in 1910. Ruwell 1984, 3.1.

${ }^{592}$ White and Horne 2002, 1-7; Romano, ix-xii. Lucy Wharton Drexel (1867-1944) is discussed later in this chapter in relation to the Penn sculpture from Warren. John Wanamaker (1838-1922) was a member and vice-president of the Board of the Penn Museum, 1896-1922. For Wanamaker, Ershkowitz 1999. Phoebe Apperson Hearst (1842-1919) was a prominent philanthropist who funded much of Penn's Etruscan acquisitions. For Hearst, Peterson 1985; Robinson 1991.

${ }_{593}$ Born in Paris, she settled in Philadelphia after marrying a prominent Philadelphia lawyer in 1870. Dyson 1998, 90; Kuklick 1996, 60-63. For Stevenson's impact on the Egyptian Collection at Penn, see O'Connor and Silverman 1979, 33-4.
} 
one the earliest Egyptologists in the United States, presenting papers at scholarly meetings and publishing papers. In the latter part of her life, she developed and taught a museum training course. ${ }^{594}$

The chief agent for purchasing objects for Penn's classical collection was Arthur L. Frothingham, Jr. (1859-1923), a professor at Princeton University. ${ }^{595}$ In the 1890 s, Stevenson commissioned Frothingham, who was then Secretary of the American School of Classical Studies in Rome, to serve as Penn's agent in Italy. ${ }^{596}$ Like his friend Richard Norton who was also associated with the American School in Rome, Frothingham was involved in the antiquities trade. On behalf of Penn, he purchased important Etruscan architectural terracottas from Tarquinia and Cerveteri and employed Italians to excavate Etruscan tombs at Vulci and Faliscan burials at Narce. These latter arrangements resulted in the acquisition of tomb groups, complete sets of grave goods from specific burials, entering the museum at Penn. Using plans, drawings, photographs, and inventories from the Italian excavators, the Penn Museum presented the contents of specific tombs as a group, one of the first archaeological displays integrated with scientific data. ${ }^{597}$ Frothingham's collecting coup for Penn was a group of Roman marbles from the

\footnotetext{
594 Sherman 1981, 48-9.

595 For Frothingham's career, Lavin 1983, 14-18; Dyson 1998, 46-47, 163-5; .

${ }^{596}$ In 1912 the American School of Classical Studies became the classical division of the American Academy in Rome. For the American Academy in Rome, see Valentine and Valentine 1973. Frothingham was associated with the Museum from 1895-1898 and was appointed Associate Curator of the Mediterranean Section in 1897, leaving that post in 1898 after disputes with Italian archaeologists and Stevenson. Ruwell , 3.54.

${ }^{597}$ Penn enhanced its Etruscan holdings when funds from Phoebe A. Hearst were used to purchase an important private collection in 1897. For the tomb groups, see Dohan 1942. Like Hawes, with whom she worked at Gournia on Crete, Edith Hayward Hall Dohan (1877-1943) was one of the first woman classical archaeologists in the United States. She served as a field archaeologist for Penn and later became Curator of the Mediterranean section, where she came into contact with the Italic materials. Her scholarship on the tomb groups at Penn was a pioneering study in Etruscan archaeology and art history. For Dohan, Morrow 2004.
} 
Sanctuary of Diana at Lake Nemi, dated to the Late Republic and early Imperial periods, obtained through funds from Lucy Wharton Drexel. Frothingham negotiated the purchase of forty-five important Roman votive statuettes and vessels from the Italian excavators, successfully vying with Wolfgang Helbig, friend of Warren and Marshall, who was representing the Ny Carlsberg Glyptotek in Copenhagen. ${ }^{598}$ Warren, thus, was only one of the sources for classical sculpture entering Penn from the 1890s through the 1930s.

\section{Warren's Roles at the Penn Museum}

Warren served as antiquities agent and advisor at Penn for more than a decade, initially to Stevenson and later to George Byron Gordon, the first Director of the University Museum (1910-27). ${ }^{599}$ Six of the sculptures from Warren entered Penn in 1901 through negotiations with Stevenson, while the seventh arrived twelve years later in 1913. Having learned of Warren's work on behalf of the MFA, Stevenson invited Warren to obtain sculpture for the Penn Museum in 1901. Her initial letter to Warren explained that Lucy Wharton Drexel, a "wealthy friend of the Museum," had agreed to finance "serious collecting." ${ }^{\circ 00}$ Within a month, Stevenson sent a check to Warren, enclosing a note from Drexel specifying her willingness to purchase only "original Greco-Roman

\footnotetext{
${ }^{598}$ For the sculptures from the Sanctuary of Diana Nemorensis and the extensive bibliography on this important site, see Romano 73-16 . In 1904 Penn obtained four Greek sculptures from Paul Arndt (18651937), the German scholar and collector: two Attic grave reliefs (MS 4019) and (MS 4020) and a Hellenistic head of Herakles (MS 4031). Romano xi. The fourth (MS 4032), a veiled female head, is now considered an eighteenth or early nineteenth-century work. Romano 276.

${ }^{599}$ For Gordon, King and Little 1986.

${ }^{600}$ Sara Yorke Stevenson to Edward Perry Warren, 28 February 1901, Stevenson Letter Book \#5 19011902, 18-19, University Pennsylvania Museum Archives. Henceforth, the University Pennsylvania Museum Archives is abbreviated as UPMA.
} 
statues—nothing else — no vases or figurines (Tanagra or otherwise) only statues. ${ }^{601}$ By the end of the year, Warren assembled six marble sculptures that met Drexel's approval: some seem to have been at Lewes House already, while others were specifically acquired through middle-men.

It is appropriate, given that the funds for the classical sculpture came from the regal Lucy Wharton Drexel, that three of the Warren marbles depict goddesses. A draped Aphrodite (MS 4025), now dated to the Late Hellenistic or Early Imperial period, was held at Lewes House before being sent to Philadelphia; the Lewes House Registers contain a drawing of the marble sculpture with the notation "Mrs. Stevenson 1901" in the margins (Figure 39). ${ }^{602}$ A second statuette from Warren (MS 4029) is a wingless Iris in flight, probably from the Antonine period. This torso of brecciate brown and purple marble has cuttings indicating that the head, one of the arms, and both feet were added separately, possibly in a different color. ${ }^{603}$ The third is a head of Athena (MS 4026) that the curatorial file records as "purchased in Cairo through E. P. Warren." The life-sized head wears a Corinthian helmet and is thought to have come from a Hellenistic relief, perhaps part of a temple or altar frieze. Two other marbles in the 1901 group from Warren-Table Support Fragment: Dionysos/Bacchus (MS 4027) ( Figure 40) and Head of Menander (MS 4028) (Figure 162) — are discussed in Chapter 6.

\footnotetext{
${ }^{601}$ Sara Yorke Stevenson to Edward Perry Warren, 29 March 1901, Stevenson Letter Book \#5 1901-1902, 188, UPMA. Other important classical sculpture at Penn purchased by Lucy Wharton Drexel include the torso of a nude god or mortal (MS 4018) in 1904 and a statue of a seated Dionysos (MS 5483) in 1911. ${ }^{602}$ Romano 2006, 48-50.

${ }^{603}$ Romano 232-34. Warren purchased the statuette in Rome through Alfredo Barsanti, a dealer who handled the sculpture from the Sanctuary of Diana at Lake Nemi that entered Penn in the 1890s.
} 
Correspondence in the Penn Museum Archives documents that contact between Warren and various members of the Museum staff continued through 1914. Warren sent notes from John Marshall in 1902 in response to Drexel's questions about the Table Support Fragment (MS 4027) (Figure 40). ${ }^{604}$ In 1904 Stevenson considered making additional purchases, and Warren provided photographs of six "portrait heads" and accompanying descriptions by John Marshall, including that of Antoninus Pius (BCMA 1906.1) (Figure 31), a sculpture that Warren gave to Bowdoin two years later. In 1913 Warren met with George B. Gordon (1870-1927), Museum Director (1910-1927), to establish what the latter termed "some practical basis of operation which would be helpful to the Museum and not distasteful to you. ${ }^{, 605}$ Gordon later sought advice from Warren about how to bargain with dealer Paul Arndt, with Warren boasting that "in the old days ... I was the only one at Lewes who got along with him.." ${ }^{606}$ He also kept Gordon abreast of the prices in antiquity sales in Paris and recommended Dr. A. C. Headlam's Greek coins as "a beginning or basis for a University Collection." 607 They also discussed the purchase of sculptures, columns, vases, and choir stalls, but these negotiations resulted only in one acquisition for Penn: the Roman Portrait Head of a Middle-Aged Woman (MS 4919) (Figure 41) that Warren obtained in 1913 through an

\footnotetext{
${ }^{604}$ Drexel had asked about the gender of the androgynous Dionysos and the significance of his upturned arm.

${ }^{605}$ Edward Perry Warren to George Gordon to E. P. Warren, 18 July 1913, G.B. Gordon Letter Books, 45, UPMA.

${ }^{606}$ Edward Perry Warren to George Gordon, 3 January 1914, UPMA.

${ }^{607}$ Edward Perry Warren to George Gordon, 27 May 1914, UPMA, and Edward Perry Warren to George Gordon, 6 October 1914, UPMA. Penn did not purchase the coins. Dr. Headlam is likely Arthur Coyley Headlam (1862-1947), a professor of divinity at Oxford.
} 
Italian dealer, his friend Fausto Benedetti. ${ }^{608}$ As one of the most important Roman sculptures in the collection, it is discussed further in Chapter $6 .{ }^{609}$

Warren's dealings with Sarah Yorke Stevenson appear to have been very business-like: Stevenson sought to add ancient marbles and Warren quickly delivered six quality pieces. However, the relationship between Warren and Gordon seems to have been more personal, even though only one purchase resulted from their more extensive negotiations. ${ }^{610}$ The correspondence in the Penn Museum archives demonstrates that Warren and Gordon were connoisseurs who enjoyed the bartering involved in seeking the highest quality antiquities to build the Penn collections. ${ }^{611}$

Although Warren's impact on the collection of Penn Museum was limited to seven Roman sculptures, the fact that six of these marbles are installed in the permanent displays in the Mediterranean Section is testimony to the high regard for his connoisseurial acumen.

\section{Warren and Bryn Mawr}

In contrast to the situation at Penn, research does not reveal any correspondence between Warren and representatives of Bryn Mawr College. One document in the files of

\footnotetext{
${ }^{608}$ A photograph and letters reveal that Penn sought a Geometric vase, in particular. Edward Perry Warren to Edith Hall, 27 January 1913 and 2 July 1913, UPMA; Edward Perry Warren to George Gordon, 24 July 1915, UPMA.

${ }^{609}$ Romano 203-5. A photograph of the head is on the Frontispiece of Penn's classical sculpture catalogue. A card in the Penn Curatorial file for MS 4919 has the notation "said to come from Sardinia." For Benedetti, see Sox 1991, 68-69.

${ }^{610}$ Warren and Gordon discussed meeting in Boston and the possibility of Gordon visiting Fewacres, Warren's home in Maine, but it is not clear if the men had contact outside of Warren's service as a consultant for Penn.

${ }^{611}$ Trained in New World ethnology, Gordon excavated at Copán, Honduras, in the 1890s and led Penn expeditions to Alaska in 1905 and 1907. His purchases also resulted in a high quality collection of Chinese objects at Penn.
} 
the Ella Riegel Memorial Museum lists thirty-one objects, primarily fragments of Greek vases, which came from Lewes House. In addition, the presence of the notation "Hoppin Bought July 1901” appearing in the Lewes House Registers confirms this connection. The following review of the history of Bryn Mawr College and its vital role in training American scholars in classical archaeology provides a context for understanding the significance of the Warren vase fragments.

Established in 1865 outside Philadelphia as a Quaker institution for women, Bryn Mawr College became the foremost institution for American women trained in classical philology and archaeology. ${ }^{612}$ Bryn Mawr's first dean and second president, M. Carey Thomas (1857-1935), who had pursued graduate studies at the Universities of Leipzig and Zurich at a time when no such opportunities were open to women in American universities, sought to duplicate the academic rigor she found in Europe. ${ }^{613}$ Initially, Bryn Mawr's curriculum focused on classical languages, history, philosophy, and science, with the students' interests in art history and archaeology met through public lectures and elective courses. However, by 1895 Thomas announced plans to establish a "lectureship in the history of art" within the Classics Department. The first appointment to this position was Richard Norton (1872-1918), who taught courses in the history of Greek and Italian art from 1896-98. When Norton left Bryn Mawr to become an administrator at the American School of Classical Studies in Rome, his friend Joseph

\footnotetext{
${ }^{612}$ Vermeule 1987b.

${ }^{613}$ For M. Carey Thomas, see Horowitz 1994. For the educational philosophy at Bryn Mawr under Thomas, see Wein 1974.
} 
Clark Hoppin (1875-1925) took charge of what became known as the Department of Classical Art and Archaeology. ${ }^{614}$

\section{Warren Fragments and Bryn Mawr Scholarship}

In five years at Bryn Mawr, Hoppin expanded the number and variety of courses on the undergraduate and graduate level, offering the History of Greek Art, Elements of Archaeology, Greek and Roman Mythology, Pausanias, Homer and the Homeric Age, and Private Life of the Greeks. The Bryn Mawr catalogue described the last course as "discussed chiefly with reference to existing monuments, especially vase painting," an appropriate emphasis given that Hoppin was one of the first American scholars to specialize in Greek vases. ${ }^{615}$ An 1893 Harvard graduate, Hoppin earned a doctoral degree at the University of Munich in1896 after excavating at the Argive Heraeum, where he worked with many of the first American archaeologists. ${ }^{616}$ Hoppin is considered to be one of the first "artifact specialists" in America archaeology and is credited as the catalyst for Greek vase studies in this country. ${ }^{617}$ He produced three pioneering studies_E Euthymides and His Followers (1917), A Handbook of Red-Figured Attic Vases (1919), and A Handbook of Greek Black-Figured Vases (1924). A collector of Greek vases, Hoppin knew Beazley and most of the collectors and agents of the day, including Warren. ${ }^{618} \mathrm{He}$ published lists of vases based on the signatures on them or on what has been called "a

\footnotetext{
${ }^{614}$ The American School of Classical Studies in Rome evolved into the American Academy in Rome in 1913.

${ }^{615}$ Bryn Mawr College Program: Academic Year 1900-01 1900, 177-78.

${ }^{616}$ For the Argive Heraeum, a project jointly sponsored by the AIA and the American School of Classical Studies at Athens, and those who participated, see Dyson 1998, 83-85

${ }^{617}$ His dissertation on Euthymides was under the supervision of A. E. Furtwängler.

${ }^{618}$ Scholars have attributed vases from Apulia to an artist, named the "Hoppin Painter" in Hoppin's honor. Scholars have identified 15 vases from this artist's workshop thought to have been near Taranto. For the Hoppin Painter, Trendall and Cambitoglou 1978, 102-22; Trendall 1989, 76.
} 
strictly philological view of connoisseurship" and, unlike Beazley, made no reference to conceptual categories like "manner, circle, or successor." ${ }^{.619}$ Beazley, it has been argued, made an effort to distinguish his work from Hoppin's lists by refusing to refer to Hoppin's as attribution. ${ }^{620}$ In 1905 Hoppin left Bryn Mawr to become the Annual Professor at the American School of Classical Studies in Athens but returned to Bryn Mawr in 1917-19 when Rhys Carpenter (1889-1980) was called to military service. As previously noted, Hoppin bequeathed his impressive vase collection to Harvard in $1925 .{ }^{621}$

In 1901 Hoppin assembled a teaching collection at Bryn Mawr composed chiefly of vase fragments with funds supplied by his two aunts, and these shards are now in the College's Ella Riegel Memorial Museum. One group of seventeen shards was purchased from Warren's friend and fellow antiquities dealer, Paul Hartwig. Notes in German, perhaps written by Hartwig, describing these pieces survive in the curatorial file. A second list records thirty-one objects, chiefly fragments of Greek vases, which Hoppin purchased from Lewes House. This inventory compiled by Hoppin contains information from Warren or one of his assistants. According to the 1971 Bryn Mawr CVA, the numbers preceded by an "R" refer to the numbers in the Lewes House Register, while those with the abbreviations "BB" and "TL" correspond to Warren's inventories called the "Black Book" and "Temporary List."

\footnotetext{
${ }^{619}$ Rouet 102.

${ }^{620}$ Beazley dismissed Hoppin's books on Greek vases as "handbooks of signed vases."Rouet 102.

${ }^{621}$ At the time of his death, Hoppin was working with the collector, Albert Gallatin, to produce a CVA of their collections. Hoppin and Gallatin 1926.

${ }^{622}$ Ashmead and Phillips 1971, vii-viii. The Lewes House Registers confirm that the "Black Book" existed because "Black Book 19" and "Black Book 17" and abbreviations such as "BB 21" and "BB 2" occur in
} 
House Registers revealed the notations "Hoppin Bought July 1901" and that the numbers of such entries match those beginning with "R" on Hoppin's list at Bryn Mawr.

One example of the correlation between the Hoppin list and the Lewes House Registers is the fragment of an Attic red-figure plate (Figure 42), now attributed to the Bryn Mawr Painter and bearing the accession number P-95. ${ }^{623}$ It is the ninth item on the list and numbered R491, with the accompanying description "centre of R.F. Pinax. Man lying down playing kottobas with his cylix. The red slip partly peeled off through lying in the sun. (Rome)." In the Lewes House Registers, the entry for R 491 is "Centre of flat dish R.F. with inscription" followed by an illegible phrase in Greek. The final notations are "Martinetti 80 lire" and "Hoppin Bought July 1901." "Martinetti" unquestionably refers to Francesco Martinetti (1833-95), a well-known dealer in Rome involved in the sale of the "Boston Throne" to Warren. ${ }^{624}$ Interestingly, the Hoppin list gives the provenance as "Rome" but does not refer to Martinetti as the source. It may be that the name of the dealer was not significant to whoever compiled the list. The omission of Martinetti's name may also reflect Warren's view or Hoppin's that a link to the murky antiquities trade should be excised. Bryn Mawr's P-95 is well known because Beazley attributed this plate fragment as well as one now in the Ashmolean Museum to the work of the "Bryn Mawr Painter." 625

the margins. However, investigations in the Lewes House Archives, the Beazley Archives, and the Archives of Sackler Library did not locate the Black Book or the Temporary List.

${ }^{623}$ Beazley 1963, 1: 456-57.

${ }^{624}$ Andrén , 69, 75-77,88-91. The notorious Martinetti also handled the "Fibula Praenestina," now considered to be a forgery. For a review of Margherita Guarducci 's 1980 expose, La cosiddetta Fibula Prenestina. Antiquari, eruditi e falsari nella Roma dell' Ottocent. See Gordon 1982.

${ }^{625}$ Robertson 1992, 83. 
The thirty-one objects that Hoppin purchased from Warren are significant in that they document the direction taken in scholarship at Bryn Mawr. Hoppin was the first in a distinguished line of scholars at the College specializing in ancient painting. Caroline Ransom Williams (1872-1952), who taught at Bryn Mawr from 1905-10, continued the focus on Greek vases and contributed a vase and fragments she obtained in the antiquities market in Rome to the College study collection. ${ }^{626}$ The most influential of these scholars was Mary Hamilton Swindler (1884-1967), a 1912 Bryn Mawr Ph. D., who taught Latin, archaeology, and ancient painting at the College for almost forty years. Like Hoppin and Williams, she donated vases and fragments to the study collection and published the Bryn Mawr vases in $1916 .{ }^{627}$ In one of her early articles crediting six vases in American collections to the Penthesilea Painter (now dated to 460-50), all of the pottery she attributed, including a fragment at Bryn Mawr (P-218), came to the United States through Warren. ${ }^{628}$ Swindler was a prolific scholar, editing the American Journal of Archaeology from 1932-44 and authoring the seminal Ancient Painting (1929), a survey from prehistory through the high Roman Empire. ${ }^{629}$ Most importantly, Swindler taught generations of students, many of whom became scholars and teachers specializing in ancient painting. She believed in "direct engagement" with the ancient materials and made use of the College's study collection in her teaching: a Bryn Mawr graduate recalls

\footnotetext{
${ }^{626}$ Swindler 1916, 308. For Caroline Ransom Williams, who earned the first Ph. D. in Classical Archaeology at the University of Chicago (1905), see Lesko 2004. "Caroline Louise Ransom Williams (1872-1952)."

http://www.brown.edu/Research/Breaking_Ground/bios/Ransom\%20Williams_Caroline\%20Louise.pdf (18 December 2010) She left Bryn Mawr to become a curator in Egyptology at the MET in 1910.

${ }^{627}$ Swindler 1916. She wrote an obituary for Hoppin.

${ }^{628}$ Her argument was that "leading museums in America" had as many examples of this artist's work as those in Europe. Swindler 1915, 399. An even earlier article attributed a kylix, which came to Philadelphia via Joseph Bonaparte in 1836, to the same artist. Swindler 1909.

${ }^{629}$ Swindler 1929. The copy in the Ekstrom Library is inscribed by Swindler to Alice Speed Stoll.
} 
that Swindler always entered the lecture hall with "hands full of fragments.",630

Undoubtedly, some of the fragments (Figure 43) which she showed to her students came from Lewes House.

Bryn Mawr developed a bond with Beazley, who visited in 1946 to examine its vase collection. The vases and fragments from Bryn Mawr were included in his Attic Red-Figured Vases in America (1917); Attic Black Figure Vase-Painters (1956 and 1978); and Attic Red-figure Vase-Painters (1942 and 1963). One of his protégés, Alexander Cambitoglou, who became a well-known specialist in pottery from South Italy, taught at Bryn Mawr from 1957-60 and assisted Beazley in updating information from the College collection. Beazley served as a resource of information about Bryn Mawr's vases for Swindler and, later, for Ann Harnwell Ashmead and Kyle Meredith Phillips, who co-authored the CVA of the Bryn Mawr red-figure ware in 1971. Another Beazley student and associate, Dietrich von Bothmer (1918-2009) who was Curator of Greek and Roman Art at the MET, provided information and photographs from Lewes House for the Bryn Mawr CVA. ${ }^{631}$

Warren's only direct connections to Bryn Mawr are the fragments he sold to Hoppin in 1901. It is fitting that these materials comprised the foundation of the College's study collection because Bryn Mawr provided training for the foremost American specialists in ancient painting, like Mary Swindler. Warren's influence was also transmitted through the bonds which Bryn Mawr faculty and students formed with

\footnotetext{
${ }^{630}$ As qtd in Leach 2004. "Mary Hamilton Swindler (1884-1967)." http://www.brown.edu/Research/Breaking_Ground/bios/Swindler_Mary\%20Hamilton.pdf (18 December 2010), 5 .

${ }^{631}$ Ashmead and Phillips 1971, ix.
} 
his collaborator, John Davidson Beazley, and Beazley protégés, Cambitoglou and Dietrich von Bothmer.

\section{Warren and the University of Chicago}

Warren antiquities arrived at the University of Chicago, another academic institution established in the Gilded Age, within ten years of its founding. In 1902 Warren gave approximately one hundred small antiquities, mostly vases fragments but also some statuettes, to Frank Bigelow Tarbell (1853-1920), the first Professor of Archaeology there. Once in the study collection of the Departments of Classics, Archeology and Art History, these objects are now in the University of Chicago's David and Alfred Smart Museum of Art. ${ }^{632}$ Beazley indicates that Warren "made gifts . . to the University of Chicago" in his tribute in Burdett and Goddard. ${ }^{633}$ Although research at the University of Chicago, the Lewes House Archives, and the Beazley and Ashmolean Archives in Oxford revealed no correspondence between Tarbell and Warren, the surviving Lewes House Registers do show entries with the notation "Given to Tarbell 1901." These notations can be verified in Tarbell's bound notebook recording antiquities he collected — now called "The Tarbell Inventory" — with descriptions, measurements, and sometimes sketches. For some antiquities, the provenance, findspot, or publication citation appears on the facing page (Figure 44). The first 101 of the 141 antiquities in the Tarbell Inventory are all labeled "Gift of Warren 1902," sometimes with information about where Warren obtained them or their findspot, such as "Bought in Naples," "

\footnotetext{
${ }^{632}$ The Warren antiquities at the University of Chicago moved several times, from a collection managed by various academic departments to more comprehensive university museum facilities. For the history of museums at the University of Chicago, see Abt and Born 1990Nielsen

${ }^{633}$ Burdett and Goddard 354.
} 
Forman sale. Pt. II, lot 298," or “From Vulci (Torlonia Coll.), Tomb LXXIX, no. 10.” On some of the entries, publication citations have been added in what is a faint and apparently different hand.

Before discussing the antiquities that Warren gave to Tarbell and the scholarship they inspired, it is necessary to understand the importance of collecting and the study of Greek and Roman art at the University of Chicago from its founding in 1892. An interest in ancient culture was palpable in Gilded Age Chicago. The most visible evidence was the complex of classically inspired structures erected to house the World's Columbia Exposition in 1893. The Museum of Science and Industry, the only surviving building from this Gilded Age celebration, still displays caryatids and friezes inspired by ancient Athens. In addition, antiquities and copies of classical sculptures were exhibited in the Beaux-Arts buildings of the newly established Field Museum (1893) and Art Institute $(1879) .{ }^{634}$

The first president of the University of Chicago, William Rainey Harper (18561906), understood the pedagogical value of antiquities and sought "to integrate artifacts with texts, and museums and laboratories with classrooms." ${ }^{, 635}$ In fact, two teaching museums — the Walker Museum (1893) for natural history, especially paleontology, and the Haskell Oriental Museum (1896) for artifacts from the ancient Near East—were

\footnotetext{
${ }^{634}$ The Field Museum was first called the Columbia Museum of Chicago; its name was changed in 1905 to honor its benefactor, Marshall Field. Established to serve as both a school and museum in 1879, the Chicago Academy of Fine Arts became known as the Art Institute in 1882.

${ }^{635}$ Nielsen 1.
} 
among the first buildings constructed on the University of Chicago campus ${ }^{636}$ President Harper recruited renowned scholars, such as William G. Hale (1849-1928), a specialist in Latin and Hebrew from Cornell University, and Paul Shorey (1857-1934), who taught Greek at Bryn Mawr, to serve on the faculty. ${ }^{637}$ Both of these imminent philologists understood the significance of classical material culture first hand, for Hale was the first director of the American School of Classical Studies in Rome (1895-96) and Shorey was a professor at the American School of Classical Studies in Athens (1901). In fact, Shorey knew Heinrich Schliemann, who may be the source of fragments from Tiryns and Mycenae now in the University of Chicago collection. ${ }^{638}$ Hale contributed fragments of three terracotta architectural decorations he purchased in Rome. ${ }^{639}$ A third professor, Frank Bigelow Tarbell, had an even more significant role in promoting the study of ancient material culture at the University of Chicago. He assembled a collection of Greek and Roman objects that were displayed in1915 in a large one-room museum on the fourth floor of the Classics Building and later in cases installed in the reading room of the

\footnotetext{
${ }^{636}$ Seidel and Taylor 1998, 15. At the cornerstone ceremony for the Haskell, Harper emphasized that a museum was needed more than a library, perhaps anticipating that the University might acquire objects from the Columbian Exposition.

${ }^{637}$ President Harper's belief in hands-on-learning is evident in his appointing John Dewey, Professor of Philosophy, Psychology and Pedagogy, in 1894. Dewey stressed the importance of manual and visual experience. Seidel and Taylor 40-1.

${ }^{638}$ Nielsen 1-2.

${ }^{639}$ An antefix in the form of a maenad's head (1967.115.401, Italic, 300-200) and fragments of two Roman Campana reliefs - Victory Sacrificing a Bull $\left(1967.115 .405,1^{\text {st }}-2^{\text {nd }}\right.$ century CE) and Youth Feeding a Griffin (11967.115.407, early $2^{\text {nd }}$ century CE). Hale, who bought these objects in Rome, gave them to the University in 1918, the same year that the Tarbell Collection was donated. Ferrari, Nielsen and Olson 1998, 109-12.
} 
adjacent Goodspeed Hall. ${ }^{640}$ He presented these antiquities, many of which came from Warren, as a gift to the University of Chicago in 1918.

Frank Bigelow Tarbell (1853-1920) graduated from Yale in 1873 and, after travel in Europe for several years, returned to New Haven, earning a Ph. D. in 1879. After serving as the first annual professor (1888-9) and secretary (1892-3) of the American School of Classical Studies in Athens, he became Professor of Classical Archeology and Greek Epigraphy at the University of Chicago in $1892 .{ }^{641}$ In his first year, he taught three courses cross-listed in the Greek and Archaeology Departments-Introduction to Classical Archaeology, Greek Mythology in Greek Art, and Greek Life from the Monuments - in addition to seven Greek literature courses. Students in the archeology courses had access to a small collection of casts and over two thousand photographs of archeological sites and ancient buildings and art as well as the more extensive antiquities and the photography collections at the Art Institute of Chicago. Archaeology courses increased steadily, and, by 1896, the Department had gained the services of James Breasted for two Egyptian archaeology classes. In addition, the Departments of Semitic Languages and Literature and Latin Languages and Literature offered cross-listed courses in Assyrian and Babylonian Life and Roman Private Life. Tarbell taught two additional classes, History of Greek Sculpture and Greek Vases and Coins, and used his newly

\footnotetext{
${ }^{640}$ Seidel and Taylor 33. The University had departmental libraries and museums, rather than large repositories serving the entire campus.

${ }^{641}$ Dyson 1998, 102-03. University of Chicago Library contains little information about Tarbell; the only document in the Smart Museum is the "Tarbell Inventory.' For an eulogy, Herrick 1921. Robert Herrick (1868-1938), a novelist and Professor of English at the University of Chicago (1893-1923). Herrick's letters to Tarbell in the Special Collections Center in the University of Chicago Library reveal that Tarbell and Herrick were friends. Research does not reveal much more than Tarbell's publishing record and the courses he taught at Chicago until his retirement in 1920.
} 
published textbook History of Greek Art (1896) in his Introduction to Classical

Archaeology course. By 1896, the University of Chicago touted that its students now had access to nearly 4,000 photographs as well as the use of the both the Field Museum and the Art Institute collections. ${ }^{642}$ In 1897-8, Breasted joined Tarbell, who had added a Seminar in Greek Vases, in the Archaeology Department. In that same year, Caroline Ransom, Chicago's first doctoral student, was announced as a Fellow. ${ }^{643}$ The 1903-4 Register announced that both Tarbell and Breasted were now in a new Department of Art, with Breasted teaching "Oriental Art from the Earliest Time to the Conquests of Alexander" and Tarbell offering a classical art sequence - "Greek Art, to the Age of Alexander" and "Late Greek Art and Roman Art"-and a course on Greek Vases and Coins ${ }^{644}$ His courses on Greek vases must have motivated him to assemble a collection of ancient ceramic material.

Tarbell published over fifty articles, reports and reviews in leading philological and archaeological journals between 1883 and 1917. Credited with being among the first to use photographs to teach classical culture, he wrote descriptions and captions for two illustrated catalogues of antiquities. ${ }^{645}$ He published two articles on Greek vases from

\footnotetext{
${ }^{642}$ Department of Archaeology 1896-7, 197-9.

${ }^{643}$ As was pointed out earlier in this chapter, Ransom taught Mary Swindler at Bryn Mawr and become a curator in the Egyptian Department at the Met.

${ }^{644}$ Department of the History of Art 1903-4, 235. In addition to those offered by Breasted and Tarbell, nine courses are listed for George Breed Zug, the Instructor in the History of Art: Medieval and Renaissance sculpture, Medieval and Florentine painting, Venetian and Modern Painting, Florentine Painting (fourteenth and fifteenth centuries), Raphael, Dutch Painting, Titian, and French and American Art.

${ }^{645}$ He wrote descriptions for photographs of ancient monuments-Illustrated Catalogue of Carbon Prints on the rise and Progress of Greek and Roman Art (1897) — and for bronze copies of ancient sculptures from Pompeii and Herculaneum_Catalogue of Bronzes in the Field Museum of Natural History Reproduced from Originals in the National Museum of Naples (1909). Dyson 1998, 103-4, 310.
} 
Warren, one in the MFA and the other a gift to the University of Chicago. ${ }^{646}$ His History

of Greek Art (1896), one of the earliest textbooks for Greek art and archaeology,

contained almost two hundred illustrations, most of them photographs from the

University of Chicago's extensive photography collection or reproduced from European

texts. ${ }^{647}$ None of the art was from American collections; and, given his interest in Greek

pottery, the chapter on painting is surprisingly brief. ${ }^{648}$

Tarbell's first efforts to acquire Attic pottery can be documented to1896, when he purchased fragments from the Smithsonian. ${ }^{649}$ Then, in 1889 he acquired two red-figure vase fragments in Athens that Beazley attributed to Euphronios (c. 510). ${ }^{650}$ Warren may have advised Tarbell in these acquisitions, but research does not verify a connection. ${ }^{651}$ The records and catalogues of the University of Chicago give 1902 as the year when Tarbell received more than one hundred gifts from Warren, and all of the entries referring to Tarbell in the Lewes House Registers except one are stamped "Given to Tarbell 1901."652 One anomaly in the Lewes House Registers is on the page facing the entry for “Greek Lamp" preceded by the number 1500 and the notation "F.B Tarbell Aug 1899";

\footnotetext{
${ }^{646}$ Tarbell 1900 and Tarbell 1908.

${ }^{647}$ Tarbell 1893. Tarbell acknowledged the assistance of his colleague, J. H. Breasted, in the first chapter which is devoted to Egyptian and Near Eastern art, a feature not included in other early textbook. iii-iv.

${ }^{648}$ As discussed in Chapter 2, the Fowler and Wheeler textbook, published less than a decade later, contained photographs of Warren's antiquities in the MFA, testimony to the impact of Warren.

${ }^{649}$ Schwarz 1996, 8.

${ }^{650}$ Based on a drawing, Beazley attributed the red-figure neck-pelike fragment (1967.115.287) to Euphronios in his catalogue of vases in American Collections, but incorrectly listed it as in the Art Institute. Beazley 1918, 30, 207. Later he pointed out that it was a fragment missing from a vase in the Villa Giulia in Rome. The Euphronios fragment in the University of Chicago collection has been published and exhibited widely. In fact, it was in a European exhibition devoted solely to Euphronios ( Paris in 1990; Milan and Berlin in 1991). For a discussion of this fragment and the bibliography, see Ferrari, Nielsen and Olson 51-3. After the other Euphronios shard in Chicago was found to be part of a kylix in Athens, it was returned to the National Museum in Athens in exchange for other pottery fragments in 1952. For this fragment, see Svatik 1939, Nielsen 6.

${ }^{651}$ Moon 1990, 24. Moon makes this very plausible suggestion but does not provide verification.

${ }^{652}$ Warren gave Tarbell the antiquities in 1901 but either did not receive or record them until 1902.
} 
in addition, this entry contains the abbreviation, "BB 117 (2)." The measurements and the description of the entry match a lamp now in the Tarbell Collection listed with unknown provenience (Attic Lamp 1967.115.826, Fifth Century). ${ }^{653}$ “BB 117 (2)” apparently refers to another inventory, the "Black Book" once kept at Lewes House and also referenced in Hoppin's list at Bryn Mawr. Two other notations appear for the lamp. One_-“JM from Fausti”_ _ refers to John Marshall who apparently obtained the lamp from Fausti Benedetti, an Italian friend of Warren and a prominent antiquities agent. ${ }^{654}$ The second-“RF from Rome 1899"- likely refers to Richard Fisher, a Lewes House assistant and long-time Oxford friend of Marshall. ${ }^{655}$ Precisely how these two notations are related is unclear, but a reasonable interpretation is that Fisher may have conveyed the lamp from Rome to Lewes House. In any case, research for this dissertation suggests that the Attic lamp (1967.115.826) now in the Smart Museum came from Warren, even though he is not credited for it.

Franklin P. Johnson, Professor of Art at the University of Chicago, taught a variety of courses and seminars in Greek and Roman art from1930 to 1950 using “archaeological materials,” some of which undoubtedly were Warren gifts to Tarbell. ${ }^{656}$ A specialist in Attic black- and red-figure vases, he published extensively and wrote three

\footnotetext{
${ }^{653}$ Ferrari, Nielsen and Olson 117-8. The Lewes House Register entry is "diameter 7 1/2 / length 9/Cut in center with raised circular ridge which allowed the lamp to be stuck on a candelabrum." Lewes House Registers, Lewes House Archives.

${ }^{654}$ For Benedetti, Sox 1991, 68-69.

${ }^{655}$ For Richard Fisher, who receives brief references in Burdett and Goddard, and later joined Warren chief protégé, Matthew Stewart Pritchard, in working for the MFA in 1901, see Sox 1991, 40-41, 174-75

${ }^{656}$ I have been unable to establish the exact dates. The Art History department at the University of Chicago does not have any records on Johnson. E-mail Message from Tara Moran, 4 April 2011, to the author. Johnson's courses included "Greek Art," "Italic, Etruscan, and Roman Art," "Greek Pottery," and "Attic Red-Figure Vase Painting" and seminars, cross-listed with the Classics Department, such as "Studies in Greek Life" and "Studies in Greek Mythology." Nielsen
} 
$A J A$ articles on Warren's gifts. ${ }^{657}$ Apparently, Johnson consulted with Beazley about the Chicago study collection assembled by Tarbell because through Beazley he discovered that seven fragments, not on the "Tarbell Inventory," came from Warren. ${ }^{658}$ In an article, he also noted that a letter he had received from Beazley identified an Attic black-figure dinos fragment (1967.115.284) as coming from Warren. ${ }^{659}$ This fragment shows racing chariots on its heavily damaged exterior and, on the interior, a warship prow terminating in a boar's-head ram. ${ }^{660}$ It has proven impossible to verify Warren as the source for this fragment. $^{661}$

The Classical Collection (1998), the catalogue for the Greek and Roman art, recognized Warren's role in forming the collection at the University of Chicago. ${ }^{62}$ The introductory essay on the history of the collection suggests that Warren "most likely

${ }^{657}$ A search of JSTOR (31 March 2011) produced over fifty articles and reviews by Johnson or reviews of his books on sculpture Lyssipos (1928) and Corinth. Results of Excavations Conducted by the American School of Classical Studies at Athens. Volume 9: Sculpture 1896-1923 (1931).

${ }^{658}$ See Johnson 1943, 385. Johnson provided this information as a form of a correction/qualification to an earlier (1938) AJA article on red-figure vases at Chicago. When and how Beazley conveyed these facts is not clear; Beazley's information may have been drawn from his notes on the vases or from Warren's registers. Beazley also revealed Warren's sources: the general location as "from Tarquinia" and "from Athens," the dealer such as "bought of Hartwig" or a combination "bought of Lambros, probably from Greece." The fragments in question are not in the Classical Catalogue of the Smart Museum (1998) nor can they be identified on the printout of Warren objects furnished for the author by the Smart Museum curatorial staff.

${ }^{659}$ Johnson 1941, 215. "Professor J. D. Beazley, having seen illustrations of the Chicago fragment, writes that in his opinion it does not belong to the Castellani dinos; also that it was formerly in the collection of Mr. E. P. Warren and, according to the Warren register, came from Attica." Johnson considers whether the Chicago fragment could be matched with other dinos fragments, the type of ship it depicts, and its attribution to Exekias.

${ }^{660}$ Ferrari, Nielsen and Olson 30-1. The fragment has also been published in a catalogue for an exhibition of Greek vases in American collections, see Moon and Berge 1979, 62-3; and a study of the Greek banquet, Lissarague 1990, 107-22.

${ }^{661}$ The 1998 University of Chicago catalogue states "Provenience unknown. From the F.B. Tarbell Collection," Ferrari, Nielsen and Olson 30. No information in the Documentary File for the dinos fragment confirms Johnson's statement. E-mail message from Richard Born, Senior Curator, The Smart Museum of Art, 7 April 2011, to the author.

${ }^{662}$ The Museum, now called The David and Arthur Smart Museum of Art, contains over eight hundred Greek and Roman antiquities, with the Warren gifts constituting approximately one-eighth of the total. Ferrari, Nielsen and Olson vi. 
directed" Frank Tarbell's acquisitions for the teaching collection at Chicago, a viable hypothesis given that Tarbell published an AJA article in 1900 on a Warren vase in the MFA, at least a year before Warren presented an assortment of antiquities to him. The variety of shapes and iconography on these vases suggest that Warren intended to supply Tarbell with a range of materials appropriate for use in the University of Chicago courses in art history and classics. ${ }^{663}$

As might be expected, Warren's gifts garnered attention from University of Chicago professors. Tarbell published one of the Warren gifts: a 1908 AJA article on the white-ground (1967.115.359) lekythos that he acknowledged in the first sentence as "bought in Athens, and of course found in some grave" as a "gift from E. P. Warren, Esquire, of Lewes, England." ${ }^{664}$ Although Franklin Johnson described the University of Chicago collection as "unpretentious," he published most of the Greek vases and fragments in the American Journal of Archaeology, always acknowledging Warren's role in assembling the study collection at the beginning of each article. In a 1938 article describing forty-four red-figure vases and fragments at Chicago, he identified six as Warren's gifts, supplying the "Tarbell Inventory" number. ${ }^{665}$ A second Johnson AJA

\footnotetext{
${ }^{663}$ As discussed above, he published a red-figure fragment (1967.115.287) attributed to Euphronios that Tarbell may have obtained through Warren's guidance.

${ }^{664}$ Tarbell 1908, 428. Tarbell called the vase "carelessly made and destitute of artistic merit" but "of considerable interest by reason of its unique design." This white-ground (1967.115.359) lekythos is discussed in Chapter 4.

665 Johnson 1938. Johnson numbered the pieces 1-46, here listed by the figure number in Johnson's article and then the present accession number. He devoted the most attention to an alabastron (Johnson 1; 1967.115.6) attributed to the Painter of Berlin 2268 (see Beazley 1963, 157) and a fragmented kylix (Johnson 2; 1967.115.341) "probably by Onesimos" (but now attributed to the Manner of Douris, see Beazley 1963, 449). The other vases and fragments from Warren included in Johnson's article were a kylix fragment (Johnson 15; 1967.115.295), which Beazley later attributed to the Euaion painter and suggested was once in the famous Campana collection in Rome ( Beazley 790-91, 796 ); a pelike (Johnson 12; 1967.115.339) now restored from forty-six fragments; a single fragment with the profile of a
} 
article five years later surveyed the Attic black-figure Greek pottery at Chicago. Among these twenty-pieces he discussed were eight vases Warren gave to Tarbell. In a third article in 1949 Johnson published four more of Warren's gifts, all non-Attic ware. ${ }^{666}$ Three are a Boeotiam kantharos (1967.115.279), dated to the late Geometric period, c. 710; a perfume vase in the shape of a ram, c.650-500 (Figure 45) ; and a stemmed bowl and lid, or pyxis, (1967.115. 275) c. $420-400 .{ }^{667}$ In the same article, Johnson also published a striking "Daunian" vase (1967.115.452), with the figurine of a woman on the body of the vessel from Apulia, c. $450-400{ }^{668}$

Many of Warren's gifts to Tarbell were "badly battered and shattered," as Johnson described a black-figure neck-amphora (1967.115.351), dated to c. 500 (Figure 46). Nevertheless, the vase's iconography with scenes from the Iliad were suited for a teaching collection. On Side A, a young man attempts to separate two combatants who might be "read" as Ajax and Odysseus quarreling over the arms of Achilles. ${ }^{669}$ The departing warrior with a woman and old man on the other side might be Hector taking leave of Andromache and Priam. ${ }^{670}$ The iconography of a second Warren gift, the blackfigure pelike (1967.115.340), is also appropriate: two men flank a sphinx sitting atop a pillar on Side A and a man in a triangular hat and high boots-perhaps Hermes - plays a

woman's head (Johnson 24; 1967.115.291) that Johnson attributed to the Kleophon Painter; and a kylix (Johnson 35; 1967.115.347) with a seated girl juggling balls with a flying Eros behind her.

666 Johnson 1949, 242-48.

${ }^{667}$ The ram vase is discussed with Warren plastic vases in Chapter 3. For the bibliography on the Geometric kantharos (1967.115.279), Ferrari, Nielsen and Olson 23. For the pyxis (1967.115. 275), Ferrari, Nielsen and Olson 25-26.

${ }^{668}$ Warren also gave Tarbell a "ring vase" (1967.115.454) from this region which Johnson did not publish. For the bibliography on these two unusual vases, see Ferrari, Nielsen and Olson 81-4. For Daunian ware, see Yntema 1990. Yet another Warren gift was an "Italic Bowl," which my research has not located at Chicago. Johnson , 247-48.

${ }^{669}$ For example, Walters and Birch 1905, 133 as cited in Johnson 1943, 388.

${ }^{670}$ Ferrari, Nielsen and Olson 34-5. 
double-flute as satyrs dance on his right and left on Side B (Figure 47). This vase has prompted speculations about the scene on Side A as a reference to Oedipus. ${ }^{671}$ Scholars also took notice of this vase, discussing its attribution and the significance of its shape. ${ }^{672}$ Other black-figure fragments from Warren included those from a loutrophoros (Figure 48), a large vessel for water used in Greek wedding ceremonies or, as in the case of this vase (1967.115.342), for funerary rituals for a young unmarried person. This vase was reconstructed from fifty-seven pieces with more than half of its surface restored in plaster. ${ }^{673}$ On one side, a prosthesis scene, or the laying out of a body, takes place while on the opposite is what has been interpreted as the performance of a lamentation by two male choruses. ${ }^{674}$ The Tarbell Inventory records that Warren purchased the vase, dated to 520-500, “in Athens, in the Dipylon."675

At 50.4 centimeters, the restored loutrophoros (1967.115.342) is by far the largest of Warren's one hundred antiquities at Chicago. Generally they are small, often broken, terracotta objects or shards suitable for a study collection. However, approximately two dozen relatively intact ceramics — a dozen vases, six terracotta figurines, and six Greek and Roman lamps_-were also included. In addition, Warren contributed one small marble, a statuette of the Aphrodite of Aphrodisias (Figure 49); as well as two intact bronze, an eight-century B.C.E. Italic Spearhead (1967.115.18) and an inscribed seventh-

\footnotetext{
${ }^{671}$ Johnson 1943, 393-94; Ferrari, Nielsen and Olson 43-44

${ }^{672}$ For attribution, Johnson cited Haspels 1936, 161; and Beazley 1956, 396. Beazley argued for the early $5^{\text {th }}$ century Eucharides Painter. In 1951 Dietrich von Bothmer discussed the black-figure pelikai according to the motifs of the decorative panels, placing Warren's vase in the group with "Lotus above, net patterns on the side" and identifying the sphinx and men as a "two men at a tomb." von Bothmer 1951, 42

${ }^{673}$ When the vase was restored is not clear. Johnson shows it in its present state in 1943.

${ }^{674}$ Ferrari, Nielsen and Olson 34-5.

675 Johnson 1955.
} 
century B.C.E. bronze basin (1967.115.17), both reportedly from Cumae. ${ }^{676}$ Other Warren gifts were a fragmentary ivory plaque (1967.115.4550) thought to have come from a second/third-century Egyptian workshop (Figure 50) and two small Greek glass vessels (Figures 51 and 52), which are discussed in Chapter 5. Despite their modest size and damaged condition, Warren's gifts were nevertheless thoughtful contributions to the study collection at the University of Chicago.

\section{Warren and the Rhode Island School of Design Museum of Art}

Edward Perry Warren's association with the Museum of Art of the Rhode Island School of Design spanned the last quarter of his life (1900-28). He served as the channel for a wide variety of Greek and Roman objects entering the Museum during its formative years. He and Eliza Metcalf Radeke (1854-1931), whose family helped found RISD, believed that the School's Museum should function as a pedagogical tool for design and art classes as well as serve as a civic museum for Providence. The correspondence between Radeke and Warren, preserved in the RISD Archives of the Fleet Library, documents Warren's impact on the RISD collection in his roles as agent, advisor, and benefactor. The letters contain insights into his collecting tastes and methods and also reveal that a warm and mutually respectful relationship evolved between the expatriate connoisseur and RISD's dedicated patroness.

Like the University of Chicago, RISD owes its founding to the prosperity of the Gilded Age. After the Civil War, Rhode Island led the country in woolen, cotton,

\footnotetext{
${ }^{676}$ The damaged and unreadable inscription may be Phoenician. Ferrari, Nielsen and Olson 158. Other unidentified bronze pieces (1967.115.43 a-e) came from Warren: a ring with hooks for attachment and three pierced discs.
} 
hardware, tool, jewelry and silverware production; and Providence, the state capital, became one of the most important New England industrial centers. ${ }^{677}$ In 1853 Providence's foremost citizens - merchants, bankers, civic leaders, artists, and silver, textile, and machine manufacturers, together with six Brown University professors and its president, Francis Wayland - met to address the lack of skilled artisans in the city. ${ }^{678}$ These men formed the Rhode Island Art Association (RIAA), with the goals "to spread the influence of 'the fine arts' and to make an extensive permanent accumulation of their monuments among us." ${ }^{679}$ Thus, from its inception, the RIAA recognized that training expert American craftsmen required access to a museum with a comprehensive collection of art. The RIAA's blend of “commercial entrepreneurship and a genuine interest in ... art as a moral and beneficial force in society, to cultivate tastes and raise the cultural standards of the city" reflected the ideas of John Ruskin and prefigured those of Charles Eliot Norton expressed twenty years later. ${ }^{680}$ The onset of the Civil War and a general financial downturn in 1857, however, disrupted the efforts of the Rhode Island Art Association to found a museum and to formalize a training program for designers and craftsmen, and the organization faded away by 1865 . Nonetheless, within a generation, the twin objectives of elevating the aesthetic sensibilities of the community and establishing a school of design were achieved, but not by the elite men of Providence.

\footnotetext{
${ }^{677}$ Coleman 1963; McLoughlin 1978, 148-49. The Corliss Steam Engine Company, the largest such factory in the world, was perhaps the most famous enterprise in Providence. George H. Corliss (1817-1888) revolutionized manufacturing by developing an engine that could operate at a constant speed, thus allowing cloth and yarn to be produced with uniform texture. For his impact on Providence, Kenny 1981. Gorham Manufacturing Company, the leading American producer of silver plate, pioneered the use of a steam engine to mechanize silversmithing, while maintaining high standards of craftsmanship. For Gorham silver, Venable 1995, 23-8.

${ }^{678}$ Over one hundred men attended the meeting. Gilkerson 1986, 27; Switzer 2008, 117 .

${ }^{679}$ Switzer 117.

${ }^{680}$ As quoted from "Meeting for the Promotion of the Fine Arts," Providence Daily Journal, 9 December 1853, unpag. in Switzer 117.
} 
The founding of the Rhode Island School of Design and its impressive Museum is credited to the wife and daughter of a successful Providence woolen manufacturer: Helen Adelia Rowe Metcalf (1835-1895) and Eliza Metcalf Radeke (1854-1931). ${ }^{681}$

The patriarch of the family, Jesse Metcalf (1827-1899) was one of the founders and later the controlling owner of Wanskuck Mills, a wool manufacturing company in Providence. ${ }^{682}$ Members of the Metcalf family assumed leadership roles in Rhode Island's political and cultural elite. ${ }^{683}$ His wife, Helen Adelia Rowe Metcalf (1835-1895), was active in the Women's Centennial Commission, which produced Rhode Island's display in the Women's Pavilion at the Philadelphia Centennial Exhibition of $1876 .{ }^{684}$ After viewing the beautiful products, particularly those of English craftsmen, in Philadelphia, the delegation of Rhode Island women who included Helen and Eliza Metcalf returned home, determined to promote both quality and experimentation in their local industries. Their model was the technical schools of South Kensington, London, which had at their center the Victoria and Albert Museum. ${ }^{685}$ After the close of the Philadelphia Centennial Exhibition of 1876, the Rhode Island women were faced with a decision about how to use the $\$ 1,500$ funds remaining from the Women's Centennial

\footnotetext{
${ }^{681}$ However, one scholar traces the RISD roots to the RIAA and emphasizes the impetus of industry's need for designers. See Austin 1995; Austin 2008c.

${ }^{682}$ Wanskuck Mill closed in the 1950s. "Wanskuck Company Mill” Providence Preservation Society (PPS) and the Rhode Island Historical Preservation \& Heritage Commission (website) (accessed 11 September 2009). http://www.artinruins.com/arch/stillinuse/wanskuckmill/ (accessed 10 March 2009). Jesse Metcalf, like S. D. Warren in Maine, provided housing for his factory workers. He and his partners built brick and wooden houses on Branch Avenue for their workers across from the mill. In 1994 the Providence Preservation Society listed this housing, together with a social hall and the mill, as "endangered." "Wanskuck Mill Houses" Providence Preservation Society (PPS) and the Rhode Island Historical Preservation \& Heritage Commission (website) http://wiki.ppsri.org/tikiindex.php?page=Wanskuck+Mill+Houses (accessed 11 September 2009).

${ }^{683}$ Gilkerson 183, 201

${ }^{684}$ For women and the Philadelphia Centennial Exhibition of 1876, see Cordato 1983. For the inventions, and displays in the Women's Pavilion, see Post 1976.

${ }^{685}$ Woodward 1985, 15; Austin 2008b, 97.
} 
Commission. Helen Metcalf proposed establishing what came to be called the Rhode Island School of Design. ${ }^{686}$

Helen Metcalf not only served as a trustee for the new institution, she acted as the first director and managed the School's finances. One RISD president commented on her extraordinary commitment to the new school in Providence:

Though a mother of five children, [Mrs. Metcalf] . . . appeared everyday on the school premises ... She chose the teachers. She managed the finances. No detail or item for purchase was too insignificant for her personal attention. She was known on occasion to sweep and dust the classrooms. ${ }^{687}$

Her husband and sons, under her prodding, compensated for persistent annual operating deficits at the School. Her husband, Jesse Metcalf, built the first permanent building for RISD, the "Waterman Building," at 11 Waterman Street. At its dedication in 1893, William C. Baker, a member of the Museum committee and a Metcalf son-in-law, expressed the hope that the building would house not only the School "but also a rare and beautiful collection of works of art." ${ }^{688}$ The fact that the School and its Museum were in the same building affirmed RISD's intention to inspire its students through direct contact

\footnotetext{
${ }^{686}$ Austin 2008a; Austin 2008b. Other American women who visited the 1876 Centennial Exhibition in Philadelphia were inspired to found organizations to promote the education of women through handicrafts. See "Candace Wheeler's Search for the Aesthetic Life," in Blanchard 45-84.

${ }^{687}$ Frazier 2008, 89. John Frazier (1889-1966) was a student in 1905 at RISD and later a professor of drawing and painting there. He served as RISD President (1955-62).

${ }^{688}$ Woodward 16. The members of the Metcalf family remain actively involved at RISD especially through its Museum of Art. The 2008 Selected Works: Museum of Art, Rhode Island School of Design is dedicated to Houghton P. Metcalf, Jr. (1920-2003) a Life Trustee, member of various committees, and long time supporter.
} 
with great works of art. From its beginning, RISD was unusual in that it provided classes for children, as well as classes and programs for women and men of all social classes. ${ }^{689}$

The first public displays of art at RISD took place in 1894 after the construction of the Waterman Building. ${ }^{690}$ They consisted of paintings, casts of ancient sculpture, pottery, modern silverware, and embroideries already owned by the School or loaned by its supporters. For the most part, such exhibitions—often consisting of autotypes and casts - were meant to instruct and inspire the students (Figure 53). ${ }^{691}$

The Metcalfs' only daughter, Eliza Metcalf (1854-1931)_"Mrs. Radeke” in her correspondence with Warren-was dedicated to creating a comprehensive art collection at RISD. After making "the grand tour" of Europe with her father in 1874, she graduated from Vassar in $1876 .{ }^{692}$ Under her mother's tutelage, she served as a hostess for the Rhode Island exhibit in the Women's Pavilion at the Centennial Fair in Philadelphia. In 1880 she married Gustav Radeke (1839-1892), a Providence physician who was familiar with the museums in his native Germany and keenly interested in folk art. Although Dr. Radeke was not officially involved with RISD, he sponsored scholarships and bought plaster casts for the drawing classes. After the deaths of her husband, father, and mother in the late 1890s, Eliza Metcalf Radeke devoted the rest of her life to RISD in a variety of leadership roles: the School's manager, its acting director and President of the Trustees

\footnotetext{
${ }^{689}$ For the 1878 and 2008 RISD mission statements, Barrett 2008, 105. Men employed as machinists, toolmakers, or jewelers were the evening students while women, to a large extent, were the day students. Austin 2008c, 220.

${ }^{690}$ Michie 2008b, 10-11.

${ }^{691}$ See photographs in Austin 1995, 230; Barrett and Martinez 2008.

${ }^{692}$ From Paris, Jesse Metcalf wrote to his wife, Helen Adelia Rowe Metcalf (10 December 1974): "[Lizzie] seems to be quite a success wherever we travel, and I believe is learning more than she could at Vassar." See “1874-1885: The Metcalf Family Letters" in Barrett and Martinez 458.
} 
(1913-31). After her death in 1931, the Metcalf legacy continued, with her niece Helen Metcalf Danforth (1887-1948) succeeding as President of the RISD Board of Trustees.

Eliza Radeke's and her mother's contributions to RISD demonstrate how women came to assume leadership positions in late nineteenth-century America. Wealthy women began to establish spheres of influence, first by forming bonds among themselves through progressive organizations like the Women's Centennial Commission. In arts and education projects, they learned management and organizational skills; and, with this expertise and growing self-confidence, they began to undertake leadership roles. ${ }^{693}$ Over the span of more than thirty years, Eliza Radeke led the effort to establish an impressive collection—spanning classical to contemporary art—at one of America's premier schools of art and design. Her rapport with the chief curators, scholars and dealers of the day and the high regard in which these men held her were assets in assembling the RISD collections. Radeke's willingness to use her own funds to acquire works for the Museum inspired her friends and family to support her efforts. A new museum building, the Eliza G. Radeke Museum was dedicated in1926; fittingly, this building still houses the classical collection, much of which was acquired through Edward Perry Warren. ${ }^{694}$

The relationship between Warren and the Rhode Island School of Design can be dated to 1900, when he agreed to serve as its agent. It is unclear how Eliza Metcalf

\footnotetext{
${ }^{693}$ Although the women of the Metcalf family took the primary responsibility for the management and nurturing of RISD, the most prestigious positions at the School often went to men "who connoted respectability and seriousness." Burnham $2008,273$.

${ }^{694}$ Her brothers, Stephen O. and Jesse H. Metcalf, provided \$400,000 to build the museum.
} 
Radeke and Ned Warren became acquainted. ${ }^{695}$ In a March 1900 letter to Radeke, Warren referred to her "kind letter" that "Mr. Updike" had forwarded to him. ${ }^{696}$ This Updike was most likely Daniel Berkeley Updike (1860-1941), an American printer and historian of typography from Providence. ${ }^{697}$ Within a year, Warren began offering various works to Radeke, mostly sixteenth-century sculpture and chasubles, but also a fragment of an ancient colossal marble foot. ${ }^{698}$ The financial arrangement between RISD and Warren is uncertain in the early stages of his involvement. In several letters, he advocated what he called "subscription sendings" whereby RISD would deposit a set amount with Warren, which he then would use to buy objects on approval. ${ }^{699}$ Some sort of an early "subscription" arrangement must have existed because, in an exchange of letters in 1921, Warren and Radeke discuss the return of $\$ 250$ to RISD to reconcile accounts.

\footnotetext{
${ }^{695}$ Michie describes Mrs. Radeke as “enlisting” Warren's services and "redirecting Warren's attention to RISD"; however, he does not document the basis for his statements. Michie 2008b, 15. Radeke certainly knew of Warren through his work on behalf of the MFA. L. Earle Rowe (1882-1937), who became the first professional director of the Museum of Art at RISD in 1912, was on the MFA staff and was a specialist in ancient art. Warren's long-time friend, Edward Robinson (1858-1931), Director at the MFA Boston (190205) and later at the Metropolitan Museum of Art (1910-31), is another possible contact.

${ }^{696}$ Edward Perry Warren to Eliza Metcalf Radeke, 7 March 1900, RISD Archives. From this point, correspondence between Warren and Radeke in the RISD Archives will be abbreviated EPW to EMR, date, RISDA or EMR to EPW, date RISDA.

${ }^{697}$ Daniel Berkeley Updike (1860-1941) surely knew the Warrens through the family's paper mills. A "Mr. Updike" is also mentioned in a Radeke letter to Warren, indicating that Updike had received a porphyry pedestal. EMR to EPW, 19 February 1921 RISDA. According to Michie, Updike was "a mutual friend" of Warren and Radeke. 2008b, 424.

${ }^{698}$ EPW to EMR, 22 August 1901, RISDA. A marble forepart of a foot (Accession number 00.003) in the RISD collection, a 1900 Gift of Friedrich Kohlhagen, entered the collection too early to be the object to which Warren refers. In addition, the Kohlhagen gift is smaller than life-size. For a description and photograph of this object, see Ridgway 1972, 95, 211.

${ }^{699}$ Warren expressed his delight in learning that RISD was putting up \$5000. EPW to EMR, 26 May 1901, RISDA. He voiced hope for a possible RISD allotment of $\$ 10,000$, with $\$ 3,000$ of that amount coming from Radeke herself. EPW to EMR 22 August 1901, RISDA. In an undated letter Radeke informed Warren that she had been unable to raise the subscription: whether that statement refers to the original $\$ 5,000$ proposal, the second one for $\$ 10,000$, or both is not clear. EMR to EPW no date, RISDA. Warren also had a "subscription" arrangement with Penn and the MFA in which a limited fund was set up so that Warren could immediately respond to opportunities in the antiquities market.
} 
The correspondence in the RISD Archives reveals that Warren's proposals to buy "lots" or groups of antiquities made members of RISD Board of Trustees uncomfortable. Counter offers - made in Radeke's letters - came from the Trustees for fewer and often less expensive objects. In replies, Warren expressed his disappointment or offered justifications for his proposed additions to the RISD collection. In some cases, he dropped the matter abruptly with an announcement that, under more scrutiny, the antiquities he had proposed for RISD had proven unsuitable or that, given the delay in the response from Providence, the objects already had gone to another museum or client.

In the early 1900s Warren became disenchanted and frustrated with the MFA Boston. His goal was to build a comprehensive collection of classical art, spanning all periods of Greek art and illustrating the range of object types and media, but the MFA was interested primarily in marbles and red-figure pottery. ${ }^{700}$ His letters to Radeke suggest he had unsuccessfully proposed that the RISD museum could fulfill his collecting aspirations:

I am disappointed because for some years I don't see my way to form a little museum after my own tastes by benefactions of my own. The Boston Museum taxes me sufficiently, \& restricts itself to classical antiquities. I wanted ever so much to have a free hand for a comparatively inexpensive collection illustrative of the styles of all epochs, \& especially adapted to those who draw from sculpture or the human figure. In the old days I should have done it myself: later I may be able to do it again. For the present you were my only chance. All my friends either go in for antiquities of classical date alone or for masterpieces. I had my own idea which was different ... ${ }^{701}$

\footnotetext{
${ }^{700}$ EPW to EMR, 24 October 1901, RISDA.

${ }^{701}$ EPW to EMR, 24 October 1901, RISDA.
} 
Warren's complaint was that Americans were too focused on buildings rather than on the art itself. His proposal was that RISD should buy antiquities under his guidance and postpone the plans for museum buildings:

Americans are now building \& endowing — now when they might buy cheaper. Later they will all be buying and will have to buy dear. To be ahead of the times now you must neither build nor endow but buy. See what we have to talk about. ${ }^{702}$ Radeke (or the RISD Board of Trustees) was not open to his scheme because Warren writes in a short note to Radeke:

I am always sorry that you cannot do the little work after my own heart which we once sketched out. It would have been an exception in my life - no restrictions, no committee deliberations, and a clear purpose. ${ }^{703}$

Radeke, members of her family, and her friends were intent on establishing a comprehensive collection at RISD and, consequently, were acquiring works from various periods and cultures, not solely Greek and Roman antiquities. Moreover, Radeke and her family were dedicated builders; in fact, the Metcalfs funded three museum building projects during Radeke's lifetime.

By 1903 Warren was frequently in America where he had established Fewacres, outside Portland, Maine. Typically, Warren spent his summers in Maine and lived in England - at Lewes or Oxford - the rest of the year, unless he was traveling on the Continent. He made references to visiting Providence and, in 1923, to the possibility of his escorting Mrs. Radeke to the Bartlett Collection at the MFA when he was in

\footnotetext{
${ }^{702}$ EPW to EMR, 24 October 1901, RISDA.

${ }^{703}$ EPW to EMR, 1 January 1902, RISDA.
} 
Boston. ${ }^{704}$ Other letters in the RISD Archives indicate that Radeke visited Bowdoin to view the Warren antiquities in its collection and that she regretted not seeing him when she made a trip to England.

Sometimes Warren adopted a conspiratorial tone with Radeke. In a 1925 letter, for example, he seemed to be whispering: "I have omitted some remarks which I should like to make in person, specially [sic] to explain why one or another object is included."705 Other letters contain advice to Radeke about purchasing antiquities on her own in Paris; he forwarded advice from his long-time friend and collecting collaborator, John Marshall, and directed one of his assistants at Lewes House to provide Radeke with the names of "safe" antiquities dealers in Paris. ${ }^{706}$

An affectionate_-almost flirtatious_- banter developed between Warren and Radeke. For example, he wrote: "Poor Bowdoin! I am sending it some minor things- the best of them are engraved gems. You have carried off what might have gone thither."707 And in regard to a sculpture he sent to Providence, Warren teased: "When it comes I hope you will tell me whether you like it-un peu, beaucoup, de tout coeur, pas du tout. Such frankness will guide me."708 Radeke's repartee came two weeks later: "frankly ... de tout coeur.",709

\footnotetext{
${ }^{704}$ For example, he promised to see the Museum and bring a statuette "by motorcar" from Boston to her home in Providence. EPW to EMR, 27 September 1923, RISDA.

${ }^{705}$ EPW to EMR, 30 April 301925 , RISDA.

${ }^{706}$ EPW to EMR, 15 July 15 1923, RISDA; Frank Gearing to EMR, 17 July 1923, RISDA.

${ }^{707}$ EPW to EMR, 3 January 1914, RISA.

${ }^{708}$ EPW to EMR, 7 December 1914, RISDA.

${ }^{709}$ EPW to EMR, 21 December 1914, RISDA.
} 
Sometimes the letters between them touch on personal matters. Mrs. Radeke and Warren frequently refer to the health of and news about friends. Warren provided updates on John and Mary Marshall's frequent illnesses, and Radeke expressed concern about the young men at Lewes House during the First World War. In the autumn of 1914, she observed, "I fear that life in England must be very sad at present, and I hope your friends that have gone to war ... are all safe., ${ }^{, 710}$

In late 1923, Radeke and Warren discussed the possibility of her employing a private secretary from among candidates at Oxford whom Warren would select. ${ }^{711}$ Such a young man, it can be assumed, would have functioned as Radeke's aide in managing her many duties at RISD and served as a liaison to Lewes House and its collecting network. A lengthy letter from Warren explained that "many talented + agreeable young men ... would be glad to come to you, since Oxford educates them far too well to give them a taste for what are called "practical pursuits.", ${ }^{, 12}$ By the following spring, however, Radeke had decided against an "Oxford secretary" and thanked Warren for his "pains":

I was in earnest when I spoke it, but I am now not inclined to enter upon it, as it seems rather convenient for me to continue with a woman. There are good things in travelling (and I hope to travel more in the future) that would be more convenient with her. I am sure in many ways an Oxford scholar would be of great help to me, and if I were a few years younger I would attempt it. ${ }^{713}$

\footnotetext{
${ }^{710}$ EMR to EPW, 27 November 1914, RISDA.

${ }^{711}$ Warren said, "At Oxford I see what I think the best kind of young men and the best for such a post." EPW to EMR, 30 December 1923, RISDA.

${ }^{712}$ EPW to EMR, 30 December1923, RISDA.

${ }^{713}$ EMR to EPW, 22 April 1924, RISDA.
} 
Here, one speculates that the increased expenses entailed with a male secretary, as well as the impropriety of her traveling with an assistant of the opposite sex, might have prompted the now seventy-year old Radeke to abandon the notion.

Whatever the reasons for Radeke's rejection of an "Oxford secretary," the seventy-five year old Warren continued to disclose his increasing frailty to his friend in Providence. In 1925 letters, for example, he confessed his dependence on his young associates, for both practical and emotional support. ${ }^{714}$ From Taromina, Sicily, Warren disclosed:

"Either I am incorrigibly hopeful, or past the age of worry. It is enough for me that I am petted. ... It is pleasantly supposed that I am unable to cross the street alone, and that doctrine is applied to railway travel, tickets, luggage ... My sister [Cornelia Warren] thought that I hadn't a family. It seems to me that I have a big one agreeably various and diverting."

The Warren-Radeke correspondence, thus, suggests that what began as a business relationship evolved into a friendship. The antiquities connoisseur from Boston and the wealthy Providence widow created what has been described as "one of the finest collections [of antiquities] in any museum between Boston and New York." ${ }^{716}$ Warren would most certainly be gratified with such an assessment, for he once expressed the hope to Eliza Radeke that his efforts for RISD "would be the colophon of my work.",117 The impact of Edward Perry Warren on the collections at the RISD Museum is

\footnotetext{
${ }^{714}$ Warren admitted he could not remember if she has been sent some paperwork and quips, "West tells me you have these papers ... I don't remember them, but he is always right." EPW to EMR 30 December 1923, RISDA.

${ }^{715}$ EPW to EMR, 12 February 1925, RISDA.

${ }^{716}$ Michie 208b, 15.

${ }^{717}$ EPW to EMR, 20 June 1925 , RISDA,
} 
undeniable. However, determining which antiquities arrived in Providence from Warren often proves to be a complex and speculative process.

Documents at RISD serve to identify Warren as the source with varying degrees of certainty. ${ }^{718}$ Museum records verify the works of art that Warren gave to RISD; however, the objects that he sold to the Museum were not usually acknowledged as such, at least not publically. As with most museums, the RISD handbooks and publications credit the donor who provided the funds to purchase an antiquity. However, typically, the records do not include an object's previous owner or the agent from whom it was purchased. For antiquities entering the RISD collection from 1900 to1928, "Mrs. Gustav Radeke" is most frequently listed as the specific donor. Occasionally, another benefactor or source is credited with the gift—“Lyra Brown Nicholson Bequest," for example. However, often the name of the patron is not supplied, with the sole acknowledgement being "Special Gift Fund" or "Museum Appropriation and Special Gift." The WarrenRadeke correspondence in the RISD Archives, nonetheless, suggests that Warren was the source of the objects labeled as "Special Gifts," with a member of the Metcalf family, a family friend, or—even more commonly—Eliza Radeke herself funding the purchase.

Another impediment to determining which antiquities came to RISD via purchases from Warren stems from his insistence that neither his name nor the provenance be publicized. Several of Warren's letters to Radeke in the RISD Archives allude to this stipulation. For example, in a 1921 message to Radeke about the Roman sarcophagus with scenes from the Trojan War (21.074) (Figure 54), Warren cautioned

${ }^{718}$ Here, I am referring to provenance or documented history of ownership. 
“. . . it occurred to me that you were not apprised of our Lewes House ways of doing things. If you look over the old reports of the Bostonian Museum (not that I think this undertaking necessary) you will see no statements of provenience are therein printed. By this prudence we have escaped trouble in Italy and the precaution, always desirable, is specially (sic) important in the case of your sarcophagus .... people will offer things only if they will find they are also protected." 719

In correspondence a few years later, Warren explained that he had included "proveniences" with the object he was selling to RISD. ${ }^{720}$ However, he pleaded that this information not be made public:

I have inserted proveniences, but I beg that no statement be made concerning [them] in print for some years. More information is contained in the Lewes books to which reference numbers are given in the margin: especially the dates of purchases are there to be found, but it would be just as well not to communicate because most are recent. ${ }^{721}$

Recent RISD publications have acknowledged Warren's role in forming the antiquities collection in Providence to varying degrees. For example, a history of the RISD museum in the 1988 handbook of collections, credited - albeit briefly-Warren in the description of the growth of the classical collection in the 1920s. ${ }^{722}$ A more recent guide to the RISD Collection extols his contributions to the Museum and asserts that Radeke's enlistment of Warren's services was one of her "most notable coups.",723

\footnotetext{
${ }^{719}$ EPW to EMR, 13 February 1921, RISDA.

${ }^{720}$ The document to which Warren alludes is the "1925 E. P. Warren List." The significance of this document and the vases, jewelry, gems, and various bronze objects itemized are discussed shortly. By "provenience," he means the history of an object's ownership, not its findspot. What he calls "provenience" is now termed "provenance."

${ }^{721}$ EPW to EMR, 30 April 1925, RISDA. The "Lewes books" are the Lewes House Registers.

${ }^{722}$ Woodward 30-31. Woodward's essay is the most comprehensive history of the Museum, according to Thomas S. Michie, who served as a curator at RISD (1984-2004) and wrote about the history of the collections. Michie 2008b, 23.

${ }^{723}$ Michie 2008b, 15.
} 
Acknowledgment of Warren's role is handled differently in the RISD catalogues devoted to antiquities. ${ }^{724}$ For example, when Stephen Bleeker Luce produced the RISD CVA in 1933, he included the previous ownership of the vases as well as their donors, whenever possible. ${ }^{725}$ He repeated the phrase "Formerly in the Warren Collection" twenty-five times in the catalogue and credited Warren as the donor of three additional vases. ${ }^{726}$ At the other extreme is the RISD catalogue of the ancient jewelry, which makes no reference to Warren despite the fact that he was unquestionably the source of twelve objects it describes. ${ }^{727}$ The omission of Warren's name in this catalogue is ironic, given his fondness for ancient gems and the 1920 catalogue of his collection at Lewes.

The records identifying a Warren antiquity at RISD come in several forms and with varying degrees of accuracy and reliability. Those antiquities documented as coming from Warren and those that were unquestionably received from sources other than

\footnotetext{
${ }^{724}$ Six of these catalogues include objects from Warren: Luce 1933; Ridgway 1972; Mitten 1975; Ashmead and Phillips 1976; Hackens 1976; and Holloway 1998. Warren's collecting did not include wall paintings or mosaics; thus, his name does not appear in Winkes 1982.

${ }^{725}$ Luce 1933. Stephen Bleeker Luce, who published widely, specialized in vase attribution and iconographic studies as well as Italic terracottas. He wrote a series of $A J A$ articles about "lost vases" in the 1920s that made him acutely aware and well informed about provenance. Luce 1917; Luce 1920; Luce 1923; Luce 1925b; and Luce 1927.

${ }^{726}$ The RISD Museum contained 129 Greek vases in 1933. In the preface of the 1933 CVA for RISD vases, Luce explained that RISD purchased twenty-five vases from Warren in 1925 and that Beazley had seen the vases and assigned attributions of painters to most of them before their sale to RISD. Information about the twenty-five vases Luce included in the CVA may have come from Beazley, but research for this dissertation has not discovered any documents that verify this assumption. Luce dedicated the 1933 CVA to Radeke, who had died in 1930 while he was researching and writing the catalogue. In his preface, he identified Radeke as the donor of 48 vases. It is likely that most or all of these came from Warren; in some cases, this theory can be verified through surviving Warren-Radeke correspondence. Luce also indicated that RISD also purchased ten other vases "through appropriation," such as 23.303 , the well known black-figure amphora signed by the potter Nikosthenes, which the Warren-Radeke correspondence indicates came from Warren.

${ }^{727}$ Hackens 1975. Hackens made few references to ownership or find spots, omissions that might be attributed to its 1962 publication date when such issues received less attention than they do now.
} 
Warren may be grouped at opposite ends of a continuum. ${ }^{728}$ Between these extremes may be arranged those antiquities that can be judged as those that are likely to have entered RISD through Warren and those that possibly arrived at RISD through Warren. The determination of RISD antiquities as "possibly Warren" and "likely Warren" groups is based on the accession date of the specific object.

Two documents in the RISD Archives indicate that Warren sold almost sixty objects to RISD. The first is a set of type-written descriptions of twelve objects-dated 1922 and supplied by J.D. Beazley at Oxford, who compiled similar lists for Bowdoin. This document will be referred to as the 1922 Beazley Descriptions. The second, also typed, but headed "Rhode Island School of Design Sending 1925, from E. P. Warren," is dated August 25, 1925 and signed "E. P. Warren." This document is less detailed and categorizes forty-five objects by medium: 23 vases (various shapes and decorative styles); 5 bronzes (a hydia, a kouros [now classified as "dubitandum"]; two Geometric fibulae [both now classified as "dubitanda"], and an Etruscan mirror); 1 silver coin; 10 gold jewelry pieces; and 7 "gems.” On this barely legible document, RISD accession numbers have been handwritten on the left side of the page. This document will be referred to as the $1925 \mathrm{E}$. P. Warren List.

Seven catalogues have been published describing antiquities in the collections of RISD's Museum of Art. As discussed earlier, Luce produced the CVA in 1933, and forty years later, Ann Harwell Ashmead and Kyle Meredith Phillips, Jr. updated and

\footnotetext{
${ }^{728}$ Examples of the antiquities that unquestionably entered from other sources include fifteen pieces of Egyptian pottery that came to the RISD Museum via the British Egyptian Exploration Fund (now known as the Egyptian Exploration Society). See preface Luce 1933. Other specimens of Egyptian ware were gifts of Radeke (15.187 and 11.029) and her brother, Stephen O. Metcalf (14.090).
} 
republished the RISD vases in Classical Vases: Excluding Attic Black-Figure, Attic RedFigure and White Ground (1976). This volume was part of an effort initiated in 1962 to publish RISD's antiquities in a series entitled Catalogue of the Classical Collection. In 1972 Brunilde Sismondo Ridgway catalogued the stone sculpture in Classical Sculpture. David Gordon Mitten published the catalogue Classical Bronzes in 1975. Tony Hackens compiled Classical Jewelry in $1976 .{ }^{729}$ Rolf Winkes published Roman Paintings and Mosaics in 1982, and R. Ross Holloway produced the latest volume in the series, Ancient Greek Coins, in 1998.

A comparison of the 1922 Beazley Descriptions and the 1925 E.P. Warren List with RISD catalogues confirms which antiquities came from Warren. All of the objects on both lists correspond to entries in the various RISD Art Museum classical catalogues with the exception of a terracotta figurine of a woman on the 1922 Beazley Descriptions and the "Cylindre Babylonian" (cylinder seal) on the 1925 E. P. Warren List. ${ }^{730}$ Thus, via these two documents, fifty-seven objects accessioned in 1922 and in 1925 can be identified as unquestionably coming to RISD through Warren.

The next sifting in this process produced results with varying degrees of reliability. An examination of the correspondence in the RISD archives either to or from Warren (1900-1928) has identified antiquities neither in the 1922 Beazley Descriptions

\footnotetext{
${ }^{729}$ It was also published as the Bulletin of Rhode Island School of Design Museum Notes Vol 62, No. 5, June 1976.

${ }^{730}$ Presumably, this statuette is a "Tanagra" figure. An inventory of Greek terracottas compiled by Caitlin Armistead for the RISD Museum of Art indicates that 21 of these objects entered the collection as "Gifts of Mrs. Radeke" or "Museum Appropriation." One of these-22.209_could very well be the one on Warren's 1925 List. However, this identification is not certain. The cylinder seal could not be found in the RISD Museum in June, 2009.
} 
nor in the 1925 E.P. Warren List. One example is the Funerary Lion (15.003), labeled as the gift of Mrs. Radeke. ${ }^{731}$ Despite the absence of Warren's name in the catalogues and Museum records, six letters from Warren unquestionably refer to this sculpture (Figure $55)^{732}$

In the case of other antiquities at RISD, the proposals and counter proposals between Warren and Radeke and gaps in the correspondence make it very difficult to determine if an object referred to in the Warren-Radeke correspondence actually entered the RISD collection. In addition, since the antiquities were often discussed in general or vague terms (for example, a "marble torso"), it is often impossible to track the history of specific objects or to correlate them with accession numbers. An example of this challenge in the identification process is the head of a "nymph or goddess" mentioned in the 1900-01 letters. Radeke was so excited about acquiring this life-sized marble fragment that one suspects it did, indeed, enter the RISD collection as the "Head of the Amazon" (01.005), an often published sculpture. 733 "Head of the Amazon" (01.005) is credited as a "gift of Mrs. Gustav Radeke" but is listed as "Provenience unknown." No

\footnotetext{
${ }^{731}$ Ridgway 1972, 32-3, 147.

${ }^{732}$ EPW to EMR - 13 July 1914; 4 August 1914; 14 October 1914; 1 January 1915; 27 November 1915; and 7 December 1915-RISDA. In one letter to Mrs. Radeke, Warren explained confusion about the price and shipping; the lion was shipped from Paris to Lewes and then to Boston in the midst of the turmoil of the First World War. To offset misunderstanding about exchange rates, Warren added a postscript: “. . . in view of the confidence which you kindly place in me and of the ease of our relations, it is a pleasure to name in a doubtful case a lower figure to you than I might name to another." Warren requested Radeke not disclose its provenance. EPW to EMR, 14 November 1914, RISGA. Thus, although the 1972 Ridgway catalogue reveals the lion was "found at Spata in Attica," no reference is made to Warren, as he requested. ${ }^{733}$ One of the earliest American texts on classical sculpture contains a photograph and describes it as "an excellent Roman copy of the Polyclitan Amazon" illustrating the "ideal for the "female figure. "Chase 1924, 62-3. It was also included in European scholarship: the Italian archaeologist Carlo Anti (18891961) in Monumenti Antichi (1920); and the German specialist on "Roman copies" Georg Lippold (188519 54) in Die Plastik,Handbuch der Archäologie (1950). For bibliography on RISD's "Head of an Amazon," Ridgway 1972, 38.This sculpture was featured in the recent exhibition of Roman sculpture at RISD. See Rethinking the Romans: New Views of Ancient Sculpture 2001, 26-7.
} 
records in the object files establish that this marble head is the same one discussed in the letters. Since Warren's letters indicate that the MFA Boston was also interested in the "head of a nymph or goddess" discussed by Warren and Radeke, perhaps the marble they were discussing in the 1900-01 correspondence went to Boston instead.

The Lewes House Registers identify some RISD antiquities that have not been credited to Warren in either the RISD curatorial records or the Warren-Radeke correspondence in the RISD Archives. For example, the RISD curatorial files or catalogues do not identify the Marble Column with Vine Motif (26.156), to be discussed in Chapter 6, as once in Warren's possession (Figure 56). Nevertheless, an entry in the Lewes House Registers not only conclusively documents that the column came from Warren, it also provides information about when, where, and how he obtained it. ${ }^{734}$ Nevertheless, the Lewes House Registers have shortcomings: first, they do not cover all Warren's collecting activities; second, although sometimes the year the object was shipped is noted, the date of arrival at the destination is never given; and third, the notation where an object was sent does not always match the object's ultimate destination. Thus, in the case of RISD's Marble Column with Vine Motif (26.156), the notation in the Lewes House Register indicates that it was sent to Fewacres in Maine in 1906. Thus, the column must have remained in Maine for two decades before it was accessed into the RISD collection in 1926.

\footnotetext{
${ }^{734}$ For the entry "1483 Marble Column" with "two great vine tendrils . . crossing and recrossing . . . Two birds pecking at fruits wh[ich] look more like cherries than grapes . . . Bought 1899 Rome from yard behind New Couch of Justice . . Fewacres 1906."
} 
In other cases, the Lewes House register books can be used to postulate that an antiquity is likely to have been added to the RISD collection. For example, this entry in the Lewes House Registers matches a terracotta figurine now the Museum:

647 TC Standing Woman Height 18.3 Sent to Providence October 1900 Much enveloped but $\mathrm{L}$ hand bare. Corner of plinth missing. Hair parted + drawn into a knot behind. c.f. JM's letter 11 March $1887^{735}$

The " 647 " is the unique number assigned to each entry in the register books and "TC" is the abbreviation for terracotta. The notation - the description of the figure, the height, the break in its plinth, and the year - tallies with the RISD Tanagra Figurine 00.008. ${ }^{736}$ The RISD donor information — “Gift of Mrs. Gustav Radeke"-also supports this identification. The match of the Lewes House Register entry with the RISD figure, nonetheless, cannot be unequivocally proven.

Finally, even though documentation for a Warren connection may be missing, one might conjecture that other RISD antiquities surely came from Warren, given their accession dates and information in various publications. Greek vases accessioned before 1928 at RISD provide an illustration of this situation. Ashmead and Phillips reported that records had been lost when the vases were moved in the Museum; these missing documents may have included evidence linking the vases to Warren. ${ }^{737}$ Such a scenario may apply to eleven vases not on the 1922 or 1925 lists from Warren, which Stephen

\footnotetext{
${ }^{735}$ The 18.3 presumably is a measurement in centimeters. "JM" is most certainly John Marshall. Investigation at the Sackler Library of the Ashmolean Museum or the Lewes House Archives has not located this letter.

${ }^{736}$ However, two labels on the underside of the plinth of Tanagra Figurine 00.008 are mysterious. A blank white one could be a faded Lewes House label, but no letters or numbers are discernable. The other label with what appears to be an accession number "52.124.A" does match either the Lewes House or the present RISD accession system.

${ }^{737}$ Ashmead and Phillips 1976, 8.
} 
Luce identified in 1933 as coming from Warren. ${ }^{738}$ In other words, Luce may have had access to now lost documentation - perhaps the missing records to which Ashmead and Phillips referred. Also, it is feasible that Luce obtained information from Radeke since Luce was working on the CVA before her death in 1931. He may also have obtained information from the RISD Director Earle Rowe, who knew Warren. Another source of information for Luce may have been Edmond Pottier, the Editor-in-Chief of the CVA, because he met with Pottier several times for suggestions and additions to the RISD $C V A .{ }^{739}$ Reportedly, Pottier added Beazley attributions and other annotations to his own "working" copies of the volumes of the $C V A{ }^{740}$ Another of Luce's associates, Lacey Davis Caskey (1880-1944), Curator at the MFA Boston from 1908-1944, was informed about provenance issues because of his close relationship with J. D. Beazley. ${ }^{741}$ In fact, Caskey's review of the RISD CVA states that it is likely "that most of the vases presented by Mrs. Radeke came through Lewes House." ${ }^{742}$

Matching the information in the 1922 Beazley Descriptions, the 1925 Warren Descriptions and various letters from Warren in the RISD Archives, as well as the Lewes House Registers against the seven RISD antiquities catalogues indicates that Edward Perry Warren was the source of seventy-three antiquities in the RISD Collections from

\footnotetext{
${ }^{738}$ Luce 1933.

${ }^{739}$ Luce 1933, preface.

${ }^{740}$ Rouet 136.

${ }^{741}$ Caskey co-wrote Attic Vase Paintings in the Museum of Fine Arts, Boston (1931) with Beazley. Luce published articles about MFA Boston vases, most of which came through Warren. One also can speculate that George H. Chase (1875-1952), Luce's teacher at Harvard and Acting Curator at the MFA until 1944, and David M. Robinson (1880-1958), a professor at Johns Hopkins University and himself a well-known vase collector, might have known about RISD vases from Warren or Beazley and shared this information with Luce. It is also possible that Luce had contact with Beazley; however, no Beazley-Luce correspondence is in the Beazley Archives at Oxford.

${ }^{742}$ Caskey 1935, 638
} 
1900 to 1928 . Moreover, using the accession dates as guides, one can postulate that one coin, thirty additional marble sculptures, and perhaps up to seventy more vases are likely to have reached RISD via Warren. These additional one hundred objects would mean that Edward Perry Warren was the likely source for approximately one hundred and seventy-five antiquities in the RISD Museum. ${ }^{743}$ Thus, Warren's reticence to be identified as the RISD's agent can be overcome with various degrees of success through archival research.

Chapter 3 has chronicled Warren's role in forming the collections of Greek and Roman art at five important—and yet different—American academic institutions. Although the number and type of objects as well as his interactions with those in charge of these museum or study collections varied, Warren's collecting had significant impact at each institution. The exhibition of Greek vases from Warren in 1895 at the Fogg constituted Harvard's first effort to use its museum to enhance its new courses in ancient art. However, the rise of Edward Forbes as Harvard's chief patron and his subsequent appointment as museum administrator and faculty member seem to have discouraged further support from Warren, even if he were so inclined. Forbes' Brahmin status and his friendship with Richard Norton, a rival antiquities agent with familial links to the Harvard elites likely inhibited Warren's further involvement. In fact, Warren's 1913 gift of the head of a giant or barbarian (BM 1913.13) might be interpreted as a means of discouraging Forbes' effort to solicit ancient sculpture from Warren. In contrast,

\footnotetext{
${ }^{743}$ In fact, one surmises that almost any antiquity that entered the RISD before Warren's death in 1928 could have come from Warren, unless the museum records indicate otherwise. It would be interesting to run a search to determine how many antiquities entered the Museum from 1900 to1928. It is my understanding that such a search cannot be performed at this time because not all antiquities have been entered into the Museum's database.
} 
Warren's relationship with Bowdoin was transparent and constant. With his establishment of Fewacres as a summer home in Maine, Bowdoin's newly built Walker Museum became a beneficiary of antiquities that the MFA and RISD did not purchase. The men's college in rural Maine served as the ideal setting for Warren to adopt the role of a generous and attentive patron whose connoisseurial expertise was beyond question. Warren's philanthropy resulted in Bowdoin's "Warren Collection" being widely recognized as the most impressive assemblage of Greek and Roman art in an American undergraduate institution. Warren's estrangement from Harvard is apparent in light of the more than five hundred gifts he made to Bowdoin and the more than one hundred objects he gave to Frank Tarbell at the newly established University of Chicago.

No correspondence has survived at Chicago that might shed light on the relationship between Warren and Tarbell. With the exception of a Greek lamp listed in the Lewes House Registers, the group of small and varied antiquities arrived in Chicago in a single "sending" from Lewes House in 1902. Little is known about Frank Tarbell other than his academic training, descriptions of his courses in the university records, and the textbooks and articles he wrote. However, he likely knew Warren and his Lewes House staff through his visits to Rome and Athens. Warren's vases and fragments, as modest as they are compared to those at Bowdoin and RISD, are the subject of a series of AJA articles, beginning in the 1930s.

As in Chicago, no correspondence from or to Warren has survived at Bryn Mawr. The only record documenting a little known sale of assorted vase fragments is a list compiled by Joseph Hoppin, who arranged to purchase them for Bryn Mawr study collection. In contrast to those given to Tarbell, these vases and fragments have not been 
extensively published. However, they gave women hands-on experience with Greek vases and contributed to Bryn Mawr's reputation as a center for scholarship and training in ancient painting.

More is known about Warren's service as an antiquities agent at the University of Pennsylvania because much of the correspondence between the collector and the curatorial staff can be found in the Museum's Archives. Only one of the many sources for classical sculpture at Penn, he functioned chiefly as a middleman and consultant, with only the head of Menander (UP MS 4028) and a statuette of Aphrodite (UP MS 4025) catalogued at Lewes.

Warren's services to RISD were the most comprehensive among the five collegiate collections because he served as an agent, middleman, and consultant. His extensive correspondence with Eliza Radeke over more than a quarter of a century provides insights into Warren's connoisseurial expertise as well as his personal values. These documents, together with the Lewes House Registers, establish that more than one hundred RISD objects entered via Warren. As demonstrated in the select catalogue in the following chapters, Warren's acquisitions for RISD have justifiably received the most attention in American scholarship. 


\section{CHAPTER 4}

\section{CERAMIC ANTIQUITIES FROM WARREN IN AMERICAN COLLECTIONS}

Without question, Greek vases were Warren's most important contribution. They are discussed first according to technique - that is, black-figure, red-figure, whiteground, and plastic — and to a certain extent by their origin — primarily, Attica and South Italy. Mold-made ceramic objects such as terracotta figurines, reliefs, and pottery follow the vases.

\section{Greek Vases}

At least seven hundred vases and fragments from Warren are in the MFA Boston, the museums at Bowdoin, Harvard, and the Rhode Island School of Design, as well as in the study collections at Bryn Mawr College and the University of Chicago. ${ }^{744}$ As explained in earlier chapters, Beazley's attribution of Greek vases to specific artists based on inscriptions and stylistic elements inspired scholars to focus on chronologies and spheres of artistic influence. The vases from Warren not only increased the prestige of collections in the United States but also encouraged art historians and archaeologists in

\footnotetext{
${ }^{744}$ Warren sold or gave more than five hundred Greek vases or fragments to the MFA, based on my search of the museum website with "Ceramic" as Medium, "Greek" for "Culture," "Vessels" as "Classification," and "Warren" for "Provenance." The search result was 502 records. (accessed 11 July 2010).
} 
the leading American academic institutions to adopt Beazley's approach in their research and teaching. The Warren vases in this discussion were selected to illustrate how they have figured in early, as well as more recent, scholarship and pedagogy.

Warren believed that Greek vases were essential components in collections of classical art in the United States. In 1892, noting that he had opportunities to acquire "vases of immense value" cheaply, he explained that they "throw light on questions of which we have scanty written records, or none ... [and] when literary accounts are late and untrustworthy [they supply] the evidence., ${ }^{745}$ Ancient vases were "particularly needful for an American museum because only in vases and coins can it hope to obtain a collection representing all phases and times, and illustrating all that we read about.",746 They not only revealed "paintings and the use of colour by the ancients," they "tell us the habits of life of the ancients, their dress, their history, their religious ideas, their myths . . . unrecorded by any historian. ${ }^{, 747}$ He reiterated these sentiments to Eliza Radeke, who sought his assistance in building the classical collection at RISD:

I had thought you would eventually want specimens of the principal types of vases such as Mycenaean, geometric, Corinthian, black-figured, early red-figured, late red-figured, a white lekythos, + perhaps Italiote (sic) Greek . . ${ }^{74}$

Radeke heeded Warren's advice, for she penned "yes" on his letter above each period or style and added annotations, revealing her eagerness to assemble a comprehensive vase

\footnotetext{
${ }^{745}$ Burdett and Goddard 152. Warren was likely referring to the 1892 sale of the van Branteghem collection in Paris. Alphonse van Branteghem (1844-1911) was a wealthy Belgian amateur connoisseur of Greek vases.

${ }^{746}$ Burdett and Goddard 152.

${ }^{747}$ Burdett and Goddard 152. Warren's emphasis on color anticipates "The Colors of Clay" exhibition in 2006 at the Getty and the scholarship focusing on decorative techniques. See Cohen 2006a. For a review of the catalogue, Boardman 2009b.

${ }^{748}$ EPW to EMR, 7 December1914, RISDA.
} 
collection at RISD. In response to her request for a vase inscribed with the name of its artist, Warren cautioned that "signed vases are often poor, \& unsigned vases equal to the best of the signed," explaining that a vase "by one of the great vase painters" would be very expensive and urging her to consider a vase with a kalos or "love name"

inscription. ${ }^{749}$ Nevertheless, six years later Radeke obtained an important signed blackfigure vase for RISD through Warren.

\section{Black-Figure Vases}

Warren chiefly acquired red-figure vases and Beazley focused much of his scholarship on painters using that technique. However, Warren often included blackfigure ware in his "sendings" and Beazley turned his attention to the artists working in the earlier method, publishing Attic Black-Figure Vase Painters in 1956, as a corollary to his work on red-figure artists. Stephen Luce, an American vase specialist active in the 1920s and 30s, touted a black-figure vase (RISD 23.303) that had been added to the RISD collection as "one of the most important acquisitions in the field of Classical art" for that year and described its "absolutely perfect preservation." ${ }^{750}$ Warren negotiated the purchase of this Attic black-figure amphora (Figure 57) made by Nikosthenes, a prolific

\footnotetext{
${ }^{749}$ In other words, a signature did not always guarantee quality. "I had a signed vase about the time when I wrote you. Marshall took it with glee to New York; he liked the form; but I would not have sent it to you, because the painting was vile." EPW to EMR, 7 December1914, RISD Archives. Eventually, Warren supplied two red-figure vases with kalos inscriptions to RISD: kylix 25.077, Luce 1933, 23-24; and, Nolan amphora 23.323, Luce 1933, 24-5.

${ }^{750}$ Luce $1925 \mathrm{a}, 38$. Luce also provided a history of the vase's ownership in this AJA article.
} 
potter in the late sixth century whose work was decorated in various methods for trade with the Etruscans. ${ }^{751}$

This striking vase with the signature of Nikosthenes at the base of its handle was an appropriate acquisition, given that the RISD collection was intended to inspire design students. With thin handles and raised bands suggesting that it was inspired by metal vases, it is among almost 150 vases signed by Nikosthenes. ${ }^{752}$ On the vase's shoulders are two men on horseback with three standing men on either side, a scene repeated on the front and back of the amphora. ${ }^{753}$ Ivy vines serve as decoration: a row of single leaves is on the upturned lip and double rows climb outside each handle. At the base of one handle is the Greek inscription, "Nikosthenes made [this]." The rest of the vase's surface is devoted to ornamentation. On the neck a chain of circles binds double palmettes and lotuses. Between the raised bands on the vase's belly, a row of alternating palmettes and tongues rise from links of dotted ovals. Below the relief bands is a zigzag pattern of lozenge shapes, then a line, and finally a band of rays at the junction of the vase and its foot. The Nikosthenes workshop is the subject of a book-length study and the vases of the

\footnotetext{
${ }^{751}$ Its distinctive shape has generated the term "Nikosthenic amphora," a storage jar thought to have been produced by Nikosthenes and his workshop for sale to the Etruscans. Cook 64, 212. His vases were decorated in red-figure, white-ground, and the Six- technique. Rasmussen and Spivey 1991, 103-4. Beazley devoted almost an entire chapter in Attic Black-Figure Vase-Painters to "Nikosthenes, Potter" and related painters. See Beazley 1956, 216-35. RISD 23.303 is attributed to the category "The Group of Louvre F 11," Beazley 1956, 220.

${ }^{752}$ Beazley assigned this vase to the Potter N and Painter N in the Group of Louvre F110 of the Nikosthenes workshop, see Tosto 1999, 217. The RISD CVA indicates that 23.303 was found in 1865 in Caere (Cerveteri ) with three other amphorae signed by Nikosthenes and once owned by the late nineteenth-century collector Augusto Castellani (1829-1914). Luce 1933, 19.

${ }^{753}$ Riders are frequently depicted on vases signed by Nikosthenes. Luce 1925, 40.
} 
"famous entrepreneur" have been employed to chart the distribution of Attic vases around the Mediterranean. ${ }^{754}$

Warren's commitment to establishing vase collections "representing all phases and times" is evident in the black-figure vases he donated to Bowdoin and Chicago. Two small vases at Bowdoin are particularly appropriate for teaching the early periods of Greek art. The Mycenaean stemmed cup (BCMA1908.4), dated to 1350-1300, demonstrates the symmetry in shape and the restrained abstract ornamentation characteristic of the Bronze Age aesthetic (Figure 58). ${ }^{755}$ Another vessel in the shape of a pomegranate (BCMA 1915.15), c. 750-730, with bands of abstract shapes and a procession of water birds illustrates Geometric decoration (Figure 59) ${ }^{756}$ Although the Bowdoin pomegranate is completely sealed, some of these wheel-made vases have a hole for liquids or perhaps pebbles allowing it to function as a rattle. ${ }^{757}$ Symbols of fertility and rebirth, terracotta pomegranates served as grave gifts, especially for Greek children. ${ }^{758}$ The 1993 traveling exhibition, "From Pasture to Polis: Art in the Age of

\footnotetext{
${ }^{754}$ The amphora at RISD was the second vase signed by Nikosthenes to arrive in an American collection. The first, purchased by the Baltimore chapter of the AIA in 1887, entered the Johns Hopkins collection and was published by David Robinson, a prominent vase specialist and collector. Robinson 1922. For the workshop, Tosto 1999a, 20-21. For distribution patterns through attributions to the Nikosthenes workshop, Tsingarida 2008, 192-93.

${ }^{755}$ For BCMA 1908.4, Herbert 1964, 53; Higginbotham and Westley 31. I observed this cup being discussed in a small group session of a Greek art and archaeology course that met in the Bowdoin College Art Museum on October 14, 2009.

${ }^{756}$ For BCMA 1915.15, which Warren bought in 1914 in Paris, see Herbert 1964, 54; Langdon 1993, 93 95; Higginbotham and Westley 2005, 32-33. For a comprehensive bibliography on the vase, see Langdon 95. For Geometric vases, see Coldstream 1968; Coldstream 1977.

${ }^{757}$ For theories about the origin of Geometric pomegranate vases, see Immerwahr 1970; Immerwahr 1989.

${ }^{758}$ Later Greek sculptures and grave monuments show figures holding pomegranates. Mertens 2010, 59. Once part of the Lambros Collection, the Bowdoin vase supposedly came from a group of twenty-one objects from a single Attic grave, Langdon 93-4.
} 
Homer," featured the Bowdoin pomegranate and four additional early Greek antiquities from Warren in other American collections. ${ }^{759}$

Examples of Warren's black-figure vases and fragments at the University of Chicago were discussed in Chapter 3. However, a small intriguing vessel from Warren, ideal for hands-on pedagogy emphasized there, warrants discussion: a Kabiric bowl (SM 1967.115.276), c. 430 consisting of thirty-five black-figure fragments, now reassembled in plaster. ${ }^{760}$ Although the black-figure technique became unfashionable except for Panathenaic amphorae during the fifth century, it continued to be used in connection with the sanctuary of the Kabiroi near Thebes. ${ }^{761}$ One of the distinctive features of Kabiric pottery is the parody of myth, especially the Odyssey. ${ }^{762}$ Scholars interpret the three figural scenes on this bowl as caricatures of the epic: one portrays Circe offering her magic potion to one of Odysseus' crew (Figure 60-A), another depicts Odysseus striking another man's shield with his sword (Figure 60-B), and the third shows a sailor carrying a sack suspended from a spear resting on his arm (Figure 60-C). Swindler published a Kabiric black-figure fragment (BM P-217) in the Bryn Mawr collection that Hoppin purchased from Warren with two figures — an old man dressed in an apron and carrying a

\footnotetext{
${ }^{759}$ Langdon 1993, 93-95. Up to three other antiquities from Warren were in the "From Pasture to Polis" exhibition. A Geometric horse pyxis (MFA 97.359) in the MFA was exhibited. Langdon 23. A Late Geometric skyphos at RISD (RISD 26.3998) likely came from Warren, see 75-6. Although not part of the exhibition, the MFA bronze deer and fawn (MFA 98.650) was included in a photograph and discussed in an essay in the exhibition catalogue, 201-02. This statuette is treated in Chapter 6.

${ }^{760}$ Robinson 1915; Kilinski 1979; Chacón 1990; Ferrari, Nielsen and Olson 27-28. Inconsistencies among the fragments indicate that they came from different vases of the same shape, perhaps decorated by the same painter. The Tarbell Inventory records that the vase arrived reconstructed from Warren in 1902. Ferrari, Nielsen and Olson 27-28.

${ }^{761}$ Schachter 1986, 66-110. Schachter refers to the deities worshipped at the Kabirion sanctuary as "Kabiroi." For these mystery gods, see Walsh 2009, 59-62. For the use of black-figure there, Vickers 1999, 62. For the interpretation of the Kabirion sanctuary as "carnival" and a review of the scholarship on the site, the vases, and the gods worshipped there, Mitchell 2009, 248-60.

${ }^{762}$ For Odysseus and Circe depicted on Kabiric pottery, see Moret 1991; Vickers 1999, 62-3; Mitchell 272-74.
} 
basket and a knife followed by a nude boy bearing a drinking cup and a pitcher to an altar. $^{763}$ The boy's apprehensive expression and the gaping mouth of the old man, who appears to be singing or shouting, are caricatures associated with depictions of religious rituals at the sanctuary. ${ }^{764}$ This fragment and the gift to Tarbell, as well as six vases from the Kabirion in the MFA collection, testify that Warren's collecting interests in vases ranged beyond the Attic repertoire. ${ }^{765}$ Kabiric vases from Warren are cited as examples of visual humor in ancient art, especially in regard to its irreverent or "the distorted" aspects. $^{766}$

\section{Red-figure Vases}

Even a cursory review of the literature on Attic red-figure vases reveals the link between Beazley's work in connoisseurship to those that Warren acquired for American collections. Such an appraisal also makes clear that a consideration of the hundreds of Attic red-figure vases and fragments Warren acquired for the MFA, Bowdoin, and RISD

\footnotetext{
${ }^{763}$ Swindler 1916, 317-18. See also the Bryn Mawr CVA, Ashmead and Phillips 1971, 266-67. A German scholar attributed it to the Kabeiros Painter in 1940.Pinney and Ridgway 1979, 130.

${ }^{764}$ Warren's fragment (P-217) was exhibited in the 1979 exhibition "Aspects of Ancient Greece" at the Allentown Art Museum (PA) with over 150 Greek antiquities. Twenty Warren antiquities at Bowdoin, RISD, Penn, and the MFA were included. For the Kabiric fragment at Bryn Mawr and its bibliography, Pinney and Ridgway 130-31.

${ }^{765}$ A "Collections Search" of the MFA website revealed that Warren also provided at least six Kabiric vases for that museum: MFA 99.532; 99.533; 99.534; 99.535; 01.8069; 01.8070. Warren also sold what is described as a child's toy, MFA 99.536, a ceramic top, from the Kabirion. Museum of Fine Arts "MFA Collections. http://www.mfa.org " (accessed 12 May 2011).

${ }^{766}$ See Walsh, who discusses three of these as "mythological burlesque": MFA 99.532, with a caricature of Achilles fighting Hector, Walsh 218-19; MFA 99.533, with a parody of the Judgment of Paris, Walsh 13738; and MFA 99.534, with pygmies fighting goats, Walsh 56-7. See Mitchell, who treats MFA 99.532, a parody of the fight between Achilles and Hector before "a wailing and naked Priam," Mitchell 271; MFA 99.533, a caricature of the "Judgment of Paris," Mitchell 270-71; MFA 99.534, pygmies fight cranes as a parody of "Panhellenic mythology," Mitchell 269; MFA 01.8069, a parody of the "Judgment of Paris," Mitchell 270.
} 
is beyond the boundaries of this dissertation. ${ }^{767}$ Although this discussion centers on key vases, chiefly in the MFA, it also addresses those he sent to RISD, Bowdoin, Harvard, Chicago, and Bryn Mawr. Beazley acknowledged the impact of Warren's acquisitions in1918 in Attic Red-Figured Vases in American Museum, with its tribute to the collector's "unwearied labor in building up the magnificent collections of vases in America."768

Both Warren and Beazley were chiefly interested in the red-figure ware produced in Attic workshops. Nevertheless, Warren also obtained "Italiote Greek" red-figure pottery for American collections: though far fewer in number, exceptional "South Italian" vases in the MFA warrant treatment later in this section.

Unquestionably, the most famous Warren vase is the name-vase (MFA 10.185), by the celebrated Pan Painter, who worked in Athens during the last quarter of the fifth century. After purchasing this red-figure bell krater (Figure 61) in 1910, Warren immediately sold it to the MFA. ${ }^{769}$ Beazley derived the name of the painter from the depiction of the sexually excited Pan pursuing a young goatherd with an ithyphallic herm in the background. On the other side of the vase, Artemis prepares to launch an arrow at the hapless Aktaion, whose hunting dogs are ripping him apart as a punishment for

\footnotetext{
${ }^{767}$ The red-figure fragments from Warren, in particular, present a challenge. Those at the University of Chicago published by Franklin P. Johnson are discussed in Chapter 3. It is worth noting that a photograph of the reconstructed Attic red-figure pelike (SM 1967.115.343) from Warren is on the cover of the Smart Museum classical catalogue. Although large sections are missing, the reconstruction of twenty-six fragments allows the viewer to inspect the figures and the vessel's shape. Two fragments of this vase are in the university collection at Heidelberg and are likely gifts from Warren. Ferrari, Nielsen and Olson 59-61. For Warren vases at Chicago, see also Taylor and Born 1990.

${ }^{768}$ Beazley 1918, vii.

${ }^{769}$ According to the MFA Collections Database: "By 1910: with Edward Perry Warren (according to Warren's records: bought in Sicily; said to be from Cumae); purchased by MFA from Edward Perry Warren, June 2, 1910 ...” (accessed 18 January 2011). Warren also sent another bell krater with the death of Aktaion (MFA 00.346) attributed to the Lykaon Painter. This scene shows Aktaion with budding antlers bracing himself for the attack of his hounds; Artemis, with her quiver on her shoulder, holds a torch and her bow. For other vases with this scene, Reeder 1995, 316-17.
} 
blundering into her bath. Despite the name Beazley assigned to the artist, the early photographs of the vase were of the Artemis-Aktaion side, a practice that continues in some textbooks. ${ }^{770}$ In fact, the MFA had the genitals of both Pan and the herm covered with black paint before it was displayed; the added paint remained until the 1960 s. $^{771}$ Now, however, both sides of Warren's Pan Painter krater can be viewed and appreciated. A recent collection handbook features photographs of both sides of the krater and admits that Warren "took a certain pleasure in submitting to the Museum Greek vases whose decoration was frankly erotic.",772 Scholars view the "juxtaposition of the scenes" on the Pan krater as testimony to the sophistication of an artist with an ability "to scrutinize the relations of men and gods with ... ferocious intent" equal to that of contemporary Athenian philosophers and tragedians. ${ }^{773}$

The Pan Painter is one of "the four great artistic personalities which [Beazley] unveiled before the First World War." 774 In Attic Red-Figured Vases in American Museums, Beazley proclaimed, "There is no finer vase in Boston, there is no finer vase

\footnotetext{
${ }^{770}$ See, for example, Beazley's Attic Red-Figured Vases in American Museums. Beazley 1918, 113. The Death of Aktaion is the only side illustrated in some popular Greek art survey books. See Cook 1997, Figure 44; Pedley 2007, 243.This side is also shown in textbooks on Greek myth, see Morford and Lenardon 2003, 205; Harris and Platzner 2008, 203 However, Boardman and Robinson include both sides. Boardman 1975, 189; Robertson 1992, 146-7. Boardman's history of Greek vase painting features only the Pan and the Priapic herm side. Boardman 2001b, 96.

${ }^{771}$ According to the history of the MFA, William D. Young removed the black paint in the early days of the curatorship of Cornelius Vermeule, who became curator in 1957. Whitehall 1970b, 864. The MFA curatorial staff confirmed that the paint was taken off in the early 1960s, E-mail message 29 June 2010 from Laura Gadbery. Young also reported cleaning the silica encrustation and lime deposits through refiring. Noble 1988, 209. It is not clear if this procedure was also used to remove the black paint.

${ }^{772}$ Rogers 1999, 8. For photographs of the Pan Painter krater, 72. Audio commentary on the MFA Collection website on the krater begins with a discussion of the Pan-Goatherd scene, describing it as "witty ... frankly erotic." (accessed 21 February 2011).

773 Osborne 1998, 154.

${ }^{774}$ Rouet 95. The others are the Berlin, Achilles, and Kleophrades Painters.
} 
anywhere . ...775 He named the artist in an important journal article in 1912 and discussed the Pan Painter and his oeuvre in Attic Red-figure Vases in American Museums (1918), Attische Vasenmaler des rotfigurigen Stils (1925), and Attic Red-Figure VasePainters $(1942,1963) .{ }^{776}$ He also wrote a monograph, Der Pan-Maler (1931), which he revised twice. ${ }^{777}$ Beazley held that the Pan Painter belonged to a group of red-figure artists he called the "mannerists" who mixed forms common in the late archaic period with those that were developing in the early classical era. ${ }^{778}$ The Pan Painter's depiction of Greek youths_- “light-built, spruce and nimble figures,” in Beazley’s connoisseurial language — must have appealed to Warren and his Lewes House circle. ${ }^{779}$ While Beazley dated the artist to c. 480-450, he cautioned that "caprices" and "archaisms" in the Pan Painter's oeuvre made it difficult to organize his vases chronologically. ${ }^{780}$ Warren sent six additional Pan Painter vases to the MFA, a well-known amphora to Bowdoin, and a lekythos to RISD, thus providing ample opportunities for American scholars and museum visitors to view his work first-hand. ${ }^{781}$ The Pan Painter's lekythos at the Boston (MFA13.198) with a hunter and his dog (Figure 62) and the amphora at Bowdoin

\footnotetext{
${ }^{775}$ Beazley 1918, 113.

${ }^{776} \mathrm{He}$ attributed 40 vases to this artist and named him in 1912. Beazley 1912, 113-8. Attische Vasenmaler des rotfigurigen Stils was published in German in 1925 and in English, as Attic Red-Figure Vase-Painters, in 1942 . He devoted a chapter in $\mathrm{RFV}^{2}$ to the Pan Painter to whom he credited more than 160 vases, see Beazley 1963, 550-61, and also 1658-59, 1158-59.

777 The monograph was reprinted in English in 1974 after his death.

${ }^{778}$ Beazley held that his teacher was the late archaic artist Myson and that his school mate was the Pig Painter, postulating "true collaborators, and pupils, the Pan Painter seems to have none." Beazley , 9. He described the Pan Painter as "a mannerist, and connected with the earlier members of the Mannerist Group . .. but far above them: an exquisite artist." Beazley 1963, 550.

${ }^{779}$ Beazley 1974b, 9 .

${ }^{780}$ Beazley 1974 b, 8 .

${ }^{781}$ In addition to the name-vase, Warren acquired six Pan Painter vases for the MFA: three lekythoi (01.8079 , 13.198, 13.199); fragments of a volute krater (95.58); and two Nolan amphorae (01. 8109 and 10.184) For a discussion of the Pan Painter and his group, see Robertson 1992, 143-52. For the Pan Painter's artistic lineage, Sourvinou-Inwood 1975.
} 
(BCMA 1913.30) with young men playing flutes (Figure 63) are recognized as treasures in these collections. ${ }^{782}$

As explained in Chapter 3, Warren had little contact with Harvard but did provide sixteen vases for the first exhibition at the Fogg. The best known of the Warren vases at Harvard is the red-figure neck-amphora (HM 1927.1500), dated c. 490 and attributed to the Berlin Painter, an artist whom Beazley introduced in 1911 and spotlighted in a 1930 monograph. ${ }^{783}$ On both sides of the Harvard amphora (Figure 23), the Berlin Painter depicted a single figure, as was his custom, standing on a key-patterned ground line. On Side A, a sea-god, whom Beazley and the Harvard Museum identified as Triton, extends his left hand in which he grasps a dolphin by its tail and coils his spotted fish-tail in a loop. On Side B, a female figure, probably one of his many sea-nymph daughters, runs to the left with outstretched arms. Beazley's skillful drawing of the sea-god provides a means of appreciating the Berlin Painter's draftsmanship that is far superior to many photographs or even a close inspection of the vase (Figure 64). The 2004 exhibition investigating Greek depictions of hybrids, “The Centaur's Smile: The Human Animal in Early Greek Art," spotlighted the Harvard vase, as well as seven other Warren antiquities in American collections. ${ }^{784}$ The catalogue identifies the sea-god as Nereus because of the

\footnotetext{
${ }^{782}$ The MFA Collections Database indicates that 13.198 is "From Gela, said to have been found in the same grave with [13.199].); purchased by MFA from Edward Perry Warren, January 2, 1913 . . " (accessed 12 January 2011).

${ }^{783}$ For the Berlin Painter, see Kurtz and Beazley 1983. In $A R F^{2}$ Beazley attributed 89 vases to the Painter of Berlin 2268 or, more commonly, the Berlin Painter. Beazley 1963, 153-57, 1629, 1700-01. Warren gave Tarbell an Attic red-figure alabastron (1967.346), which Beazley credited to the Berlin Painter. For this vase, Ferrari, Nielsen and Olson 54-55.

${ }^{784}$ Padgett 2003, 346-48. The other Warren black-figure vase in the exhibition was the MFA's Middle Protocorinthian I Aryballos (95.12); for a discussion of iconography and bibliography of this vase, see Padgett 2003, 181-83. In addition, the catalogue discussed four other Warren vases in the MFA not exhibited in "The Centaur Smiles": a Corinthian aryballos (MFA 01.8072); a red-figure kylix (MFA
} 
"civilized attire" that hides "the junction between his human and fish sections" and the scepter he grasps in his right hand. ${ }^{785}$

As noted previously, the relationship between Warren and Beazley was symbiotic: Warren supplied Greek vases and fragments to American collections, and Beazley and his followers attributed them, thereby inculcating the objects with prestige and meaning. Beazley's practice of inventing names for artists not only underscored the value of the vases that Warren procured for American collections but also honored the institutions that received them. For example, as explained in Chapter 3, Beazley's assignment of the moniker "Bryn Mawr Painter" served to reinforce the College's scholarship in ancient painting. ${ }^{786}$ The co-authors of Bryn Mawr CVA began the catalogue of the college's vases and fragments with the eponymous plate (Figure 42), thus highlighting the pride in the name of this painter. ${ }^{787}$

Beazley commemorated Warren's long association with Bowdoin College by identifying three vase painters: the Bowdoin Painter, the Bowdoin Eye Painter, and Painter of the Bowdoin Box. Over the years, Beazley's theories about painters underwent revision, requiring the reassignment of attributions and the merger or

03.788), attributed to Makron; a red-figure hydria (MFA 01.8072), attributed to the Leningrad Painter; and a Corinthian aryballos (MFA 01.8100), depicting Odysseus and the sirens. Padgett 2003, 32-4, 34-5, 77.

${ }^{785}$ Herakles forced Nereus to reveal the way to the Garden of the Hesperides. Padgett 2003, 347-48. The catalogue discusses both sides of the vase, as well as its shape, a type of red-figure neck-amphora called a "doubleen."

${ }^{786}$ Beazley apparently created the "Bryn Mawr Painter" by 1925 when the first edition of his Attic RedFigure Vase-Painter was published because he references the name to that edition in $A R V^{2}$. See Beazley 1963, 456. He must have done so after 1916 because Swindler does not use this name for the pinax when she published the Bryn Mawr Collection. Swindler , 331-32. Beazley also attributed a red-figure plate at Oxford and two red-figure plate fragments at Harvard (60.350 and 60.351) to the Bryn Mawr Painter. Beazley 1963, 456-57. For the Harvard fragments, see Paul 1997, 31-32, 60.

${ }^{787}$ For the Bryn Mawr Painter, Swindler 1916, 331-32; Ashmead and Phillips 1971, 3. 
elimination of artistic personalities. For example, the Bowdoin Painter was a black-figure artist Beazley had previously called the "Athena Painter," who took up red-figure and white-ground techniques later in his career. ${ }^{788}$ Beazley eliminated the Painter of the Bowdoin Box and assigned the lidded red-figure pyxis (BCMA 1915.14), his name vase, to the Heraion Painter. ${ }^{789}$ Then, the lekythoi formerly credited to the "Painter of the Bowdoin Box" were "given" to the Bowdoin Painter, a red-figure artist of 490-480. 790

Warren gave Bowdoin two of the Bowdoin Painter's red-figure lekythoi: the name vase (BCMA 1920.1) with a seated boy playing the aulos; and a second lekythos (BCMA 1913.15) with a crouching lion. The name vase (Figure 65) epitomizes the artist's characteristic simplicity in subject matter and in composition. His love for geometric precision is evident in the triangle formed by the musician's arms and his instruments, the rectangle defined by the chair legs, and the parallel lines of the flute case and the player's back. The Bowdoin Painter garners the most attention from scholars because he is now credited with more than two hundred and fifty vases, mostly lekythoi. $^{791}$

The third of Beazley's artist is the Bowdoin Eye Painter, an Attic red-figure cup specialist, dated to 525-515. ${ }^{792}$ The name-vase (BCMA 1913.2) is designated an "eye

\footnotetext{
${ }^{788}$ Herbert 1964, 64. For Beazley's early attribution before his revision, Beazley 1918, 70. For the Athena Painter, Beazley 1956, 522-24.

${ }^{789}$ For the Heraion Painter, named for a plate found in the Temple of Hera on Delos, see Beazley 1963, $142-44$.

${ }^{790}$ Boardman 1989, 37. Beazley said that the Bowdoin Painter "began in the late archaic period, but went on working as late as the third quarter of the fifth century." Beazley 1963, 678,

${ }^{791}$ Herbert 1964, 63-5. For the vases attributed to the Bowdoin Painter and the Manner of the Bowdoin Painter, see Beazley 1963, 677-94, 1665-6, 1706.

${ }^{792}$ Herbert 1964, 61; Beazley 1918, 12-13. The cup came from Cerveteri. For the Bowdoin-Eye Painter's sixteen cups and three others "Near the Bowdoin-Eye Painter," see Beazley 1963, 166-68.
} 
cup" because of the apotropaic eyes prominently displayed on the outer rim among the nude athletes (Figure 66). One youth holds halters, hand-weights used in jumping competitions and for strength training. In the tondo, another youth, wearing greaves and carrying a shield and helmet, runs in what has been interpreted as the hoplitodromos, a race that tested athletic and military prowess. ${ }^{793}$ The Bowdoin Museum's adoption of the scene in the tondo as one of its emblems has made Warren's vase familiar to those acquainted with the college.

Another example of how a name-vase obtained through Warren enhanced the prestige of an American collegiate collection is the Providence Painter's amphora (RISD 15.003). ${ }^{794}$ Despite its heavily mended state, the vessel's elegant form and composition (Figure 67) are immediately evident. ${ }^{795}$ Its shape, designed to hold oil or wine, provided ample space for decoration. This particular type, with the neck meeting the body at a sharp angle, is known as a neck-amphora and often has twisted handles, as in the case of this vase. ${ }^{796}$ This amphora is dated c. 500-475, placing it at the end of the Archaic period when numerous high quality vases were produced in Athens for export to Etruria and South Italy ${ }^{797}$ A single elegant figure gestures in theatrical fashion on each side of the vessel, as is typical of the artist's work, and the drapery hangs in the characteristic “Archaizing” folds.

\footnotetext{
${ }^{793}$ Higginbotham and Westley 23, 62-3.

${ }^{794}$ Beazley 1916, 76-8; Beazley 1963, 635-46, 1663, 1701.

${ }^{795}$ One handle is restored, and the missing upper third of the figure on Side B has been filled in.

${ }^{796}$ Cook 210.

${ }^{797}$ Boardman 1975, 179.
} 
On side A, which is the better preserved, a laurel-crowned Apollo extends a phiale in his outstretched right hand, while holding a lyre aloft in his left. ${ }^{798}$ The long haired young god presents his face in profile, as he looks to his right and displays the folds of his long chiton and the front of his elaborate stringed instrument. He stands centered on a meander ground line against the black background. On the heavily damaged side B, only the bottom half of a similarly dressed woman — presumably Artemis moving to the left and holding a pitcher in her right hand-has survived. A lantern slide (Figure 68) preserved in RISD's Visual Resources indicates that the amphora was used to inspire budding designers and artists at the School. Ironically, the RISD catalogues and $C V A$ do not credit Warren as the source of this vase, but correspondence shows that the amphora is unquestionably from Warren. ${ }^{799}$

Beazley assigned almost fifty vases to the Providence Painter's hand in one of his most significant works, Attic Red-Figured Vases in American Museums, published in 1918, three years after RISD's acquisition of the vase. Research does not indicate that Beazley visited Providence on the trip he made to America to compile material for this publication. Thus, one must assume that he saw the vase in Oxford or at Lewes House before it was shipped to America. ${ }^{800}$ Since the publication of Beazley’s book, almost 150 pots have been attributed to this vase painter. ${ }^{801}$ In 1919, Eliza Radeke reported to

\footnotetext{
798 This depiction of the god is the Apollo Citharoedus.

${ }^{799}$ It is not listed in the 1922 Beazley Descriptions or the 1925 Warren Descriptions, but see EPW to EMR, 7 December 1914, RISD Archives.

${ }^{800}$ In his preface, Beazley thanked professors and curators at Boston, Cambridge, New York, Philadelphia, Bryn Mawr, Baltimore, and New Haven but does not mention Providence or RISD. Beazley 1918. Research for this dissertation has not revealed that he visited Providence or RISD.

${ }^{801}$ Boardman 1975, 194. For Beazley's list of the Providence Painter and the Manner of the Providence Painter vases in $\mathrm{ARF}^{2}$, Beazley 1963, 635-46.
} 
Warren that she was "much pleased that Mr. Beazley mentioned the 'Providence Painter' in his fine book on vases. ${ }^{.802}$

Beazley and other scholars discussed the Providence Painter's amphora in numerous publications. He took up the artist's work at the end of the eighth chapter, "Smaller Pots of the Ripe Archaic Period," in the Attic Red-Figured Vases in American Museums thereby placing this anonymous artist among those working in Athens during the late sixth and early fifth century. ${ }^{803}$ Here, he ceremoniously bestowed the name Providence Painter on the artist - "Let him be called the Providence Painter after the large neck-amphora with twisted handles, formerly of the Basseggio and Jekyll collections, now in Providence"-and created his oeuvre by assigning forty-eight vases in the red-figure style to this artist. Beazley called "the Providence Painter" an "excellent artist," who worked with a master he had already titled "the Berlin Painter." ${ }^{804}$ In his assessment of the Providence Painter, Beazley is the confident connoisseur, observing that this artist lacks the "charm" of his teacher, the Berlin Painter- "prose to the other's poetry"—-but nonetheless "sober, honest, and often noble," possessing "a masculine beauty of its own." $\$ 805$

\footnotetext{
${ }^{802}$ EMR to EPW, 30 July 1919, RISD Archives. The same letter indicates that a discussion took place about Beazley publishing an article on the Greek vases in the RISD collection; however, this project, like Beazley's Bowdoin catalogue, never materialized.

${ }^{803}$ Beazley 1918, 76-80.

${ }^{804}$ Beazley claimed that the Berlin Painter specialized in embellishing larger vessels, like amphorae, usually placing one figure against the black background. The figures on either side are often related to another, as they are on his pupil's amphora in Providence. In fact, a viewer might imagine that Artemis is moving to her left toward the other side in order to fill her brother's phiale with her pitcher. In $\mathrm{ARF}^{2}$, he calls the Providence Painter "the best" of those painting Nolan amphorae and lekythoi, Beazley 1963, 635. ${ }^{805}$ Beazley 1918, 76. Beazley did not provide an illustration for the name vase; rather, he included photographs and drawings of other vases he attributed to the Providence Painter. Beazley listed the RISD vase as one of 47 attributed to the Providence Painter. Beazley 1918, 75-80.
} 
Interestingly, like many Greek vases that Warren acquired from collectors, the findspot of the Providence Painter amphora, as well as its modern ownership, is known. ${ }^{806}$ Eduard Gerhard, who is credited with being the first to study Greek vases systematically before Beazley, included it in his report on the excavations of the Etruscan tombs on Lucien Bonaparte's land at Vulci. ${ }^{807}$ Beazley, who had access to Warren's records, documented that the collector had purchased the amphora from the Basseggio Collection. One of the first American vase specialists, Joseph Clark Hoppin, included an entry on the RISD amphora but, like Beazley, did not illustrate the vase in Volume II of his Attic Red-Figured Vases (1919). ${ }^{808}$ In 1922 Beazley returned to the Providence amphora in an article discussing depictions of Apollo Citharoedus. ${ }^{809}$ Beazley's Attische Vasenmaler des rotfigurigen Stills (1925) and Hubert Philipart's Antiquités Classiques aux États-Unis (1928) also included the Providence Painter's name vase. ${ }^{810}$ Thus, by 1933, when Luce compiled the CVA for the RISD vases, scholars-publishing in English,

\footnotetext{
${ }^{806}$ Unlike many antiquities collectors and agents of his day, Warren meticulously recorded such information at Lewes House and, as discussed in Chapter 3, often conveyed it to museums.

${ }^{807}$ Luce 1917, 217. Gerhard's report was Auserlesene griech Vasenbilder (1839-1858) where the RISD amphora was illustrated in Plate 24. Eduard Gerhard (1795-1867), a German archaeologist, was a member of the Insituto di Corrispondenza Archeologica which was a forerunner of the German Archaeological Institute. He is credited with being among the first to view Greek vases as a means to study myth and to recognize the chronology in styles. See Fowler and Wheeler 20-21. For background on the "excavations" at Vulci and the "glutted market" for vases, see Nørskov 58-60, 90-91.

${ }^{808}$ Hoppin 1919b provides a list of the vases attributed to the Providence Painter who he says worked during the "ripe archaic period" in a style derived from the Berlin Painter. In the preface of his two volume handbook, Hoppin explains that he was only able to see the first proof of Beazley's catalogue. Although complimentary of Beazley's work in the attribution of unsigned vases, Hoppin also "protest[s] against the indiscriminate habit of attributing vases." Hoppin 1919a. Because Beazley had been publishing the attribution of vases since around 1910, Hoppin's comment is critical of Beazley's methodology. As discussed in Chapter 4, Hoppin purchased vases and fragments for Bryn Mawr from Warren. He credited Warren in his list of those who assisted him in the Handbook, but lists him as "Edward Warren of Lewes," a designation which Warren did not approve.

${ }^{809}$ Beazley 1922, 92-93.

${ }^{810}$ Beazley's volume was revised and published in English in 1942 and 1963.
} 
French, and German — had taken into account the school's "eponymous" amphora. ${ }^{811}$ Recent surveys of Greek vases, such as Boardman's Athenian Red Figure Vases: The Archaic Period (1975), discuss the Providence Painter. ${ }^{812}$ Robertson, in particular, enhanced the prestige of the Providence Painter by placing him into the context of a workshop of distinct artistic personalities in The Art of Vase-Painting in Classical Athens (1992). ${ }^{813}$ Without question, this Attic red-figured amphora exemplifies the quality of the antiquities Warren obtained for the collections of the Rhode Island School of Design and the extent to which objects Warren collected have figured in scholarship.

\section{Bilingual Vases}

Beazley's theory of how and why the red-figure supplanted the black-figure style first appeared in Attic Red-figured Vases in American Museums (1918), in regard to two vessels that Warren had obtained for the MFA in 1899 and $1901 .^{814}$ Later, in a 1928 British Academy lecture, Beazley elaborated on how the red-figure technique first appeared in a style of decoration he called "bilingual":

[A] struggle between the two techniques ... [with] at first a compromise: blackfigure agreeing to take one side of the vase, red-figure the other. But red-figure won; and black-figure, though never quite driven out, was soon driven under. And for some time, many painters worked in both techniques; but most of the best painters turned to the new; and the great experiments and great changes in style take place in red-figure, and in black figure are merely reflective. ${ }^{815}$

\footnotetext{
${ }^{811}$ Franklin Johnson's review of Luce's RISD CVA points out "the eponymous vase" is outstanding. Johnson 1934, 278

${ }^{812}$ Boardman 1975, 93-95.

${ }^{813}$ Robertson 1992, 173-78. He considered the Providence Painter one of the Berlin Painter's earliest apprentices, second only to the later pupil, the Achilles Painter. For the Pan Painter's style, see Smith 2006. ${ }^{814}$ Beazley 1918, 3-5.

815 "Attic Black-figure: A Sketch," the Annual Lecture on Aspects of Art, Henrietta Hertz Trust, 27 June 1928, published in Proceedings of the British Academy 14 (1928). Nine vases carry the signature
} 
Beazley traced this decisive moment in Greek vase painting to an artist who decorated vases signed by the potter Andokides, whose career is dated c. 530-25. Some of the most interesting vessels have the same subject rendered in the older black-figure style on one side and the new red-figure on the other (thus, the label "bilingual"). On an amphora (MFA 99.538), which Warren sent to the MFA, Herakles, clad in his lion skin and carrying empty wine skins, drives a bull festooned with ribbons, in black-figure on one side and red-figure on the other (Figures 69 and 70). ${ }^{816}$ Similarly, another Warren bilingual amphora (MFA 01.8037) shows Achilles and Ajax playing dice on both sides (Figure 71) ${ }^{817}$ Beazley attributed the red-figure sides of both vases to an artist he called the Andokides Painter, while he credited the black-figure scenes to the Lysippides Painter. Even though he admitted that the two artists could possibly be the same person, Beazley changed his mind several times about whether one or two artists were involved, but finally settled on two. Although his attribution to different painters is widely accepted, the matter remains unsettled. ${ }^{818}$

The details on the bi-lingual amphora (MFA99.538) with Herakles and the bull are almost exactly the same on the red-figure and black-figure sides, while on other vessels, such as the one (01.8037) with Ajax and Achilles playing a board game, there

\footnotetext{
“Andokeides eopiesen” or "made by Andokides." Rpt. In Kurtz 1989a 1-25.. M. Cook calls the term bilingual "an unpleasant designation"but agrees that the Andokides Painter originated the red-figure technique. Cook 1997, 158, 325.

${ }^{816}$ The vase (99.538), with a bull representing one of the cattle of Geryon, possesses an impressive history of English ownership from the mid-nineteenth century until Warren bought it at a Sotheby auction in 1899 and immediately sold to the MFA. See MFA Collection Database, Museum of Fine Arts "MFA Collections. http://www.mfa.org " (accessed 19 August 2010).

${ }^{817}$ Warren bought amphora (01.8037), which came from Orvieto, from the collection of Alfred Bourguignon in 1901. See MFA Collection Database, Museum of Fine Arts "MFA Collections. http://www.mfa.org " (accessed 19 August 2010).

${ }^{818}$ Boardman 1975, 15-18.
} 
are marked differences. Ever the connoisseur, Beazley observed that the latter Warren amphora is "sound but not very interesting work" and far inferior to scenes created by Exekias, the master black-figure painter considered to be the teacher of the Andokides Painter/Lysippides Painter. ${ }^{819}$ Boston's Herakles amphora, which is the first illustration in his 1918 book, earned Beazley's praise for detail, veracity, and "character." ${ }^{820}$ Most scholars concur with Beazley's assessment, with books on Greek art featuring Warren's Herakles amphora (MFA 99.538) as one of the earliest examples of the red-figure technique. ${ }^{821}$ However, the "inferior" amphora (MFA 01.8037) showing Achilles and Ajax is included in a recent edition of a widely used art history survey textbook, Gardner's Art through the Ages. It serves double duty: to illustrate the bilingual technique and the manner in which students copied their master Exekias, whose black-figure depiction of the same scene is considered a tour de force in Greek vase painting. ${ }^{822}$ Some scholars propose that the juxtaposition of the methods of decoration on the same vase may have functioned as a form of "publicity for the new red-figure technique, demonstrating its possibilities by comparison." 823

The Andokides Painter continues to be a topic of scholarly debate and Warren's amphora frequently appears in publications and exhibitions. ${ }^{824}$ In fact, Boston's bilingual Herakles amphora was showcased in "The Colors of Clay," a 2006 exhibition of

\footnotetext{
${ }^{819}$ Beazley 1918, 4.

${ }^{820}$ Beazley 1918, 4. Boston 99.538 is Figure 1.

${ }^{821}$ See, for example, color photographs of the black-figure side of MFA 99.538 on the front cover and of the red-figure side on the back cover, as well as a side-by-side photographs inside (as Figure 13) in Biers 1996. Color photographs appear in Pedley 2007, 203. Robertson's survey of Greek vase painting contains black and white photographs of 99.538, Robertson 1992, 10. See also, Noble 110-11.

${ }^{822}$ The model for Warren's amphora (99.538) is Exekias' black-figure depiction of Achilles and Ajax in the Musei Vaticani. For such an association, see Gardner and Kleiner 101.

${ }^{823}$ Mertens 106.

${ }^{824}$ See von Bothmer 1966; Cohen 1978; Cohen 2006a, 29-32; Cohen 2006b, 18-25.
} 
Athenian vases at the J. Paul Getty Museum. This exhibition, which included eight other MFA vases from Warren, focused on the range of shapes and decorative techniques employed in Athenian workshops.

\section{White-ground Vases}

Warren collected a number of vases known as "white-ground," a technique that arose in the Early Classical period among Attic red-figure painters. Lines became softer, washes in yellow, purple, blue, green, and brownish red were added, and the drawing became freer and allowed for more innovation than either the black- or red-figure styles. Although high quality white-ground painting first appeared in cup tondos, this technique was more commonly used for lekythoi, oil flasks used in funerary rituals. Because the perishable colors and friable white slip proved unsuitable for daily use, lekythoi became the favored shape for white ground decoration. ${ }^{825}$ Recent scholarship has shown that specialized workshops developed in Athens during the later fifth century, producing large numbers of white-ground lekythoi. ${ }^{826}$ Warren gave four such vases to Bowdoin, all of which show a visit to a tomb, a favored subject. ${ }^{827}$ One of these, lekythos (BCMA 1913.31), dated c. 420-425, shows a grave monument festooned with ribbons (Figure 72). To the left of the stele, a kneeling woman touches her head with her left hand and raises her right above her head, while on the other side a young man gestures toward the stele

\footnotetext{
${ }^{825}$ Cook 1997, 169. For the history of scholarship on white-ground vases, Oakley 2004, 1-4. See also, Kurtz 1975; Boardman 2001, 92-6.

${ }^{826}$ Kurtz 1995; Oakley 2004.

${ }^{827}$ BCMA 1913.31 (Near the Painter of Munich 2335); 1923.25 (the Quadrant Painter); and 1923.26 (School of the Achilles Painter); and 1930.82 (a badly damaged vase that came as a bequest after Warren's death).
} 
with his right hand. According to one interpretation, the male is the spirit of the deceased present at the tomb and the woman is grieving for him. ${ }^{828}$

The University of Chicago received a curious white lekythos among the 1902 gifts from Warren (SM 1967.359). Its iconography is unusual: no human figures are present, only three stelae on a common base (Figure 73). Three vertical inscriptions, interpreted as masculine names to the right of each monument, have faded as happens frequently on white-ground vases. ${ }^{829}$ However, when Tarbell published the vase in a 1908 $A J A$ article, he included a drawing of the now lost inscriptions and other details (Figure 73). ${ }^{830}$ Some scholars interpret the lekythos as commemorating the burial of three men interred in a shared grave while others view the scene as three individual memorials, with each name referring to a specific grave and its particular stele. ${ }^{831}$

Warren also sold a white ground lekythos to the MFA (MFA 13.201), which Beazley attributed to the Achilles Painter. Here, a girl brings a chest to a woman, who turns to gaze at her (Figure 74). The kalos inscription on this vase is in stoichedon, a method of writing in which the letters are aligned both vertically and horizontally. ${ }^{832}$ Although scholars have traditionally interpreted this scheme as depicting a "mistress and

\footnotetext{
${ }^{828}$ Higginbotham and Westley 44-5; Herbert 1964, 75.

${ }^{829}$ Ferrari, Nielsen and Olson 75-6. Immerwahr does not include this inscription in his Survey of Attic Scripts.

${ }^{830}$ Tarbell 1908. Tarbell provided the Greek letters that he was able to read, indicating that the words seem to be "masculine names." Tarbell 1908, 428-29 Tarbell also wrote about architecture on Greek vases but did not refer to this lekythos. Tarbell 1910a.

${ }^{831}$ Immerwahr 1990, 100. In the latter case, each inscription beside a stele should be read as "on" the stele.

${ }^{832}$ The inscription: "“Axiopeithes, son of Alkimachos, is handsome' (AXIOPEITHES KALOS

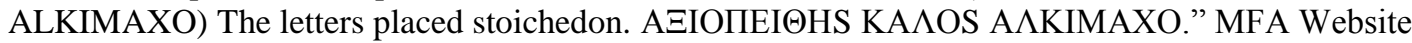
Database, Museum of Fine Arts "MFA Collections. http://www.mfa.org " (accessed 25 January 2011). For this inscription and other "tabell $1990,101$. 
maid," this identification has been reconsidered. ${ }^{833}$ One scholar included this vase as among a group of white lekythoi with bridal scenes, which memorialize women who died before or early in their marriages. ${ }^{834}$ Dated to 450-40., this vase was included in the 2006 "Colors of Clay" exhibition because it shows the underdrawing of the younger woman's dress. That exhibition's catalogue observes that the women may be family members because nothing identifies the younger woman as a slave or servant. ${ }^{835}$ Reconciling the kalos inscription with the funeral function and its iconography of the vase remains a challenge. The "Colors of Clay" catalogue suggests that the inscription both "offset(s) the difference in height between the two figures," as well as "enhances the formality of the scene." ${ }^{836}$ The catalogue also notes the importance of Warren's recording that the vase came from Gela, Sicily, and emphasizes that this findspot proves the high quality Attic vase was prized enough in antiquity to be imported. ${ }^{837}$ The Achilles Painter-as Beazley named this artist who is now credited with more than three hundred vases - has received considerable attention from prominent vase specialists. ${ }^{838}$

An unusual vase from Warren (MFA 13.4503) is a kylix with wishbone handles attributed by Beazley to the Workshop of Sotades and Hegesiboulos II. Its inclusion in the "Colors of Clay" exhibition exemplifies how Warren's vases figure prominently in new approaches to scholarship in Greek vases ( Figure 75). This tiny cup's paper-thin

\footnotetext{
${ }^{833}$ Oakley 2000, 228. Oakley does not discuss this specific vase.

${ }^{834}$ Reilly 1989, 220.

${ }^{835}$ Cohen 2006a, 227.

${ }^{836}$ Cohen 2006a, 227.

${ }^{837}$ Cohen 2006a, 227.

${ }^{838}$ For a monograph on the Achilles Painter, Oakley 1997.
} 
walls and delicate wish-bone handles terminate in button finials. ${ }^{839}$ With its fragile whiteground interior and "coral-red" exterior, this vessel probably was never intended for actual use. The rare color combination warrants attention because few potters employed the distinctive shiny orange-red Athenian ceramic gloss, especially with white-ground. ${ }^{840}$ The cup is also interesting because painting and inscription were added to its tondo in the nineteenth century, only to be exposed as forgeries in the 1890s (Figure 76). ${ }^{841}$

Recent research into its complicated ownership history has prompted speculation about the vase's provenance. The MFA records indicate that the kylix was in the Count Michel Tyszkiewicz Collection by1897 and only that it was "by date unknown with Edward Perry Warren," who gave it to the Museum in $1913 .{ }^{842}$ However, notes found in an 1894 sales catalogue prompted Dyfri Williams to argue that it should be counted as the tenth vase in what was previously thought to be a group of nine Greek vases discovered in 1890 in Athens' Sotades Tomb. ${ }^{843}$ Williams credits the Lewes House Registers as a source for the provenance and praises Warren and his assistants for preserving findspot information for a clearer understanding of the context for the vases. $^{844}$

${ }^{839}$ MFA 13.4053 is only $6.1 \mathrm{~cm}(23 / 8 \mathrm{in}$.$) and 14.5 \mathrm{~cm}$ diameter (5 11/16 in.)

${ }^{840}$ For the coral-red technique, Cohen 1970-1971; Cohen 2006c.

${ }^{841}$ Andrén 94-5; Cohen 2006a, 302-3.The fake nineteenth-century decoration in the tondo was four figures from Greek myth, each with inscribed names: Nephele; her twin children Phrixos and Helle; and the wicked stepmother, Ino. A potter's signature was also forged. For other forged vases, see von Bothmer 1998.

${ }^{842}$ Museum of Fine Arts "MFA Collections. http://www.mfa.org " (accessed 5 February 2010).

${ }^{843}$ The Sotades Tomb is so called because the vases came from the workshop of Sotades, an inventive potter active from 470 to 460 . For Sotades and his workshop, see Burn 1985; Hoffmann 1997. For the argument that the findspot of MFA 13.4503 was the Sotades Tomb, see Williams 2004, 106-10.

${ }^{844}$ Williams 2006a, 293. 


\section{South Italian Vases}

Although Warren and his contemporaries favored Athenian vases, particularly those from the late Archaic and early Classical periods, he also collected and sent South Italian and Etruscan vases to American collections. ${ }^{845}$ The term "South Italian" is applied to vases, usually red-figure, manufactured by Greeks in South Italy and Sicily from the late fifth through fourth centuries, and scholars subcategorize them into the styles of five regions: Lucania, Apulia, Campania, Paestum, and Sicily. Beazley's disciple, A.D. Trendall, specialized in attributing such vases to artists and workshops, establishing relative chronologies, and analyzing the iconography as clues to lost Greek plays and illustrations of theatrical practices. ${ }^{846}$

Warren gave South Italian vases to Bowdoin and the University of Chicago and he sold them to RISD; however, the MFA boasts his best known acquisitions. An early purchase (MFA 99.5400) is the name vase of the Boston Orestes Painter, whom Trendall considered to be a close follower of Python, one of the two Paestan vase painters who signed their work (Figure 77). ${ }^{847}$ On side A of the tall amphora dated to 335-320, two young men and a young woman stand on either side of an Ionic column. The bodies of

\footnotetext{
${ }^{845}$ Warren also collected other Italiote vases, perhaps by immigrant craftsmen, identified as "Etruscan" and "Faliscan." Warren gave Tarbell a black glaze kantharos (SM 1967.115.354) that is likely Etruscan. Ferrari, Nielsen and Olson 84. The MFA obtained three Etruscan plastic head vases from Warren - MFA 03.795, 07.863, and 07.864 - while Bowdoin received the Faliscan red-figure stamnos (BCMA 1913.9). Warren also sent the MFA a Faliscan skyphos-krater (MFA 97.37). Museums in the United States acquired more of these types of vase beginning in the 1950s, when the illegal looting of ancient graves became prevalent in southern Italy.

${ }^{846}$ For an overview, see Trendall 1989, 1-16. With his protégé Alexander Cambitoglou, Trendall produced handbooks cataloguing the regional workshops. Trendall 1973; Trendall and Cambitoglou 1978; Trendall 1987. For vases and theater, Trendall and Webster 1971; Taplin 1992; Green 1994; Green and Handley 1995; Taplin 2007.

${ }^{847}$ Trendall 1989, 202-05.
} 
two female observers — one winged — with snakes in their hair are cut off, a convention indicating that they are in the background. Scholars interpret this scene as Electra, Orestes, and Pylades at the tomb of Agamemnon under the scrutiny of the Furies. ${ }^{848}$ Side B shows a wreathed youth at the left facing a woman holding a mirror, perhaps the recognition scene of Orestes and Electra. In this interpretation, the heads in the upper field behind a hill are the Eumenides. ${ }^{849}$ These possible iconographical links to Aeschylus' tragedy, Choephoroi, have insured Warren's Paestan vase a place in scholarship and in national exhibitions. ${ }^{850}$

An equally notable South Italian vase from Warren is the Apulian red-figure volute-krater (MFA 03.804) attributed to the school of the Varrese Painter (Figure 78). Trendall judged the Varrese Painter to be "one of the most significant painters of midfourth century." ${ }^{, 851}$ Almost two hundred vases have been attributed to him, and he exerted "considerable influence," not only on his immediate followers but also on those associated with the important Darius Painter. ${ }^{852}$

The MFA's vase, dated c. 340 , towers at 1.25 meters and is decorated with four gods and ten figures - each identified by an inscription. The elaborate ornamental motifs exemplify the Apulian departure from Attic conventions. Its handles rise from swan necks with volutes on each shoulder ending in plastic female masks. Beneath the

\footnotetext{
${ }^{848}$ Carpenter 1991, 236.

849 Trendall and Webster 41-44.

${ }^{850}$ For the bibliography and exhibition history of this vase, see Padgett, Comstock, Herrmann and Vermeule 1993, 185. See also 1991, 236; Boardman 2001, 115.

${ }^{851}$ Trendall 1989, 83.

${ }^{852}$ Trendall 1989, 83. The artist's name comes from the Varrese Tomb near Canosa in which some of his vases were found.
} 
handles, a wide band of ornate palmettes in two registers separates the two sides of the vessel; a band of leafy grape vine snakes around its tall foot. At the center of the neck on side A, Helios drives a quadriga; and, on side B, Eros sits on a flower holding a phiale. The belly contains a complex visual narrative perhaps inspired by the Aethiopis, a continuation of the epic cycle of poems connected with the Trojan War. On side A, Achilles sits in a pavilion or tent with his mentor Phoenix after killing his fellow Greek Thersites, who had taunted the hero about his love for the Amazon queen Penthesilea. The decapitated body of Thersites lies sprawled before them in the lower register. The other figures are identified by Greek inscriptions near each of them. Heroes like Agamemnon, Menelaus, and Diomedes, each standing on individual groundlines, are shown reacting to the wrathful deed. Four figures, also labeled with names, are in the upper register. To the right of the pavilion, Hermes stands with cross-legs, wearing his winged shoes and holding a caduceus and traveling hat in his left hand and a tall branch in his right. Behind him, Athena dressed in yellow shoes and a white diadem, sits on a shield; she wears not only her aegis but also jewelry — a bracelet, necklace, and earrings. To the left of the pavilion, Pan leans against a tree with a spotted animal skin flung over his shoulder while a winged, snake-haired female, the personification of Vengeance, sits with a spear in one hand and a sword in the other. ${ }^{853}$ Scholars argue that this vase depicts scenes from Achilles Kills Thersites, a lost tragedy by Chairemon, a mid-fourth century Athenian playwright. ${ }^{854}$ The foreshortening of the pavilion's columns and frieze as well

\footnotetext{
${ }^{853}$ For the identification of the various figures, see Padgett, Comstock, Herrmann and Vermeule 99-104; Taplin 2007, 3 .

${ }^{854}$ Storey and Allan 2005. On Side B, a young man and a horse are shown in a naikos or tomb with three figures on either side holding various offerings. The interpretation of this side is not clear because the figures are not labeled. The horseman may be Thersites in his tomb or Achilles after he has joined the
} 
as the shading on Achilles' military equipment - the chariot wheels, greaves, shield, helmet, and sword - hanging from the rafters shows the artist's effort to suggest the third dimension. The tiered half-figures, the foreshortening in the various seated figures, and the individual groundlines are conventions employed to suggest space.

Warren's gift of a third — and much less known — South Italian vase to Boston provides a clue as to his appreciation of the comic: a small red-figure Apulian oenochoe (MFA 13.93). The sole decoration on this vessel, dated c. 360-350, is a comic actor (Figure 79). Wearing tights, a mask, and a short belted tunic that exposes a dangling false phallus, he runs to the left with his eye looking backwards as if he is escaping a pursuer. Specialists in Greek comedy interpret his apparent haste and worried glance as those of a thieving slave, a stock character in Old and Middle Comedy. ${ }^{855}$

Although Attic vases were Warren's collecting forte, his purchases of South Italian vases like the Orestes Painter's amphora, the spectacular krater attributed to the Varrese Painter, and the Apulian phylax vase appear in scholarship employing material culture as a means of better understanding Greek drama. His acquisition of these vases beginning in 1899 anticipated the fascination with South Italian ceramics that inspired the MFA's purchases of vases of dubious provenance during the 1980 s and 90 s. ${ }^{856}$

heroic dead. For the interpretation of Side B, as well as the non-figural decoration, see Padgett, Comstock, Herrmann and Vermeule 99-104

${ }^{855}$ Bieber 1961, 142-43; Padgett, Comstock, Herrmann and Vermeule 79. Another example of a South Italian vase from Warren with a phylax actor is a calyx krater in the Gnathian technique, c. 350 (MFA 00.363). Here, a comic actor playing an old man is depicted in misadventures with a courtesan. Kondoleon, Grossmann and Ledig 2008, 124.

${ }^{856}$ See, for example, a series of articles in the Boston Globe cited in Gill and Chippindale 2006. "From Boston to Rome: Reflections on Returning Antiquities." http://www.proquest.com.echo.louisville.edu/ (13 May 2011). 


\section{Plastic Vases}

Warren also collected and sent plastic vases to American collections, in which the potter modeled the vase into a sculptural form or applied decorative elements. The designation "plastic" encompasses a wide range of techniques, from relief ornamentation applied to larger sculptural works, to hand-built and wheel-produced elements, such as handles and rims attached to mold-made vases. ${ }^{857}$ Scholars consider such relief ornamentation a novelty introduced by Athenian workshops, an evocation of the attachments used to conceal the riveting on metal cups. ${ }^{858}$

Other plastic vases are mold-made in which wheel-thrown elements are incorporated. Tarbell's Inventory records the provenance of Warren's gift of a small vase in the shape of a ram (SM 1967.115.396) as "from Thebes" and "bought in Athens." 859 Reconstructed from eight pieces, the mold-made body with its wheel-formed spout was probably used for perfume (Figure 45). Such a vessel illustrating ancient manufacturing techniques was an appropriate gift from Warren to the teaching collection at Chicago, where John Dewey had promoted hands-on pedagogical methods in all academic disciplines. ${ }^{860}$

\footnotetext{
${ }^{857}$ True 2006.

${ }^{858}$ Cohen 2008, 11. For example, Warren sent a black-figure cup to Bowdoin (BCMA 1915.43) decorated with the relief of a lion's head on the base of its handle. This one-handled kantharos, dated c. 510-490, is painted with a single scene of seven horsemen accompanied by dogs Herbert 1964, 59. This shape, a form of wine cup associated with Dionysos, usually has two vertical handles. Other plastic vases from Warren at Bowdoin were cups in the form of a female head (BCMA 1913.27), an African's head (BCMA 1923.19); and a rhyton in the form of a ram's head (BCMA 1923.23). Herbert 1964, 67-8

859 The Tarbell Inventory, Curatorial Files, Smart Museum of Art, University of Chicago.

${ }^{860}$ Johnson 1949, 244; Ferrari, Nielsen and Olson 24. Warren also gave Tarbell a Tarentine griffin-headed rhyton, (SM 1967.115.3620), Ferrari, Nielsen and Olson 79-80.
} 
Warren acquired a variety of plastic vases produced in late sixth and early fifth century Athenian workshops and inspired by Near Eastern metal ware. ${ }^{861}$ Some are in the shape of animal heads such as a red-figure cup in the form of a donkey's head (MFA 03.787) that Warren sold to the MFA in $1903 .{ }^{862}$ This vase (Figure 80)can be interpreted as pastiche of jests for its user/viewer. One joke comes with the realization that its contents had to be thoroughly consumed before the vessel could be set down. With its braying mouth and bridle, its shape recalls the mount of Dionysos and may have been thought of as a mask, "literally intended to make an ass of [its] user" when the drinker lifted his head to drain the vessel. ${ }^{863}$ It is also argued that the rhyton may have had sexual associations in that the donkey's laid back ears and extended tongue may suggest a state of sexual arousal ${ }^{864}$ At the top of the animal's head, the shape transitions into a flanged cup with a handle. Here, the theme of ribald drinking continues with a scene of two satyrs pursuing a maenad. One in a billowing leopard skin leaps over a drinking horn while his similarly clad partner crouches in ambush. Blinded by their passions for wine and sex, satyrs functioned as what one scholar calls the "antithetical representations" of humans, functioning as a warning about the dangers of excess to drinkers at the symposium. ${ }^{865}$

\footnotetext{
${ }^{861}$ True 2006, 246-7. For shapes of Greek ceramic vessels imitating metal, see Gill 1985; Vickers 1985a; Vickers $1985 \mathrm{~b}$.

${ }^{862}$ The cup is attributed to the Brygos Painter and dated c. 480. Museum of Fine Arts "MFA Collections. http://www.mfa.org " (accessed 27 February 2011). Athenian workshops also produced vases in the shape of other animal heads, usually rams and dogs and - more rarely — those of birds like doves or vultures. See, for example, a rhyton in the form of a ram's head (BCMA 1923.23).

${ }^{863}$ Kozloff 1980, 212 as quoted in Ebbinghaus 2008, 153.

${ }^{864}$ Hoffmann 1997, 6-2. Donkeys are usually ithyphallic when they carry Dionysos. Hoffman also cites Beazley's reference to the donkey's phallus as an "alternative symbol of Dionysos."

${ }^{865}$ Mitchell 86, 160.
} 
Warren also sent plastic vases known as "head vases." "866 Produced in single or janiform variations, usually of Africans or women, but sometimes in conjoined combinations to offer contrasts in gender and race, these vases suggest a Greek affinity for playing with alternate identities. ${ }^{867}$ Female heads are thought to refer to the women who poured the wine or provided entertainment at the symposium. ${ }^{868}$ In 1929 Beazley classified Attic head vases, assigning the name "Group L The Providence Group" to a subset with women's heads. ${ }^{869}$ "Providence," of course, is an acknowledgement of both Warren and RISD in that it refers to the name vase (RISD 22.213) that Warren obtained for Eliza Radeke. This red-figure oenochoe, c. 490 (Figure 81), is in the form of a woman's head with her eyebrows and eyes outlined in black gloss and the rows of curls framing her face made up of relief dots. Patterned ribbons across her forehead and the back of her head keep her checkered sakkos in place. Characteristic of the "Group L The Providence Group" are a raised palmette-patterned shoulder, trefoil mouth, and looped strap handle. ${ }^{870}$ Beazley observed that such anthropomorphic vases are reminiscent of the late Archaic marble korai found on the Acropolis. ${ }^{871}$

\footnotetext{
${ }^{866}$ Head vases served as a perfume containers and pitchers as well as drinking vessels.

${ }^{867}$ At the MFA, see, for example, the janiform vases of two black-men (98.888) and a red-figure kantharos with heads of a woman and a satyr (98.926) from Warren. For the Greek fascination with "the other," see Lissarrague 1995. Warren gave Bowdoin cups in shapes of "the other," see-for example — cups in the form of a female (1913.27) and a Negro's head (1923.19).

${ }^{868}$ Another variation of a head vase from Warren is the Rhodian aryballos in the form of bust of a gorgon (MFA 99.510) featured in “The Centaur's Smile" exhibition. Padgett 2003, 210-11.

${ }^{869}$ Beazley 1929, 56-8, Fig 10.

${ }^{870}$ Warren obtained much less elaborately decorated vases in the shape of a woman's head: a single-headed version (01.8152) sold to the MFA and two janiform kantharoi, one given to Harvard (1927.144) and the other to Tarbell (1967.115.353) The latter vase, now at the University Chicago, has been determined to be a forgery. Ferrari, Nielsen and Olson 205.

871 Beazley 1929, 44.
} 
An unusual plastic vase from Warren, a patera (MFA 98.886) with black and white vertical ribs on its exterior, was showcased in the "Colors of Clay" exhibition (Figure 82). The ribbing is reminiscent of a gold or silver libation bowl, perhaps inspired by Persian models. ${ }^{872}$ The exterior of the lip boasts the name of its potter in the inscription, "Sotades made [me]." In the center of its white-ground interior sits a separately-fashioned clay cicada which was fixed to an omphalos with clay slip. This vessel, together with eight other vases, was found in the Sotades Tomb in Athens. ${ }^{873}$ Recent analyses of the clay and slip indicate that the vessel probably came from the same workshop producing the other plastic vessels like the white-ground kylix (MFA 13.4503) from Warren that Williams traced to the Sotades Tomb (Figure 75). ${ }^{874}$ Moreover, the cicada is intriguing, for like the owl and the olive tree, it served as a symbol of Athens and perhaps referred to the Athenians' claim to autochthony. ${ }^{875}$ Some scholars also interpret this grave gift with a cicada perched in its center as an indication of a belief in an afterlife. ${ }^{876}$

Another Warren plastic vase featured in the "Colors of Clay" exhibition demonstrates that a careful examination of museum records can serve to further our understanding of Greek vases acquired by Warren for American collections. One of them is a hitherto little noticed fragmentary black-figure oil aryballos (MFA 95.55), a small

\footnotetext{
${ }^{872}$ For the argument that Greek vases are versions of now-lost metal vessels, see Vickers 1985a; Vickers and Gill 1994.

${ }^{873}$ All nine vases were once in the Alphonse van Branteghem Collection. For the catalogue essay and the scholarship on the Sotades Tomb, Williams 2006a. For Sotades, Williams 2004b.

${ }^{874}$ Cohen 2006a, 311-12.

${ }^{875}$ Hoffmann 1988, 756. The Athenians claimed that they had always lived in Attica, literally springing from the earth. Thus, the association can be made with the cicada which emerges from the ground. For the Athenian belief in autochthony, Rosivach 1987.

${ }^{876}$ Hoffmann 1988.
} 
container for the oil with which Greek men used to slick their bodies before athletic exercise (Figure 83). It was published in the catalogue for the "Games for the Gods," an MFA exhibition commemorating the 2004 Olympic Games in Athens, and illustrated with photographs of Greek antiquities primarily in Boston. As might be expected, more than seventy five of the objects illustrating aspects of Greek athletics came from Warren, including this aryballos, identified in the "Games for the Gods" catalogue as an Attic black figure "oil flask (aryballos) in the shape of an ox-head," dated c. 520-500. ${ }^{877}$ The later "Colors of Clay" clarified the earlier description, noting that the aryballos had two sides: the better preserved in the form of a long horn black bull and the other in the shape of a penis and scrotum. This revelation was prompted by the investigation of the "sendings list” from Warren preserved in the MFA files. In it, Warren's entry reads "Sent bottle in the form of a phallus" with the added note "part was broken off after the sale and lost. This was before I got it." ${ }^{878}$ This information prompted a new interpretation of this vase in the "Colors of Clay" exhibition: the curator suggested that such an object "would surely have been titillating in the homoerotic culture of ancient Athens" and that the phallus "would have vied with the bull's head for the attention of the viewer." 879

This aryballos is an appropriate object with which to close this discussion of Greek vases that Warren acquired for American collections. It underscores that the objects he selected to include in his "sendings" continue to serve as avenues for a deeper understanding of Greek values and preoccupations. In particular, this vase illustrates the

\footnotetext{
${ }^{877}$ Herrmann and Kondoleon 2004, 133, 184. Warren acquired this unattributed black-figure vase in the 1892 van Branteghem Sale. Warren gave another plastic vase of this type (MFA 13.105), with a depiction of a man courting a youth and the inscription "Priapos epoiesen " ("Priapos made it").

${ }^{878}$ Warren as quoted in Cohen 2006b, 261.

${ }^{879}$ Cohen 2006b, 261.
} 
delight of the ancient artist in "disguising the functional nature of a clay vessel.",880

When this aryballos is considered in the context of other Warren vases-for example, the Kabiric bowl decorated with caricatures of Greek literature now in the University of Chicago collection; the Pan Painter's once "censored" krater in the MFA; and the unusual vessels from the Sotades Tomb—one recognizes not only the sophistication of the ancient Greeks who created these objects but also the taste of the expatriate connoisseur who selected these intriguing vases.

\section{Terracotta Sculpture}

Unlike Greek vases, other terracotta objects from Warren, such as sculpture, figurines, and reliefs, have received less scholarly attention. An exception, however, is the life-size terracotta head of a man (MFA 01.8008), one of the few such Roman sculptures of its kind to have survived (Figure 84). For this reason, this portrait, dated to the late Republic and reported to have come from Cumae, frequently appears in MFA publications and surveys of Roman sculpture. ${ }^{881}$ Harvard scholar George Chase included this work in his 1924 catalogue of classical sculpture in American collections, and curator L. D. Caskey used three photographs of the head in his 1925 handbook of the Greek and Roman sculpture in the MFA. ${ }^{882}$ Eager to connect the head to Roman death masks that

\footnotetext{
880 True 240.

${ }^{881}$ This head may be the one that von Mach listed in the 1905 edition of A Handbook of Greek and Roman Sculpture under Roman portraits in "Portraits of Unknown Men and Women" ( "Unknown Man, terracotta," \# 436 front and \#437 profile). The head is not discussed in the text; the numbers refer to a "University Prints" series, which I have been unable to obtain. von Mach 1905, xxviii.

${ }^{882}$ Chase 1924, 172-3; Museum of Fine Arts and Caskey 1925, 189-91. Caskey limited the 1925 MFA catalogue to stone sculpture, yet he decided to include the rare terracotta. Warren obtained another Republican portrait, a damaged marble head (99.343) in 1899. Chase 1924, 173-74; Museum of Fine Arts and Caskey 1925,198. For the head in MFA catalogues, see also, Chase 1950, 142-43. Caskey, the MFA
} 
the Greek historian Polybius describes in his Histories, 6.53-4, Chase and Caskey proposed that the sculpture was created from a mold taken from the face of a live subject. ${ }^{883}$ However, in a recent survey of Roman sculpture, Kleiner argues that the MFA terracotta head is "too animated" to have been based on a cast and is more likely a "bozzetto," a preliminary model for a "more finished work of bronze or marble." 884 Another scholar suggests other viable theories: that the use of terracotta for such a portrait may reflect the continuing popularity of the material in areas with a long tradition of working in the medium or that it may have been a cheap substitute for stone and bronze. $^{885}$

Most of the Greek terracotta sculptures Warren obtained for American collections were much smaller and often strike many viewers as strange and far from the ideal of ancient aesthetics. Warren delighted especially in terracotta figurines that conveyed a sense of the comic or the absurd; those depicting actors, now in the MFA, appeared in the important American publications on the Greek and Roman theater. ${ }^{886}$ The bell-shaped female figurine from Boeotia (MFA 98.891) dated c.720-690, is well known because of its curious shape and movable legs (Figure 85). The birds and decorative motifs such as the pinwheels and swastikas on its circular wheel-manufactured torso are also found on

curator and collaborator with Beazley, and Chase, a professor of ancient art at Harvard and a MFA curator, are discussed in Chapter 3.

${ }^{883}$ Recent scholarship discounts the connection between Republican portraiture and death masks. Gruen $1992,155$.

${ }^{884}$ Kleiner 1992, 37-8. The 2008 MFA classical catalogue, however, claims that medical imaging technology confirms that the "portrait was made, at least in part, using a mold taken directly from the face of a living person.” Kondoleon, Grossmann and Ledig, 172.

${ }^{885}$ Fejfer 2008, 177-78.

${ }^{886}$ See, for example, Bieber 1963, 39-42, 81, 95. This dissertation will not discuss the theatrical figurines from Warren. Chapter 3 discusses the pleasure he found in terracotta grotesques as demonstrated in his introductory remarks for a proposed catalogue of his collection at Bowdoin. 
Geometric pottery. Because such figurines—or, dolls, as they are sometimes called—are rare in American collections, Warren's often appear in publications. ${ }^{887}$

Less familiar are Geometric "idols" he donated to Bowdoin, such as BCMA 1923.29, dated to 650-600 and thought to have been inspired by earlier Mycenaean types. ${ }^{888}$ Scholars interpret the Bowdoin figurine (Figure 86) with its characteristic stumpy arms and pinched-out nose as a woman. The spiral on her head is a crown while the painted vertical zigzags represent her hair and the horizontal decorations are interpreted as a necklace with pendants. The figurine may have been associated with the worship of Demeter and Persephone, but the lack of an archaeological context makes such identification speculative. ${ }^{889}$

Like many collectors of his day, Warren acquired numerous "Tanagra" figures, so-called because of the town of Tanagra in Boeotia where they were first found. ${ }^{890}$ Coroplast production centers around the Mediterranean mass-produced thousands of figurines, beginning in the Early Classical period in South Italy and extending through the Hellenistic and Roman periods. Sometimes signed or stamped with the insignia of their workshops, they come in a variety of shapes and textures and often retain traces of polychromatic details. ${ }^{891}$ Many of these objects appear to have had a religious context, yet the harvesting of these charming figurines from Hellenistic cemeteries in Tanagra and

\footnotetext{
${ }^{887}$ Higgins 1967, 23. For MFA publications, see Chase 1950, 14-16 ; MFA: A Guide to the Collection of the Museum of Fine Arts, Boston 1999, 63; Kondoleon, Grossmann and Ledig 162. Another ceramic "doll" (BCMA 1923.10) is discussed later in this chapter.

${ }^{888}$ Herbert 1964, 91-92. Similar figures at Bowdoin are BCMA 1923.27 and 1923.28. For Mycenaean terracotta figurines to which Herbert refers, French 1971.

${ }^{889}$ Herbert 1964, 91-2.

${ }^{890}$ For the context, Becq 2010.

${ }^{891}$ Uhlenbrock 1990b.
} 
Myrina in the late nineteenth century has left little, if any, documentation of their findspots. Furthermore, "restorers" learned that they could profit from modeling figures similar to the ones they had reconstructed. ${ }^{892}$ The Lewes House Registers contain notations that "TC's" - as terracotta figurines were labeled in the ledgers-were “destroyed," likely because their authenticity was suspect. Not all forgeries were caught at Lewes House, as demonstrated by Warren's gift to Tarbell of a figurine of a woman with a bird perched on her hand, now judged to be a modern work at the University of Chicago. $^{893}$

Since "Tanagra" figurines were less expensive and far more obtainable than those in marble and bronze, they became fashionable among collectors in the United States and Great Britain in Warren's era. The Lewes House Registers show that Warren acquired the figurines from Athenian dealers, like Lambros, who set themselves up as "the sole intermediaries" between the peasants "harvesting" the figurines and the buyers, including antiquities firms, like Rollin and Feuardent, in Paris. ${ }^{894}$ As Lapatin points out, "Tanagras, in short, suited what people in the late nineteenth century wanted to see in . . . the past. ${ }^{, 895}$ In fact, one of the first antiquities that Eliza Metcalf Radeke purchased from Warren for RISD was the statuette of a standing woman wrapped in a tunic (RISD 00.006). Dorothy Burr Thompson, the first American specialist on these antiquities,

\footnotetext{
${ }^{892}$ Andrén 66-7; Lapatin 2002, 40-3.

${ }^{893}$ The catalogue of classical art in the Smart Museum at the University of Chicago notes this figurine (fabricated from seven fragments and apparently accessioned as two distinct objects, SM 1967.115.60 and SM 1967.115. 157) now serves as "a record of nineteenth-century classicizing sentiments." It also questions the authenticity of another Warren gift to Tarbell, a janiform head kantharos (1967.115.353). Ferrari, Nielsen and Olson 204-05.

${ }^{894}$ Mathieux 2010, 17.

${ }^{895}$ Lapatin 2002, 43.
} 
wrote her doctoral dissertation on the more than one hundred MFA figurines from Myrina, a small coastal city north of Smyrna in present day Turkey, almost all of which came from Warren in $1901 .^{896}$

Early textbooks on Greek art described these terracotta statuettes as "charming" and "bright as spring flowers." ${ }^{, 897}$ In his survey of Greek Art, Tarbell asserted that although the terracotta male figures were "doubtless regarded in their own day [as the product of] very humble craftsmen," "the best of them [captures] the secret of graceful poses and draperies." ${ }^{898}$ He praised "the frank and innocent nudity . . . so characteristic . . of the best Greek art." ${ }^{899}$ Warren seemed to have shared Tarbell's opinions, for he contributed figurines of nude Erotes and youths to the study collection at Chicago. ${ }^{900} \mathrm{~A}$ terracotta figurine of Eros (MFA 87.1), it should be recalled, was the first antiquity that Warren acquired for the MFA (Figure 8). ${ }^{901}$ Terracottas of nude young men, which one scholar recently described as "a cheap kind of eroticism" during the late nineteenth century, may have offered a homoerotic fascination for Warren and fellow collectors. ${ }^{902}$ However, other figurines, such as the grotesques he gave to Bowdoin, appealed to his sense of humor and the absurd. ${ }^{903}$ Another well-known Warren terracotta in the MFA is a playful Eros wearing the lion skin of Herakles (MFA 00.321) dated to the first century (Figure 87). The winged boy smiles and wags the finger of his right hand to taunt the

\footnotetext{
${ }^{896}$ Thompson 1934, v. For recent scholarship on the production of figurines from Myrina, Tezgor 2010.

${ }^{897}$ Gardner 133.

898 Tarbell 1905, 245.

899 Tarbell 1905, 125.

900 The Smart Museum collection contains fragments of Erotes (1967.115.499 and 1967.115.499), Ferrari, Nielsen and Olson 104-05; and figurines of a boy at a herm (1967.115.61) and a youth (1967.115.58), all from Warren. Ferrari, Nielsen and Olson 108-09.

${ }^{901}$ For the discussion of this figurine, see Chapter 3.

902 Mathieux 19.

${ }^{903}$ See Chapter 3.
} 
viewer with something held behind his back in his left hand, perhaps a joking reference to the apples of the Hesperides. The figurine also seems to imply that love, as personified by Eros, can easily overpower the most powerful human strength represented by Herakles. Modeled rather than cast, this statuette is thought to have been inspired by a large-scale bronze created by the renowned fourth-century Greek sculptor Lysippos. ${ }^{904}$ The 20102011 exhibition "Heroes: Mortals and Myths in Ancient Greece" included another terracotta Herakles from Warren (MFA 01.7967) conveying a more reflective slant on the demi-god (Figure 88). ${ }^{905}$ With a full beard, deep set eyes, and furrowed brow, the brooding hero appears to be exhausted and reclines on his lion skin, a depiction interpreted as emblematic of the hero's "essential humanity." 906

A comprehensive publication of terracotta figurines in American museums did not appear in the United States until after Warren's death in 1928. Dorothy Burr Thompson's catalogue, Terra-cottas from Myrina in the Museum of Fine Arts, Boston (1934), is acknowledged as the pioneering work that established terracotta figurines as a field of study ${ }^{907}$ In 1990-91, an exhibition honoring Thompson on her ninetieth birthday, "The

\footnotetext{
${ }^{904}$ Kondoleon, Grossmann and Ledig, 90. According to the MFA Collection Database, Eros playing Herakles (00321) came from Myrina and once belonged to A. Fontrier of Smyrna. MFA collection handbooks often feature the statuette : A Handbook of the Museum of Fine Arts Boston 1914, 114; Chase 1950, 118; Kondoleon, Grossmann and Ledig 90. Warren acquired a second, and less-published, terracotta Eros, dressed as Harpokrates (00.322), from the same source. Museum of Fine Arts "MFA Collections. http://www.mfa.org " (accessed 5 February 2011). See also Higgins 1966, 117.

${ }^{905}$ Albersmeier 2009, 212-13. Organized chiefly by the Walters Art Museum, the exhibition was hosted at the Frist Center of Visual Arts, the San Diego Museum of Art, and the Onassis Cultural Center in New York in 2010-11.

${ }^{906}$ Larson 2009, 32. The weary Herakles is a popular Hellenistic type inspired by a work of Lysippos. Nearly twice life-size, the marble Farnese Herakles, now in Museo Archeologico Nazionale, Naples, was a must-see on the eighteenth- and nineteenth-century "Grand Tour." Large scale copies and plaster casts subsequently appeared in displays of classical sculpture.

${ }_{907}$ Dorothy Burr Thompson (1900-2001) earned her doctoral degree at Bryn Mawr with Mary Hamilton Swindler and Rhys Carpenter. This book was essentially her 1931 dissertation. For Thompson's career, Havelock 1981; for her obituary, "Keen Eye: Archaeologist Dorothy Burr Thompson." 2001.
} 
Coroplast's Art: Greek Terracottas of the Hellenistic World,” provided an opportunity for viewing over fifty figurines selected from fifteen American Collections in three university venues. As might be expected, at least sixteen of the terracotta figurines in the exhibition can be documented as coming from Warren. ${ }^{908}$

Recent exhibitions in the United States have focused on how these terracotta objects provide a means of understanding Greek daily life. The groundbreaking 2003 exhibition, "Coming of Age in Ancient Greece," featured ten terracottas acquired by Warren now in American collections. ${ }^{909}$ A pair of terracottas from Tanagra dated c. fourth century (MFA 01.7799 and MFA 01.7798), depicts two young women engaged in a game of knucklebones and, thus, have been displayed together (Figure 89). ${ }^{910}$ Another statuette of a woman carrying another on her back (MFA03.894) is thought to depict the ephedrismos, a little understood game to which ancient written sources allude (Figure 90). ${ }^{911}$ Two other Warren terracotta figurines in the "Coming of Age in Ancient Greece" exhibition dated to $\mathrm{c}$. fifth century and reportedly from Tanagra illustrate the interactions

http://www.brynmawr.edu/alumnae/bulletin/home.htm (3 February 2011); for a student's tribute to Thompson, Uhlenbrock 1990a, 8-9.

${ }^{908}$ MFA 01.7874; 01.7797; 01.7843; 01.7807; 10.230 ; 01.7788; 01.7798; 13.159; 01.7897; 03.894; 01.7682; 01.7697; 01.7690; 01.7625; 01.7959; 01.7613. The exhibition was hosted at the Art Museum, Princeton University; the College Art Gallery of the College of New Paltz, State University of New York; and the Arthur M. Sackler Museum, Harvard University.

${ }^{909}$ Eight can be unquestionably documented as from Warren. Seven are in the MFA: the Hellenistic Kourotrophos (01.7747); Seated Man Offering Grapes to a Girl (97.350); Standing Girl with Tiara and Tambourine (1.7860); Woman Teaching Girl to cook (01.7788) ; Girls Playing Knucklebones ( 01.7799) ( 01.7798); and Girl Seated with tambourine and wreath (10.230). The eighth is at Bowdoin: Attic molded terracotta doll holding rattles (1913.028). Two others also are most likely from Warren. "Seated Infant Girl with Outstretched Arms (02.38), which is listed as an anonymous gift to the MFA from "the Estate of Mrs. Susan C. Warren" certainly must have come originally from Ned Warren. The Girls Playing Ephedrismos from the MET (07.286.4) is listed as "Ex Collection of John Marshall."

${ }^{910}$ The MFA Collections database only indicates that they were both bought in Paris by 1901. Museum of Fine Arts "MFA Collections. http://www.mfa.org " (accessed 7 July 2011). The separate figurines were photographed together in one of early MFA guidebooks, A Handbook of the Museum of Fine Arts Boston 1916, 105. See also, Uhlenbrock 1990e, 118-19; Neils and Oakley 2003, 277.

${ }^{911}$ Uhlenbrock 1990e, 128-29; for ephedrismos, see also Neils and Oakley , 277. 
of adults with children: a balding old man offering grapes and a pomegranate to a girl (MFA 97.350) (Figure 91); and a woman teaching a girl to cook (MFA 01.7788) (Figure 92). ${ }^{912}$ Whether the original function of these figurines was other than funerary remains a matter of debate. Although Stewart proposed that the terracotta depicting the cooking lesson may have been intended for children, "vaguely instructive, like toy cooking sets today," other scholars have argued that these figurines are religious in nature, associated with marriage rites. ${ }^{913}$

The Attic terracotta jointed doll (BCMA 1913.028), featured in "Coming of Age in Ancient Greece," was also included in the Bowdoin College Art Museum's “Ars Antiqua" exhibition (Figure 36). ${ }^{914}$ By the late fifth century, dolls like the one at Bowdoin were nude so that children could clothe them. This doll's hairdo indicates that it was from the late classical period. ${ }^{915}$ Dated to the mid-fourth century, she holds krotala, a type of rattle or castanets, and may have served as a votive or apotropaic device hung from a tree branch where the wind could animate it; alternatively, it may have been a toy that was a grave gift for a girl. ${ }^{916}$

Our understanding of the original function of Greek terracotta statuettes and dolls is limited. Extant information about Greek women is almost entirely from the point of view of elite men and little has been recorded about the findspots of the figurines which

\footnotetext{
${ }^{912}$ For MFA 97.350 and its bibliography, Neils and Oakley 233. For MFA 01.7788 and its bibliography, Neils and Oakley 257.

${ }^{913}$ Stewart 2008, 186. The MFA terracotta from Warren is one of two antiquities Stewart illustrates in his discussion of Greek children. For a religious interpretation, Jeammet 2010, 49.

${ }^{914}$ In the "Coming of Age" exhibition, the Warren's doll at Bowdoin was included with two other joined terracotta dolls in American collections, a Corinthian doll at the Met (1944.44.11.8) and a Boeotian doll (y1947-205) from the Princeton University collection. Neils and Oakley 267-68.

${ }_{915}$ For BCMA 1913.028 and the bibliography on jointed dolls, Neils and Oakley 267.

${ }^{916}$ Herbert 1964, 102; Higginbotham and Westley 55; Neils and Oakley 267.
} 
might provide contextual clues. Nevertheless, Bowdoin's “Ars Antiqua” exhibition suggests that the Tanagra figurines from Warren can serve as "vivid examples of the dress of Greek women." The catalogue explains that traces of the original paint on a figure of a woman holding a fan (BCMA 1915.12.1), dated to the late fourth century, show that Greek women dyed their hair with henna; and the surviving pink mantle and blue chiton reveal a taste for colorful clothing (Figure 93). ${ }^{917}$ Another terracotta figurine (BCMA 1908.10), c. fourth century, wears a kerchief and holds a garland that the exhibition catalogue proposes might have served to decorate the doors of houses and shrines (Figure 93). Other hypotheses about these garlands include displays at festivals and in processions or gifts to the dead.

A Hellenistic statuette of a young woman (MFA 98.893) from the Tomb of the Erotes in Eretria serves as an apt object to close this discussion of terracotta figurines from Warren in American museums because more is known about its findspot. ${ }^{918}$ The statuette (Figure 94) was among a group of sixty-five objects he acquired from the Tomb of the Erotes, a Hellenistic chamber tomb in Eretria, all of which entered the MFA in 1889 except for an intaglio ring (MFA 21.1213) that arrived forty-two years later. ${ }^{919}$ The tomb group included terracotta figurines and reliefs, as well as gold diadems, earrings, rings, and bracelets. ${ }^{920}$ The barrel-vaulted tomb derives its name from twenty-eight

\footnotetext{
${ }^{917}$ Herbert Higginbotham and Westley 56-57.

${ }^{918}$ MFA curator, Cornelius Vermeule, explained that " shortly before the turn of the present century, a peasant working near Eretria stumbled upon the intact contents of the chamber tomb ..." Vermeule 1965, 367

${ }^{919}$ A search of the MFA Collections database indicates that sixty-five objects from Warren were accessioned from the Tomb of the Erotes, with all arriving in 1898, except for a ring (MFA 21.1213), which was accessioned three years later. Museum of Fine Arts "MFA Collections. http://www.mfa.org " (accessed 20 May 2011).

${ }^{920}$ The jewelry is discussed later in this chapter.
} 
terracotta Eros figurines thought to have been suspended within a wall niche. ${ }^{921}$ The Erotes or "spirits" are mold-made but individualized with details added through separate casting or free-hand additions. These figurines have been interpreted as daimones, links between gods and humans, or representations of the dead or the dead's soul, suggesting a conception of death as "the eternal resting place of the liberated and blessed soul.",922 Most of the winged figurines grasp musical instruments while others hold perfume containers, chests, or kerchiefs. Warren also obtained twenty-eight miniature round and oval terracotta shields, decorated in relief with thunderbolts, stars, and six variations on the heads of Alexander-Helios, Medusa, and youths. ${ }^{923}$ These small reliefs $(9-10 \mathrm{~cm})$ are thought to have been attached to funerary furniture. The tomb contained two stone couches which held the remains of two men while two stone thrones and a bone chest were reserved for the burials of women. Inscriptions and three phases of interior decoration indicate that the tomb was used over at least three generations. ${ }^{924}$ Dating the objects is problematic: the various objects are labeled "early Hellenistic" or c. 375-325, on the basis of style. The 1980-1982 exhibition, "The Search for Alexander," included examples of the terracotta figurines and the shield reliefs and exhibited them with the jewelry from the tomb. ${ }^{925}$ Examples of the grave goods from the Tomb of the Erotes in

\footnotetext{
921 According to the MFA Collection database, they are approximately $10 \mathrm{~cm}$ tall and some show evidence that they were suspended with string. Museum of Fine Arts "MFA Collections. http://www.mfa.org " (accessed 12 July 2011).

922 Becq, Jeammet and Mathieux 2010, 146.

${ }^{923}$ In 1965,Vermeule briefly discussed eighteen of the terracotta shields in an article surveying tondo portraits. Vermeule 1965, 367-70.

${ }^{924}$ Yalouris, Andronikos, Rhomiopoulou, Herrmann and Vermeule 1980, 1, 149-513.

${ }^{925}$ The terracotta Erotes were MFA 97.300 and 97.301; the four miniature terracotta shields included MFA 97, 323; 97.327; 97.334; and 97.345. Yalouris, Andronikos, Rhomiopoulou, Herrmann and Vermeule 15152. The jewelry will be treated on the section devoted to metal later in this chapter.
} 
the MFA collection appeared in various publications; however, the tomb and its contents were not fully published until $2008 .^{926}$

The MFA figurine (MFA 98.893) is much larger than any of the other terracotta sculptures or reliefs from the Tomb of the Erotes. ${ }^{927}$ The clothed woman leans against a pillar, with her left elbow resting on its top and her left foot placed on its base. She wears a large ring on her left hand. Given the "swarm" of Erotes with instruments, she may be Euterpe, the muse of music. A pin-hole in the top of the pillar indicates that a now lost second figure, perhaps an Eros, once sat there, thus suggesting that she is Aphrodite. ${ }^{928}$ Whatever the identity, the scale of the figurine and the fact that Warren's records indicate that it was found on a table in the tomb underscore its importance. The similarity between the large ring worn by the figurine and the heavy garnet intaglio ring (MFA 21.1213) found in the same tomb prompts additional speculation: perhaps the terracotta sculpture of the woman is a portrait of one of the women who was interred in the Tomb or a depiction of its patron's notion of the ideal Greek woman. ${ }^{929}$ As in the case of the vases from the Sotades Tomb in Athens, Warren's purchase of a variety of objects from a

\footnotetext{
${ }^{926}$ The site was first published in 1899 by K. Kourouniotis, a Greek archaeologist with whom British and American scholars in the American and British Schools of Classical Studies collaborated in various excavations. Kourouniotis excavated at Pylos with American archaeologist, Carl Blegen. See Dickins and Kourouniotis 1906Kourouniotis and Blegen 1939. Higgins mentions the jewelry indirectly in regard to a Hellenistic "family tomb." Higgins 1980, 157, 223. Swiss archaeologists published the site and its contents in 2008. See Huguenot 2008. For the bibliography on the Erotes, the statuette, and the shield reliefs, Huguenot 30-31.

927 According to the MFA Collection database, the statuette is $39.4 \mathrm{~cm}$ high in contrast to the Erotes and shields which measure about $3 \mathrm{~cm}$. Museum of Fine Arts "MFA Collections. http://www.mfa.org " (accessed 12 July 2011).

${ }^{928}$ The MFA labels the statuette as Aphrodite; however, the fact that the figure is clothed rather than naked does not support this identification. See Becq, Jeammet and Mathieux 146.

${ }^{929}$ Chapter 5 discusses the ring more thoroughly in relation to the other jewelry from the Erotes Tomb.
} 
single findspot - in this case, the Tomb of the Erotes — contributes to an understanding of the context for the antiquities.

The inclusion of Warren's terracotta figurines in national exhibitions like "Coming of Age in Ancient Greece" and in "The Search for Alexander" as well as Bowdoin's "Ars Antiqua" testifies to the importance of his acquisition of antiquities heretofore considered less sophisticated and less valuable than Greek vases and large scale sculptures. Now these objects, formerly displayed in crowded cases or relegated to storage, are "coming of age" themselves through the work of scholars and curators seeking to understand children, women, and aspects of daily life seldom, if ever, mentioned in ancient texts. In addition, the recent scholarship on terracotta figurines from Warren also provides a window into early twentieth-century academia, when scholars like Dorothy Burr Thompson gravitated to research areas outside the male-dominated spheres of field archaeology and "high art." Warren's terracotta figurines also gain new significance from the information that they add about the sense of playfulness on the part of the ancient viewer, a quality that — as this dissertation asserts—Warren both recognized and shared.

\section{Terracotta Reliefs}

Warren acquired mold-produced terracotta Roman objects—chiefly vessels but also a few reliefs and lamps—-for American collections. ${ }^{930}$ The vessels and reliefs are

\footnotetext{
${ }^{930}$ As a rule, Warren did not collect Greek and Roman lamps. One Greek lamp was discussed in relation to documenting which antiquities entered the University of Chicago via Warren in Chapter 3. At least six ceramic lamps and a lamp filler from Warren are in the MFA, with several among the "erotica" given in
} 
early Imperial in date in what has been called the "Neo-Attic" style. Characteristic elements such as "plant decoration, lightly posed figures, and heraldic composition" are reminiscent of Classical Greek art. ${ }^{931}$ The subject matter usually is presented in an elegant but detached manner, often in eclectic combinations. Gods, heroes, winged victories, cupids, satyrs, and scenes of sacrifice serve a more decorative than religious function in these Roman works. Zanker argues that these subjects and their treatment are in a "new style" of the "private sphere," borrowed from the political imagery that developed during the reign of Augustus. This imagery found on temples, in imperial residences, and on grand monuments like the Ara Pacis was first imitated in the furnishings and decorations of the villas of the wealthy. Mass production in terracotta, however, permitted the non-elite to adopt and adapt such images for the household and the tomb and "set the natural workings of the marketplace in motion." 932

Typical of the Neo-Attic style are Roman architectural revetments, commonly called "Campana reliefs" after the famous collector, Giovanni Pietro Campana (18081880). These plaques — which served as decoration in temples, houses, gardens, and tombs — were readily available in the late nineteenth- and early twentieth-century antiquities market in Italy; however, little is known of their findspots. ${ }^{933}$ Campana plaques entered various collections in the United States, but they were often relegated to

1908. Since none of the MFA lamps were produced via molds or have figured in scholarship, no Roman lamps are included in this selective catalogue.

931 Grandjouuan, Markson and Rotroff 1989, 37.

932 Zanker 1988, 256-57.

${ }^{933}$ For these plaques and other Roman terracotta objects, see Sarti 2001. Little has been written in English about Campana reliefs; most of the research is by German and Italian scholars. 
storage and seldom studied. ${ }^{934}$ Warren gave five fragments, all dated to the first-century C.E., to Bowdoin: two harvesting scenes, one with Erotes (BCMA 1913.44), and the other with satyrs (BCMA 1913.29), and three with relief heads. ${ }^{935}$ A sixth, and the most complete, Campana relief at Bowdoin (BCMA 1927.24.1-2), shows a statue of a victorious athlete in a palaestra (Figure 95). Interestingly, Warren only acquired two Campana reliefs for the MFA, both similar in subject matter to Bowdoin's revetment, but much larger and more complete than Bowdoin's fragmented piece. One of the MFA panels ( MFA 03.883) displays a pediment with tritons holding a shield and a colonnade with five statues, each placed on a base between Corinthian columns (Figure 96). In the center, the largest statue of Herakles is flanked by a pair of boxers and then an athlete cleaning himself with a strigil and a victor holding a palm. Scholars suggest that this relief may illustrate how ancient Roman collectors may have used or reused Greek statuary for display in public spaces. ${ }^{936}$ The same terracotta relief, together with a second one from Warren in the MFA, were featured in a 2004 exhibition, "Games for the Gods" celebrating the Greek athlete and the Olympic spirit. ${ }^{937}$

\footnotetext{
${ }^{934}$ Campana reliefs entered American collections from sources other than Warren. For example, W. G. Hale gave Tarbell two fragments he purchased in Rome. Ferrari, Nielsen and Olson 110-12. In 1888 the MFA purchased five Campana plaques from Rodolfo Lanciani, who obtained them from Warren's friend, Alessandro Fausti. Museum of Fine Arts "MFA Collections. http://www.mfa.org " (accessed 5 February 2011). The MFA and the MET have the largest and most impressive Campana reliefs in the United States. ${ }^{935}$ Dionysus (BCMA 1913.47); the Gorgon Medusa (BCMA 1913.45); and the Egyptian god Ammon (BCMA 1913.48). Herbert 1964, 113-15.

${ }_{936}$ Vermeule 1977, 29; Howard 1990, 26-7.

${ }^{937}$ Herrmann and Kondoleon 2004, 140-41.
} 


\section{Mold Made Terracotta Vessels and Lamps}

Arretine ware, a type of a Roman ceramic with molded relief decorations, entered American collections in large numbers from Warren. ${ }^{938}$ He gave or sold more than onehundred pieces to the MFA—mostly pottery and mold fragments but also stamps or puncheons. ${ }^{939}$ He presented Bowdoin with the fragment of a bowl and three pieces of molds, with bands of egg-and-dart relief or borders of grape vines. ${ }^{940}$

Pliny, Martial and other ancient writers, as well as Giorgio Vasari, make references to the reddish ware from Arretium (Arezzo). ${ }^{941}$ According to Pliny, the inspiration for Arretine ware was repoussé decoration on silver vessels, with pattern pieces produced in molds made from the metal surfaces. ${ }^{942}$ The 1975 reprint of the MFA Arretine catalogue contains an addendum with illustrations of comparable ancient silver in the Museum to support the theory that Arretine pottery served as "inferior" versions of

\footnotetext{
938 The Greek taste for ceramic vessels "painted" with slip gave way to those with relief decoration. At first, such pottery was black, but by the second and first centuries BCE, the production of red ware began to be produced throughout the Empire. Red glossy pottery is known by various names derived from the centers of production: Megarian, Pergamene, Samian, and North African. "Arretine" pottery, produced in Italy and imitated in Gaul and Britain, is considered to be the finest, For production methods, see Brown 1976. The catalogue for the collection at the Ashmolean Museum uses the more general term "Italian terra-sigillata." Warren also was the source of Arretine ware now in the Ashmolean Museum, Oxford. Brown 19681968, xvii.

${ }^{939}$ Caskey 1917, 2. According to Arthur Fairbanks in the preface of the 1916 MFA Arretine catalogue, the MFA bought 28 pieces of Arretine ware and molds from Rodolfo Lanciani in 1888. Chase, Comstock and Vermeule 1975. Checking the concordance in the Arretine catalogue with the "Collections Search" indicates that Warren sent Arretine pottery to the MFA in 1897, 1898, 1900, 1901, 1903, 1904, 1908, 1910, and 1913. Two stamps or puncheons (MFA 37.190 and 37.191) from Warren but not accessioned until 1937 have been judged forgeries.

${ }^{940}$ For BCMA 1915.32, 1915.33, 1915.34, 1923.20, see Herbert 1964, 82-83.

${ }^{941}$ Vasari related that he discovered the remains of an ancient kiln and that he gave ancient vases and fragments to Lorenzo de' Medici. For the history of collecting Arretine pottery, see Chase, Comstock and Vermeule 1975, 1-7.

${ }^{942}$ Natural History 3.3, 157. Chase, Comstock and Vermeule 26.
} 
metal vessels. ${ }^{943}$ Usually dated to the first century C.E., Arretine ware had been found throughout the Roman Empire. In the 1880s and 1890s, vases, molds, and fragments were excavated in Arezzo and sold to American antiquities collectors, like Warren and James Loeb. ${ }^{944}$ George H. Chase published a catalogue for the MFA's Arretine collection in 1916, reusing the introduction he had written in 1908 for the Loeb Collection. Chase's MFA catalogue was reprinted and enlarged in $1975 .{ }^{945}$ Sometimes Arretine pottery is signed, prompting scholars to reconstruct workshops and spheres of influence as has been done for Greek vases. ${ }^{946}$ During the first half of the twentieth century, Arretine ware received attention in the MFA handbooks. ${ }^{947}$

Scholars have taken a renewed interest in Arretine ware. John Clarke, for example, in his study of humor and "transgression in Roman visual culture" discusses the MFA Arretine mold (MFA 98.870) with images of Hercules and Omphale as not only a parody of the relationship between Antony and Cleopatra as well as a possible

\footnotetext{
${ }^{943}$ For Arretine and other terracotta vessels as imitations of metal vases, see Vickers 1985; Hayes 1991; Vickers 1994; Vickers and Gill 1994. Other scholars postulate that the Roman pottery inspired Renaissance paintings. For the Arretine influence on Giulio Romano and Raphael, see Toby 1979.

944 James Loeb amassed a collection of more than 600 Arretine pieces and commissioned a catalogue from George Chase. For James Loeb (1867-1933), the collector and philanthropist who established the Loeb Classical Library and a chair of classical archaeology at Harvard and the AIA's Charles Eliot Norton Lecture series, see "The Founder: James Loeb." The Harvard University Press: Loeb Classical Library. http://www.hup.harvard.edu/features/loeb/founder.html (11 March 2011). Loeb first lent and later gave Arretine pottery to Harvard's Fogg Museum and the Metropolitan Museum, which touted these acquisitions. In 1909, Robinson announced the acquisition of 15 Arretine molds at the MET. Robinson 1909, 125. These molds may have come from Warren via John Marshall. In 1923 Richter called the Arretine pottery among the MET's “most prized and rare" objects. Richter 1923, 135.

${ }^{945}$ Chase, Comstock and Vermeule 1975.

${ }^{946}$ Pryce 1942; Chase 1947. For the most part, American scholarship on Roman Arretine ware is based on the archaeological work done in the Agora and Corinth by the American School of Classical Studies at Athens, see Homer Thompson 1934b. Thompson was married to Dorothy Burr (Thompson), the specialist in terracotta figurines. G. Roger Edwards, who was discussed in the history of the Warren collection at Bowdoin, published the relief pottery at Corinth, Edwards 1975.

${ }^{947}$ For example, two photographs of casts from the Arretine molds are in A Handbook of the Museum of Fine Arts Boston 1916, 18. As might be expected given his interest, Chase devoted four photographs and a drawing of Arretine pottery in his catalogue of Greek and Roman antiquities in the MFA. Chase 1950, 15660.
} 
representation of "social anxiety" among Roman males concerning "the increasing power and liberation of Roman women. ${ }^{948}$ Other scholars have become interested in Arretine ware because its iconography and designs can often be traced to Hellenistic sculpture, painting and metal vessels, as in the case of Andrew Stewart's proposal that the hunt scenes on some of Warren's Arretine molds in the MFA may reproduce a lost bronze sculptural group by Euthykrates of Sikyon. An example is a mold fragment (MFA 98.953), on which a youth with a Macedonian-style cloak thrusts his spear at a charging boar (Figure 97); a second fragment (MFA 98.984) shows a young horseman, whom Stewart suggests may be Alexander (Figure 98). ${ }^{949}$ Other scholars hypothesize that a third fragment (MFA 98.882), with a lion attacking a fallen man and another man swinging an axe (Figure 99) was inspired by the lost bronze group by the fourth-century sculptors, Lysippus and Leochares, at Delphi. ${ }^{950}$

Although not strictly-speaking Arretine ware, another mold-made vessel (MFA 99.542) was among the more than twelve Warren objects in the exhibition, "The Search for Alexander." ${ }^{951}$ Identified as "Italian Megarian" or "Italo-Megarian," this cup (Figure 100) bears the signature of Caius Popilius, who had a ceramic workshop in Umbria, c. $110-80 .{ }^{952}$ According to one scholar, its battle scene with multiple figures may have been

\footnotetext{
${ }^{948}$ Clarke 2007, 173-75.

${ }^{949}$ Stewart 1993, 48 and 392.

${ }^{950}$ Chase, Comstock and Vermeule 81-2. For the sculptural group, see Bieber 1949, 380. The MFA Database does not provide dates for the Arretine molds discussed above; they are labeled only as Roman.

${ }^{951}$ Antiquities from American, European, and Greek collections were included in this exhibition hosted by five leading museums in the United States between 1980 and 1982.

${ }^{952}$ Warren acquired two other bowls with relief decoration with the signature of Caius Popilius at the auction of the A. van Branteghem Collection in 1895 in Paris - MFA 95.95 and 95.60 - both with nonfigural decoration. Museum of Fine Arts "MFA Collections. http://www.mfa.org " (accessed 12 May 2011). Although Chase did not include these three bowls in his catalogue of Arretine ware at the MFA, he mentioned them briefly as a related group. Chase, Comstock and Vermeule 1975, 8. Warren gave a gray
} 
derived from the same lost panel painting that inspired the famous "Alexander mosaic" from the House of the Faun in Pompeii. ${ }^{953}$

Given the collector's acquisition of the "Warren Cup" and Greek vases with sexually explicit scenes, it is not surprising that he also amassed a quantity of Arretine ware with erotic imagery. Pottery and mold fragments of this type were accessioned in three groups at the MFA as purchases and gifts from Warren in 1898, 1908, and $1913 .{ }^{954}$ Warren also conveyed vases and molds with erotic scenes to Beazley, who gave them to the Ashmolean Museum in $1966 .{ }^{955}$ George Chase's 1916 catalogue of the Arretine pottery in the MFA provided descriptions of fifteen mold fragments and nine bowl fragments under the category "symposia" but included no illustrations of them. However, the 1975 reprint of the MFA catalogue added thirteen photographs of these fragments with male-female and male-male intercourse (Figures 101). ${ }^{956}$ Arretine ware with erotic

bowl with relief (BCMA 1915.16), which Herbert identified as "south Russian ware," and a "Megarian" bowl (BCMA 1930.81) to Bowdoin. Herbert 1964, 82. For the misuse of the term "Megarian" and the origins of this group, see Baur 1941; Rotroff 1978.

${ }_{953}$ Both the cup and mosaic may have been based on the lost painting by Philoxenos of Eretria for King Cassander, sometime after 318, of the Battle of Issus. For problems in interpreting the mosaic as a reflection of a lost "Greek" painting and the dating of the mosaic, Bergmann 1995, 81-2. For other "borrowings" of Alexander imagery, Giuliani 1977.

${ }^{954}$ Those with the "Res." prefix are listed as having been gifts in 1908 and accessioned in 1910. These are in the so called "Collection of Warren Erotica."

${ }^{955}$ The Ashmolean catalogue only indicates that the Arretine ware was "Once, Warren collection." Warren likely gave these objects to Beazley, but it is not clear when this transfer took place. Seven Beazley gifts are identified as once with Warren, and five of these have what the catalogue describes as "scenes of lovemaking." A photograph of a scene of man and woman engaged in coitus (1966.250) serves as the frontispiece of the Ashmolean catalogue

${ }^{956}$ For Arretine pottery in the MFA, see Chase, Comstock and Vermeule 66. The Arretine ware with the accession number Res. 08.33 came in the 1908 gift; others from Warren arrived in 1913. These thirteen photographs are under the section "The E.P. Warren Collection" in this order with catalogue, accession, and plate numbers, respectively: (Catalogue 54) Res 08.33e, Plate XLI - bowl fragment with two men on a couch; (Catalogue 55 ) Res. 08.33g, Plates XLI and LXII-three pieces of a bowl fragment with two malefemale pairs; (Catalogue 57) Res. 08.33d, Plates XLIII - four pieces of a bowl fragment with two malefemale pairs; (Catalogue 58) 13.103, Plate XLIV - bowl fragment with male-female pair; (Catalogue 59) Res. 08.33f, Plate XLIV - bowl fragment with male-male pair; (Catalogue 53); 13.109 Plates XLV and XLVI thirteen fragments of a bowl fragment a male-female pair and a male-male pair; (No Catalogue 
imagery has figured prominently in recent studies of Greek and Roman art and culture.

Zanker, for instance, discusses the pottery as an example of the Hellenistic influence on

Roman art and includes a photograph of a relief showing a male-female couple in coitus. ${ }^{957}$ Some of this Arretine ware, as well as other antiquities Warren obtained for the MFA, appeared in the books, Eros in Greece (1978) and Sex or Symbol? Erotic Images of Greece and Rome (1982). ${ }^{958}$ The Arretine pottery in the MFA also serves as comparanda for the Warren Cup: Clarke includes four mold and bowl fragments and John Pollini made use of one fragment in their articles about the cup. ${ }^{959}$ Clarke observes that erotic imagery on Arretine ware, particularly MFA 13.109 with its depiction of both heterosexual and same-sex couples engaged in intercourse (Figure 102), reflects "the balance of opposites" and "the positive conception of all manner of lovemaking" among the Romans. ${ }^{960}$ His observations about the significance of the Arretine fragment are reinforced in the catalogue of the groundbreaking 1996-1997 exhibition "I Claudia, Women in Ancient Rome." According to this exhibition's catalogue, the fact that household objects like the Arretine ware existed suggests that erotic imagery was "casual" in ancient Rome and the modern view that such scenes are examples of "male-

number) Res. 08.33h ; (Catalogue 39) Res. 08.33c Plates XLVIII, XLIX, and L-fourteen mold fragments with many missing parts showing three pairs, two male-female and one male-male, with three ithyphallic herms; and (Catalogue 43) Res. 08.33b Plate LI.—mold fragment with male-female pair.

${ }^{957}$ See Fig. 87 and the discussion, Zanker 2010, 142-44. Once in Warren's possession, the cup is in the Ashmolean. The ownership history of this object supports the close relationship of Beazley and Warren and suggests they shared a taste for antiquities with sexually explicit subject matter.

${ }^{958}$ See MFA 13.109, Boardman and LaRocca 1978, 165; MFA04.24, a mold with satyrs and fauns in a vintage scene, Johns 1982, figure 38.

${ }^{959}$ See the articles in the 1993 Art Bulletin, Clarke 1993, 282-85; Pollini , 31. The British Museum monograph on the Warren Cup also includes a photograph of Warren's Arretine piece (MFA 13.109), with reliefs of male-female and male-male coitus. Williams 2006b, 43.

${ }^{960}$ Clarke 1998, 114-15. 
oriented pornography” is “anachronistic." 961 Ramage and Ramage’s Roman Art:

Romulus to Constantine (2010) includes one of Warren's Arretine pieces (MFA 13.109), as well as the Warren Cup in its treatment of early Imperial art, testifying to changes in the attitude to sexuality in American education which the expatriate from Boston would undeniably approve..$^{962}$

More than a century after Warren began sending painted vases, terracotta sculptures, and mold-made reliefs and vessels to the United States, scholars continue to reexamine these antiquities for new insights into Greek and Roman culture and, thereby, to gain a deeper appreciation of the artists who produced them and the people who used them. The breadth of Warren's collecting and the extent of his impact on American scholarship are also evident in the objects, like coins and gems, for which he had an affinity.

\footnotetext{
${ }^{961}$ Kleiner and Matheson 1996, 90-91. An essay in the catalogue discussing "the gay, fun-loving set ... (whose) extravagant parties ... often climaxing with love-making" in the elite circles of the late Republic and early Empire also makes reference to Warren's Arretine fragment (MFA 13.109). Williams 1996, 13233. For another Warren object that has been interpreted in a similar manner, see the Corinthian mirror and case (MFA Res. 08.32c.2), discussed in Chapter 5.

${ }_{962}$ Ramage asserts that the Romans, like the Greeks, were "very interested in homosexual love." The malemale sexual activity depicted on both the silver cup and terracotta bowl indicates that the upper classes and the ordinary people shared this interest. Ramage and Ramage 2010, 137-38.
} 


\section{CHAPTER 5}

\section{WARREN ANTIQUITIES IN PRECIOUS MATERIALS IN AMERICAN COLLECTIONS}

Warren's encyclopedic collecting activities are reflected in a variety of small objects in precious materials that he sent to American museums, with the MFA receiving the greatest number. Beginning in the late 1890s, Warren amassed impressive collections of gems and Greek coins which he eventually published in commissioned catalogues. ${ }^{963}$ For the most part, these personal collections were ultimately sold or given to the MFA in lots where they formed the foundation of the museum's holdings in coins and gems. Warren was also generous to Bowdoin where he deliberately set out to build a study collection of coins and gems. A much smaller number of these types of objects entered RISD as gifts and purchases. Bowdoin and — to a lesser extent—RISD also received small antiquities in gold, silver, and glass. In addition, Warren gave glass and one ivory plaque fragment to Tarbell at the University of Chicago. The following assessment of Warren's contributions to American collections in these media begins with coins and gems, followed by silver and gold, mostly in the form of jewelry. This chapter closes with a discussion of ivory objects and an appraisal of ancient glass.

${ }^{963}$ For the gems, Boardman and Beazley 2002; for the coins, Regling 1906. 


\section{Coins}

Early in his collecting enterprises, Warren became fascinated with numismatics, especially Greek coins, an interest he shared with John Marshall. ${ }^{964}$ In the reminiscences appearing in the Burdett and Goddard biography, Warren recalled "worshipping” Greek coins on his first visit to Greece in $1886 .{ }^{965}$ His attraction to coin collecting may have been encouraged by the scholarship of the acclaimed late-nineteenth numismatic expert at Oxford, Percy Gardner, who compiled the first catalogues of the Greek coins in the British Museum and wrote an important article relating images on Greek coins to monumental Greek sculpture. ${ }^{966}$ In 1906 Warren commissioned a catalogue of his Greek coins from Kurt Regling, a German specialist in ancient coins. ${ }^{967}$

Matthew Stewart Pritchard, one of the most prominent Lewes House associates, was instrumental not only in acquiring Greek coins from leading collections but also in persuading the MFA to purchase them. In 1904, with advocacy from Isabella Stewart

\footnotetext{
${ }^{964}$ For Marshall's interest in coins, see Burdett and Goddard 137. Warren concentrated on Greek coins but acquired other types. In 1920 he gave more than 75 coins to Bowdoin: a mixture of Greek, Roman, Bactrian, Carthaginian and Byzantine, as well as English and French, currencies. For the coins at Bowdoin, Herbert 1964, 139-76. Most Greek coins in the RISD Museum came from Henry Augustus Green in 1940. The provenance of the coins at RISD is not always clear. However, Warren gave a gold aureus of Lucius Verus (RISD 14.024) to RISD. See Museum of Art 2008, 80.

${ }^{965}$ Burdett and Goddard 61.

${ }^{966}$ Gardner's Numismatic Commentary on Pausanias (1887), co-authored with German scholar Friedrich Imhoof-Blumer (1838-1920), discussed coins as they can employed in understanding Pausanias' Guide to Greece. Gardner called numismatics "the Grammar of Greek Art" and devoted a chapter to coins in his influential textbook on Greek art. Gardner 1926, 324-34. For an overview of the "scientific" scholarship in Greek numismatics in the late nineteenth century beginning with Percy Gardner, see the introduction to Gardner's Archaeology and the Types of Greek Coins (originally published in 1883), Thompson 1965, iiixii.

${ }^{967}$ For Warren's catalogue of Greek coins, see Regling 1906. Very few copies of this catalogue have survived; the catalogue in Bowdoin's George J. Mitchell Department of Special Collections \& Archives is unquestionably a gift from Warren. For an acknowledgement of the catalogue, see Brett in Museum of Fine Arts 1955, xiii. For a contemporary review of the catalogue, Wroth 1907. Regling also wrote a catalogue for a Berlin collection of Greek coins, Die antike Münzen als Kunstwerk (1924) and was among the first scholars to use die linking to organize coinage. Carradice and Price 1988, 13. For Regling in the history of numismatic scholarship, see Elkins 2009, 37.
} 
Gardner, Pritchard induced the MFA to purchase over one thousand Greek coins that he and Warren had obtained from William Greenwell, a famous English collector. ${ }^{968}$ Eventually, almost 2,000 Greek coins entered the MFA from Warren, but a formal catalogue of the Museum's collection was not published until 1955, although earlier MFA collection handbooks and publications devoted considerable attention to these coins. ${ }^{969}$ In 1913, Arthur Fairbanks, the MFA Director (1907-1925), wrote a handbook on Greek gods and heroes in the collection, with coins featured as illustrations. ${ }^{970}$ Cornelius C. Vermeule, MFA Curator of Classical Art (1957-1996), was an avid numismatist and published two studies on Greek and Roman religion using the MFA coin collection. ${ }^{971}$ This dissertation cannot address how the numerous coins that Warren sent to the MFA figure in numismatic scholarship; nevertheless, it highlights ways in which the MFA and collegiate museums have integrated them into exhibitions and collection handbooks.

Warren also presented Greek coins to Bowdoin and RISD. In fact, his first gift to Bowdoin in 1895 was a silver tetradrachm from Syracuse (BCMA 1895.1), dated to 317-

\footnotetext{
${ }^{968}$ William Greenwell (1820-1918), a canon of Durham Cathedral, was a well-known amateur archaeologist and collector. At a luncheon at her mansion on the Fenway, Isabella Stewart Gardner convinced key MFA trustees to purchase the Greenwell coins. Whitehall, 188-89; Sox 1991, 183. ${ }^{969}$ In 1902 the MFA produced an "appreciative survey of the coins" of over 500 coins purchased from Warren through the Catherine Paige Perkins Fund. Agnes Baldwin Brett, Honorary Curator of Classical Coins, published the current catalogue, in which she acknowledged Warren's role in establishing the collections. Museum of Fine Arts and Brett, 1955, xiii. The Brett catalogue was reprinted and updated in 1974. For Agnes Baldwin Brett (1876-1955), one of the first women to study at the American School of Classical Studies in Athens (1901-02), see Gray 2005. "Agnes Baldwin Brett: A Pioneer Numismatist and Archaeologist at the ANS." http://ansmagazine.com/Summer05/Brett (3 May 2011). The 1906 and 1914 MFA handbooks devote six pages to coins with illustrations of thirty-one coins. See A Handbook of the Museum of Fine Arts, Boston 1906, 66-72, and A Handbook of the Museum of Fine Arts Boston 1914, 1228 .

${ }^{970}$ The book was revised in 1922, 1927, and 1948. Chase 1948. For Arthur Fairbanks (1864-1944), see the AJA obituary, Luce and Field 1944.

${ }^{971}$ Vermeule 1983; Vermeule 1987a.
} 
310. The silver "owls" of Athens - "the most prolific, influential, and lasting coinages of the ancient world"- - served as gifts included in Warren's "sendings." "972 Usually in the form of a tetradrachm made from the rich silver mines at Laurion, these ubiquitous coins display the profile of the helmeted Athena on the obverse and her attributes, the owl and an olive sprig, on the reverse. ${ }^{973}$ The silver "owls" given to Bowdoin (BCMA 1920.8.55) and RISD (RISD 13.1493) show a small crescent moon at the back of the bird, sometimes interpreted as an allusion to the victory at Salamis that took place in the moon's last quarter (Figure 103). ${ }^{974}$ Warren's “owls” appeared in catalogues for both collegiate museums as illustrations of how coins functioned as propaganda for Athenian political and economic dominance. ${ }^{975}$ Bowdoin's collection of coins came from a number of donors, with Warren giving numismatic samplings—mostly Greek coins but also Roman, Byzantine, and early European — over three decades. ${ }^{976}$ In Ancient Art in Bowdoin College (1964), Herbert published eighty assorted coins from Warren. ${ }^{977}$

Greek coins with equestrian imagery which Warren conveyed to the MFA received attention in the 2004 MFA exhibition, "Games for the Gods," and in the 1980-

\footnotetext{
${ }^{972}$ Kraay 1956, 43. For the classification of Athenian coins, Starr 1970.

${ }^{973}$ These features persisted in the city's coinage for well over two centuries.

974 The moon also could be an added symbol for the nocturnal owl. Jenkins 1972, 81-2.

${ }^{975}$ BCMA 1920.8.55 is dated c. 514-407, Higginbotham and Westley 2005, 83-4; and RISD 13.1493 is dated c. 460-4340, Museum of Art, 80.

${ }_{976}$ Bowdoin's coins came from several patrons: Warren's relative, George Warren Hammond, included coins among his gifts; 130 entered from Henry Johnson, the director of the Museum and art history professor, as gifts and through purchase; the prominent collector, John Max Wulfing (1895-1929) donated fifty Roman coins in 1926. For Wulfing, the bulk of whose numismatic collection went to Washington University, St. Louis, see Herbert 1996.

${ }^{977}$ Herbert 1964, 144-61. Herbert included five Roman, twenty Byzantine, and five early European coins Warren donated. The BCMA curatorial records indicate that over 75 coins came from Warren in 1920, alone.
} 
82 touring exhibition, "The Search of Alexander." 978 Horse racing was particularly popular on the coins minted by Phillip II of Macedon, who won equestrian competitions at the Olympic Games in 356. ${ }^{979}$ Thus, "Games for the Gods" employed Warren's gold stater (MFA 00.164) to illustrate the Greek love for equestrian competition (Figure 104). The reverse of the coin shows a biga, a two-horse chariot, a reference to Phillip's victory. A thunderbolt under the horse's front legs may have served double duty: as an attribute of Zeus, it linked Phillip to the god honored at Olympia, and it also functioned as a symbol of the mint. ${ }^{980}$ Beneath the ground line in the "exergue," as the lower part of the coin is called, is the inscription "of Philip." The laurel crowned head of Apollo on the obverse refers to Phillip's claim to Pan-Hellenic leadership. ${ }^{981}$ Phillip's exploitation of the mines at Amphipolis permitted the minting of gold coins such as this one to pay mercenaries and to promote his image. ${ }^{982}$ Another Warren coin minted at Pella under Philip II, featured in "The Search for Alexander," also testifies to his self-promotion. This silver tetradrachm (MFA 00.166), which Warren sold to the MFA in 1900, shows on the reverse a laurel-crowned Zeus alluding both to the statue of the god at Olympia and to the Phillip's benefactions at the sanctuary (Figure 105). ${ }^{983}$ On the obverse, a jockey on

\footnotetext{
978 At least 100 of the 161 antiquities featured in the exhibition catalogue for "Games of the Gods" entered the MFA from Warren. See Herrmann and Kondoleon 2004.

979 Arnold-Biucchi 2006, 31.

${ }^{980}$ Price 1979.

${ }^{981}$ Howgego 1995, 65-66. Phillip II fought on behalf of the Amphictionic League whose center was Delphi, the most important sanctuary of Apollo. Arnold-Biucchi 31. The Greeks used "stater" to refer both to the weight and the coin and refers to the heaviest denomination. Arnold-Biucchi 19. The sequence and chronology of the coins minted under Phillip II are complicated. See Price 1979.

${ }^{982}$ Howgego 48. Phillip took over the gold mines at Krenides, renaming it "Philippi" in 357 BCE. ArnoldBiucchi 29. The first-century Greek historian, Diodorus Siculus, is the source for much of this information. For Philip's use of coins as propaganda, see also Carradice and Price , 104-07.

${ }^{983}$ For example, Phillip commissioned the Phillipeion c. 339, the circular building in the northwest corner of the sanctuary which displayed statues of Phillip and Alexander and their family.
} 
horseback with a palm, the thunderbolt of Zeus beneath the horse, and the inscription "of Phillip" refer to the king's victory in equestrian competition at Olympia. ${ }^{984}$

Warren also sent examples of the beautiful coinage produced in fifth and fourthcentury Sicily to American collections. Especially striking are those produced in Syracuse, where its rulers minted vast quantities of silver coins, typically with variations of four-horse chariots on the obverse and heads of the Arethusa, the sea goddess, framed by dolphins on the reverse. ${ }^{985}$ Warren presented several Sicilian coins to Bowdoin: in addition to a fourth-century tetradrachm (BCMA1895.1), his first gift to the College, he gave a fifth-century Syracusan decadrachm (BCMA 1914.6.1), which was featured in the catalogue for "Ars Antiqua" (Figure 106). ${ }^{986}$ A variation from the same mint (MFA 04.556) in the MFA shows a profile of Arethusa (Figure 107). ${ }^{987}$ The dolphins are attributes of Arethusa and, in a broad sense, of Syracuse itself. ${ }^{988}$ On the obverse, Nike flies with the wreath of victory. Beneath the horses' hooves is a loose chariot wheel, hinting at the dangers of the contest and perhaps to the treachery of Pelops in his victory over King Oinomaos. ${ }^{989}$ Like so many Warren antiquities, this coin sports a distinguished British ownership pedigree: originally in the collection of Edward H. Bunbury, an

\footnotetext{
${ }^{984}$ Yalouris, Andronikos, Rhomiopoulou, Herrmann and Vermeule 107.

${ }^{985}$ Often these coins are signed by the artists: for example, Sosion and Eumenes c. 425 BCE; Eukleidas and Euainetos c. 415 BCE; Phrygillos and Kimon c.410 BCE. For a survey of the coins of Syracuse, see Jenkins 1972, 145-182.

${ }^{986}$ Decadrachm of Syracuse (1914.6.1) c. 412-405 BCE, reverse and obverse, Higginbotham and Westley 82-3; The recent handbook to the MFA classical art spotlights another of Warren's silver decadrachm from Syracuse (MFA 03.946) - this one signed by Euainetos. A Kondoleon, Grossmann and Ledig 122. ${ }_{987}$ Sayles 2007, 243.

${ }^{988}$ Sayles 249.

${ }^{989}$ Herrmann and Kondoleon 119 and 182. Pelops sabotaged the chariot of Oinomaos to win the king's daughter Hippodameia; thus, the wheel may be a reminder that treachery brings retribution.
} 
authority on ancient geography, it passed to Canon Greenwell, a noted antiquarian with a “predilection” for Sicilian coins, from whom Warren purchased it. ${ }^{990}$

Coins and gems continued to be collecting interests for Warren, and he made efforts in "the last eight years of his life in finding the perfect homes for [these] treasured antiquities. ${ }^{991}$ Except for a few coins and gems that entered RISD, most of Warren's personal collections were sold and given to the MFA, with the remaining donated to Bowdoin.

\section{Gems}

According to Boardman, Warren took "especial pleasure" in collecting ancient gemstones, an enthusiasm he shared with his friend, John Beazley. ${ }^{992}$ Beginning in the Sumerian period, c. 5000, craftsmen engraved figures, designs, and sometimes inscriptions into the surface of semiprecious stones to produce an impression in wax or clay. In the ancient Near East, Egypt, and Aegean, these so called "intaglios" were often in the form of cylindrical beads that could be worn as pins, necklaces, or wristlets. After the sixth century, Greeks, Romans, and Etruscans wore the intaglios and cameos in rings. When set into precious metal, such gems or "finger rings" became more a matter of fashion than of business among the elite. ${ }^{993}$ In the third century, artisans began producing cameos, a type of relief cut into stones with banded layers of color, thereby creating

\footnotetext{
${ }^{990}$ Wroth 154. For Edward H. Bunbury (1811-1895), see “Obituary: Sir Edward H. Bunbury, Bart 1895."

991 Vermeule 2002, 3.

992 Boardman 1999, 217.

993 Boardman 2001a, 13-18. For stones and techniques used, see Boardman 2001a, 374-82; "Carvers and Collectors: The Lasting Allure of Ancient Gems." The J. Paul Getty Museum. 2009. http://www.getty.edu/art/exhibitions/gems/ (18 May 2011).
} 
white figures against a colored background. Since glyptic images are difficult to examine or photograph, they traditionally are studied through impressions.

Beazley, as was pointed out previously, catalogued Warren's gems in 1920 in The Lewes House Collection of Ancient Gems. ${ }^{994}$ Warren's interest in gems may have been encouraged in Oxford, where Nevil Story Maskelyne (1823 - 1911) had amassed a notable gem collection as well as an impressive assemblage of casts from gems in private and public collections. ${ }^{995}$ Beazley made extensive use of these impressions, which entered the Oxford Cast Gallery; Warren may have had access to them on his frequent visits to Oxford. In Warren's time gems, like vases and sculpture, were believed to have reached their zenith in Greece. Thus, in a Bulletin of the Museum of Fine Arts article highlighting twenty-six of the Lewes House gems in the MFA collection, Museum Director, L. D. Caskey, proclaimed that gems trace "the whole history of Greek art." The imprints they produce should be considered "miniature reliefs . . . with the perfection of their workmanship" warranting their inclusion "as a branch of sculpture rather as one of the minor arts." 996 Caskey also emphasized that gems figured prominently in

\footnotetext{
${ }^{994}$ Only 300 of the 400 printed copies of the 1920 catalogue were sold; it was republished with updated references and enlarged photographs of impressions in 2002. Boardman and Beazley 2002, 1.

995 Boardman 1999, 218. Story Maskelyn, a Professor of Mineralogy, catalogued the Marlborough gems in 1870. For Story Maskelyne, Morton 1987.

${ }^{996}$ Caskey 1928, 46. These sentiments echo Winckelmann's view that"the stages of art are found to a much greater extent in a collection of engraved gems than can be discerned in the larger monuments that are left to us." As quoted in Lapatin 2010. "Art History Carved in Agate."

http://entertainment.timesonline.co.uk/tol/arts_and_entertainment/the_tls/article7151086.ece (16 June 2010) (accessed 21 May 2011).
} 
connoisseurial tradition, first in the late Republic and then from the Renaissance and eighteenth-century up to the present. ${ }^{997}$

Most of Warren's glyptic antiquities went to the MFA, but others were sent to Bowdoin and RISD. Herbert's 1964 Bowdoin catalogue describes thirty-one assorted Warren gems, most of them arriving in $1915 .{ }^{998}$ The oldest gem stone in the Bowdoin collection came as a bequest after Warren's death, a carnelian bead with the intaglio of a charging stag (BCMA 1930.209) that Boardman identified in 1961 as Middle Minoan III (c. 1600). ${ }^{999}$ Warren also gave Roman cameos to Bowdoin: a miniature portrait of a Roman couple (BCMA 1914.10) dated to the first century has appeared in two Bowdoin catalogues (Figure 108). ${ }^{1000}$ The tiny busts of the man and woman carved from layered chalcedony blend the naturalism of the late Republican aesthetic with the taste for Greek idealism and offer testimony to the power of such gems in showing "the importance of portraiture in the private sphere."

Hackens' 1976 RISD catalogue listed only twelve ancient gems in the collegiate collection at Providence, nine of which are credited as "Museum appropriation and

\footnotetext{
${ }^{997}$ By implication, then, Warren was in the ranks of Pompey, Julius Caesar, Lorenzo de Medici, and the Dukes of Devonshire and Marlborough.

${ }^{998}$ Herbert 1964 131-35. A cross-check with the BCMA database printout (10 October 2008) confirms this number. Herbert dismisses Stanley Casson's 1934 sixteen-page catalogue as "a booklet" discussing the gems "only summarily." Herbert 1964, 10. He also explained that six gems on the Casson list could not be found.

${ }^{999}$ Herbert explained that in 1961 he sought assistance from Boardman in identifying and dating this gem, which Casson had labeled Archaic Greek, thirty years earlier. Herbert 1964, 131.

${ }^{1000}$ Herbert 1964, 134; Higginbotham and Westley 75. Warren also gave Bowdoin a fragment of another Roman cameo (BCMA 1915), dated to the late second century CE, which Casson thought to be a portrait of Antoninus Pius but Herbert identified as a head of Commodus. Herbert 1964, 135.

${ }^{1001}$ Higginbotham and Westley 75. The cameo was likely a wedding memento. Warren bought a white and brown sardonyx cameo gem stone from the Tyszkiewicz Collection with frontally-facing busts of a JulioClaudian couple, side by side (MFA 98.754). According to the MFA Collections database, the couple might be Nero and Octavia, Claudius and Messalina, or Caligula and Drusilla. Museum of Fine Arts "MFA Collections. http://www.mfa.org " (accessed 1 June 2011).
} 
special gifts" or "Gift of Mrs. Gustav Radeke." 1002 However, given their accession dates, all nine could have come from Warren. In fact, the 1925 Beazley Descriptions in the RISD Archives proves that at least five gems came from Warren. ${ }^{1003}$ All have an annotation on the list - usually "bought" or "found" with a place name of the provenance for each object. This group includes an oval chalcedony Greek seal stone (RISD 25.097), with a deer suckling Telephos, "Bought in Athens" and dated to the fifth century; an oval scaraboid seal stone (RISD 25.098) now dated to the Archaic period, depicting Odysseus being carried by the ram, "Bought from Marseilles" and "Found near Tarentum"; an amber-red sard intaglio (RISD 25.099) with a profile of a bearded man, "Epicurus," "Bought in Athens," dated to mid-first century B.C.E.; and what may be a Late Helladic II or Late Minoan serpentine seal stone (RISD 25.096), "with a man tossed by a bull," "Bought in Athens."1004 The fifth gem on the 1925 Beazley list and in Hackens' 1976 RISD catalogue is a gem (RISD 25.094), attributed to Dioskourides, one of the distinguished artisans of the Augustan Age. ${ }^{1005}$

\footnotetext{
${ }^{1002}$ Hackens 1976. Research shows that information about previous ownership was provenance apparently not recorded in the RISD curatorial files. As a rule, the Hackens catalogue only documents the donor or source of funding.

${ }^{1003}$ It is not clear whether Hackens knew about or used the 1922 Warren List or the 1925 Beazley Descriptions. Both documents are typed, but it is not clear if they are typewritten copies or lists that arrived in this form from Warren and Beazley. Typically, Warren's correspondence was handwritten, usually by one of his assistants at Lewes House or Fewacres.

${ }^{1004}$ Hackens indicated that the editors of the Corpus of Minoan and Mycenaean Gems determined that the last object showing a male figure vaunting a bull (25.097) was a modern copy. Hackens 1976, 144. Also, on the 1925 Beazley List is a Mycenaean stone ring, "Bought in Athens" with the handwritten accession number 25.095. However, the ring is not in the Hackens catalogue. The Curator of Ancient Art suggests that doubts about the ring's authenticity may account for its exclusion.Gina Borromeo, 25 July 2011, e-mail to author.

${ }^{1005}$ In the MFA, the signature of Dioskourides is on a fragmented sard with Bellerophon mastering Pegasus (MFA 27.737). Two unsigned MFA gems are assigned to the engraver: a sard intaglio with the head of Io (MFA 21.1261) and a sard cameo with a satyr pulling a boy toward him (MFA 21.1220).
} 
This Roman intaglio (RISD 25.094) shows a winged victory and the signature of the engraver-Dioskourides—inscribed prominently on its surface (Figure 109). The 1925 Beazley List describes the gem as "Rock crystal. Signature of Dioskourides. Found at Kertesh." ${ }^{1006}$ Mounted in a modern ring, the gem shows Victory with a jug in her raised right hand and a patera in her left. Dioskourides, a Greek artisan from Asia Minor, is considered one of the master artists of the Early Empire. ${ }^{1007}$ Called "a major glory of the Providence collection," this intaglio is one of only eleven signed gems by Dioskourides. ${ }^{1008}$ The fame of Dioskourides prompted later carvers to copy his works and forge his signature. ${ }^{1009}$ The depiction of Victory parallels those in the contemporary stucco panels of the Villa Farnesina, Rome. ${ }^{1010}$ According to the 1976 catalogue, the goddess' clinging drapery, details in the feathers of her wings, and "especially the threequarters view of the face, are clear signs of a distinguished master of engraving in a period with true feeling for classical taste." 1011

Caskey touted the 197 ancient gems Warren conveyed to the MFA as his "crowning achievement," the "famous collection, now for the first time shown in its entirety" in "its permanent home."1012 Among the Warren gems are those with

\footnotetext{
${ }^{1006}$ Hackens states "Said to come from Kertesch." This gem is an anomaly in the RISD catalogue because it is the only Warren gem stone with such information, obviously taken from the 1925 Warren List.

${ }^{1007}$ Dioskourides was a Greek artist, but his "work can be understood within the framework of Roman art." Reputed to have been the carver of the personal seal of Augustus, he is mentioned in Pliny, Suetonius, and Dio Cassius. Plantzos 1999, 96.

${ }^{1008}$ Hackens 1976, 129

1009 "Carvers and Collectors: The Lasting Allure of Ancient Gems." (accessed 21 May 2011).

${ }^{1010}$ The Villa Farnesina is believed to have been the property of Marcus V. Agrippa and Augustus' daughter, Julia.

${ }_{1011}$ Hackens 1976, 150-51.

1012 Caskey , 46- 47. Caskey's article, "The Warren Collection of Engraved Gems," is confined to twentysix of the most important gems, illustrated via enlarged photographs of plaster imprints. The total number
} 
distinguished histories of ownership. One celebrated accession is the cameo with the wedding of Cupid and Psyche (MFA 99.101), signed in Greek by Tryphon and dated to the Late Republic or Early Empire, which Warren purchased in an 1899 sale of the Marlborough Gems in London (Figure 110). ${ }^{1013}$ At this liquidation of the most important collection of engraved gems ever formed in England, Warren vied with the British Museum, the Victoria and Albert Museum, and another important Gilded Age collector, Henry Walters. ${ }^{1014}$ The iconography is enigmatic: the gem shows five winged figures on a groundline. Slightly to the right of center, an Eros clasps a burning torch against his left shoulder and pulls a cord that binds a veiled couple. At the far left, another Eros holds a tray of fruit above the couple's heads while, on the right, a third removes a cloth from a stool. The signature of the gem carver is visible above the flames of the torch. Tradition identifies the couple as Cupid and Psyche at their wedding; however, the recent MFA handbook postulates that the iconography may blend the imagery of the cult of Dionysos with that of Roman marriage ritual. ${ }^{1015}$ Boardman observes that the cameo is "something of a mystery still." ${ }^{, 1016}$

The cameo, composed of two layers of onyx with the tiny white figures in relief against a black background, was "the prize piece" of the Marlborough Collection and

of "gems" from Warren in the MFA is difficult to determine via the database on the MFA website because they are sometimes classified as "seals" and sometimes as "jewelry."

1013 The inscription is "TRYPHON EPOIEI."

${ }^{1014}$ Although Walters did not acquire the famous, Cupid and Psyche cameo, he purchased the largest number of gems (107), most now in the Walters Art Gallery. For the Marlborough gems in the Walters and the history of the Marlborough collection, Scarisbrick 1981. Most of the buyers were dealers, often working for specific clients. Boardman 2009a, 19.

${ }^{1015}$ Kondoleon, Grossmann and Ledig 91.

1016 Boardman 2008. "The Marlborough Gems." http://www.beazley.ox.ac.uk/archive/lectures/boardman.htm (accessed 22 May 2011). 
"certainly the one most talked about and copied."1017 The Renaissance artist and antiquarian Pirro Ligorio (1514-83) drew the gemstone. Peter Paul Rubens, himself a collector, gave it to his friend Thomas Howard, the fourteenth Earl of Arundel, from whom it passed into the collection of the Duke of Marlborough at Blenheim. ${ }^{1018}$ The gem influenced the work of the painter Johann Zoffany (1733-1810) and the potter Josiah Wedgwood (1730-1795). ${ }^{1019}$ As might be expected, a photo of Tryphon's cameo and a description of it appeared in both the 1906 and 1914 editions of the Museum's handbook, as well as in the recent guide to the MFA's classical collection. ${ }^{1020}$ It has an extensive bibliography, especially since it was frequently copied via drawings beginning in the seventeenth century. ${ }^{1021}$

Warren's gemstones at the MFA have also proven to be important in the study of Roman portraiture. Another gem from the Marlborough Collection is the turquoise cameo with a bust of Livia (99.109), dated to the first century C.E. (Figure 111). ${ }^{1022}$ With one shoulder bare and wearing a laurel crown, Livia is depicted as Venus Genetrix. In fact, an essay in the "I Claudia" exhibition catalogue asserts that Warren's cameo is the earliest surviving image of an empress as a goddess. ${ }^{1023}$ Livia looks down at either a bust or the head of a full statue of a male, but the identification of the male head is not certain because the cameo is cracked and the lower half missing. Although the MFA

\footnotetext{
1017 Boardman "The Marlborough Gems." (accessed 22 May 2011).

1018 Neverov 1979, 428.

${ }^{1019}$ For the ownership of 99.101, see MFA website collection database, Museum of Fine Arts "MFA Collections. http://www.mfa.org " (accessed 30 July 2010). In the early MFA handbooks, two pages are devoted to groups of engraved gems with this cameo given its own page. See MFA (1916), 90, $115,116$.

${ }^{1020}$ Kondoleon, Grossmann and Ledig 91.

1021 Jaffé 1993, 104; Boardman 2009a, 30-5.

${ }^{1022}$ For the history of ownership of 99.109, see the MFA website collection database, Museum of Fine Arts "MFA Collections. http://www.mfa.org " (accessed 20 May 2011).

${ }^{1023}$ Matheson 1996, 184.
} 
identifies the busts as Livia and Augustus, scholars disagree as to whether the laurel-

crowned head is the deified Augustus or one of Livia's sons, Tiberius or Drusus I. ${ }^{1024}$ The iconography provides evidence for the importance of the bond between Roman mothers and sons, but an accurate interpretation of its significance depends on whether a man or a woman-Tiberius or Livia, perhaps—commissioned it. ${ }^{1025}$ In a study of Livia's numerous portraits, Bartman identifies the scene as Livia gazing at a bust of Drusus, her deceased son. ${ }^{1026}$

A much published Lewes House sard intaglio (MFA 27.733), entered the MFA collection the year before Warren's death (Figure 112). ${ }^{1027}$ Like many Roman gems, it is inscribed in Greek " Popilius Albanus," who is identified as the owner." ${ }^{1028}$ Augustus is depicted in the guise of Neptune in a quadriga pulled by seahorses, with Triton and a dolphin as his escorts. Based on coins of the same period, Beazley dated the gem c. 30 B.C.E., connecting it to the Battle of Actium the year before:

The short hair and beardless face of the driver, perhaps also his youthful body, show that he is not Poseidon. The features are portrait-like and therefore mortal. At the period to which belongs, no one but Augustus could have figured as

\footnotetext{
${ }^{1024}$ For Livia with a laurel crown, see Flory 1995, 48.

1025 Kleiner 2000, 47-8. In her survey of Roman sculpture, Kleiner holds that cameos had a "limited audience" and were intended as "as state or family presentation pieces." Kleiner 1992, 77.

${ }^{1026}$ Bartman 1999

1027 The gem appeared in Reinach's Apollo, one of the first illustrated art history textbooks (1904, 1907, 1917, 1935). Only two antiquities from collections in the United States are discussed and illustrated; both are from the MFA via Warren. The other was the bronze Minerva statuette (MFA 87.7), identified as "Athene Promachos." Reinach 52, 81.

${ }^{1028}$ For the ownership history of MFA 27.733, see the MFA website collection database, Museum of Fine Arts "MFA Collections. http://www.mfa.org " (accessed 20 May 2011). Like many of Warren's best known acquisitions, it was bought from the sale of the Count Michel Tyszkiewicz collection. For the inscription, Caskey $1928,50$.
} 
Poseidon: and the features, in fact, bear an unmistakable (sic) resemblance to those of Augustus. ${ }^{1029}$

As with the famous Cupid-Psyche cameo, other Lewes House gems in the MFA are signed. For example, a Greek steatite scarab with an ithyphallic satyr tuning his lyre (MFA 27.673) is signed by Onesimos, a glyptic artist who Beazley identified in the 1920 catalogue based on the "very hastily written" inscription. ${ }^{1030}$ Boardman later classified the gem (Figure 113) as an "island scarab," dated to the late Archaic period and postulated that the green translucent stone most likely came from Melos. The MFA gem is one of three gems signed by Onesimos. Dubbing it the engraver's "best—almost the best of all Archaic gems," Boardman described the satyr as "head thrown back to catch the tone, his shaggy body and tail bristling with attention which he will divide only between music and love.",1031

In compiling the catalogue for Warren's collection and attributing unsigned gems to masters and schools, Beazley employed the same approach he used for vases. However, by and large, ancient gems have not received as much attention in scholarship and exhibitions as Greek vases, and gems and jewelry are often grouped in one

\footnotetext{
${ }^{1029}$ Boardman and Beazley 2002, 67. Sources on the art and culture of the Early Empire frequently discuss this gem. See, for example, Zanker 1988, 97-98, 374. A recent catalogue of Hellenistic gems points out that the head of defeated enemy can be detected under the feet of the horses, a portrayal of victory in "the Greek-Hellenistic way." Plantzos 96. For the bibliography on MFA 27.333, Boardman and Beazley 2002, $67,119$.

${ }^{1030}$ Boardman and Beazley 2002, 23-24. Beazley corrected Furtwängler's 1900 reading of the signature as "Onesilos" and dated Onesimos to the last quarter of the sixth century BCE on the basis of stylistic kinship to another engraver of Greek gems, Syries. Other gems have since been attributed to Onesimos.

${ }^{1031}$ Boardman 2001b, 147. He also lists two scarabs signed by Onesimos, now in Paris. Boardman 2001b, 184. See also "Later Archaic Greek Gems: Island Scarabs." http://www.beazley.ox.ac.uk/gems/ (accessed 23 May 2011).
} 
category. ${ }^{1032}$ Nevertheless, recent scholarship and exhibitions suggest a fresh interest in gem collectors and the impact of gems on modern artists. For example, a symposium "Engraved Gems: Survivals and Revivals" at Washington's National Gallery of Art in 1994 attracted scholars from Canada, Germany, Great Britain, Italy, and Russia, as well as the United States. ${ }^{1033}$ The 2009 "Carvers and Collectors: The Lasting Allure of Ancient Gems" at the Getty Villa ranked Warren as among the eight "most avid and influential" collectors of gems from the fifteenth through the twentieth century-the sole American to be designated as such. ${ }^{1034}$ This exhibition highlighted five of Warren's treasures from the Lewes House Collection. In addition to the Cupid and Psyche cameo, these gems included a Greek chalcedony intaglio of nude young man grasping the bridle of a horse (MFA27.677), dated to c. 500 and signed by the engraver Epimenes. ${ }^{1035}$ Beazley thoroughly discussed this gemstone (Figure 114) which Warren obtained from Count Tyszkiewicz, carefully analyzing its inscription and making numerous parallels with Greek art in other media, particularly Attic vases. ${ }^{1036}$ Another (MFA 27.734) is a striking Roman convex garnet, dated to 100 B.C.E and now set in a gold ring (Figure

\footnotetext{
${ }^{1032}$ See, for example, at Bowdoin, "Engraved Gems and Jewelry," in Herbert 1964, 128-38, and at RISD where gems are included in the jewelry catalogue, Hackens 1976. The Roman ring (BCMA 1923.115) with a cameo is discussed below.

${ }^{1033}$ Brown 1977. Although none of Warren's gems was the focus of any of the papers, one essay touches on contemporaries of Peter Paul Rubens who once owned the Cupid and Psyche cameo in the Lewes House Collection. Rubens and gem collectors in his circle were interested in acquiring and creating "ithyphallic gems." Such a fascination seems akin to Warren's, as evident in the "Erotica" that he gave to the MFA, chiefly in 1908. Jaffé 1997, 184-91.

1034 "Carvers and Collectors: The Lasting Allure of Ancient Gems." Warren is labeled as "British" even though his birth place was Massachusetts. http://www.getty.edu/art/exhibitions/gems/collectors.html (accessed 7/10/12).

${ }^{1035}$ For the bibliography, Boardman and Beazley 2002, 106. Beazley assigned another Lewes House gemstone from Tyszkiewicz (MFA 21.1194,)"probably" to Epimenes. Its image is a naked youth, who kneels as he draws a bow. Boardman and Beazley 2002, 25.

${ }^{1036}$ Boardman and Beazley 2002, 25-7. Tyszkiewicz said that it came from the Egyptian Delta, probably Naucratis, the site of a Greek emporium.
} 
115). Once owned by famous eighteenth- and nineteenth- century British collectors, the intaglio is the shaggy head of Sirius, the dog star, with the artist's signature in Greek, "Gaios epoiei," inscribed on its collar. ${ }^{1037}$ Research connected with the Getty exhibition yielded information about the previously discussed RISD 25.094, with the signature of "Dioskourides." Not only is it "more likely chalcedony than rock crystal," reservations were raised about its authenticity. ${ }^{1038}$ A text panel for the "Carvers and Collectors" exhibition pointed out discrepancies in RISD's gift from Warren. First of all, the signature deviates from those on ancient gems. Moreover, on a genuine intaglio Nike would pour with her left hand because in an impression the image is reversed. Finally, the drapery on the RISD gem suggests that it may have been copied from Roman reliefs by a late-eighteenth-century carver. ${ }^{1039}$ For these reasons, the Getty exhibition judged RISD's intaglio "problematic," a description that has been applied to another well-known Warren antiquity, the "Boston Throne," to be discussed in Chapter 6.

\section{Objects in Silver, Electrum, and Gold}

In comparison to coins and gems, Warren conveyed far fewer antiquities in silver, gold, and electrum to American collections. ${ }^{1040}$ However, two silver antiquities from

\footnotetext{
${ }^{1037}$ Its owners included the Dukes of Chesterfield, Bessborough, and Marlborough. For the catalogues and the bibliography, see Boardman and Beazley 2002, 71,120.

1038 Kenneth Lapatin, 23 May 2011, e-mail to the author.

${ }^{1039}$ For a discussion of copies and counterfeits of ancient gems, see "Emulation and Forgery" in http://www.getty.edu/art/exhibitions/gems/collectors.html (accessed 7/10/12).

${ }^{1040}$ The Warren Cup in the British Museum is the collector's most famous possession and one of the best known surviving luxury objects of the Greco-Roman world. Made of nearly pure silver, the vessel is composed of a thin-walled outer bowl decorated with repoussé figural scenes and a thicker inner liner with a solid lip. The inner cup has the dual function of facilitating the cleaning of the vessel and strengthening the fragile outer cup. The silver has traces of copper, gold and lead. For the cup in the context of ancient silver vessels and detailed photography, Williams 2006b, 7-15.
} 
Warren do merit discussion here. ${ }^{1041}$ One is the Roman inkwell (MFA 01.8189), said to have come from Cologne, now in the MFA (Figure 116). Dated to the third century C.E., this cylindrical object held ink for writing on papyrus, a much more expensive practice than using tabulae (wax tablets). Three bands of incised lines decorate its exterior, and a wreath and a wave pattern in relief embellish its hexagonal lid. A now-lost stopper would have prevented the ink from drying out. It first received attention in the 1977 exhibition, "Silver for the Gods: 800 Years of Greek and Roman Silver" at the Toledo Museum of Art. ${ }^{1042}$ The 1996-1997 "I Claudia: Women in Ancient Rome" exhibition also featured the inkwell and suggested that it might well have been used by a literate woman like Julia Domna, the wife of the emperor Septimius Severus. ${ }^{1043}$ A second and lesser known Warren silver object is at Bowdoin, a tiny statuette identified as 'Eros" in the 1925 list of gifts from Warren (Figure 117). ${ }^{1044}$ Dated c. $200-100$, it was exhibited in the 2005 "Ars Antiqua" exhibition and labeled "Harpokrates."1045 Cast in silver, the child

\footnotetext{
${ }^{1041}$ Research has located only four other silver objects from Warren in American collections. Bowdoin has a Roman silver ladle (BCMA 1927.11) dated to the first century CE , with a curving handle ending in a dog's head. Herbert 1964, 204. Warren also acquired three small silver sculptures for the MFA which Vermeule published in a 1972 monograph: MFA 01.8187, a Greco-Roman gilded silver statuette of a standing Aphrodite, see Vermeule 1974b, 25; MFA 03.771, a Roman silver seated Mercury holding a purse, see Vermeule 1974b, 15 ; MFA 10.172, the gilded silver leg and foot of a seated statuette, see Vermeule $1974 b, 10$. Since these small antiquities have not been widely published or exhibited, they will not be discussed here.

1042 Oliver 1977, 171. "Silver for the Gods" was hosted at the Toledo Museum of Art, the Nelson-Atkins Museum of Art in Kansas City, and the Kimball Art Museum in Fort Worth, in 1977-78, featuring 118 silver antiquities from thirty American and European museums and private collections. The fact that among the 10 MFA silver objects in the exhibition only the inkwell came from Warren is testimony to how few silver antiquities he handled.

1043 Kleiner and Matheson 155.

${ }^{1044}$ Andrews 1925, 60. Herbert does not include BCMA 1915.52 in his 1964 catalogue. Identifying the statuette as "Eros" is logical because both gods are represented as chubby boys. In fact, early in his collecting on behalf of the MFA, Warren acquired a terracotta Eros dressed as Harpocrates (MFA 00.322).

${ }^{1045}$ Higginbotham and Westley 90. The statuette is less than $13 / 4$ inches tall. Although the catalogue for "Ars Antiqua" spells the name of the god as "Harpokrates," this dissertation employs "Harpocrates" used in the BCMA and MFA databases. Both designations are transliterations of the Greek version of his Egyptian name, "Horus the child."
} 
raises his right index finger to his mouth and holds a cornucopia in his left hand. Wearing a necklace and uraeus crown, he stands on a base between a four-legged animal and a staff around which a snake has wrapped itself. ${ }^{1046}$ Variations of Harpocrates appear in statuettes, amulets and jewelry and in a wide range of media. Because Warren's statuette has an attachment on its back, it could also have functioned as an amulet or pin. ${ }^{1047}$

In 1899 at a sale in London, Warren acquired a variety of jewelry in electrum, a naturally occurring alloy of silver and gold, sometimes called "white gold," with almost all of the objects going to the MFA. ${ }^{1048}$ Called "East Greek" because they were found at Kameiros on the north-eastern coast of Rhodes, they are dated c. 660-650, during the "Orientalizing" period when iconography was borrowed from the ancient Near East. 1049 Although no documentation exists about their context, the items likely came from tombs. ${ }^{1050}$ Some of the jewelry is non-figural, consisting of tiny granulated rosettes, while others, chiefly plaques thought to serve as ornaments fastened with hooks to garments,

\footnotetext{
${ }^{1046}$ The staff may once have extended upward to the left hand as in a bronze statuette of the god now in the Cleveland Museum of Art. Cooney 1972. The animal may be a dog or hyena, associated with Anubis; the snake was sacred to Isis and often appears as an attribute of Harpocrates. Other depictions show him with the cornucopia. For Harpocrates in sculpture in the context of similar gods, see Hall 1977.

${ }^{1047}$ For Harpocrates pendants, see Scheurleer 1996. For a similar silver statuette of Harpocrates found in the Thames in the late nineteenth century, see Johns 1996, 106. This version wears a gold body-chain and has a gold ring attached to its back. For other variations of Harpocrates statuettes in gold and silver, Vermeule 1974b, 20, 26-30.

${ }^{1048}$ According to the MFA Collection database, Warren bought the electrum jewelry at the Foreman Sale in London in 1899. Museum of Fine Arts "MFA Collections. http://www.mfa.org " (accessed 30 May 2011). Warren also gave Bowdoin an electrum diadem (BCMA 1923.1) which Herbert described as badly fragmented and labeled as Greek, c. eight century. Herbert 1964, 135-36.

${ }^{1049}$ Warren's electrum jewelry has appeared in several MFA handbooks and catalogue. Chase 1950, 25-6; Kondoleon, Grossmann and Ledig 2008, 158. All of Warren's electrum pieces at the MFA were included in a comprehensive study of jewelry from workshops on Rhodes and other islands. See Laffineur 1978. The MFA contains almost all the jewelry of this type in American collections. The Metropolitan Museum of Art has an earring and rosette of this type from Rhodes, both of which likely entered through John Marshall given their accession dates in 1906 and 1912. The Bowdoin diadem (BCMA 1923.1) is not listed in the Laffineur catalogue. According to Laffineur, the largest holdings of jewelry from Rhodes are in the British, Victoria and Albert, and Ashmolean Museums.

${ }^{1050}$ Higgins 1980, 115.
} 
are embossed with humans and hybrid-creatures. ${ }^{1051}$ After pressing sheets into molds or hammered on a relief core to create the repoussé figures, craftsmen added decorative detail with stamps or puncheons. Six plaques show a centaur in composite view with his head facing frontally, raising his right hand to his chest and grasping a small animal, most likely a fawn, in his left. The triangular face and wig-like hair are characteristics of the so called "Daedalic style," popular in the seventh century. ${ }^{1052}$ A pair of Warren's centaur plaques (MFA 99.386 and 99.388) were featured in “The Centaur's Smile" exhibition in 2003, where they were interpreted as "a demonstration of authority over the natural world related to the image of the Potnia Theron" or the "Mistress of the Animals" (Figure 118). ${ }^{1053}$ This motif — a winged Artemis holding lions at each side — appears on another group of electrum ornaments Warren sent to the MFA. ${ }^{1054}$ Still other plaques, like MFA 99.397, show an unusual variation on this theme: a winged female figure with the lower half of her body in the form of a bee (Figure 118). ${ }^{1055}$ This mysterious creature, called "bee-woman" or Melissa (from the Greek word for honey bee), appears to have originated on Rhodes. Although her identity and significance are not completely understood, scholars consider this composite female akin to Artemis. The "bee-woman"

\footnotetext{
${ }^{1051}$ The limitations inherent in this dissertation prevent discuss of an electrum earring with griffin heads (MFA 99.378) and various rosettes and diadems (MFA 99.404-.435). Warren bought these objects at the same sale in 1899.

${ }^{1052}$ The six plaques with centaurs are MFA 99.385-.390. For these pectoral ornaments and iconography, Higgins 1980, 115-17. The sole decoration on two other Warren plaques (MFA 99.402 and 99.403) are a pair of frontal faces of women in this style.

${ }_{1053}$ Padgett 2003, 144-45. The "The Centaur's Smile" contained a number of Warren antiquities in a range of media: vases, bronzes, and terracotta figurines. Related to the electrum plaques in regard to production process but not in findspot is the fragment of a Greek bronze relief from Warren (MFA 98.652), c. 550500 , with the repoussé face of a gorgon. It may have decorated a shield or tripod or been part of a bronze revetment left as a votive. Padgett 2003, 323-24.

${ }^{1054}$ Nine electrum plaques from Warren at the MFA are the "Mistress of the Animals" type (MFA 99.381.384 and $99.391-.395)$.

${ }^{1055}$ Six of the plaques are decorated with "the bee-woman" (MFA 99.396-.401). For the iconography, Lawler 1954.
} 
from Rhodes is now included among the inventory of hybrid female creatures from the East who appear frequently in Greek art and literature - the sirens, sphinxes, and Gorgons.

A much more familiar winged female appears in the form of a gold earring from Warren in the MFA, undeniably one of the most famous pieces of ancient jewelry. This earring with Nike driving a chariot (MFA 98.788), which Warren bought from the Count Michel Tyszkiewicz Collection, has been extensively published in scholarly and popular venues. ${ }^{1056}$ Standing in a chariot pulled by two rearing horses, the goddess of victory (Figure 119) dangles from a palmette composed of curved petals and stamens with granulated centers. Close inspection reveals the technical skill of the ancient goldsmith. The details of the figure's face convey her resolute expression as she pulls back on the reins, and the lines in the quills on her outstretched wings are carefully rendered. Not only does Nike wear earrings and bracelets, the wheels of her chariot revolve. Dated to the late Classical or early Hellenistic period, this piece was featured in the 1906 and 1904 MFA handbooks and remains one of the most popular objects in the collection. ${ }^{1057}$ It was spotlighted as "one of the largest, finest, and most complex Greek earrings" in the 1965 exhibition, "Greek Gold: Jewelry from the Age of Alexander."1058 Scholars hypothesize it

\footnotetext{
${ }^{1056}$ For the bibliography on the earring, see Hoffmann and Davidson 1965, 82. The MFA earring was on a "quiz" on identifying the 60 best-known pieces of art in American museums. Lerman 1967, 103. Also on the quiz were the Bartlett and Chios Heads, discussed later in this chapter.

${ }^{1057}$ See A Handbook of the Museum of Fine Arts, Boston (1906), 65; A Handbook of the Museum of Fine Arts Boston (1914), 84; MFA: A Guide to the Collection of the Museum of Fine Arts, Boston 1999, 77; Kondoleon, Grossmann and Ledig 42. See also, Higgins 1980, 28-9. The MFA's earring received more publicity when it was stolen in 1963 and then recovered in 1964 through the efforts of a Boston University archaeology class. For those circumstances, Whitehall 1970b, 676-77.

${ }^{1058}$ Hoffmann and Davidson 1965. The MFA, Brooklyn Museum, and Virginia Museum of Fine Arts, Richmond, hosted the exhibition. Seven other pieces of gold jewelry in the MFA from Warren, two of which are discussed below, were also featured in the "Greek Gold" exhibition.
} 
was created in the Greek workshop where earrings now in the Metropolitan Museum of Art and the Hermitage Museum were manufactured. ${ }^{1059}$

In addition to the MFA, Warren provided ancient jewelry to two collegiate collections. To Bowdoin, he gave eleven pieces of Greek, Etruscan, and Roman jewelry, four of which arrived in $1923 .{ }^{1060}$ In his catalogue, Herbert featured two Greek gold pieces with lion heads, a popular Hellenistic motif: an earring composed of woven strands terminating in an open lion's mouth and a necklace (BCMA 1923.34); and a necklace made up of double-links that join pear-shaped sards and end in a lion's head finial (BCMA 1923.36). ${ }^{1061}$ A third relatively unknown Warren bequest to Bowdoin, a Roman ring (BCMA 1923.115), dated to the first or second century C.E., was selected for a 1983 jewelry exhibition at RISD. ${ }^{1062}$ Slightly flattened into an oval, the gold ring (Figure 120) has a sardonyx cameo with the head of a bearded satyr or Silenus, a motif popular in the early Empire. On both sides are busts, one a man and a woman. Herbert suggested that the ring may have been a betrothal token, marriage ring, or seal. ${ }^{1063}$ It

\footnotetext{
${ }^{1059}$ Hoffmann and Davidson 80-85. These included three rings with intaglios: Ring with Lion Attacking Dolphin (98.795); Ring with Deer Hunt (21.1204); Ring with Donkey (27.701); two bow fibulae (99.371 and 99.372). Two other objects, a fragment of a diadem (98.798) and a necklace (98.794) are discussed below.

${ }^{1060}$ The Greek earrings include a griffin (BCMA 1923.33); lion (BCMA 1923.34); and hunting dog (BCMA 1930.14). The rest of the Warren jewelry bequests are composed of a Greek gold ring (BCMA 1928.10); Etruscan gold ring (BCMA 1915.78); Roman gold rings ( BCMA 1915.102 and BCMA 1923.115); silver Roman ring (BCMA 1923.13); a Greek gold necklace (BCMA 1923.36), bracelet (BCMA 1923.35), and pin (BCMA 1928.9). For Warren's jewelry at Bowdoin, see Herbert 1964, 135-38.

${ }^{1061}$ Herbert 1964,137. Both pieces are dated to the third century.

${ }^{1062}$ Art history graduate students at Brown University and archaeology students at the Catholic University at Louvain-la-Neuve organized "Gold Jewelry: Craft, Style, and Meaning from Mycenae to Constantinopolis" with ancient pieces of jewelry chiefly from five collegiate collections, five civic museums, and a private collection in the United States. See Hackens and Winkes 1983. ${ }^{1063}$ Herbert 1964, 137-38.
} 
deserves further study as evidence for the Roman practice of using rings as marriage symbols. $^{1064}$

The 1922 Beazley Descriptions and the 1925 E. P. Warren List verify thirteen pieces of ancient jewelry from Warren in the RISD collection. ${ }^{1065}$ Beazley noted that a pair of Etruscan earrings (RISD 22.208a, b) had come from the same Etruscan tomb as a gold ring (RISD 22.207) and a bronze shield boss in the form of a ram's head (RISD 22.206). ${ }^{1066}$ Despite their brevity, Beazley’s notations about the findspot provide a general context for these objects that are not found in the RISD catalogue. ${ }^{1067}$ The shield boss, gold ring, and earrings suggest that the tomb may have belonged to an elite man and woman. Dated to the sixth century the earrings (RISD 22.208a, b) show signs of wear in antiquity (Figure 121). Made of bent gold strips, they end in a hinge at each side to be fastened with a silver pin. ${ }^{1068}$ The filigree decoration on the outer surface is composed of

\footnotetext{
${ }^{1064}$ For a Roman engagement ring at Yale, a betrothal ring at the Walters, and a necklace with a marriage scene and amulet at the Met in the "I Claudia" exhibition, Kleiner and Matheson 1996, 150-52. For Roman rings as love-tokens and marriage rings with "confronted-busts," see Johns 62-5.

${ }^{1065}$ The eleven objects (with the RISD accession number followed by the Hackens catalogue [HC] number as a concordance) on the 1925 Warren list consist of a double-bodied sphinx ornament (25.101 [HC 19]) mentioned in his letters and which Warren's list indicates as "Bought in Paris from a Greek"; four single earrings (25.102 [HC 35]; 25.103 [HC 33]; 25.104 [HC 29]; 25.114 [HC 32]); three paired earrings (25.106 a, b [HC 4]; 25.107 [HC 6] a, b; 25.115 a, b [HC 25]). In addition, three rings came from Warren-a Greek finger ring with a flying victory (25.105 [HC 13]); Hellenistic finger ring with a head of Eros (25.116 [HC 36]); and a late Roman finger ring with a sard bezel (25.108[HC 67]) carved with what Warren called the "head of Cybele" but actually is that of a turret-crowned Tyche, or another city-goddess. The accession numbers correspond with those found in the catalogue of ancient jewelry at RISD, Hackens 1976.

${ }^{1066}$ For the Etruscan gold ring (RISD 22.207), see Hackens 1976, 35; for the bronze ram's head (RISD 22.206), see Mitten 1975, 176. It is not clear why Hackens did not include this contextual information about the pieces. Beazley does not indicate the location of the tomb or when the objects were found.

${ }^{1067}$ Eliza Radeke and a fund established by the renowned Providence jewelry firm, Ostby and Barton, the world's leading producer of rings in the early twentieth century, purchased the jewelry. Hackens observed that the RISD jewelry collection was begun "when excellent pieces were available to discerning collectors and before the forgery of ancient jewelry had become widespread." Hackens 1976, 6.

${ }^{1068}$ Higgins 1980, 139. Called a baule because of a resemblance to a small valise or bag, this variety of earrings evolved from the seventh century through the fifth century BCE. The chief ornamentation is fine
} 
a central flower with four smaller rosettes at each corner. Six pendants hang from a raised edge on one side. Certainly, these earrings and two additional pairs that Warren provided in 1925-(RISD 25.106, b and 25.107a, b) — justify the assertion that Etruscan gold jewelry is "the most innovative and magnificent of the classical world." ${ }^{1069}$ Etruscan earrings were readily available from dealers before the First World War: Warren sold an even more elaborate pair of the same type to the MFA in $1903 .^{1070}$

A lack of context for many antiquities limits the study of Greek and Roman art in all media, especially in regard to "the origin of jewelry in collections and archaeological finds." 1071 The picture changed dramatically beginning in the 1960s when the discovery of spectacular gold jewelry and metal vessels in Macedonian tombs brought attention to the Hellenistic jewelry in the MFA. Jewelry that Warren purchased from the Tomb of the Erotes in 1899 was highlighted in two important American exhibitions. The 1965 "Greek Gold from the Age of Alexander," held at the MFA, Brooklyn Museum of Art, and the Virginia Museum of Fine Arts, Richmond, exhibited Hellenistic gold jewelry from more than twenty-five American and European museums and collectors. ${ }^{1072}$ More than a decade later American and Greek sponsorship produced “The Search of Alexander," a comprehensive exhibition of Hellenistic art that travelled four major American civic

filigree and attached ornaments as seen in RISD 22.208a, b, acquired from Warren. The silver pin would have passed through the lobe of the wearer's ear.

1069 de Puma 1994, 55. The Etruscan earnings (RISD 25.106a, b and RISD 27.107a, b) as well as the Hellenistic finger ring (RISD 25.116) on the E. P. Warren 1925 list were exhibited in "Gold Jewelry: Craft, Style, and Meaning from Mycenae to Constantinopolis" in the RISD Museum of Art in 1983. ${ }^{1070}$ The MFA's Etruscan baule earrings (MFA 03.765-766) from Warren are complex geometric ensembles decorated with granulation and filigree work. See Kondoleon, Grossmann and Ledig 143. Warren does not seem to have given such opulent jewelry to Bowdoin: Herbert catalogued only one Etruscan piece from Warren, a ring with a scarab insert (BCMA 1915.78). Herbert 1964, 137.

${ }^{1071}$ Calinescu 1996, xii.

${ }^{1072}$ Hoffmann and Davidson 1965. Nine of these pieces came to the MFA from Warren. 
museums (1980-1982). ${ }^{1073}$ This lavish exhibition contained not only jewelry but also terracottas, ceramic and metal vessels, marbles, and ivories from American and European collections which were displayed with the finds from Vergina, Pella, and Derveni and other recently excavated sites. A gold diadem and a necklace from among the grave goods that Warren obtained from the Tomb of the Erotes were in both exhibitions, but the approaches to these pieces were distinctly different.

The crown (MFA 98.794) is in the form of an elaborate trellis entwined with vegetative forms - acanthus, pomegranate, and honeysuckle — with inlays of carnelian and glass (Figure 122). The necklace (MFA 98.798), a link-in-link gold chain alternating with carved garnet links, has a gold closure in the form of a cast Eros on a cylindrical base with winged lions (Figure 123). The "Greek Gold" catalogue provides detailed photographs and laboratory and stylistic analyses to confirm the authenticity of these pieces and suggests a relationship with other examples of Hellenistic jewelry. The two MFA pieces are discussed apart from one another, the diadem with other Hellenistic crowns and the necklace with nine Hellenistic necklaces from various collections and findspots.

Fifteen years later, "The Search of Alexander" exhibition took a more contextualized approach to these objects: the diadem and necklace were shown with a third piece of Warren jewelry from the Tomb of the Erotes, a gold ring with a garnet intaglio (MFA 21.1213), as well as terracotta figures and miniature shields that served as

\footnotetext{
${ }^{1073}$ Yalouris, Andronikos, Rhomiopoulou, Herrmann and Vermeule 1980.
} 
tomb decoration. ${ }^{1074}$ Signed by its engraver, Gelon, the gemstone (Figure 124) has been published in European scholarship, most recently in the 2008 study of the tomb. ${ }^{1075}$ The "Search for Alexander" catalogue encourages viewers to note the "small scale and exquisite conceit" of the terracottas and jewelry from the Tomb of the Erotes, qualities that reflected the tastes of its owner who "surely wore [the jewelry] in life." 1076 It also discusses the heavy ring with its garnet intaglio of Aphrodite bending over to pick up the shield and spear of her lover Ares, pointing out that her hair is in the style worn by Arsinoe II and Berenike II, Hellenistic queens in Alexandria during the early third century. Based on the contextual information, the catalogue suggests that the difference in the scale of the gold intaglio ring "from the other miniaturistic jewelry from the same tomb" offers "a hint but certainly no proof that it might have belonged to another, perhaps later, member of the family group."1077 "The Search for Alexander" exhibition was significant because it presented objects from the same archaeological context, rather than grouping according to medium or function as was done in the earlier "Greek Gold" exhibition. In "The Search for Alexander," the gold diadem and necklace were not only

\footnotetext{
1074 Yalouris, Andronikos, Rhomiopoulou, Herrmann and Vermeule 149-53. Two terracotta Erotes and four terracotta shields were also in the exhibition. As explained earlier in this chapter, another MFA object Warren purchased with the group, a large terracotta figurine of a woman wearing a ring (MFA 98.983) was not included in the exhibition, but it is mentioned in the entry for MFA 21.1213.

${ }^{1075}$ For the bibliography, Boardman and Beazley 2002, 118. In Beazley's 1920 publication of Warren's collection, he included a photograph of one of the terracotta figurines from the Tomb of the Erotes with his entry, demonstrating his awareness of the importance of context. Boardman and Beazley 2002, 65. See also 1076 Yalouris, Andronikos, Rhomiopoulou, Herrmann and Vermeule 150.

1077 Yalouris, Andronikos, Rhomiopoulou, Herrmann and Vermeule 153. Warren did not acquire the ring with the garnet intaglio of "Aphrodite Arming" in the 1899 purchase of more than sixty objects from the Tomb, but rather fifteen years later from Arthur Evans, who had bought it from a Greek collector in the early 1900s. The ownership record on the MFA Collections website for MFA 21.123 is "By 1898: Anastasios Rhousopoulos Collection (according to Ephemeris Archaiologike [1899], p. 228, note 1, where it is said to have come from a chamber tomb containing terracotta figurines of Erotes, a large terracotta figure, terracotta shields, and gold jewelry at Eretria); by 1900-1904: Arthur J. Evans Collection (according to Burlington Fine Arts Club, Exhibition of Ancient Greek Art [1904], p. 174); by 1914: with Edward Perry Warren." Museum of Fine Arts "MFA Collections. http://www.mfa.org " (accessed 12 June 2011). For Evans and his gemstones, especially those purported to be Minoan, see Lapatin 202,18,104,157-59
} 
reunited with the intaglio ring but also with the terracotta figurines and shields to provide a glimpse into the shifts in tastes that can be detected in the multi-generational family tomb.

\section{Ivory}

Although Warren sent ivory and glass antiquities to American collections, research for this dissertation has not located any documentation about them from Warren. The MFA received over 70 glass pieces as gifts and purchases, and at least one ivory gift from Warren. ${ }^{1078}$ He gave ivory and glass objects to Bowdoin from 1908 through 1930, with a number of very small objects - like ivory needles, hair pins, and spoons and fragments of ancient glass - arriving after his death. ${ }^{1079}$ In 1902 Warren presented Tarbell at the University of Chicago with two intact Greek glass containers and a fragmentary ivory plaque which were published in the 1998 classical catalogue of the Smart Museum.

Three Roman ivories that Warren gave to museums in the United States merit treatment here. ${ }^{1080}$ One is a Roman flute (BCMA 1928.2), dated to c. 200 C. E., which

\footnotetext{
${ }^{1078}$ His mother gave an ivory hair pin (MFA 94.301) and a plaque (MFA 94.300) in 1894 and left an ivory statuette of a monkey holding a vase (MFA 02.641) as a bequest, objects she may have collected in her own travels. Warren gave Egyptian antiquities partially made out of ivory (MFA 02.641) and an eighteenthcentury Italian bone and ivory walking cane (MFA 28.829). A search of the MFA Collections on the museum website using "Warren and glass" produced 70 pieces of glass from Warren in the Greek and Roman collection. (accessed 12 May 2011).

${ }^{1079}$ According to a printout of Warren antiquities provided by the Bowdoin College Art Museum staff on 8 October 2008, twenty pieces of glass identified as "vase bases," "bowl base fragments," or "vase fragments," and around a dozen ivory needles, hair pins, and spoons were accessioned as gifts from Warren in 1930. None have been dated or labeled as Greek or Roman, but they are likely Roman. An earlier "sending" of glass came in 1908 when he gave three intact glass vessels - a vase with seven handles (BCMA1908.21), bottle (BCMA1908.22), and amphora (BCMA 1908.23) — and seventeen glass fragments. ${ }^{1080}$ For Roman art in ivory and bone, Henig 1983, 163-4.
} 
was a gift to Bowdoin. ${ }^{1081}$ With eight holes on the front and two in the back, the curved instrument (Figure 37) has eight jointed sections, including a bulbous mouthpiece and flared ending. ${ }^{1082}$ Held vertically, it was played by blowing through double reeds fitted into the mouthpiece while covering and uncovering the finger holes. It was featured with other Warren gifts of "ordinary objects" in the "Ars Antiqua" exhibition to illustrate daily life in ancient Greece and Rome. ${ }^{1083}$ In 1902 Warren gave Tarbell eight pieces of an ivory plaque (SM 1967.115.453), which the Tarbell Inventory records as "purchased in Italy." Such reliefs are thought to have decorated wooden cosmetic boxes, jewelry chests, or furniture. Six of the fragments show a partially-draped male figure with shoulderlength hair seated against a hanging curtain (Figure 50). He leans on his bent left elbow as he faces right in three-quarter view. ${ }^{1084}$ His right arm is raised, the forearm resting on his head and the fingers touching his hair in what is known as the "Lykeios pose" appearing in depictions of Apollo and Dionysos. ${ }^{1085}$ This languid pose, together with the clinging drapery on the lower half of his body conveys "a latent eroticism."1086 Based on similar plaques, one scholar has postulated that this plaque was carved in Alexandria in the late second century C.E. and identified the figure as Dionysos. ${ }^{1087}$

\footnotetext{
${ }^{1081}$ Herbert identifies the flute, die, three needles, three spoons, and six hairpins as "Roman work," provides descriptions, and sometimes offers commentary or references on the ivories in the final chapter, "Miscellaneous Objects." Herbert 1964, 204-06.

1082 Herbert called the ivory wind instrument a "musical pipe." The Metropolitan has two examples of ivory "ancient Roman tibia" in the Crosby Brown Collection of Musical Instruments (1889).

1083 The jointed Greek doll (BCMA 1913.28), Tanagra figurines of women (BCMA 1908.10, 1915.12.3, 1923.2), Bowdoin-Eye Painter cup (BCMA19.13.2) that have already been discussed as well as Roman dice and tesserae in chalcedony, ivory, and terracotta. Higginbotham and Westley 52-69.

${ }^{1084}$ Ferrari, Nielsen and Olson 168.

1085 Hadzisteliou-Price 1972, 52-3.

1086 Bartman 2002, 253. This "latent eroticism" may have prompted Warren and/or his Lewes House assistants to acquire the ivory and perhaps give it to Tarbell.

${ }^{1087}$ Hadzisteliou-Price 49-55.
} 
An ivory phallus on two legs (MFA Res.08.35d) epitomizes the irreverent side of Warren's collecting tastes (Figure 125). ${ }^{1088}$ Donated to the MFA in 1908, it was in his personal collection of "classical erotica" accessioned in 1910, but concern that such objects might prove "offensive to the Boston viewing public" relegated it to "dark storage" until 1964. ${ }^{1089}$ Attitudes toward this type of object have changed, for similar bronze figurines from Warren's collection have been published in the MFA bronze catalogue. ${ }^{1090}$ The lack of contextual information for the ivory phallus is reflected in the MFA labeling of it as "Greco-Roman" without any indication as to the dating on the MFA Collection database. ${ }^{1091}$ In Looking at Laughter, Clarke observes that "phalli take on a life of their own" and connects their presence in Roman visual culture as part of joking rituals. ${ }^{1092}$ In this context, the ivory may have functioned as a "powerful apotropaion" in the form of a fascinum, a phallic object that would "avert evil by distracting, confusing, attracting, or repelling a demon." ${ }^{\text {"1093 }}$ The ivory figurine (MFA Res.08.35d), on the other hand, may be a modern creation foisted on Warren or one of his Lewes House assistants. One also might entertain the possibility that Warren was not

\footnotetext{
1088 The MFA Collection database contains no records of previous ownership for MFA Res.08.035d, Museum of Fine Arts "MFA Collections. http://www.mfa.org " (accessed 30 May 2011).

${ }^{1089}$ Vermeule 1969, 9.

${ }^{1090}$ For example, two bronzes — an anthromorphized phallus described as a "seated figure," (MFA RES. 08.320) and "crossed phalloi" with an attached vine-leaf (MFA Res. 08.321) — are in the MFA catalogue of bronzes. Comstock and Vermeule 1971, 122, 154.

${ }^{1091}$ Museum of Fine Arts "MFA Collections. http://www.mfa.org " (accessed 30 May 2011). The database includes a question mark ("Greco-Roman?") implying that its authenticity may be in question.

1092 Clarke 2007, 70.

1093 Clarke 2007, 69.
} 
concerned about its authenticity, perhaps acquiring it for the sake of novelty or as a joke to be shared among his friends and, by 1908, a prank aimed at the staid MFA. ${ }^{1094}$

\section{Glass}

Although Warren did not specialize in ancient glass, he bought impressive examples of Roman objects for the MFA in the 1890s, which were published in the late 1960s, first in the Boston Museum Bulletin, and then in a catalogue of selected objects in the collection. ${ }^{1095}$ He also gave two small Greek glass oil containers to Tarbell and at least twelve almost intact glass vessels and over a hundred fragments to Bowdoin. ${ }^{1096}$ Publications of ancient glass usually focus on production techniques and patterns of distribution. However, scholars have begun to examine glass as evidence for Roman fashion and taste. ${ }^{1097}$ Ancient craftsmen created vessels by various methods: applying molten glass or sections of glass rods to preformed cores; casting in open and closed

\footnotetext{
${ }^{1094}$ My research has not located any comments from Warren about this object; it does not seem to have been published.

${ }^{1095}$ von Saldern 1966; von Saldern 1968. Among American academic museums, Yale developed the most significant collection of ancient glass, beginning in the early 1900s. See Matheson 1980. Other important American collections of ancient glass are in the Toledo Museum of Art and the Corning Museum of Glass. For the Toledo collection, begun in 1913, see Grose 1989; Page 2006. For the Corning collection, Goldstein 1979; Whitehouse 1988; Stern 1995; Whitehouse 1997.

${ }^{1096}$ For ancient glass in the University of Chicago collection, Ferrari, Nielsen and Olson 169-84. The Tarbell teaching collection included at least twenty examples of Greek and Roman glass: only two are documented as coming from Warren. For ancient glass at Bowdoin, see Herbert 1964, 184-95. Herbert lists 177 pieces, all except one are Roman. Mary and Harriet Walker gave 44 pieces in 1894, but Herbert could locate fewer than half of these early gifts. George Warren Hammond, Henry Johnson, and Dana Estes also contributed ancient glass.

${ }^{1097}$ For recent scholarship in ancient glass, Stern 2002. For a treatment of ancient glass as a response to changes in ancient tastes, see Fleming 1999; Stern 1999. The Corning Museum of Glass and the Getty Villa sponsored "Reflecting Antiquity," an exhibition of modern glass inspired by ancient Roman glass, in 2007. Whitehouse 2007. No glass pieces from Warren were included in the 2007 exhibition.
} 
molds; and blowing, a first-century innovation that made mass production possible. Wheel cutting and engraving were also employed during the Roman period. ${ }^{1098}$

The small Greek glass vessels that Warren gave Tarbell at the University of Chicago were core-formed, an early method whereby hot glass was gathered around a form of clay and other organic materials like animal dung and vegetable matter. ${ }^{1099}$ Patterns of trails or threads of glass in contrasting colors created the simple decoration of horizontal lines and zigzags. ${ }^{1100}$ Such a form, or core, was employed to produce the dark blue aryballos (SM 1967.115.808), with yellow and turquoise spirals (Figure 51); and the opaque white alabastron (SM 1967.115.814), embellished with purple bands (Figure 52). ${ }^{1101}$ Both gifts from Warren are Greek and dated to the late sixth and early fifth centuries. ${ }^{1102}$ The handles, which were formed separately and then attached, allowed these containers to be suspended from straps.

The glass that Warren acquired for the MFA demonstrates more sophisticated production techniques developed in Hellenistic and Roman workshops. Purchased from the famous Tyszkiewicz Collection and said to come from Palestrina, a ribbon-glass alabastron (MFA 98.938) is made of cones of blue and green glass placed side by side

\footnotetext{
1098 Price 1976, 111, 123.

${ }^{1099}$ For these production and decorating processes, see Hess and Wright 2005, 18, 85.

${ }^{1100}$ Hess and Wright 18, 85 .

${ }^{1101}$ For core-formed glass perfume bottles, Goldstein 2006, 22-3.

1102 The Tarbell Inventory lists the aryballos (SM 1967.115.808) as bought at the Forman Sale and alabastron (SM 1967.115.814) as "purchased in Athens" and "said to come from Thebes." Ferrari, Nielsen and Olson 169. According to the MFA Collections database, Warren sold a similar alabastron to the MFA in 1901 (MFA 01.8224) which he had obtained from a shop in Pozzouli. The chevron decorations on the MFA alabastron are more intricate than those on the vessel in Chicago. Museum of Fine Arts "MFA Collections. http://www.mfa.org " (accessed 30 May 2011).
} 
with alternating bands of clear glass embedded in gold leaf (Figure 126). ${ }^{1103}$ These "ribbons" were then fused in molds or around a core to create the shape. Understandably, various MFA publications have featured this stunning object as one of the Museum's most important holdings in ancient glass. ${ }^{1104}$ Warren also obtained examples of the moldmade glass known as mosaic (or millefiori) formed by fusing cross-sections of glass canes. A blue and white ribbed mosaic bowl (MFA 99.442) from Warren is an impressive example of how Roman artisans imitated in glass semi-precious agate or onyx (Figure 127). ${ }^{1105}$ A vibrantly colored amphora with "splash" decoration (MFA 01.822), dated to the first century C.E., illustrates a Roman glass blowing technique whereby partially inflated blue "gather" — a mass of molten glass at the end blow pipe-was rolled over chips of white and yellow glass for "pickup decoration" (Figure 128). ${ }^{1106}$

Roman craftsmen employed intricate gem-cutting and engraving techniques to create reliefs from fused layers of colored glass, usually white figures against a blue background. ${ }^{1107}$ The most celebrated example of Roman cameo glass is the Portland Vase in the British Museum, dated to the Late Republic/Early Empire. From its discovery in the early seventeenth century, the Portland Vase has been exhaustively studied and

\footnotetext{
${ }^{1103}$ Warren purchased a similar alabastron from the same sale (MFA 98.939). Museum of Fine Arts "MFA Collections. http://www.mfa.org " (accessed 30 May 2011).

${ }^{1104}$ It serves as the frontispiece for the MFA catalogue of ancient glass, von Saldern 168. See also Kondoleon, Grossmann and Ledig 177. Here, it is compared with a recently acquired silver alabastron (MFA 1974.138) to demonstrate how glass imitated metal. Another Warren acquisition, a glass pyxis (MFA 94.454), is also cited as an example of ribbon glass. von Saldern 1966, 9; von Saldern 1968, number 17.

1105 The MFA catalogue categorizes the bowl as “pillar-molded.” von Saldern 1968, number 12. Recent scholarship questions the use of this term that is borrowed from modern glass making. Hess and Wright 56. See also Taylor and Hill 2007, 78-9.

${ }^{1106}$ Warren purchased the 5 1/4-inch amphora in Athens. von Saldern 1968, figure 23.

${ }^{1107}$ For the origins, methods of production, and examples of Roman cameo glass, Goldstein 1982; Harden 1987. For recent research on production, Gudenrath 2007.
} 
frequently copied, most notably by Josiah Wedgwood. ${ }^{1108}$ As might be expected, Warren collected Roman cameo glass, mostly fragments which he sold to the MFA and gave to Bowdoin. Herbert listed seven fragments of cameo glass at Bowdoin from Warren, referring to the Portland Vase as a context. The exhibition "Ars Antiqua" featured a Warren fragment (BCMA 1915.58) dated to the second century and "said to be from Egypt" that depicts a woman in Egyptian dress with a basket on her shoulder (Figure 129). She may be part a religious procession, given that the head of a sheep is visible at the bottom of the fragment. The exhibition catalogue proposes a Ptolemaic connection, suggesting that the flat surface of the glass fragment might indicate its use as "a decorative appliqué for a piece of furniture or a box." ${ }^{\text {1109 }}$

Among the fragments of cameo glass from Warren in the MFA is a Roman plaque with Heracles Slaying the Keryneian Stag (MFA 13.212). ${ }^{1110}$ With a raised border at the top and bottom, this rectangular fragment (Figure 130) may have been part of a miniature frieze depicting the hero's labors, perhaps ultimately inspired by those on the metopes of Treasury of the Athenians at Delphi and the Temple of Zeus at Olympia. The MFA plaque shows the hero and the stag between two trees in white against a blue background. Although the stag bounds forward with raised front legs, one of Heracles' arrows is already buried in its neck. The hero shifts his weight to his bent right leg as he turns to

\footnotetext{
${ }^{1108}$ For the vase's history and its scholarship, Brooks 2004. In 1990 the Journal of Glass Studies devoted a volume to the Portland Vase. JGS Vol. 32.

${ }^{1109}$ Higginbotham and Westley 91. "Ars Antiqua" offered Warren's cameo fragment and the previously discussed silver Harpokrates (BCMA 1915.52) as examples of the exotic culture of Alexandria. The exhibition organized Warren antiquities on the theme of "A Tale of Three Cities," i.e. Corinth, Athens, and Alexandria

${ }_{1110}$ von Saldern 1968, number 24. Warren also sold the MFA two fragments in 1898 (MFA 98.764 and MFA 98.765) and a third (MFA 01.8236) in 1901, all with Dionysian imagery.
} 
pull another arrow from his quiver. This composition is in the Neo-Attic style, popular in the Late Republican and Early Imperial periods, similar to that seen on Campana reliefs and Arretine ware. Scholars conjecture that glass panels may have been inserted into walls or used to decorate wooden furniture. ${ }^{1111}$ Although the plaque has not been widely published, it appeared in early MFA catalogues where its similarity to the famous

Portland Vase was noted. $^{1112}$

Warren's acquisitions in ivory and glass for American collections are modest in comparison to the hundreds of vases and other objects with which he was associated. Nevertheless, these objects demonstrate his commitment to establish comprehensive Greek and Roman collections in American museums.

\footnotetext{
${ }^{1111}$ Two cameo panels of a similar type with scenes depicting Dionysos and Ariadne were found in 1960 in the House of Fabius Rufus. Harden 1987, 70-3.

${ }^{1112}$ Chase 1950,169 . The plaque is the last antiquity in the catalogue, almost an afterthought.
} 


\section{CHAPTER 6}

\section{WARREN'S BRONZE AND STONE SCULPTURES IN AMERICAN COLLECTIONS}

Ancient sculpture in bronze and stone are Warren's best known contributions to American collections and, like Greek vases, these antiquities have garnered considerable attention in scholarship. This final chapter discusses Greek Etruscan, and Roman bronzes and then turns to a survey of sculpture in stone which the collector conveyed to the MFA and academic museums in the United States.

\section{Bronze}

Warren sent hundreds of ancient bronzes to four institutions in the United States - Bowdoin, the University Chicago, the MFA, and RISD — with those in the MFA and RISD appearing most frequently in publications over the last century. ${ }^{1113}$ As a rule, bronzes acquired by Warren in American collections consist of small sculptures and decorative fragments, often attached to ritual or luxury metal vessels. Exceptions are

${ }^{1113}$ No bronzes from Warren entered the collections of Harvard and the University of Pennsylvania. 
the bronze portrait head of a Ptolemaic queen (acquired for the MFA in 1896, statuettes for the MFA and RISD, and fragments of large scale bronze sculpture for the MFA. ${ }^{1114}$ After an overview of Warren's bronzes in each collection, this section begins with a discussion of bronze objects and fragments associated with daily life.

As with Greek vases, most of Warren's bronzes—well over 700 — went to the MFA. ${ }^{1115}$ Research verifies that no bronzes from Warren are in the museums at Harvard and the University of Pennsylvanian. Bowdoin received at least forty bronze objects from Warren, with more than half consisting of "implements" and "utensils." Warren gave Tarbell at the University of Chicago a few bronze objects but only two have been published, both in the Smart Museum's handbook. ${ }^{116}$ The RISD catalogue of bronze antiquities credits Warren with only two bronze sculptures: the figurine of a man in a cloak (RISD 20.056) and a statuette of Aphrodite (RISD 26.117), both of which are treated in this chapter. However, research has revealed perhaps up to six more bronzes in the RISD catalogue may be traced to Warren. Most assuredly, the Etruscan shield boss in the form of a ram's head (RISD 22.206), dated c. 530-490, is from Warren because it is

\footnotetext{
${ }^{1114}$ The ground-breaking exhibition, "The Fire of Hephaistos" (1996-07), which focused on ancient technology, conservation and technical studies, validated Warren's acquisitions of fragments of life-sized bronze sculpture. Seven of the "body parts" he acquired for the MFA were among the thirteen such fragments from American collections: "Back of Himation-clad Statue of a Man" (MFA 01.7528); "Left Arm and Hand of a Man" (MFA 96.667); "Right Arm and hand of a Man, perhaps Herakles" (MFA 01.7517); "Right Forearm and Hand of A Woman" (MFA 10.163); Right Hand of a Woman (MFA 01.7495); and "Right Foot Wearing Sandal" (MFA 01.7509).

${ }^{1115}$ See the over seven hundred bronze objects in the 1971 catalogue, in which Warren is credited for "most of the masterpieces." MFA bronze catalogue, Comstock and Vermeule 1971, vii.

${ }^{1116}$ Ferrari, Nielsen and Olson 156-58. Warren gave two bronze antiquities to Tarbell, an "Italic" spearhead (SM 1967.115.18) "purchased in Italy" dated to the eighth century; and a shallow basin (SM 1967.115.17), "purchased in Naples" and "said to come from Cumae." A color photograph of the bronze basin is featured in the catalogue (Plate 12). Perhaps it once served as a burial urn, for its rim has a damaged inscription in what is thought to be the Phoenician script. Neither of Warren's gifts has been published other than in the Smart Museum classical catalogue. Other unidentified small bronze fragments are catalogued as coming from Warren, but little is known about them and nothing about his motivation for including them among the gifts to Tarbell.
} 
included in the 1922 Beazley Descriptions. Two other bronze pieces in the RISD catalogue are on the 1925 E. P. Warren List: a "hydria said to be from near Delphi" (RISD 25.112) and an inscribed Etruscan mirror "Bought in Oxford. Artemis" (RISD 25.071). ${ }^{1117}$ Warren's 1922 list also includes a pair of fibulae (RISD 25.092a and b) and a "kouros" (RISD 25.113), both placed in the Dubitanda section of the catalogue. ${ }^{1118}$ Finally, a bronze vase in the shape of an African's head (RISD 11.035) may be the one Warren discussed with Radeke in a letter he sent her in $1913 .{ }^{1119}$

Although Warren sometimes purchased intact bronze vessels, the abundant bronze fragments — handles, attachments, and decorations_-available from dealers and middlemen seemed to have caught Warren's eye, and his acquisitions play an important role in scholarship and in the exhibitions of ancient bronze. ${ }^{1120}$ He obtained bronze mirrors (discs, cases and their figural stands); cistae, boxes for cosmetics and jewelry, and cista handles and feet; and paterae and their fragmentary decorations. ${ }^{1121}$ Among the most widely published of these pieces is a Greek mirror stand (MFA 04.7) of Aeginetan

\footnotetext{
${ }^{1117}$ The bronze vessel (RISD 25.112) offered as a prize in athletic competitions or as a votive contains an inscription on its rim in Boeotian Greek: "from the Games at Thebes." Mitten suggests that this vessel may have been used as an ash urn in a chamber tomb and credits it as a "Museum Appropriation and Special Gift," a designation used for antiquities obtained from Warren. Mitten 1975, 46. He indicates that the mirror, RISD (25.07), is from the Alessandro Castellani Collection in Rome based on drawings in the 1884 Castellani catalogue and in E. Gerhard's Etruskische Spiegel V, which Mitten includes in the entry for this object. Mitten 1975, 128-31.

${ }^{1118}$ For the fibulae (RISD 25.092a, b,), Mitten 1975, 200-02. For the "kouros" (RISD 25.113), Mitten 1975, 205-07.

${ }^{1119}$ EPW to EMR, 8 December 1913, RISDA. Here, Warren acknowledged "the cheque for the Negroid Head" and informed her "I will let you know what Mr. Marshall says about the date ..." Note: RISD 11.035 was accessioned a decade or more before the 1922 Beazley descriptions and 1925 E. P. Warren List. Mitten indicated that RISD 11.035 was a Radeke gift, a credit often used for purchases from Warren. Mitten 1975, 62-5.

${ }^{1120}$ For a trio of complete bronze vessels found together in South Italy that Warren sold to the MFA, see the two oinochoi (MFA 99.841 and 99.479)and a volute krater (MFA 99.483). Comstock and Vermeule 1971, 296-7, 311, 316.

${ }^{1121}$ These MFA objects are described in the Museum's bronzes catalogue, Comstock and Vermeule 1971.
} 
manufacture, c. 500, in the form of a figure of Aphrodite, elegantly draped like the Acropolis korai, with Erotes perched heraldicallyon her shoulders (Figure 131). ${ }^{1122} \mathrm{He}$ also acquired ten Etruscan mirrors for Boston and, as explained above, at least one for RISD. ${ }^{1123}$ At least sixteen additional Greek mirrors and fragments from Warren are in the MFA, including an engraved Corinthian mirror disc and case. Once hidden away in the collection of "erotic art," a bronze mirror and case (Res.08.32c.1 and RES.08.32c.2) are now not only exhibited in the MFA galleries, but they also figure prominently in publications on the sexual attitudes and practices of the ancient Greeks and Romans. This mirror and its case, both decorated with scenes of heterosexual couples engaged in coitus, demonstrate Warren's interest in matters that MFA visitors of his time would have considered shocking. On the exterior of the mirror, rendered in relief line, a couple reclines on a bed and an Eros flies overhead extending a ribbon to the pair (Figure 132). The woman's body is exposed to the viewer as she lifts her right leg for the man's entry and extends her right arm to pull his face towards hers. In a scene incised on the inside surface, a man stands behind a woman as she leans against the bed and guides his penis with her hand (Figure 133). According to Clarke, this luxurious object may indicate a change in sexual attitudes of the Greek elite that carried "a more romantic and flattering" attitude toward women, different than shown in the erotic escapades on the pottery created for symposia. ${ }^{1124}$ He speculates that this mirror may have belonged to one of the

\footnotetext{
1122 For this late Archaic mirror stand and its scholarship, see Kozloff and Mitten 1988, 75-76.

${ }^{1123}$ For Warren's mirrors at the MFA, see Comstock and Vermeule 1971, 240-68.

${ }^{1124}$ For contrast, see the Nikosthenes red-figure kantharos (MFA 95.61), dated 520-510, that Warren obtained. On one side of this cup three youth frolic with nude courtesans while on the other side youths engage in an orgy featuring fellatio and a ménage à trois.
} 
famously accomplished Corinthian courtesans or to a married woman who believed she "should play an active role in achieving sexual pleasure for herself and her husband."1125

Warren also acquired Greek bronze decorations once attached to the rim of vessels. The siren with spread wings (MFA 99.458), a motif adapted from Near Eastern art and frequently found on Archaic metal vessels, was in the 2003 exhibition "The Centaur's Smile." ${ }^{1126}$ Warren's siren (Figure 134) is thought to be one of a pair, dated c. 650 , which scholars have traced to Olympia. ${ }^{127}$ One of the most intriguing bronzes at Bowdoin is a Roman decorative attachment in the form of Priapus (BCAM 1915.37), dated to the late first century B.C.E. and given in 1915. ${ }^{1128}$ Two publications of the Bowdoin antiquities collection include photographs of this elongated figure with arms akimbo who thrusts his hips forward to display his erect phallus (Figure 135). ${ }^{1129}$ The catalogue for "Ars Antiqua" interpreted this object as functioning as "a scarecrow of sorts

\footnotetext{
${ }^{1125}$ Clarke 1989, 26. Clarke also interprets the Eros as offering the ribbon as a symbol of victory to the man. Clarke 2003b, 49.

${ }^{1126}$ For the bibliography of MFA 99.458, Padgett 2003, 286. For other MFA bronze sirens from Warren, see the handle from a hydria, (MFA 99.467) and an intact oinochoe (MFA 99.481). Warren's bronze Etruscan handle in the form of Triton (MFA 01.7508) was also included in "The Centaur's Smile." Padgett 2003, 339. Also in the exhibition was the Etruscan centaur handle (MFA 09.291), a gift of Harold Parsons. Padgett 2003, 215-17. It likely came to Parsons via his work for Warren at Lewes House or perhaps a gift of Warren to Parsons, who then gave it to the MFA. For Harold Parsons, see Chapter 2.

${ }^{1127}$ Warren presented Bowdoin with a similar bronze siren (BCMA 1915.26), c. 470-460. In this case, the siren stands on a palmette to serve as the base of a back handle for a hydria, one of the common uses for these hybrid creatures in the fifth century. Herbert 1964, 118. For other ancient sirens and their Egyptian origins, see Cooney 1968. For the scholarship on bronze siren attachments, Muscarella 1991, 16-24. He provides a reconstruction of a cauldron from Gordion (Plate Ia).

${ }^{1128}$ As a rule, Warren's gifts to Bowdoin were not so overtly sexual. A Roman amulet in the form of a phallus with a ring for suspension (1930.27), arrived after Warren's death in an assortment of over 200 small objects (ivory hairpins, terracotta tesserae, glass and vase fragments) from Lewes.

${ }^{1129}$ Herbert 1964, 120, figure 427; Higginbotham and Westley 55.
} 
$\ldots$... and as an example of the ubiquitous presence of fertility symbols in everyday

ancient life, constantly reminding both men and women of their duty to procreate." $" 1130$

As might be expected, several bronze statuettes of Priapus were among the "erotica" that Warren gave to the MFA in $1908 .{ }^{1131}$ However, the Warren gift to the MFA that seems closest in spirit to Bowdoin's Priapus is the Etruscan ithyphallic figurine with a drinking horn (MFA 13.112), which may have served as the decoration on the top of a kottabos stand. ${ }^{1132}$ Whatever his original context, the satyr dances as he lifts a horn or a rhyton to his upturned mouth (Figure 136). ${ }^{1133}$ Exhibited in the 1998 "The Gods Delight: The Human Figure in Classical Bronze" and dated to 450, Warren's gift conveys the exuberant escape the Etruscans found in the wine, dancing, and drinking games of the symposium.

Other important small bronzes from Warren were ex-votives of animals, offerings made at sanctuaries. Statuettes of bulls and horses from the Kabeirion were often available to collectors like Warren. ${ }^{1134}$ The votive bull (MFA 98.663), dated c. 490, in the MFA, for example, is inscribed "Homoloïchos [dedicated this] to a child of Kabeirion,"

\footnotetext{
${ }^{1130}$ Higginbotham and Westley 55.

${ }^{1131}$ Both were in the "Erotica" given to the MFA in 1908. See Priapus pouring oil on his phallus (MFA Res. 08.32m) and Priapus holding four children in the skirts of his garment (MFA Res. 08.32p.) Warren also collected Roman bronze statuettes of this type: two that also were once among his "Erotica" are the "phallic dwarf" (Res. 08.32D), and the "boxing dwarf" (MFA Res. 08.32k), featured in the 1988-1989 exhibition “The Gods Delight." Kozloff and Mitten 1998, 306-12. The MFA bronze catalogue lists twenty bronzes from Warren's "Erotica."

${ }^{1132}$ For the drinking game of kottabos, see Kurke 1999, 278-84.

1133 The MFA bronze catalogue identifies the object he lifts as a musical instrument while the 1998 exhibition labels it a drinking horn. Comstock and Vermeule 1971, 160; Kozloff and Mitten 228-30. Other Warren bronze satyrs in the MFA include a dancing Silenus (MFA 98.669) "from Epidaurus"; a young standing satyr (MFA 96.704) purchased in Rome and "presumably from the Tiber"; a young running satyr (MFA 01.7510) "bought in Athens"; a kneeling ithyphallic satyr (Res. 08.32.b) "bought in Smyrna"; and a vessel in the shape of a satyr's head (01.7468) "bought in Rome."

${ }^{1134}$ For bulls and horses as votives, Langdon 1993, 56-7, 155-56. For the Kabeirion, see Chapter 4.
} 
while Bowdoin received a bovine votive (Figure 33) with a more generic inscription with "the Sacred Kabeirion" (BCMA 1927.14). ${ }^{1135}$ A bronze horse (BCAM 1923.109), dated to c. 725 , may have been an offering from newly ascended Greek aristocracy, with the horse symbolizing their status (Figure 137). ${ }^{1136}$ One of the most beloved animals in the MFA's collection is Warren's Geometric doe nursing her fawn (MFA 98.650) also from the Kabeirion. This whimsical pair (Figure 138) appears frequently in the MFA handbooks. ${ }^{1137}$ An American specialist in ancient bronzes suggested that "the same gifted sculptor" of this work also created other bronzes in American and European collections, bestowing on him the moniker "The Master of the Boston Deer and Faun." 1138

The best known of Warren's bronzes is the so called "Mantiklos Apollo" (MFA 03.997), dated 700-675. This bronze (Figure 139) marks a major milestone in Greek sculpture, when the interpretation of the male body moves from geometric forms into more naturalistic rendition. Its inscription--Mantiklos donated me as a tithe to the far shooter, the bearer of the Silver Bow. You, Phoebus (Apollo) give something pleasing in return"—indicates its "original votive purpose," but whether the figure—now missing its right arm, lower legs, and accessories — is Apollo or the votary, Mantiklos, depends on how the figure is reconstructed. ${ }^{1139}$ Some scholars have argued that this nude male once wore a helmet and held a spear, thus, making him Mantiklos. Conversely, others contend

\footnotetext{
${ }_{1135}^{1136}$ Comstock and Vermeule 56; Higginbotham and Westley 46-7.

${ }^{1136}$ For the significance of bronze horses in early Greek art, see Osborne 24-7.

${ }^{1137}$ For the bibliography until 1970, see Comstock and Vermeule 5. For more recent scholarship, Langdon 1993, 200.

${ }^{1138}$ Mitten 1967, 13-16

${ }^{1139}$ The inscription in Archaic Boeotian, running boustrophedron from the figure's right knee up the thigh, across the groin, and down to the left knee then turns to run retrograde. Museum of Fine Arts "MFA Collections. http://www.mfa.org " (accessed 6 June 2101); Kozloff and Mitten 53-54.
} 
that the figure formerly held a silver bow, the attribute of Apollo. According to Count Tyszkiewicz, the owner prior to Warren, the statuette was bought in Thebes, an assertion supported by linguistic analysis of the inscription, as well as stylistic features. ${ }^{1140}$ The figurine is a popular monument taught in the survey of Western art, as well as in Greek art and archaeology courses in American colleges and universities. ${ }^{1141}$

Other early Greek bronze figures from Warren have inspired considerable scholarly discourse about chronology, workshops, and iconography. Two examples are two statuettes in the MFA, both identified as "Hermes Kriophoros" (MFA 99.489, c.500490, and MFA 04.6, c.520-500). Wearing belted tunic and broad brimmed hats, both bearded men grasp young rams in their left arms while extending their right arms toward the viewer( Figure 140). On the larger figure (MFA 99.489), remnants of a wing are visible on one foot, a feature that has led scholars to identify both figures as Hermes, the protector of flocks. ${ }^{1142}$ According to the RISD bronze catalogue, Warren provided a smaller bronze figure of a Greek shepherd (RISD 20.056) dated 520-500, from Arcadia. ${ }^{1143}$ Garbed in a cloak, boots, and hat appropriate for winter, this rustic figure (Figure 141) is a stock representation of a herder and was probably a votive to Pan, another divine protector of flocks in the Greek countryside. ${ }^{1144}$ Warren's letter to Eliza Radeke in 1919 about what he calls the "amusing little bronze . . . not at all in the style of

\footnotetext{
${ }^{1140}$ For the extensive bibliography, see Kozloff and Mitten 56-7.

${ }^{1141}$ For the Mantiklos Apollo in surveys of western art, see Gardner and Kleiner 89. For textbooks in Greek art and archaeology with the sculpture, Biers 142-3; Pedley 142-3.

1142 The outstretched right hand of each "Hermes" likely could have once held the kerykeion or caduceus, a snake entwined staff, another of the god's attributes.

${ }^{1143}$ Mitten reported that "a note in E. P. Warren's handwriting" in the object file indicated the little bronze "shepherd," similar to the one in the Metropolitan collection, came from a sanctuary of Pan in Arcadia. Mitten 1975, 44, note 1. It is not on the 1922 Beazley Descriptions and 1925 E.P. Warren List. ${ }^{1144}$ Mitten 1975, 44.
} 
Watteau" captures the delight he found in the little statuette. He suggested that she should imagine

a policeman in a usually long cloak ... clothed for cold weather in what is really a cloak with lapels pinned together. Since this would flutter in the wind, he holds it together with hands inside . . . the face is bearded and archaic and there is a sugar-loaf hat turned up behind . . . but I do not know whether this is meant to be comic as in modern caricatures; perhaps it is only rustic execution. ${ }^{1145}$

Warren's description of the bronze shepherd demonstrates not only his keen eye for antiquities, especially those that otherwise might have gone unnoticed and underappreciated, but also recalls the enjoyment he found in "antiquities . . . that need less explanation to be enjoyed." 1146

No large-scale bronze sculptures entered American collections via Warren. Early in his collecting career, however, he purchased a life-size head of a young woman (MFA 96.712), which has frequently appeared in print (Figure 142). The acquisition of this impressive Hellenistic work from the Tyszkiewicz Collection constituted one of Warren's first collecting triumphs. ${ }^{1147}$ Much of the discussion about it focuses on the identification of the woman who may be Arsinoë II (c. 316-270), daughter of Ptolemy I and wife of three Ptolemaic kings, based on numismatic portraits. Prominent twentieth-century American scholars in Greek and Roman art_- George H. Chase, Dorothy Burr Thompson, G. M. A. Richter, and Cornelius C. Vermeule-wrote about this piece. ${ }^{1148}$ After her arrival in Boston, the treasured portrait remained on display in the MFA for a

\footnotetext{
${ }^{1145}$ EPW to ERM, 12 July 1919, RISDA.

1146 "Preface by E.P. Warren," n.d., BCMA.

${ }^{1147}$ For the history of this bronze portrait, reportedly from Memphis, and the famous collector the Polish collector, Count Michael Tyszkiewicz, Mattusch 1996, 296-7.

${ }^{1148}$ For a selected bibliography, see Mattusch 1996, 298.
} 
century. Its first exhibition outside the MFA was "The Fire of Hephaistos” (1996-07)

which highlighted the most important large classical bronzes in North American

collections.

A discussion of Warren's ancient bronzes would be incomplete without mention of the statuette of Aphrodite (RISD 26.117), the most published of all the antiquities in the RISD collection that entered through Warren's efforts . As documented in

correspondence in the RISD Museum curatorial files, the story of how this bronze entered the RISD collection not only reveals the complex machinations of the antiquities market, it also testifies to Warren's dedication to Eliza Radeke and the RISD Museum. ${ }^{1149}$ In 1926 Warren, who by this time had withdrawn from the active pursuit of antiquities on behalf of the MFA Boston, confessed to Radeke, "I have been so long out of the market." 1150 Nevertheless, he made one last foray into the international antiquities souk on her behalf, after receiving a tip from his friend John Marshall, then the Metropolitan Museum antiquities agent. ${ }^{1151}$ Warren enclosed a photograph of the bronze statuette that he described as once belonging "to a Czar who gave to a Stroganoff" and now "in Paris

\footnotetext{
${ }^{1149}$ The seven documents in the Curatorial Files of the RISD Museum of Art are identified here by the name of the writer, the date, the recipient, and CF-RISD (Curatorial Files of the RISD Museum of Art). Warren is abbreviated to EPW; Eliza Metcalf Radeke to EMR; Earl Rowe, the RISD Director; Charles Murray West, Warren's British assistant in residence at Fewacres, Warren's home in Maine, is CMW. West often handled shipments of antiquities. To my knowledge, copies of these documents are not in the RISD Archives.

${ }_{1150}$ EPW, 20 March 1926, to EMR, CF-RISD. Warren wrote from Paris.

${ }^{1151}$ After Marshall's wife Mary died in 1925, Warren and Marshall resumed their close relationship. Warren disclosed that all he knew about the piece was "from [John] Marshall." Over Marshall's objections ("he growls at the museum"), the Metropolitan had rejected the statuette. EPW, Wednesday January 1926, to EMR C-RISD. The letter is in Warren's own handwriting, who was then in Rome with John Marshall. The lack of a date or exact address may be due to the fact that Warren, who customarily had a secretary for such tasks, apparently was writing the letter himself. Warren frequently complained about the quill pens he used when writing his own correspondence. This letter ends: "Well; there is the duty done, with many suppressed curses on pen + paper, neither to my liking. I can't make pens for this paper."
} 
in the hands of one Frey." ${ }^{1152}$ He reported that the right foot and left arm had been restored, but the work was so well done that "J. M. [John Marshall] would not alter it." He added that despite the high asking price,

... if the statuette is as good as J.M. thinks, it is worth buying at whatever reduction we can get ... It is not a piece for a committee but for a benefactor. The prices of bronzes frighten committees. If you were so bold as to entrust me with powers, I would go, contrary to my programme, to Paris . . . I think it a work on which I should have a clear judgment ... ${ }^{1153}$

By March 13, 1926 Warren had made appointments with Frey. ${ }^{1154}$ Then, within a week, Warren arrived in Paris to examine the Aphrodite first hand and wrote a long letter to Radeke describing the bronze. He gushed that "the figure does come under the rubric of exceptions ... a great rarity." ${ }^{1155}$ He added, "it is only plain that a high price would be excusable." He advised making an offer of "nine thousand [pounds], now, and perhaps effect the purchase with eight thousand but ... I could not hope for so low a price." ${ }^{1156} \mathrm{~A}$ letter of thanks to Warren indicates that the bronze had arrived in Providence by May 19, 1926: "we are all very much delighted with it and very proud in possessing such a beautiful Greek bronze."1157

Aphrodite stands with her weight shifted on her bent right leg (Figure 143). The knee of her more sharply bent left leg extends outward on a diagonal, with the heel

\footnotetext{
1152 The "one Frey" to whom Warren refers is a Dr. von Frey, who specialized in collecting paintings.

${ }^{1153}$ EPW, Wednesday January 1926, to EMR C-RISD.

${ }^{1154}$ EPW, 13 March1926, to EMR C-RISD

${ }^{1155}$ EPW, 30 January 1926, to EMR C-RISD.

${ }^{1156}$ EPW, 30 January 1926, to EMR C-RISD. Two telegrams from Paris-EPW, 18 March 1926, and,19 March 1926, to EMR C-RISD - indicate that he had bargained the owner down to an acceptable price with no export duty or commissions.

${ }^{1157}$ This May 19, 1926 typed letter to "Mr. Edward P. Warren, Fewacres, Westbrook, Maine" is not signed. Either Radeke or Earl Rowe or both could have written it. The letter in Curatorial files may be an unsigned copy retained as a record. A telegram - "Chenuter, Paris," 8 April 1926, Providence School of Design, CRISD - announced that the "antique bronze statuette" was being shipped by steamer from Havre to New York. Although it is not clear who "Chenuter" is, the name may refer to a shipping agent in France.
} 
slightly lifted. The shift in weight forces her left shoulder and her right hip up, creating a curve in her torso. Her right arm stretches upward, with the forearm lifting toward her head. Her wrist shows traces of a silver bracelet and the fingers bend inward. The left arm turns outward to the left at a thirty-degree angle with its extended hand holding a round object, perhaps the apple from the Judgment of Paris. She tilts her head downward as she glances toward her left hand. Faint traces of silver inlay survive on two sections of ribbon binding her hair and knotted at the back. ${ }^{1158}$ Both ear lobes are pierced for earrings. Her lips are recessed, suggesting they were formerly inlaid with copper. Her pupils show sockets, probably once containing inserts. The statuette's right leg below the calf and the left arm, beginning at the shoulder, have been repaired. Corrosion on the arm, back, and buttocks may be "artificial patination" from restoration. ${ }^{1159}$

During the last two decades of the twentieth century, exhibitions and scholarly attention have confirmed the high regard that Warren and Marshall held for the RISD Aphrodite. In 1988-9 it was one of the seventy-three sculptures in the exhibition "The Gods Delight: The Human Figure in Classical Bronze" that celebrated not only the "infinite variety of forms" ancient artists used in creating "the human shape" in bronze but also "the American achievement, launched by that most voracious of all collectors, J. P. Morgan, and by the expatriate Bostonian, Edward Perry Warren, searching for the Museum of Fine Arts." ${ }^{1160}$ Among the first to acknowledge the important role of collectors, "The Gods Delight" exhibition featured nine bronzes that Warren acquired on

\footnotetext{
${ }^{1158}$ The entry in The Gods Delight catalogue thirteen years later states that silver inlay remains in the upper band while only traces survive in the lower. Kozloff and Mitten 115.

${ }^{1159}$ Mitten 1975, 74, note 3.

${ }^{1160}$ Kozloff and Mitten 1998, 1-2.
} 
behalf of the MFA Boston. ${ }^{1161}$ RISD's Aphrodite was a luminary in the Greek section in the exhibition catalogue with four photographs documenting its form and an impressive bibliography verifying its place in scholarship. ${ }^{1162}$

The 1996 "The Fire of Hephaistos" exhibition focused on how technology informs our understanding of the RISD statuette. ${ }^{1163}$ The RISD Aphrodite was compared with those in the MET (MET 35.122) and the Toledo Museum of Art (1968.72). All three are similar in size and considered to have been inspired by a now lost life-sized depiction of the goddess originally created by Praxiteles or a sculptor from his "school." An interdisciplinary team of scholars discovered that the three bronzes were created through indirect lost wax castings using one model for the series. Molds from that model then produced hollow wax figurines which were then finished individually. ${ }^{1164} \mathrm{X}$ radiography of the RISD Aphrodite also revealed modern repairs at the left knee and

\footnotetext{
${ }^{1161}$ In addition to RISD's Aphrodite, at least nine bronzes from Warren were featured in this exhibition, all now in the MFA. Five are Greek: Mantiklos Apollo (03.997); Archaic Artemis (98.658); Aphrodite and Erotes Mirror Stand (04.7); and two versions of Hermes Kriophoros (99.489 and 04.6). Four are Etruscan: Apollo (98.653); Dancer (01.7482); Patera Support in the form of nude girl (98.679); and Silenus with drinking horn (13.112).

${ }^{1162}$ Kozloff and Mitten 113-19.

${ }^{1163}$ As explained at the beginning of this chapter, Warren bronzes now in the MFA were among the fiftyfive bronzes and bronze fragments in "The Fire of Hephaistos," originating at Harvard, and travelling to the Toledo and Tampa Museums of Art. The three intact sculptures included Portrait Head of A Woman (Arsinoë II) (96.712); Phallic Dwarf (Res. 08.32D); and Boxing Dwarf (Res. 08.32K).

${ }^{1164}$ The Toledo Aphrodite, missing both legs at the knees and left arm, is unrestored. The Metropolitan sculpture, also known as the Haviland Aphrodite, was restored based on the RISD statuette, which itself had been restored in the eighteenth and nineteenth centuries. Researchers superimposed X-radiographic films of the three bronze statuettes to demonstrate that the contours of the torsos and upper legs match. Measurements from the same points on each statuette further substantiated that the three statuettes were based on a common model. The differences in the positioning of the limbs and surface detailing occurred in the finishing of each wax model. Mattusch 1996, 267-72.
} 
upper right arm, confirming late nineteenth suspicions that the entire left arm and right foot are modern restorations. ${ }^{1165}$

Scholars of the late nineteenth and early twentieth century were preoccupied with the RISD Aphrodite's "long and still slightly mysterious pedigree."1166 European and American connoisseurs and academics speculated about its previous ownership and possible connections to lost masterpieces described by ancient authors. French and Swiss archeologists debated about its ownership history. ${ }^{1167}$ In 1933, long-time curator at New York's Metropolitan and noted scholar, Gisela Richter (1882-1972), speculated about whether the RISD bronze was Greek or Roman and how it related to Pliny's descriptions of ancient masterpieces. ${ }^{1168}$ Like many of her generation, Richter was influenced by the methodology of Giovanni Morelli, who emphasized careful observation of stylistic details and took a "connoisseurial" approach. ${ }^{1169}$ Richter compared the RISD statuette to the Metropolitan's "Havilland Aphrodite" and postulated that the inspiration for both was a lost bronze by Praxiteles described by Pliny, depicting a woman putting on a bracelet or

\footnotetext{
${ }^{1165}$ Mattusch 1996, 269-72.

${ }^{1166}$ Mitten 1975, 69.

1167 Saloman Reinach (1858-1932), French archaeologist and scholar, initiated a controversy when he traced it to a plaster cast of an ancient sculpture rumored to be in Russia. See Reinach 1899. Waldemar Déonna, (1880-1959), Swiss archaeologist and authority on Greek sculpture, pointed out a silver copy of the bronze Aphrodite in the background of an 1822 French portrait. See Déonna 1924. Convoluted scholarly debate ensued about whether the statuette in the portrait was based on the original bronze or a copy and, if a copy, whether it was a plaster or silver version. In the course of this debate, Reinach asserted that the Russian nobleman had obtained the original statuette from Pompeii or Herculaneum in the late eighteenth or early nineteenth century. In the RISD catalogue, Mitten concluded that the details of the statuette's ownership and how and when it left Russia remain unclear; however, the basic story of a refugee with the bronze fleeing the Russian Revolution was "probably correct" and that it changed owners frequently until Frey purchased it. Mitten 1975, 69.

${ }^{1168}$ Richter 1933.

${ }^{1169}$ Bernard Berenson, Warren friend and protégé, did the same with Renaissance paintings and drawings, as did Beazley in his attribution of Greek vases. American scholars in the last half of the twentieth century have criticized Richter's methodology. For a negative assessment of Richter's approach, see Maxmin 1973.
} 
necklace (pseliumenen) or a woman holding a garland (stepanusam). ${ }^{1170}$ Richter reported no doubts about either's authenticity because "the style and the physical conditions of both bronzes point to an ancient origin." 1171 The similarities between the two statuettes, Richter claimed, could be explained by the fact that the Providence Aphrodite was a copy of the Havilland or "more probably that the two ... go back to the same famous original." 1172 In the latter scenario, the Havilland Aphrodite was "an approximately contemporary reproduction," while the Providence was “a later, Roman copy."1173 Richter's assessment of her Museum's Havilland statuette as being earlier meant it was closer to the Greek and, therefore, superior to the "Roman" RISD Aphrodite. The final sentence in Richter's article_- "Nothing could be more illuminating to our understanding of fourth century art than a study of these two beautiful bronzes, each eloquent of the ideals of its time" — encapsulates the methodology and values of scholars in the first half of the twentieth century and furnishes a glimpse into an undercurrent of rivalry among American curators. ${ }^{1174}$

The RISD Aphrodite is a fitting antiquity with which to close this discussion of Warren's bronzes in American collections. It is significant that the statuette reached

\footnotetext{
${ }^{1170}$ Richter refers to Natural History, XXXIV, 70. Lacking the archaeological context for the statuettes, Richter drew on stylistic details in her argument for the superiority of the Haviland Aphrodite: the "gentle," "quiet," and "refined" "sensitiveness" and "restraint" in the Haviland bronze is contrasted with the "dramatic" "restless," and "hard in execution" qualities in the Providence statuette. Richter 1933, 50. ${ }^{1171}$ Richter 1933, 48.

1172 Richter 1933, 50.

${ }^{1173}$ She dated the Haviland sculpture to the fourth century on the basis of its "delicacy and restraint" and declared that she could "still feel the quiet restraint of the classical age" in it; the "forms are gentler in their transitions" and "their transitions ... more refined" than in the Providence Aphrodite. Richter 1933, 50. ${ }^{1174}$ Richter 1933, 50. Richter's assertion that the Haviland Aphrodite was closer to the Greek original appears self-serving, for such a conclusion supported the Metropolitan's acquisition of it and-according to Warren - the Metropolitan's rejection of the RISD Aphrodite. See EPW to EMR, N. D. January 1926, RISDA-CF.
} 
Providence in 1926, the year that RISD's new museum building on Benefit Street was dedicated to honor Warren's friend, Eliza G. Radeke, the bronze's donor. The statuette, with its possible connections to ancient texts and its romanticized ownership history, provides a vivid illustration of the extent to which Warren is associated with the varied approaches taken in the collecting of Greek and Roman art. These range from highly subjective arguments based on style to objective assessments resting on quantifiable and technological analysis.

\section{Stone}

Warren's acquisitions of stone antiquities for American collections are numerous, second only to vases, and, as in the case of objects in other media, he sent the greatest number and variety to the MFA. Thus, selecting examples from the more than two hundred marbles he sent to Boston is a difficult task. The marble heads of Greek goddesses - the "Bartlett Head" (MFA03.743) and the Chios Head (MFA 10.70) —are among the most beloved classical sculptures in American collections. ${ }^{1175}$ Equally well known among scholars is the three-sided marble relief (MFA 08.205), commonly called the "Boston Throne," which has generated abundant speculation about its iconography and authenticity. A discussion of these three Warren sculptures will serve as the close of this section. The Roman Mercury (MFA 95.67), thought to be inspired by Polykleitos, has already been covered in the discussion of the Lewes House enterprises (Figure

\footnotetext{
${ }^{1175}$ Photographs of these two sculptures were among the sixty famous works of art in American museums in the 1967 Mademoiselle “quiz," Lerman 103.
} 
18). ${ }^{1176}$ This chapter discusses twenty additional marbles chosen to illustrate the range and significance of Warren's impact on the MFA collection.

No stone antiquities went to Bryn Mawr from Warren, and, as detailed in Chapter 3 , he sent only one marble sculpture to Harvard, the badly damaged head of a giant or barbarian (HM 1913.13) (Figure 27). ${ }^{1177}$ Although he included two small stone works among his 1901 gifts to Tarbell at the University of Chicago, including the Statuette of Aphrodite of Aphrodisias (SM 1967.115.413) (Figure 49), they are not included in this section because neither has received significant scholarly attention. ${ }^{1178}$ The University of Pennsylvania Museum of Archaeology and Anthropology purchased six marble sculptures through Warren, four of which are discussed here. With the exception of the marble relief of the sleeping Herakles (Figure 32), one of Warren's first gifts to Bowdoin already treated in Chapter 3, most of the stone sculptures in his sendings to that collegiate collection are small fragments, usually from statuettes. ${ }^{1179}$ However, Bowdoin's cinerary urn (Figure 38) warrants consideration because it is the only object of that type that Warren acquired. As is true of antiquities in other media at RISD, it is difficult to determine which marbles accessioned between 1900 and 1928 arrived through Warren. Nevertheless, archival records show that he acquired two important Roman sarcophagi

\footnotetext{
1176 Chapter 2.

1177 The scholarship on HM 1913.13 has been covered in Chapter 3.

1178 The marble statuette of Aphrodite of Ephesus (SM 1967.115.413) at the University of Chicago was discussed briefly in Chapter 3. The alabastron (SM 1967.115.547), which the Tarbell Inventory indicates as "from the Torlonia Collection," is unpublished except in the catalogue of the Smart Museum. Ferrari, Nielsen and Olson 138.

${ }^{1179}$ Warren also presented Bowdoin with four stone sculptures that lie outside the boundaries of the dissertation on Greek and Roman art: the gypsum head of Assurnasirpal II, from Nimrud (BCMA 1906.4), c. $900-850$; the alabaster head of Christ or John the Baptist, (BCMA 1906.3), c. fifteenth century reportedly from Milan; the limestone head of a bearded king (BCMA 1915.100), perhaps from Rheims Cathedral and dated to the thirteenth century; and the marble head of an old man (BCMA 1908.7), perhaps eighteenth century and bought at Naples. For the last three, Herbert 1964, 43-44.
} 
for RISD in the early 1920s. Thus, this section explores the circumstances of their arrival in Providence and the prominence in scholarship of one of them (RISD 21.074) (Figure 54).

Although most Warren antiquities in stone are marble, one intriguing exception is a seated youth with African features (MFA 01.8210), a statuette carved in steatite, a material favored in Egypt and the Near East. ${ }^{1180}$ His arms and knees are drawn up tightly to his bony body; around his ankles are what have been interpreted as bracelets or shackles (Figure 144). It is not clear whether this object is Greek or Roman, but it is dated to the Hellenistic period. The object served as a container, for the plinth upon which the figure sits is a hollow box and the seated boy serves as its cover, sliding into grooves. When this piece was included in the "Coming of Age in Ancient Greece" exhibition, the catalogue interpreted it as an example of how Africans were portrayed as "utilitarian objects no doubt deliberately related to the subservient position of blacks ... in Greek society."

Among the marble objects Warren sent to American collections are fragments of Greek and Roman architectural elements and furnishings. ${ }^{1182}$ One of the few ancient

\footnotetext{
${ }^{1180}$ Already noted in Chapter 3 was the Assyrian gypsum relief of the head of Assurnasirpal II (BCMA 1906.4). Another exception is the head of an Egyptian priest (MFA 04.749), dated to 380-343 and reported to have come from Serapeum, Saqqara. This tiny head $(10.2 \mathrm{~cm})$ in greywacke is popularly called the "Boston Green Head," and is inscribed with the name of the god, Ptah-Sokar. Like many of Warren's acquisitions, it has an interesting ownership history in that it reportedly once belonged to "'Prince Plonplon," a cousin of Napoleon III. See MFA: A Guide to the Collection of the Museum of Fine Arts, Boston , 1999, 39; the MFA Collection database, Museum of Fine Arts "MFA Collections. http://www.mfa.org " (accessed 16 July 2011).

${ }^{1181}$ Neils and Oakley 262.

${ }^{1182}$ Smaller Roman architectural fragments from Warren in the MFA have been published and exhibited, such as the capital of a Corinthian pilaster (MFA 01.8211), with a Silenus standing among acanthus leaves; and two pieces of relief from marble vases, Hermes carrying the infant Dionysos (MFA 01.8213) and a grapevine and the head of a satyr (MFA 01.8215). Vermeule 1964, 332-34; For the catalogue of "The
} 
columns that he sent to American collections is the Roman column (RISD 26.156), now dated c. 120 C.E., decorated with vines and birds, already discussed as coming from Lewes House. $^{1183}$ The annotations in the Lewes House Registers note that this tapering column (Figure 56) decorated with crisscrossing vines was composed of three pieces - or "drums — and missing its base. ${ }^{1184}$ Although the Lewes House Registers dated it to the Augustan period, the RISD Museum now labels it Hadrianic. ${ }^{1185}$ As demonstrated in a lantern slide (Figure 145) now in the RISD Visual Resources Library, the column was an appropriate antiquity for design and art history classes. A marble head and raised right arm of Dionysos (UPM MS 4027) in the Penn Museum is thought to have served as the upper part of a table support because remnants of a circular strut can be detected behind the left ear. This interpretation is suggested by intact trapezophori, or pedestals, in which the figure of an inebriated Dionysos leans against a pillar and a satyr. ${ }^{1186}$ In the marble fragment at Penn dated to the first or second century C.E., the god (Figure 40 ) rests his arm atop his wreathed head in a variation of the "Lykeios pose." ${ }^{1187}$ Such supports are common in Pompeii, often used as a single leg for marble tables set against walls. Recent

Ruins of Rome" organized at the University of Pennsylvania and the Massachusetts Institute of Technology, 1961-1963, see Smith 1960. For these fragments in the MFA sculpture catalogue, Comstock and Vermeule , 193,196-97. The three-sided relief (MFA 08.205), which may have served an architectural function, comes at the end of this section

${ }^{1183}$ For this discussion of RISD 26.156, see Chapter 3. In 2009, the RISD conservator cleaned the column and documented its condition with photographs which also show the detail in the carving.

${ }^{1184}$ The measurements and descriptions of the Lewes House Registers match those in Ridgway's catalogue. Ridgway indicates the "Provenience unknown" and "Museum Appropriation." Ridgway 1972, 114.

${ }_{1185}$ Ridgway 1972, 114. In the later period, artists imitated the natural imagery popular in the Early Empire to suggest a favorable comparison between the reigns of Hadrian and Augustus. The current RISD label speculates that the column may have come from Hadrian's Villa at Tivoli.

${ }_{1186}$ Romano 248. As explained in Chapter 3, this androgynous depiction of the god prompted questions from Drexel.

${ }^{1187}$ Similar to that of Apollo on the ivory plaque Warren gave to Tarbell discussed in Chapter 5 
research holds that such tables could have been used in public and private contexts and in religious or funerary settings. ${ }^{1188}$

Not surprisingly, Warren secured the largest and most impressive architectural marbles for the MFA. One of the largest is a pair of relief panels with griffins framed by intricate moldings (MFA 03.747 and MFA 03.748), dated to $175-200$ C.E. ${ }^{1189}$ Warren bought these panels from "a private source," who claimed they had once been on the wall of the cathedral in Sorrento. ${ }^{1190}$ The panels, now separated from each other with vertical cuts, were once part of the same architectural frieze. Although one section (MFA 03.748) is missing its upper border, the winged monster and the spirals of acanthus vine attached to its tail match those on the other relief (Figure 146). Originally the sections were joined, so that the griffins flanked candelabra, similarly depicted in the frieze of the Temple of Antoninus Pius and Faustina in the Roman Forum. ${ }^{1191}$ This piece is apt illustration of how ancient architectural pieces have survived — albeit, in a fragmentary state - through stages of "repurposing. Eventually, via Warren, these panels became "art" displayed in the classical galleries of the MFA.

Another of Warren's important Roman sculptures in the MFA is the relief of Mithras slaying a bull (MFA 92.2692), dated 125-75 C.E. It shows the god straddling the back of the bull and grasping the animal's nostrils to pull its head so that he can

\footnotetext{
${ }^{1188}$ Romano 248.

${ }^{1189}$ Comstock and Vermeule 1976, 192; Museum of Fine Arts "MFA Collections. http://www.mfa.org " (accessed 17 June 2011).

${ }^{1190}$ See MFA Collection database, Museum of Fine Arts "MFA Collections. http://www.mfa.org " (accessed 18 June 2011).

${ }^{1191}$ Kondoleon, Grossmann and Ledig 160. For a reconstruction of the frieze on the Temple of Antoninus and Faustina, c. 141 C.E., see Thomas 2007, 34.
} 
plunge a sword into its throat (Figure 147). Although the upper section and part of the right side of the relief are missing, the figure's costume - particularly the trousers, tunic, and cloak - as well as the snake with its tail wrapped around the bull's back leg and the dog attacking his throat indicates that the scene is the tauroctony, or the slaying of the bull that was the focus in underground Mithraea, shrines of Mithras, throughout the empire. ${ }^{1192}$ According to Warren's records, the relief was found near the Tiber in Rome. Research has revealed no mention of this relief in Warren's correspondence, but the fact that this impressive sculpture entered the MFA as his gift in 1892, at the very beginning of his collecting enterprise, prompts speculation as to his motives. ${ }^{1193}$ Perhaps the gift was intended to impress the MFA Trustees with his collecting prowess and generosity, for it insured that his name was linked with the sculpture on gallery labels and museum publications. In addition, beginning in the late 1890s, Belgian scholar, Franz Cumont (1868-1947) pioneered research employing archaeological evidence for Mithraism, demonstrating Warren's understanding of the importance of such sculpture. ${ }^{194}$ A photograph of Warren's 1892 gift to the MFA, in fact, was published in Cumont's influential book. ${ }^{1195}$ This gift from Warren, together with his acquisition of Rhodian jewelry and South Italian vases, suggests that he was aware of the value of antiquities from the peripheries of the Greek and Roman world. It also testifies to his recognition

\footnotetext{
1192 This scene was depicted in sculpture, wall paintings, and mosaics of mithraea.

1193 The fragmented sculpture now measures $65 \times 85 \mathrm{~cm}$, indicating that the original work was "monumental in scale." The high quality marble has been traced to Carrara and expertly carved.

${ }^{1194}$ Cumont's important study, Textes Et Monuments Figurés Relatifs Aux Mystères De Mithra., was published in 1896. Because little contemporary literature concerning Mithraism survived, Cumont relied on the sculpture, wall paintings, and mosaics to supplement the few references and inscriptions to develop an understanding of this cult's theology and rituals. For Cumont's impact on the study of "syncretism" in ancient religion, see Elm 2001. For the historiography on Mithraism, including Cumont's and recent theories, see Hinnells 1990; Swerdlow 1991; Griffiths 1991.

${ }^{1195}$ Cumont 1959, 24.
} 
that material culture is as important as philology in understanding ancient culture.

Moreover, given that the exclusively male cult was popular among Roman soldiers and veterans, the relief may had exerted a special appeal for Warren, who was in the process of setting up his own secret "brotherhood" at Lewes. Even in its damaged condition, the MFA relief remains one of the most imposing depictions of the Mithras Tauroctonos in an American collection. ${ }^{1196}$

The only architectural decoration from Warren identified as Greek is a marble depiction of Leda and the Swan (MFA 04.14), dated to the late fifth century. Although much of the sculpture is missing - the swan's head, neck, and tail as well as Leda's head, and much of her arms and right leg-the iconography is clear (Figure 148). With her dress falling unclasped below her breast, Leda presses Zeus, disguised as a swan, against her exposed body to protect the bird from an eagle which the god sent as a trick to enable his seduction of the girl. Even in its damaged state, the sculpture creates a tension in that it "both conceals and reveals the female body." 1197 Warren purchased it from the Farnese Palace at Caprarola where it had apparently been reused as a fountain during the Renaissance. ${ }^{1198}$ Some American scholars, like Caskey and Carpenter, associated it stylistically with the famous parapet reliefs from the Temple of Athena Nike on the Athenian Acropolis. Others, Comstock and Vermeule, for example, postulated that it

\footnotetext{
${ }^{1196}$ See, in contrast, the small marble fragment (76.AA.63) at the J. Paul Getty Museum. Oikonomides 1977.

${ }^{1197}$ As the label for a similar Roman sculpture at the Getty (70.AA.110) describes the composition. See "Leda and the Swan," http://www.getty.edu/art/gettyguide/artObjectDetails?artobj=7639 (accessed 7/10/12).

${ }^{1198}$ Both the heads of Leda and the swan are missing on the sculpture. A bronze water pipe in the swan's neck suggests that they were once restored in bronze so as to serve as part of a fountain. Comstock and Vermeule 1976, 29.
} 
came from the Temple of Nemesis at Rhamnous. ${ }^{1199}$ More recently, Ridgway speculated that Warren's Leda and the Swan could have been paired with Ganymede and the eagle as a pendant. ${ }^{1200}$ Whatever their conjectures about its origins and use, scholars agree that this sculpture is a fifth-century Greek original in Parian marble, likely brought to Rome as booty during the late Republic.

Other Greek sculptures in stone from Warren have funerary contexts. The widely published limestone lion from Perachora (MFA 97.289), dated to 550, sits on a plinth with his tail arranged neatly beside him and displays a gaping mouth as if roaring (Figure 149). ${ }^{1201}$ Such lions were usually created in pairs to serve as guardians in cemeteries, but no close parallel has been found for Warren's. ${ }^{1202}$ The lion has proven popular at the MFA, warranting frequent appearances in the museum handbooks; a photograph demonstrates the prominent place it was assigned in the newly renovated MFA classical gallery (Figure 150). ${ }^{1203}$ A smaller and more heavily damaged marble version of a funerary lion (RSID 15.003) at RISD is dated to 390. The posture of the RISD lion (Figure 55) indicates that it is crouched, ready to spring. Both Vermeule and Ridgeway

\footnotetext{
${ }^{1199}$ For this theory and the sculpture's bibliography, see Comstock and Vermeule 1976, 29-30.

${ }^{1200}$ Ridgway 1981, 67-8.

${ }^{1201}$ The Collections Search on the MFA website, indicates that in 1897 Warren purchased MFA 97.289 which had been found seven years earlier "at Perachora, above Loutraki, near the Isthmus of Corinth." Comstock and Vermeule 9.

${ }^{1202}$ Vermeule developed a list of Greek lions in various collections, attributing them to sculptors and matching "mates," but found none for MFA 97.289. Vermeule and Kersburg 1968, 99-101. For its extensive bibliography, see Comstock and Vermeule 1976, 10. For its context in Greek sculpture, Ridgway 1977, 152-3.

${ }^{1203}$ Chase 1950; MFA: A Guide to the Collection of the Museum of Fine Arts, Boston 1999, 64-5; Kondoleon, Grossmann and Ledig 2008, 152-53
} 
researched Greek lions of a similar date but could not identify a pendant for Warren's in Providence. $^{1204}$

Warren seemed intent on acquiring a variety of Greek funerary monuments for the MFA, and two of them have fascinating histories. ${ }^{1205}$ In 1903 he purchased the top and shaft of an Archaic grave marker (MFA 03.753), c. 550-500, which Beazley described as "one of the finest examples of archaic Greek ornament." 206 Its decoration consists of two pairs of stacked volutes with a stylized lotus at their juncture, crowned with an anthemion in the form of a seven-lobbed palmette (Figure 151). Warren purchased it from Frank Calvert (1828-1908), who discovered the site of Troy at Hisarlik before Schliemann launched his famous excavation there. ${ }^{1207}$ Calvert reportedly found the gravestone at or near the "Tumulus of Ajax" on the Hellespont and, before he sold it to Warren, displayed it for years outside his house at "Thymbra Farm," his estate at Batak in the Troad. The "Calvert stele," as the monument is sometimes called, appears in an 1892 photograph of Calvert's sister-in-law at Thymbra Farm (Figure 152). ${ }^{1208}$ In 1995

\footnotetext{
${ }^{1204}$ Vermeule identified six Greek lions in American collections, listing them chronologically and attributing them to workshops. Vermeule and Kersburg, 99 In 1968 Vermeule suggested that a lion then on the antiquities market might match the one in Providence, but Ridgway points out that, although it might have come from the same workshop, it cannot be paired with RISD's because its head turns in the same direction. Ridgway 1972, 33.

${ }^{1205}$ The limitations on this dissertation prevent a discussion of other important Greek stelae from Warren in the MFA. Noteworthy are the relief of a horse and rider from Thebes (MFA 99.339), an example of the type of monument for the equestrian class in the late Archaic period, and the Attic stele of a woman holding a mirror (MFA 04.16), dated to the Classical period. The preface to 1976 classical sculpture observes that Warren "never really cared for the canonical large Attic grave stelae." Comstock and Vermeule 1976, xii. This assertion does not seem justifiable.

${ }^{1206}$ In his essay on Warren's collecting in Burdett and Goddard 1941, 356. For MFA 03.573, Comstock and Vermeule 1976, 15-16. Warren did have a keen eye for ornament, as evident in an acroterion (MFA 04.17) of acanthus leaves from a fourth-century stele.

${ }^{1207}$ For Calvert and Schliemann at Troy, see Allen 1999.

${ }^{1208}$ Eveline Eugenie Abbott Calvert (1829-1911), a talented linguist whose prominent mercantile family lived in Smyrna, was married to Frank's older brother Frederick William ( 1882-1927), Allen 25, 28 , 85.
} 
Cornelius Vermeule added to the stele's mystery by suggesting that Hadrian erected the stele in 124 C.E. when he restored the tomb of Ajax at Troy. ${ }^{1209}$

Like the Pan Painter's vase (MFA 10.185) on which paint was once employed to render it acceptable for display in the MFA galleries, a stele from Warren (MFA 08.288) prompted concerns in the early 1900s. This tall funerary stele, dated c. 550, shows a nude athlete, crowned with the wreath of victory and holding a strap attached to an aryballos (Figure 153). Youths were invariably depicted in heroic or, as this case, athletic nudity on the stelae of this period. ${ }^{1210}$ The frontal eye and musculature of his legs and arms are also distinct Archaic conventions. His left hand holds two pomegranates, fruit with chthonic associations. Inscribed on the panel above the figure remain two letters, $\Theta \mathrm{O}$, the first two letters of a man's name that once ran vertically above the figure. ${ }^{1211}$ Warren acquired this monument in 1900 from Thebes; however, the MFA refused to purchase the stele because of concerns about museum visitors seeing the lower half of the figure's body. ${ }^{1212}$

Beazley commented:

The result of such extreme sensitiveness was that many admirable vases and other objects were not held suitable for submission [for purchase] to the trustees, and passed into the Museum as gifts, some from Warren, and some from his brother Fiske. $^{1213}$

Calvert chose the name "Thymbra" because of its associations with stories connected to the Trojan War involving Cassandra, Achilles, Trolius, and Laocoön.

${ }^{1209}$ Vermeule 1995, 473. Allen proposes that the stele may have come from the cemetery near Karanlik Limani which Calvert excavated and notes that Vermeule's entry contains "garbled family information."

Allen 358, note 24.

${ }^{1210}$ Shapiro 1991, 632.

${ }^{1211}$ Comstock and Vermeule 1976, 11.

${ }^{1212}$ The seven foot tall stele was reconstructed from five fragments.

${ }^{1213}$ Beazley, as quoted in Burdett and Goddard 355. 
Indeed, the MFA refused to purchase the stele but accepted it when it was offered as a gift from Fiske Warren in 1908. Apprently it was not in its present form when it entered the collection, because Caskey's 1925 sculpture catalogue contains a photograph of the five fragments and a drawing of their position in a proposed reconstruction (Figure 154). ${ }^{1214}$ In contrast to its initial hesitation about accepting the funerary relief, the MFA now touts the stele as one of the highlights of its classical collection, "embodying the ancient Greek ideal of arete (excellence)."1215

Yet another type of Greek funerary sculpture from Warren is the large marble lekythos (MFA 96.700) dated c. 390-380. ${ }^{1216}$ Like similar monuments from the Kerameikos Cemetery in Athens, its shallow decorative band depicts a family group (Figure 155), with the deceased and five members of his household identified. With his name inscribed above his head, Kallias, the elderly bearded man sitting on a klismos, clasps the hand of his wife, Arete, in the dexiosis, a gesture often found on grave monuments. ${ }^{1217}$ Behind her a second woman, Kallis, is in turn followed by a smaller and unnamed woman — probably a slave — with two boxes in her left hand and a cord attached to a third box in her right (Figure 155: Detail). Another young woman, Eubios, and a young man, Demainete, stand behind the chair, probably the children of Kallias. His partial nudity and the strigil he holds are signs that Demainete engaged in the athletic

\footnotetext{
${ }^{1214}$ Whitehall comments that the stele "languished in fragments for a good half century." Whitehall 674. See also, Museum of Fine Arts and Caskey 1925, 425.

1215 Kondoleon, Grossmann and Ledig 120.

${ }^{1216}$ For Greek stelae in the form of marble vases in relief and in the round, see Kurtz and Boardman 19711971, 127-29. In addition, Warren gave Bowdoin a fragment of a Roman funerary urn (BCMA 1923.42.) dated to the first century C.E. Herbert 1964, 37.

${ }^{1217}$ For this gesture in Greek funerary art, see Davies 1985, 627-29; Pemberton 1989.
} 
training expected of a freeborn son of the Athenian aristocracy. ${ }^{1218}$ This relief and inscriptions reflect the focus on the family in Athens as the center of civic life at the beginning of the fourth century. ${ }^{1219}$

Generally, Warren and the MFA favored Greek over Roman funerary sculpture; in fact, no Roman sarcophagus or cinerary urn entered the MFA through his collecting efforts. $^{1220}$ However, two Roman funerary reliefs that Warren acquired for the Museum not only provide insights into the tastes of Warren and the MFA curators of the day but also illustrate how material culture is now used to learn more about Roman women and the family. Frequently featured in publications is the Palmyrene limestone funerary relief (MFA 22.659) of Aththaia, dated c. 150-200 C.E. Palmyrene reliefs were used to seal burial compartments in the underground tombs of wealthy merchants of Palmyra, Roman Syria. Its Greek rather than Aramaic inscription, "Aththaia, daughter of Malchos, happy one, farewell," reveals "a desire to connect with the Hellenic cultural heritage of the eastern Mediterranean." ${ }^{1221}$ The deceased raises her right hand to her veil in a gesture conveying the modesty expected of women and wears an impressive array of jewelry: an engraved diadem, two necklaces, bracelets on each wrist, three rings, and a large circular brooch with three pendants (Figure 156). This remarkable sculpture has appeared in MFA collection handbooks, scholarship on ancient jewelry, and textbooks on Roman

\footnotetext{
1218 Kondoleon, Grossmann and Ledig 103. For other symbols identifying sons, see Shapiro 2003, 106.

${ }^{1219}$ Kurtz and Boardman 1971, 90, 200-01.

${ }^{1220}$ Most of MFA Roman sarcophagi arrived after 1950; a number of sarcophagus fragments came from the Charles C. Perkins collections in 1976. Well known MFA Etruscan sarcophagi arrived before and after Warren's time: MFA 86.145a,b that once belonged to James Jackson Jarves, and MFA 1975.799, the gift of Cornelius Vermeule. See also Vermeule 1962.

${ }^{1221}$ Kondoleon, Grossmann and Ledig 166.
} 
women. ${ }^{1222}$ Its inclusion in these publications is noteworthy because generally Warren and Lacey D. Caskey, the MFA Classical Curator from 1912 to 1944, were ardent Hellenists. ${ }^{1223}$ In fact, Warren did not seem attracted to reliefs from Palmyra and rarely acquired them while Caskey omitted the Palmyrene - as well the Cypriote and Etruscan—sculptures in MFA in his 1925 catalogue of Greek and Roman sculpture. ${ }^{1224}$ Thus, it is interesting that Caskey often displayed Warren's Palmyrene funerary relief of Aththaia (MFA 22.659), even when space in the classical galleries was limited. ${ }^{1225}$ The Greek inscription and the opinion that the relief possesses an "early Greek purity" may have prompted its inclusion. ${ }^{1226}$ The relief is also unusual in that Warren did not obtain it through his collecting enterprises, but rather he provided the funds with which to purchase it as a memorial to his sister, Cornelia, who had died in $1921 .{ }^{1227}$

The second relief given by Warren, a Roman tombstone with busts of a woman and her son (MFA 99.348) has been interpreted as evidence that a least some Roman

\footnotetext{
${ }^{1222}$ See the MFA publications, MFA: A Guide to the Collection of the Museum of Fine Arts, Boston, 1999, 94; Kondoleon, Grossmann and Ledig 2008, 166. For the relief as an illustration of ancient jewelry, Ogden 1982, 19. For the relief in a textbook on Roman women, see D'Ambra 2007, 127.

${ }^{1223}$ The introduction to Sculpture in Stone, "The Growth and development of the Collection," notes that Caskey, the Classical Curator (1912-44), was a "Hellenist," and, thus, not as interested in Roman sculpture. Comstock and Vermeule 1967, ix-x.

${ }^{1224}$ Warren had given another less impressive Palmyrene work in 1896 (MFA 96.682) depicting the head of priest. By 1925 the MFA had an large collection of Cypriot sculpture, the result of purchases from Luigi Palma Cesnola in 1872 and gifts from the Egypt Exploration Fund in 1886 and 1888. The publisher Dana Estes gave nine Palmyrene sculptures to the MFA in 1910. Comstock and Vermeule 1967, x, 255-60. Comstock and Vermeule also point out that curator Caskey left Palmyrene sculpture out of his 1925 catalogue and saw it "only in terms of its early Grecian purity." However, he did display Warren's "Aththaia." For Dana Estes, who also collected Cypriot and Egyptian antiquities and gave them to Bowdoin, see Herbert 1964, 3. Warren surely knew Estes through the publisher's connections with the Warren Mills

${ }^{1225}$ MFA 22.659 is usually the only Palmyrene relief in MFA handbooks. See, for example, Chase 1950, 154; Kondoleon, Grossmann and Ledig 166.

${ }^{1226}$ Comstock and Vermeule 1976, x.

${ }^{1227}$ The MFA Collections database indicates "by date unknown: Miss Amy Curtis Collection; August 24, 1922: purchased from Miss Amy Curtis by MFA with funds provided by Edward Perry Warren." (accessed 21 June 2011). For Warren's relationship with his sister Cornelia, see Chapter 1.
} 
women exercised control over the manner in which they were memorialized. The hairstyles of the middle-aged woman and her son date the monument to the Trajanic or early Hadrianic period (110-120 C.E.). This monument (Figure 157), which Warren bought in Naples, had originally been part of a roadside tomb or a columbarium, where the inscription announced that Petronia Hedone had comissioned the monument for herself, her young son Lucius Petronius Philemon, and her freedmen and freedwomen. ${ }^{1228}$ The catalogue for the 1996 "I, Claudia" exhibition noted that the commemoration of a mother and son alone is unusual and provides "definitive evidence" that the Roman matron took "pride in her social status and her role as mother." ${ }^{2229}$ One scholar argued that neither divorce nor the death of her husband explains his absence because he would have retained potestas in a divorce or would have still been memorialized if he had predeceased her. ${ }^{1230}$ Another observed that Petronia Hedone's lined face and fashionable coiffure perhaps reflect "how she wanted to appear to posterity, in contrast to portraits ... controlled by others, in particular, her husband."1231 Thus, Warren's relief provides a means of studying what Kleiner postulates to be a deliberate defiance of tradition in commissioning such a monument, evidence for a Roman woman's “willful quest for freedom." 1232

\footnotetext{
${ }^{1228}$ The inscription is translated "Petronia Hedone made (this monument) for herself and for Lucius Petronius Philemon, her son, and for her freedmen and freedwomen and their descendants." The hole at the bottom at the juncture of the busts suggests it was later used as a fountain. Comstock and Vermeule 1976, 23.

${ }^{1229}$ Kleiner and Matheson 1996, 201.

${ }^{1230}$ Kleiner 2000, 54.

${ }^{1231}$ Matheson 2000, 128.

1232 Kleiner 2000, 57.
} 
Research for this dissertation has revealed that Warren sent only one Roman cinerary urn to an American collection (BCMA 1927.20): a fragmented cylindrical marble chest with enigmatic decoration and a puzzling inscription to Bowdoin. ${ }^{1233}$ This urn (Figure 38), as will be discussed below, and a sarcophagus that he obtained for RISD figure in the ongoing debate among scholars about whether or not Roman funerary monuments reflect a belief in life after death, as Franz Cumont argued decades ago. The Bowdoin cinerarium is fragmentary, but the circular front wall and the base were restored before its arrival in 1927. The relief consists of three groups of figures, each on its own ground line: a woman with a child draped over her shoulder in a chariot drawn by winged serpents; a male figure with two bulls; and a woman holding a cornucopia who seems to be catching a falling figure. In a 1960 AJA article on the urn, Herbert stressed the challenges in understanding its iconography and determining its date. He postulated that the three scenes allude to the Orphic belief that the soul underwent a "process of ascent and descent, of death and resurrection," identifying the woman with the child as Medea escaping after the murders of her children; the man as Jason pondering how to yoke the bronze-hoofed bulls; and the woman with cornucopia as Gaea, the earth goddess. ${ }^{1234} \mathrm{He}$ also argued that this imagery was "significant and communicative," in offering evidence for the Romans' belief in life after death. ${ }^{1235}$

\footnotetext{
${ }^{1233}$ For the historiography on the scholarship of Roman ash urns, see Davies 2010, 21-39. For other urns in this shape, see Scheffer 1987, 40-53.

${ }^{1234}$ Herbert 1960a, 77.

${ }^{1235}$ In 1922 Cumont gave a series of lectures at Yale entitled "After Life in Roman Paganism," which was published under the same title, Cumont . A.D. Nock (1902-1963) countered that reliefs on ash urns and sarcophagi were merely "ornamental." Nock 1946. Herbert cites both scholars. Herbert 1960a, 77. This issue remains unresolved; in fact, references to Herbert's essay and the Bowdoin ash urn appear in a recent analysis of sarcophagi with depictions of Medea. See Gessert 2004, 230, 233. In the second part of his article, Herbert postulated that the reuse of the urn reconciles the contradiction between its Hadrianic style,
} 
According to the curatorial records, Warren gave sarcophagus fragments to both Bowdoin and RISD, but no intact sarcophagi arrived in the United States via Warren. ${ }^{1236}$ According to Vermeule, Warren did not consider sarcophagi "great works of ancient art" and he was "frightened off by the seemingly high price" of those available on the market. ${ }^{1237}$ Vermeule noted that he saw a letter from Warren addressed to his brother, Sam, indicating that when the "Triumph" sarcophagi now in the Walters Art Museum had been offered to him at more than twice what he considered their value, he did not pursue them further. ${ }^{1238}$ However, research in the RISD Archives proves that Warren did procure two Roman sarcophagi in 1921: the Pamphylian sarcophagus (RISD 21.074), c. 150 C.E. with scenes from the Trojan War, and the "Niobid sarcophagus" (RISD 21.706), c. 200 C.E. As explained in Chapter 3, Warren requested that his name not be recorded in the provenance records for the objects he obtained for RISD. Vermeule, it seems, did not know that Warren was involved in these RISD acquisitions, for he does not mention the collector in the entry for either RISD sarcophagus in his 1962 inventory. ${ }^{1239}$ Nevertheless, a series of letters and other documents in the RISD Archives verify that both sarcophagi were obtained through Warren's efforts.

craftsmanship, and Greek imagery with its inscription's more characteristically fourth-century letter formation and name ("LAMPADIUS"). As explained in Chapter 3, Herbert published the Greek and Latin inscriptions at Bowdoin, many of which were Warren's gifts to the college. Herbert 1962.

${ }^{1236}$ Warren presented reliefs with horses' heads to Bowdoin (BCMA 1915.36.1-.2) that Herbert suggested may once have been part of a chariot group on a sarcophagus. Herbert 1964. 35. The RISD classical sculpture catalogue credits Warren with a triangular relief fragment from a sarcophagus (RISD 20.327). Ridgway 1972, 105. This fact is supported by a 1920 letter in which Warren informed Radeke that "the horse's head is a gift." EPW to EMW, 29 June 1920, RISDA. Ridgway hypothesized that Warren“s donation of the horse relief may have come from a lion-hunt sarcophagus, dating it c. 220-240, perhaps from the same workshop that produced a slab in the courtyard of the Palazzo Giustiniani in Rome. Ridgway 1972, 105.

1237 Vermeule 1962, 99.

${ }^{1238}$ Vermeule 1962, 100. For these elaborate sarcophaghi, see Lehmann and Olsen 1944

${ }^{1239}$ Vermeule 1962, 105. 
Warren's first reference to the sarcophagi can be found two years before they were accessioned at RISD in what he called "a long letter before breakfast" to Radeke in July $1919 .{ }^{1240}$ In regard to two other unidentifiable sculptures RISD was then considering purchasing, he observed

Marbles are comparably cheap unless extraordinary like the sarcophagi, which indeed are monumental pieces, purchases suitable for Morgan ... People run for little things which are Greek whereas the marbles usually are not; they run for cabinet pieces; they run for bronze. But in a museum, the marbles are mainly noticed ... ${ }^{1241}$

In February 1920, he sent photographs of both sarcophagi, provided measurements, and enumerated three points which made "the purchase desirable" for RISD:

First, that you will never get such sarcophagi again; second, that Mr. Marshall has not seen them, by lucky chance ... ; third, that the exchange is so favorable that you get them at a small price. ${ }^{1242}$

Warren successfully convinced Radeke and the RISD Museum officials to purchase both sarcophagi, and they arrived in Providence in 1921, despite complications in shipping them from France. ${ }^{1243}$

\footnotetext{
${ }^{1240} \mathrm{He}$ closed the eleven page letter with the confession that his friends told him that he "confuse(s) [his] correspondents with too much and too accurate detail.” EPW to EME, 12 July 1919, RISDA.

${ }^{1241}$ EPW to EME, 1 January 1920, RISDA.

1242 EPW to EME, 7 February 1920, RISDA. Warren had introduced the second and third points in an earlier letter: EPW to EMR, 3 January 1920, RISDA.

${ }^{1243}$ Letters and a newspaper clipping in the RISD Archives reveal that a new French law regulating the exportation of art work caused a delay in shipping the sarcophagi from France in September 1920. Warren supplied "Mr. Metcalf" (presumably, Jesse Metcalf, Radeke's brother) with photographs to show that they had been shipped to Paris from Italy in 1913. EPW to Mr. Metcalf,14 October 1920, RISDA. A letter from the "Third Secretary of Embassy" in Paris (the signature of the secretary is illegible) indicates that Metcalf successfully applied in person to have the sarcophagi, resulting in the "French government" authorizing exportation "tax free" as "an exception." The "Embassy" seems to refer to the American Embassy, but no nationality is designated in the typewritten letter. "Third Secretary of Embassy" 29 November 1920 to Jesse Houghton Metcalf, RISDA. This sequence of events is supported by the fact that the sarcophagi were not accessioned at RISD until 1921.
} 
Both RISD sarcophagi acquired through Warren have appeared in publications, with the more intact Pamphylian sarcophagus (RISD 21.074) attracting attention in European, as well as American scholarship (Figure 54 ). ${ }^{1244}$ With the shift from cremation to inhumation beginning in the Hadrianic period, numerous workshops in Rome, Athens, and Asia produced elaborately carved coffins for wealthy Roman patrons. In the western part of the Empire, sarcophagi with three decorated sides were placed against the wall of the interiors of tombs while those produced in the east (such as RISD 21.074 ) with four decorated sides and gabled roofs were designed to be set up outdoors or in the middle of a chamber tomb. Based on its stylistic features, RISD's sarcophagus is thought to have been produced along the southern coast of present-day Turkey and is classified as "Pamphylian" based on a system devised by German scholars. ${ }^{1245}$

With its corners decorated with leafy acroteria, the gabled lid imitates Corinthian roof tiles terminating in lion heads. At each corner of the sarcophagus, male figures interpreted as either caryatids or the Seasons rise from acanthus clusters. ${ }^{1246}$ The relief on the front shows Achilles dragging the body of Hector before the walls of Troy and the mourning Andromache, depicted in much larger scale than other figures, seated on the far

\footnotetext{
${ }^{1244}$ This dissertation will not discuss the "Niobid sarcophagus" (RISD 21.706). See Renger 1969.

${ }^{1245}$ Rodenwaldt 1933, 188, 200-01. He placed the RISD sarcophagus in the "Pamphylian class" based on its lid. Pamphylia is a region on the southern coast of Asia Minor where workshops produced such sarcophagi. Gerhardt Rodenwaldt (1886-1945), who specialized in sarcophagi, was at the Universities of Giessen and Berlin. Medwid , 261-2. He and his student George Hanfmann (1911-86), who taught at Johns Hopkins and Harvard, had an enormous impact on American scholarship. For the historiography of this specialty favored by German scholars, Elsner 2010.

${ }^{1246}$ Young viewed the sarcophagus "architectonically." Young 1931, 144-45. Hanfmann held that the corner figures were the Seasons, speculating this typically western iconography might have been requested by a Roman patron from a workshop in Asia Minor. For an overview of this issue and others in the scholarship, see Ridgway 1972, 96-98.
} 
right (Figure 54). ${ }^{1247}$ On the back, three nude Erotes hunt lions with dogs in a rocky landscape, iconography that combines two common motifs - Cupids and hunting scenes - on sarcophagi from Asia Minor (Figure 158). On the left end, a youth hurls a boulder at a lioness who has thrown a companion to his knees (Figure 159). On the opposite end, two youths face one another from either side of a column; one rests a lyre on its capital and the other holds a horn (Figure 159).

After being published in a 1933 article in the Art Bulletin, the RISD sarcophagus became well known and now appears in textbooks for survey courses in Roman art. ${ }^{1248}$ The apparent discontinuity among the four scenes has challenged scholars attempting to interpret the meaning of the sarcophagus. In the Art Bulletin, Young ventured that the right end may depict Amphion receiving the lyre from Hermes and that, while the left has no mythological association, it might be "loosely connected in [that is, hunting] theme with the back of the sarcophagus." ${ }^{\text {"249 }}$ Ridgway offered the explanation that the two ends represent the dead man interred in the sarcophagus as

a man of culture and a man of action, on the right receiving a lyre and on the left saving a companion in danger ... The long sides can then be reconciled with the ends by visualizing the episodes from the Iliad as a typical epic subject and the lion hunt as a typical sport. ${ }^{1250}$

\footnotetext{
${ }^{1247}$ Achilles is shown twice, once confronting Hector and then mounting the chariot to which Hector's naked body is tied. Athena, Priam, and Andromache's attendant women are also present. Young discusses the various identification possibilities extensively, citing literary passages and comparanda in various media, and argues that three episodes are depicted here. Young 145-50.

1248 A. W. Lawrence (1900-91) was the first scholar to publish the sarcophagus (1929), including a photograph of the back relief (Plate 148B), which he called "a parody of a big game hunt." Lawrence 1929, 374. For the College Art article, Young 1933. For a textbook using the sarcophagus, Ramage and Ramage 2009, 253-4.

1249 Young 152

${ }^{1250}$ Ridgway 1972, 97.
} 
She admitted that she was puzzled about the discrepancies in proportion between the long and slender figures on the front side and those on the ends with the chubby and out-ofscale Erotes on the back. The current labels for the recently conserved sarcophagus (RISD 21.074) reconcile the decoration by explaining that artists with different techniques and styles often worked on the same workshop project. All the scenes, however, seem connected by the themes of courage and nobility that would honor the deceased. ${ }^{1251}$

Warren further enriched American collections with Roman portraits. Unlike Petronia Hedone discussed above, little is known about another middle-aged Roman woman whose marble head Warren acquired for the University of Pennsylvania in 1913 (UPM MS 4919). ${ }^{1252}$ This portrait (Figure 41) was meant to be inserted into a statue, as indicated by the rough surface of the underside of its "bib-bust." 1253 The ears are pierced for earrings. Parted in the middle, her hair is arranged in a variation of the melon coiffure favored by Antonia II and Drusilla, dating the head to c. $30-40$ C.E. ${ }^{1254}$ Although not a member of the imperial household, this unknown woman seems to possess nobility and strong character. ${ }^{1255}$ Perhaps it was in recognition of these qualities that this Roman portrait served as the frontispiece for the 2006 classical sculpture catalogue at Penn. ${ }^{1256}$

\footnotetext{
${ }^{1251}$ Found in fragments, the more than one hundred pieces of the sarcophagus were joined before it reached the RISD Museum. The recent conservation makes clear what is original and what is restored. Gina Borromeo, 25 July 2011, e-mail to the author.

${ }^{1252}$ For the circumstances of its acquisition, see Chapter 3.

${ }^{1253}$ For older women in Roman art, Matheson 2000.

${ }^{1254}$ Romano 204-05. For Tiberian and Caligulan portraits, Rose 1997, 65-8.

${ }^{1255}$ Romano 205.

${ }^{1256}$ Romano 205.
} 
Other Roman portraits from Warren are among the best-known sculptures in American collections precisely because they are more easily identifiable. Spotlighted as the frontispiece of the MFA's 1976 classical sculpture catalogue, the head of Augustus (MFA 99.344) has been widely published and exhibited in American exhibitions (Figure 160). ${ }^{1257}$ Reportedly found in Ariccia in the late eighteenth century, it was once in the collection of the Cardinal Despuig (1745-1813) on Majorca, where it underwent restorations before Warren's purchase. Carved from Parian marble, the idealized head was intended to fit into a full length statue. Although scholars agree that it is a posthumous portrait, they disagree about its dating: the suggestion in the 1940s was that the Antinous-like curls are Hadrianic (117-38 C.E) while recent MFA publications propose a date in the reign of Claudius (41-50 C.E.). ${ }^{1258}$ Another well-known sculpture from Warren is the head of Antoninus Pius (BCMA 1906.1), one of his first gifts to Bowdoin, previously discussed in Chapter 3. Since portraits served as the symbolic presence of the emperor at official ceremonies throughout the Empire, they were based on standard models to insure immediate recognition. Thus, with the Bowdoin head (Figure 31), like others in a group that scholars call the "Formia Type" with the distinctive curls on the forehead, the emperor is depicted as "a never aging adult with the same curly hair and short but plastically rendered beard" of his adopted father,

\footnotetext{
${ }^{1257}$ It was in an exhibition at Metropolitan Museum of Art in 1939, the Harvard's Fogg in 1949, and the Worcester Museum in 1952. For its bibliography, Comstock and Vermeule 1976, 208. See also Kleiner 1992, 69, who identifies the MFA portrait of Augustus as having the "Primaporta coiffure." Warren also gave a Roman portrait head (BCMA 1913.58) to Bowdoin, which Herbert lists as "perhaps of the emperor Claudius." According to Herbert, Cornelius Vermeule noted the resemblance of Bowdoin's head to portraits of Claudius. Herbert 1964, 37.

${ }^{1258}$ For a Hadrianic date, Comstock and Vermeule 1976, 208. For Claudian, MFA: A Guide to the Collection of the Museum of Fine Arts, Boston 199, 86; Museum of Fine Arts "MFA Collections. http://www.mfa.org " (accessed 22 June 2011).
} 
Hadrian. ${ }^{1259}$ Bowdoin's Head of Antoninus Pius was featured in the exhibition "I, Claudia," as well as in a popular American textbook. ${ }^{1260}$

Other Roman portrait heads are imaginary likenesses of Greek authors, functioning for the Romans as "icons in a peculiar cult of Greek culture and learning." Although Greek artists had produced only full life-size portraits, the Romans usually had only the heads copied and placed on busts or herms. Scholars have focused on identifying and dating these portrait heads: the best known American publication, Richter's threevolume The Portraits of the Greeks (1965), was organized chronologically according to when the subjects lived. ${ }^{1262}$ Portraits of the Greek playwright Menander were clearly popular with the Romans because Richter recorded fifty-four marble versions of it. ${ }^{1263}$ Warren acquired two in 1897 and Richter included both in her work. Scholarly discussions of Warren's Menaders, both dated to the Early Empire, inevitably turn to how close they are to the lost bronze statue created by the sons of Praxiteles for the Theater of Dionysos in Athens soon after the playwright's death. ${ }^{1264}$ Warren sent one of the "hermbusts" of Menander (MFA 97.288), reportedly found in Torre Annunziata, near the Bay of Naples, to Boston. This widely published bust (Figure 161), carved from Pentelic marble and dated to the Roman Imperial period, has slots in both shoulders for wooden

\footnotetext{
${ }^{1259}$ The portraits of Antonius Pius are classified in three types. Kleiner 1992, 268. In 1939 the Max Wegner categorized Bowdoin's head as a "free repetition of the "Formia" type created at the beginning of his reign. However, Herbert judged it superior to those in the group. Herbert 1964, 42.

${ }^{1260}$ Museum of Fine Arts 1972, Number 54; Kleiner and Matheson 1996, 71; Ramage and Ramage 2009, 259.

1261 Zanker 1995, 10.

1262 Richter 1965. For the historiography through 1950, see Bieber 1955, 254.

${ }^{1263}$ Richter 1965, 224. A more recent inventory is seventy-one. Zanker 1995, 80.

${ }^{1264}$ Pausanias $(1.21,1)$ refers to this bronze statue by Kephisodotos and Timarchos. Its inscribed base was discovered in 1862 behind the Theater of Dionysos in Athens. Romano 69. For a recent reconstruction of the statue via plaster casts, Zanker 1995, 78-80. For the Greek context for such honorific portraits, Dillon 2006, 102.
} 
inserts from which garlands were hung. ${ }^{1265}$ Warren retained the other bust of Menander (UPM MS 4028) at Lewes House for four years until he sold it to Penn in 1901 in the group of marbles funded by Lucy Wharton Drexel. ${ }^{1266}$ This portrait bust (Figure 162) is interesting because much more is known about its archeological context. According to Lucio Marianai, the Italian archaeologist and antiquities dealer who published the circumstances of its finding in an 1897 report, the Penn Menander was found in a Roman villa at Montecelio, with at least ten other marble sculptures appropriate for a display in a garden or portico. $^{1267}$

The best known of the portraits of "Greek intellectuals" from Warren is the head of Homer (MFA 04.13), which Warren purchased in Rome and exhibited in the Burlington Fine Arts Club in London before sending it to Boston. The MFA announcements rated its importance as equal to that of the "Marlborough cameo" and appraised the depiction of Homer as "one of the finest of those extant." 268 Despite the loss of most of its nose and a fragment from the right side of the neck, the skillful carving of the poet's hair, beard, and face conveys the powerful personality of the legendary poet (Figure 163). Other details make his identity obvious: the ribbon, awarded to victors in athletic and artistic competitions, around the balding head testifies to his poetic accomplishments while the lidded eyes and raised eyebrows suggest his blindness. Its size and the working on the base of the neck indicate that the head, dated to the Late Republic or Early Imperial periods, was intended to be inserted in a life-size sculpture,

\footnotetext{
${ }^{1265}$ MFA Collection database, Museum of Fine Arts "MFA Collections. http://www.mfa.org " (accessed 17 July 2011). For its extensive bibliography, see Comstock and Vermeule 1976, 77-78.

${ }^{1266}$ See Chapter 3.

${ }^{1267}$ Neudecker 1988, 170-71; Romano 69-71.

${ }^{1268}$ Two Greek Marbles Recently Acquired 1905, 4; Gilman 1907, 44
} 
perhaps in a gallery of Greek poets, playwrights, and philosophers in a Roman library or garden. ${ }^{1269}$ Zanker interprets the muscles on the brow and forehead as "active features" resulting in "highly dramatic" vision of the "divine Homer."1270

Two marble heads of goddesses - the "Bartlett Head" (MFA 03.743) and Youthful Goddess" or "The Maiden of Chios" (MFA 10.70) — are among the most iconic sculptures in the MFA collection (Figure 164 ). In 1903, “The Bartlett Head” (MFA 03.743), usually identified as Aphrodite with her hair caught up with ribbon and knotted twice behind her head (Figure 165), arrived in a shipment of almost three hundred antiquities from Lewes House, financed through a \$100,000 unrestricted gift from the Boston attorney, Francis Bartlett. ${ }^{1271}$ Matthew Stewart Pritchard, one of Warren's Lewes House assistants, purchased the head in Athens, reportedly after the wife of its owner assured him that Praxiteles was the sculptor. ${ }^{1272}$ Soon after its arrival, the Bartlett Head was the focus of popular adulation, prompted to a large extent by Baldwin Cooper's photographs commissioned by the MFA. ${ }^{1273}$ By 1905, the survey of classical sculpture accompanying the "University Prints" used widely in American colleges and universities

\footnotetext{
${ }^{1269}$ Kondoleon, Grossmann and Ledig 16. For the extensive bibliography on the portrait of Homer, Comstock and Vermeule 1976, 75

${ }^{1270}$ Zanker 1995, 159-71.

${ }^{1271}$ For the January 1900 letter from Edward Robinson to Edward Perry Warren about the bequest,. Whitehall 162-3. For Francis Bartlett (1836-1913), who provided several large gifts used to expand the MFA classical collection, see Whitehall 162-3,169, 292. A search of the MFA Collection database with Credit Line $=$ Francis Bartlett produced 999 results (accessed 21 July 2010).

1272 Sox 1991, 176. According to Sox, who had access to an unpublished biography of Matthew Pritchard, the sale was made at a tennis party in Athens. The MFA collection database gives the findspot as "opposite the Monasteri Rwy station, Athens." The owner was "Mr. Pallis."

${ }^{1273}$ Baldwin Cooper's photograph of the Bartlett Head for the MFA is the style of the Adolphe Braun, the photographer for the Vatican and the National Museums of France during the 1860s and 1870s, Bergstein 1992. Caskey credited Cooper with taking fifty-four of the photographs for the 1925 MFA sculpture catalogue. Museum of Fine Arts and Caskey
} 
included a photograph of the Bartlett Head. ${ }^{1274}$ In The American Light (1907), Henry James wrote an ekphrasis, entitled "The Lonely Aphrodite" in which he described his emotional experience with the masterpiece." 1275 Recent studies on the influence of photography and art history on Sigmund Freud suggest that a photograph of the Bartlett Head had an impact on his theories. ${ }^{1276}$ The earliest scholarship on the sculpture was John Marshall's 1909 description and announcement in the German Archaeological Institute's Antike Denkmäler. ${ }^{1277}$ In 1925 Caskey accounted for the similarity between the MFA's head and those on famous Praxitilean sculptures like the Hermes and the Knidian Aphrodite with the hypothesis that the MFA's sculpture had been created by "a contemporary sculptor under his influence," a theory repeated in the MFA sculpture catalogue fifty-years later. $^{1278}$ The Bartlett Head is frequently cited as a comparandum to other sculptures and appears in numerous popular publications on sculpture. ${ }^{1279}$

The second head Warren sent to Boston, (MFA 10.70), the "Youthful Goddess" or "The Maiden of Chios," was famous before it reached the MFA because Warren displayed it in the 1903 Ancient Greek Art exhibition in London. ${ }^{1280}$ Its head, neck, and

\footnotetext{
${ }^{1274}$ See Plate 46 in von Mach 1905.

1275 James 1907.

${ }^{1276}$ Antiquities and photographs of them functioned in "the metaphorical guise of memories and daydreams" in Freud's theories. One of the books in Freud's library, Maximilian Ahrem's Das Weib in der antiken Kunst (1914), contained a photograph of the Bartlett head. Bergstein 2010, 37-42, 163.

${ }^{1277}$ Marshall 1909b. For the photograph, see Plate 60.

${ }^{1278}$ Museum of Fine Arts and Caskey 71; Comstock and Vermeule 1976, 39.

${ }^{1279}$ For the Bartlett Head, see the classical sculpture catalogue for the Santa Barbara Museum of Art, del Chiaro 1984. For the Bartlett Head in a popular or "coffee table book," von Holst 1967, 259. For the bibliography of the Bartlett Head, Comstock and Vermeule 1976, 39.

${ }^{1280}$ The head was found on the island of Chios during the Crimean War (1884-85) and passed through several Greek owners before Warren bought it in 1900. After lending the sculpture to the MFA in 1909, Warren sold it to the Museum. For the provenance/ownership history of MFA 10.70, see the Collection database on the MFA website. Museum of Fine Arts "MFA Collections. http://www.mfa.org " (accessed 22 July 2010). For the efforts to raise the funds to purchase the head, see Whitehall 168. Also, Burdett and Goddard 229.
} 
shoulders were shaped for a draped statue; a mantle once covered the head and would have cast shadows on the face (Figure 166). Her gaze and the softness of the face were immediately recognized as characteristics of the work of Praxiteles. Marshall, who had found the head in Greece, became obsessed with defending it. ${ }^{1281}$ In a 1903 exchange in The Burlington Magazine for Connoisseurs, Marshall vigorously responded to assertions that the piece had been "reworked," citing the opinions of Auguste Rodin who had seen the sculpture in London. ${ }^{1282}$ Rodin himself contributed a rhapsodic ekphrasis in a French publication about "La tête Warren.",1283 Then, in 1909, the year before the MFA accessioned the piece, Marshall published a lengthy article, "Of the Head of a Youthful Goddess, found in Chios," in Antike Denkmäler in which he compared it with other ancient sculptures attributed to Praxiteles or his influence, employing photographs of casts of the Chios Head. ${ }^{1284}$ Research for this dissertation in the archives of Sackler Library of the Ashmolean has led to the discovery of a stack of papers and notebooks that likely are Marshall's drafts and notes for this essay. ${ }^{1285}$ Investigations at the British School in Rome during the last decade uncovered a set of almost ninety photographs that Marshall used in his effort to authenticate the Chios Head and justify its significance; they include plaster casts of details of the head as well as studies of other marbles. ${ }^{1286}$ Rodin, a friend of Warren and Marshall and himself an avid antiquities collector, shared

\footnotetext{
${ }^{1281}$ Warren expressed unwavering confidence in Marshall's acquisition of the head. See excerpts from letters, Burdett and Goddard 216-17.

1282 Marshall 1903.

1283 Rodin 1904.

1284 Marshall 1909a.

${ }^{1285}$ These fragile papers in the Sackler were in such disorganization that it was impossible to examine them thoroughly.

${ }^{1286}$ Crawford 2003. Crawford was attempting to reconstruct the extensive collections of photographs at the British School in Rome when he discovered the photographs in a drawer with Marshall's annotated card index. Caesare Faraglia, a photographer employed by academics and collectors in Rome, took many of these photographs.
} 
Marshall's obsession with the sculpture. In letters to Warren and Marshall, he extolled "the half-open lips" and compared the marble to "a flower, a perfect jewel" and offered to trade a group of his own sculptures for it with the promise that, after his death, the head from Chios would return to Warren. ${ }^{1287}$ A photograph of "La Tête Warren" that Rodin cherished is now in the Musée Rodin. ${ }^{1288}$ The enigmatic sculpture's extensive bibliography is ample proof of its allure in scholarship as well as popular publications. ${ }^{1289}$ The presence of the "Youthful Goddess, found at Chios" in recent articles on the history of photography testifies to its enduring appeal as does its appearance in Greek art and archaeology text books. ${ }^{1290}$ A photograph of the sculpture graced the recent cover of one of the most popular American textbooks used to teach the survey of art history. ${ }^{1291}$

The three-sided relief (MFA 08.205), popularly called "The Boston Throne," which the Museum now dates to the Classical period, c. 450-440, serves as an appropriate close for this catalogue of Warren antiquities in American collections, for it has proven to be his most controversial acquisition. The scholarship is substantial: the bibliography requires four single-spaced columns in the MFA catalogue on marble sculpture. ${ }^{1292}$ The work had been in Warren's possession for over a decade before it entered the MFA Collection in 1908. According to Beazley, Warren bought the relief in Rome in 1896

\footnotetext{
${ }^{1287}$ Garnier 2009.

1288 The photograph taken around 1904 by Frederich Hollyer (1837-1933), a British engraver and photographer, shows the Chios Head on a slanted wooden base. See Figure 17, Garnier .

${ }^{1289}$ Twice as many entries are listed in the bibliography for the Chios Head as compared to that of the Bartlett Head in the 1976 catalogue of the classical stone sculpture in the MFA. See Comstock and Vermeule 1967, 40-41.

${ }^{1290}$ For recent scholarship in the history of photography that address the role of the Chios Head, see Bergstein 1992; Hariharan 1992; Crawford 2003. For a textbook which employs it as an example of original fourth-century Greek sculpture, Biers 271.

${ }^{1291}$ Kleiner 2010.

${ }^{1292}$ Comstock and Vermeule 1976, 24-25.
} 
after much negotiation, but it remained in Lewes for over a decade before its arrival in Boston and was not exhibited until 1909 when it was installed in the new MFA building on the Fenway. ${ }^{1293}$ The MFA catalogue's description of the findspot is as mysterious as the sculpture's iconography: "Found, according to rumor, in the same region as the Ludovisi Relief, in the area of the ancient Gardens of Sallust” in Rome. ${ }^{1294}$ The arguments about the Boston Throne's iconography and authenticity stress its connection to the Ludovisi Relief — now in the Palazzo Altemps in Rome and dated c. 480-470which Warren also attempted, unsuccessfully, to obtain for Boston. ${ }^{1295}$ The Ludovisi "Throne" is usually thought to depict the birth of the transparently draped Aphrodite from the sea assisted by two women, with side panels of a draped woman holding an incense burner and a nude girl playing the pipes. ${ }^{1296}$

The iconography of the Boston sculpture is more enigmatic: on the central panel a nude boy stands with outstretched wings and a veiled woman is seated on either side, one lifting her left hand and smiling while the other bows her head (Figure 167). The slots cut into the middle of the panel are thought to have secured a metal scale. Two seated figures

\footnotetext{
${ }^{1293}$ Burdett and Goddard refer to Warren's "enthusiasm and self-sacrifice" in holding the relief until "the Museum could be induced" to buy it. Burdett and Goddard 71. Most of the other references to the relief in Burdett and Goddard are in Beazley's essay, "Warren as Collector."

${ }^{1294}$ Comstock and Vermeule 1976, 20. The MFA Collection database provide more specific information: "Found in Rome in a private villa on via Boncampagni in the same region as the Ludovisi relief, in the area of the ancient Gardens of Sallust (the Ludovisi Quarter) on the Pincian Hill; acquired successively by Valenzi, Jandolo, Martinetti, and Hartwig before being purchased by Edward Perry Warren in 1896; purchased by MFA from Edward Perry Warren, May 5, 1908 ... "”

${ }^{1295}$ For what is known about the discovery of both "Thrones," see Hartswick 119-24. For the topography and history of the general area of the findspot, see pp. 1-30.

${ }^{1296}$ One widely used textbook on Greek art discusses the Ludovisi Throne as an example of "the Western Greek trait" of transparent drapery, notes that it shares themes found on terracotta reliefs from Locri, and suggests it may have "decorated an architectural feature of the Temple of Aphrodite" there, thus dating it to 480-70. Pedley 240-41.
} 
are depicted on the side panels: a young man plays a lyre and an aged woman holds a now missing object, chiseled off before the relief's discovery (Figure 168).

The Boston Throne prompted debate about its iconography, origin, function, and authenticity immediately upon its arrival at the MFA. The stream of articles about the relief began with Warren's close friend, John Marshall, and their German associate, Franz Studniczka (1860-1929) in the Burlington Magazine and the Jahrbuch des Deutschemark Archaölogischen Instituts. ${ }^{1297}$ Most scholars identified the winged youth as Eros engaged in judgment, but the interpretations of the overall scene differed. Some argued he was weighing the souls of heroes-Achilles and Hector or Achilles and Memnon — while others favored the dispute over Adonis between the goddesses Aphrodite and Persephone. ${ }^{1298}$ By1925, the MFA catalogue listed well over twenty-five scholars who had written about the relief, including Arthur Fairbanks, Salomon Reinach, Ernest Gardner, George H. Chase, Richard Norton, Gisela Richter, and Harriet Boyd Hawes. $^{1299}$

As early as 1913, scholars expressed reservations about the relief. ${ }^{1300}$ Questions surfaced about the Boston Relief's authenticity chiefly because Warren purchased it through Paul Hartwig, Wolfgang Helbig, and Francesco Martinetti, all of whom were

\footnotetext{
${ }^{1297}$ Marshall 1910; Studniczka 1911. Studniczka, Professor of Archaeology at the University of Leipzig from 1896 to 1929, based his interpretation on parallels with scenes on Attic vases. The vases and shards with the notations "to Leipzig" in the Lewes House Registers likely went to Studniczka

${ }^{1298}$ For a summary of the various theories, see Richter 1920; Caskey 1918

${ }^{1299}$ For the bibliography, Museum of Fine Arts and Caskey 1925, 93-4.

${ }^{1300}$ See Gardner 1913 E. A. Gardner was a specialist on ancient sculpture and the brother of Oxford's Percy Gardner. Richard Norton, the son of Charles Eliot Norton and himself an antiquities agent in Rome before the First World War, answered Gardner's assertions. Norton 1914.
} 
associated with forgeries of antiquities. ${ }^{1301}$ Nevertheless, the MFA has continuously displayed Warren's “three-sided relief," and published a defense of its authenticity in 1968 citing technical analyses. ${ }^{1302}$ In 1996, the Ludovisi and Boston Thrones were exhibited side by side in the exhibition, "Magna Graecia," in Venice inciting more controversy about the authenticity of the relief that Warren acquired for Boston a hundred years earlier. ${ }^{1303}$ The 2008 guide to the MFA classical collections sidestepped the issue of the sculpture's legitimacy by admitting that "occasionally" doubts have been raised about the relief and then explaining the "most satisfying interpretation of [its] enigmatic scene."1304 Ridgway, one of the foremost American specialists in Greek sculpture, stressed that evaluating the legitimacy of the Boston Throne is "compounded by the failure so far to reach a clear understanding of its counterpart in Rome" and that she tentatively accepts(ed) that both thrones were made around 460-450, in a workshop strongly open to northern Ionic influences, and were taken to Rome simultaneously for cultic purposes, perhaps during the Late Republican period. ${ }^{1305}$

\footnotetext{
1301 These friends of Warren and Marshall and fellow antiquities agents in Rome were discussed in Chapter 2. One recent accusation in this vein came from Thomas Hoving (1931-2009), Director of the Metropolitan Museum of Art from 1967-77, who blamed Wolfgang Helbig: “ . . it is a fake, a wholesale phony concocted by one of the more amazing forgery gangs ever to have plied the dark trade, led by a faker with the most chutzpah in history." Hoving 257.

1302 This defense ends scathingly: “ . . . the claim that the Boston relief is a forgery can, except as a psychological curiosity, now be forgotten, together with the misguided ingenuity, the misleading scholarship, the innuendo, and even, lately, the arrogance with which it has been supported." Young and Ashmole 1968, 159.

${ }^{1303}$ See Eisenburg 1996, who claims that both "thrones" are modern forgeries. For the MFA position, published as part of a symposium on the two three-sided reliefs, Herrmann 1997.

${ }^{1304}$ In this scenario, Aphrodite and Demeter are determining how long Persephone must stay in the Underworld with her abductor, Hades, by means of a now missing metal scales held by Eros. The slot in the higher position near Demeter indicates that mother's love triumphs, for it was ultimately decided that Persephone would spend more of the year aboveground. The catalogue entry ends ". . . scientific studies of their surface and historical research on their provenance provide strong evidence of authenticity."

Kondoleon, Grossmann and Ledig , 88.

${ }^{1305}$ Ridgway 1990b, 241-42.
} 
The controversies that continue to swirl about the Boston Throne demonstrate that Warren's sculptures continue to be important in the study of Greek and Roman art. His acquisition of the relief (MFA 08.205) represents the heights of his risk-taking, for he held the sculpture for twelve years (1896-1908) before the MFA agreed to its purchase. Flush with capital at the onset of his collecting enterprise, he rushed to purchase for the MFA what he believed to be one of the few remaining monumental Greek marbles available at the turn of the century. ${ }^{1306}$ The bibliography of Warren's relief is a veritable Who's Who of twentieth-century specialists in Greek sculpture. The volume of scholarship on the iconography and authenticity of this controversial sculpture alone substantiates the impact of Warren's collecting on the study of classical art in America.

\footnotetext{
${ }^{1306}$ Research for this dissertation has not revealed any doubts on the collector's part about the authenticity
} of his famous piece. 


\section{CONCLUSION}

In his acquisition of Greek and Roman art for the Museum of Fine Arts, Boston and academic collections, Edward Perry Warren embodied the noblesse oblige that created important cultural and educational institutions in the Gilded Age. In many ways, he was a product of his nouveau riche family. His philanthropic inclinations were akin to those of his parents and his sister Cornelia. His speculations in the antiquities market indicate that he was an opportunist, like his father. Despite their differences in taste, he and his mother shared an obsessive need to acquire objects and express themselves through décor. Similar to his reclusive brother Henry, Warren was drawn to scholarship; however, like Henry and the eccentric Fiske, his interests and idiosyncrasies relegated him to the fringes of Brahmin Boston, elite Harvard, and — in Ned's case-donnish Oxford. In the heydays of his antiquities enterprise, he and his elder brother Sam, the MFA trustee, were allies in expanding that museum's classical collection. However, conflicts between the brothers over the management of the Warren Trust and profound differences in their values resulted in estrangement and Sam's suicide.

Warren's openness about his homosexuality coupled with the lack of attention given to the role of the collector/agent resulted in his relative anonymity in scholarship and the histories of museums and collections. However, beginning in the 1970s with the focus on social art history, scholars and curators began to acknowledge Warren when 
they realized that his antiquities serve as the means of exploring daily life, polyvalence, the art of the non-elite, and gender/sexuality in the Greek and Roman world. ${ }^{1307}$ The collector's connoisseurial vision extended to those antiquities that testify to the ancients' sense of playfulness and humor. More recently, specialists investigating visual cultural as a means of understanding sexual identity in the late nineteenth and early twentieth centuries are turning their attention to Warren and his Lewes House circle.

Much in Warren's life and work remains puzzling. Although he enrolled in Charles Eliot Norton's classes in art history at Harvard, he neither took Harold North Fowler's pioneering courses in archaeology nor participated in the activities of the newly formed Archaeological Institute of America. Instead, Warren fled Boston for philhellenic, homosocial Oxford where the tutorial system and the burgeoning interest in classical art reinforced his romanticized notions of male-friendship and inspired his collecting enterprises. At Oxford, Warren formed life-long life bonds: foremost were those with his lover and business associate John Marshall, who served as the collecting agent for the Metropolitan Museum of Art, and J. D. Beazley, who became one of the most influential scholars in classical art and archaeology. Even though he spurned Boston, he devoted himself to expanding the MFA holdings in Greek and Roman art beyond the traditional cast galleries. Even after the MFA's priorities changed from the expansion of its classical collection, as he advocated, to the construction of more spacious facilities on the Fenway, Warren continued to provide antiquities to the museum. Despite his disdain for American education, he provided hundreds of Greek

${ }^{1307}$ For social art history, Clarke 2003a, 1. 
and Roman objects for collegiate museums and teaching collections, most impressively for Bowdoin and RISD.

Through his collecting ventures, Warren forged links in the United States, first with Edward Robinson at the MFA and, then in the 1920s, with Eliza Metcalf Radeke, the patron and guiding force of the Rhode Island School of Design Museum of Art. Without question, Warren had a pivotal role in forming this collegiate museum: sculptures, such as the bronze statuette of Aphrodite (RISD 26.117) and the Roman sarcophagi (RISD 21.074 and 21.076), as well as vases he obtained for RISD have been published widely. The letters of Radeke and Warren offer insights into the backstage wheeling-dealing of the antiquity enterprises of their day. Their correspondence testifies to her unwavering determination to establish a high quality museum in Providence as well as the friendship that developed between these remarkable individuals in the last decade of their lives.

This dissertation provides an assessment of Warren's contributions to six important collegiate collections in the United States and an estimation of his role at each institution. His connections with the Harvard and Chicago remain hazy. In 1895 at the onset of his Lewes enterprises, Warren provided an assortment of Greek vases when Harvard's Fogg Museum was established and his friend, Edward Robinson, inaugurated courses on the ancient vessels. The arrival of his gift of the damaged Colossal Head (HM 1913.13) almost two decades later coupled with the cursory references to Warren's collecting in the Harvard publications, correspondence files, and curatorial records suggest a rivalry — perhaps disapprobation — between Warren and Edward Forbes. The circumstances surrounding Warren's donation of various small and unusual antiquities to 
Frank Tarbell at the University of Chicago are unclear as well. One can hypothesize that Tarbell became acquainted with Warren or his circle in Rome and Athens in the 1880s and 90s. The Tarbell Inventory and the notations in the Lewes House Registers verify the gifts, yet the archives at Chicago reveal little about Tarbell and nothing about his connection to Warren or Lewes House. Nevertheless, the vases and fragments from Warren at Chicago inspired Tarbell and his successor, Franklin Johnson, to contribute to the emergent American scholarship.

Warren was most generous to Bowdoin College, where his donation of more than five hundred objects over twenty-five years of patronage constitutes the foundation of its premier antiquities collection. Correspondence and reports at Bowdoin chronicle two decades of Warren patronage. The collector not only supervised the display of antiquities in the Bowdoin galleries and wrote a preface to a brief catalogue in 1924, he also proposed that Beazley should write a comprehensive guide to his collection. Although the Beazley catalogue never came about, Beazley exchanged information about Warren vases in the early 1940 s with G. Rogers Edwards, who had been inspired as a Bowdoin student to become a vase scholar. Warren's gifts were spotlighted in the 1960 s through the publications of the Bowdoin professor, Kevin Herbert, and in the college's recent exhibitions, most notably “Ars Antiqua” (2005).

In comparison to Bowdoin, RISD, and Chicago, Warren's influence was less at Bryn Mawr. He sold to thirty-one ceramic pieces_-principally fragments of Greek vases - to Joseph Hoppin, one of the first American vase specialists, who founded that college's teaching collection. The Lewes House Registers confirm Hoppin's inventory list at Bryn Mawr and shed light on provenance and ownership history of these materials. 
Research does not reveal further Warren connections with Bryn Mawr; nonetheless, the arrival of the Lewes House fragments marks the beginning of that college's focus on ancient painting. Warren conveyed seven Roman marbles to University of Pennsylvania Museum of Archaeology and Anthropology. He was one of several expert connoisseuragents whom Sara Yorke Stevenson and George Byron Gordon employed to build Penn's classical collection, where the portrait heads from Warren, Menander (MS 40208) and the Middle-Aged Woman (MS 4919), are two of the best-known sculptures. Letters in the Penn Museum Archives suggest that Stevenson and Warren had a cordial business-like relationship while Warren and Gordon may have been friends.

This dissertation discusses only a fraction of the thousands of Warren antiquities in American museums, yet it offers ample proof of the collector's impact on scholarship and exhibitions in the United States. It puts him into the context of other important—and until now, better-known-American collectors and museum-patrons like Forbes and Loeb. Warren's focus, as shown here, was building collections rather than erecting structures. His taste in Greek and Roman art was encyclopedic, encompassing diverse media and periods and including objects from humble as well as élite social strata. Warren's labor on behalf of the MFA and collegiate collections was pivotal in expanding the study of Greek and Roman culture beyond the boundaries of classical philology and the plaster copies of canonical sculpture. His collecting has provided students, scholars, and museum visitors with opportunities to ponder a variety of ancient objects, which both delight and confound their viewers.

Above all, this dissertation underscores the fact that additional research on Warren's collecting is warranted, especially in the Lewes House Registers. The 
preservation of these valuable resources is paramount, perhaps through digitalization, which would also make them more accessible. The Lewes House Registers offer promise for identifying more antiquities from Warren at RISD as well as vases in the Reading and St. Louis Museums. Further work with the Registers could also result in a data base that scholars and curators could employ to "join" fragments of ancient vases, terracottas, ivory, jewelry, glass, bronzes, and marbles scattered in American, British, and German teaching collections and museums. Finally, this dissertation justifies the organization of an exhibition devoted to Warren's "sendings," a project that would illustrate the breadth and depth of his collecting as well as its impact on the rise of Greek and Roman art history as an academic discipline in the United States. 


\section{REFERENCES}

The Shelley's http://www.the-shelleys.co.uk/ (5 April 2010).

Abt, Jeffrey and Richard A. Born. 1990. "A History of the Collection." In The David and Alfred Smart Museum of Art: A Guide to the Collections. 13-9. New York: Hudson Hills Press.

Albersmeier, Sabine. 2009. Heroes: Mortals and Myths in Ancient Greece. New Haven, CT: Yale University Press.

Aldrich, Robert. 1993. The Seduction of the Mediterranean: Writing, Art, and Homosexual Fantasy. London: Routledge.

Alexander, Christine. 1953. "A Portrait of Livia." The Metropolitan Museum of Art Bulletin, New Series 11 (6): 168-71.

Allen, Susan Heuck. 1999. Finding the Walls of Troy: Frank Calvert and Heinrich Schliemann at Hisarlik. Berkeley, CA: University of California Press.

Amfitheatrof, Erik. 1980. The Enchanted Ground: Americans in Italy, 1760-1980. Boston: Little, Brown and Company.

Amory, Cleveland. 1947. The Proper Bostonians. New York: E. P. Dutton \& Co, Inc.

Anderson, Patricia McGaw. 1998. The Architecture of Bowdoin College. Brunswick, ME: Bowdoin College Museum of Art.

Andrén, Arvid. 1986. Deeds and Misdeeds in Classical Art and Antiquities. Partille, Sweden: P. Äström. 
Andrews, Henry. 1920-21. "Report of the Director of the Museum of Fine Arts." Report of the President of Bowdoin College

Andrews, Henry. 1923. "Report of the Director of the Museum of Fine Arts." Report of the President of Bowdoin College

Andrews, Henry. 1924. "Report of the Director of the Museum of Fine Arts." Report of the President of Bowdoin

Andrews, Henry. 1925. "Report of the Director of the Museum of Fine Arts." Report of the President of Bowdoin

Andrews, Henry. 1926. "Report of the Director of the Museum of Fine Arts." Report of the President of Bowdoin College

Andrews, Henry. 1928. "Report of the Director of the Museum of Fine Arts." Report of the President of Bowdoin

Andrews, Henry. 1930. Descriptive Catalogue of the Paintings, Sculpture and Drawings of the Walker Collection. 4th ed. Brunswick, ME: The Record Press.

Andrews, Henry. 1931. "Report of the Director of the Museum of Fine Arts." Report of the President of Bowdoin College

Andrews, Henry. 1933. "Report of the Director of the Museum of Fine Arts." Report of the President of Bowdoin College

Aphrodite and the Gods of Love. 2011. Edited by C. Kondoleon. Boston: Museum of Fine Arts, Boston.

Arnold-Biucchi, Carmen. 2006. Alexander's Coins and Alexander's Image. Cambridge, MA: Harvard University Art Museums.

Ashmead, Ann Harnwell and Kyle Meredith Phillips. 1971. CVA United States of America, Fasicule 13: The Ella Riegel Memorial Museum, Bryn Mawr College, Fascicule 1. Princeton, NJ: Princeton University Press. 
Ashmead, Ann Harnwell and Kyle Meredith Phillips. 1976. Catalogue of the Classical Collection Museum of Art, Rhode Island School of Design: Classical Vases, Excluding Attic Black-Figure, Attic Red-Figure and Attic White Ground. Providence, RI: Museum of Art, Rhode Island School of Design.

Ashmole, Bernard. 1985. "Sir John Beazley (1885-1970)." In Beazley and Oxford. 57-71. Oxford: Oxford University Committee for Archaeology.

Austin, Nancy. 1995. "Educating American Designers for Industry, 1853-1903." Proceedings of the American Antiquarian Society 105: 211-30.

Austin, Nancy. 2008a. "What a Beginning is Worth." In 'infinite radius': Founding Rhode Island School of Design. 170-95. Providence, RI: Rhode Island School of Design.

Austin, Nancy. 2008b. "No Honors to Divide." In 'infinite radius': Founding Rhode Island School of Design. 197-217. Providence, RI: Rhode Island School of Design.

Austin, Nancy. 2008c. "The Jones Bequest Lawsuit: The Meaning of a Museum at RISD." In 'infinite radius': Founding Rhode Island School of Design. 218-40. Providence, RI: Rhode Island School of Design.

Barrett, Dawn. 2008. "Selective Collective Memory." In 'infinite radius': Founding Rhode Island School of Design. 96-105. Providence, RI: Rhode Island School of Design.

Barrett, Dawn and Andrew Martinez. 2008. 'infinite radius': Founding Rhode Island School of Design. Providence, RI: Rhode Island School of Design.

Bartman, Elizabeth. 1999. Portraits of Livia: Imagining the Imperial Woman in Augustan Rome. Cambridge: Cambridge University Press.

Bartman, Elizabeth. 2002. "Eros's Flame: Images of Sexy Boys in Roman Ideal Sculpture." In The Ancient Art of Emmulation. 249-71. Ann Arbor, MI: The University of Michigan Press.

Basu, Sayoni. 2004. "Flecker, (Herman) James Elroy (1884-1915) " In Oxford Dictionary of National Biography. On-line Edition. H. C. G. Matthew and B. 
Harrison. Oxford: Oxford University Press.

http://www.oxforddnb.com.echo.louisville.edu/view/article/33162 (10 July 2010).

Baur, P. V. C. 1941. "Megarian Bowls in the Rebecca Darlington Stoddard Collection of Greek and Italian Vases in Yale University." AJA 45 (2): 229-48.

Beam, Phillip C. 1991. Personal Recollections of the Museum of Art and the Department of Art at Bowdoin College. Brunswick, ME: Bowdoin College Art Museum.

Beard, Mary. 1991. "Adopting an Approach II." In Looking at Greek Vases. 12-35. Cambridge: Cambridge University Press.

Beard, Mary. 1993. "Casts and Cast-Offs: The Origins of the Museum of Classical Archaeology." Proceedings of the Cambridge Philological Society 39: 1-29.

Beazley, John Davidson. 1912. "The Master of the Boston Pan-Krater." JHS 32: 354-69.

Beazley, John Davidson. 1918. Attic Red-Figured Vases in American Museums. Cambridge, MA: Harvard University Press.

Beazley, John Davidson. 1922. "Citharoedus." JHS 42: 70-98.

Beazley, John Davidson. 1927. CVA, Fascicule 3, Fascicule 1 Great Britain. Oxford, Ashmolean Museum. Oxford: Clarendon Press.

Beazley, John Davidson. 1929. "Charinos." JHS 49: 38-78.

Beazley, John Davidson. 1956. ABV. Oxford: Clarendon Press.

Beazley, John Davidson. 1963. $A R V^{2} .2^{\text {nd }}$ ed. Oxford: Clarendon Press.

Beazley, John Davidson. 1972. Paralipomena: Additions to Attic Black-figure Vasepainters and to Attic Red-figure Vase-painters. Oxford: Clarendon Press.

Beazley, John Davidson. 1974. The Pan Painter. Mainz: Verlag P. von Zabern. 
Beazley, John Davidson. 1989a. Attic Black-figure: A Sketch. Edited by D. G. Kurtz. Oxford: Clarendon Press.

Beazley, John Davidson. 1989b. The Berlin Painter. Edited by D. C. Kurtz. Oxford: Clarendon Press.

Beazley, John Davidson, Humfry Payne, et al. 1931. CVA, Fascicule 9, Fascicule 2 Great Britain. Oxford, Ashmolean Museum. Oxford: Clarendon Press.

Becker, David P. 1985. Old Master Drawings at Bowdoin College. Brunswick, ME: Bowdoin College Museum of Art.

Becq, Juliet, Violaine Jeammet, et al. 2010. "Divinities and Figurines in Boeotia." In Tanagras: Figurines for Life and Eternity. 142-59. Paris: Musée du Louvre.

Becq, Juliette. 2010. "The Discovery of the Tanagras." In Tanagras: Figurines for Life and Eternity. 16. Paris: Musée du Louvre.

Bellamy, Edward and Cecelia Tichi. 1986. Looking Backward, 2000-1887. New York: Penguin Books.

Berenson, Mary and Rollin van N. Hadley. 1987. The Letters of Bernard Berenson and Isabella Stewart Gardner, 1887-1924, with Correspondence by Mary Berenson. Boston: Northeastern University Press.

Bergmann, Bettina. 1995. "Greek Masterpieces and Roman Recreative Fictions." Harvard Studies in Classical Philology 97: 79-120.

Bergstein, Mary. 1992. "Lonely Aphrodites: On the Documentary Photography of Sculpture." The Art Bulletin 74 (3): 475-98.

Bergstein, Mary. 2010. Mirrors of Memory: Freud, Photography, and the History of Art. Ithaca, NY: Cornell University Press.

Bieber, Margaret. 1949. "The Portraits of Alexander the Great." Proceedings of the American Philosophical Society 93 (5): 373-427. 
Bieber, Margaret. 1955. "Review: [Les Portraits Grecs by Vagn Poulsen]." AJA 59 (3): 254-5.

Bieber, Margaret. 1961. The History of the Greek and Roman Theater. 2nd ed. Princeton, NJ: Princeton University Press.

Biers, William R. 1996. The Archaeology of Greece: An Introduction. Ithaca, NY: Cornell University Press.

"Biographical Note: Forbes, Edward Waldo, 1873-1969." Harvard Art Museum Archives http://oasis.lib.harvard.edu/oasis/deliver/ art00005

Blanchard, Mary Warner. 1998. Oscar Wilde's America: Counterculture in the Gilded Age. New Haven, CT: Yale University Press.

Boardman, John. 1975. Athenian Red Figure Vases: The Archaic Period. London: Thames \& Hudson.

Boardman, John. 1985. "100 Years of Classical Archaelogy at Oxford." In Beazley and Oxford. 43-55. Oxford: Oxford University Committee for Archaeology.

Boardman, John. 1989. Athenian Red Figure Vases: The Classical Period. New York: Thames \& Hudson.

Boardman, John. 1999. "The Lewes House Gems: Warren and Beazley." In Classicism to Neo-classicism: Essays Dedicated to Gertrude Seidmann. 217-25. Oxford: BAR International Series 793.

Boardman, John. 2001a. Greek Gems and Finger Rings: Early Bronze to Late Classical. London: Thames \& Hudson.

Boardman, John. 2001b. The History of Greek Vases: Potters, Painters, and Pictures. London: Thames \& Hudson.

Boardman, John. 2008. "The Marlborough Gems." Beazley Archive Lecture Series. http://www.beazley.ox.ac.uk/archive/lectures/boardman.htm

Boardman, John. 2009a. The Marlborough Gems. Oxford: Oxford University Press. 
Boardman, John. 2009b. "Review [The Colors of Clay: Special Techniques in Athenian Vases--Beth Cohen]." IJCT 16 (1): 88-90.

Boardman, John and J. D. Beazley. 2002. The Lewes House Collection of Ancient Gems: [now at the Museum of Fine Arts, Boston]. Oxford: Archeopress.

Boardman, John and Eugenio LaRocca. 1978. Eros In Greece. London: John Murray.

"Bowdoin College Museum of Art." 1977. The Burlington Magazine 119 (894): 672.

Bradley, Simon and Nikolaus Pevsner. 1998. London: The City of Churches. London: Penguin Books.

"A Brief History of Papermaking in Maine." Maine Pulp and Paper Association. http://www.pulpandpaper.org/history_of_papermaking.shtml (17 June 2009).

"British Museum Collection Database "

http://www.britishmuseum.org/research/search_the_collection_database/term_det ails.aspx?bioId=93014 (10 April 2010).

"Brooks Phillips, 1835-1893. Papers of Phillips Brooks: An Inventory." Harvard University Archives http://oasis.lib.harvard.edu/oasis/deliver/ hua11004 April 2009).

Brooks, Robin. 2004. The Portland Vase: The Extraordinary Odyssey of a Mysterious Roman Treasure. New York: HarperCollins.

Brown, A. C. 1968. Catalogue of Italian Terra-Sigillata in the Ashmolean Museum. Oxford: Clarendon Press.

Brown, Clifford Malcolm. 1977. Engraved Gems: Survivals and Revivals. Washington, D.C.: National Gallery of Art, Washington.

Brown, David. 1976. "Pottery." In Roman Crafts. 74-91. New York: New York University Press.

Brush, Kathryn. 2003. Vastly More Than Brick \& Mortar: Reinventing the Fogg Art Museum in the 1920s. Cambridge, MA: Harvard Art Museums. 
Bryn Mawr College Program: Academic Year 1900-01. 1900. Philadelphia, PA.

Burdett, Osbert and E. H. Goddard. 1941. Edward Perry Warren: The Biography of a Connoisseur. London: Christophers.

Burke, Margaret R. 1981. "History of the Collection." In Handbook of the Collections. Brunswick, ME: Bowdoin College Museum of Art.

Burn, Lucilla. 1985. "'Honey Pots: Three White Ground Cups by the Sotades Painter"." AntK 28: 93-105.

Burnham, Helen. 2008. "Cultural Leadership in the Gilded Age: The Founding of the Rhode Island School of Design." In 'infinite radius': Founding Rhode Island School of Design. 243-76. Providence, RI: Rhode Island School of Design.

Burt, Nathaniel. 1977. Palaces for the People: A Social History of the American Art Museum. Boston, MA: Little, Brown, and Company.

Calder, William. 1996. "Warren, Edward Perry (1860-1928)." In An Encyclopedia of the History of Classical Archaeology. 1186. Westport, CT: Greenwood Press.

Calhoun, Charles C. 1987. "An Acorn in the Forest." Bowdoin (September): 2-12.

Calinescu, Andriana. 1996. Ancient Jewelry and Archaeology. Bloomington, IN: Indiana University Press.

Candeloro, Dominic. 1979. "The Single Tax Movement and Progressivism, 1880-1920." American Journal of Economics and Sociology 38 (2): 113-27.

Carnegie, Andrew. 1969. The Gospel of Wealth, and Other Timely Essays. Cambridge, MA: Belknap Press of the Harvard University Press.

Carpenter, Kenneth E. 1994. "James Bowdoin III as Library Builder." In The Legacy of James Bowdoin III. 85-125. Brunswick, ME: Bowdoin College Museum of Art.

Carpenter, Thomas H. 1991. Art and Myth in Ancient Greece: A Handbook. London: Thames and Hudson. 
Carradice, Ian and Martin Price. 1988. Coinage in the Greek World. London: Seaby.

"Carvers and Collectors: The Lasting Allure of Ancient Gems." The J. Paul Getty Museum http://www.getty.edu/art/exhibitions/gems/ (18 May 2011).

Caskey, L. D. 1917. "Arretine Pottery." BMFA 15 (87): 1-2.

Caskey, L. D. 1918. "The Ludovisi Relief and Its Companion Piece in Boston." AJA 22 (2): 101-45.

Caskey, L. D. 1928. "The Warren Collection of Engraved Gems." Bulletin of the Museum of Fine Arts 26 (155): 46-50.

Caskey, L. D. 1935. "Review: [CVA, U. S. A. fasc. 2; Providence, Museum of the Rhode Island School of Design, fasc. 1 by Luce, Stephen Bleecker]." AJA 39 (4): 627-8.

Casson, Stanley. 1934. Descriptive Catalogue of the Warren Classical Collection of Bowdoin College. Brunswick, ME: The Record Press.

Chacón, H. Rafael. 1990. "Kabric Bowl: Odysseus' Men before Circe, Two Combatants, circa 430-420." In The David and Alfred Smart Museum of Art: A Guide to the Collection. 26-7. New York: Hudson Hills Press.

Chase, George H. 1917. "The MeLeager in the Fogg Museum and Related Works in America." The Bulletin of the College Art Association of America 1 (3): 109-16.

Chase, George H. 1924. Greek and Roman Sculpture in American Collections. Cambridge, MA: Harvard University Press.

Chase, George H. 1930. "The Fine Arts 1874-1929." In The Development of Harvard University Since the Inauguration of President Eliot 1869-1929. 131-49. Cambridge, MA: Harvard University Press.

Chase, George H. 1947. "Two Arretine Puncheons." BMFA 45 (260): 38-42.

Chase, George H. 1948. Greek Gods and Heroes, as Represented in the Classical Collections of the Museum. Fourth ed. Cambridge, MA: Harvard University Press. 
Chase, George H. 1950. Greek and Roman Antiquities: A Guide to the Classical Collection. Boston: Museum of Fine Arts, Boston.

Chase, George H., Mary B. Comstock, et al. 1975. Catalogue of Arrentine Pottery. Cambridge, MA: Houghton Mifflin Company.

Clark, Gregory and S. Michael Halloran. 1993. Oratorical Culture in Nineteenth-century America: Transformations in the Theory and Practice of Rhetoric. Carbondale, IL: Southern Illinois University Press.

Clarke, John R. 1993. "The Warren Cup and the Contexts for Representations of Male-toMale Lovemaking in Augustan and Early Julio-Claudian Art." ArtB 75 (2): 27594.

Clarke, John R. 1998. Looking at Lovemaking: Constructions of Sexuality in Roman Art, 100 B.C.-A.D. 250. Berkeley, CA: University of California Press.

Clarke, John R. 2003a. Art in the Lives of Ordinary Romans. Berkely, CA: University of California Press.

Clarke, John R. 2003b. Roman Sex 100 B.C. - A. D. 250. New York: Henry N. Abrams, Inc.

Clarke, John R. 2007. Looking at Laughter: Humor, Power, and Transgression in Roman Visual Culture, 100 B.C.-A.D. 250. Berkeley, CA: University of California Press.

Cohen, Beth. 1970-1971. "Observations on Coral-Red." Marsyas 15: 1-12.

Cohen, Beth. 1978. Attic Bilingual Vases and Their Painters. New York: Garland Publishers.

Cohen, Beth. 2006a. The Colors of Clay: Special Techniques in Athenian Vases. Los Angeles, CA: The J. Paul Getty Museum.

Cohen, Beth. 2006b. "Bilingual Vases and Vase-Painters." In The Colors of Clay: Special Techniques in Athenian Vases. 18-25. Los Angles, CA: The J. Paul Getty Museum. 
Cohen, Beth. 2006c. "Coral-red Gloss; Potters, Painters, and Painter-Potters." In The Colors of Clay: Special Techniques in Athenian Vases. Los Angeles, CA: The J. Paul Getty Museum.

Cohen, Beth. 2008. "The Colors of Clay: Combining Special Techniques on Athenian Vases." In Papers on Special Techniques in Athenian Vases. Los Angeles, CA: The J. Paul Getty Museum.

Coldstream, J. N. 1968. Greek Geometric Pottery: A Survey of Ten Local Styles and Their Chronology. London: Methuen.

Coldstream, J. N. 1977. Geometric Greece. New York, NY: St Martin's Press.

Coleman, Peter J. 1963. The Transformation of Rhode Island, 1790-1860. Providence, RI: Brown University Press.

Coltman, Viccy. 2009. Classical Sculpture And the Culture of Collecting in Britain Since 1760. Oxford: Oxford University Press.

Comstock, Mary B. and Cornelius C. Vermeule. 1971. Greek, Etruscan, \& Roman Bronzes in the Museum of Fine Arts Boston. Greenwich, CT: New York Graphic Society.

Comstock, Mary B. and Cornelius C. Vermeule. 1976. Sculpture in Stone: The Greek, Roman, and Etruscan Collections in the Museum of Fine Arts Boston. Boston, MA: Museum of Fine Arts.

Constable, William George. 1964. Art Collecting in the United States of America: An Outline of the History. New York: Thomas Nelson and Sons Ltd.

Cook, R. M. 1965. "Review: [Ancient Art in Bowdoin College by Kevin Herbert]." CJ 15 (2): 236.

Cook, R. M. 1997. Greek Painted Pottery. 3rd ed. New York: Routledge.

Cooney, John D. 1968. "Siren and Ba, Birds of a Feather." BClevMus 55 (8): 262-71.

Cooney, John D. 1972. "Harpocrates, the Dutiful Son." BClevMus 59 (10): 284-90. 
Cooper, Wendy A. 1993. Classical Taste in America 1800-1840. New York: Abbeville Press.

Cordato, Mary. 1983. "Toward a New Century: Women and the Philadelphia Centennial Exhibit." Pennsylvania Magazine of History and Biography 107: 113-35.

Cordery, Stacy A. 2007. "Women in Industrializing America." In The Gilded Age: Perspectives on the Origins of Modern America. 119-41. Lanham, MD: Rowman \& Littlefield.

"Cornelia Warren and the Story of Cedar Hill." (n. d.). S. D. Warren Company

Craven, Wayne. 1994. American Art: History and Culture. Madison, WI: Brown \& Benchmark.

Crawford, Alistair. 2003. "John Marshal: Dealer in Antiquities and Collector of Photography." History of Photography 27 (2): 99-110.

Crocker, Ruth C. 2007. "Cultural and Intellectual Life in the Gilded Age." In The Gilded Age: Perspectives on the Origins of Modern America. 211-37. Lanham, MD: Rowman \& Littlefield.

Cumont, Franz Valery Marie. 1959. After Life in Roman Paganism: Lectures Delivered at Yale University on the Silliman Foundation. New York: Dover Publications.

Cuno, James B. 1996. Harvard's Art Museums: 100 Years of Collecting. Cambridge, MA: Harvard University Art Museums.

Cushing, Stanley Ellis and David B. Dearinger. 2006. Acquired Tastes: 200 Years of Collecting for the Boston Athenceum. Boston, MA: University Press of New England.

D'Ambra, Eve. 2007. Roman Women. New York: Cambridge University Press.

"Dana Estes." 1898, 2 July Publishers' Weekly: 9-10.

Davidson, James. 2007. The Greeks and Greek Love: A Bold New Exploration of the Ancient World. New York: Random House. 
Davies, Glenys. 1985. "The Significance of the Handshake Motif in Classical Funerary Art." AJA 89 (4): 627-40.

Davies, Glenys. 2010. "Before Sarcophagi." In Life, Death and Representation: Some New Works on Roman Sarcophagi. 21-53. Berlin: Walter de Gruyter.

Davis, Whitney. 2001. "Homoerotic Art Collection from 1750-1920." Art History 24 (2): 247-77.

de Puma, Richard D. 1994. "Etruscan Art." Art Institute of Chicago Museum Studies 20 (1): 55-61.

"Dealers and Auction Houses etc up to 1945." Pitts River Museum http://history.prm.ox.ac.uk/page_73.html (10 April 2010).

Dearinger, David B. 2006. Collecting Paintings and Sculpture for the Boston Athenceum. Edited by S. E. Cushing and D. B. Dearinger. Boston, MA: University Press of New England.

del Chiaro, Mario 1984. Classical Art Sculpture. Santa Barbara, CA: Santa Barbara Museum of Art.

Demarest, David P. 1992. "'The River Ran Red': Homestead 1892." In Pittsburgh Series in Social and Labor History. Pittsburgh: University of Pittsburgh Press.

Déonna, Waldemar. 1924. "Quelques statuettes d'Aphrodite." Aréthuse I: 108-12.

"Department of Archaeology." 1896-7. Register of the University of Chicago

"Department of the History of Art." 1903-4. University of Chicago Register

Dickins, Guy and K. Kourouniotis. 1906. "Damophon of Messene: II." BSA 13: 357-404.

Dillaway, Charles K. 1881. "Education, Past and Present. The Rise of Free Education and Educational Institutions." In The Memorial History of Boston, including Suffolk County, Massachusetts. 234-55. Boston, MA: J. R. Osgood and Company. 
Dillon, Shelia. 2006. Ancient Greek Portrait Sculpture: Contexts, Subjects, and Styles. New York: Cambridge University Press.

DiMaggio, Paul. 1982a. "Cultural Entrepreneurship in Nineteenth-Century Boston Part I: The Creation of An Organizational Base for High Culture in America." Media, Culture and Society 4: 33-50.

DiMaggio, Paul. 1982b. "Cultural Entrepreneurship in Nineteenth-Century Boston Part II: The Classification and Framing of American Art." Media, Culture and Society 4: 303-22.

Dimond, V. Scott. 2008. James Bowdoin III: Pursuing Style in the Age of Independence. Brunswick, ME: Bowdoin College Art Museum.

Dinsmoor, William B. 1943. "Early American Studies of Mediterranean Archaeology." Proceedings of the American Philosophical Society 87 (1): 70-104.

Dobson, John M. 1978. America's Ascent: The United States Becomes a Great Power, 1880-1914. DeKalb, IL: Northern University Press.

Dohan, Edith Hall. 1942. Italic Tomb-Groups in the University Museum. Philadelphia, PA: University of Pennsylvania Press.

Dolkart, Andrew S. 2002. Cooper-Hewitt, National Design Museum: The Andrew and Louise Carnegie Mansion. New York: Scala Publishers in association with Cooper-Hewitt, National Design Museum.

Donahue, Alice. 1958. "One Hundred Years of the American Journal of Archaeology." AJA 89: 3-30.

Dover, Kenneth James. 1989. Greek Homosexuality. Cambridge, MA: Harvard University Press.

Dowling, Linda. 1994. Hellenism and Homosexuality in Victorian Oxford. Ithaca, NY: Cornell University Press.

Dowling, Linda. 2007. Charles Eliot Norton: The Art of Reform in Nineteenth-Century America. Durham, NH: University of New Hampshire Press. 
Duffy, Timothy P. 1996. "The Gender of Letters: Charles Eliot Norton and the Decline of the Amateur Intellectual Tradition." The New England Quarterly 69 (1): 91-109.

Dyson, Stephen L. 1998. Ancient Marbles to American Shores: Classical Archaeology in the United States. Philadelphia, PA: University of Pennsylvania Press.

Dyson, Stephen L. 2006. In Pursuit of Ancient Pasts: A History of Classical Archaeology in the Nineteenth and Twentieth Centuries. New Haven: Yale University Press.

Ebbinghaus, Susanne. 2008. "Of Rams, Women, and Orientals: A Brief History of Attic Plastic vases." In Papers on Special Techniques in Athenian Vases. 145-60. Los Angeles, CA: The J. Paul Getty Museum.

"Edward Reeves Photography." http://www.edwardreeves.com/about.html (16 April 2010).

Edwards, Catherine. 1999. Roman Presences: Receptions of Rome in European Culture, 1789-1945. Cambridge: Cambridge University Press.

Edwards, G. Roger. 1975. "Corinthian Hellenistic Pottery." Corinth 7 (3): iii-254.

Edwards, Rebecca. 2006. New Spirits: Americans in the Gilded Age, 1865-1905. New York: Oxford University Press.

Eisenburg, J. D. 1996. "The Ludovisi and Boston Thrones." Minerva 7: 29-41.

Elkins, Nathan Thomas. 2009. "Coins, Contexts , and an Iconographic Approach to the 21st Century." In Coins in Context I: New Perspectives for the Interpretation of Coin Find: Colloquium Frankfurt A.M., October 25-27, 2007. Mainz: P. von Zabern.

Ellis, Heather. 2007. "Newman and Arnold: Classics, Christianity and Manliness in Tractarian Oxford." In Oxford Classics: Teaching and Learning 1800-2000. 4663. London: Gerald Duckworth \& Company.

Elm, Susanna. 2001. "Cumont's Legacy (Review of Les syncrétismes religieux dans le monde Méditerranéen antique. Actes du Colloque International en l'honneur de Franz Cumont à l'occasion du cinquantième anniversaire de sa mort. Rome, 
Academia Belgica, 25-27 septembre 1997 by C. Bonnet; A. Motte)." CR 51 (2): 289-91.

Elsner, Jàs. 2010. "Introduction." In Life, Death and Representation: Some New Work on Roman Sarcophagi. 1-20. Berlin: Walter De Gruyter.

Engel, A. J. 1983. From Clergyman to Don: The Rise of the Academic Profession in Nineteenth-century Oxford. Oxford: Clarendon Press.

Ershkowitz, Herbert. 1999. John Wanamaker: Philadelphia Merchant. Conshohocren, PA: Combined Pub.

Evangelista, Stefano. 2007. "Walter Pater's Teaching in Oxford: Classics and Aestheticism." In Oxford Classics: Teaching and Learning 1800-2000. London: Gerald Duckworth \& Co.

Fairbanks, Arthur. 1931. "Edward Robinson as Curator of the Classical Department." BMFA 29 (173): 51-2.

Fejfer, Jane. 2008. Roman Portraits in Context. Berlin: Walter de Gruyter.

Ferrari, Gloria. 2002. Figures of Speech: Men and Maidens in Ancient Greece. Chicago, IL: University of Chicago Press.

Ferrari, Gloria, Christina M. Nielsen, et al. 1998. The Classical Collection. Chicago, IL: The David and Alfred Smart Museum of Art, The University of Chicago.

Fisher, H. A. L. 1940. An Unfinished Biography. Oxford: Oxford University Press.

Fleming, Donald. 1986a. "Eliot's New Broom." In Glimpses of the Harvard Past. 63-76. Cambridge, MA: Harvard University Press.

Fleming, Donald. 1986b. "Harvard's Golden Age." In Glimpses of the Harvard Past. 7795. Cambridge, MA: Harvard University Press.

Fleming, Stuart J. 1999. Roman Glass: Reflections of Cultural Change. Philadelphia, PA: University of Pennsylvania Museum of Archaeology and Anthropology. 
Flory, Marleen B. 1995. "The Symbolism of Laurel in Cameo Portraits of Livia." MAAR 40: 43-68.

Fogg Art Museum Harvard University Handbook. 1936. 3rd ed. Cambridge, MA: Harvard University.

Forbes, Edward W. 1918a. "The Art Museum and the Teaching of the Fine Arts." The Bulletin of the College Art Association of America 1 (4): 120-9.

Forbes, Edward W. 1918b. "Report of the Fogg Art Museum, 1918-19." Annual Report (Fogg Art Museum) (1918/1919): 1-6.

Forbes, Edward W. 1926. "Report of the Fogg Art Museum, 1926-27." Annual Report (Fogg Art Museum). 1-15

Forbes, Edward W. 1941. "The Beginnings of the Art Department and of the Fogg Museum of Art at Harvard." Cambridge Historical Society 27: 11-27.

Forbes, Edward W. 1971. Edward Waldo Forbes: Yankee Visionary. Cambridge, MA: Fogg Art Museum, Harvard University.

Fothergill, John. 1949. My Three Inns. London: Chatto \& Windus.

"The Founder: James Loeb." The Harvard University Press: Loeb Classical Library http://www.hup.harvard.edu/features/loeb/founder.html (11 March 2011).

Fowler, Harold North and James Rignall Wheeler. 1901. A Handbook of Greek Archaeology. New York: American Book Company.

Frazier, John R. 2008. "History of the Rhode Island School of Design: Address to the Rhode Island Historical Society, November 13, 1960." In 'infinite radius': Founding Rhode Island School of Design 87-92. Providence, RI: Rhode Island School of Design.

French, Elizabeth. 1971. "The Development of Mycenaean Terracotta Figurines." BSA 66: 101-87. 
Gajda, Amy. 2008. "What if Samuel D. Warren Hadn't Married a Senator's Daughter?: Uncovering the Press Coverage That Lead to 'The Right to Privacy'." Michigan State Law Review 35: 35-60.

Gardiner, J. H. and Robert Pierce. 1914. Harvard. New York: Oxford University Press.

Gardner, E. A. 1913. "The Boston Counterpart of the 'Ludovisi Throne'." JHS 33: 73-83.

Gardner, Helen and Fred S. Kleiner. 2010. Gardner's Art Through the Ages: The Western Perspective. 13th ed. Boston: Wadsworth.

Gardner, Percy. 1926. The Principles of Greek Art. New York, NY: The Macmillan Company.

Garnier, Bénédicte. 2002. Rodin—Antiquity is My Youth: A Sculptor's Collection. Paris: Musée Rodin

Geffcken, Katherine. 2001. "The Academy's Archaeological Study Collection." Classical Society: American Academy in Rome Newsletter: 14-5.

General Catalogue of Bowdoin College and the Medical School of Maine: A Biographical Record of Alumni and Officers 1794-1950. 1950. Brunswick, ME: Bowdoin College.

"George Justice Furniture Restoration." http://www.georgejustice.co.uk/index.htm (16 April 2010).

Gessert, Genevieve. 2004. "Myth as Consolatio: Medea on Roman Sarcophagi." Greece \& Rome 51 (2): 217-49.

Giberti, Bruno. 2002. Designing the Centennial: A History of the 1876 International Exhibition in Philadelphia. Lexington, KY: University Press of Kentucky.

Gilkerson, John S. 1986. Middle-Class Providence, 1820-1940. Princeton, NJ: Princeton University Press. 
Gill, David. 1985. "Classical Greek Fictile Imitations of Precious Metal Vases." In Pots \& Pans: A Colloquium on Precious Metals and Ceramics in the Muslim, Chinese, and Greco-Roman Worlds, Oxford 1985. 9-30. Oxford: Oxford University Press.

Gill, David and Christopher Chippindale. 2006. "From Boston to Rome: Reflections on Returning Antiquities." International Journal of Cultural Property. http://www.proquest.com.echo.louisville.edu/ (13 May 2011).

Gilman, Benjamin Ives. 1907. "The Museum Past, Present, and Future." Museum of Fine Arts Bulletin 5 (27): 42-7.

Giuliani, Luca. 1977. "Alexander in Ruvo, Eretria und Sidon." AntK 20: 26-42.

Goldstein, Sidney M. 1979. Pre-Roman and Early Roman Glass in the Corning Museum of Glass. Corning, NY: Corning Museum of Glass.

Goldstein, Sidney M. 1982. Cameo Glass: Masterpieces from 2000 years of Glassmaking Corning, NY: Corning Museum of Glass.

Goldstein, Sidney M. 2006. "Core-formed Glass Perfume Bottles." In The Art of Glass: Toledo Museum of Art. 22-3. London: Toledo Museum of Art.

Gordon, Arthur E. 1982. "Review: [Margherita Guarducci-La Cosiddetta Fibula Prenestina: Antiquari, Eruditi E Falsari Nella Roma Dell'ottocento ]." CJ 78 (1): 64-70.

Grandjouuan, Clairève, Eileen Markson, et al. 1989. Hellenistic Relief Molds from the Athenian Agora. Princeton, N. J: American School of Classical Studies.

Gray, Aviva. 2005. "Agnes Baldwin Brett: A Pioneer Numismatist and Archaeologist at the ANS." American Numismatic Society Magazine on-line edition. http://ansmagazine.com/Summer05/Brett (3 May 2011).

Green, J. R. 1994. Theatre in Ancient Greek Society. New York: Routledge.

Green, J. R. and Eric Handley. 1995. Images of the Greek Theatre. Austin, TX:

University of Texas. 
Green, Martin. 1976. Children of the Sun: A Narrative of "Decadence" in England After 1918. New York: Basic Books, Inc. Publishers.

Green, Martin. 1989. The Mount Vernon Street Warrens: A Boston Story, 1860-1910. New York: Charles Scribner's Sons.

Griffiths, J. Gwyn. 1991. "Review: A Mystery Solved?" CR 41 (1): 122-4.

Grose, David Frederick. 1989. Early Ancient Glass. New York: Hudson Hills Press with theToledo Museum of Art.

Gruen, Eric S. 1992. Culture and National Identity in Republican Rome. Ithaca, NY: Cornell University Press.

Grundy, G. B. 1945. Fifty-Five Years at Oxford: An Unconventional Autobiography. London: Methueun \& Co. LTD.

Gudenrath, William. 2007. "The Making of Roman and 19th-Century Cameo Glass." In Reflecting Antiquity: Modern Glass Inspired by Ancient Rome. 61-72. Corning, NY: Corning Museum of Glass.

"A Guide to the Martin Green Papers, 1960-2000." Tufts University Digital Collections and Archives http://hdl.handle.net/10427/14683 (June 7).

Hackens, Tony. 1976. Catalogue of the Classical Collection: Classical Jewelry. Providence, RI: Museum of Art, Rhode Island School of Design.

Hackens, Tony and Rolf Winkes. 1983. Gold Jewelry: Craft, Style, and Meaning from Mycenae to Constantinopolis. Louvain-La-Neuve, Belgium: Art and Archaeology Publications.

Hadzisteliou-Price, Theodora. 1972. "Aurelian Ivory Plaque with Dionysos Triumphant." ArchCl 24: 48-58.

Hall, Emma Swain. 1977. "Harpocrates and Other Child Deities in Ancient Egyptian Sculpture." JARCE 14: 55-8. 
Halperin, David M. 1989. Sex Before Sexuality: Pederasty, Politics, and Power in Classical Athens. Edited by M. B. Duberman, M. Vicinus and G. Chauncey. New York: New American Library.

Halperin, David M. 1990. One Hundred Years of Homosexuality: And Other Essays on Greek Love. New York: Routledge.

Hamilakis, Yannis. 2007. The Nation and Its Ruins: Antiquity, Archaeology, and the National Imagination in Greece. Oxford: Oxford University Press.

A Handbook of the Museum of Fine Arts Boston.1914. Boston, MA: Museum of Fine Arts Boston.

A Handbook of the Museum of Fine Arts, Boston.1906. Boston, MA: Museum of Fine Arts, Boston.

Harden, Donald B. 1987. Glass of the Caesars. Milan: Olivetti.

Hariharan, P. 1992. "Display Holography: A Technical Retrospect." Leonardo 25 (5): 431-7.

Harris, Neil. 1962. "The Gilded Age Revisited: Boston and the Museum Movement." American Quarterly 14 (4): 545-66.

Harris, Stephen L. and Cloria Platzner. 2008. Classical Mythology: Images and Insights. 5th ed. Boston: McGraw-Hill.

Hartswick, Kim J. 2004. The Gardens of Sallust: A Changing Landscape. Austin, TX: University of Texas Press.

Harvard. 1874-84. "Harvard College Catalogues." Harvard University Archives Reel 5 Hu $20.41 \mathrm{mfP}$

Harvard. 1879-80. "The Courses of Instruction Catalogue, Harvard College." Harvard Archives HUG 8500.16

Haskell, Francis and Nickolas Penny. 1981. Taste and the Antique: The Lure of Classical Sculpture, 1500-1900. New Haven, CT: Yale University Press. 
Haspels, C. H. Emilie. 1936. Attic Black-Figured Lekythoi. Paris: E. de Boccard.

Hatch, Louis C. 1927. The History of Bowdoin College. Portland, ME: Loring, Short \& Harmon.

Hatt, Michael. 2007. "Space, Surface, Self: Homosexuality and the Aesthetic Surface." Visual Culture in Britain 8 (1): 105-208.

Havelock, Christine Mitchell. 1981. "Dorothy Burr Thompson (b. 1900): Classical Archaeologist." In Women as Interpreters of the Visual Arts, 1820-1979. 357-75. Westport, CT: Greenwood Press.

Hawthorne, Nathaniel. 1889. The Marble Faun; or, The Romance of Monte Beni. New York: Houghton Mifflin and Company.

Hayes, J. W. 1991. "Fine Wares in the Hellenistic World." In Looking at Greek Vases. 183-202. Cambridge: Cambridge University Press.

Henig, Martin. 1983. "The Luxury Arts: Decorative Metalwork, Engraved Gems, and Jewelry " In A Handbook of Roman Art: A Comprehensive Survey of All the Arts of the Roman World. 139-65. Ithaca, NY: Cornell University.

Herbert, Kevin. 1957. "The Identity of Plutarch's Lost Scipio." AJP 78 (1): 83-8.

Herbert, Kevin. 1958. "The Classical World in Recent Fiction." CJ 53 (6): 242-52.

Herbert, Kevin. 1959. "Terracotta Figurines at Bowdoin College." CJ 55 (3): 98-111.

Herbert, Kevin. 1960a. "A Roman Cinerary Urn at Bowdoin College." AJA 64 (1): 76-8.

Herbert, Kevin. 1960b. Terracotta Figurines in the Walker Art Building. Brunswick, ME: Bowdoin College.

Herbert, Kevin. 1960c. "The Theseus Theme: Some Recent Versions." CJ 55 (4): 175-85.

Herbert, Kevin. 1962. "Greek and Latin Inscriptions at Bowdoin." AJA 66 (4): 381-7. 
Herbert, Kevin. 1964. Ancient Art in Bowdoin College: A Descriptive Catalogue of the Warren and other Collections. Cambridge, MA: Harvard University Press.

Herbert, Kevin. 1971. "The Illustrated Lecture and Its Role in Classical Studies." CJ 66 (3): 227-32.

Herbert, Kevin. 1972. Greek and Latin Inscriptions in the Brooklyn Museum. Brooklyn, NY: The Brooklyn Museum.

Herbert, Kevin. 1973. "The Classics Advanced Placement Program: Analysis and Prognosis." CJ 69 (2): 139-45.

Herbert, Kevin. 1996. The John Max Wulfing Collection in Washington University: Roman Imperial Coins, Augustus to Hadrian and Antonine Selections, 31 BC-AD 180. Wauconda, Ill Bolchazy-Carducci Publishers.

Herrick, Robert. 1921. "Frank Bigelow Tarbell." The University Record

Herrmann, John J. 1997. "The Authenticity of the Boston Throne: A View from Boston." In Il Trono Ludovisi e il Trono di Boston: Convegno di Studi, September 12, 1996. 13-7. Venice: Quaderni di Palazzo Grassi

Herrmann, John J. and Christine Kondoleon. 2004. Games for the Gods: the Greek Athlete and the Olympic Spirit. Boston, MA: Museum of Fine Arts Boston.

Hess, Catherine and Karol Wright. 2005. Looking at Glass. Los Angeles, CA.: The J. Paul Getty Museum.

Higginbotham, James A. and Katherine M. Westley. 2005. Ars Antiqua: Treasures from the Ancient Mediterranean World at Bowdoin College. Brunswick, ME: Bowdoin College.

Higgins, Reynold. 1967. Greek Terracottas. London: Methuen.

Higgins, Reynold. 1980. Greek and Roman Jewelry. 2nd ed. Berkeley, CA: University of California Press. 
Hill, Dorthy Kent. 1965. "Review: [Kevin Herbert--Ancient Art in Bowdoin College]." AJA 69 (3): 274.

Hilliard, David. 1982. "Unenglish and Unmanly: Anglo-Catholicism and Homosexuality." Victorian Studies 25 (2): 181-210.

Hinchliff, Peter and John Prest. 2004. "Jowett, Benjamin (1817-1893)." In Oxford Dictionary of National Biography. On-line Edition. H. C. G. Matthew, B. Harrison and L. Goldman. Oxford: Oxford University Press. http://www.oxforddnb.com.echo.louisville.edu/view/article/15143

Hinnells, John R. 1990. "Review: [Planetary Gods and Planetary Orders in the Mysteries of Mithras by R. Beck]." JRS 80: 236-7.

Hiss, Priscilla and Roberta Fansler. 1934. Research in Fine Arts in the Colleges \& Universities of the United States. New York, NY: Carnegie Corporation.

Hoffmann, Herbert. 1988. "The Cicada on the Omphalos." Antiquity 62: 744-49.

Hoffmann, Herbert. 1997. Sotades: Symbols of Immortality on Greek Vases. Oxford: Clarendon Press.

Hoffmann, Herbert and Patricia F. Davidson. 1965. Greek Gold: Jewelry from the Age of Alexander. Mainz/Rhein: Verlag Phillip Von Zabern.

Holloway, R. Ross. 1998. Catalogue of the Classical Collection Museum of Art, Rhode Island School of Design: Ancient Greek Coins. Providence, RI: Art and Archaeology Publications.

Hoppin, Joseph Clark. 1919a. A Handbook of Attic Red-Figured Vases. Cambridge, MA: Harvard University Press.

Hoppin, Joseph Clark. 1919b. A Handbook of Attic Red-figured Vases. Cambridge, MA: Harvard University Press.

Hoppin, Joseph Clark and Albert F. Gallatin. 1926. CVA - United States of America Hoppin and Gallatin Collections: Fascicule 1. Cambridge, MA: Harvard University Press. 
Horan, David. 2000. Oxford: A Cultural and Literary Companion. New York: Interlink Books.

Horowitz, Helen Lefkowitz. 1994. The Power and Passion of M. Carey Thomas. New York: Alfred A. Knopf.

Hoving, Thomas. 1996. False Impressions: The Hunt for Big-Time Art Fakes. New York: Simon \& Shuster.

Howard, Seymour. 1990. Antiquity Restored: Essays on the Afterlife of the Antique. Vienna: IRSA.

Howarth, Janet. 2004. "Sidgwick, Arthur (1840-1920)." In Oxford Dictionary of National Biography. On-line Edition. H. C. G. Matthew and B. Harrison. Oxford: Oxford University Press. http://www.oxforddnb.com.echo.louisville.edu/view/article/48597

Howe, Winifred E. 1913. A History of the Metropolitan Museum of Art, with a Chapter on the Early Institutions of Art in New York. New York: Gilliss Press.

Howells, William Dean and Don Lewis Cook. 1982. The Rise of Silas Lapham: An Authoritative Text, Composition and Backgrounds, Contemporary Responses, Criticism. New York: Norton.

Howgego, Christopher. 1995. Ancient History from Coins. New York: Routledge.

Huguenot, Caroline. 2008. La Tombe Aux Érotes Et La Tombe D'amarynthos: Architecture Funéraire Et Présence Macédonienne En Grèce Centrale. Gollion: Infolio.

Hussey, Arthur M. 1994. "James Bowdoin III and Geology at Bowdoin College." In The Legacy of James Bowdoin III. 127-39. Brunswick, ME: Bowdoin College Museum of Art.

Immerwahr, Henry I. 1990. Attic Script: A Survey. New York: Clarendon Press.

Immerwahr, Sara A. 1970. "The Pomegranate Vase: A Mycenaean-Geometric Link." AJA 74 (2): 197. 
Immerwahr, Sara A. 1989. "The Pomegranate Vase: Its Origins and Continuity." Hesperia 58 (4): 397-410.

Jaffé, David. 1993. "Aspects of Gem Collecting in the Early Seventeenth Century, Nicolas-Claude Peiresc and Lelio Pasqualini." BurlMag 135 (1079): 103-20.

Jaffé, David. 1997. "Reproducing and Reading Gems in Robens' Circle." In Engraved Gems: Survivals and Revivals. 181-93. Washington, DC: National Gallery of Art, Washington.

Jaher, Frederick Cople. 1986. The Boston Brahmins in the Age of Industrial Capitalism. Edited by F. C. Jaher. New York: The Free Press.

James, Henry. 1907. "The Lonely Aphrodite." In The American Scene. 252-3. New York: Harper.

Jeammet, Violaine. 2010. "Boeotian "Genre" Scenes." In Tanagras: Figurines for Life and Eternity. 49-56. Paris: Musée du Louvre.

Jenkins, G. K. 1972. Ancient Greek Coins. New York, NY: G. P. Putnam's Sons.

Jenkins, Ian. 1992. Archaeologists \& Aesthetes: in the Sculpture Galleries of the British Museum 1800-1939. London: British Museum Press.

Jenkins, Ian and Kim Sloan. 1996. Vases and Volcanoes: Sir William Hamilton and His Collection. London: The British Museum.

Jenkyns, Richard. 1980. The Victoriana and Ancient Greece. Cambridge, MA: Harvard University Press.

Johns, Catherine. 1982. Sex or Symbol ? Erotic Images of Greece and Rome. Austin, TX: University of Texas Press.

Johns, Catherine. 1996. The Jewelry of Roman Britain. Ann Arbor, MI: The University of Michigan Press.

Johnson, Dorthy, Ethel Beatrice Abrahams, et al. 1964. Ancient Greek Dress. Chicago: Argonaut. 
Johnson, Franklin P. 1934. "Review: [Corpus Vasorum Antiquorum by Luce, Stephen Bleecker; Ingen, Wilhelmina van]." CP 29 (3): 278.

Johnson, Franklin P. 1938. "Red-Figured Pottery at Chicago." AJA 42 (3): 345-61.

Johnson, Franklin P. 1941. "A Fragment of an Attic Dinos." Art in America 29: 208-16.

Johnson, Franklin P. 1943. "Black-Figure Pottery at Chicago." AJA 47 (4): 385-402.

Johnson, Franklin P. 1949. "Eight Pieces of Pottery." AJA 53 (3): 241-8.

Johnson, Franklin P. 1955. "A Note on Owl Skyphoi." AJA 59 (2): 119-24.

Johnson, Henry. 1895. Descriptive Catalogue of the Bowdoin College Art Collections. Brunswick, ME: Bowdoin College.

Johnson, Henry. 1907. "Report of the Curator of Art Collections " Report of the President of Bowdoin College.

Johnson, Henry. 1916. "Report of the Curator of Art Collections." Report of the President of Bowdoin College.

Johnston, Theresa. 2003. "About A Boy." Stanford 31 (July/August): 38-43.

Judge, Harry. 2006. "H. A. L. Fisher: Scholar and Minister." Oxford Review of Education 32 (1): 5-21.

"Keen Eye: Archaeologist Dorothy Burr Thompson." 2001. Bryn Mawr Alumnae Bulletin Online. http://www.brynmawr.edu/alumnae/bulletin/home.htm (3 February 2011).

Kelsey, Frances W. 1919. "Richard Norton." Art and Archaeology 8: 328-35.

Kenny, Robert W. 1981. "George H. Corliss: Engineer, Architect, Philanthropist." Rhode Island History 40: 48-61. 
Kershaw, Gordon E. 1976. James Bowdoin: Patriot and Man of the Enlightenment. Brunswick, ME: Bowdoin College.

Kilinski, Karl. 1979. "Boeotian Kabric Bowl." In Greek Vase-Painting in Midwestern Collections. 216-17. Chicago: The Art Institute.

Kimmel, Michael S. 2006. Manhood in America : A Cultural History. New York: Oxford University Press.

King, Eleanor M. and Bryce P. Little. 1986. "George Byron Gordon and the Early Development of the University Museum." In Raven's Journey: The World of Alaska's Native People. 16-51. Philadelphia, PA: University Museum, University of Pennsylvania.

Kisluk-Grosheide, Daniëlle O. 1994. "The Marquand Mansion." MMAJ 29: 151-81.

Klein, Maury and Harvey A. Kantor. 1976. Prisoners of Progress: American Industrial Cities 1850-1920. New York: Macmillan Company.

Kleiner, Diana E. E. 2000. "Family Ties: Mothers and Sons in Elite and Non-Elite Roman Art." In I Claudia II: Women in Roman Art and Society. 43-60. Austin, TX: University of Texas Press.

Kleiner, Diana E. E. 1992. Roman Sculpture. New Haven, CT: Yale University Press.

Kleiner, Diana E. E. and Susan B. Matheson. 1996. I, Claudia: Women in Ancient Rome. New Haven, CT: Yale University Art Gallery.

Kleiner, Fred S. 2010. Gardner's Art through the Ages: A Global History. Thirteenth ed. Wadsworth.

Kline, Katy. 2005. "Introduction." In Ars Antiqua: Treasures from the Ancient Mediterranean at Bowdoin College. 8-11. Brunswick, ME: Bowdoin College.

Kondoleon, Christine, Richard A. Grossmann, et al. 2008. MFA Highlights: Classical Art. Boston, MA: Museum of Fine Arts, Boston. 
Kourouniotis, K. and Carl W. Blegen. 1939. "Excavations at Pylos, 1939." AJA 43 (4): $557-76$.

Kozloff, Arielle P. 1980. "Companions of Dionysus." BClevMus 67 (7): 207-19.

Kozloff, Arielle P. and David Gordon Mitten. 1988. The Gods Delight: The Human Figure in Classical Bronze. Cleveland, OH: The Cleveland Museum of Art.

Kraay, Colin M. 1956. "The Archaic Owls of Athens: Classification and Chronology." NC 16 (43-68).

Krause, Paul. 1992. The Battle for Homestead, 1880-1892: Politics, Culture, and Steel. Pittsburg, PA: University of Pittsburg.

Kuklick, Bruce. 1996. Puritans in Babylon: The Ancient Near East and American Intellectual Life 1880-1930. Princeton, NJ: Princenton University.

Kurke, Leslie. 1999. Coins, Bodies, Games, and Gold: The Politics of Meaning in Archaic Greece. Princeton, NJ: Princeton University Press.

Kurtz, Donna C. 1975. Athenian White Lekythoi: Patterns and Painters. Oxford: Clarendon Press.

Kurtz, Donna C. 1985. Beazley and Oxford. Oxford: Oxford University Committee for Archaeology.

Kurtz, Donna C. 2000. The Reception of Classical Art in Britain: An Oxford Story of Plaster Casts from the Antique. Oxford: The Beazley Archive and Archaeopress.

Kurtz, Donna C. and J. D. Beazley. 1983. The Berlin Painter. Oxford: Clarendon Press.

Kurtz, Donna C. and John Boardman. 1971. Greek Burial Customs. Ithaca, NY: Cornell University Press.

Laffineur, Robert. 1978. L'Orfèverie Rhodienne Orientalissante. Athens: École Française d'Athènes. 
Lago, Mary. 2008. "Rothenstein, Sir William (1872-1945) " In Oxford Dictionary of National Biography. On-line Edition. H. C. G. Matthew and B. Harrison. Oxford: Oxford University Press. http://www.oxforddnb.com.echo.louisville.edu/view/article/ (23 June 2010).

"Lanciani, Roberto." 1930. AJA 34 (1): 62.

"Lane, George Martin, 1823-1897 " Harvard University Archives http://oasis.lib.harvard.edu/oasis/deliver/ hua14004 (25 June 2009).

Langdon, Susan Helen. 1993. From Pasture to Polis: Art in the Age of Homer. Columbia, MO: University of Missouri Press.

Lapatin, Kenneth. 2002. Mysteries of the Snake Goddess: Art, Desire, and the Forging of History. Boston, MA: Houghton Mifflin Company.

Lapatin, Kenneth. 2010. "Art History Carved in Agate." Times Literary Supplement. http://entertainment.timesonline.co.uk/tol/arts_and_entertainment/the tls/article71 51086.ece (16 June 2010).

Larrabee, Stephen Addison. 1957. Hellas Observed: The American Experience of Greece 1775-1865. New York: New York University Press.

Larson, Jennifer. 2009. "The Singularity of Herakles." In Heroes: Mortals and Myths in Ancient Greece. 31-8. New Haven, CT: Yale University Press.

"Later Archaic Greek Gems: Island Scarabs." http://www.beazley.ox.ac.uk/gems/

Laurie, Bruce and Eric Foner. 1989. Artisans into Workers: Labor in Nineteenth-Century America. New York: Hill and Wang.

Lavin, Marilyn Aronberg. 1983. The Eye of the Tiger: The Founding and Development of the Department of Art and Archaeology, 1883-1923, Princeton University. Princeton, NJ: The Department of Art and Archaeology and The Art Museum, Princeton University.

Lawler, Lillian B. 1954. "Bee Dances and the "Sacred Bees"." CW 47 (7): 103-6. 
Lawrence, A.W. 1929. Classical Sculpture. New York: Jonathan Cape \& Harrison Smith.

Leach, Eleanor Winsor. 2004. "Mary Hamilton Swindler (1884-1967)." Breaking Ground: Women in Old World Archaeology. http://www.brown.edu/Research/Breaking_Ground/bios/Swindler_Mary\%20Ham ilton.pdf (18 December 2010).

Lears, T. J. Jackson. 1981. No Place of Grace: Antimoderns and the Transformation of American Culture 1880-1920. New York: Pantheon Books.

Lehmann, Karl and Erling C. Olsen. 1944. Dionysiac Sarcophagi in Baltimore. New York: Institute of Fine Arts, New York University, and the Trustees of the Walters Art Gallery, Baltimore.

Lerman, Leo. 1967. "Where is it?" Mademoiselle 65 (2): 103-05.

Lesko, Barbara S. 2004. "Caroline Louise Ransom Williams (1872-1952)." Breaking Ground: Women in Old World Archaeology. http://www.brown.edu/Research/Breaking_Ground/bios/Ransom\%20Williams_C aroline\%20Louise.pdf (18 December 2010).

Lewis, Michael J. 2005. The Pennsylvania Academy of Fine Arts as Building and Idea. Edited by M. Hain and A. Baker. Philadelphia, PA: Pennsylvania Academy of the Fine Arts.

Lissarague, François. 1990. The Aesthetics of the Greek Banquet: Images of Wine and Ritual Princeton, NJ: Princeton University Press.

Lissarrague, François. 1995. "Identity and otherness: The Case of the Attic Head Vases and Plastic Vases." Source XI (1): 4-9.

Luce, Stephen Bleecker. 1917. "Some Lost Vases Found." AJA 21 (4): 409-16.

Luce, Stephen Bleecker. 1920. "Notes on "Lost" Vases." AJA 24 (3): 271-2.

Luce, Stephen Bleecker. 1923. "Notes on "Lost" Vases: II." AJA 27 (2): 184-7. 
Luce, Stephen Bleecker. 1925a. "Nicosthenes: His Activity and Affiliations." AJA 29 (1): $38-52$.

Luce, Stephen Bleecker. 1925b. "Notes on "Lost" Vases: III." AJA 29 (2): 188-90.

Luce, Stephen Bleecker. 1927. "Notes on "Lost" Vases: IV." AJA 31 (2): 177-9.

Luce, Stephen Bleecker. 1933. CVA: United States of America; Providence-Museum of the Rhode Island School of Design, Fascicule 1. Cambridge, MA: Harvard University Press.

Luce, Stephen Bleecker and Henry Field. 1944. "Arthur Fairbanks." AJA 48 (2): 179-80.

MacGregor, Arthur. 2001. The Ashmolean Museum: A Brief History of the Museum and Its Collections. London: Jonathan Horne Publications.

Marshall, John. 1903. "Letter to the Editor." BurlMag 2 (6): 376.

Marshall, John. 1909a. "Head of a Goddess, from Chios." AntDenk: 10-2.

Marshall, John. 1909b. "Head of Aphrodite." AntDenk: 12.

Marshall, John. 1910. "The Interpretation of the Large Greek Relief in Boston." BurlMag 17 (88): 247-50.

Matheson, Susan B. 1980. Ancient Glass in the Yale University Art Gallery. New Haven, CT: Yale University Art Gallery.

Matheson, Susan B. 1996. "The Divine Claudia: Women as Goddesses in Roman Art." In I Claudia: Women in Ancient Rome. 182-93. Austin, TX: The University of Texas Press.

Matheson, Susan B. 2000. "The Elder Claudia: Older Women in Roman Art." In I Claudia II: Women in Roman Art and Society. 125-38. Austin, TX: University of Texas Press. 
Mathieux, Néguine. 2010. "Tanagras in Paris: A Bourgeoise Dream." In Tanagras: Figurines for Life and Eternity. 17-9. Paris: Musée du Louvre.

Mattusch, Carol C. 1996. The Fire of Hephaistos: Large Classical Bronzes from North American Collections. Cambridge, MA: Harvard University Press.

Maxmin, Jody. 1973. "Review: The Anatomy Lesson of Dr. Richter." Arion 1 (4): 740-4.

May, Stephen. 2005. "An Enduring Legacy: The Pennsylvania Academy of Fine Arts, 1805-2005." In Pennsylvania Academy of Fine Arts, 1805-2005: 200 Years of Excellence. 10-27. Philadelphia, PA: Pennsylvania Academy of Fine Arts.

McCarthy, Kathleen D. 1985. "Creating the American Athens: Cities, Cultural Institutions, and the Arts, 1840-1930." American Quarterly 37 (3): 426-39.

McCullough, David. 1972. The Great Bridge. New York: Simon and Schuster.

McIntyre, A. McVoy. 1975. Beacon Hill: A Walking Tour. Boston, MA: Little, Brown \& Company.

McLoughlin, William Gerald. 1978. Rhode Island: A Bicentennial History. New York: W.W. Norton \& Company.

McNeal, R. A. 1995. "Athens and Nineteenth-Century Panoramic Art." IJCT 1 (3): 8097.

Medwid, Linda M. 2000. The Makers of Classical Archaeology: A Reference Work. Amherst, NJ: Humanity Books.

Mertens, Joan R. 2010. How to Read Greek Vases. New York: The Metropolitan Museum of Art.

MFA: A Guide to the Collection of the Museum of Fine Arts, Boston. 1999. Boston, MA: Museum of Fine Arts, Boston.

Michie, Thomas S. 2008a. Building a Notable Collection: The Growth and Evolution of the RISD Art Museum 1877-1915. Edited by D. Barrett and A. Martinez. Providence, RI: Rhode Island School of Design. 
Michie, Thomas S. 2008b. "A History of the Collection." In Selected Works. 10-24. Providence, RI: Museum of Art, Rhode Island School of Design.

Miles, Margaret M. 2008. Art as Plunder: The Ancient Origins of Debate about Cultural Property. New York: Cambridge University Press.

Miller, Lillian B. 1966. Patrons and Patriotism: The Encouragement of the Fine Arts in the United States 1790-1860. Chicago: University of Chicago Press.

Miller, Lillian B. 1970. "Review: [Museum of Fine Arts, Boston: A Centennial History by Whitehill, Walter Muir]." AHR 75 (7): 2136-8.

Miller, Lillian B. 1994. "The Legacy: The Walker Gift, 1894." In The Legacy of James Bowdoin III. 187-215. Brunswick, ME: Bowdoin College Museum of Art.

Mitchell, Alexandre G. 2009. Greek Vase-painting and the Origins of Visual Humour. Cambridge: Cambridge University Press.

Mitten, David Gordon. 1967. "The Earliest Greek Sculptures in the Museum." Boston Museum Bulletin 65 (339): 4-18.

Mitten, David Gordon. 1975. Catalogue of the Classical Collection Museum of Art, Rhode Island School of Design: Classical Bronzes. Providence, RI: Museum of Art, Rhode Island School of Design.

Moignard, Elizabeth. 1990. "Review: [Greek Vases: Lectures by J. D. Beazley, ed. Donna Kurtz]." CR 40 (2): 514.

Moon, Warren G. 1990. "Euphronios." In The David and Alfred Smart Museum of Art: A Guide to the Collections. 22-4. Chicago, IL: Hudson Hills Press.

Moon, Warren G. and Louise Berge. 1979. Greek Vase-Painting in Midwestern Collections. Chicago, IL: The Art Institute.

Moore, Barbara W. and Gail Weesner. 1992. Beacon Hill: A Living Portrait. Boston, MA: Century Hill Press. 
Moore, Charles H. 1897. "[Report of the Fogg Art Museum, 1897-98]." Annual Report (Fogg Art Museum) (1897/1898): 1-5.

Moret, Jean-Marc. 1991. "Circé Tisseuse sur les Vases du Cabirion." RA 2: 227-66.

Morford, Mark P. O. and Robert J. Lenardon. 2003. Classical Mythology. 7th ed. New York: Oxford University Press.

Morris, Jan. 1978. Oxford. Oxford: Oxford University Press.

Morrison, Samuel Eliot. 1930. The Development of Harvard University Since the Inauguration of President Eliot 1869-1929. Cambridge, MA: Harvard University Press.

Morrison, Samuel Eliot. 1936. Three Centuries of Harvard 1636-1936. Cambridge, MA: Harvard University Press.

Morrow, Katherine Dohan. 2004. "Edith Hayward Hall Dohan (1879-1943)." In Breaking Ground: Pioneering Women Archaeologists. 274-97. Ann Arbor, MI: University of Michigan Press.

Morton, Vonda. 1987. Oxford Rebels: The Life and Friends of Nevil Story Maskelyne 1823-1911: Pioneer Oxford Scientist, Photographer and Politician. Gloucester: Sutton.

Murray, Priscilla M. and Curtis N. Runnels. 2007. "Harold North Fowler and the Beginnings of American Study Tours in Greece." Hesperia 76 (3): 597-626.

Muscarella, Oscar White. 1991. "Greek and Oriental Cauldron Attachments." In Greece between East and West, 10th-8th Centuries BC: Papers of the Meeting at the Institute of Fine Arts, New York University, March 15-16th, 1990. 16-45. Mainz, Rhine: Verlag Philipp von Zabern.

Museum of Art, Rhode Island School of Design. 2008. Selected Works. Providence, RI: Museum of Art, Rhode Island School of Design.

Museum of Fine Arts, Boston "The MFA Collections." http://www.mfa.org 
Museum of Fine Arts, Boston. 1972. Greek \& Roman Portraits 470 BC - AD 500. Boston, MA: Museum of Fine Arts, Boston.

Museum of Fine Arts, Boston, and Agnes Baldwin Brett. 1955. Catalogue of Greek Coins. Boston, MA: Museum of Fine Arts.

Museum of Fine Arts, Boston and Lacey D. Caskey. 1925. Catalogue of Greek and Roman Sculpture. Cambridge, MA: Pub. for the Museum of Fine Arts, Boston, by the Harvard University Press.

Nasaw, David. 2006. Andrew Carnegie. New York: Penguin Press.

Neils, Jenifer. 1997. 'Lost' and Found: Adam Buck's Wedding of Dionysos. Edited by J. H. Oakley, W. D. E. Coulson and O. Palagia. Athens, Greece: Oxbow Books.

Neils, Jennifer and John H. Oakley. 2003. Coming of Age in Ancient Greece: Images of Childhood from the Classical Past. New Haven, CT: Yale Univesity Press.

Neudecker, Richard. 1988. Die Skulpturenausstattung Römischer Villen in Italien. Mainz am Rhein: P. von Zabern.

Neverov, Oleg. 1979. "Gems in the Collection of Rubens." BurlMag 121 (916): 424-32.

Nielsen, Christina M. 1998. "A History of the Classical Collection at the University of Chicago." In The Classical Collection. 1-8. Chicago, IL: David and Alfred Smart Museum of Art, University of Chicago.

Noble, Joseph Veach. 1988. The Techniques of Painted Attic Pottery. London: Thames and Hudson.

Nock, Arthur Darby. 1946. "Sarcophagi and Symbolism." AJA 50 (1): 140-70.

Nørskov, Vinnie. 2002. Greek Vases in New Contexts: The Collecting and Trading of Greek Vases: An Aspect of the Modern Reception of Antiquity. Aarhus: Aarhus University Press.

Norton, Richard. 1914. "The Boston Counterpart of the Ludovisi Throne." JHS 34: 6675. 
O'Connor, David and David Silverman. 1979. "The University Museum in Egypt: The Past." Expedition 21 (2): 4-44.

Oakley, John H. 1997. The Achilles Painter. Mainz: P. von Zabern.

Oakley, John H. 1998. "Why Study a Greek Vase Painter?--A Response to Whitley's 'Beazley as Theorist'." Antiquity 72: 209-13.

Oakley, John H. 2000. "Some 'Other' Members of the Athenian Household: Maids and Mistresses in Fifth-century Athenian Art." In Not the Classical Ideal: Athens and the Construction of the Other. Leiden: Brill.

Oakley, John H. 2004. Picturing Death in Classical Athens: The Evidence of the White Lekythoi. New York: Cambridge University Press.

Oakley, John H. 2009. "State of the Discipline: Greek Vase Painting." AJA 113: 599-627.

"Obituary: Sir Edward H. Bunbury, Bart." 1895. The Geographical Journal 5 (5): 498500.

Oettermann, Stephan. 1997. The Panorama: History of a Mass Medium New York: Zone Books.

Ogden, Jack. 1982. Jewelry of the Ancient World. New York: Rizzoli International Publications.

Oikonomides, Al N. 1977. "A New Mithraic Tauroctony in the J. Paul Getty Museum." The J. Paul Getty Museum Journal 5: 85-90.

Oliver, Andrew. 1977. Silver for the Gods: 800 Years of Greek and Roman Silver. Toledo, OH: The Toledo Museum of Art.

Orcutt, Kimberly A. 2006. "Personal collecting Meets Institutional Vision: The Origins of Harvard's Fogg Art Museum." Journal of the History of Collections 18 (2): $267-84$. 
Osborne, Carol Margot, Paul Venable Turner, et al. 1986. Museum Builders in the West: The Stanfords as Collectors and Patrons of Art, 1870-1906. Stanford, CA:

Stanford University Museum of Art, Stanford University.

Osborne, Robin. 1998. Archaic and Classical Greek Art. New York: Oxford University Press.

Otter, S. M. den. 2009. "Case, Thomas (1844-1925)." In Oxford Dictionary of National Biography. On-line Edition. H. C. G. Matthew and B. Harrison. Oxford: Oxford University Press. (24 January 2009).

Ovenell, R. F. 1986. The Ashmolean Museum 1683-1894. Oxford: Clarendon Press.

Padgett, J. Michael. 2003. The Centaur's Smile: The Human Animal in Early Greek Art. Princeton, NJ: Princeton University Art Museum.

Padgett, J. Michael, Mary B. Comstock, et al. 1993. Vase-Painting in Italy: Red-figure and Related Works in the Museum of Fine Arts, Boston. Boston, MA: Museum of Fine Arts, Boston.

Page, Jutta-Anette. 2006. The Art of Glass: Toledo Museum of Art. London: D. Giles Limited.

Painter, Richard W. 2001. "Contracting Around Conflicts in a Family Representation: Louis Brandeis and the Warren Trust." University of Chicago Law School Roundtable 8: 352-80.

Paul, Aaron J. 1997. "Fragments of Antiquity: Drawing upon Greek Vases." Harvard University Art Museums Bulletin 5 (2): 1-87.

Pedley, John Griffiths. 2007. Greek Art and Archaeology. 4th ed. Upper Saddle River, NJ: Prentice-Hall.

Pemberton, Elizabeth. 1989. "The Dexiosis on Attic Gravestones." MeditArch 2: 45-50.

Peterson, Richard H. 1985. "Philanthropic Phoebe: The Educational Charity of Phoebe Apperson Hearst." California History 64 (4): 284-9. 
Pfister-Haas, Susanne. 2006. CVA Deutschland. Leipzig-Antikenmuseum der Universität.CVA, Bd. 80. . München: C.H. Beck.

Picon, Carlos A. 2007. Art of the Classical World in the Metropolitan Museum of Art. New Haven, CT: Yale University Press.

Pinney, Gloria Ferrari and Brunilde Sismondo Ridgway. 1979. Aspects of Ancient Greece: An Exhibition ... ; Allentown Art Museum, September 16 Through December 30, 1979. Allentown, PA.

Plantzos, Demetris. 1999. Hellenistic Engraved Gems. Oxford: Clarendon Press.

Pollak, Ludwig and Margarete Merkel Guldan. 1994. Römische Memoiren: Künstler, Kunstliebhaber und Gelehrte 1893-1943. Roma: "L'Erma" di Bretschneider.

Pollini, John. 1999. "The Warren Cup: Homoerotic Love and Symposial Rhetoric in Silver." ArtB 81 (1): 21-52.

Poole, Helen. 2000. Lewes Past. Chichester, West Sussex: Phillimore.

Porter, Barbara N. 1989. Assyrian Bas-Reliefs at the Bowdoin College Museum of Art. Brunswick, ME: Bowdoin College Museum of Art.

Potts, Alex. 1994. Flesh and the Ideal: Winckelmann and the Origins of Art History. New Haven, CT: Yale University Press.

Potvin, John. 2005. "Vapour and Steam: The Victorian Turkish Bath, Homosocial Health, and Male Bodies on Display." Journal of Design History 18 (4): 319-33.

Potvin, John. 2008. Material and Visual Cultures Beyond Male Bonding, 1870-1914. Burlington, VT: Ashgate.

Potvin, John. 2009. "Collecting Intimacy One Object at a Time: Material Culture, Perception, and the Spaces of Aesthetic Companionship." In Material Cultures, 1740-1920: The Meanings and Pleasures of Collecting. 191-207. Burlington, VT: Ashgate. 
Poulet, Anne L. 2003. Jean-Antoine Houdon: Sculptor of the Enlightenment. Washington, DC: National Gallery of Art.

Prescott, Dorothy. 1958. The Story of Cedar Hill. Belmont, MA: self-published.

Price, Jennifer. 1976. "Glass." In Roman Crafts. 110-25. New York: New York University Press.

Price, M. Jessop. 1979. "The Coinage of Phillip II." The Numismatic Chronicle 139: 23041.

Pryce, T. Davies. 1942. "Roman Decorated Red-Glazed Ware of the Late First Century B.C. and the Early First Century A.D." JRS 32: 14-26.

Ramage, Nancy H. and Andrew Ramage. 2010. Roman Art: Romulus to Constantine. Fifth ed. Upper Saddle River, NJ: Pearson Prentice Hall.

Reed, Walter A. 1910. "Warren, S. D. Harvard College, Class of 1875."

Reeder, Ellen. 1995. Pandora: Women in Ancient Greece. Princeton, NJ: Princeton University Press.

Regling, Kurt. 1906. Die Griechishen Münzen der Sammlung Warren. Berlin: Druck Und Verlag Von Georg Reimer.

Reilly, Joan. 1989. "Many Brides: 'Mistress and Maid'on Athenian Lekythoi." Hesperia 58 (4): 411-44.

Reinach, Salomon. 1899. "Deux Statuettes d'Aphrodite." RA 35: 369-75.

Reinach, Salomon. 1935. Apollo: An Illustrated Manual of the History of Art Throughout the Ages. New York: Charles Scribner's Sons.

Reinhold, Meyer. 1984. Classica Americana: The Greek and Roman Heritage in the United States. Detroit, MI: Wayne State University Press. 
Renger, Marta Osterstrom. 1969. "The Providence Niobid Sarcophagus." AJA 73 (2): $179-84$.

Renn, Melissa. 2007. "Charles Herbert Moore and the Teaching of Art at Harvard." In The Last Ruskinians: Charles Eliot Norton, Charles Herbert Moore, and Their Circle. 41-5. Cambridge, MA: Harvard Art Museums.

"Report of the President of Bowdoin College." 1893-4. George J. Mitchell Dept. of Special Collections \& Archives of the Bowdoin College Library

Rethinking the Romans: New Views of Ancient Sculpture.2001. Providence, RI: Museum of Art, Rhode Island School of Design.

Richard, Carl J. 2009. The Golden Age of the Classics in America: Greece, Rome, and the Antebellum United States. Cambridge, MA: Harvard University Press.

Richter, Gisela M. A. 1920. "The Subject of the Ludovisi and Boston Reliefs." JHS 40: $113-23$.

Richter, Gisela M. A. 1923. "Classical Department: Miscellaneous Accessions." BMMA 18 (5): $124-7$.

Richter, Gisela M. A. 1933. "Two Bronze Statuettes." AJA 37 (1): 48-51.

Richter, Gisela M. A. 1965. The Portraits of the Greeks. London: Phaidon Press.

Richter, Gisela M. A. and Charles Fergus Binns. 1937. Etruscan Terracotta Warriors in the Metropolitan Museum of Art. New York: Metropolitan Museum of Art.

Ridgway, Brunilde Sismondo. 1972. Catalogue of the Classical Collection: Classical Sculpture. Providence, RI: Museum of Art, Rhode Island School of Design.

Ridgway, Brunilde Sismondo. 1977. The Archaic Style in Greek Sculpture. Princeton, NJ: Princeton University Press.

Ridgway, Brunilde Sismondo. 1981. Fifth Century Styles in Greek Sculpture. Princeton, NJ: Princeton University Press. 
Ridgway, Brunilde Sismondo. 1990b. Hellenistic Sculpture III: The Styles of ca. 100-31 B.C. Madison, WI: The University of Wisconsin Press.

Robertson, Martin. 1991. "Adopting an Approach I." In Looking at Greek Vases. 1-12. Cambridge: Cambridge University Press.

Robertson, Martin. 1992. The Art of Vase-Painting in Classical Athens. Cambridge: Cambridge University Press.

Robinson, David M. 1915. "Two Unpublished Vase Illustrations from Homer." AJA 19 (1): 78-9.

Robinson, David M. 1917. "On Reproductions for the College Museum and Art Gallery." The Bulletin of the College Art Association of America 1 (3): 15-21.

Robinson, David M. 1922. "An Amphora of Nicosthenes in Baltimore." AJA 26 (1): 54-8.

Robinson, Edward. 1891. Museum of Fine Arts Boston Catalogue of Casts: Greek and Roman Sculpture. Boston, MA: Houghton Mifflin Company.

Robinson, Edward. 1909. "Department of Classical Art: The Accessions of 1908. V. Miscellaneous." BMMA 4 (7): 124-30.

Robinson, Judith. 1991. The Hearsts: An American Dynasty Newark, DE: University of Delaware Press.

Robinson, Martin. 2004. "Beazley, Sir John Davidson (1885-1970 " In Oxford Dictionary of National Biography. On-line Edition. H. C. G. Matthew and B. Harrison. Oxford: Oxford University Press. http://www.oxforddnb.com.echo.louisville.edu/view/article/30664 (7 July 2010).

Robinson, Paul. 1999. Gay Lives: Homosexual Autobiography from John Addington Symonds to Paul Monette. Chicago, IL: University of Chicago Press.

Rodenwaldt, Gerhart. 1933. "Sarcophagi from Xanthos." JHS 53: 181-213.

Rodin, Auguste. 1904. "La tête Warren." Le Musée 6: 298-301. 
Rogers, Malcolm. 1999. "A Brief History of the Museum." In A Guide to the Collections of the Museum of Fine Arts, Boston. 6-18. Boston, MA: Museum of Fine Arts, Boston.

Romano, Irene Bald. 2006. Classical Sculpture: Catalogue of the Cypriot, Greek, and Roman Sculpture in the University of Pennsylvania Museum of Archaeology and Anthropology. Philadelphia, PA: University of Pennsylvania Museum of Archaeology and Anthropology.

Rose, Brian Charles. 1997. Dynastic Commemoration and Imperial Portraiture in the Julio-Claudian period. Cambridge: Cambridge University Press.

Rose, Charles. 2007. 'I am much inclined to it': The Story of Lewes House. Lewes, East Sussex: Lewes District Council

Rosivach, Vincent J. 1987. "Autochthony and the Athenians." CQ 37 (2): 294-306.

Rothenstein, William. 1931. Men and Memories: Recollections of William Rothenstein 1872-1900. New York: Coaward-McCann, Inc.

Rotroff, Susan I. 1978. "Hellenistic Athenian Pottery: "Megarian Bowls"." CurrAnthr 19 (2): 387-8.

Rouet, Philippe. 2001. Approaches to the Study of Attic Vases: Beazley and Pottier. New York: Oxford University Press.

Rowe, Marilyn B. 1952. Highlights of Westbrook History. Westbrook, ME: Westbrook Woman's Club.

Rowse, A. L. 1977. Homosexuals in History: A Study of Ambivalence in Society, Literature and the Arts. New York: Carroll \& Graf Publishers, Inc.

Russell, David R. 2002. Institutionalizing English: Rhetoric on the Boundaries. Edited by D. R. Shumway and C. Dionne. Albany, NY: State University of New York Press.

Ruwell, Mary Elizabeth. 1984. A Guide to the University Museum Archives of the University of Pennsylvania. Philadelphia, PA: The University Museum, University of Pennsylvania. 
Ryan, A. 2010. "Fisher, Herbert Albert Laurens (1865-1940)." In Oxford National Biography. On-line edition. H. C. G. Matthew and B. Harrison. Oxford: Oxford University Press. http://www.oxforddnb.com.echo.louisville.edu/view/article/33141

Rydell, Robert W. 1984. All the World's a Fair: Visions of Empire at American International Expositions, 1876-1916. Chicago: University of Chicago.

Saltzman, Cynthia. 2008. Old Masters, New World: America's Raid on Europe's Great Pictures 1880-World War I. New York: Viking.

Samuel Dennis Warren (September 13, 1817--May 11, 1888): A Tribute from the People of Cumberland Mills.1888. Cambridge, MA: Riverside Press.

Samuels, Ernest. 1979. Bernard Berenson: The Making of A Connoisseur. Cambridge, MA: Belknap Press.

Samuels, Warren J. 1984. "A Centenary Reconsideration of Bellamy's Looking Backward." American Journal of Economics and Sociology 43 (2): 129-48.

Sarti, Susanna. 2001. Giovanni Pietro Campana (1808-1880): The Man and His Collection. Oxford: Archaeopress.

Sayles, Wayne G. 2007. Ancient Coin Collecting II: Numismatic Art of the Greek World. 2nd ed. Iola, WI: Krause Publications.

Scarisbrick, Diana. 1981. "Henry Walters and the Marlborough Gems." The Journal of the Walters Art Gallery 39: 49-3.

Schachter, Albert. 1986. "Cults of Boiotia: Herakles to Poseidon." Institute of Classical Studies (38.2).

Scheffer, Charlotte. 1987. Roman Cinerary Urns in Stockholm Collections. Stockholm: Museum of Mediterranean and Near Eastern Antiquities.

Scheurleer, Robert A. Lunsingh. 1996. "From Statue to Pendant: Roman Harpocrates Pendants in Gold, Silver, and Bronze." In Ancient Jewelry and Archaeology. 15271. Bloomington, IN: Indiana University Press. 
Schwartz, Paul W. 1959. "Warren House." Harvard Crimson. http://www.thecrimson.com/article.aspx?ref=159569

Schwarz, Shirley J. 1996. Greek Vases in the National Museum of Natural History, Smithsonian Institution Washington D.C. Rome: L'Erma di Bretschneider.

Seidel, Linda and Katherine Taylor. 1998. Visual Pedagogy at the University of Chicago. Chicago, IL: The David and Alfred Smart Museum of Art, The University of Chicago.

Select Exhibition of Sir John and Lady Beazley's Gifts to the Ashmolean Museum 19121966.1967. Oxford: Oxford University Press for the Ashmolean Museum.

Shackel, Paul A. and Matthew M. Paulus. 2006. "The Gilded Age and Working-Class Industrial Communities." American Anthropologist 108 (4): 828-41.

Shand-Tucci, Douglass. 1995. Boston Bohemia 1881-1900. Amherst, MA: University of Massachusetts Press.

Shand-Tucci, Douglass. 2003. The Crimson Letter: Harvard, Homosexuality, and the Shaping of American Culture. New York: St. Martin's Press.

Shapiro, H. A. 1991. "The Iconography of Mourning in Athenian Art." AJA 95 (4): 62956.

Shapiro, H. A. 2003. "Fathers and Sons, Men and Boys." In Coming of Age in Ancient Greece. 84-111. New Haven, CT: Yale University Press.

Shelley, Percy Bysshe and Anthony D. Knerr. 1984. Shelley's Adonais: A Critical Edition. New York: Columbia University Press.

Shelley, Percy Bysshe, Zachary Leader, et al. 2003. The Major Works. New York: Oxford University Press.

Sherman, Claire Richter. 1981. "Widening Horizons (1890-1930)." In Women as Interpreters of the Visual Arts, 1820-1979. 27-59. Westport, CT: Greenwood Press. 
Sherwood, James. 1973. No Golden Journey: A Biography of James Elroy Flecker. London: Heinemann.

Silver, Vernon. 2009. The Lost Chalice: The Epic Hunt for a Priceless Masterpiece. New York: William Morrow.

"Sir John Beazley." The Beazley Archive http://www.beazley.ox.ac.uk/pottery/collection/johnbeazley.htm (7 July 2010).

"Slater Memorial Museum." Norwich Free Academy http://www.norwichfreeacademy.com/museum/ (16 April 2009).

Smith, Amy C. 2006. "The Evolution of the Pan Painter's Artistic Style." Hesperia 75 (4): 435-51.

Smith, Diana M. and Kathleen Burns "Susan Wilbur Jones, b. 1893." http://drs.library.yale.edu (5 February 2010).

Smith, Robert C. 1960. The Ruins of Rome: [Catalog of an Exhibition, University Museum, University of Pennsylvania]. Philadelphia, PA: University Museum, University of Pennsylvania.

Smith, Timothy d'Arch. 1970. Love in Earnest: Some Notes on the Lives and Writings of English 'Uranian' Poets from 1889 to 1930. London: Routledge \& K. Paul.

Smyth, Herbert Weir. 1930. "The Classics 1867-1929." In The Development of Harvard University Since the Inauguration of President Eliot 1869-1929. 33-64. Cambridge, MA: Harvard University Press.

Sourvinou-Inwood, Christiane. 1975. "Who Was the Teacher of the Pan Painter?" JHS 95: 107-21.

Sox, David. 1991. Bachelors of Art: Edward Perry Warren \& the Lewes House Brotherhood. London: Fourth Estate.

Sox, David. 2005. "Warren, Edward Perry (1860-1928)." In Oxford Dictionary of National Biography. Online edition. L. Goldman. Oxford, England: Oxford University Press. 
http://www.oxforddnb.com.echo.louisville.edu/view/article/58542 (April 1, 2010).

Sox, David. 2006. The Lewes House Brotherhood and Bloomsbury. Lewes, East Sussex: Lewes District Council.

"Special Collections." Boston Athenæum http://www.bostonathenaeum.org/collections.html (16 August 2009).

Sprague, Laura Fecych. 1994. "Theophilus Wheeler Walker and the Gore Place." In The Legacy of Janes Bowdoin III. 216-23. Brunswick, ME: Bowdoin College Museum of Art.

Sprague, Laura Fecych. 2007. The Walker Sisters and Collecting in Victorian Boston. Brunswick, ME: Bowdoin College Museum of Art.

Standiford, Les. 2005. Meet You in Hell: Andrew Carnegie, Henry Clay Frick, and the Bitter Partnership that Transformed America. New York: Crown Publishers.

Starr, Chester G. 1970. Athenian Coinage 480-449 B.C. Oxford: Clarendon Press.

Stebbins, Theodore E. 1992. The Lure of Italy: American Artists and the Italian Experience, 1760-1914. Boston: Museum of Fine Arts.

Stern, E. Marianne. 1995. Roman Mold-blown Glass: the First through Sixth Centuries. Rome: L'Erma.

Stern, E. Marianne. 1999. "Roman Glassblowing in a Cultural Context." AJA 103 (3): 441-84.

Stern, E. Marianne. 2002. "Review: Glass Is Hot." AJA 106 (3): 463-71.

Stewart, Andrew. 1977. Skopas of Paros. Park Ridge, NJ: Noyes Press.

Stewart, Andrew. 1993. Faces of Power: Alexander's Image and Hellenistic Politics. Berkeley, CA: University of California Press. 
Stewart, Andrew. 2008. Classical Greece and the Birth of Western Art. Cambridge: Cambridge University Press.

Stewart, Iain Jeremy. 2003. "Putting the Pieces Together: The Collecting Practices of Edward Perry Warren (1860-1928) and the Museum of Fine Arts, Boston." master's thesis, Concordia University.

Storey, Ian C. and Arelene Allan. 2005. A Guide to Ancient Greek Drama. Oxford: Blackwell Publishing.

Story, Ronald. 1975. "Class and Culture in Boston: The Athenaeum, 1807-1860." American Quarterly 27 (2): 178-99.

Stray, Christopher. 1968. Classic Transformed: Schools, Universities, and Society in England, 1830-1960. Oxford: Clarendon Press.

Studniczka, Franz. 1911. JdI 26: 50-192.

Sutherland, Arthur E. 1967. The Law at Harvard: A History of Ideas and Men, 18171967. Cambridge, MA: Belknap Press of Harvard University Press.

Svatik, Eleanor. 1939. "A Euphronios Kylix." ArtB 21 (3): 251-71.

Swan, Mabel Munson. 1940. The Athencum Gallery 1827-1873: The Boston Athenceum as an Early Patron of Art. Boston: The Boston Athenæum

Swerdlow, N. M. 1991. "On the Cosmical Mysteries of Mithras." CP 86 (1): 48-63.

Swindler, Mary Hamilton. 1909. "Another Vase by the Master of the Penthesilea Cylix." AJA 13 (2): 142-50.

Swindler, Mary Hamilton. 1915. "The Penthesilea Master." AJA 19 (4): 398-417.

Swindler, Mary Hamilton. 1916. "The Bryn Mawr Collection of Greek Vases." AJA 20 (3): $308-45$. 
Swindler, Mary Hamilton. 1929. Ancient Painting, from the Earliest Times to the Period of Christian Art. New Haven, CT: Yale University Press.

Switzer, Russell. 2008. "Configuration of Aesthetic and Capital." In 'infinite radius': Founding Rhode Island School of Design. 106-69. Providence, RI: Rhode Island School of Design.

Taplin, Oliver. 1992. Comic Angels: And Other Approaches to Greek Drama through Vase-paintings. Oxford: Clarendon Press.

Taplin, Oliver. 2007. Pots \& Plays: Interactions between Tragedy and Greek Vasepainting of the Fourth Century B. C. Los Angeles, CA: The J. Paul Getty Museum.

Tarbell, F. B. 1893. "Letters from Greece." The American Journal of Archaeology and of the History of the Fine Arts 8 (2): 230-8.

Tarbell, F. B. 1900. "A Signed Cylix by Duris, in Boston." AJA 4 (2): 183-91.

Tarbell, F. B. 1905. A History of Greek Art. New York: Grossett \& Dunlap.

Tarbell, F. B. 1908. "A White Athenian Lecythus Belonging to the University of Chicago." AJA 12 (4): 428-30.

Tarbell, F. B. 1910a. "Architecture on Attic Vases." AJA 14 (4): 428-33.

Tarbell, F. B. 1910b. "Review: [Greek Archaeology by Fowler, Harold North; Wheeler, James Rignall] " CP 5 (2): 232-4.

"A Taste of Dieppe." http://www.dieppe.fr/mini-sites/a-taste-of-dieppe/pages/a-longhistory-107 (5 April 2010).

Taylor, Mark and David Hill. 2007. "The Reproduction of Roman Glass." In Reflecting Antiquity: Modern Glass Inspired by Ancient Rome. 75-81. Corning, NY: Corning Museum of Glass.

Taylor, Sue and Richard A. Born. 1990. The David and Alfred Smart Museum of Art: A Guide to the Collection. New York: Hudson Hills Press. 
Tezgor, D. Kassab. 2010. "Alexandria and Myrina." In Tanagras: Figurines for Life and Eternity. 186-89. Paris: Musée du Louvre.

Thomas, Edmund. 2007. Monumentality and the Roman Empire: Architecture in the Antonine Age. Oxford: Oxford University Press.

Thomas, George E. and David B. Brownlee. 1999. Building America's First University: An Historical and Architectural Guide to the University of Pennsylvania. Philadelphia, PA: University of Pennsylvania Press.

Thompson, Dorothy Burr. 1934a. Terra-cottas from Myrina in the Museum of Fine Arts, Boston. Vienna: A. Holzhausens Nachfolger.

Thompson, Homer A. 1934b. "Two Centuries of Hellenistic Pottery." Hesperia 3 (4): 311-476.

Thompson, Margaret. 1965. "Introduction." In Archaelogy and the Types of Greek Coins. Chicago: Argonault Publishers.

Thornton, R. K. R. 2007. "Johnson, Lionel Pigot (1867-1902)." In Oxford Dictionary of National Biography. online ed. H. C. G. Matthew and B. Harrison. Oxford: Oxford University Press. (June 22, 2010).

Toby, Yuen. 1979. "Giulio Romano, Giovanni da Udine and Raphael: Some Influences from the Minor Arts of Antiquity." JWarb 42: 263-72.

Tompkins, E. Berkeley. 1970. Anti-Imperialism in the United States: The Great Debate, 1890-1920. Philadelphia, PA: University of Pennsylvania Press.

Tosto, Vincent. 1999. The Black-Figure Pottery Signed Nikosthenesepoiesen. Amsterdam: Allard Pierson Museum.

Trask, David F. 1981. The War With Spain in 1898. New York: Macmillan Publishing Company, Inc.

Trendall, A. D. 1973. The Red-figured Vases of Lucania, Campania and Sicily. London: Institute of Classical Studies. 
Trendall, A. D. 1987. The Red-Figured Vases of Paestum. London: The British School at Rome.

Trendall, A. D. 1989. Red Figure Vases of South Italy and Sicily: A Handbook. New York: Thames and Hudson.

Trendall, A. D. and Alexander Cambitoglou. 1978. The Red-Figured Vases of Apulia. Oxford: Clarendon Press.

Trendall, A. D. and T. B. L. Webster. 1971. Illustrations of Greek Drama. London: Phaidon.

True, Marion. 2006. "Athenian Potters and the Production of Plastic Vases." In The Colors of Clay: Special Techniques in Athenian Vases. 240-49. Los Angeles, CA: The J. Paul Getty Museum.

Tsingarida, Athena. 2008. "Color for Market? Special Techniques and Distribution Patterns in Late Archaic and Early Classical Greece." In Papers on Special Techniques in Athenian Vases. 187-206. Los Angeles, CA: The J. Paul Getty Museum.

Twain, Mark and Charles Dudley Warner. 1996. The Gilded Age. New York: Oxford University Press.

"Two Greek Marbles Recently Acquired." 1905. Museum of Fine Arts Bulletin 3 (1): 3-5.

Uhlenbrock, Jaimee P. 1990a. "Preface." In The Coroplast's Art: Greek Terracottas of the Hellenistic World. 8-9. New Rochelle, NY: College Art Gallery, The College at New Paltz, State University of New York.

Uhlenbrock, Jaimee P. 1990b. "The Coroplast and His Craft." In The Coroplast's Art: Greek Terracottas of the Hellenistic World. 15-21. New Rochelle, NY: College Art Gallery, The College at New Paltz, State University of New York.

Uhlenbrock, Jamiee P. 1990e. The Coroplast's Art: Greek Terracottas of the Hellenistic World. New Rochelle, NY: College Art Gallery, The College of New Paltz, State University of New York. 
Urofsky, Melvin I. 2009. Louis D. Brandeis: A Life. New York: Pantheon Books.

Usher, Jan. 2004. Sappi/Warren Release Papers:150 Years. Westbrook, ME: Sappi.

Valentine, Lucia N. and Alan Chester Valentine. 1973. The American Academy in Rome, 1894-1969. Charlottesville, VA University Press of Virginia.

Vance, Norman. 1985. The Sinews of the Spirit: The Ideal of Christian Manliness in Victorian Literature and Religious Thought. New York: Cambridge University Press.

Vance, William L. 1989. America's Rome. New Haven, CT: Yale University Press.

Vanderbilt, Kermit. 1959. Charles Eliot Norton: Apostle of Culture in a Democracy. Cambridge, MA: Harvard University Press.

Venable, Charles L. 1995. Silver in America 1840-1940: A Century of Splendor. Dallas, TX: Dallas Museum of Art.

Vermeule, Cornelius C. 1962. "Roman Sarcophagi in America: A Short Inventory." In Festschrift für Friedrich Matz. 98-109. Mainz: Verlag Phillipp von Zabern.

Vermeule, Cornelius C. 1964. "Greek, Etruscan, and Roman Sculptures in the Museum of Fine Arts, Boston." AJA 68 (4): 323-41.

Vermeule, Cornelius C. 1965. "A Greek Theme and Its Survivals: The Ruler's Shield (Tondo Image) in Tomb and Temple." PAPS 109 (6): 361-97.

Vermeule, Cornelius C. 1974b. Greek and Roman Sculpture in Gold and Silver. Boston, MA: Museum of Fine Arts Boston.

Vermeule, Cornelius C. 1977. Greek Sculpture and Roman Taste: The Purpose and Setting of Graeco-Roman Art in Italy and the Greek Imperial East. Ann Arbor, MI: University of Michigan Press.

Vermeule, Cornelius C. 1983. Divinities and Mythological Scenes in Greek Imperial Art. Cambridge, MA: Spink and Son, LTD. 
Vermeule, Cornelius C. 1987a. The Cult Images of Imperial Rome. Roma: Giorgio Bretschneider Editore.

Vermeule, Cornelius C. 1995. "Neon Illion and Ilium Novum: Kings, Soldiers, Citizens, and Tourists at Classical Troy." In The Ages of Homer: A Tribute to Emily Townsend Vermeule. 467-82. Austin,TX: The University of Texas Press.

Vermeule, Cornelius C. 2002. "The Collector and Collection." In The Lewes House Collection of Ancient Gems [now at the Museum of Fine Arts, Boston. 3-5. London: Archaeopress.

Vermeule, Cornelius C. and Amy Brauer. 1990. Stone Sculptures: The Greek, Roman, and Etruscan Collections of the Harvard University Art Museums. Cambridge, MA: Harvard University Art Museums.

Vermeule, Cornelius C. and P. von Kersburg. 1968. "Appendix: Lions, Attic and Related." APA 72 (2): 99-101.

Vermeule, Emily. 1969. "Some Erotica in Boston." AntK 12: 9-15.

Vermeule, Emily. 1987b. "The Key to the Fields: The Classics at Bryn Mawr." In A Century Recalled: Essays in Honor of Bryn Mawr College. 163-72. Bryn Mawr, PA: Bryn Mawr College Library.

Veysey, Laurence R. 1965. The Emergence of the American University. Chicago: University of Chicago Press.

Vickers, Michael. 1985a. "Artful Crafts: The Influence of Metal Work on Athenian Painted Pottery." JHS 105: 108-28.

Vickers, Michael. 1985b. "Silver, Copper and Ceramics in Ancient Athens." In Pots \& Pans: A Colloquium on Precious Metals and Cermaics in the Muslim, Chinese, and Greco-Roman Worlds, Oxford 1985. 137-51. Oxford: Oxford University Press.

Vickers, Michael. 1994. "Nabataea, India, Gaul, and Carthage: Reflections on Hellenistic and Roman Gold Vessels and Red-Gloss Pottery." AJA 98 (2): 231-48. 
Vickers, Michael. 1999. Ancient Greek Pottery. Oxford: Ashmolean Museum.

Vickers, Michael. 2006. The Arundel and Pomfret Marbles in Oxford. Oxford: Ashmolean Museum.

Vickers, Michael and David Gill. 1994. Artful Crafts: Ancient Greek Silverware and Pottery. Oxford: Clarendon.

von Bothmer, Dietrich. 1966. "Andokides the Potter and the Andokides Painter." The Metropolitan Museum of Art Bulletin 24 (6): 201-12.

von Bothmer, Dietrich. 1995. "Review: [Martin Kilmer's Greek Erotica on Attic RedFigure Vases]." CJ 91 (1): 82-6.

von Bothmer, Dietrich. 1998. "Forgeries on Greek Vases: An Overview of a Perplexing Problem." Minerva 9 (2): 8-17.

von Bothmer, Dietrich 1951. "Attic Black-Figured Pelikai." JHS 71: 40-7.

von Bothmer, Dietrich 1987. Greek Vase Painting: Two-hundred Years of Connoisseurship. Edited by M. True. Los Angeles, CA: J. Paul Getty Museum.

von Bothmer, Dietrich and Joseph Veach Noble. 1961. An Inquiry into the Forgery of the Etruscan Terracotta Warriors in the Metropolitan Museum of Art. New York: Metropolitan Museum of Art.

von Holst, Niels 1967. Creators, Collectors and Connoisseurs: The Anatomy of Artistic Taste from Antiquity to the Present Day. New York: G. P. Putnam's Sons.

von Mach, Edmund. 1905. A Handbook of Greek and Roman Sculpture: to Accompany a Collection of Reproductions of Greek and Roman Sculpture (the University Prints). Boston, MA: Bureau of University Travel.

von Saldern, Axel. 1968. Ancient Glass in the Museum of Fine Arts, Boston. Meriden, CT: Museum of Fine Arts, Boston.

von Saldern, Axel 1966. "Ancient Glass." Boston Museum Bulletin 64 (335): 4-17. 
Walsh, David. 2009. Distorted Ideals in Greek Vase-Painting: The World of Mythological Burlesque. Cambridge: Cambridge University Press.

Walters, Henry Beauchamp and Samuel Birch. 1905. History of Ancient Pottery, Greek, Etruscan, and Roman. London: J. Murray.

Warner, Deborah. 1976. The Women's Pavilion. Edited by R. C. Post. Washington: National Museum of History and Technology, Smithsonian Institution.

"Warren Congregational Church, Westbrook, ca. 1950." Maine Historical Society. http://www.mainememory.net (17 September 2008).

Warren, Cornelia. 1908. A Memorial to my Mother. Boston, MA: Merrymount Press.

Warren, Edward Perry, Michael Matthew Kaylor, et al. 2009. A Defence of Uranian Love. Kansas City, Mo: Valancourt Books.

Warren, Henry Clarke. 1896. Buddhism in Translations. Cambridge, MA: Harvard University.

"Warren Memorial Library, Westbrook, 1943." Maine Historical Society. http://www.mainememory.net (17 September 2008).

Warren, Samuel D. 1912. "Necrology: George Warren Hammond." In Proccedings of the Pocumtech Valley Memorial Association 1905-1911. Deerfield, MA.

Waterhouse, Helen. 1986. The British School at Athens: The First Hundred Years. London: The British School at Athens.

Waters, Sarah. 1995. "'The Most Famous Fairy in History': Antinous and Homosexual Fantasy." Journal of the History of Sexuality 6 (2): 194-230.

Watson, Peter and Cecilia Todeschini. 2006. The Medici Conspiracy: The Illicit Journey of Looted Antiquities from Italy's Tomb Raiders to the World's Greatest Museums. New York: Public Affairs.

Waugh, Evelyn. 1945. Brideshead Revisited. New York: A.A. Knopf. 
Wegner, Susan E. 1994. "Copies and Education: James Bowdoin's Painting Collection in the Life of the College." In The Legacy of James Bowdoin III. 141-71. Brunswick, ME: Bowdoin College Art Museum.

Weigle, Anastasia S. 2000. A Presence in the Community: The Warren Family Legacy. Portland, ME: Warren Memorial Foundation and Cornelia Warren Community Association.

Wein, Roberta. 1974. "Women's Colleges and Domesticity, 1875-1918." History of Education Quarterly 14 (1): 31-47.

West, Richard V. 1972. The Walker Art Building Murals. Brunswick, ME: Bowdoin College Museum of Art.

"Westbrook's Warren Memorial Library Will Close." WMTV http://www.wmtw.com/news/18874655/detail.html (18 June 2009).

White, Donald and Lee Horne. 2002. Guide to the Etruscan and Roman Worlds at the University of Pennsylvania Museum of Archaeology and Anthropology. Philadelphia, PA: University of Pennsylvania Museum of Archaeology and Anthropology.

Whitehall, Walter Muir. 1970a. Museum of Fine Arts Boston: A Centennial History. Cambridge, MA: Harvard University Press.

Whitehall, Walter Muir. 1970b. Museum of Fine Arts: A Centennial History. Cambridge, MA: The Belknap Press of Harvard University Press.

Whitehill, Walter Muir. 1969. "Edward Waldo Forbes 1873-1969." Boston Museum Bulletin 67 (348): 93-6.

Whitehouse, David. 1988. Glass of the Roman Empire. Corning, NY: The Corning Museum of Glass.

Whitehouse, David. 1997. Roman Glass in the Corning Museum of Glass. Corning, NY: Corning Museum of Glass.

Whitehouse, David. 2007. Reflecting Antiquity. Corning, NY: Corning Museum of Glass. 
Whiting, Lilian. 1902. Boston Days, the City of Beautiful Ideals; Concord, and its Famous Authors; the Golden Age of Genius; Dawn of the Twentieth Century. Boston: Little, Brown and Co.

Whitley, James. 1997. "Beazley as Theorist." Antiquity 71 (271): 40-7.

Williams, Craig A. 2010. Roman Homosexuality. 2nd ed. Oxford: Oxford University.

Williams, Dyfri. 1991. The Invention of the Red-Figure Technique and the Race Between Vase-Painting and Free Painting. Edited by T. Rasmussen and N. Spivey. New York: Cambridge University Press.

Williams, Dyfri. 2004. "Sotades: Plastic and White." In Greek Art in View: Essays in Honor of Brian Sparkes. 95-120. Oxford: Oxbow Press.

Williams, Dyfri. 2006a. "The Sotades Tomb." In The Colors of Clay: Special Techniques in Athenian Vases. 292-98. Los Angeles, CA: The J. Paul Getty Museum.

Williams, Dyfri. 2006b. The Warren Cup. London: The British Museum Press.

Williams, Gordon. 1996. Representations of Roman Women in Literature. Austin, TX: University of Texas Press.

Wills, Garry. 1984. Cincinnatus: George Washington and the Enlightenment. Garden City, NJ: Doubleday.

Winkes, Rolf. 1982. Catalogue of the Classical Collection Museum of Art, Rhode Island School of Design: Roman Paintings and Mosaics. Providence, RI: Museum of Art, Rhode Island School of Design.

Winterer, Caroline. 2002. The Culture of Classicism: Ancient Greece and Rome in American Intellectual Life, 1780-1910. Baltimore, MD: The Johns Hopkins University Press.

Woodward, Carla Mathes. 1985. "Acquisition, Preservation, and Education: A History of the Museum." In A Handbook of the Museum of Art. 10-60. Providence, RI: Museum of Art, Rhode Island School of Design. 
Wright, Nathalia. 1963. Horatio Greenough: The First American Sculptor. Philadelphia, PA: University of Pennsylvania Press.

Wroth, Warwick. 1907. "Review: A Collection of Greek Coins." CR 21 (5): 153-4.

Yalouris, Nikolas, Manolis Andronikos, et al. 1980. The Search for Alexander: An Exhibition. Boston, MA: Published with the cooperation of the Greek Ministry of Culture and Sciences [by] New York Graphic Society.

Yntema, Douwe Geert. 1990. The Matt-Painted Pottery of Southern Italy. Utrecht: Congedo.

Young, J. Donald. 1931. "A Sarcophagus at Providence." ArtB 13 (2): 138-59.

Young, William J. and Bernard Ashmole. 1968. "The Boston Relief and the Ludovisi Throne." Boston Museum Bulletin 66 (346): 124-66.

Zanker, Paul. 1988. The Power of Images in the Age of Augustus. Ann Arbor, MI: University of Michigan Press.

Zanker, Paul. 1995. The Mask of Socrates: The Image of the Intellectual in Antiquity. Berkeley, CA: University of California Press.

Zanker, Paul. 2010. Roman Art. Los Angeles, CA: The J. Paul Getty Museum. 


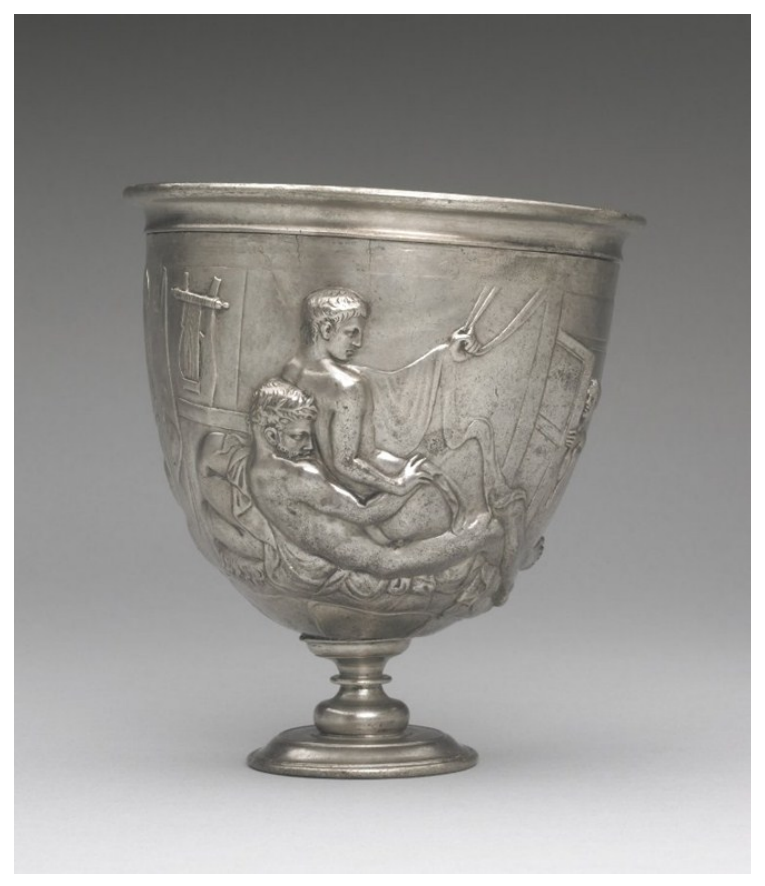

Side A

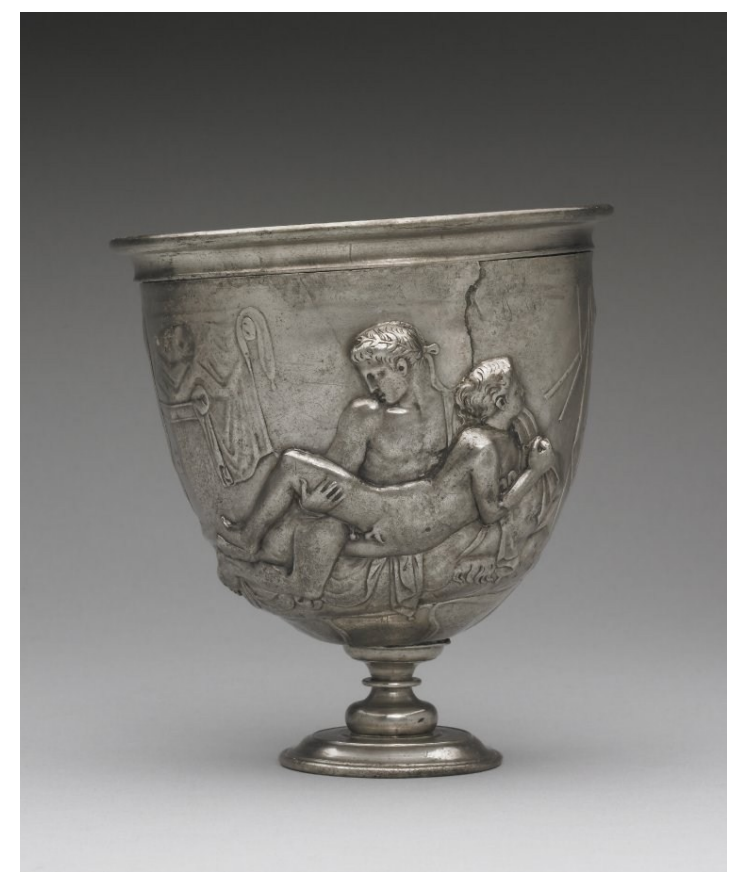

Side B

\section{Figure 1}

\section{Stemmed Dirnking Cup}

The British Museum

AN594242001

Roman, 15 B.C.E.-15 C.E.

Height: $11 \mathrm{~cm}$; Diameter: $11 \mathrm{~cm}$

Silver

http://www.britishmuseum.org/research/search_the_collection_database/ search_object_details.aspx?

ojectid $=410332 \&$ partid $=1 \&$ search $\bar{T}$ ext $=$ Warren + Cup\&fromADBC $=$ ad\&to $A D B C=a d$ \&physicalAttribute $=$ on\& productionInfo $=$ on \&numpages $=10 \&$ orig $=\% 2$ fresearch $\%$ 2fsearch_the_collection_database.aspx\&currentPage $=1$

(accessed 7/17/12) 


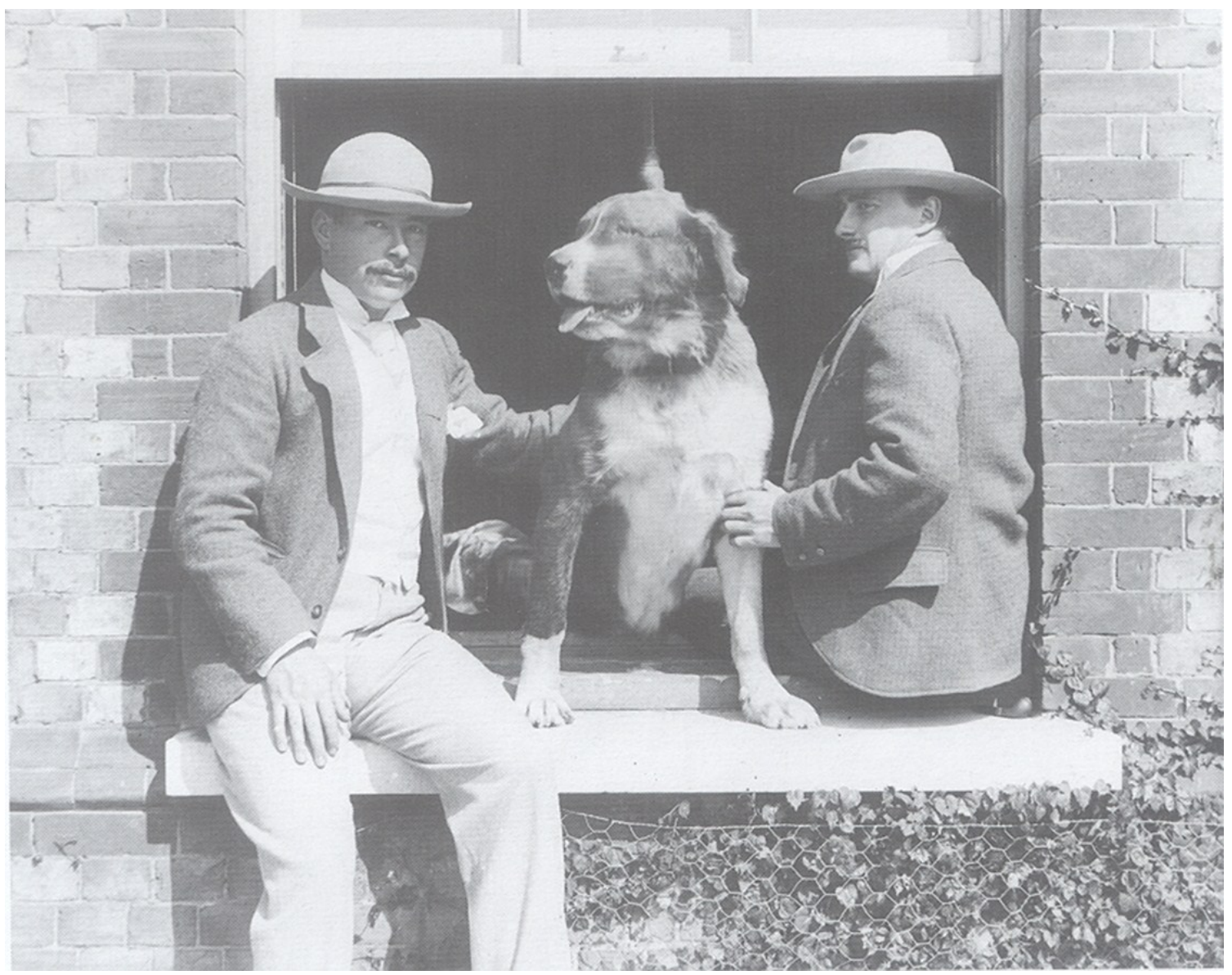

$\underline{\text { Figure } 2}$

Ned Warren and John Marshall at Lewes House Edward Reeves Photograph

John Potvin, Material and Visual Cultures Beyond Male Bonding 1870-1914 2008) 


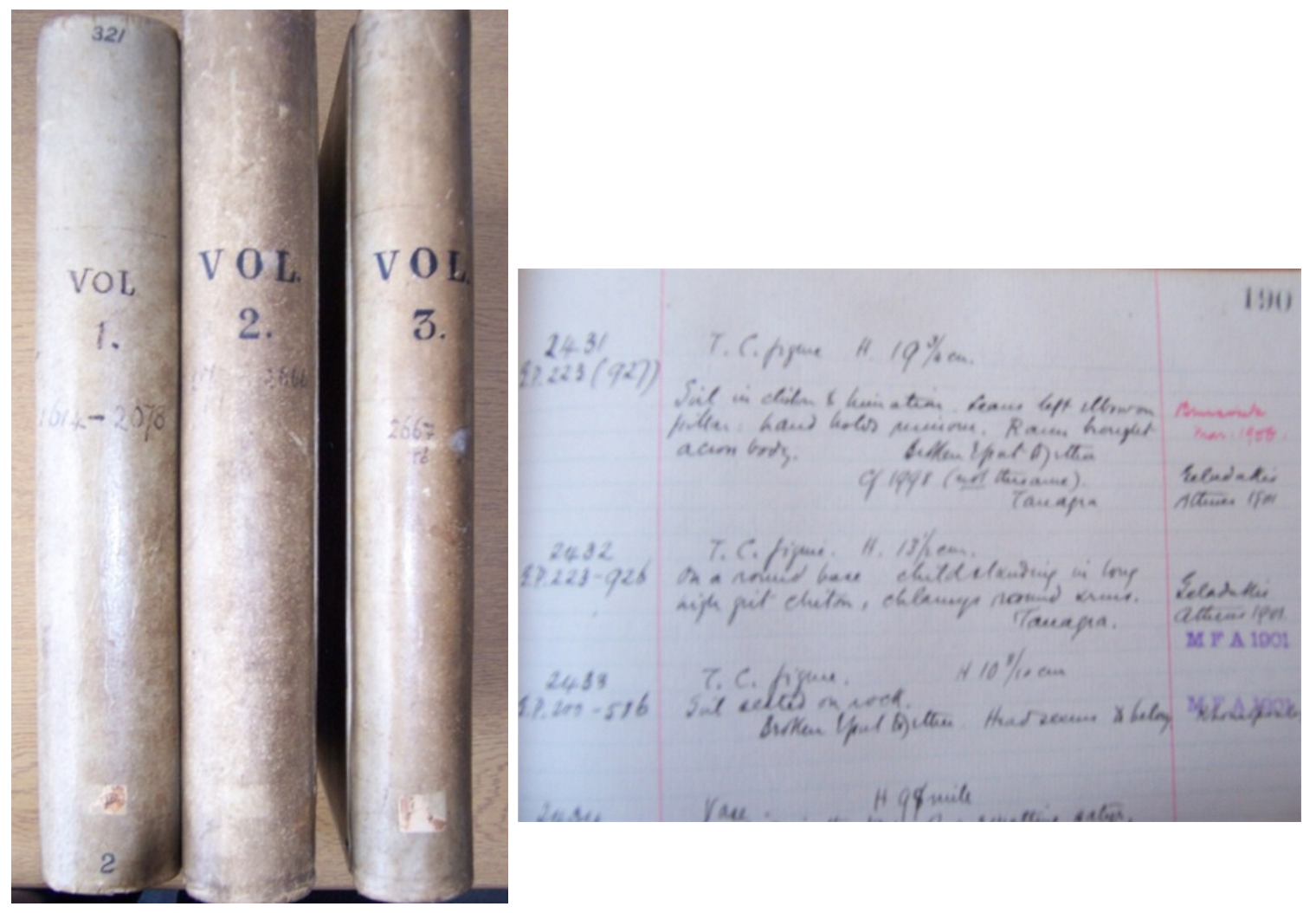

Figure 3

Lewes House Registers

Author's photographs 


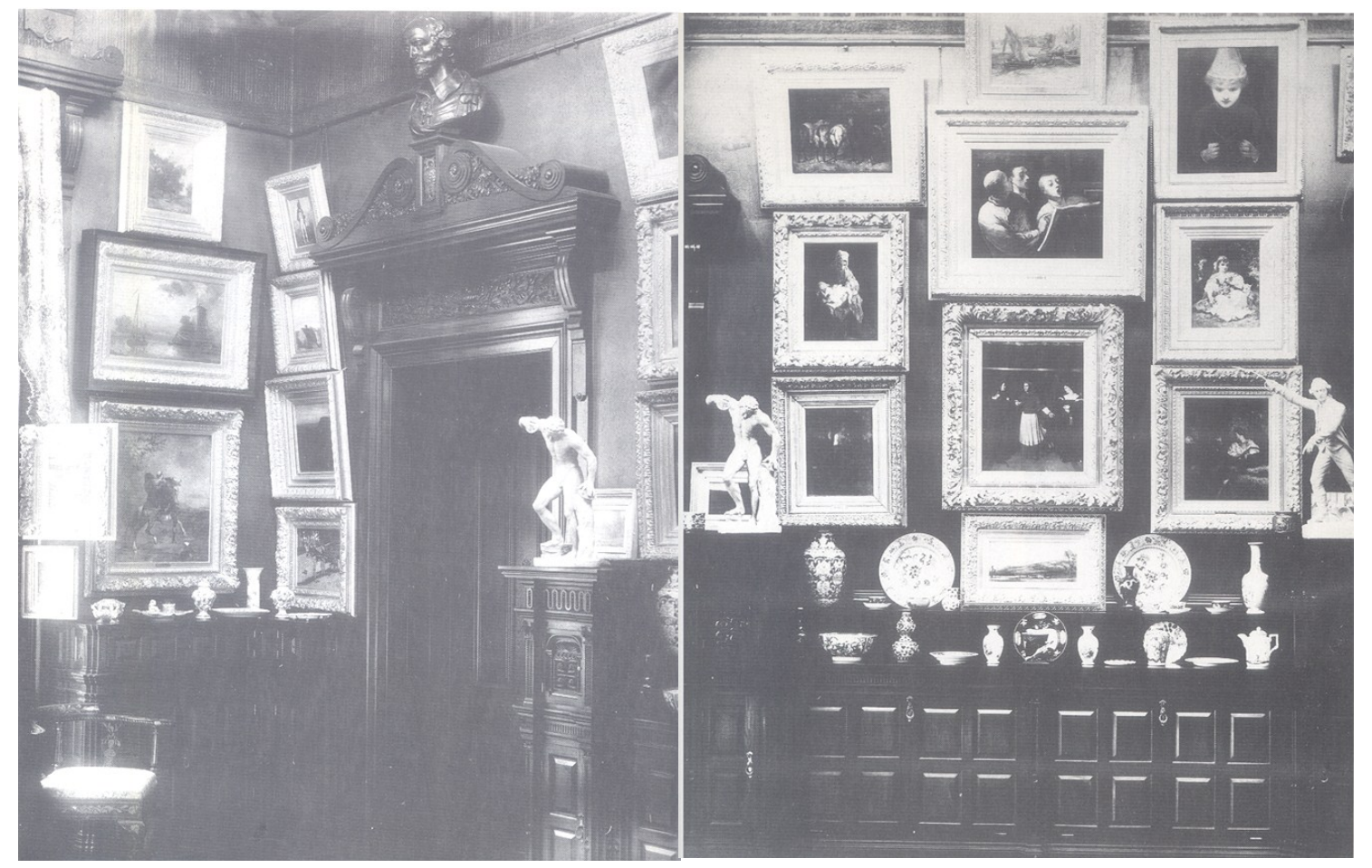

$\underline{\text { Figure } 4}$

Interior of the Warren Home: 67 Mount Vernon Street

Martin Green, The Mount Vernon Street Warrens: A Boston Story, 1860-1910

(1976) 


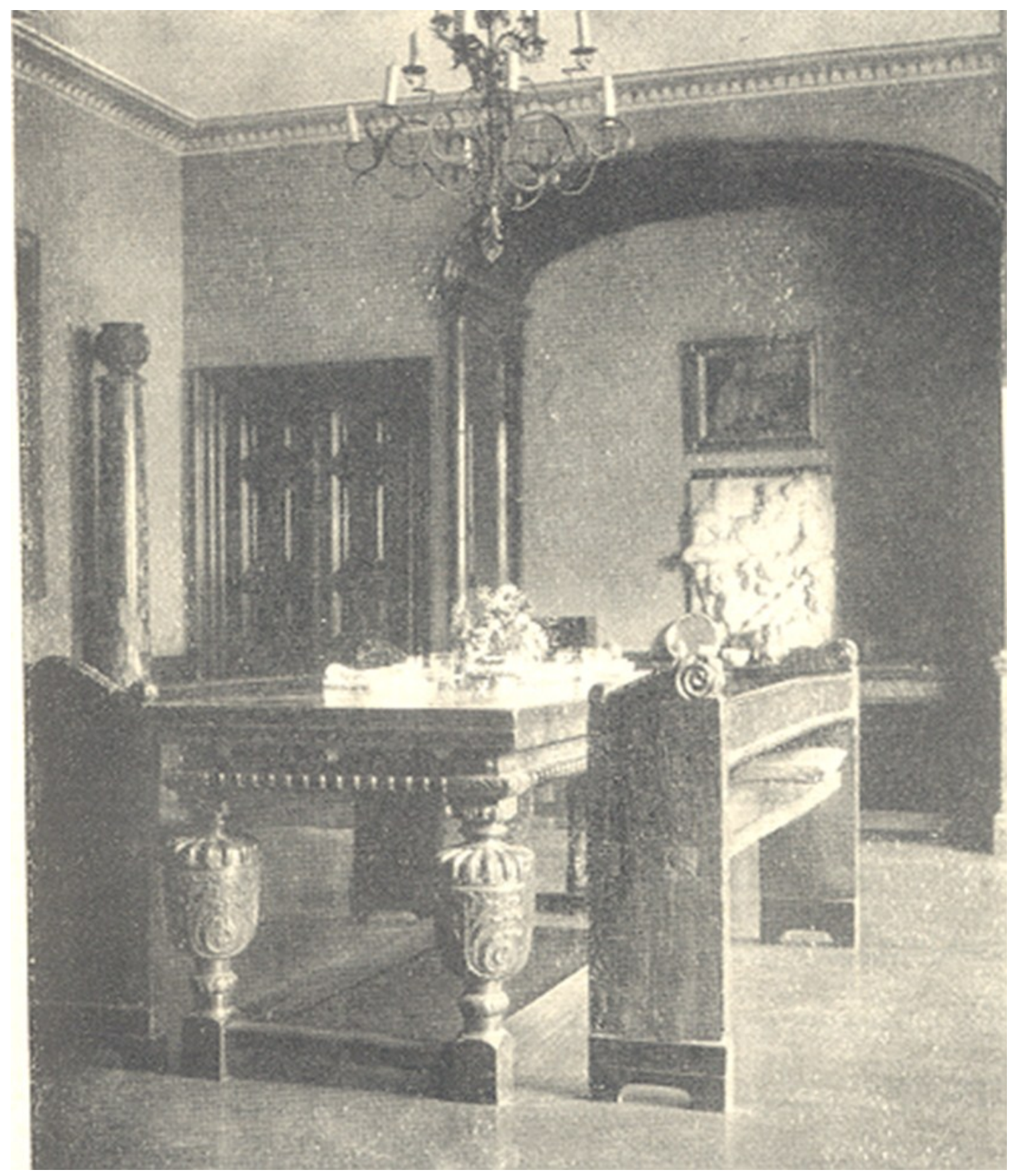

Figure 5

Lewes House: Dining Room

Osbert Burdett and E.H. Goddard

Edward Perry Warren: The Biography of a Connoisseur (1941) 


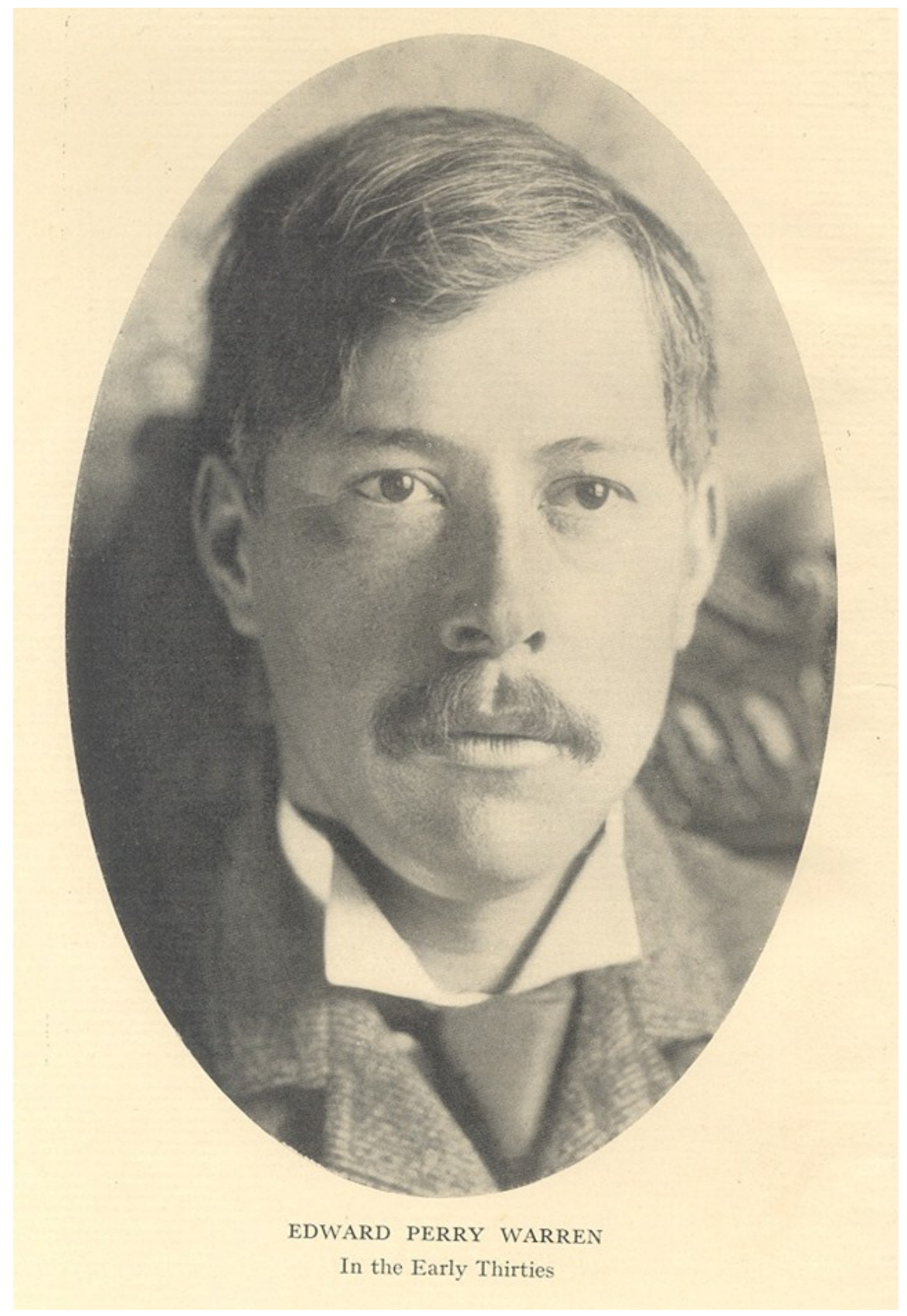

Figure 6

Edward Perry Warren

Osbert Burdett and E.H. Goddard

Edward Perry Warren: The Biography of a Connoisseur (1941) 


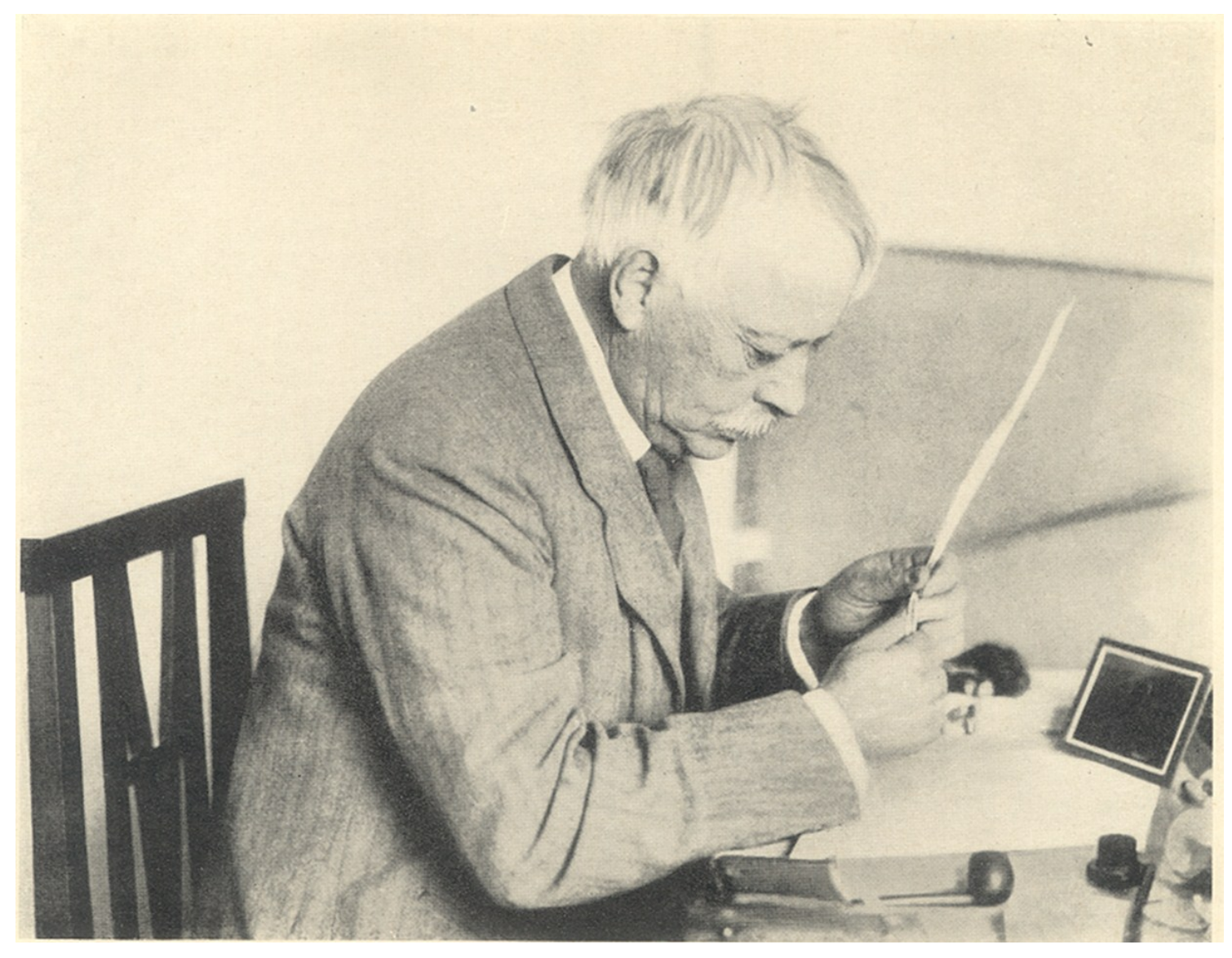

Figure 7

Edward Perry Warren

Osbert Burdett and E.H. Goddard

Edward Perry Warren: The Biography of a Connoisseur

(1941) 


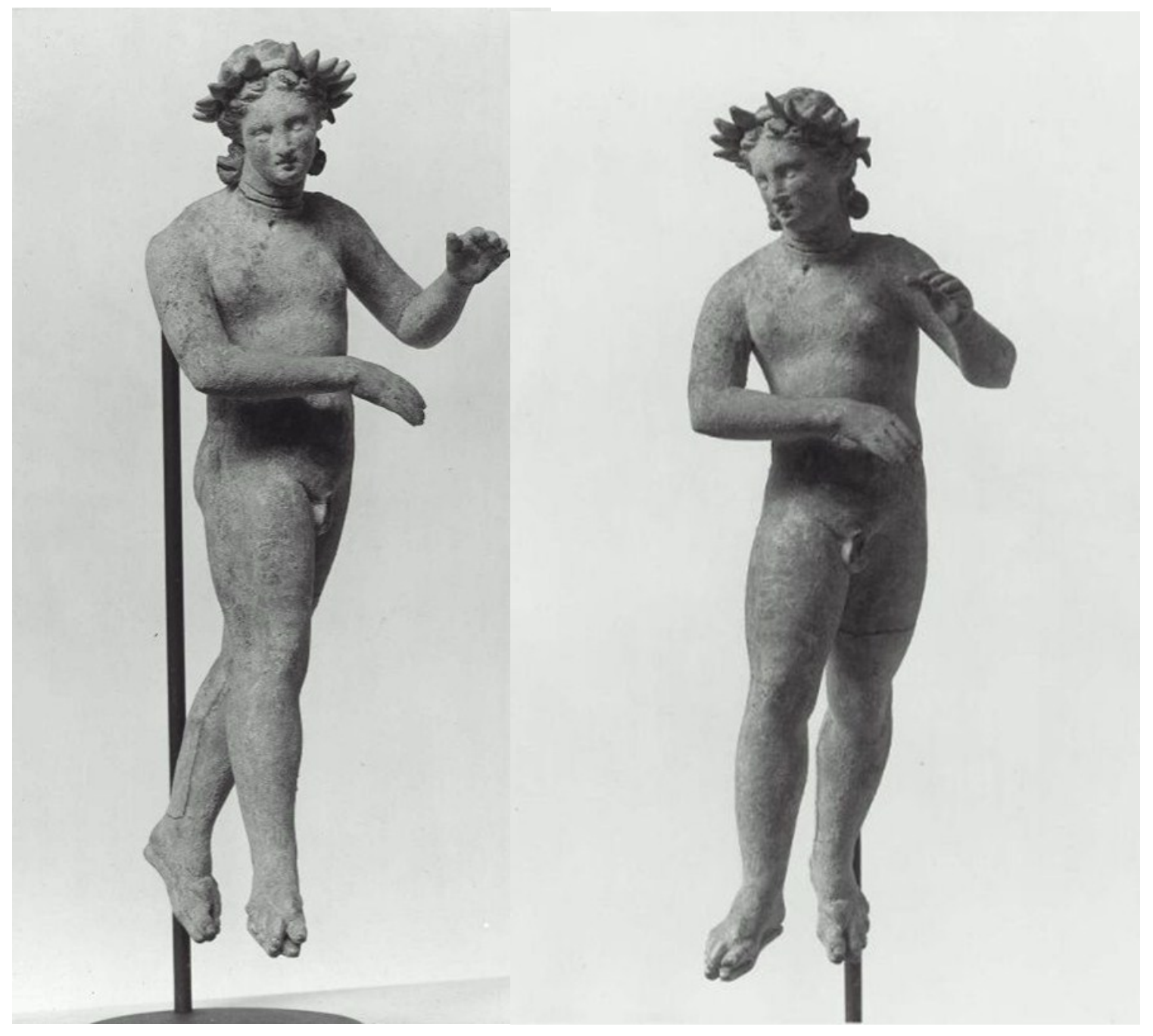

$\underline{\text { Figure } 8}$

Terracotta Statuette of a Young Man

MFA 87.1

East Greek, Hellenistic Period, Second Century B.C.E.

$32.2 \mathrm{~cm}$ (12 11/16 in.)

MFA Collections

http://www.mfa.org/collections/object/statuette-of-a-male-figure-152080

(accessed 7/17/12) 


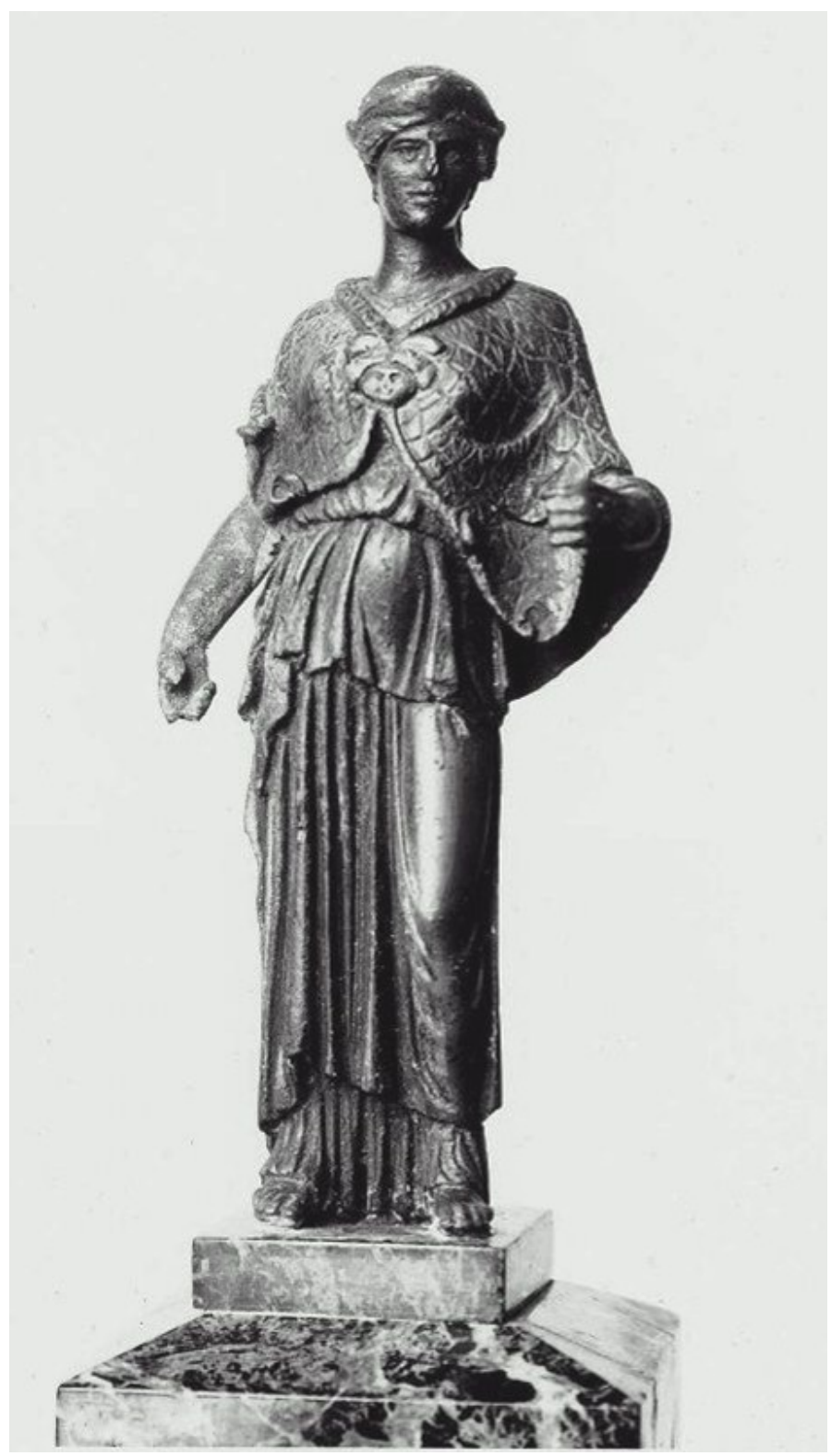

$\underline{\text { Figure } 9}$

Statuette of Minerva

MFA Boston 87.7

Roman, Imperial Period, First or Second Century C.E.

Height: $15.1 \mathrm{~cm}$ (5 15/16 in.)

Bronze

MFA Collections

http://www.mfa.org/collections/object/statuette-of-minerva-152733

(accessed 7/17/12) 


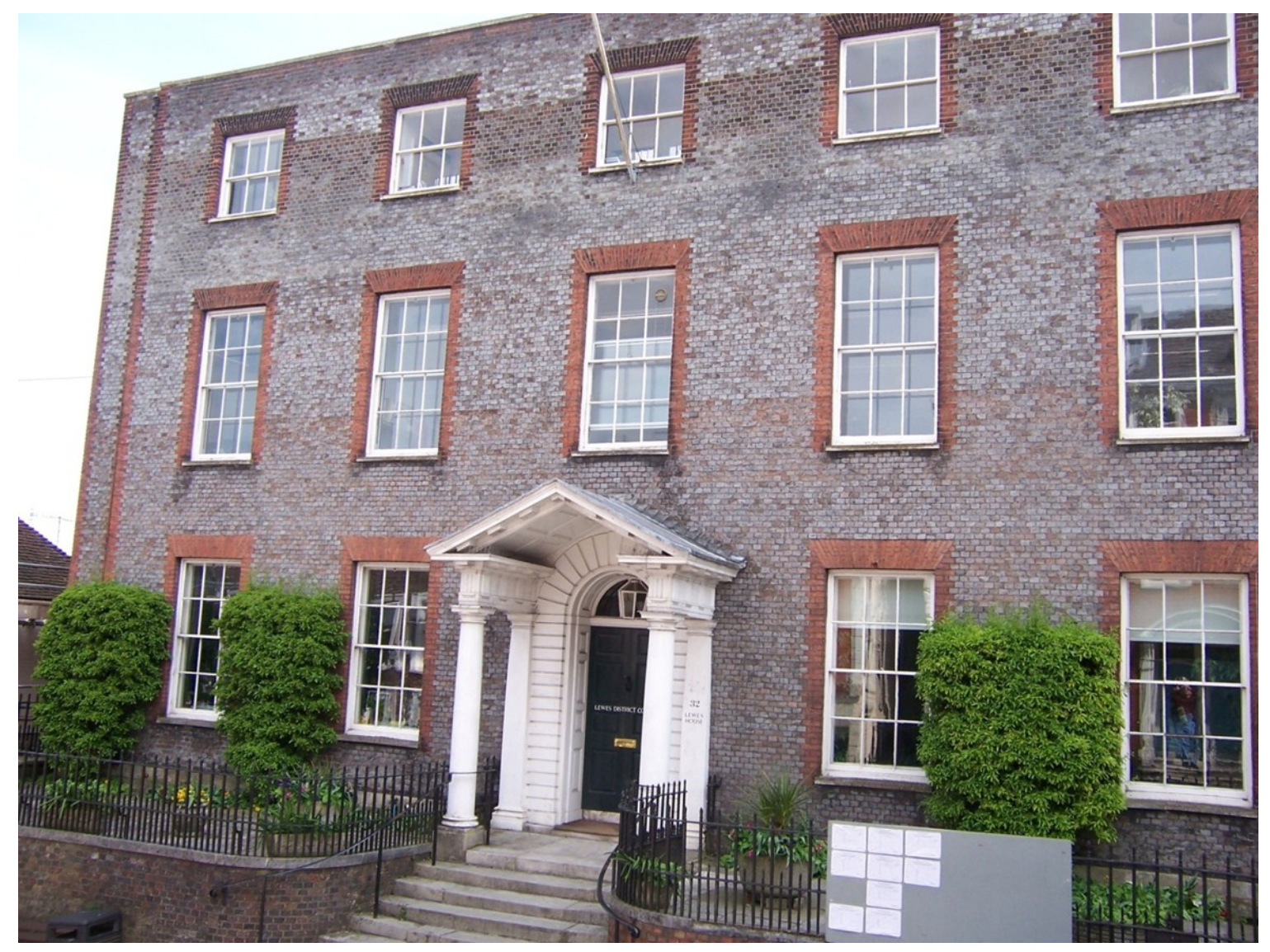

$\underline{\text { Figure } 10}$

Lewes House: Front Author's Photograph 


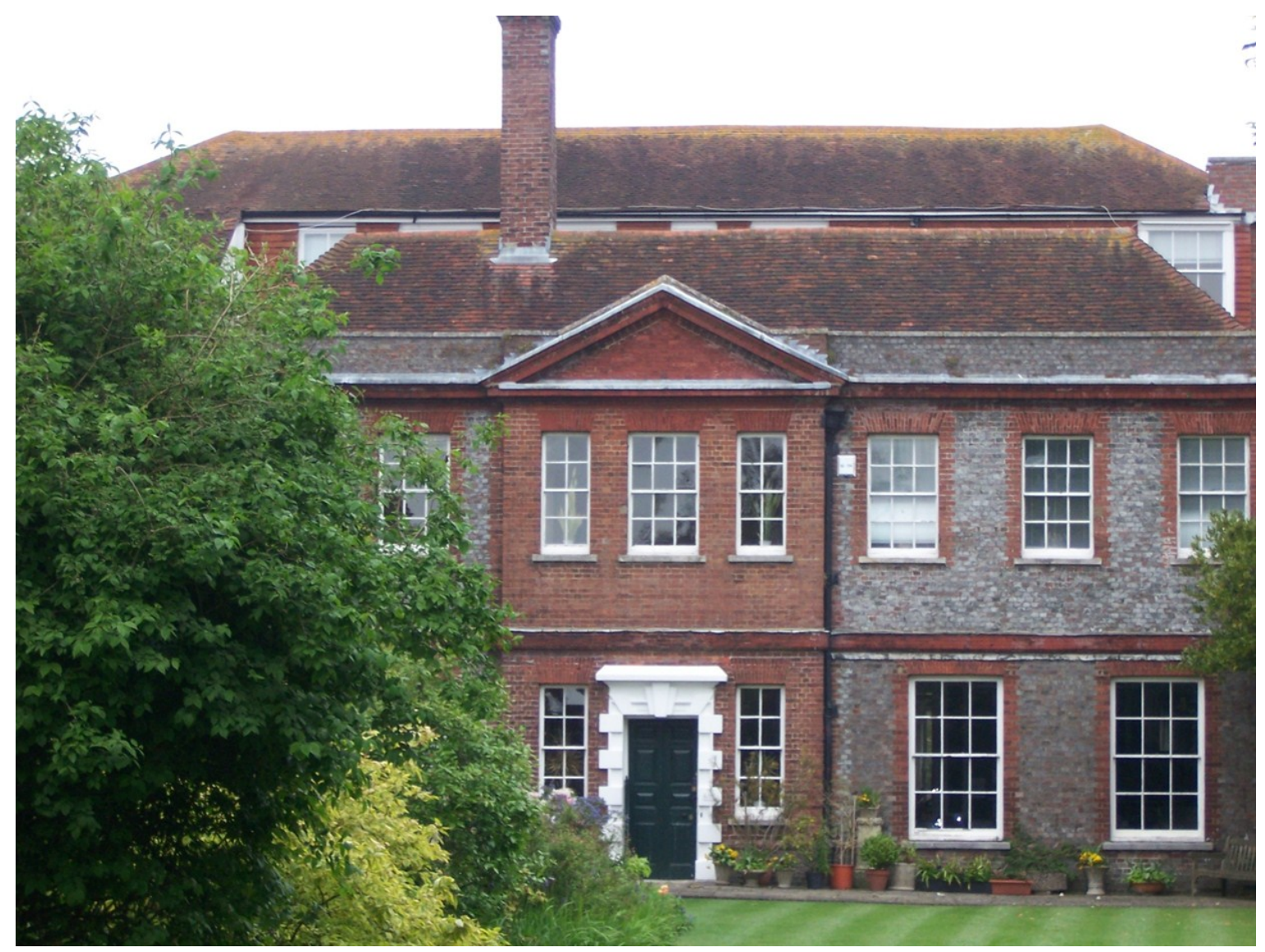

Figure 11

Lewes House: Garden Front

Author's photograph 


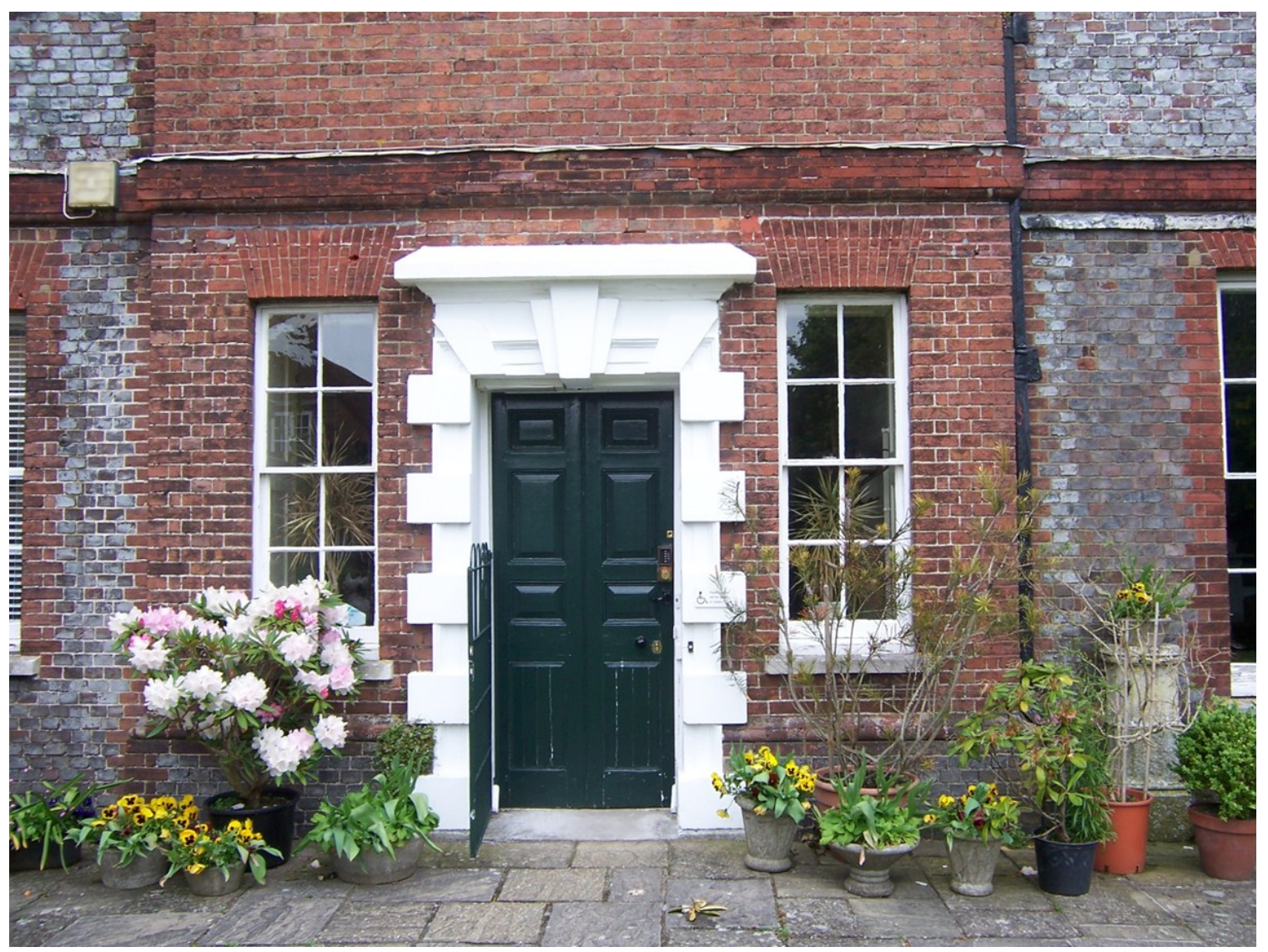

Figure 12

Lewes House: Garden Front — detail

Author's photograph 


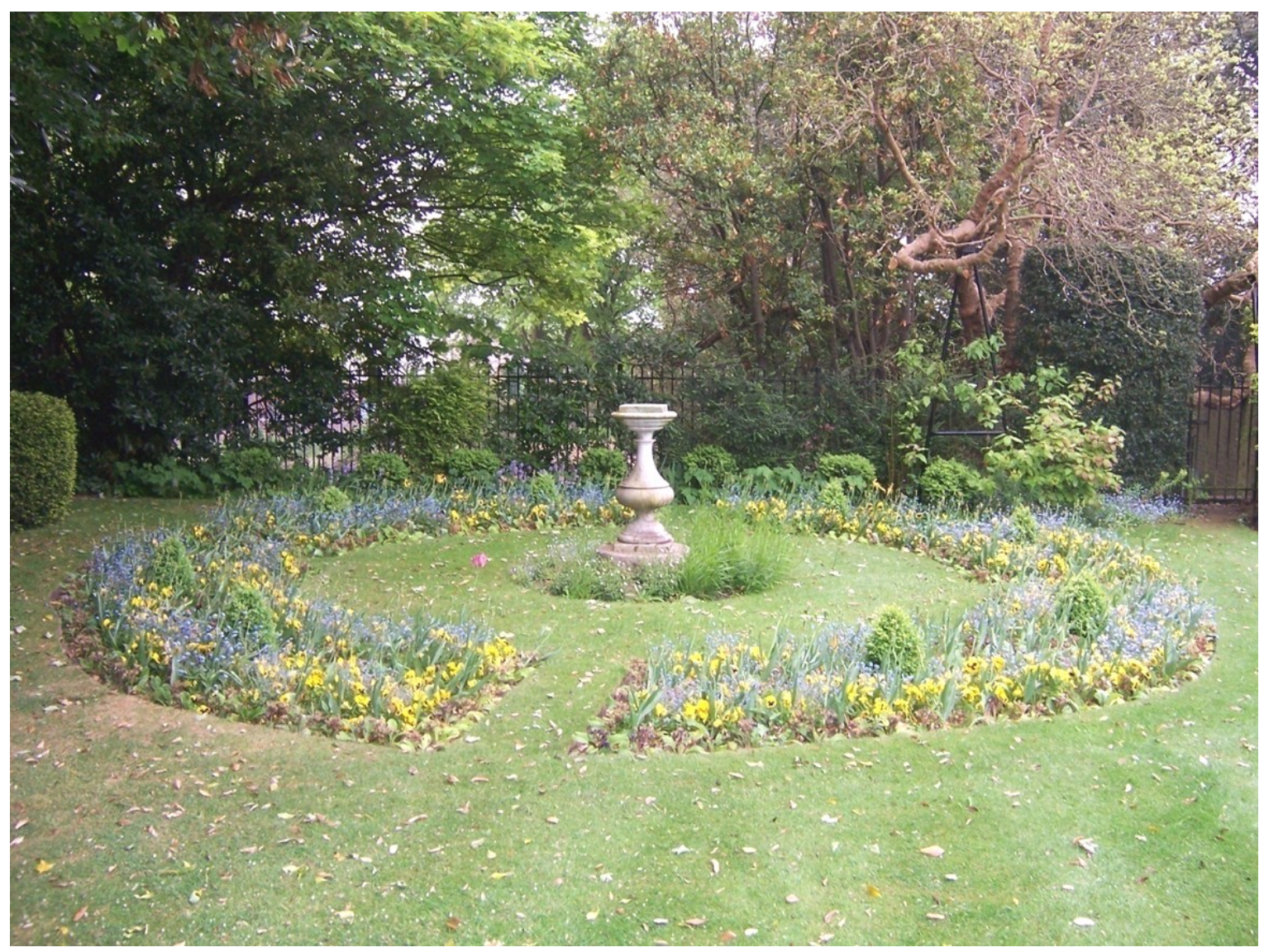

\section{Figure 13}

Lewes House: Garden with Plinth Author's photograph 


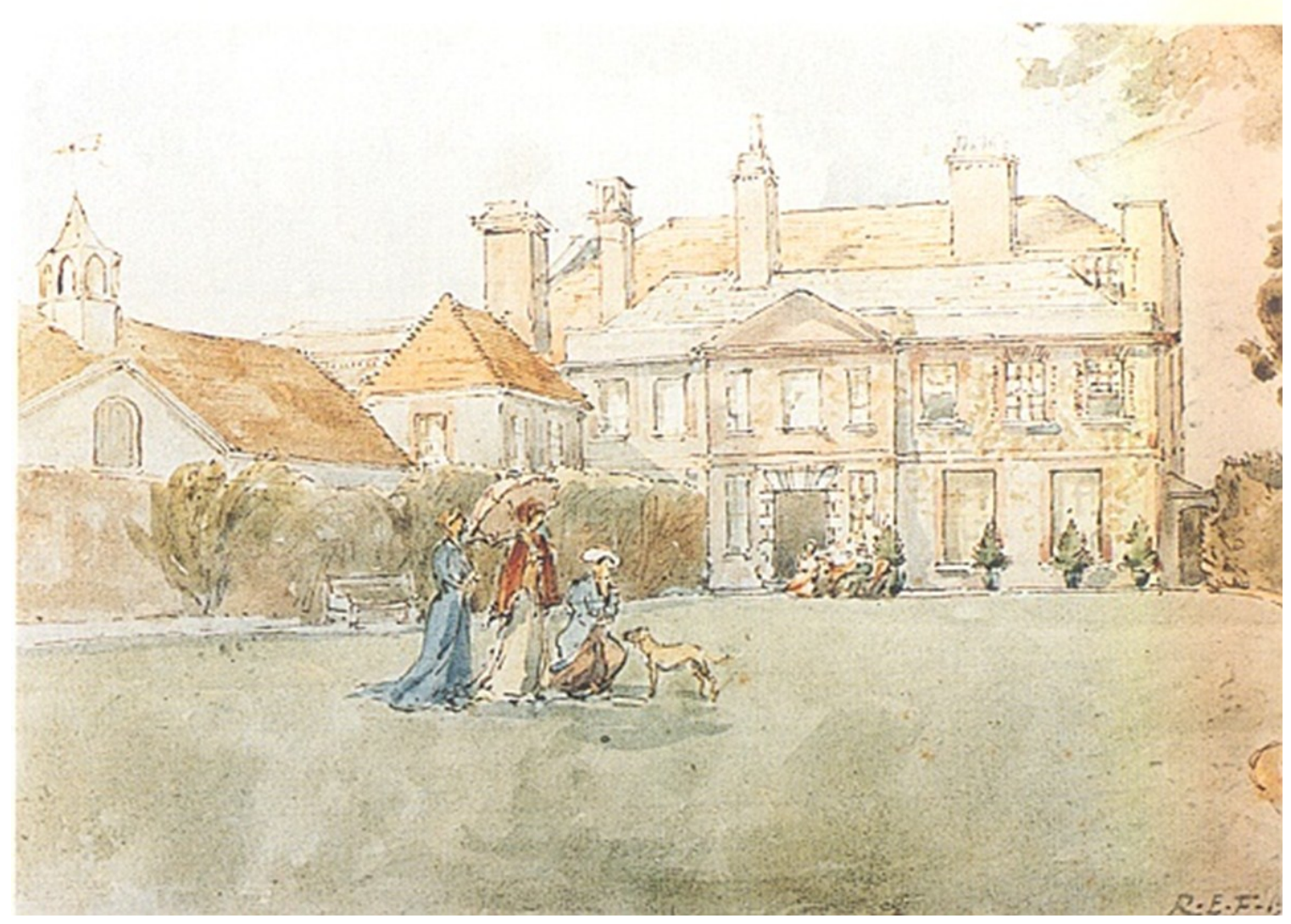

Figure 14

Lewes House, watercolor by Roger Fry (1908)

Dyfri Williams, The Warren Cup (2006) 


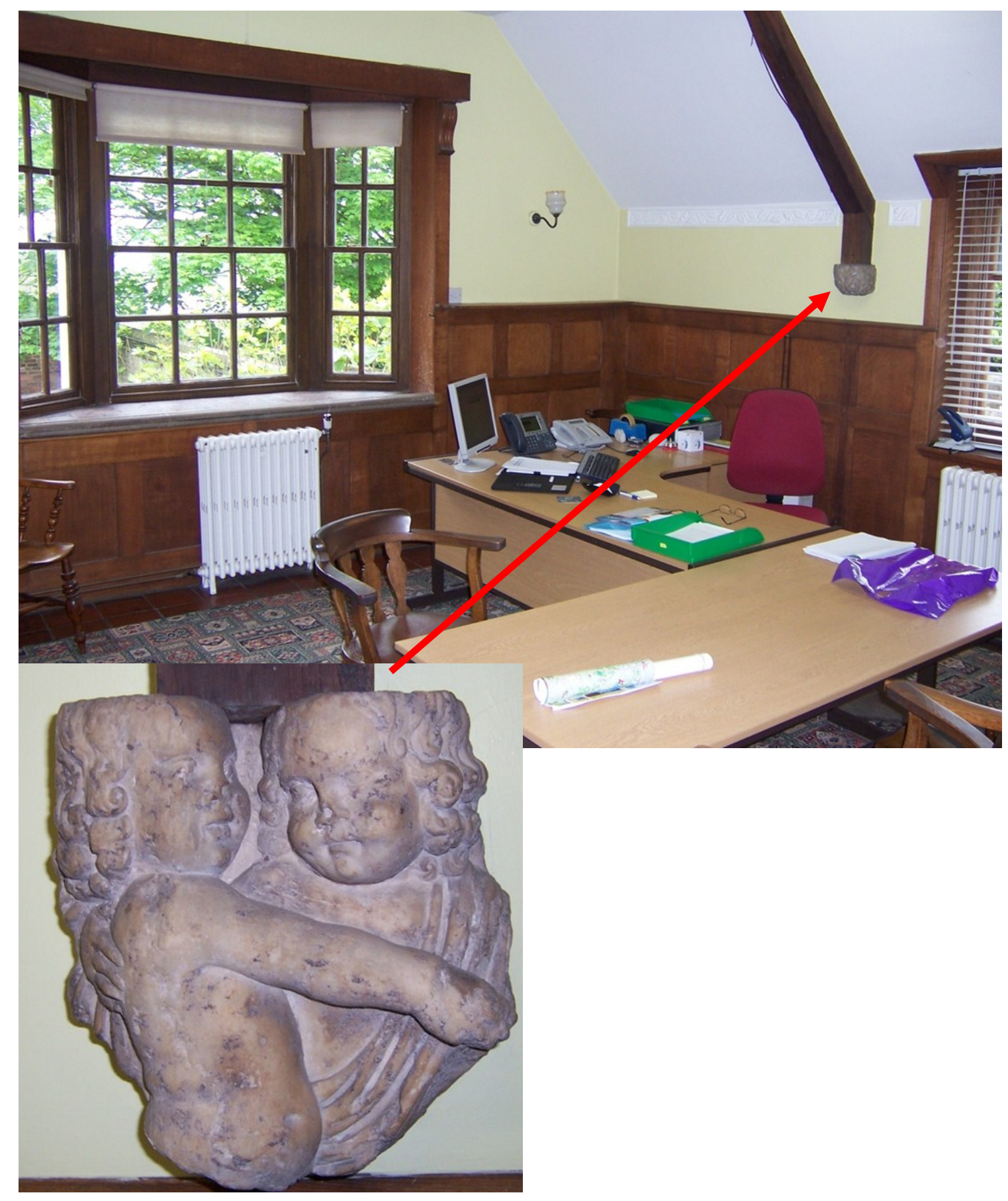

Figure 15

Lewes House: Warren's Study in "Thebes"

Author's photographs 


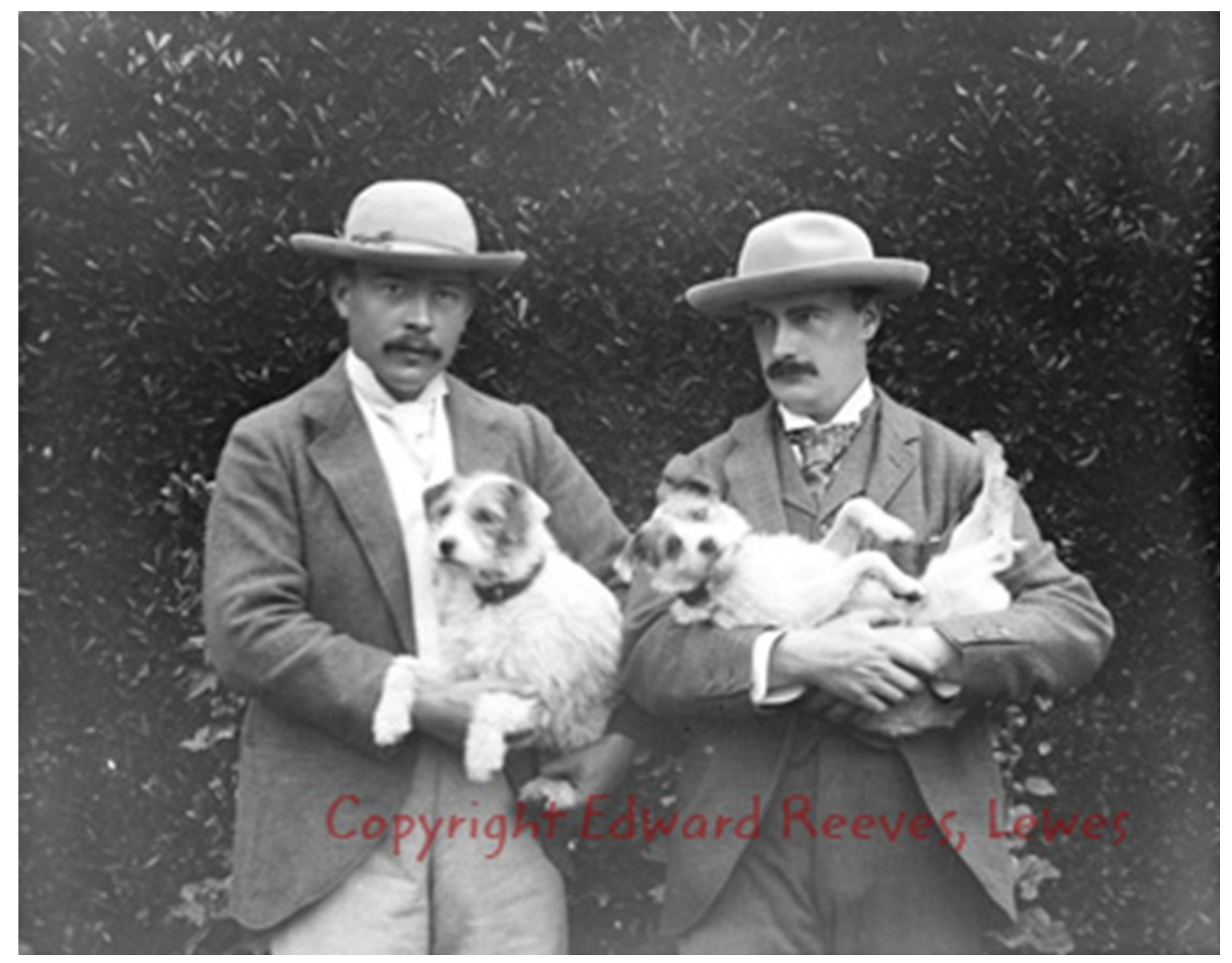

$\underline{\text { Figure } 16}$

Edward Perry Warren and John Marshall WO 193

Edward Reeves Photography 


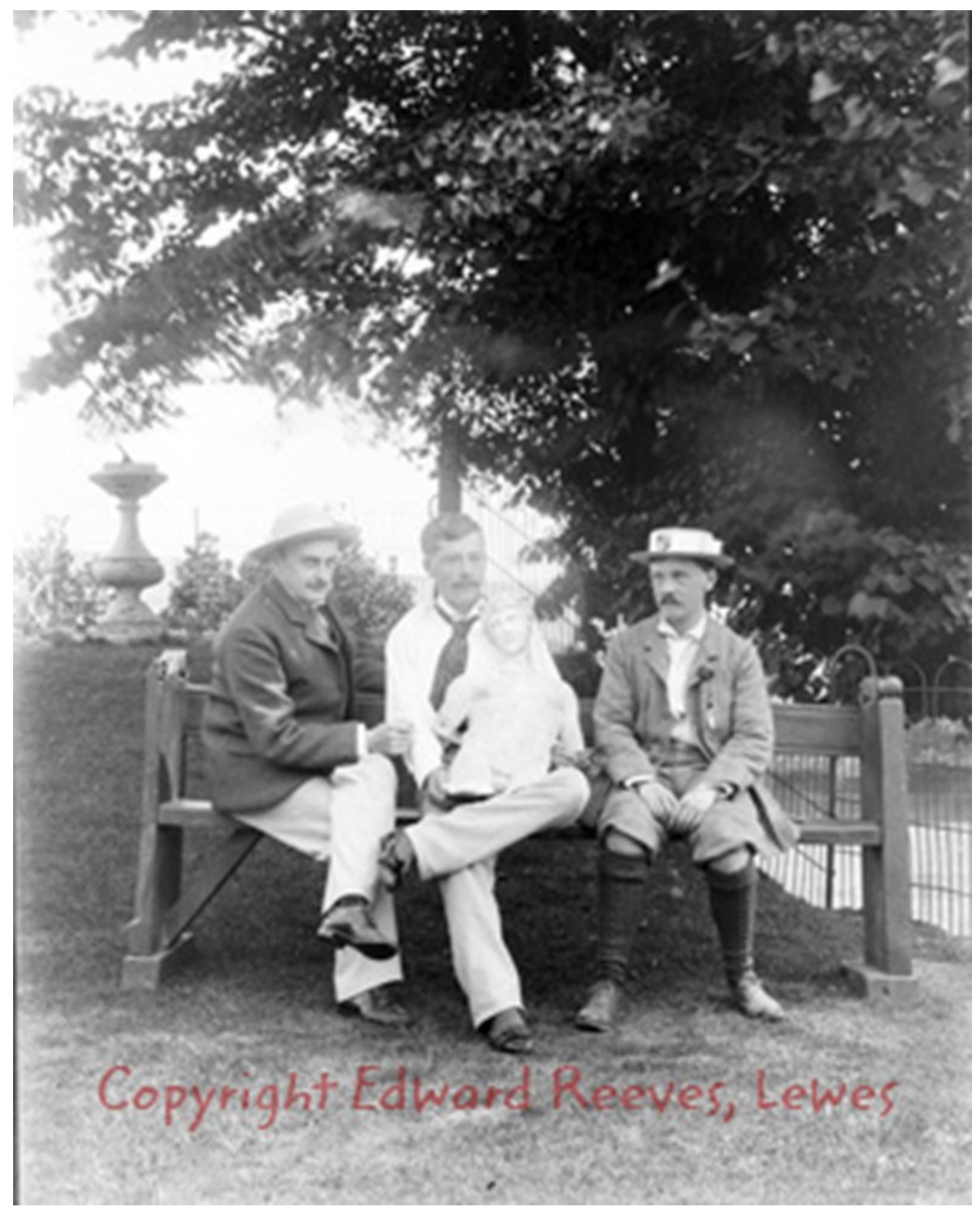

Figure 17

Edward Perry Warren, John Marshall, and unidentified man

WO 186B

Edward Reeves Photography 


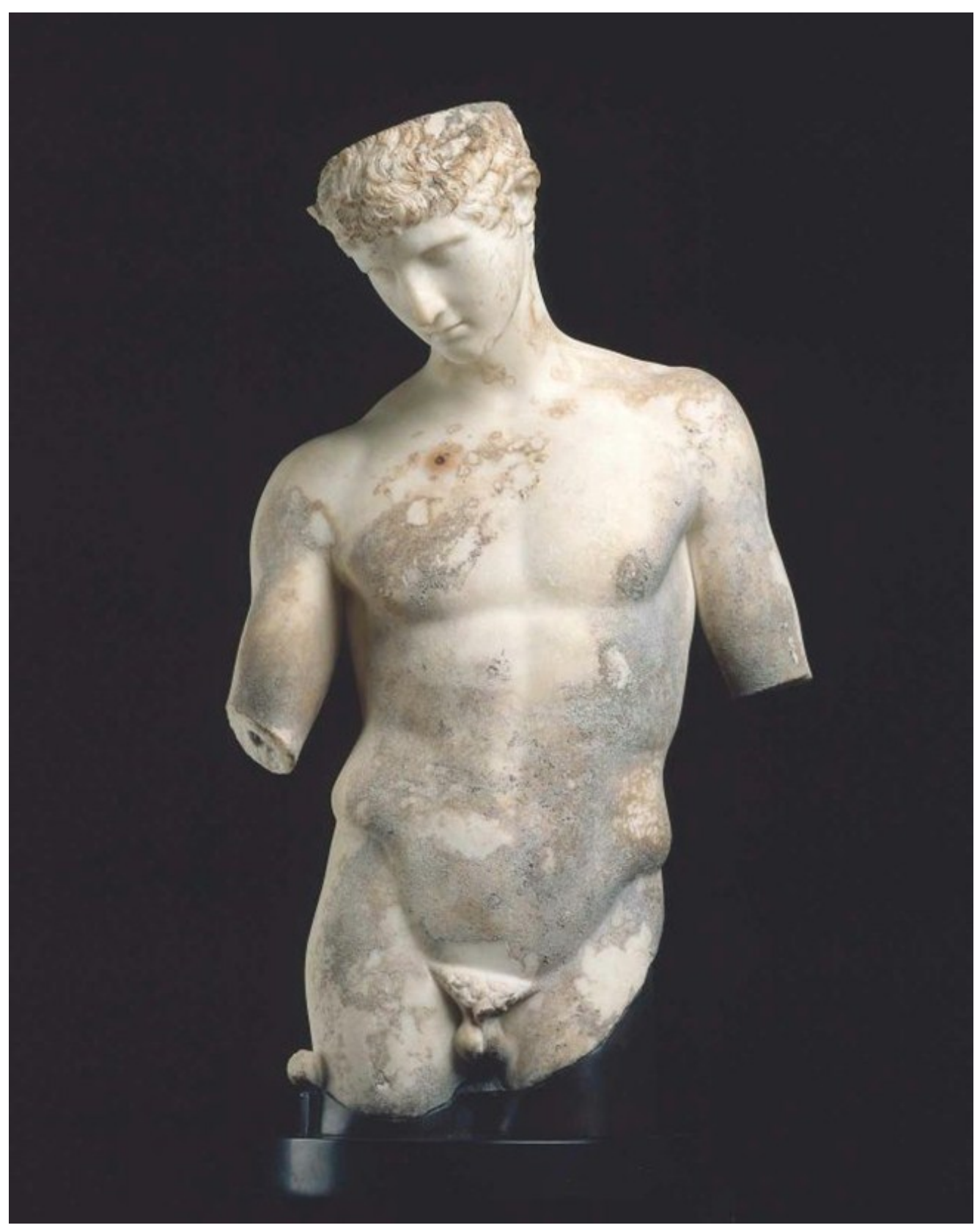

$\underline{\text { Figure } 18}$

\author{
Mercury (Hermes) \\ MFA 95.67 \\ Roman, Imperial Period, 30-40 C.E. \\ Marble \\ $72 \mathrm{~cm}$ (28 3/8in.) \\ MFA Collection
}

MFA Collections http:/www.mfa.org/collections/object/mercury-hermes-151148 (accessed 7/17/12) 

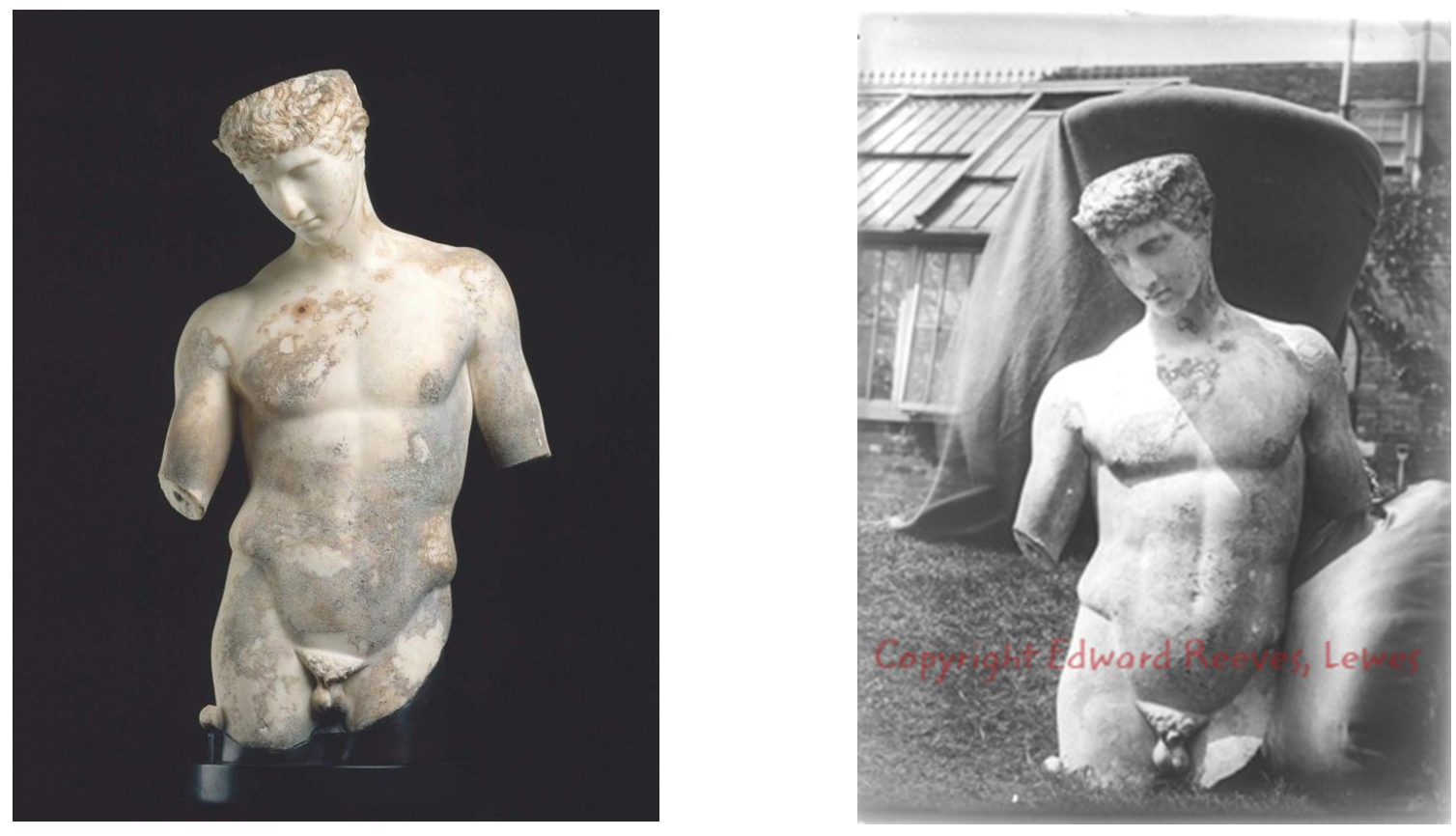

$\underline{\text { Figure } 19}$

\section{Mercury (Hermes)}

MFA 95.67

Roman, Imperial Period, 30-40 C.E. Marble

$72 \mathrm{~cm}$ (28 3/8in.)

MFA Collection

MFA Collections

http://www.mfa.org/collections/object/

mercury-hermes-151148

(accessed 7/17/12)
Mercury (Hermes) at Lewes House

WO 183

Edward Reeves Photography 


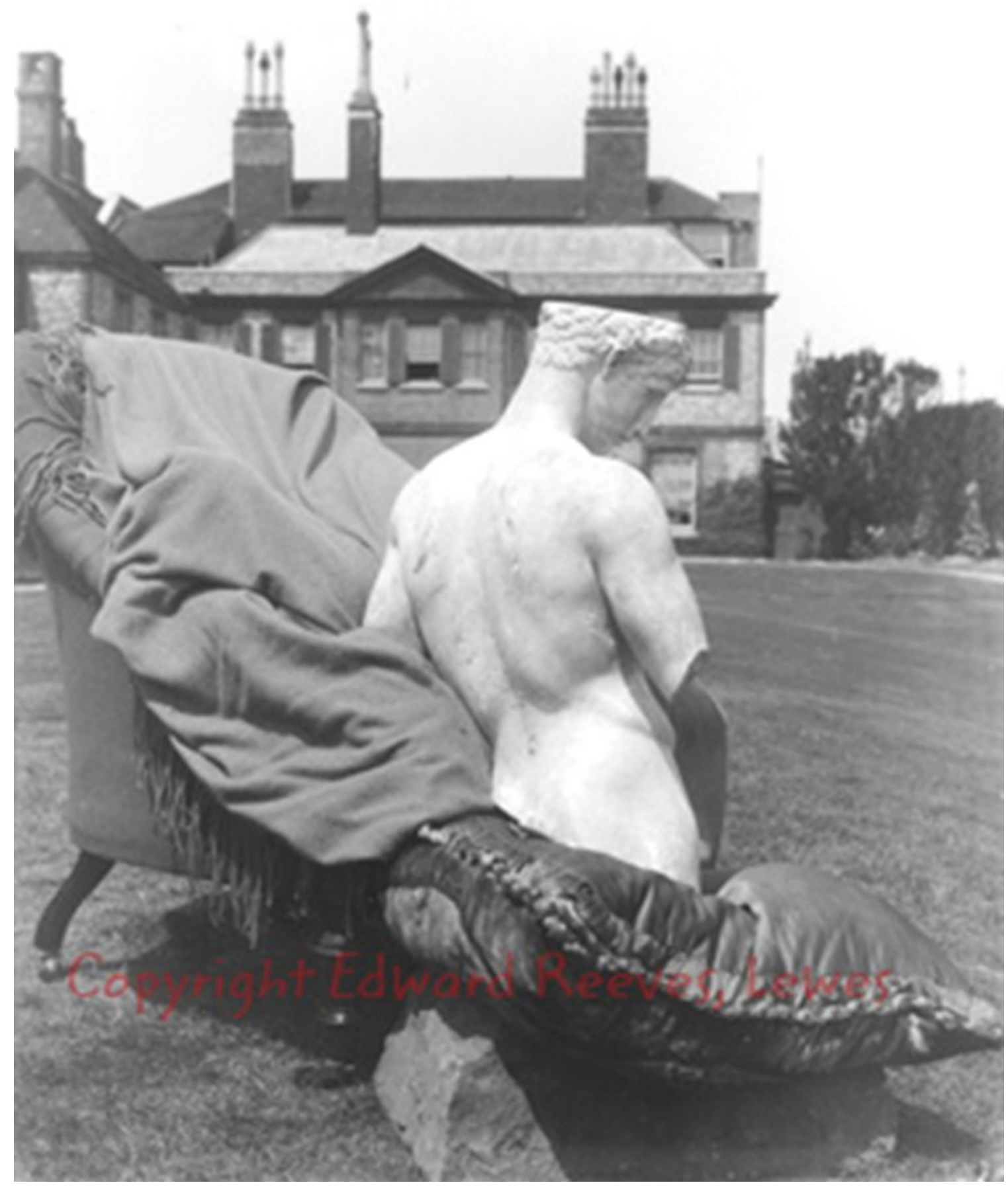

$\underline{\text { Figure } 20}$

Mercury (Hermes) at Lewes House

WO 184

Edward Reeves Photography 


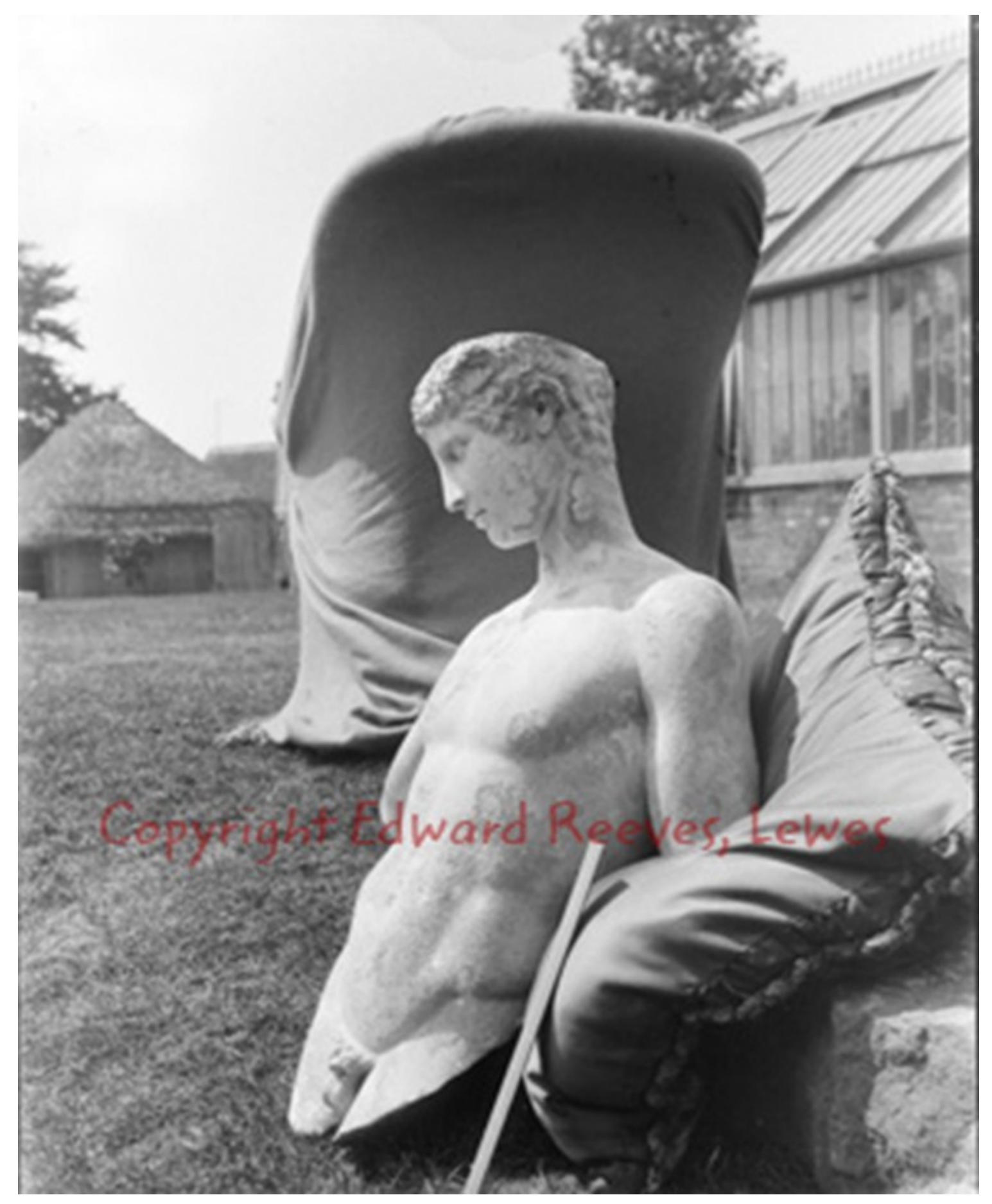

Figure 21

Mercury (Hermes) at Lewes House

WO 185

Edward Reeves Photography 


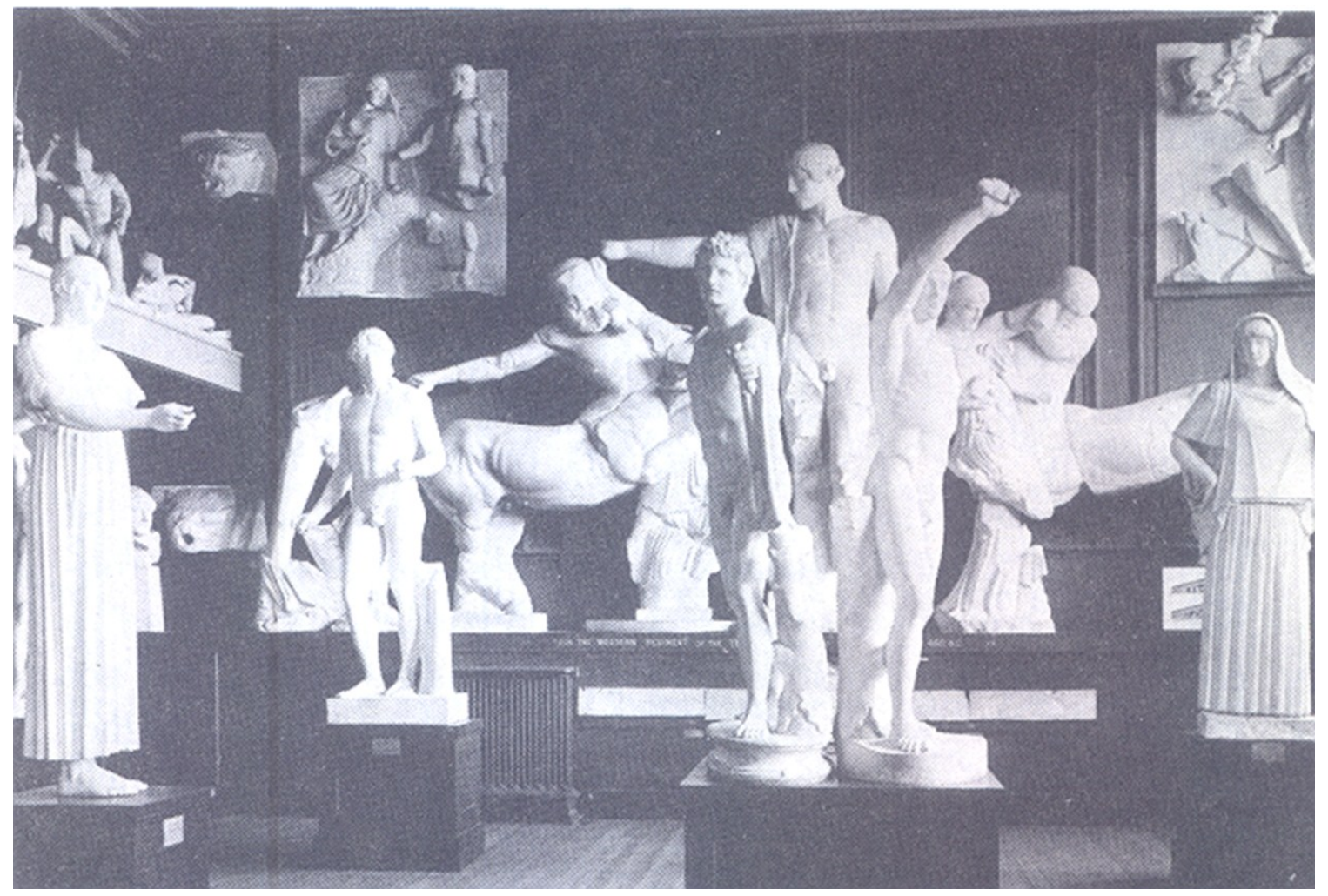

\section{Figure 22}

The Cast Gallery in the Museum of Fine Arts, Boston

Walter Muir Whitehall, Museum of Fine Arts Boston: A Centennial History, Vol I (1970) 


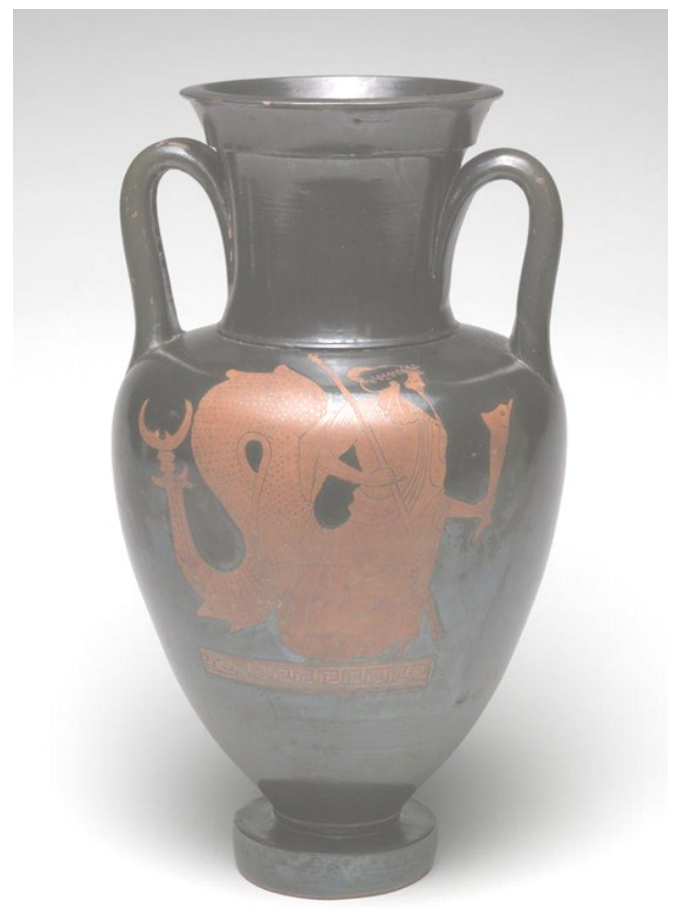

Side A

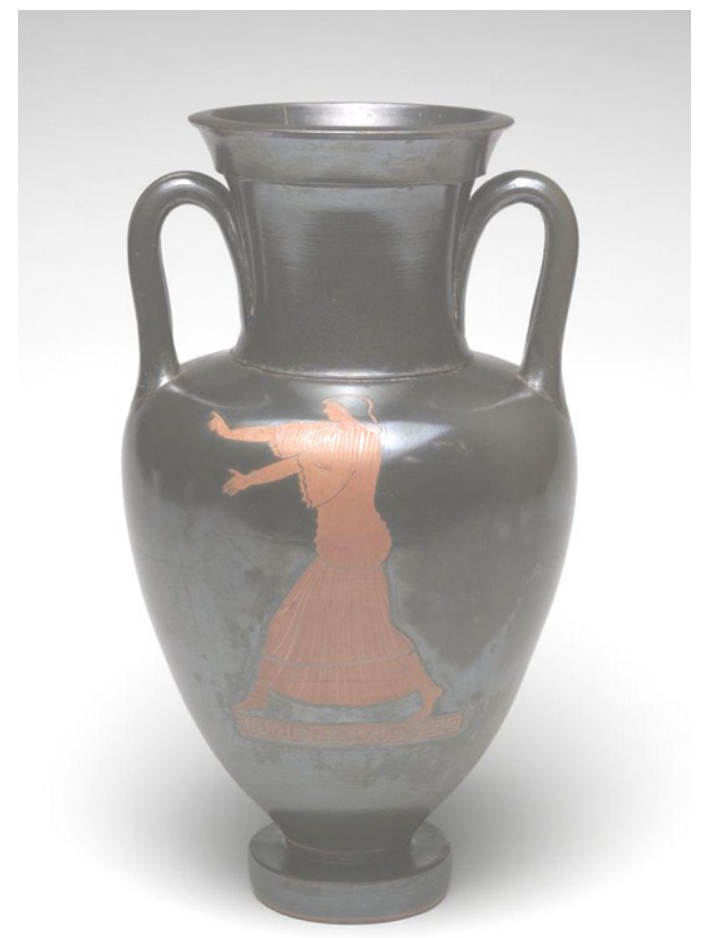

Side B

\section{Figure 23}

Attic Red-figure Amphora Attributed to the Berlin Painter

HM 1927.150

600-480 B.C.E.

Height: $30.8 \mathrm{~cm}$; Diameter:18 cm. (12 1/8 x 7 1/16 in.)

Harvard Museums Curatorial Office 


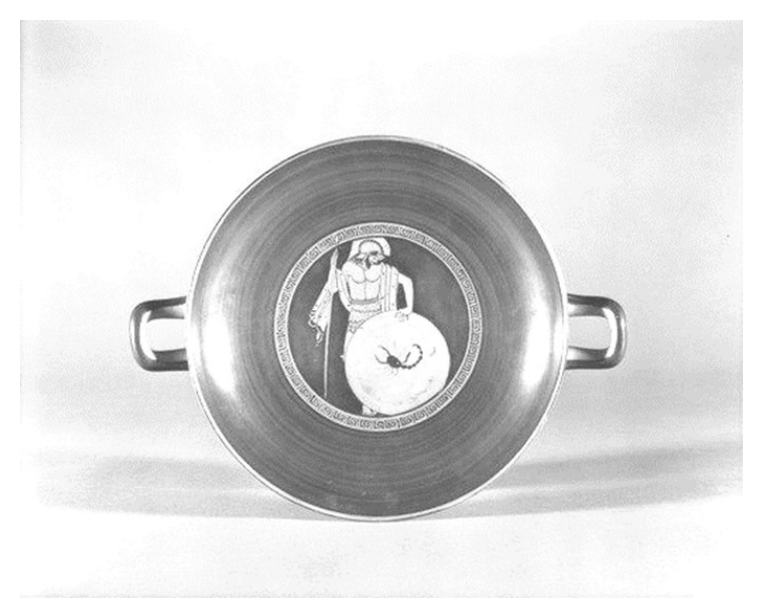

Interior

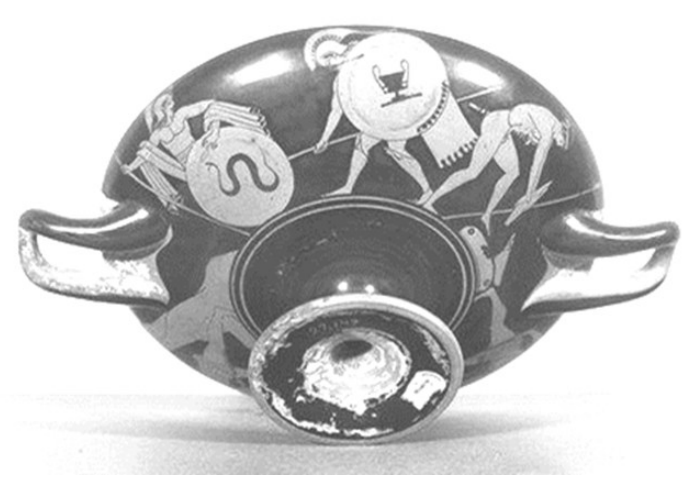

Exterior

Figure 24

Attic Red-figure Kylix

HM 1927.1149

c.600-480 B.C.E.

Attributed to the Foundry Painter

Height: 9.7 (3 13/16in) ; Width: $23.3 \mathrm{~cm}$ (9 3/16 in

Harvard Museums Curatorial Office 

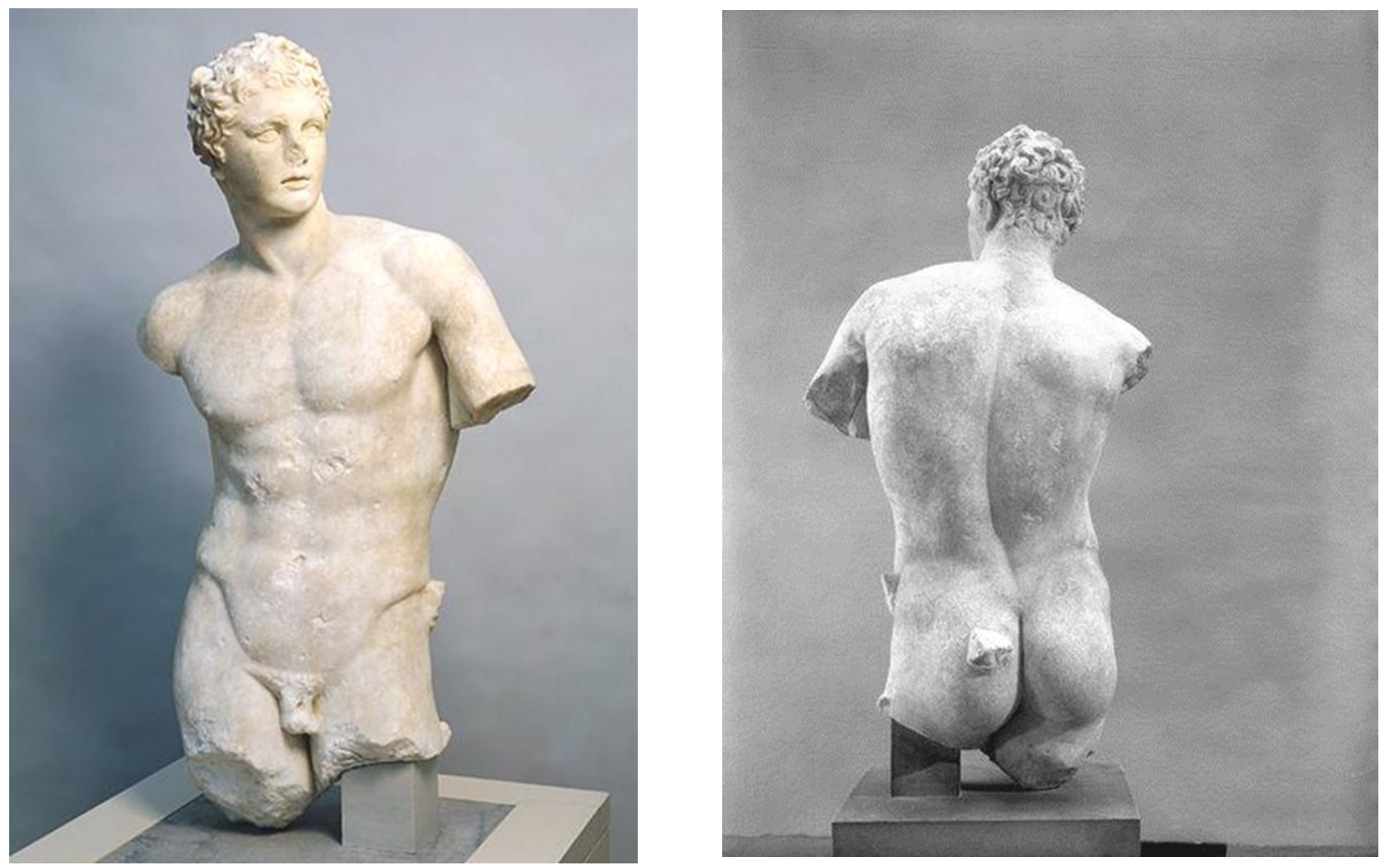

\section{Figure 25}

\section{Meleager \\ HM 1926.48}

Roman period, Early to Middle Imperial, c. 31 B.C.E.-235 C.E.

Statue of Meleager, Roman copy of a Fourth Century B.C. E. Greek original by Skopas, 100-200 C.E.

Marble

Height: $123 \mathrm{~cm}$ Width: $63 \mathrm{~cm} \mathrm{w} \mathrm{x} 42 \mathrm{~cm} \mathrm{~d}(48$ 7/16 x 24 13/16 x 16 9/16 in.)

Harvard Museums Curatorial Office 

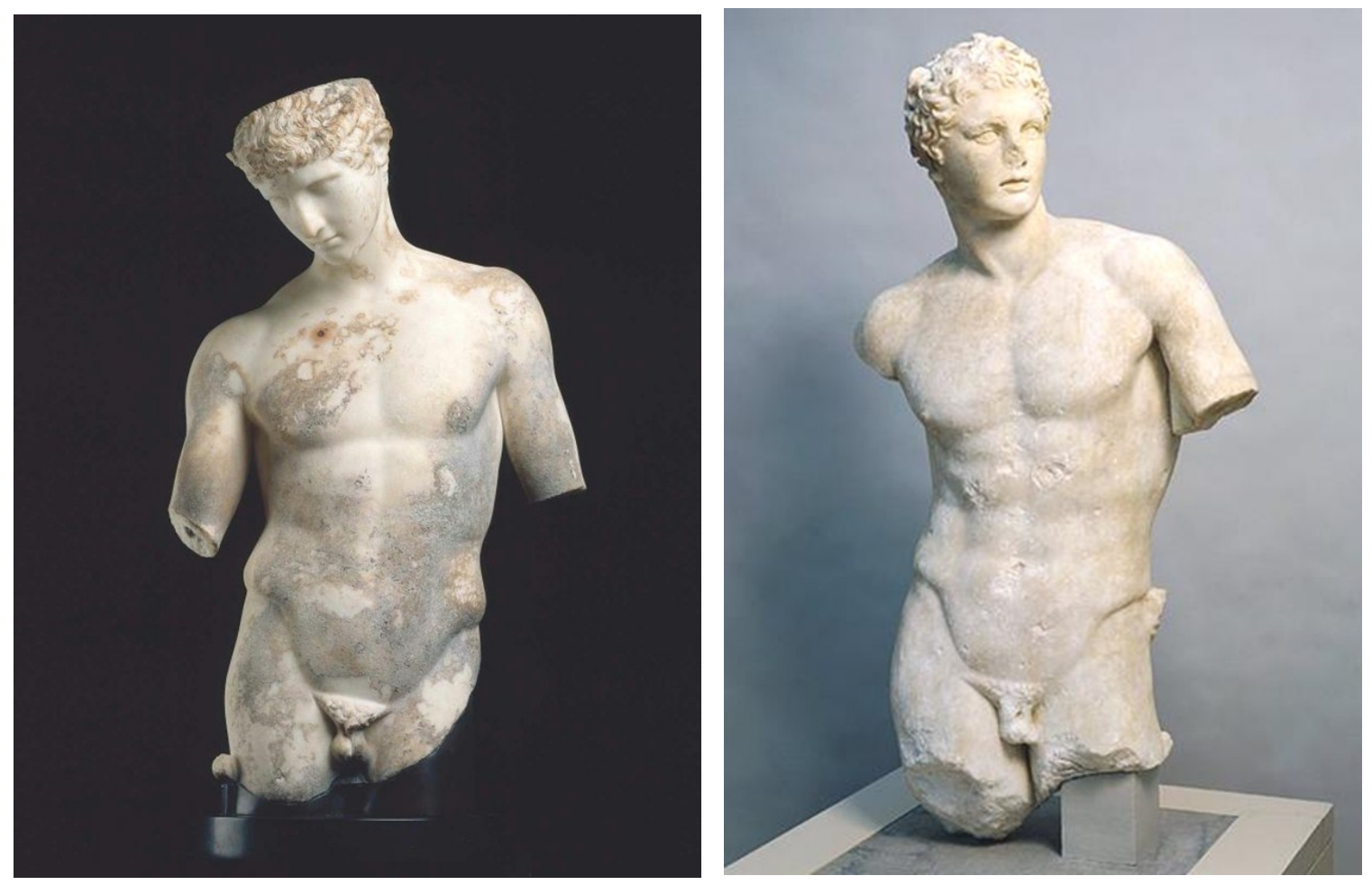

Figure 26

Mercury (Hermes)

MFA 95.67

Roman, Imperial Period, 30-40 C.E.

Marble

$72 \mathrm{~cm}(28$ 3/8in.)

MFA Collection

MFA Collections http://www.mfa.org/ collections/object/mercury-hermes151148

(accessed 7/17/12)
Meleager

HM 1926.48

Roman period, Early to Middle Imperial, c. 31 B.C.E. -235 C.E.

Roman copy of a Fourth Century B.C.E. Greek original by Skopas, 100-200 C.E. Marble

Height: $123 \mathrm{~cm}$ Width: $63 \mathrm{~cm} \mathrm{x} 42 \mathrm{~cm}$ (48 7/16 x 24 13/16 x 16 9/16 in.) Harvard Museums Curatorial Office 


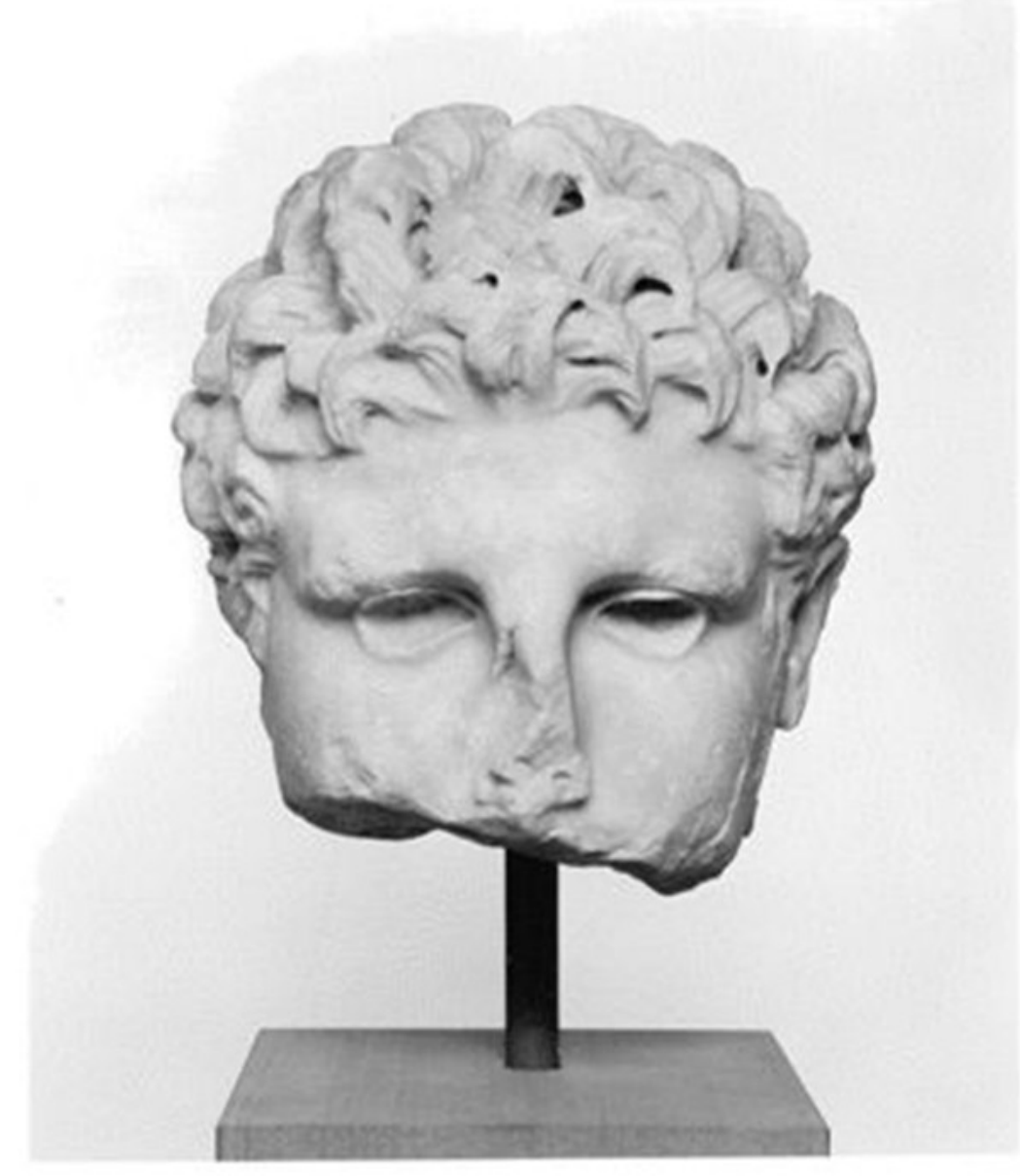

Figure 27

Colossal Head of a Giant or Barbarian

HM 1913.13

Present Mount

Roman period, First or Second Century C.E.

Roman copy of 150 B.C.E. type

Marble

Height $0.45 \mathrm{~m}$

Harvard Museums Curatorial Office 

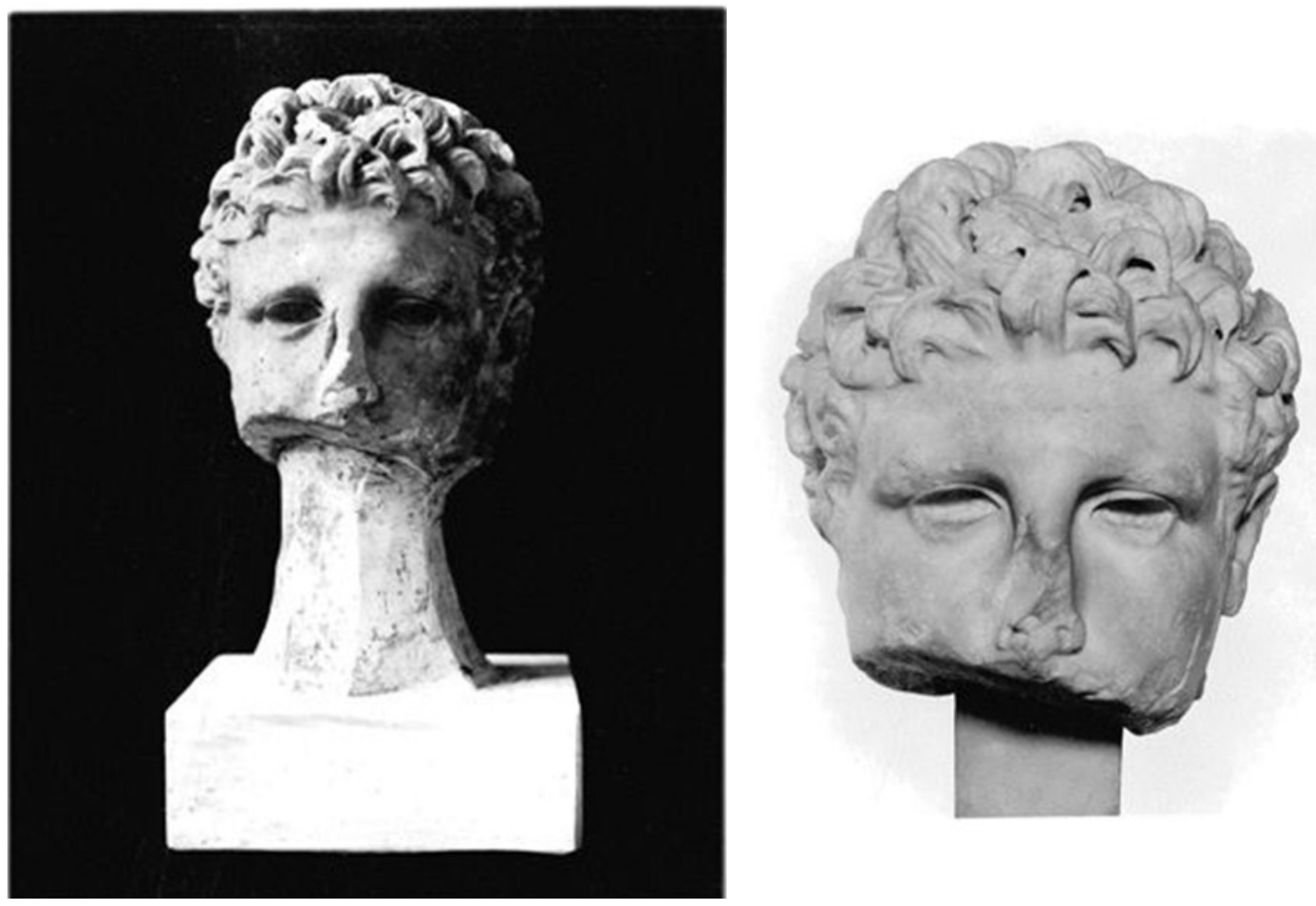

$\underline{\text { Figure } 28}$

Colossal Head of a Giant or Barbarian

HM 1913.13

Earlier Mounts

Roman period, First or Second Century C.E.

Roman copy of 150 B.C.E. type Marble

Height $0.45 \mathrm{~m}$

Harvard Museums Curatorial Office 


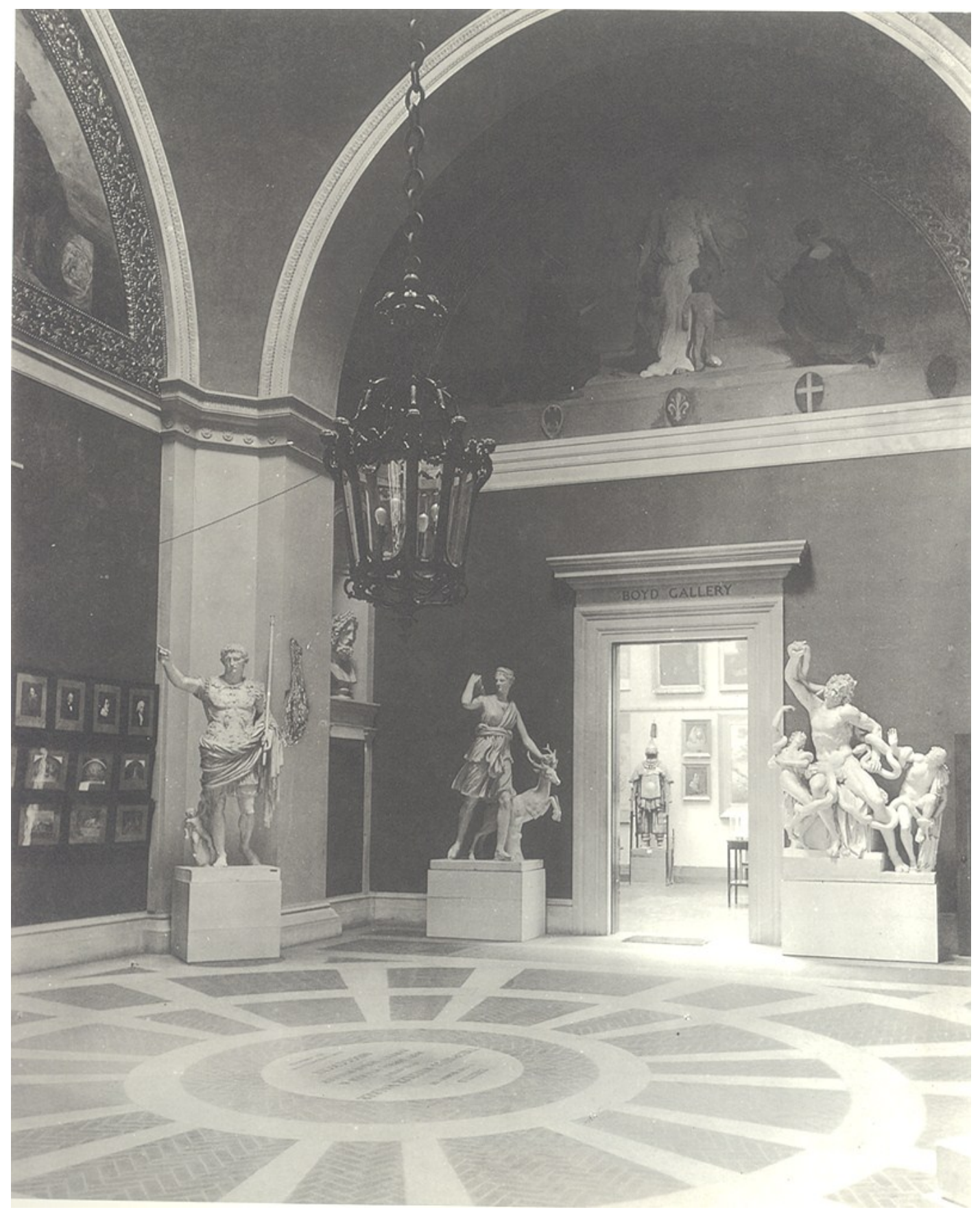

Figure 29

Rotunda of Walker Art Building, Bowdoin College, before 1937

James A. Higginbotham and Katherine M. Westley

Ars Antiqua: Treasures from the Ancient Mediterranean World at Bowdoin College (2005) 


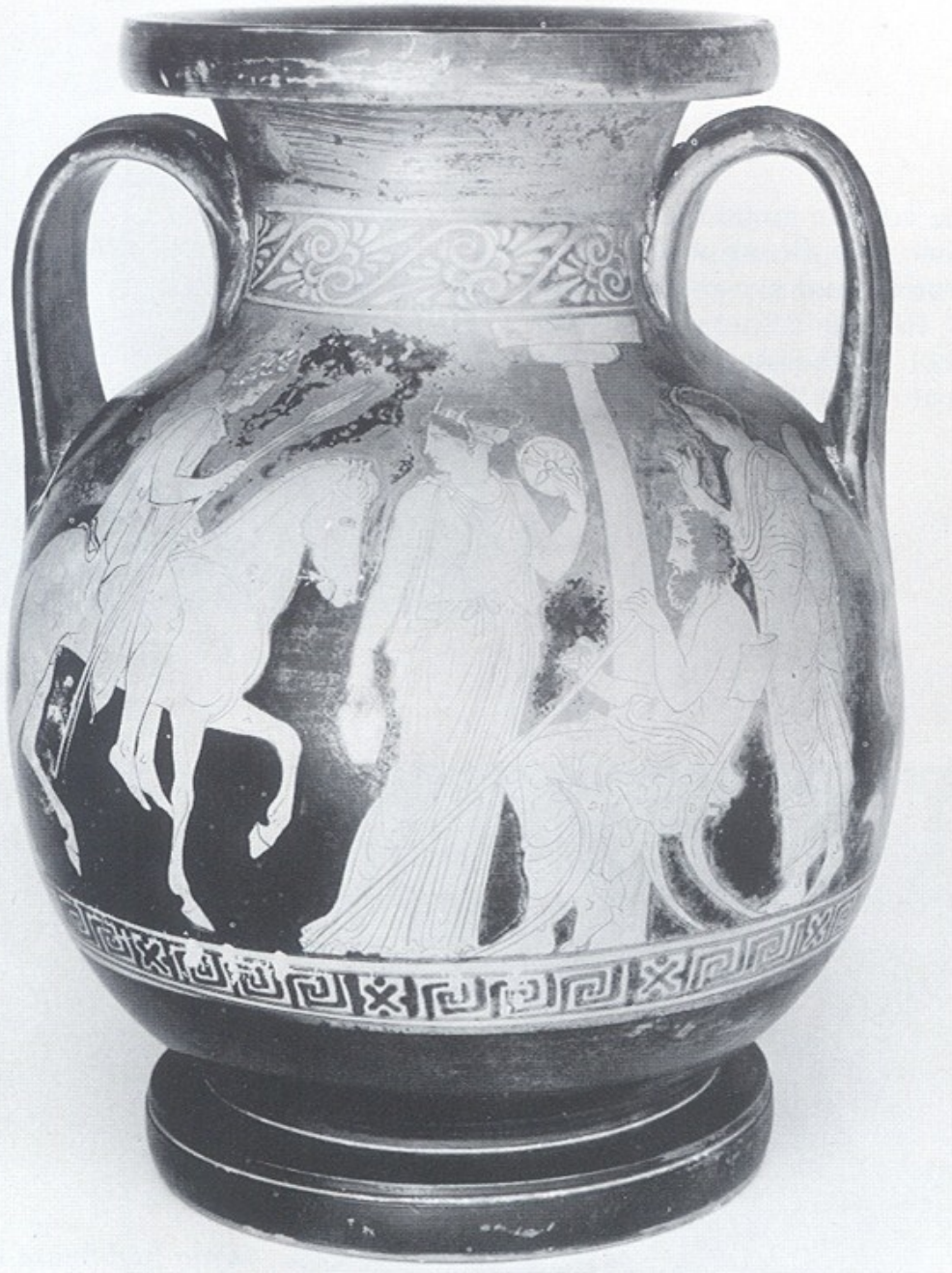

Figure 30

Attic Red-figure Pelike: Side A BCMA 1895.2

c. $425-420$

Attributed to the Dinos Painter

Height 0.400 m; Diameter of lip: 0.205 m; Diameter of Base 0.205 m Kevin Herbert Ancient Art in Bowdoin College: A Descriptive Catalogue of the Warren and Other Collections (1964) 


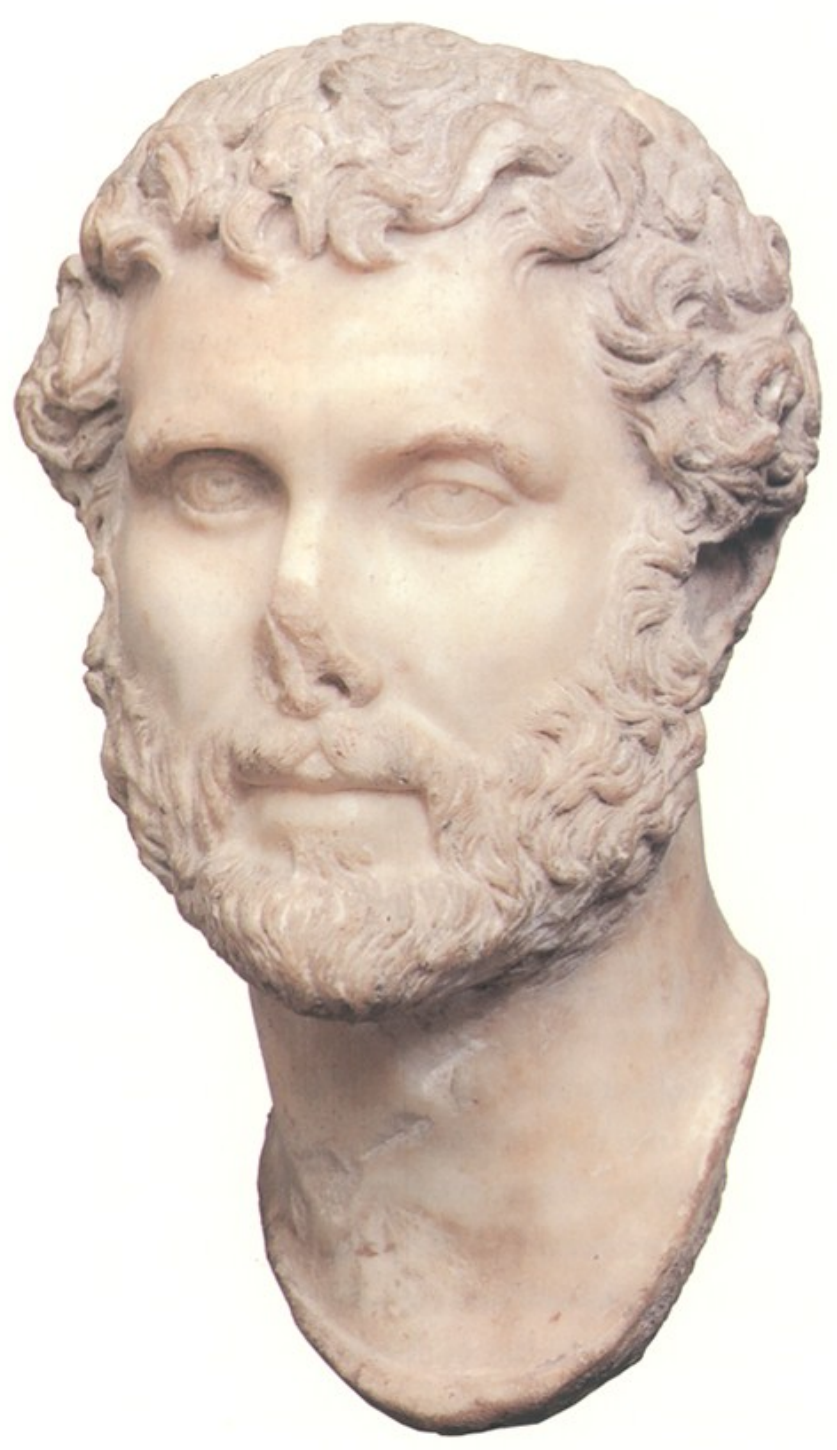

Figure 31

Antonius Pius

BCMA1906.1

Roman, c. $138-140$ C.E .

Height: 15 1/4 ; Width: 8 3/16; Depth: 8 11/16 in Marble

James A. Higginbotham and Katherine M. Westley Ars Antiqua: Treasures from the Ancient Mediterranean World at Bowdoin College (2005) 


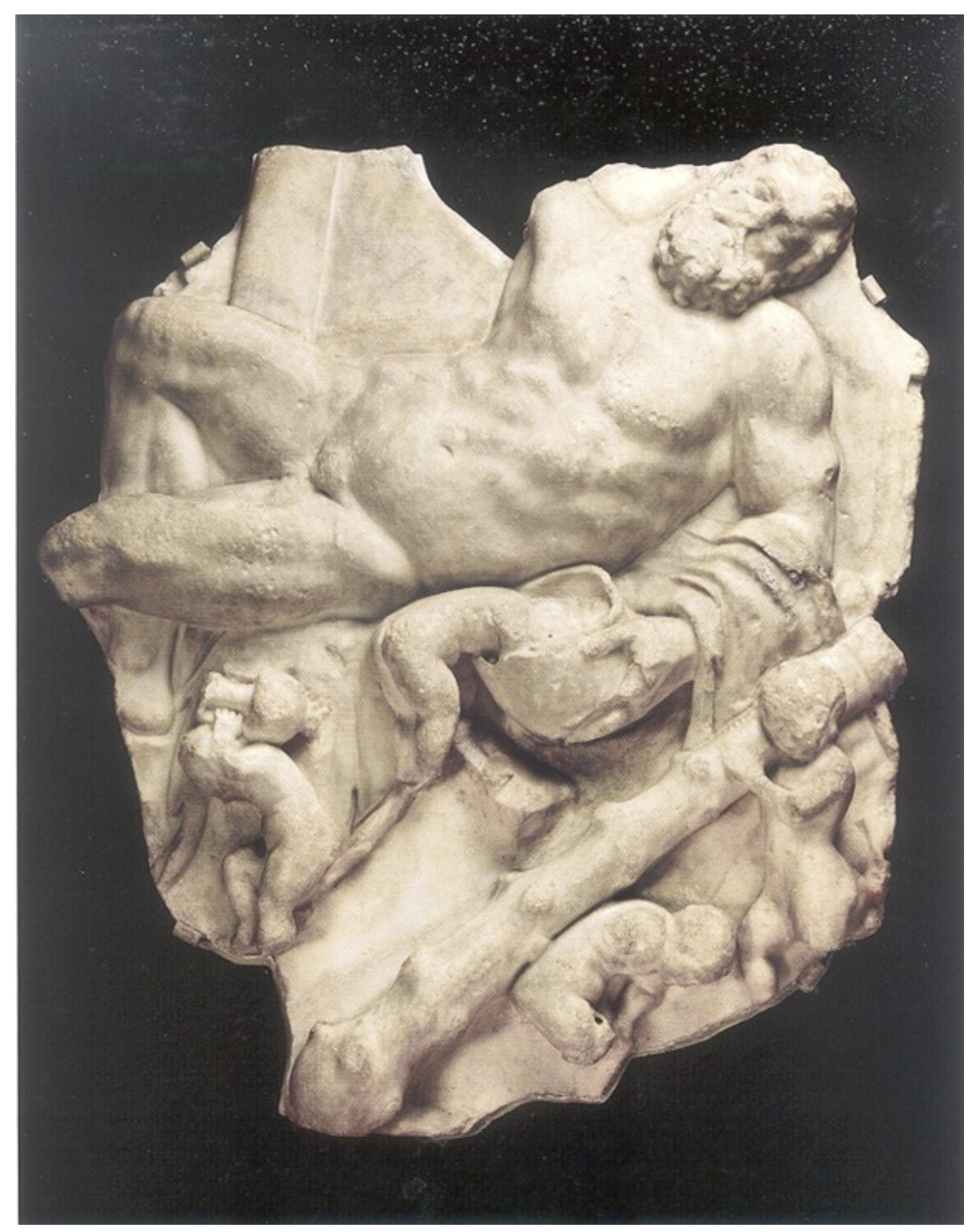

Figure 32

Relief of a Sleeping Herakles

First Century B.C.E

Height: $91.5 \mathrm{~cm}$ (36 in)

Marble

Christine Kondoleon. Ed.

Aphrodite and the Gods of Love (2011) 


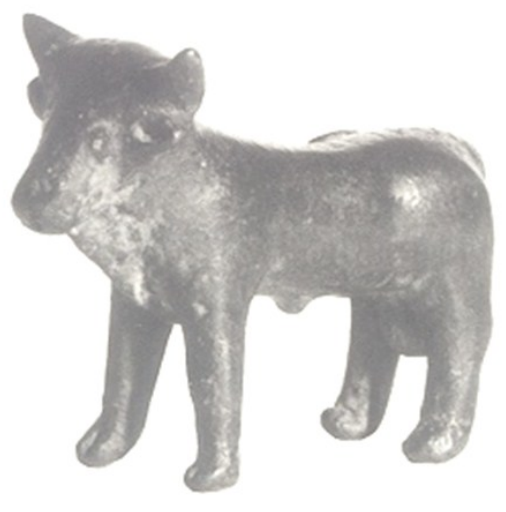

Side View

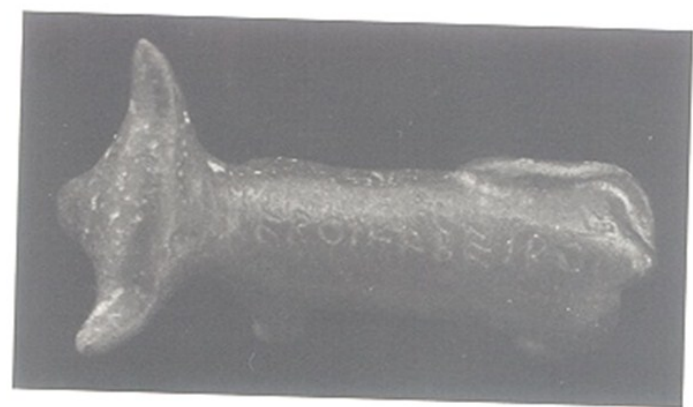

Detail: Inscription

\section{$\underline{\text { Figure } 33}$}

Statuette of a Bull

BCMA 1923.109

Greek, c. 500-460

Height:1 3/8 ; Length:1 5/8 in

Bronze

James A. Higginbotham and Katherine M. Westley

Ars Antiqua: Treasures from the Ancient Mediterranean World at Bowdoin College (2005) 


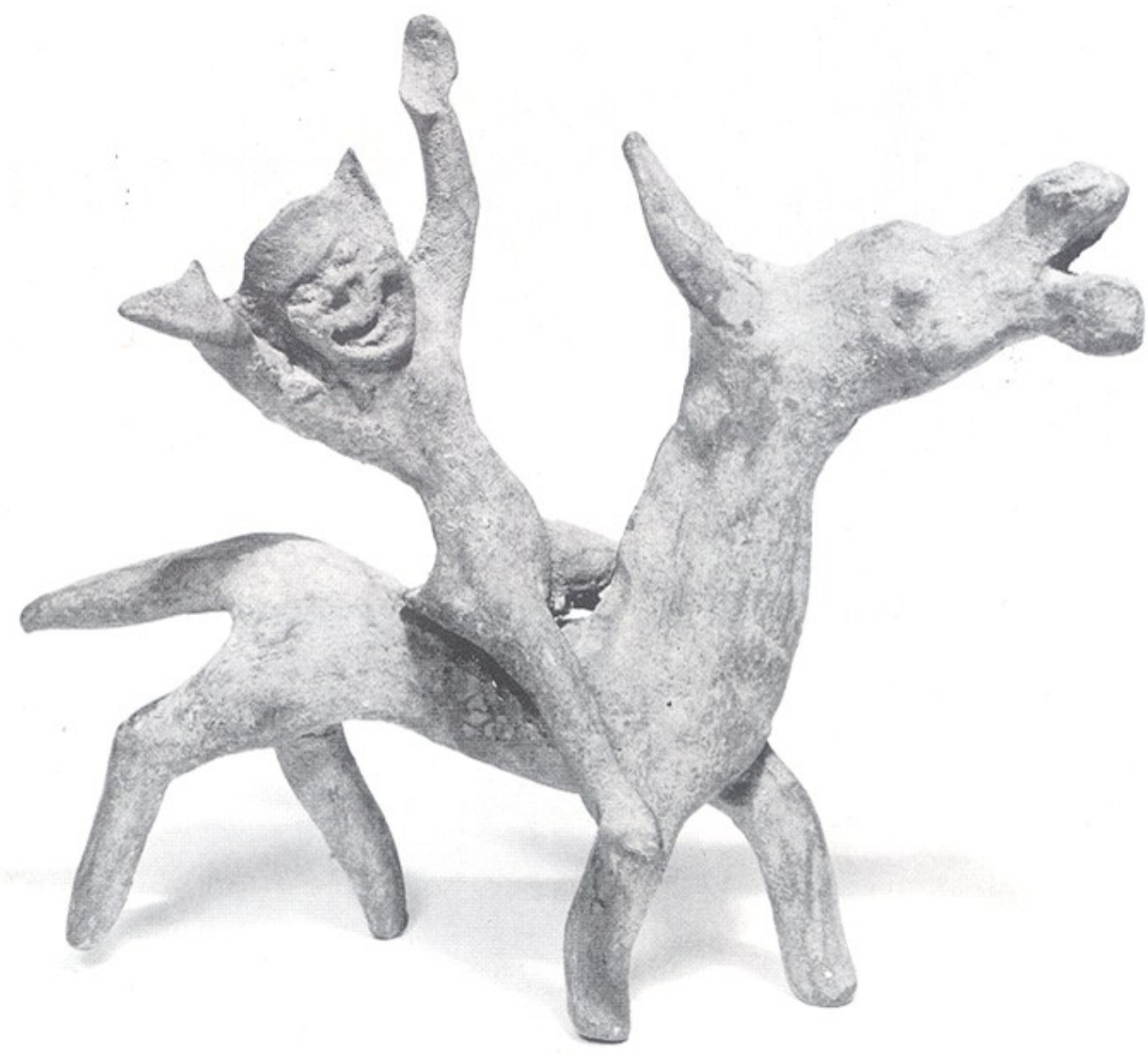

Figure 34

Tanagra Comic Figure on a Donkey

BCMA 1923.10

525-500

Height $0.090 \mathrm{~m}$; Length $0.105 \mathrm{~m}$

Terracotta

Kevin Herbert

Ancient Art in Bowdoin College:

A Descriptive Catalogue of the Warren and Other Collections

(1964) 


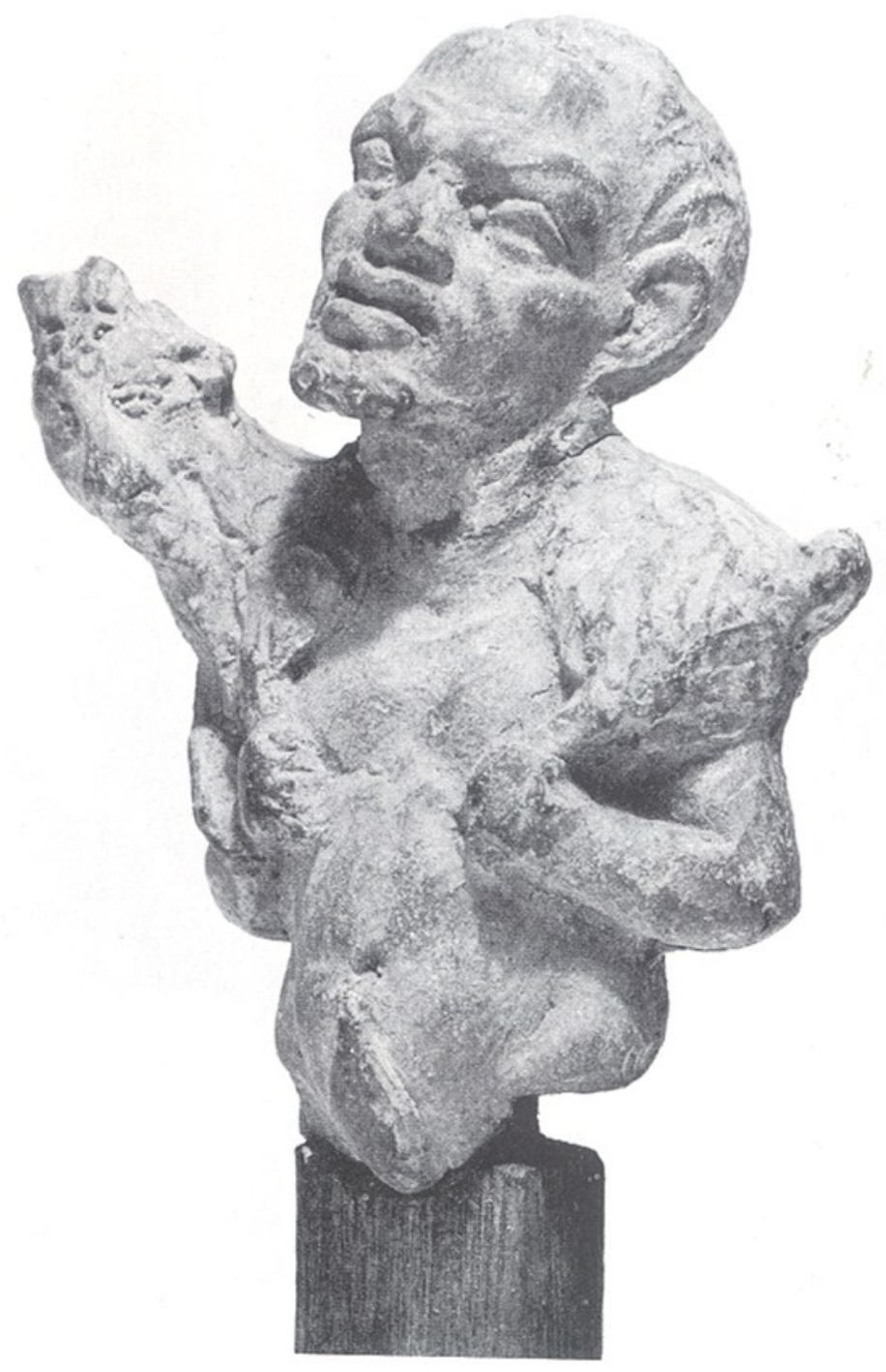

$\underline{\text { Figure } 35}$

Dwarf Carrying a Kid on His Shoulders

BCMA 1915.51

Eastern Greek, Second or First Century B.C.E.

Height: $0.062 \mathrm{~m}$

Terracotta

Kevin Herbert

Ancient Art in Bowdoin College:

A Descriptive Catalogue of the Warren and Other Collections

(1964) 


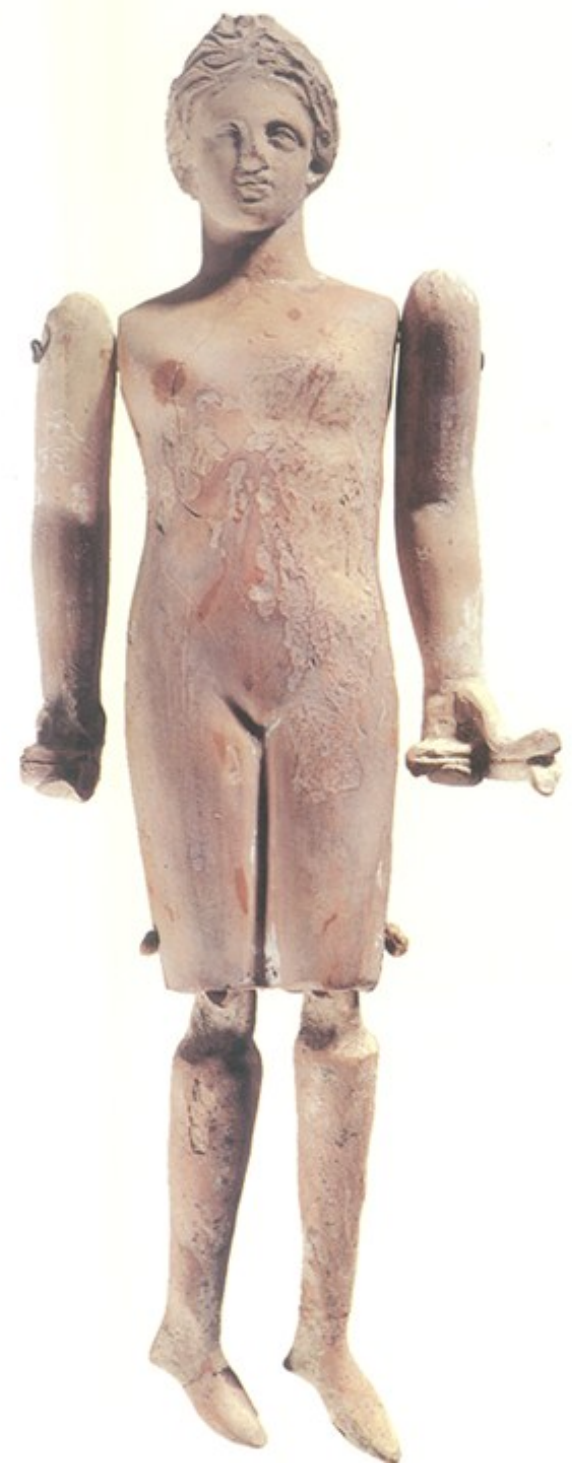

$\underline{\text { Figure } 36}$

Terracotta Jointed Female Doll Holding Rattles

BCMA 1913.028

Greek, c. 400-350

Height: $7 \frac{1}{2}$;Width: 3 1/16; Length :1 3/16 in

James A. Higginbotham and Katherine M. Westley

Ars Antiqua: Treasures from the Ancient Mediterranean World at Bowdoin College

(2005) 


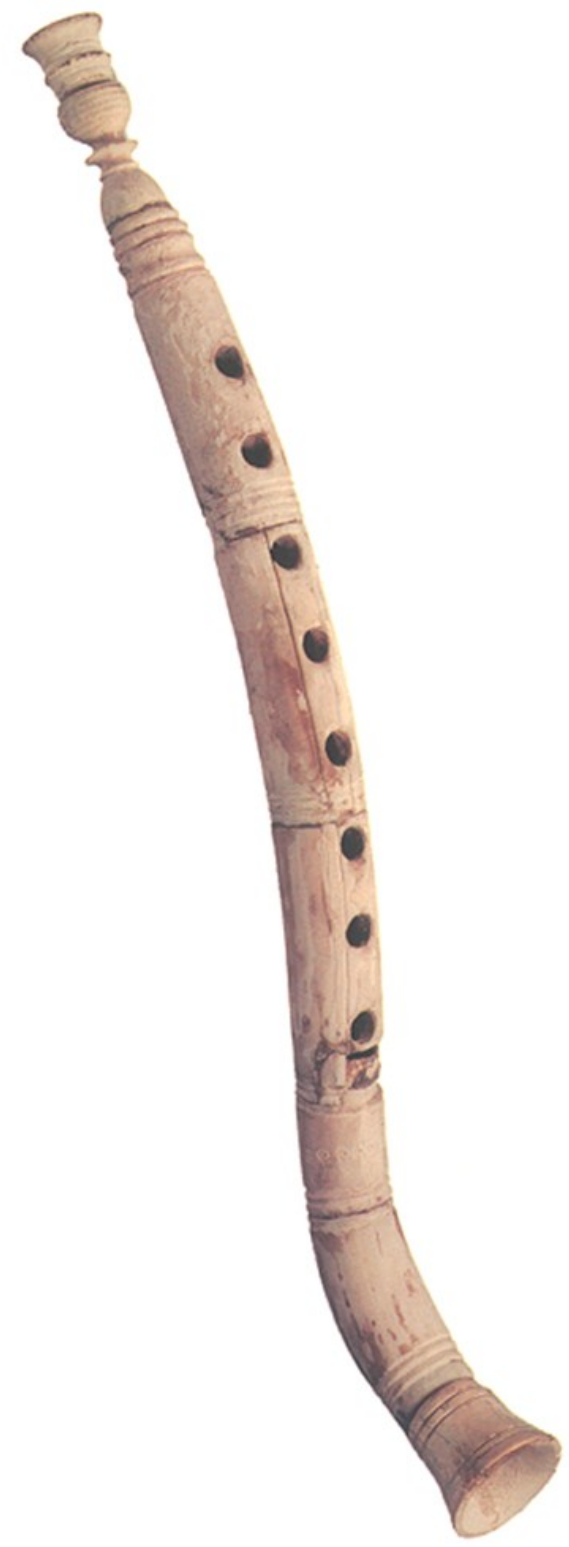

$\underline{\text { Figure } 37}$

Flute

BCMA 1928.2

Roman

First-Second Century C.E.

$127 / 8 \times 11 / 8$ inches

Ivory

James A. Higginbotham and Katherine M. Westley

Ars Antiqua: Treasures from the Ancient Mediterranean World at Bowdoin College

(2005) 


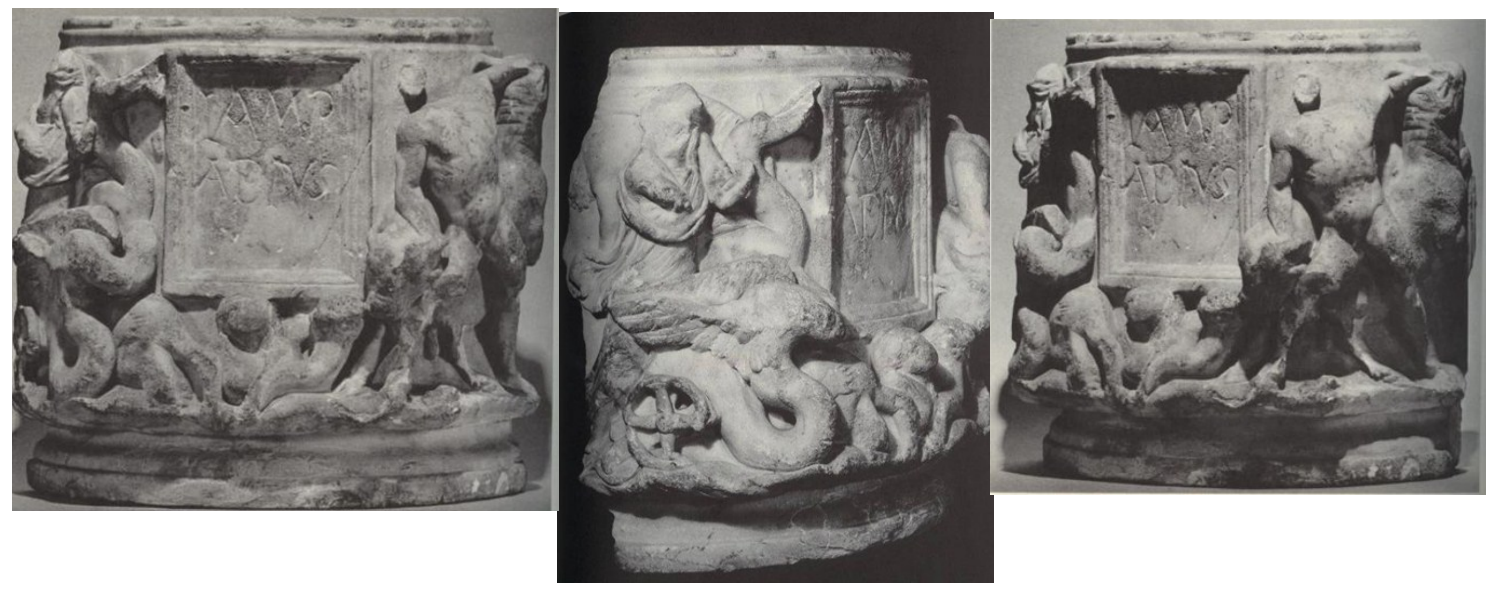

$\underline{\text { Figure } 38}$

Front Wall of a Cinerary Urn

BCMA 1927.20

Roman, Second Century C.E.

Height: 0.355 m Diameter: $0.273 \mathrm{~m}$

Marble

Kevin Herbert, "A Roman Cinerary Urn at Bowdoin College” AJA (1960), 76-8. 

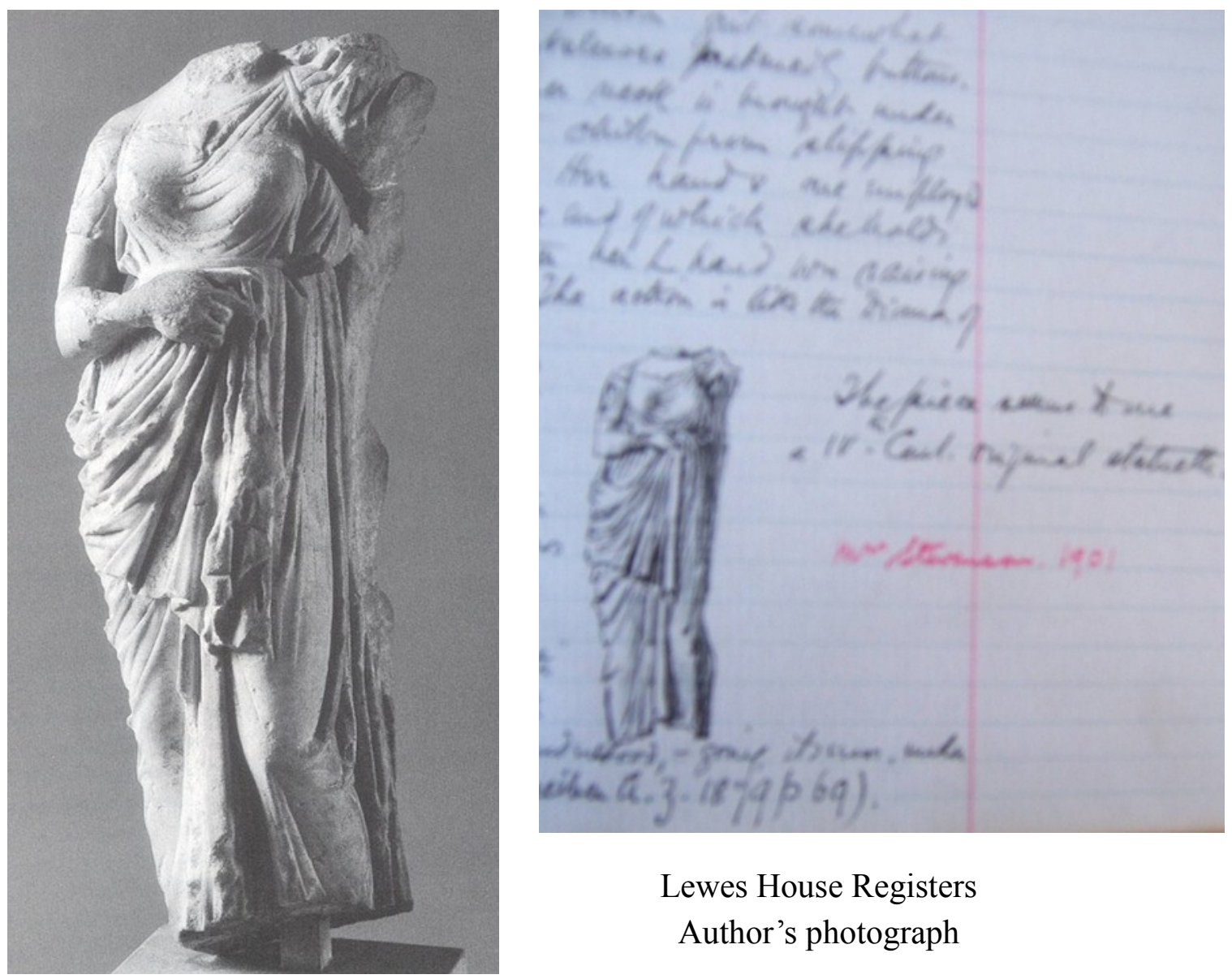

Lewes House Registers

Author's photograph

\section{$\underline{\text { Figure } 39}$}

Female Statuette: Aphrodite

MS 40275

Late Hellenistic or Early Imperial Period Marble

P.H. O.406; Max. W. 0.15; Max Depth 0.108 m.

University of Pennsylvania Museum of Archaeology and Anthropology

Irene Bald Romano, Classical Sculpture (2006) 


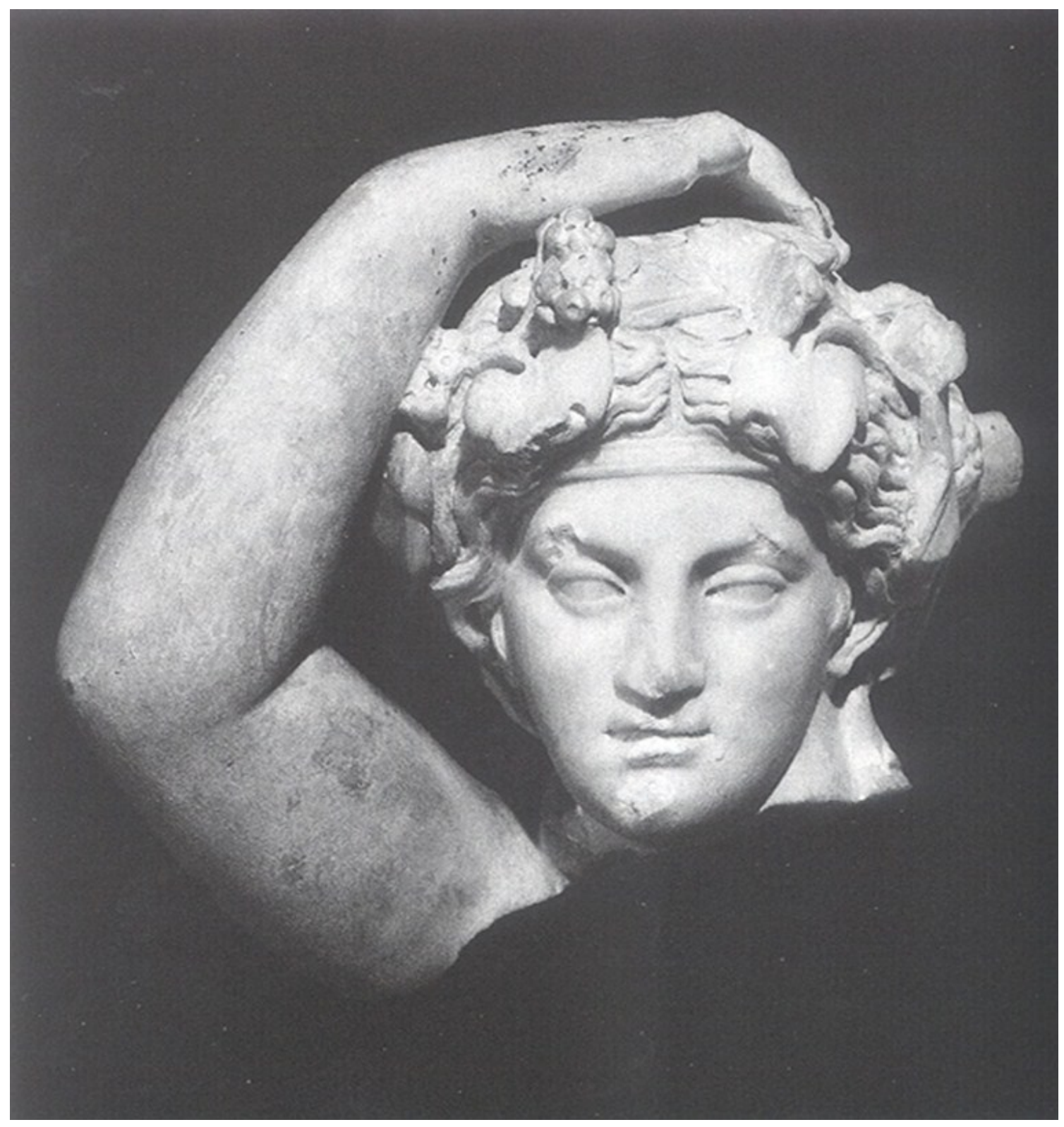

Figure 40

Table Support Fragment (?): Dionysos/Bacchus MS 4027

Roman, Imperial Period, First-Second Century C.E. Marble

P.H.O.185; Height : Head 0.13; Max. P. W. 0.225; Max. P. Depth 0.125m

University of Pennsylvania Museum of Archaeology and Anthropology

Irene Bald Romano, Classical Sculpture (2006) 


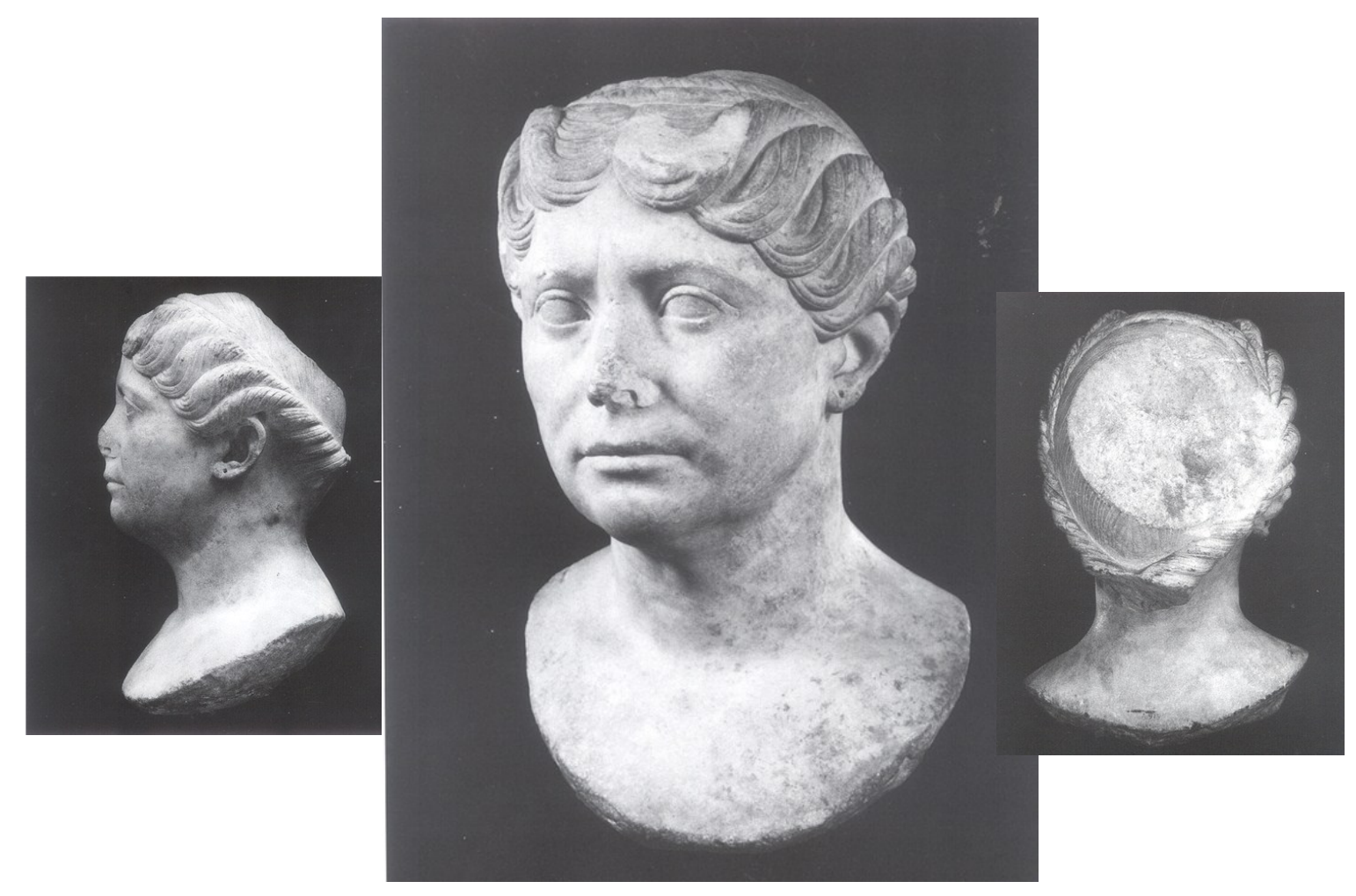

Figure 41

Portrait of a Middle-Aged Woman

MS 4919

Roman, Imperial Period, second quarter of First Century C.E.

Medium grade white marble

H.O.355; Max. W. neck 0.22;W. Head 0.18; Depth $0.21 \mathrm{~m}$

University of Pennsylvania Museum of Archaeology and Anthropology

Irene Bald Romano, Classical Sculpture (2006) 


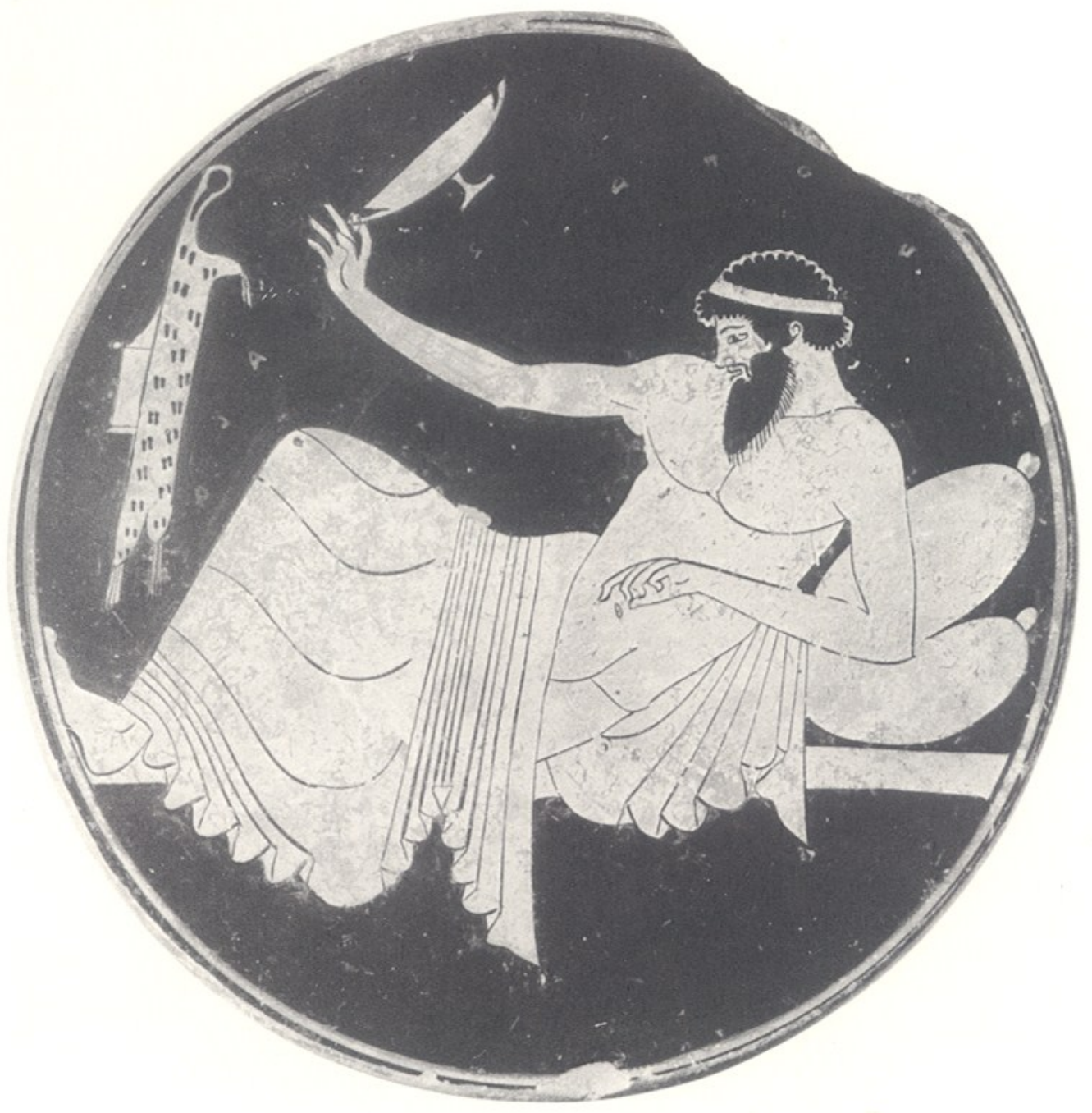

$\underline{\text { Figure } 42}$

Red-figure Plate

Attributed to the Bryn Mawr Painter

P-95

490

Diameter 0.149m; Present Height 0.009m

BM CVA Plate 1 


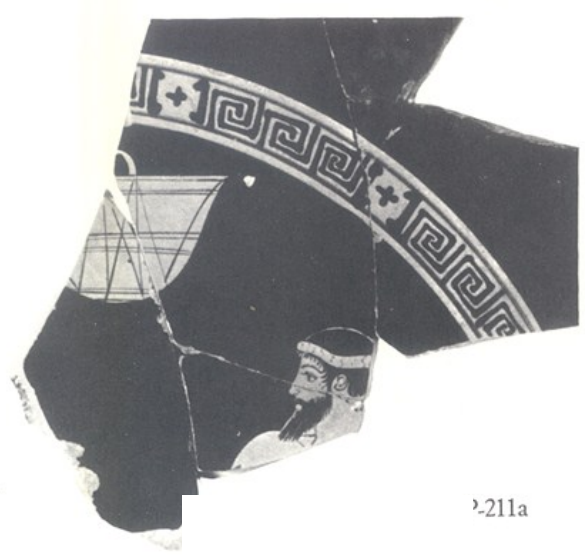

Exterior Side A
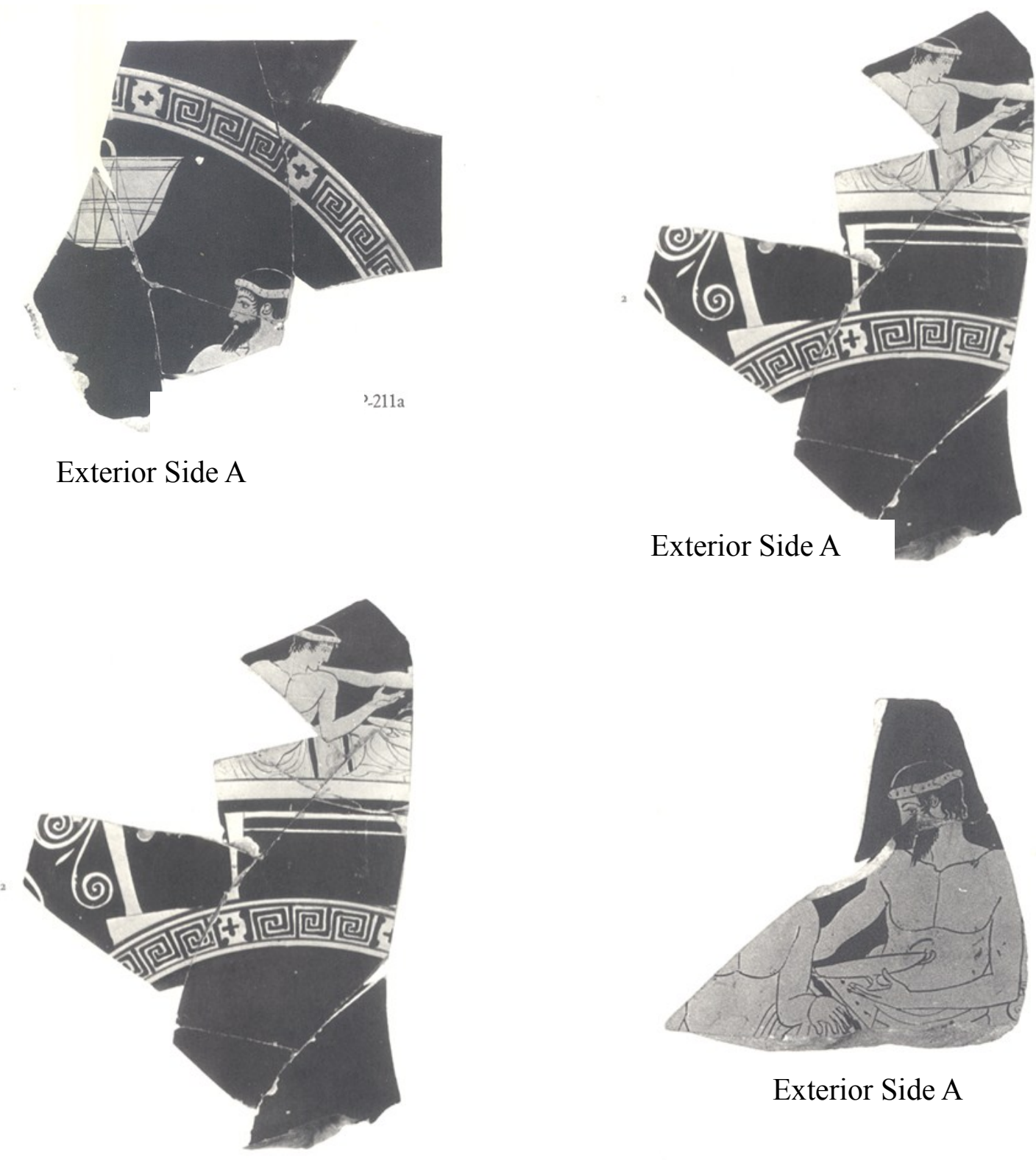

Exterior Side A

Exterior Side B

$\underline{\text { Figure } 43}$

Red-figure Kylix Fragments

Bryn Mawr P-211 a, P 211-b, P211-c,

Attributed to the Euaion Painter c. 460-50

BM CVA Plate 22 


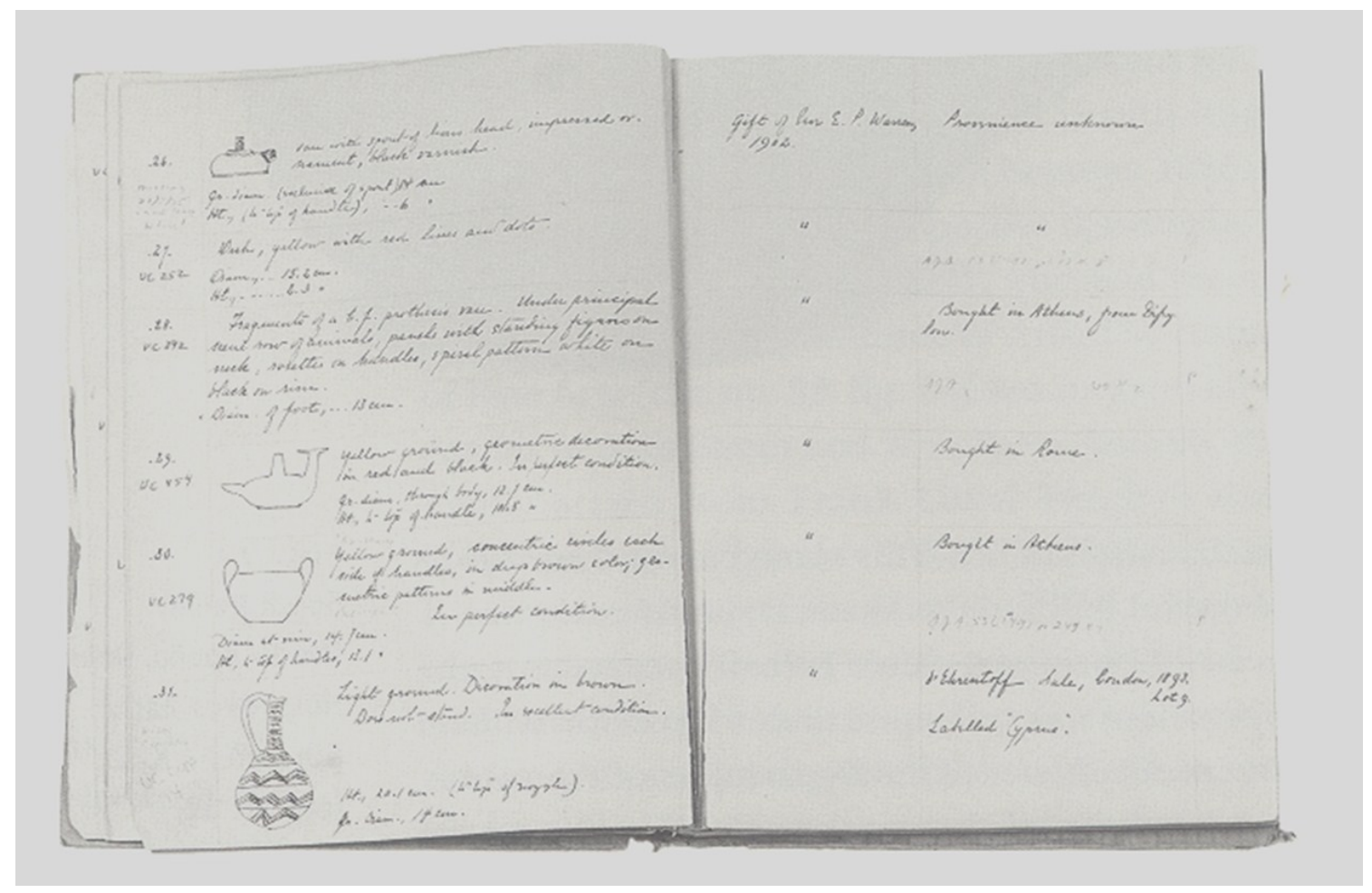

Figure 44

Tarbell Inventory

Linda Seidel and Katherine Taylor

Visual Pedagogy at the University of Chicago

(1998) 


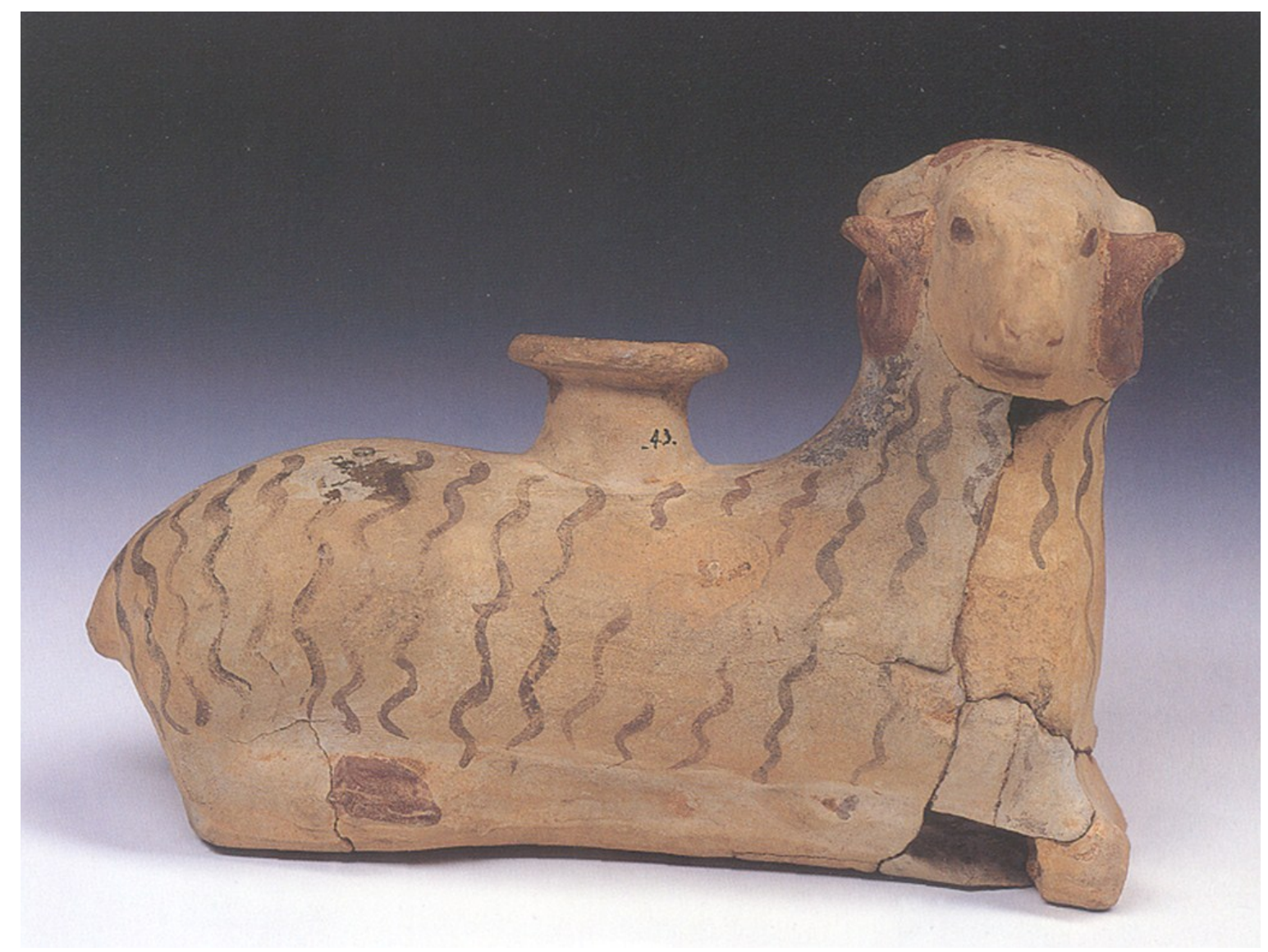

Figure 45

Boeotian Ram Vase

SM 1967.115.396

Greek, Late Sixth-Early Fifth Century

Height: 10.9 cm (4 1/4); Length: 15.4 cm (6); Width: $6 \mathrm{~cm}$ (2 3/8);

Diameter of Mouth: $3.3 \mathrm{~cm}\left(1 \frac{1}{4}\right)$

The David and Alfred Smart Museum of Art, the University of Chicago

Gloria Ferrari, Christina M. Nelson, et al. The Classical Collection (1998) 


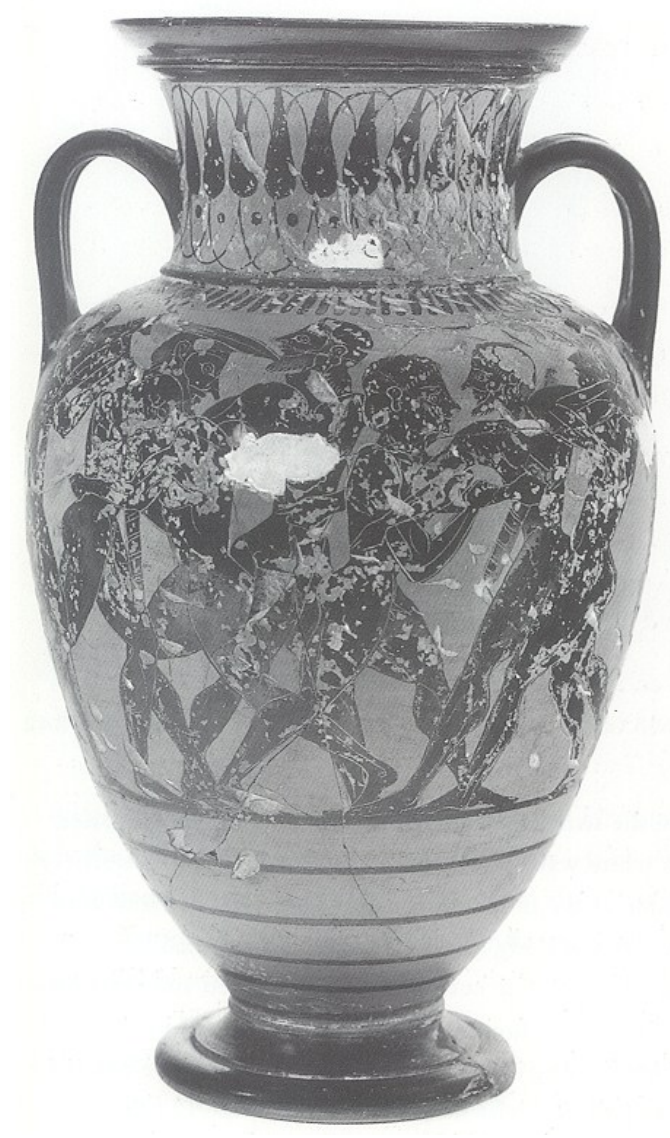

Side A

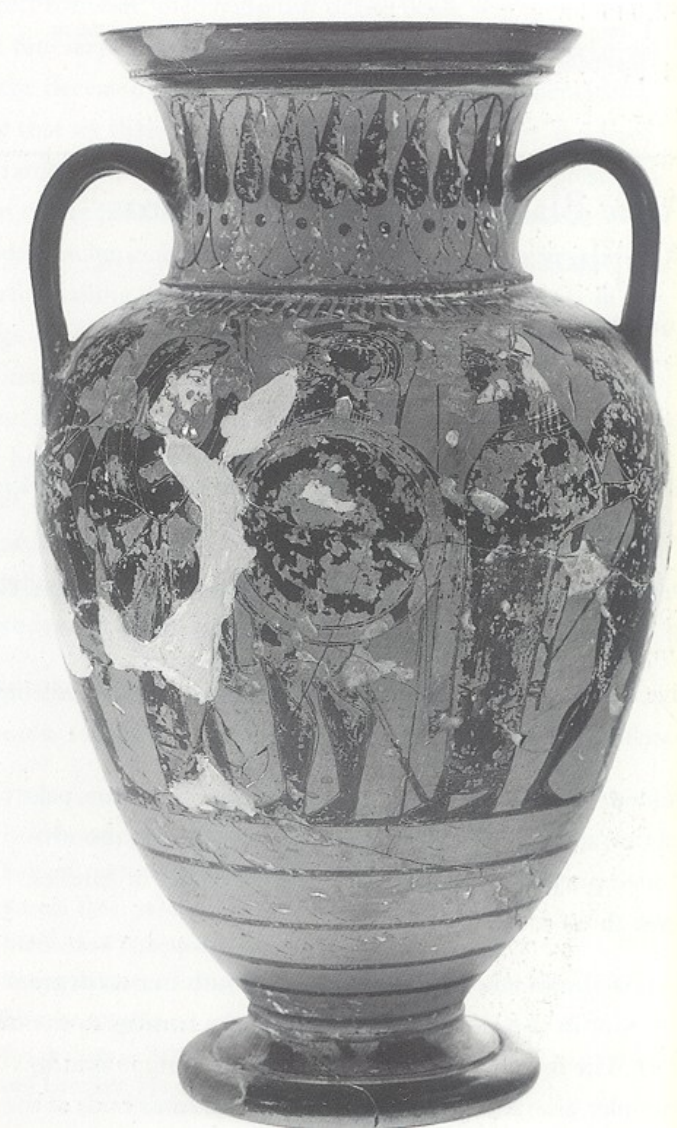

Side B

Figure 46

Attic Black-figure Amphora

SM 1967.115.351

$520-500$

Attributed to Near the Painter N

Height: 22.6 cm (8 7/8 in); Max. Diameter 13.9 (5 1/2 in); Diameter of rim 10.3 (4 1/8 in); Diameter of Foot: $7.6 \mathrm{~cm}$ ( 3 in )

The David and Alfred Smart Museum of Art, the University of Chicago

Gloria Ferrari, Christina M. Nelson, et al

The Classical Collection (1998) 


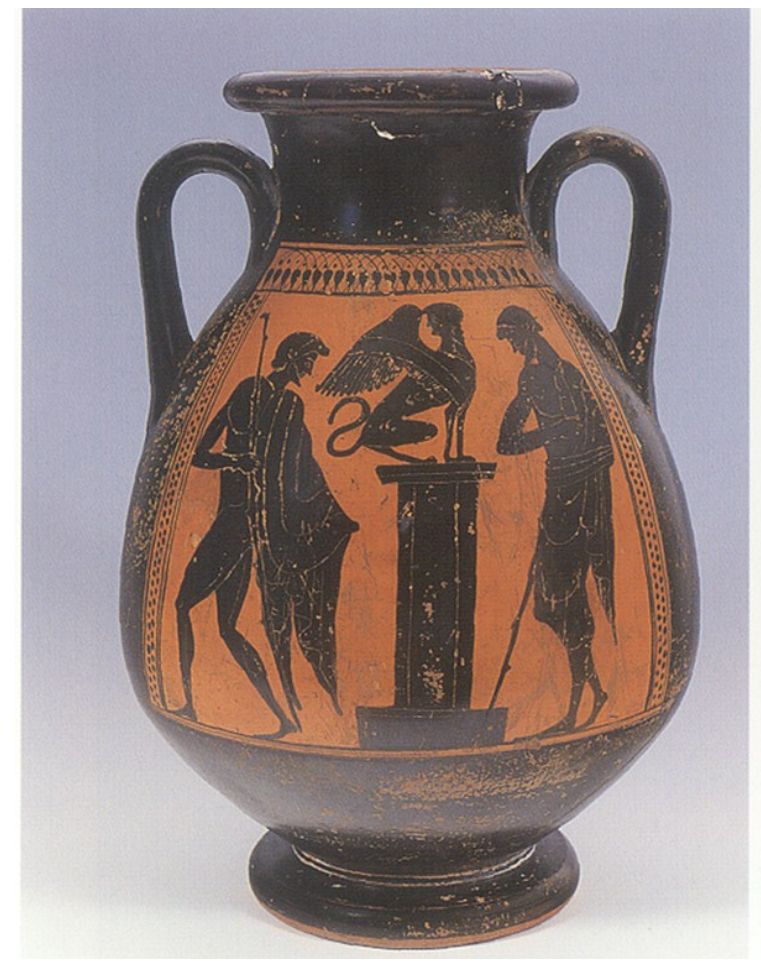

Side A

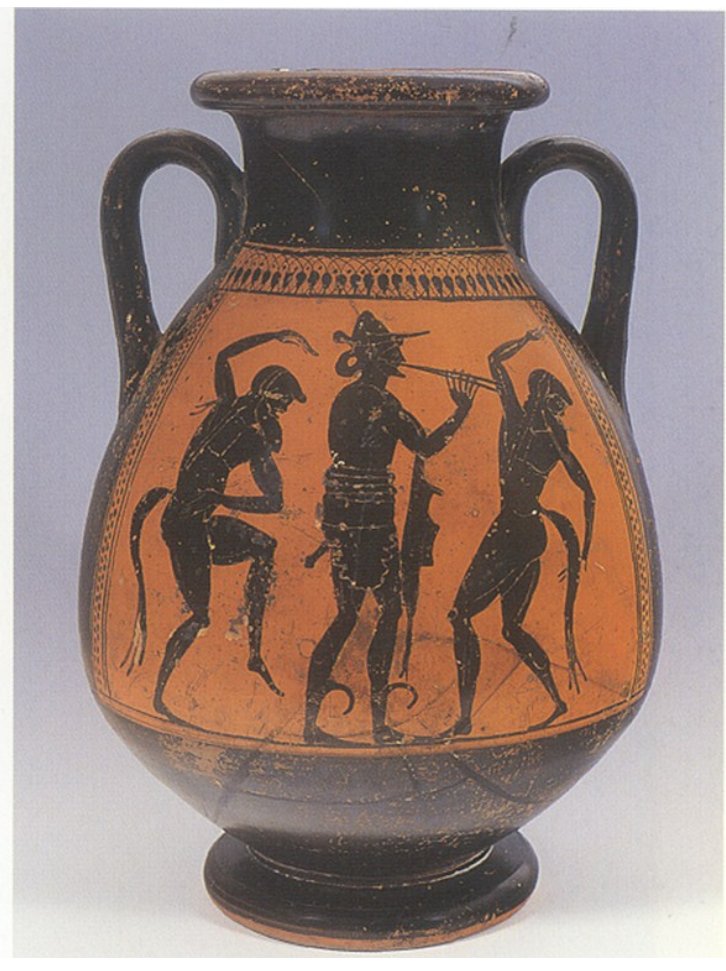

Side B

\section{Figure 47}

Attic Black-figure Pelike

SM 1967.115.340

490-480

Attributed to the Eucharides Painter

Height: 34.7 cm (13 3/4 in); Diameter of mouth: 15 (5 3/4 in); Diameter w/handles 24.4 (8 7/8 in); Diameter of foot (restored) 14 (5 1/2 in); Diameter of Foot: $7.6 \mathrm{~cm}$ (3 in )

The David and Alfred Smart Museum of Art, the University of Chicago Gloria Ferrari, Christina M. Nelson, et al. The Classical Collection (1998) 


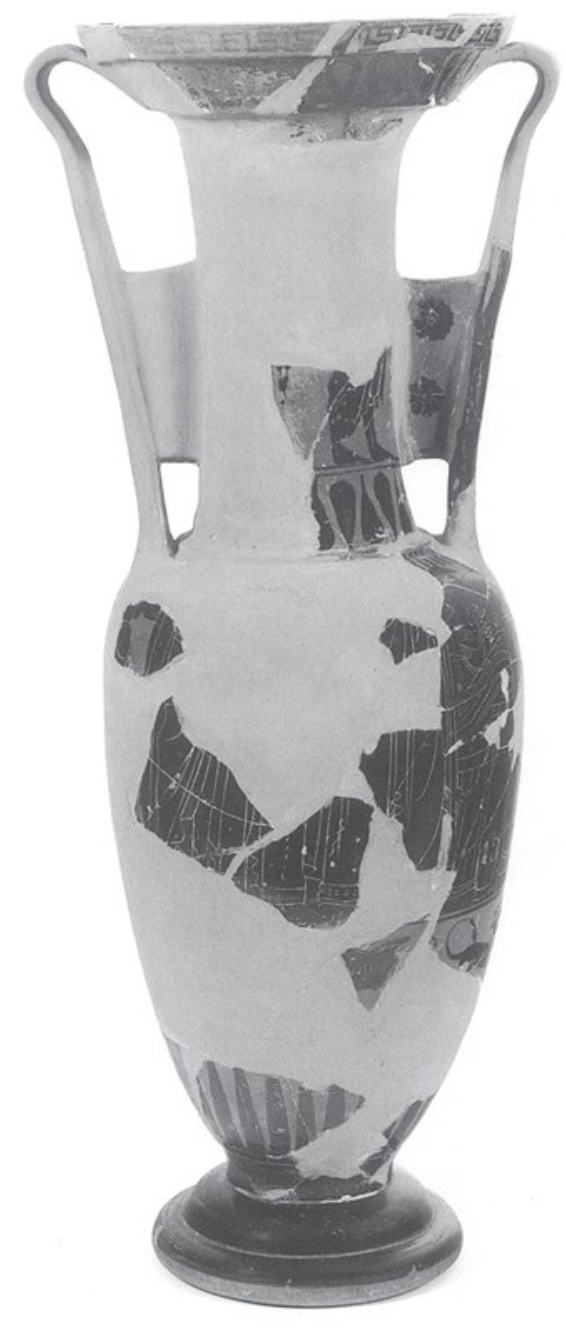

Side A

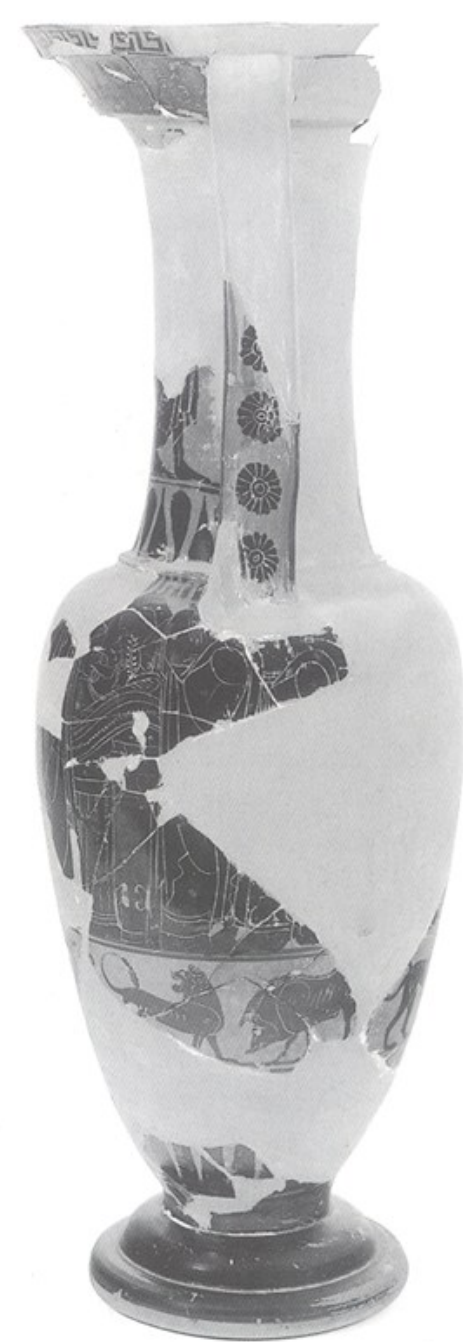

Side B

\section{$\underline{\text { Figure } 48}$}

Attic Black-figure Loutrophoros Amphora

SM 1967.115.342

520-500

As restored: Height: $50.4 \mathrm{~cm}$ (19 3/4 in); Diameter as restored $17.2 \mathrm{~cm}\left(6 \frac{3}{4} \mathrm{in}\right)$;

Diameter of rim $18.5 \mathrm{~cm}$ ( $73 / 8$ in ); Diameter of Foot: $13 \mathrm{~cm}$. (5 1/8 in

The David and Alfred Smart Museum of Art, the University of Chicago Gloria Ferrari, Christina M. Nelson, et al. The Classical Collection (1998) 


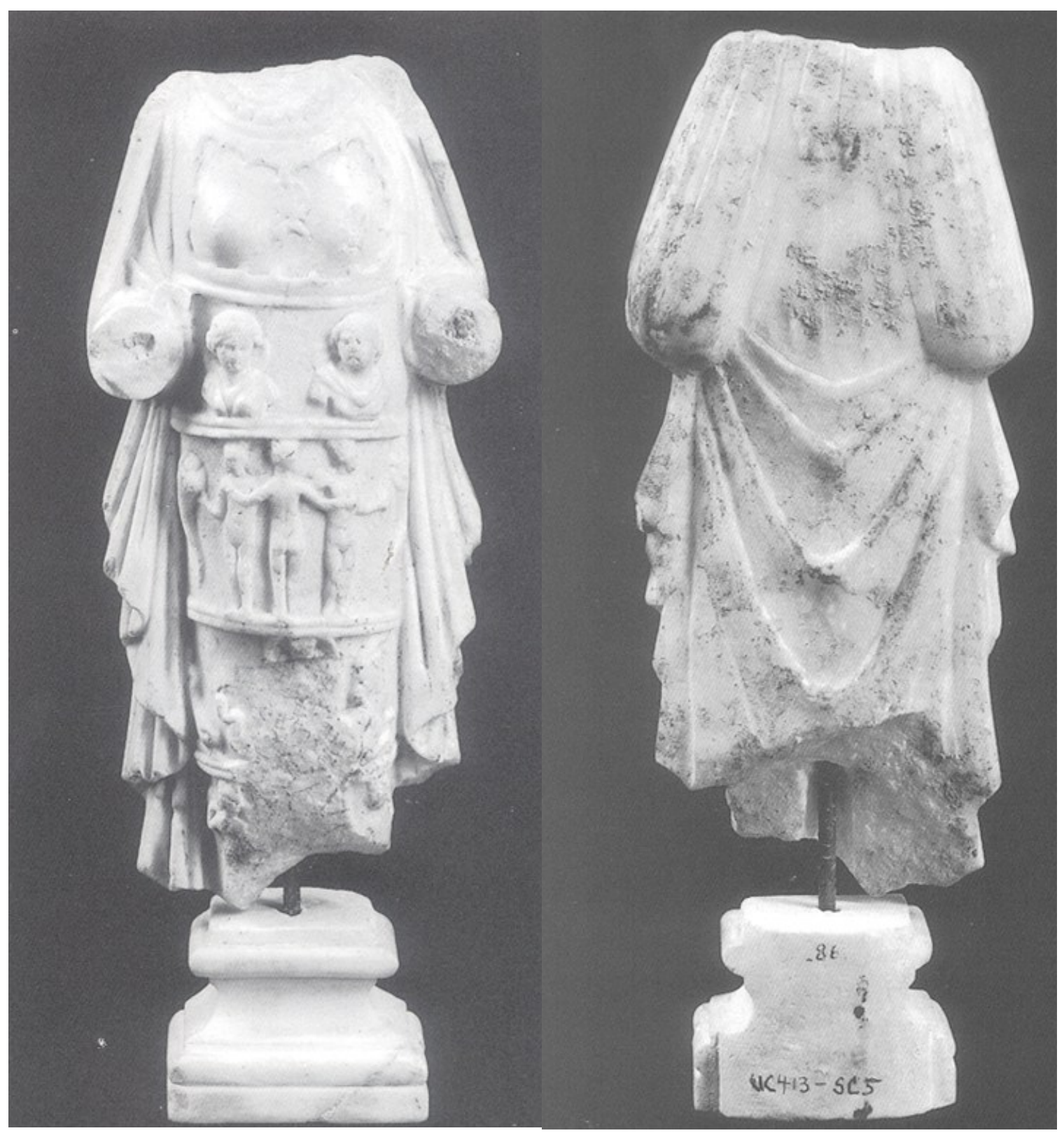

Figure 49

Statuette of Aphrodite of Aphrodisias

SM 1967.115.413

Mid-Second Century C.E.

Height: $19.9 \mathrm{~cm}$ (7 13/16 in); Width at elbows: $9.3 \mathrm{~cm}(3$ 5/8 in)

Marble

The David and Alfred Smart Museum of Art, the University of Chicago

Gloria Ferrari, Christina M. Nelson, et al. The Classical Collection (1998) 


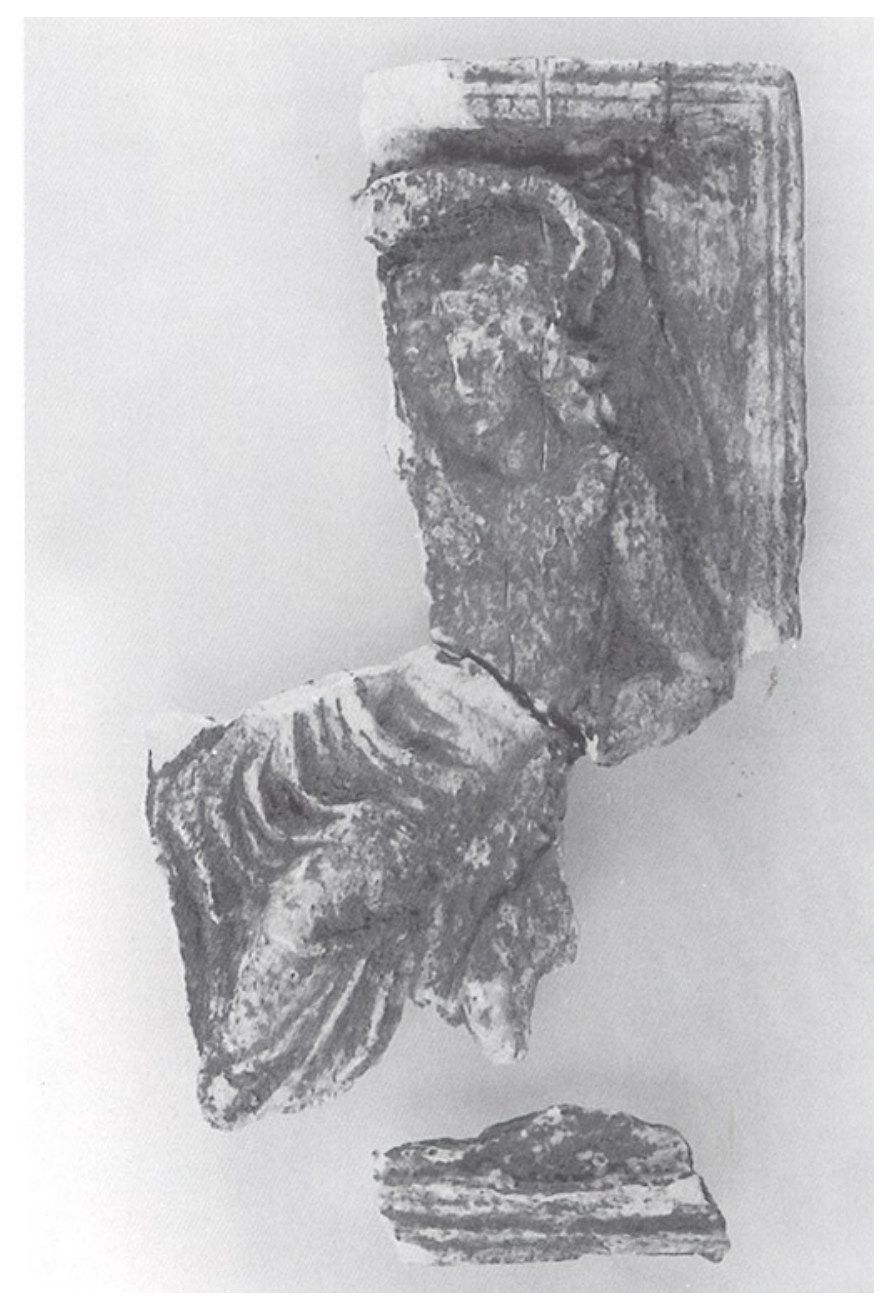

$\underline{\text { Figure } 50}$

\author{
Plaque Fragment \\ SM 1967.115.4550 \\ Second-Third Century C.E. \\ Height: $7 \mathrm{~cm}$ (2 7/8); Maximum Width: 3 (1 3/4); Thickness at Frame: $0.5 \mathrm{Cm}(3 / 16)$ \\ Ivory \\ The David and Alfred Smart Museum of Art, the University of Chicago \\ Gloria Ferrari, Christina M. Nelson, et al. The Classical Collection (1998)
}




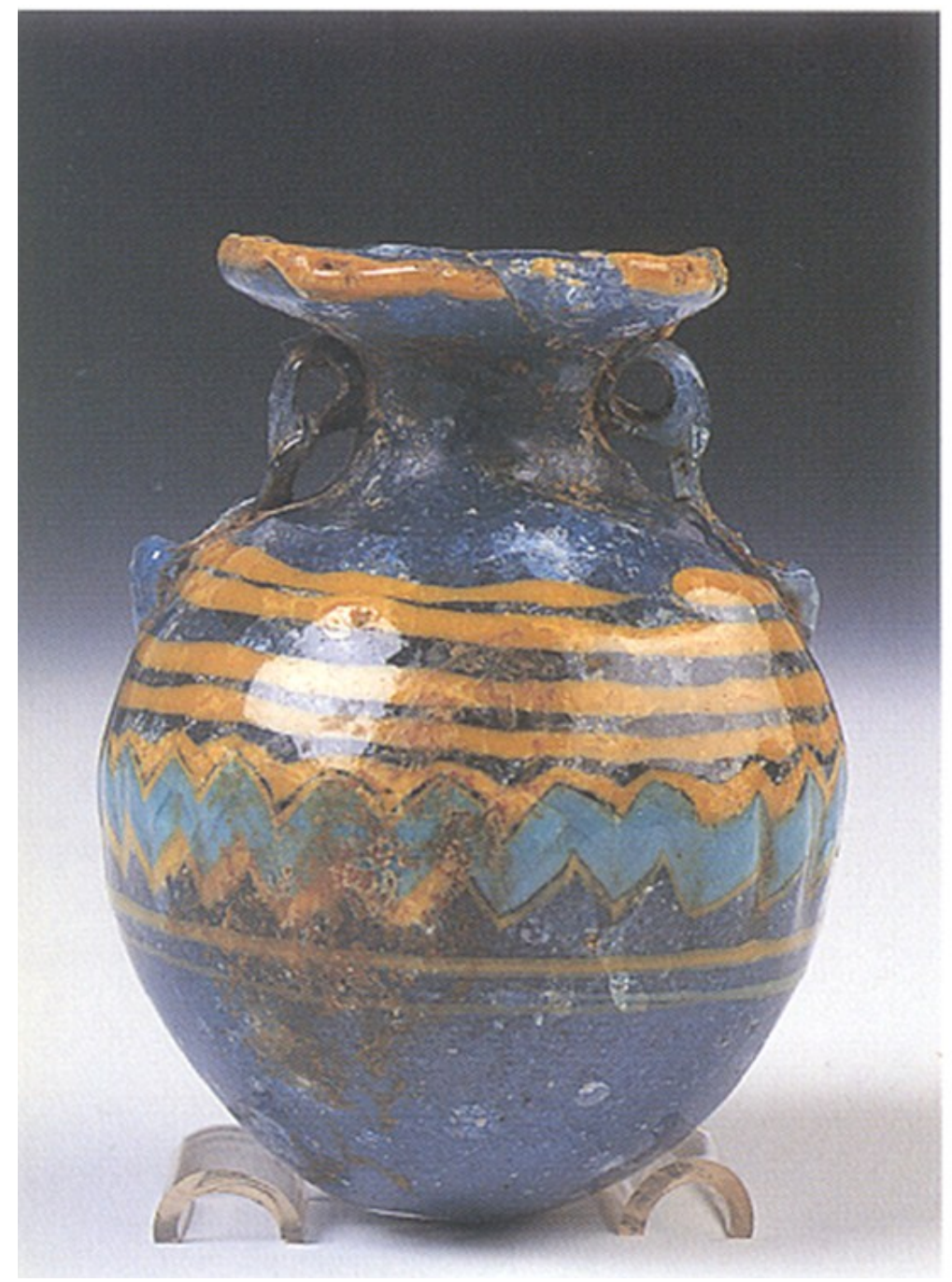

Figure 51

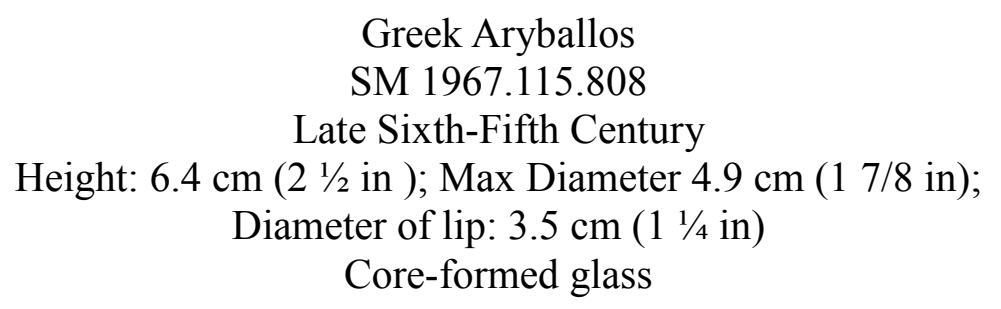

The David and Alfred Smart Museum of Art, the University of Chicago Gloria Ferrari, Christina M. Nelson, et al. The Classical Collection (1998) 


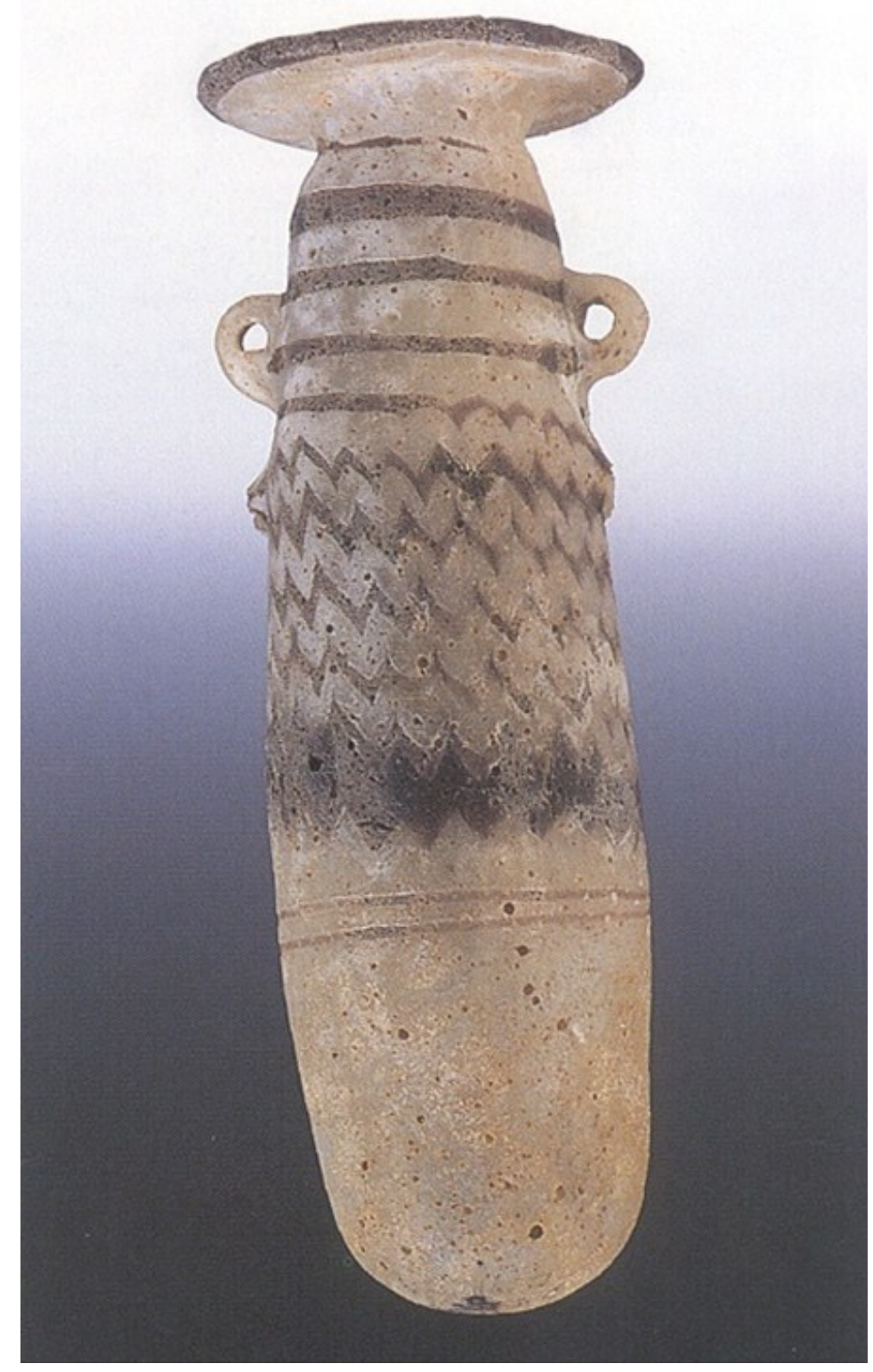

$\underline{\text { Figure } 52}$

Greek Alabastron

SM 1967.115.814

Late Sixth-Fifth Century

Height: 10 cm (3 7/8 ); Maximum Diameter: 3 (1 1/8 ); Diameter of lip: 3.5 (1 1/2) Core-formed glass

The David and Alfred Smart Museum of Art, the University of Chicago Gloria Ferrari, Christina M. Nelson, et al. The Classical Collection (1998) 


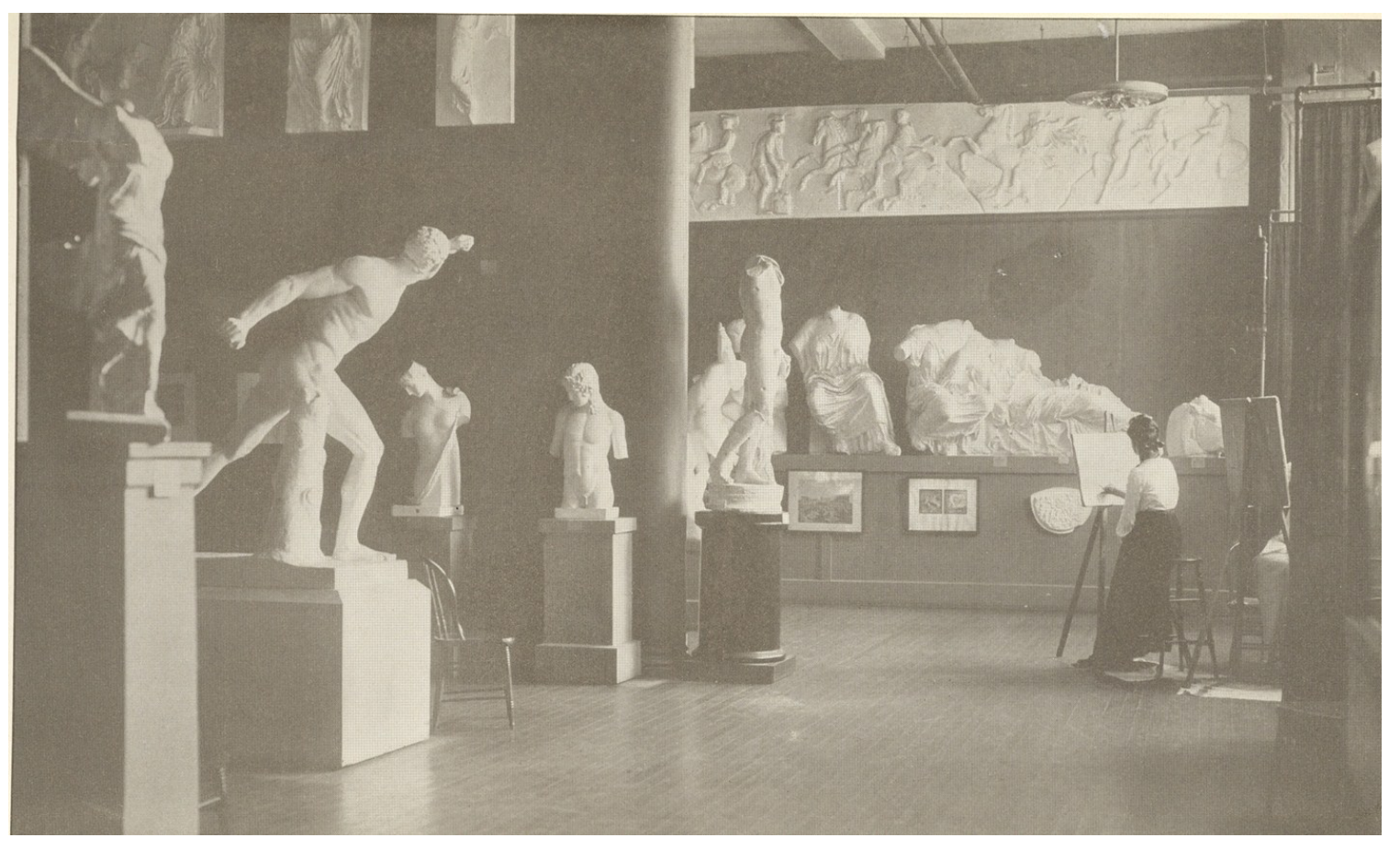

Figure 53

RISD Cast Gallery 1904

RISD Visual Resources 


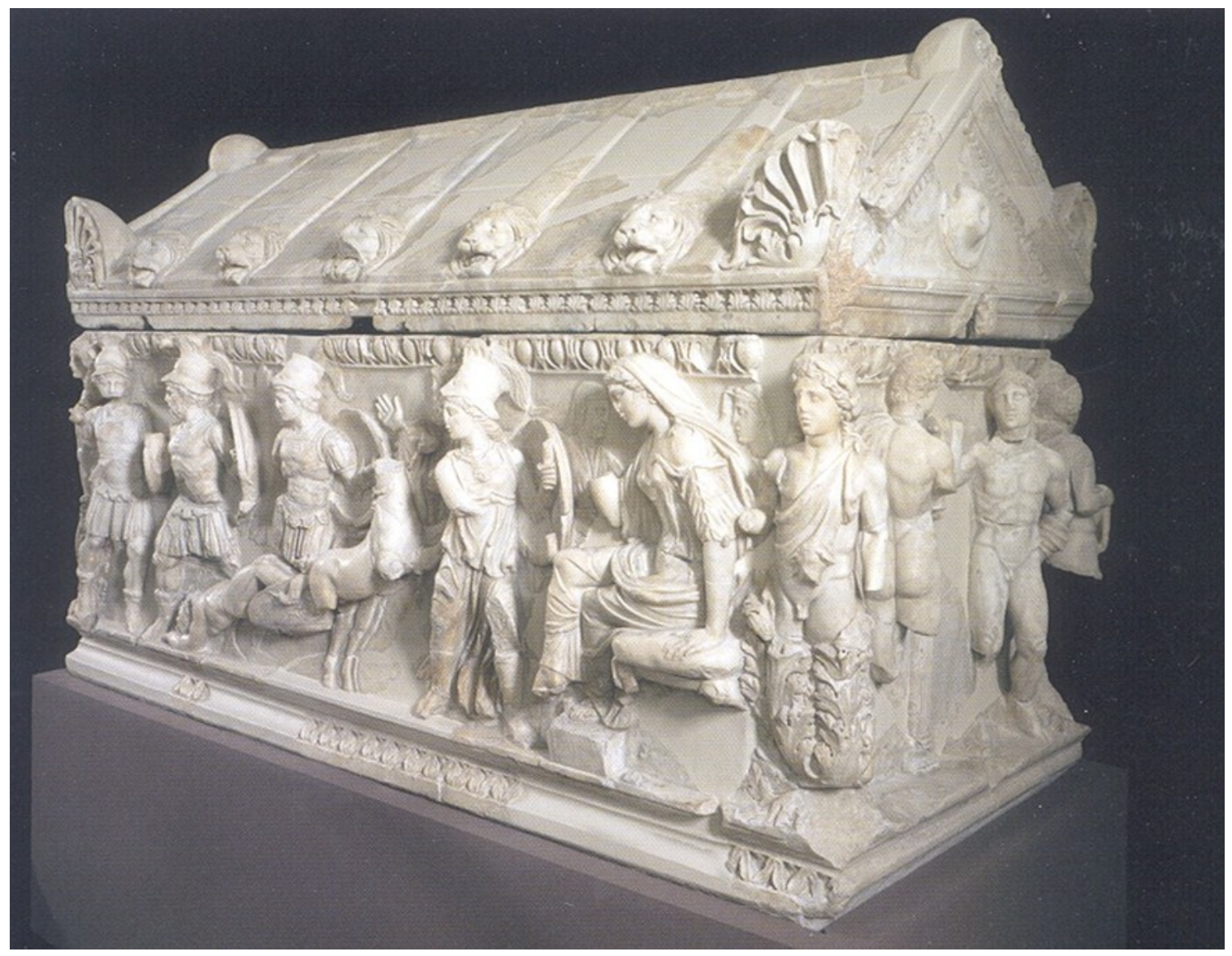

Figure 54

Pamphylian Sarcophagus

RISD 21.074

Roman, Imperial Period, Second half of Second Century C.E. H. of through 85.5 (33 1/4); L. 232.9 (91 3/4); D: $107.7\left(42 \frac{1}{1 / 2}\right) \mathrm{cm}$ H. of Lid 54.9 (21 5/8); L: 224.5 (88 1/4); D: 97.8 (38 1/2) Marble

Museum of Art Rhode Island School of Design, Selected Works (2008) 

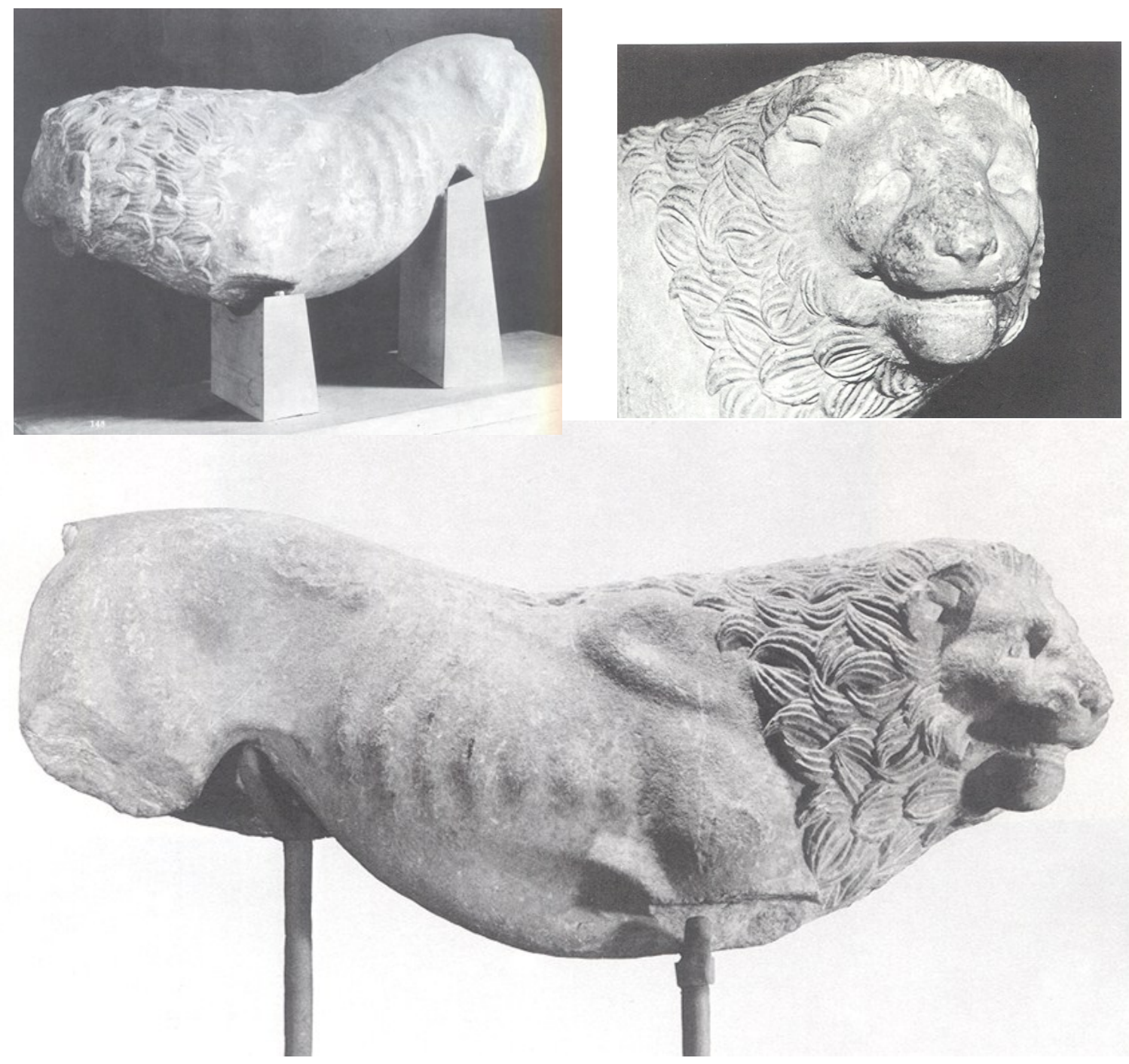

Figure 55

Funerary Lion

RISD 15.003

C. $390-380$ B.C.E.

Pentelic marble

H. 18 3/4; L 38 3/8; D. 10 5/8 (46.7; 97.4; 29.9 cm)

Rhode School of Design Art Museum

Brunilde Sismondo Ridgway

Catalogue of the Classical Collection: Classical Sculpture 


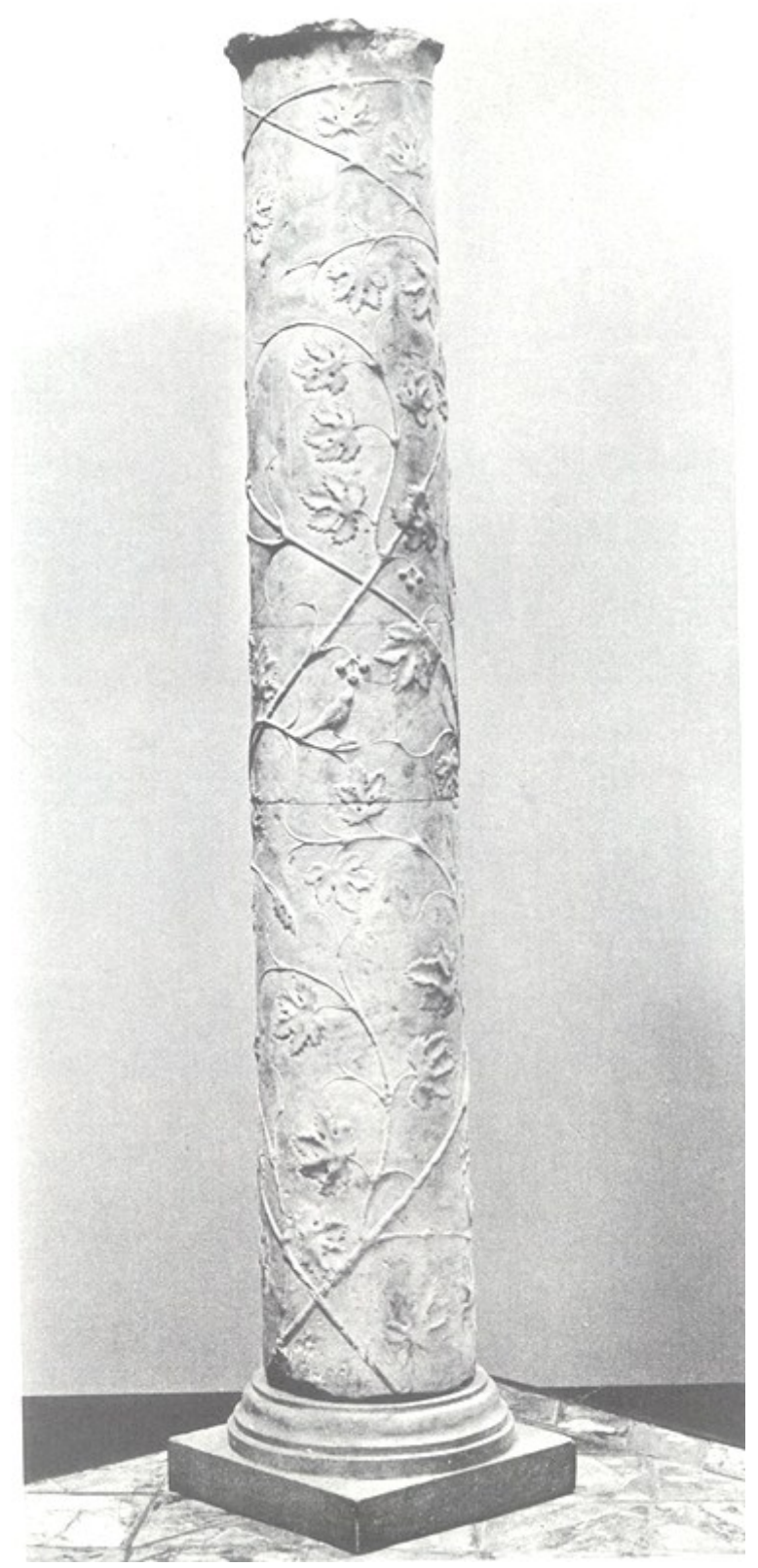

$\underline{\text { Figure } 56}$

\section{Marble Column with Vine Motif}

RISD 26.156

Roman, c. 120 C.E.

Height: $170.1 \mathrm{~cm}$ (66 15/16 in ); Diameter $27.4 \mathrm{~cm}$. (10 1/4 in) Rhode Island School of Design Art Museum

Brunilde Sismondo Ridgway

Catalogue of the Classical Collection: Classical Sculpture

(1972) 

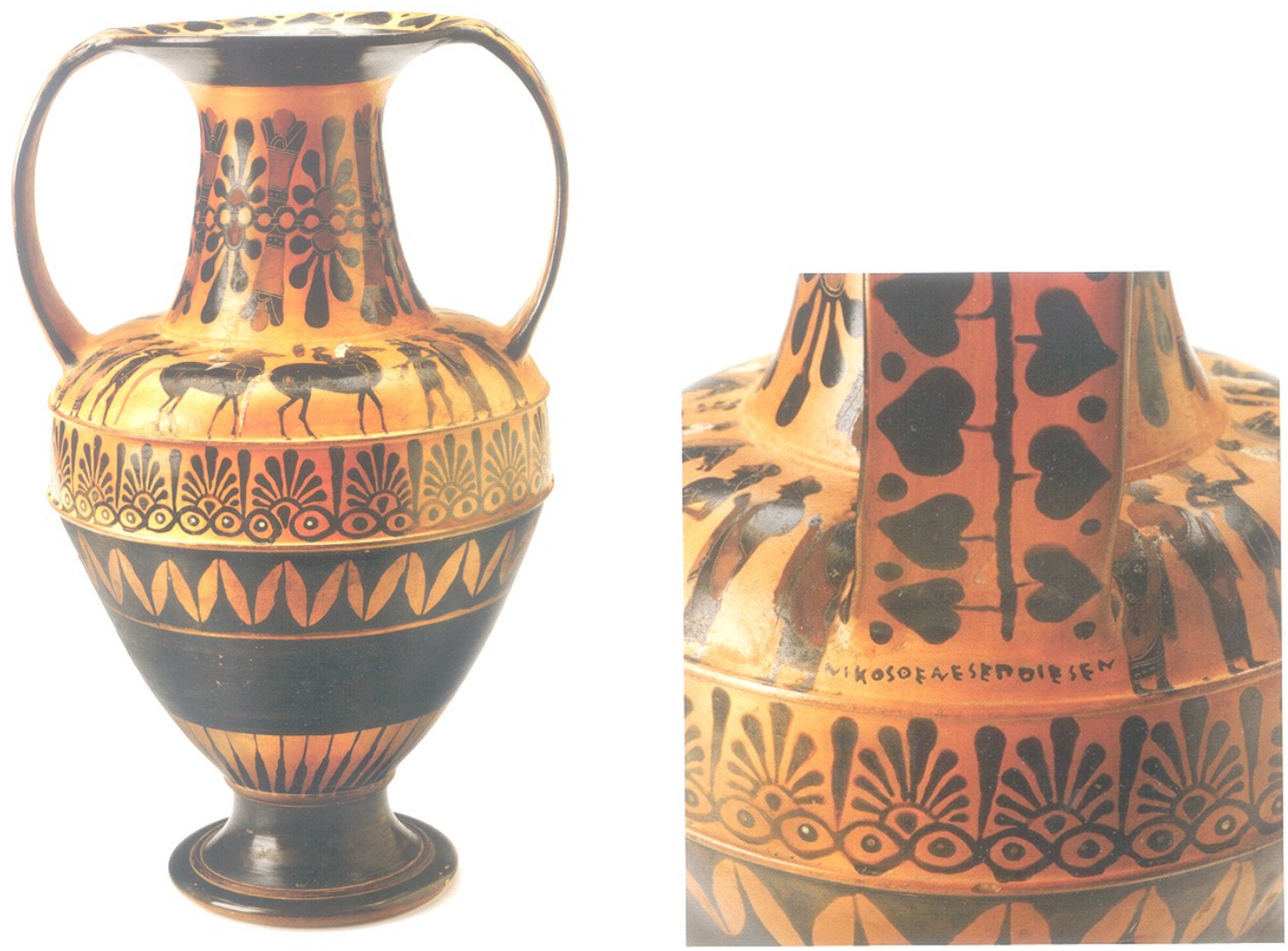

Side A

Detail

\section{Figure 57}

Attic Black-figure Amphora

RISD 23.303

c. $535-525$

Height: 11 13/16 in

Signed by the potter Nikosthenes

Selected Works, Museum of Art, Rhode Island School of Design.

(2008) 


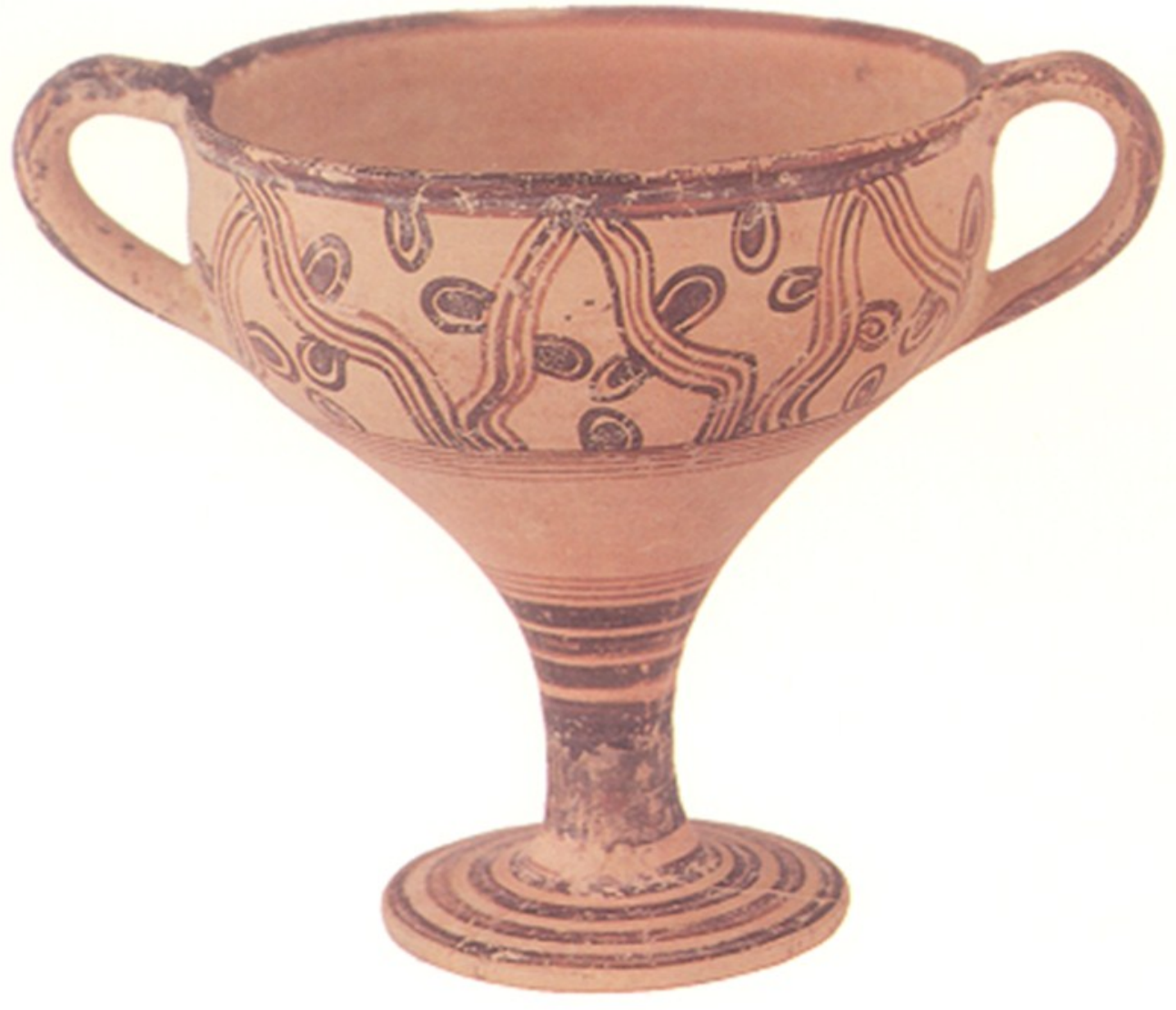

$\underline{\text { Figure } 58}$

\section{Mycenaean Kylix \\ BCMA 1908.4 \\ c. $1350-1300$}

Height: 6 5/8; Diameter 6 1/8 inches

James A. Higginbotham and Katherine M. Westley

Ars Antiqua: Treasures from the Ancient Mediterranean World at Bowdoin College (2005) 


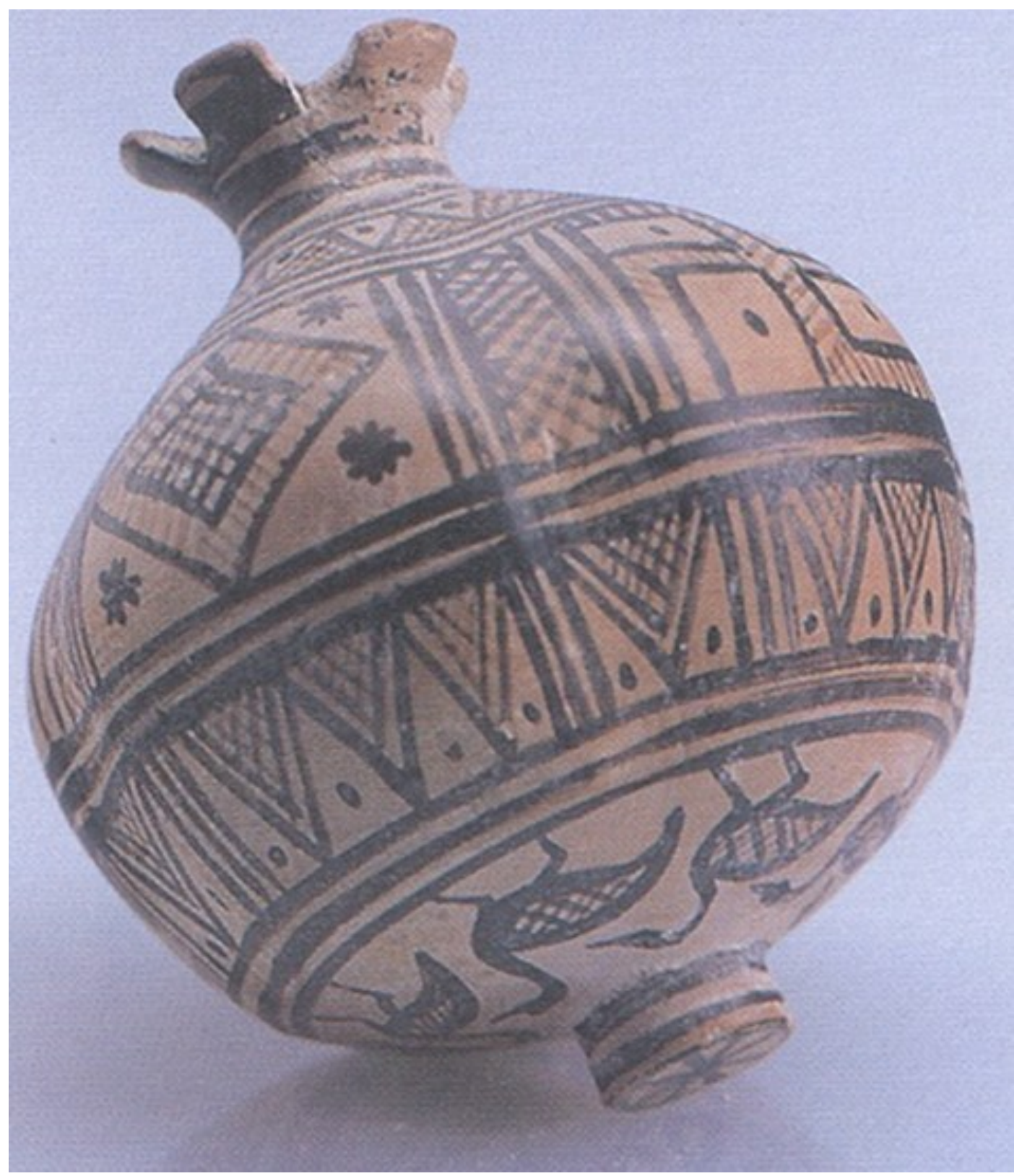

Figure 59

Attic Geometric Vase in the Form of a Pomegranate BCMA 1915.15

c. $750-735$

Height: 4 1/8 inches; Diameter: 3 9/26 inches Bowdoin College Museum of Art

Susan Helen Langdon, From Pasture to Polis: Art in the Age of Homer (1993) 

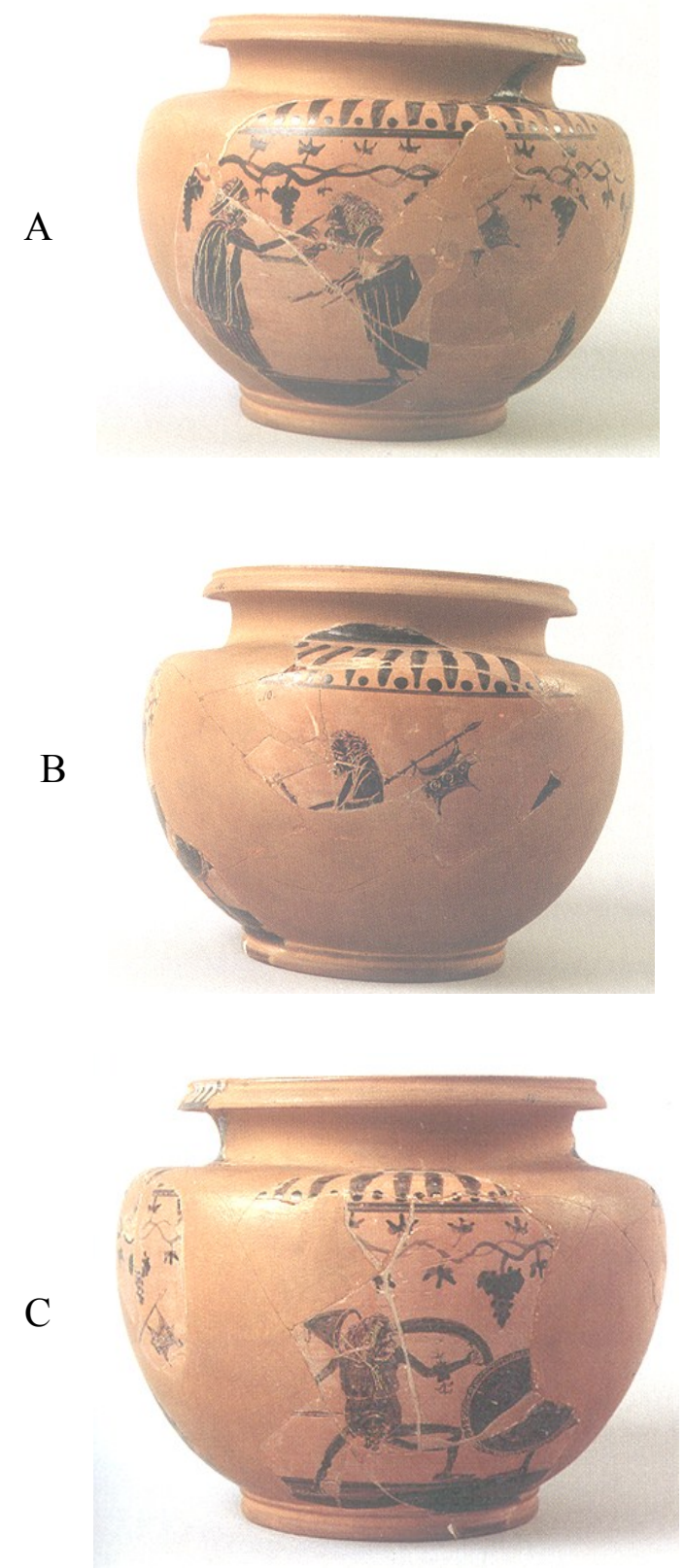

Figure 60

Boeotian Kabiric Black-figure Bowl Three views (35 fragments)

SM 1967.115.276 430-420

As restored: Height: $14.3 \mathrm{~cm}$ (5 5/8 in); Max. Diameter $18.1 \mathrm{~cm}$ (7 1/8 in); Diameter of mouth: $13.6 \mathrm{~cm}$ (5 3/8 in); Diameter of foot: $9.9 \mathrm{~cm}$ (3 7/8 in)

Sue Taylor and Richard A. Born

The David and Alfred Smart Museum of Art: A Guide to the Collection (1990) 


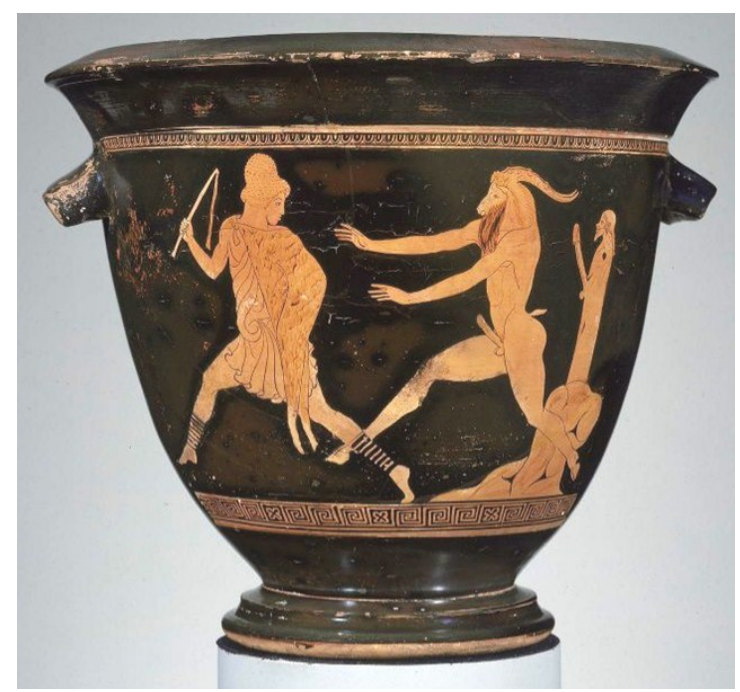

Side A

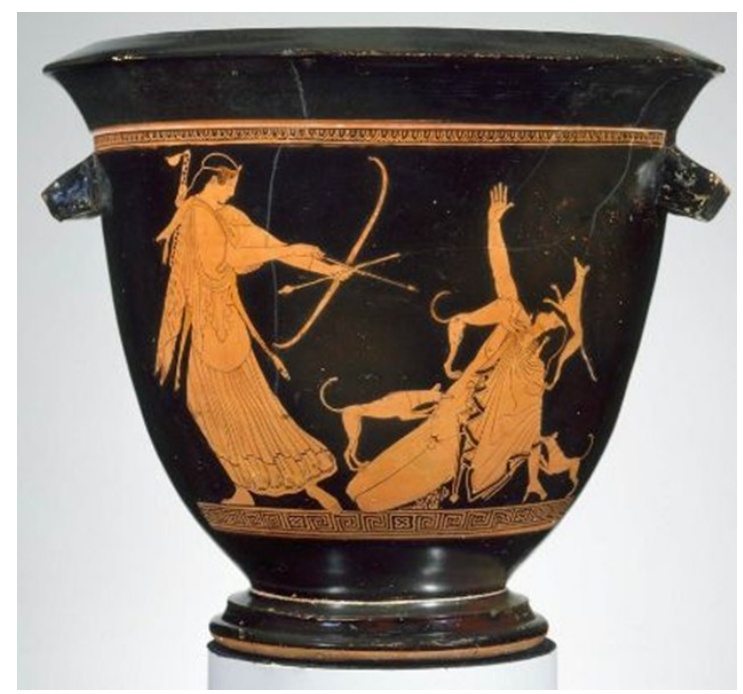

Side B

Figure 61

Attic Red-figure Krater

MFA 10.185

c. 470

Height: $37 \mathrm{~cm}$ (14 9/16 in.); diameter: $42.5 \mathrm{~cm}$ (16 3/4 in.)

Attributed to the Pan Painter

MFA Collections Database

http://www.mfa.org/collections/object/mixing-bowl-bell-krater-153654

(accessed 9/22/12) 


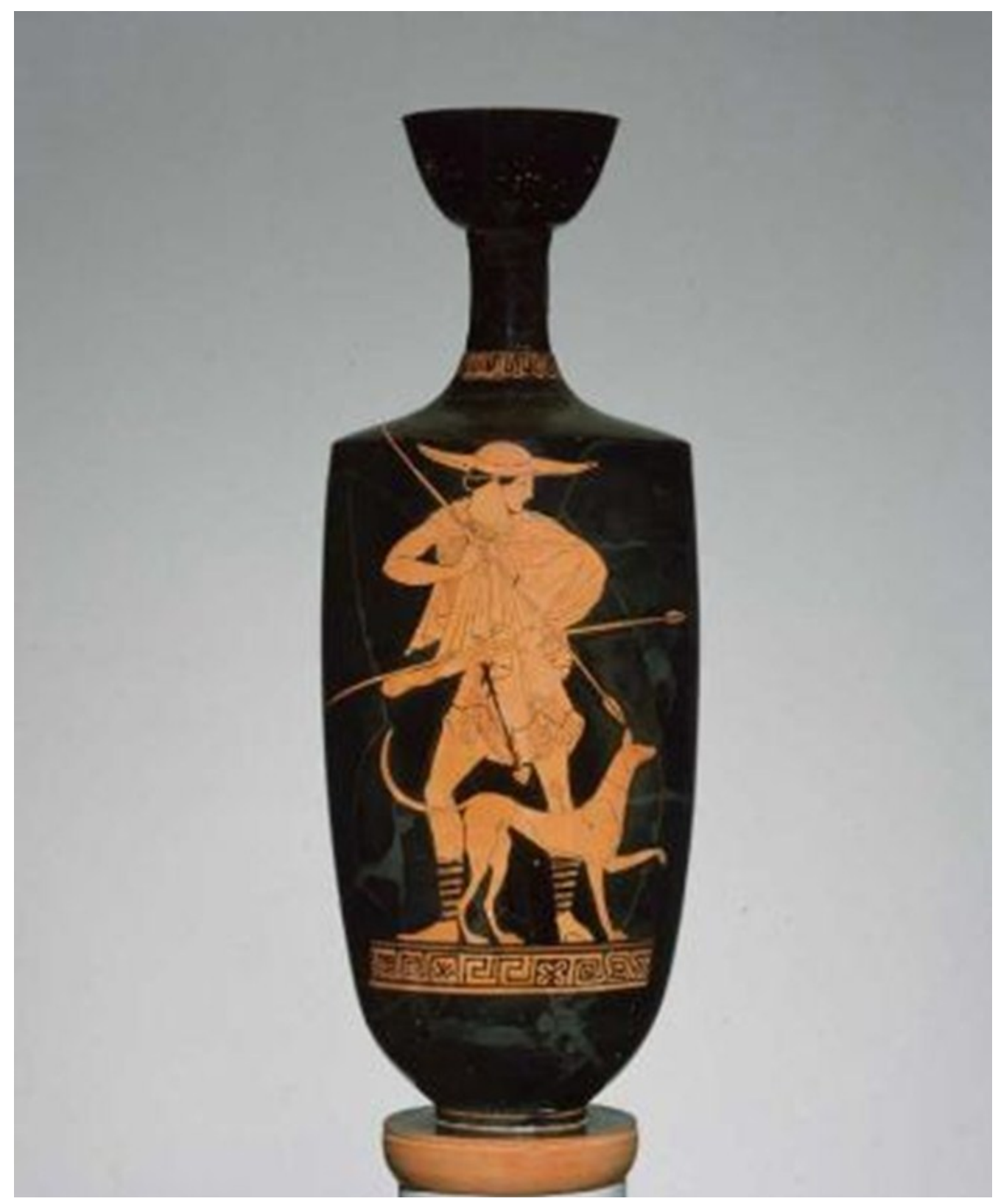

Figure 62

Attic Red-figure Lekythos

Attributed to the Pan Painter

MFA 13.198

$$
\text { c. } 470
$$

Height: $39.2 \mathrm{~cm}$ (15 7/16 in.)

MFA Collections Database

http://www.mfa.org/collections/object/oil-flask-lekythos-with-the-hunter-kephalos-andhis-dog-28 (accessed 7/16/12) 


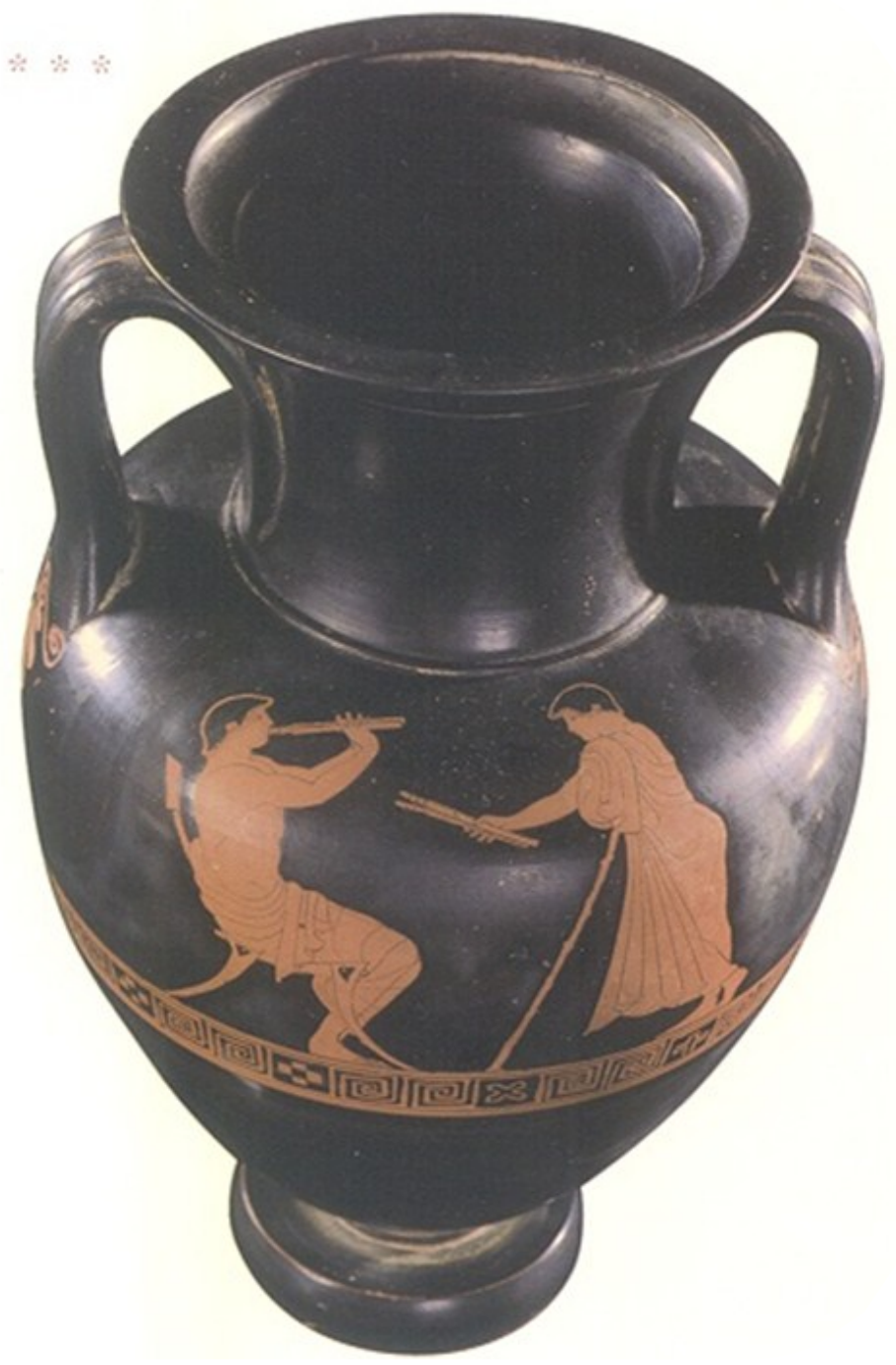

Figure 63

Attic Red-figure Nolan Amphora

BCMA 1913.30

c. 460

Height: 12 3/16; diameter: 7 11/16

Attributed to the Pan Painter

James A. Higginbotham and Katherine M. Westley

Ars Antiqua: Treasures from the Ancient Mediterranean World at Bowdoin College

(2005) 


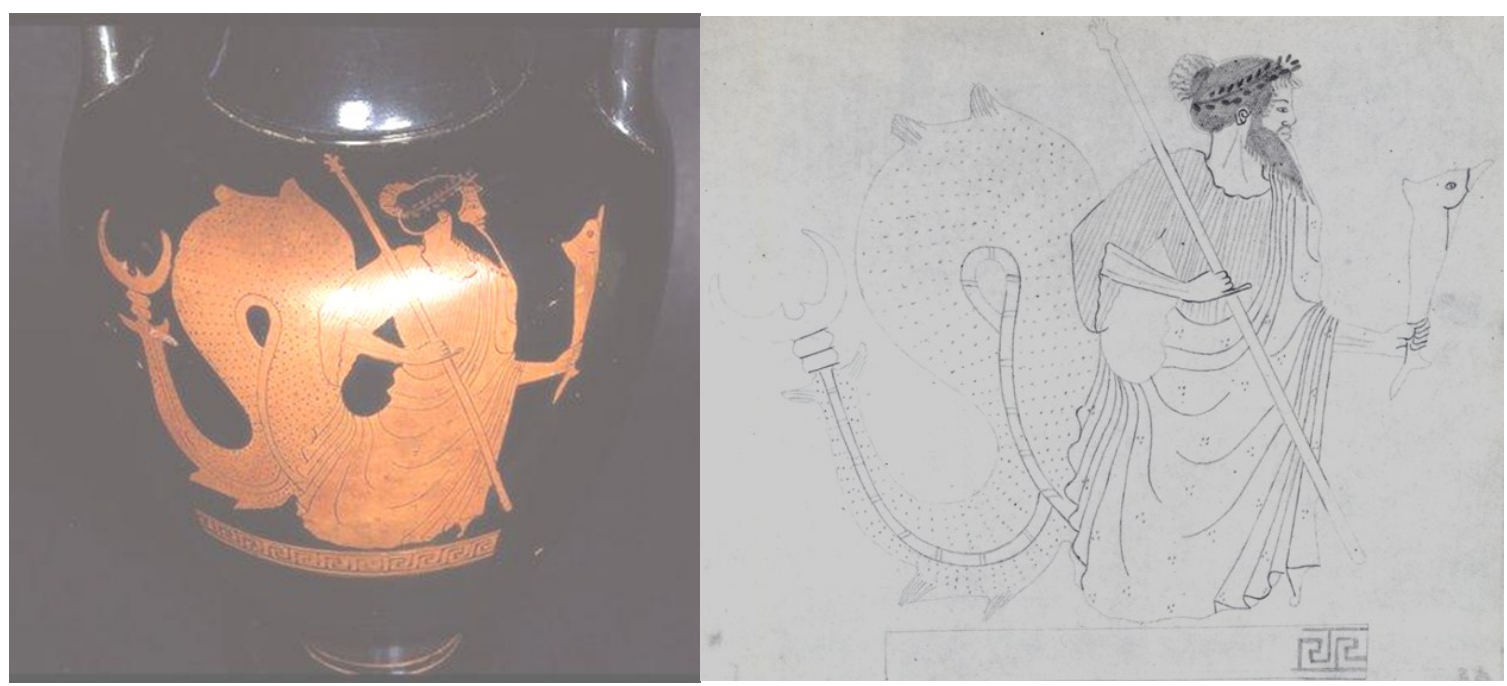

Figure 64

Side A: Attic Red-figure

Neck Amphora

HM 1927.150

Attributed to the Pan Painter

Harvard Museums

Curatorial Office
Beazley's drawing: Side A: Harvard 1927.150

Donna C. Kurtz \& J. D. Beazley

The Berlin Painter (1983)

Plate X 


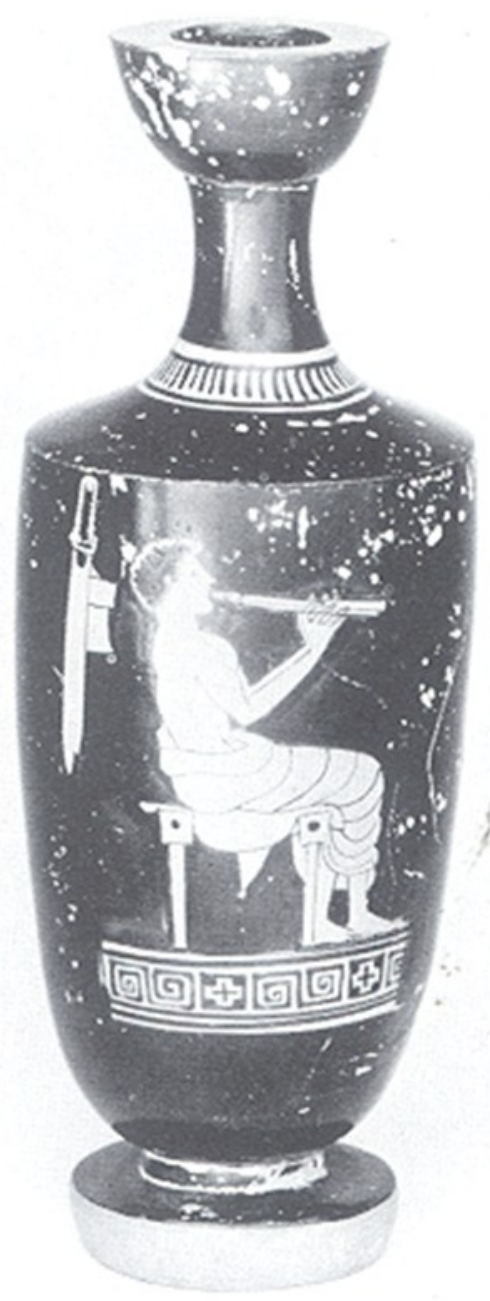

Figure 65

Attic Red-figure Lekythos

BCMA 1920.1

Greek, Early Classical Period, c. 490-80

Height: $0.200 \mathrm{~m}$; diameter at lip: $0.43 \mathrm{~m}$; diameter at base $0.048 \mathrm{~m}$

Attributed to the Bowdoin Painter

Bowdoin College Art Museum

Kevin Herbert

Ancient Art in Bowdoin College: A Descriptive Catalogue of the Warren and Other

Collections (1964) 

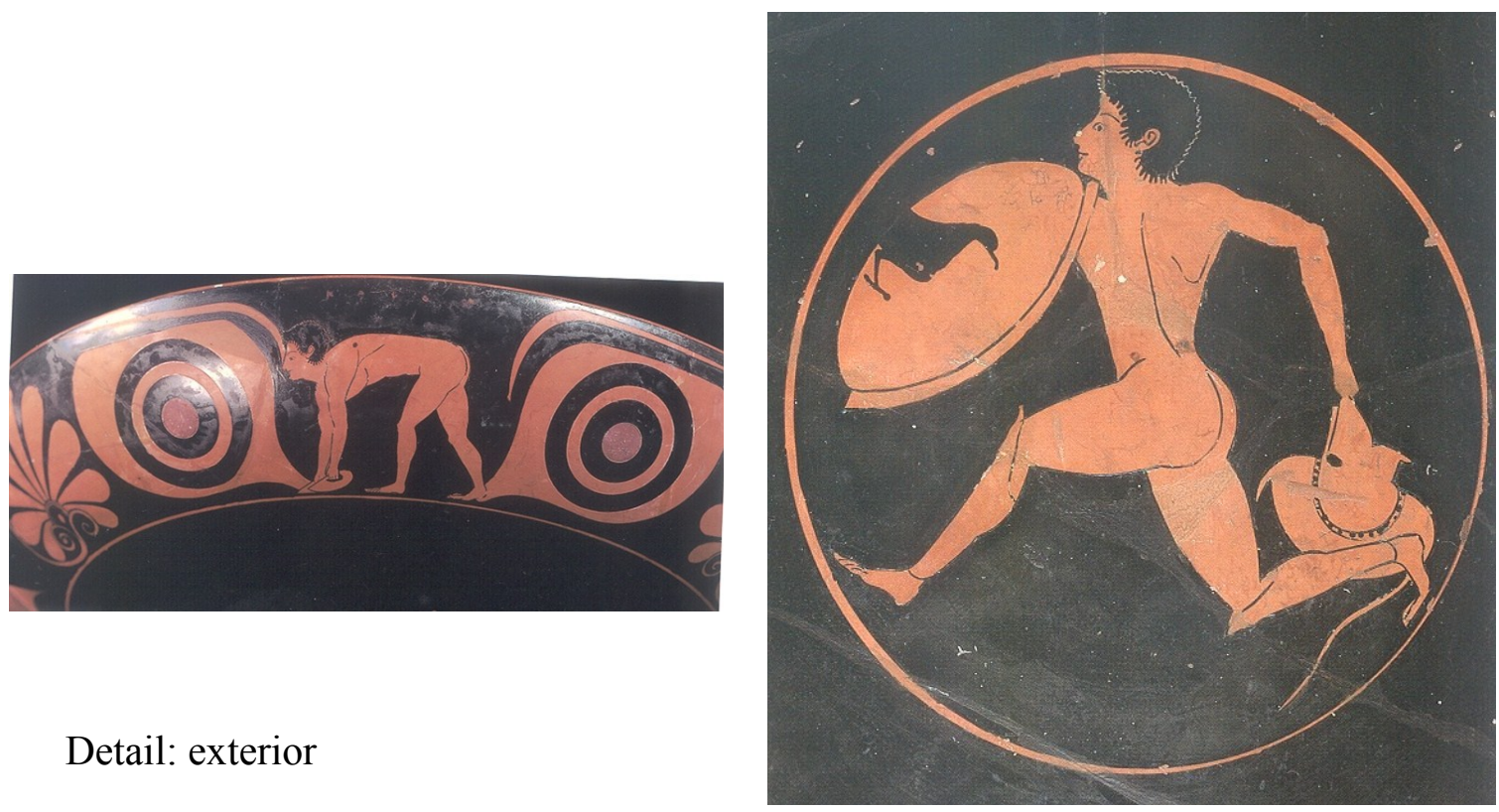

Detail: exterior

Detail: tondo

Figure 66

Attic Red-figure Kylix

BCMA 1913.2

Greek, Classical Period, c. 525

Height: 0.0.135 m.; diameter of lip: $0.328 \mathrm{~m}$.; diameter of base $0.0125 \mathrm{~m}$

Attributed to the Bowdoin Eye Painter

Bowdoin College Art Museum

James A. Higginbotham and Katherine M. Westley

Ars Antiqua: Treasures from the Ancient Mediterranean World at Bowdoin College

(2005) 


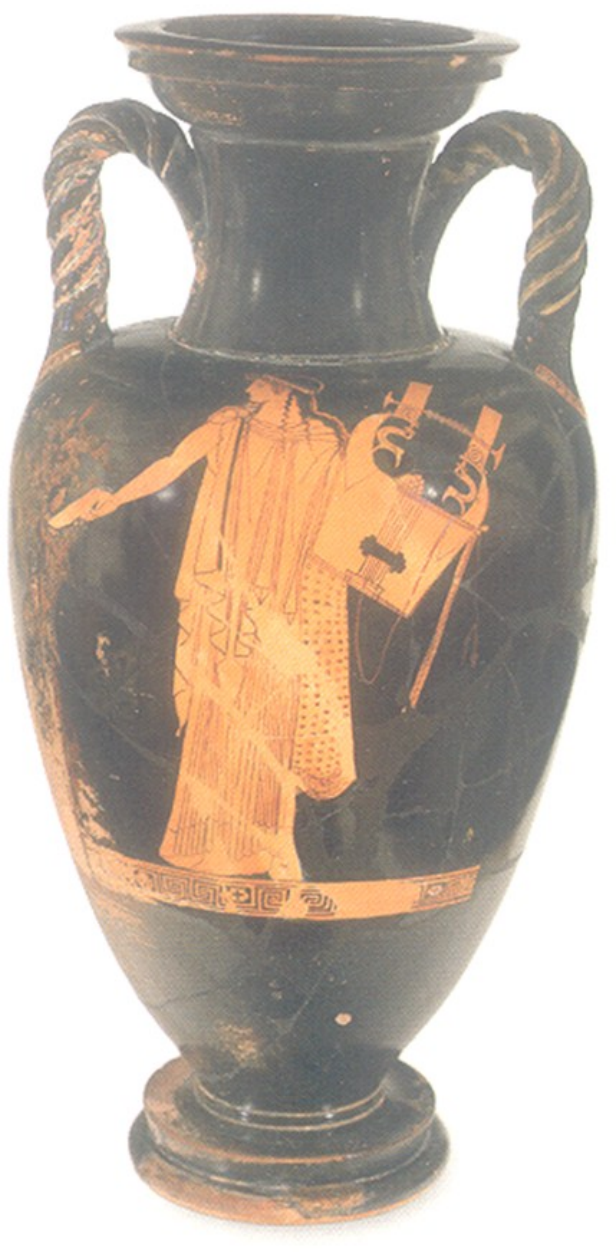

Side A

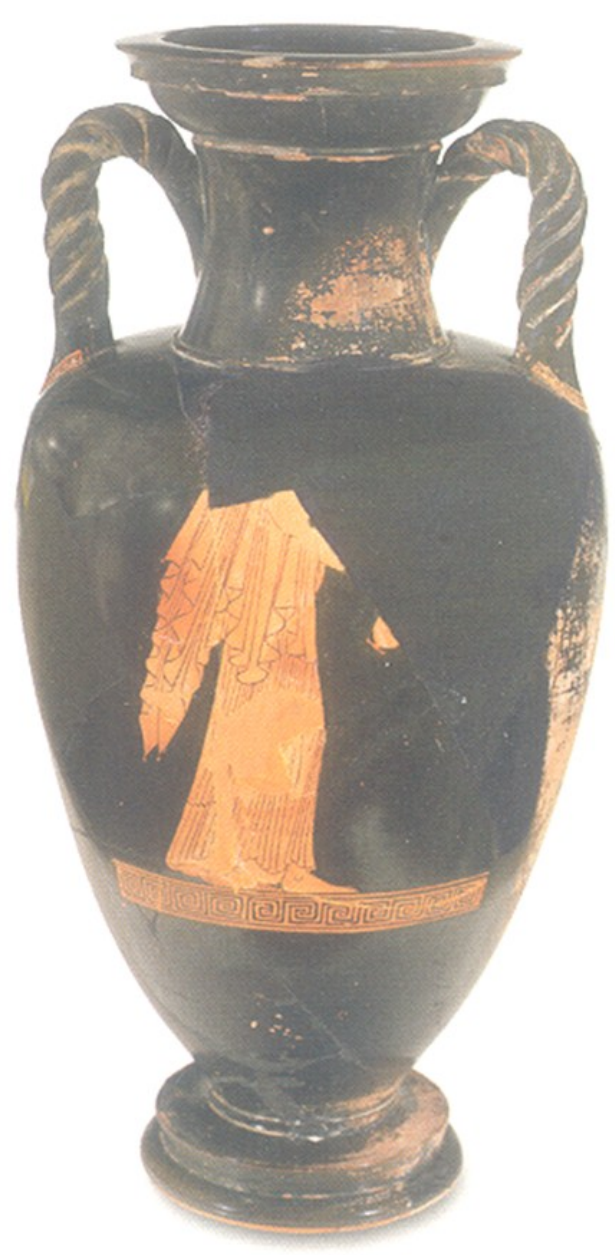

Side B

\section{Figure 67}

Attic Red-figure Amphora

RISD 15.03

Greek, c. 500-475

Height: 20 inches

Attributed to the Providence Painter

Rhode Island School of Design Art Museum

Selected Works, Museum of Art, Rhode Island School of Design.

(2008) 


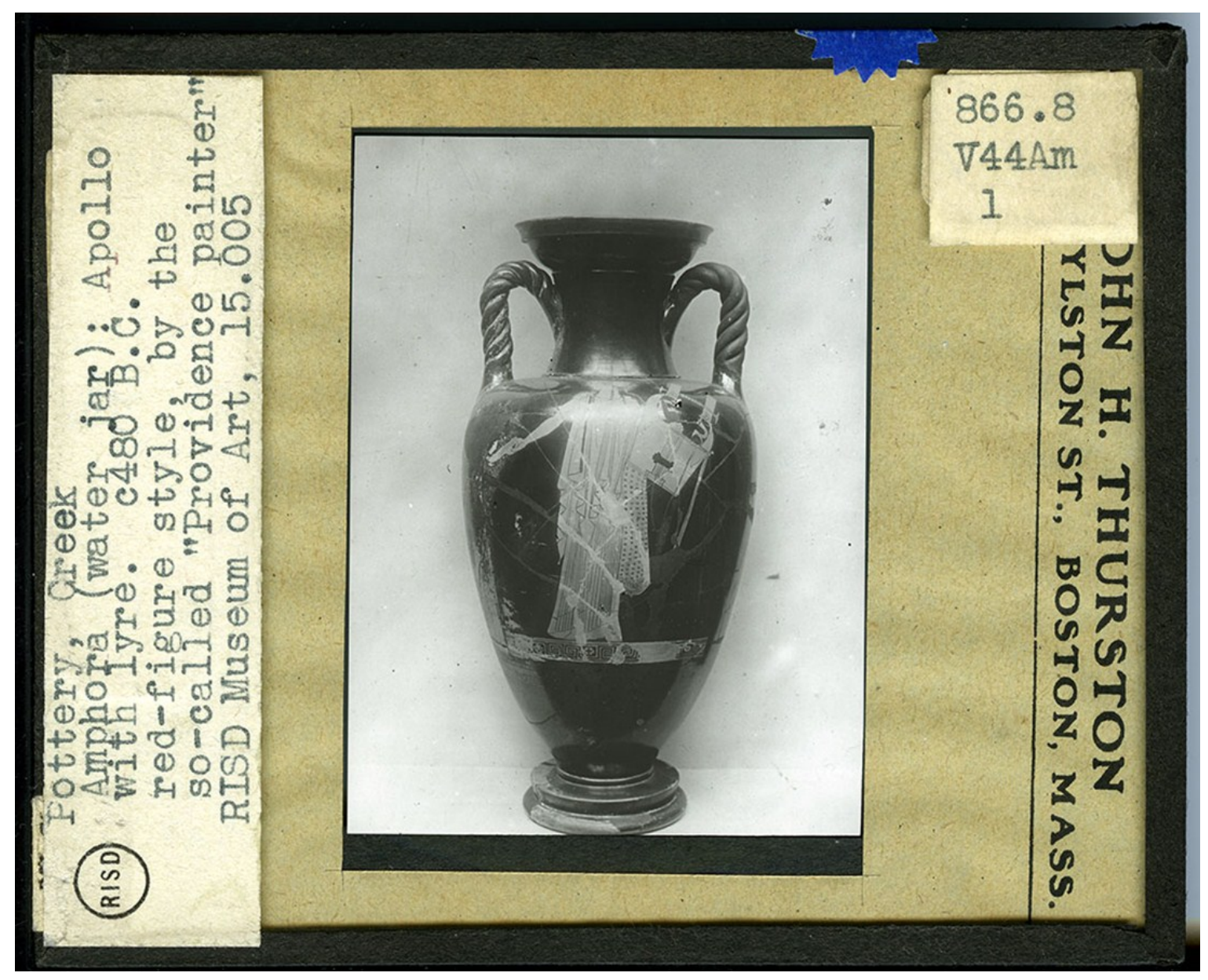

Figure 68

Lantern Slide

Attic Red-figure Amphora

RISD 15.003

RISD Visual Resources 


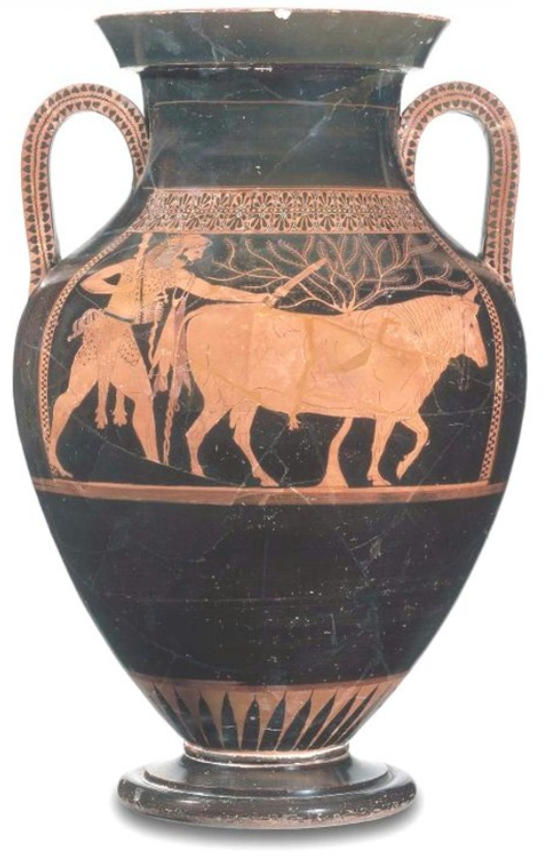

Side A

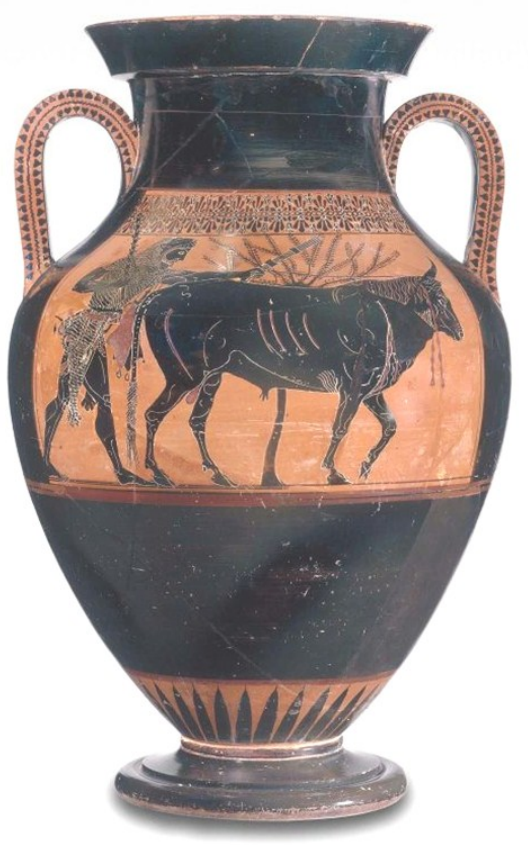

Side A

\section{Figure 69}

Attic Bilingual Amphora

MFA 99.538

Greek, Archaic Period, c. 525-520

Height: $53.2 \mathrm{~cm}(20$ 15/16 in.)

Side A: Attributed to the Andokides Painter

Side B: Attributed to the Lysippides Painter

Museum of Fine Arts, Boston Database

http://www.mfa.org/collections/object/two-handled-jar-amphora-with-herakles-drivinga-bull-to-sacrifice-153401

(accessed 7/20/12) 


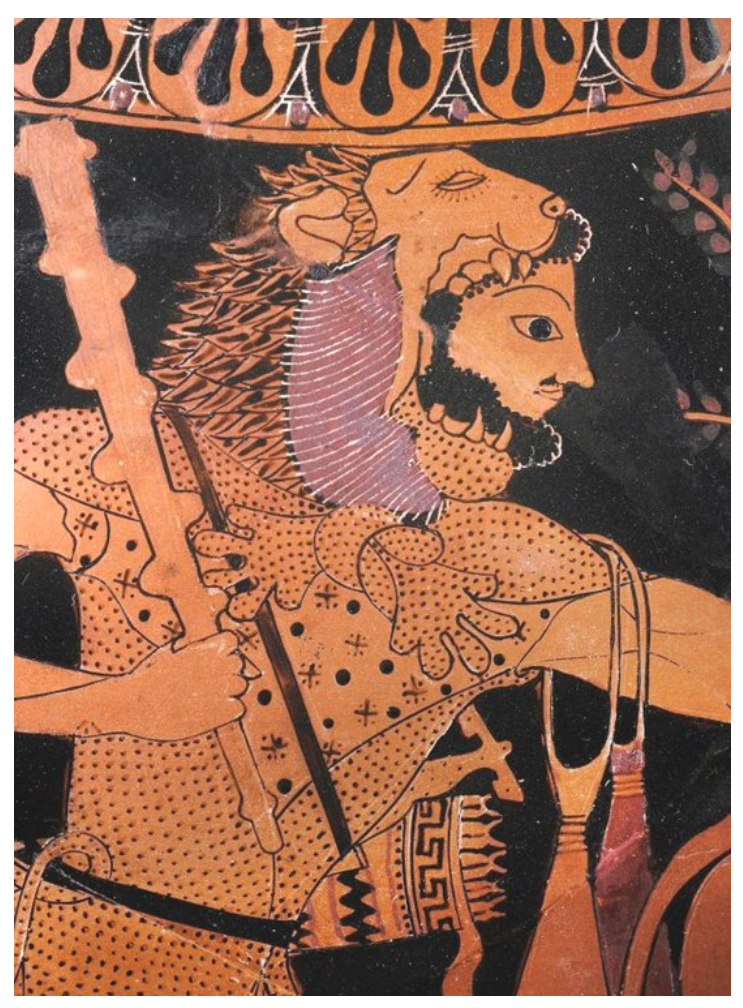

Side A:detail

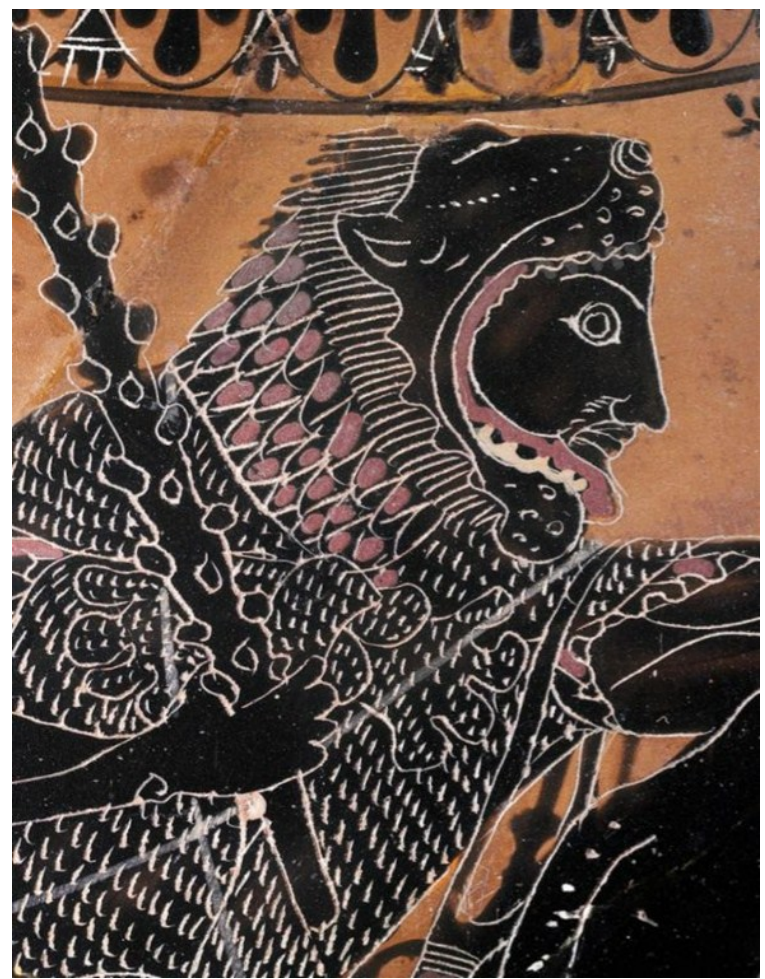

Side B: detail

$\underline{\text { Figure } 70}$

Attic Bilingual Amphora

MFA 99.538

Greek, Archaic Period, c. 525-520

Height: $53.2 \mathrm{~cm}$ (20 15/16 in.)

Side A: Attributed to the Andokides Painter

Side B: Attributed to the Lysippides Painter

Museum of Fine Arts, Boston Database

http://www.mfa.org/collections/object/two-handled-jar-amphora-with-herakles-driving -a-bull-to-sacrifice-153401

(accessed 7/20/12) 


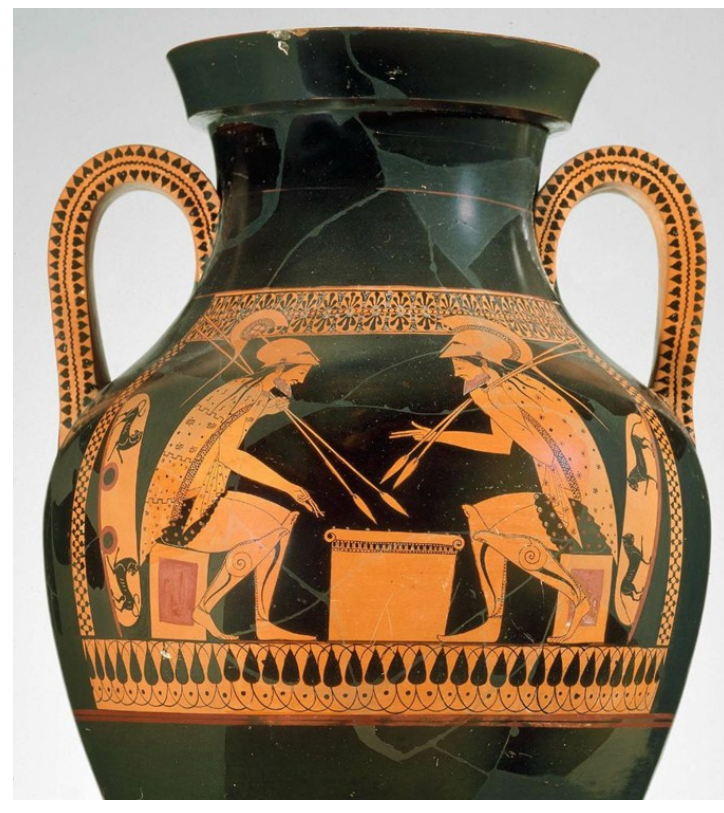

Side A

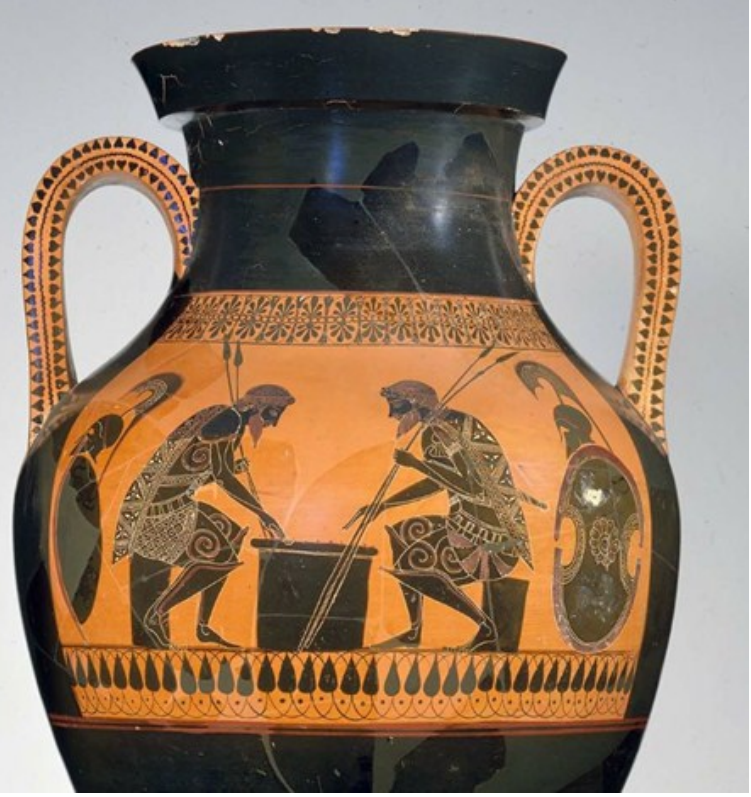

Side B

\section{Figure 71}

Attic Bilingual Amphora MFA 01.8037

Greek, Archaic Period, c. 525-520

Height: $55.5 \mathrm{~cm}$ (21 7/8 in.); diameter: $34 \mathrm{~cm}$ (13 3/8 in.)

Side A: Attributed to the Andokides Painter

Side B: Attributed to the Lysippides Painter

Museum of Fine Arts, Boston Database

http://www.mfa.org/collections/object/two-handled-jar-amphora-with-heraklesdriving-a-bull-to-sacrifice-153401

(accessed 7/20/12) 


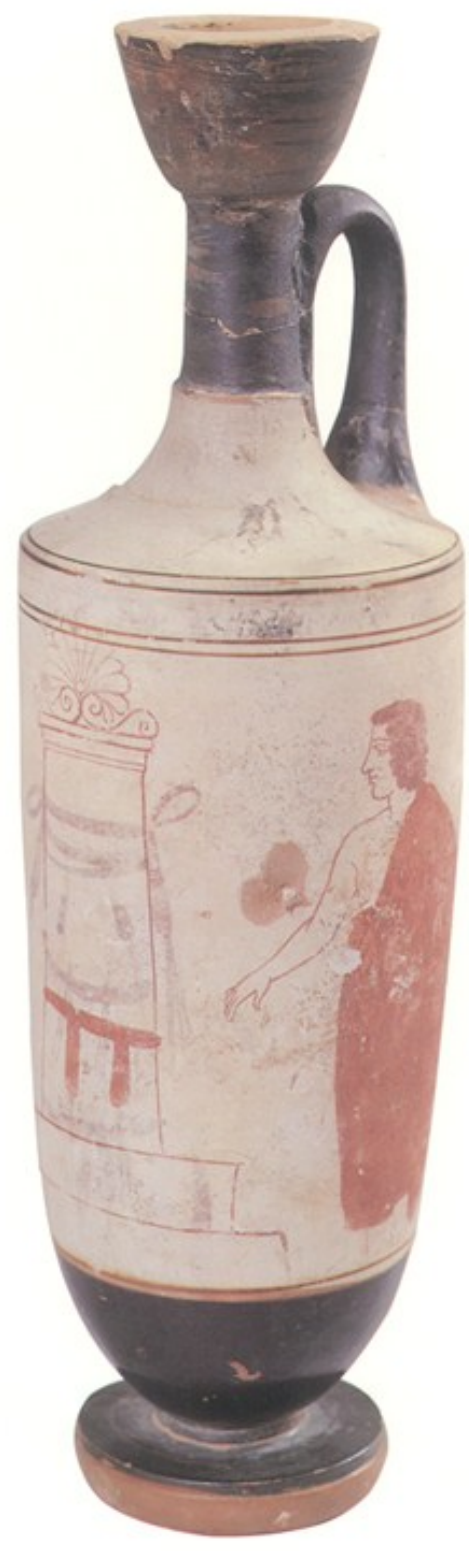

$\underline{\text { Figure } 72}$

Attic White-ground Lekythos

BCMA 1913.31

Greek, c. 425-400

Height: 0.280 m (10 15/16 in.); Diameter: 0.049 m. (3 1/4 in); Base 0.074)

Attributed to Near the Painter of Munich 2335

Bowdoin College Art Museum

James A. Higginbotham and Katherine M. Westley

Ars Antiqua: Treasures from the Ancient Mediterranean World at Bowdoin College (2005) 

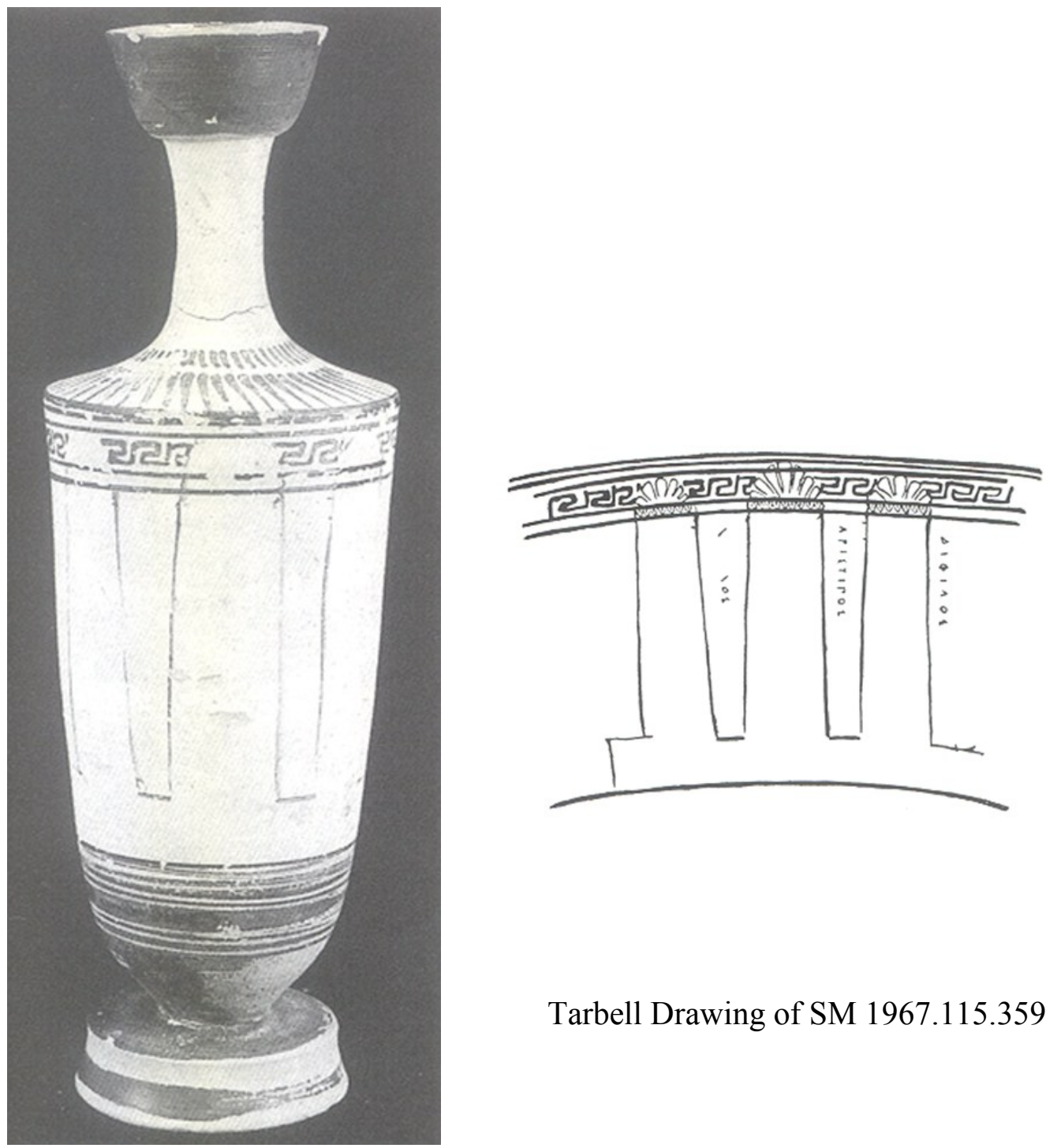

Tarbell Drawing of SM 1967.115.359

\section{Figure 73}

Attic White-ground Lekythos

SM 1967.115.359

Greek, c. 470-430

Height: $24 \mathrm{~cm}\left(9 \frac{1}{2}\right)$; Maximum Diameter: $8 \mathrm{~cm}\left(3 \frac{1}{4}\right)$; Diameter of mouth: $5 \mathrm{~cm}(2)$;

Diameter of foot: $6.1 \mathrm{~cm}(23 / 8)$

Attributed to the Beldam Workshop

The David and Alfred Smart Museum of Art, University of Chicago

Gloria Ferrari, Christina M. Nelson, et al. The Classical Collection (1998) 


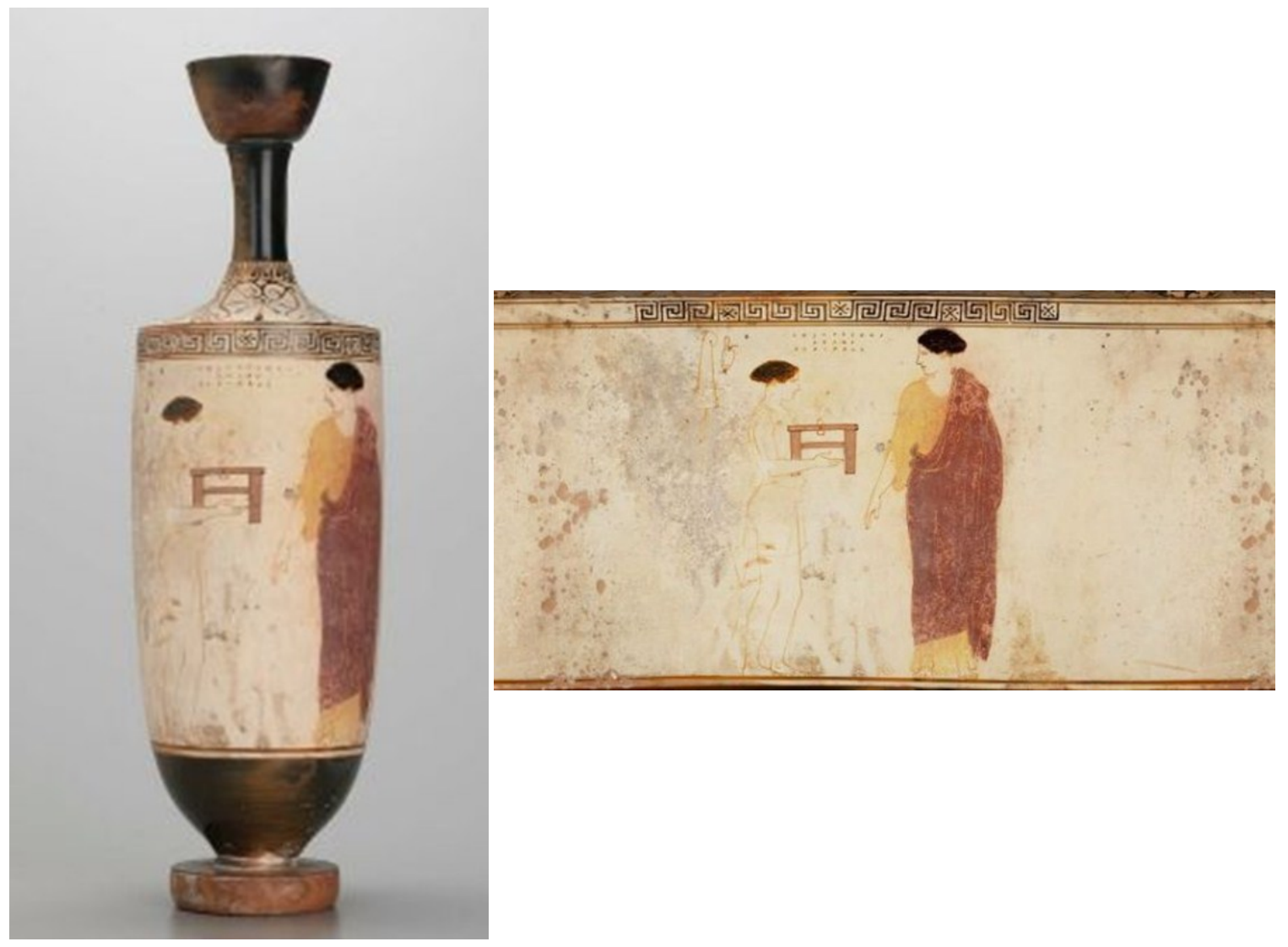

Figure 74

Attic White-ground Lekythos

MFA 13.201

Greek, Classical Period, c. 440

Height: $38.4 \mathrm{~cm}$ (15 1/8 in.)

Attributed to the Achilles Painter

Museum of Fine Arts, Boston Database

http://www.mfa.org/collections/object/oil-flask-lekythos-with-woman-and-servant-girl153996

(accessed 7/20/12) 


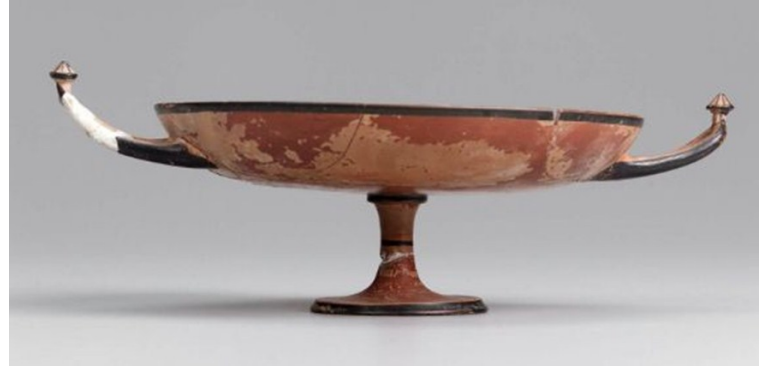

Exterior

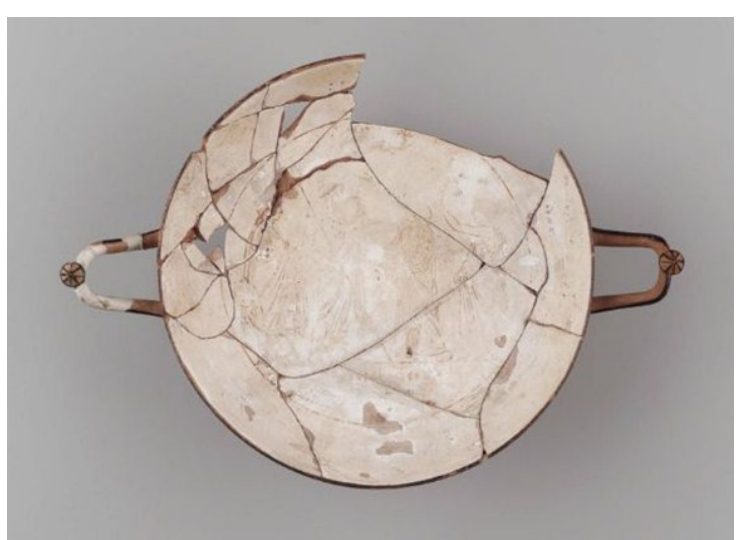

Interior

\section{Figure 75}

Attic White-ground and Coral-red Kylix with Wish-bone Handles

MFA 13.4503

Greek, Classical Period, c. $460-450$

Height: $6.1 \mathrm{~cm}$ (2 3/8 in.); diameter $14.5 \mathrm{~cm}$ (5 11/16 in.)

Attributed to Sotades as potter

Museum of Fine Arts, Boston Database

http://www.mfa.org/collections/object/drinking-cup-kylix-153941

(accessed 7/20/12) 


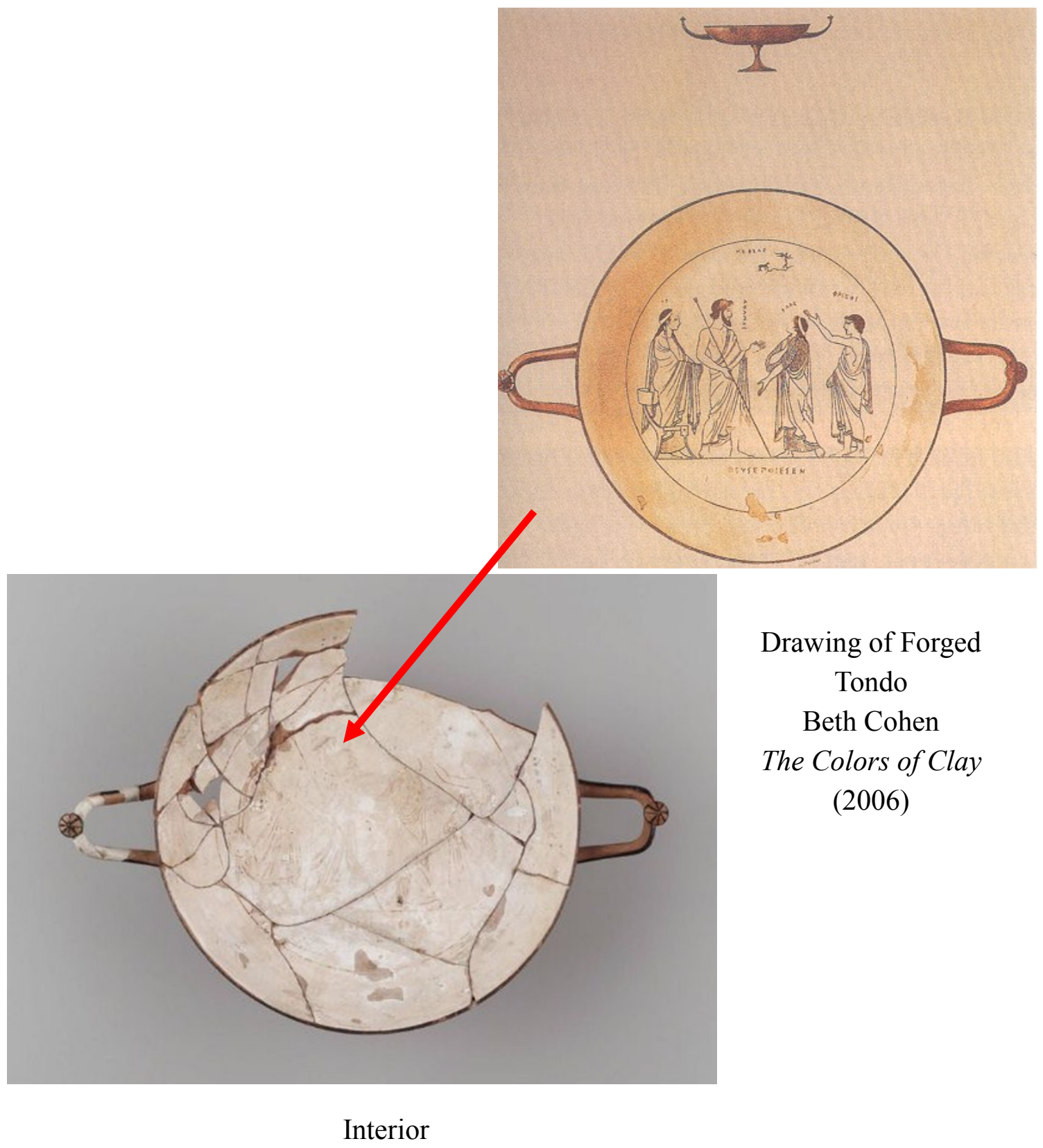

Figure 76

Attic White-ground and Coral-red Kylix with wish-bone handles MFA 13.4503

Greek, Classical Period, c. 460-450

Height: $6.1 \mathrm{~cm}$ (2 3/8 in.); diameter $14.5 \mathrm{~cm}$ (5 11/16 in.)

Attributed to Sotades as potter

Museum of Fine Arts, Boston Database

http://www.mfa.org/collections/object/drinking-cup-kylix-153941

(accessed 7/20/12) 

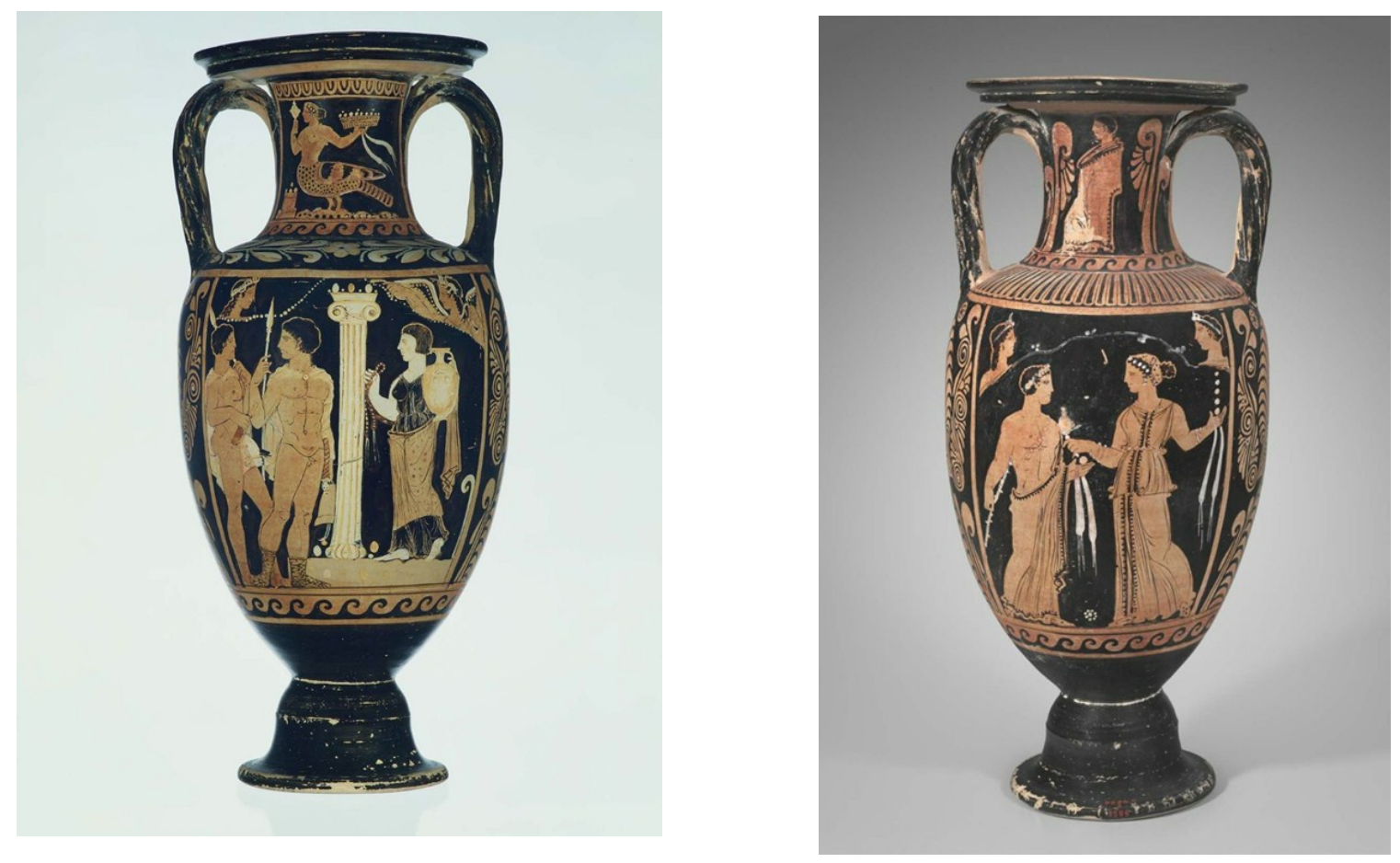

Side A

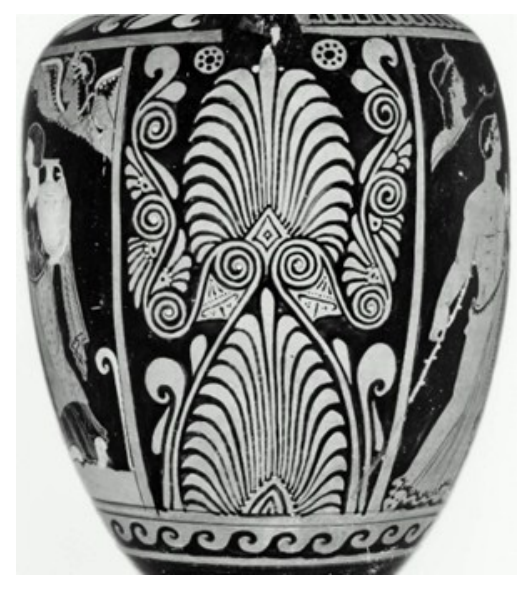

Side B

Side

\section{Figure 77}

\section{Paestan Red-figure Amphora} MFA 99.540

Greek, South Italian, Late Classical to Early Hellenistic Period, c. 335-320

$$
1.3 \mathrm{~cm}(203 / 16 \text { in.) }
$$

Attributed to the Boston Orestes Painter

Museum of Fine Arts, Boston Database

http://www.mfa.org/collections/object/neck-amphora-with-twisted-handles-154193

(accessed 7/20/12) 


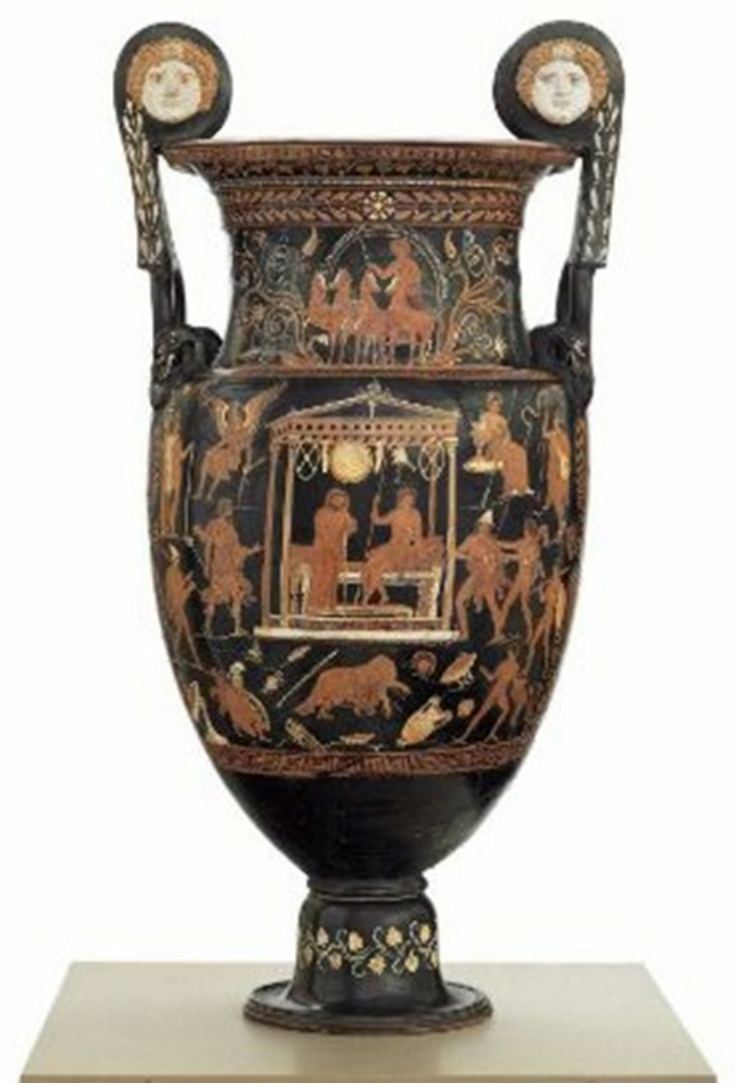

Side A

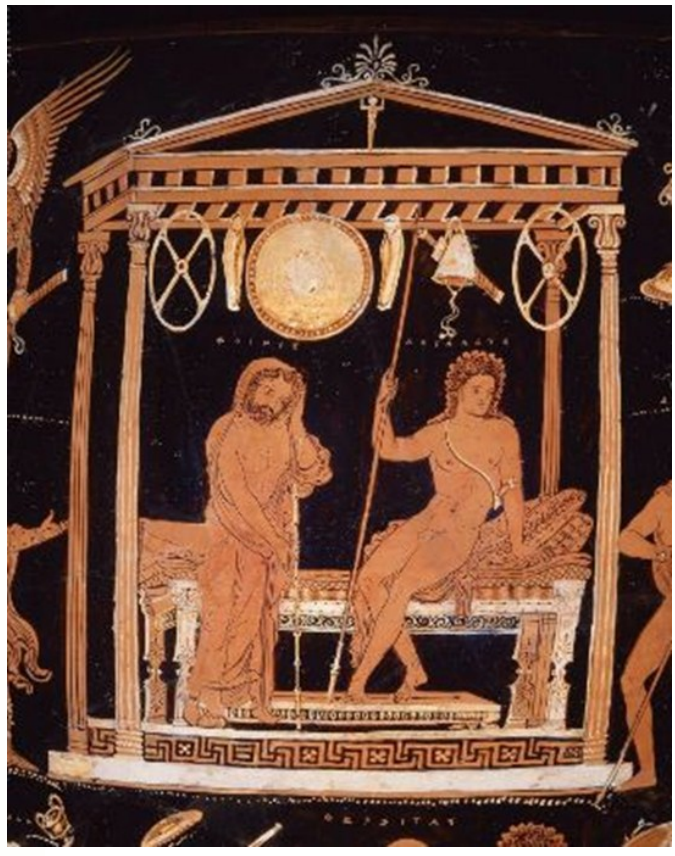

Side A detail

Figure 78

Apulian Red-figure Volute Krater MFA 03.804

Greek, South Italian, Late Classical Period, c. 340

Height: $124.6 \mathrm{~cm}$ (49 1/16 in.); diameter: $56 \mathrm{~cm}$ (22 1/16 in.)

Attributed to the Varrese Painter

Museum of Fine Arts, Boston Database

http://www.mfa.org/collections/object/mixing-bowl-volute-krater-154078

(accessed 7/20/12) 


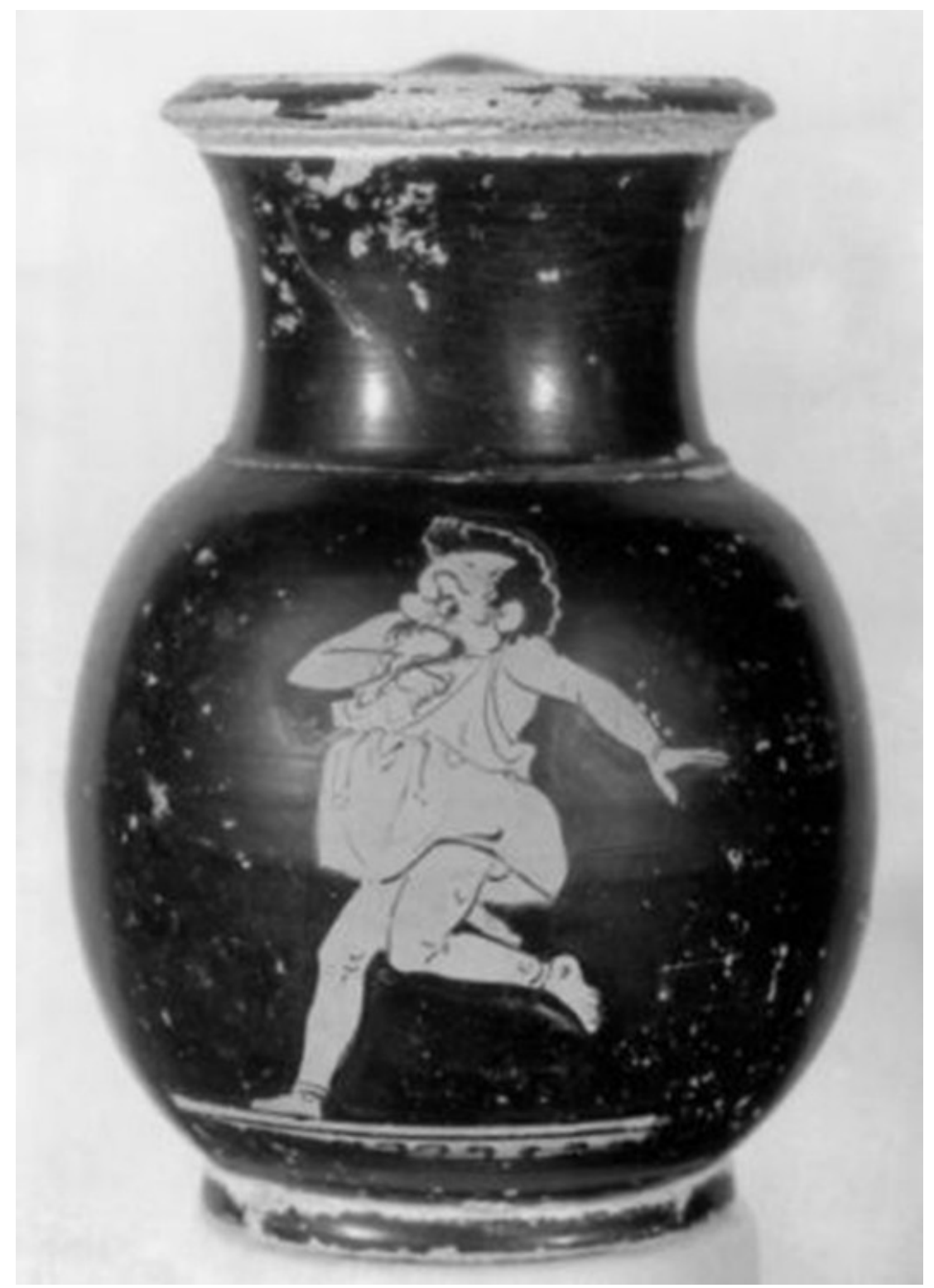

Figure 79

Apulian Red-figure Oenochoe

MFA 13.93

Greek, South Italian, Classical Period, c. $360-350$

Height: $18 \mathrm{~cm}$ (7 1/16 in.)

Museum of Fine Arts, Boston Database

http://www.mfa.org/collections/object/pitcher-oinochoe-154086

(accessed 7/20/12) 


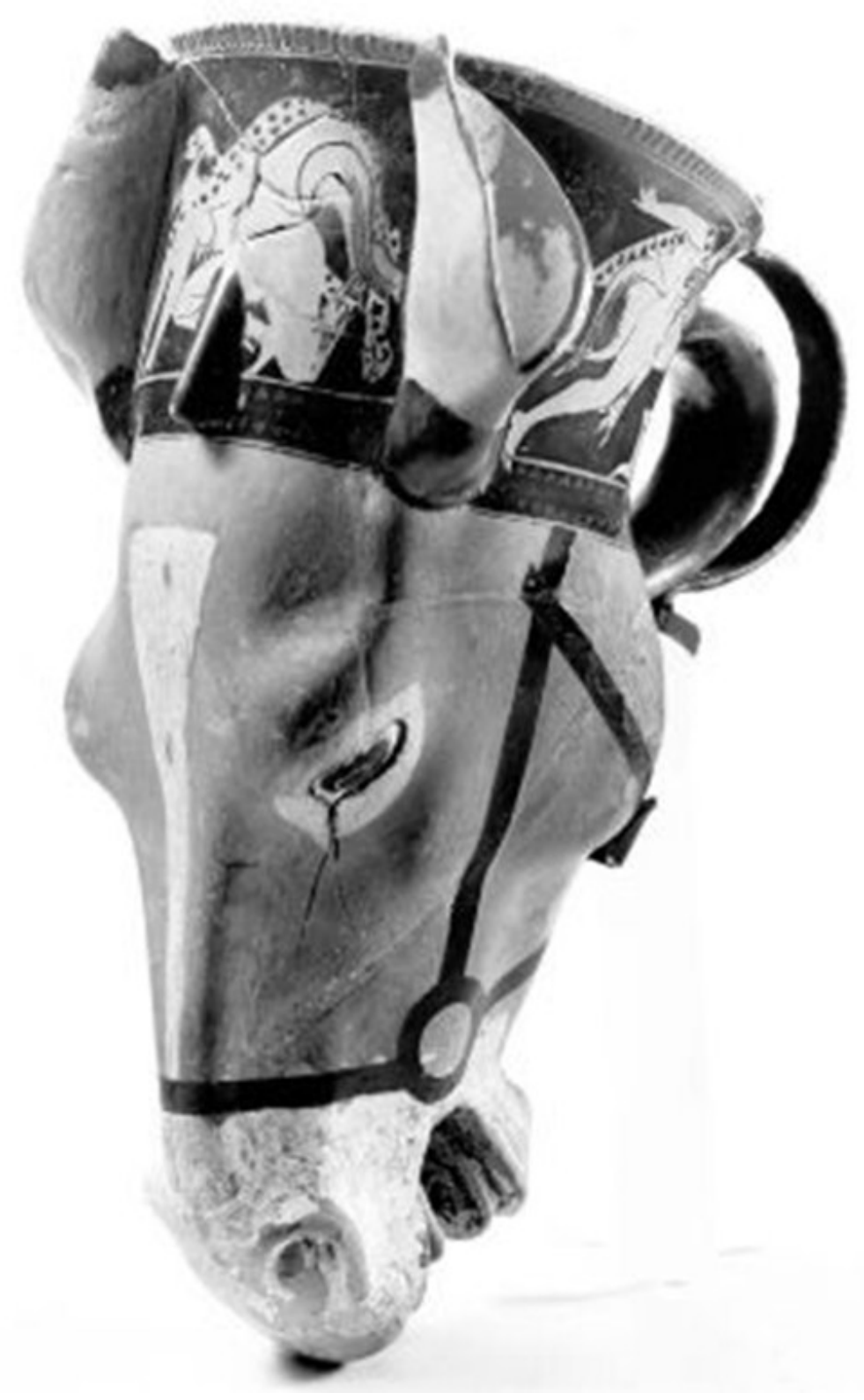

Figure 80

Attic Red-figure Cup in the Shape of a Donkey's Head MFA 03.787

Greek, Late Archaic Period, c. 480

Length: $25.4 \mathrm{~cm}$ (10 in.) Diameter: $12 \mathrm{~cm}$. (4 3/4 in)

Attributed to the Brygos Painter

Museum of Fine Arts, Boston Database

http://www.mfa.org/collections/object/cup-in-the-shape-of-a-donkey-s-head-153866 (accessed 7/20/12) 


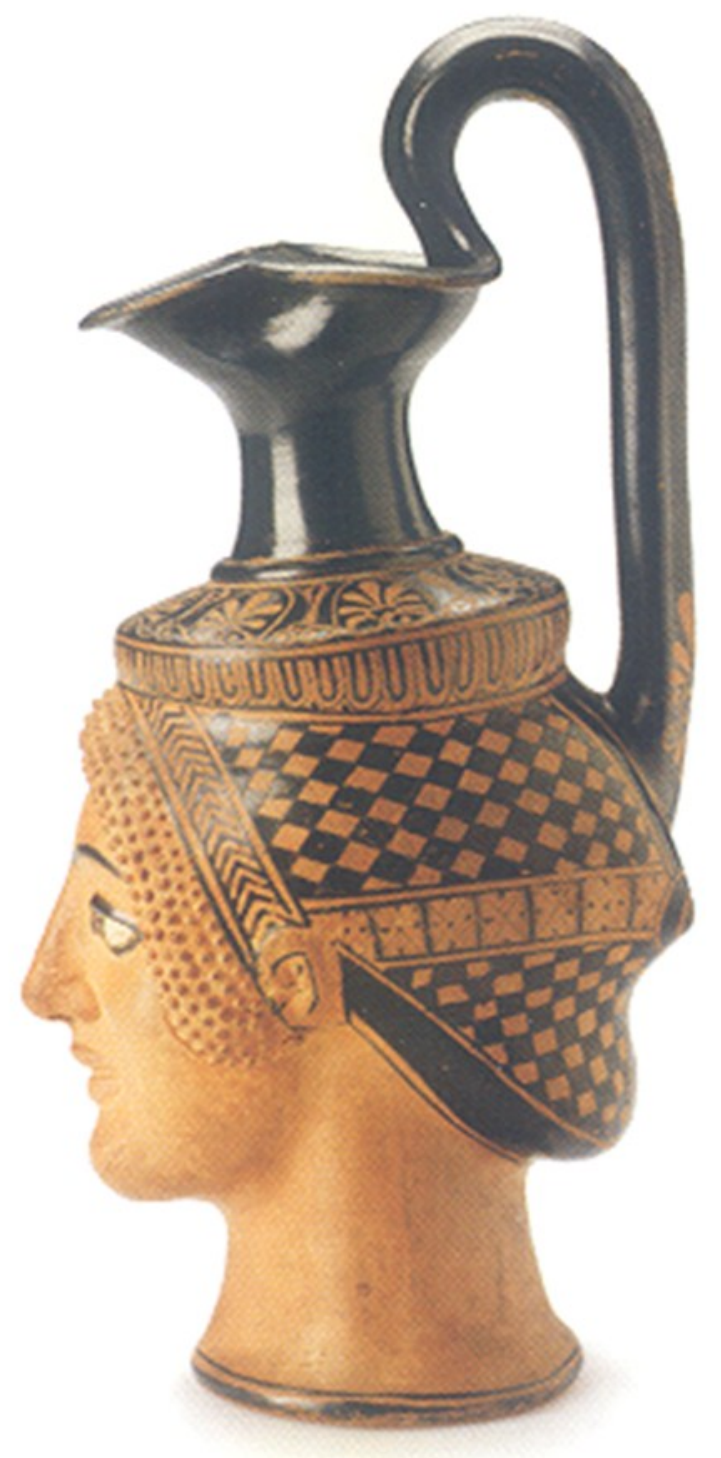

$\underline{\text { Figure } 81}$

Attic Red-figure Oenochoe in Form of a Woman's Head RISD 22.213

Greek, c. 490

Height: 9 3/8 inches

Attributed to Group L: The Providence Group

Rhode Island School of Design Art Museum

Selected Works, Museum of Art, Rhode Island School of Design. (2008) 


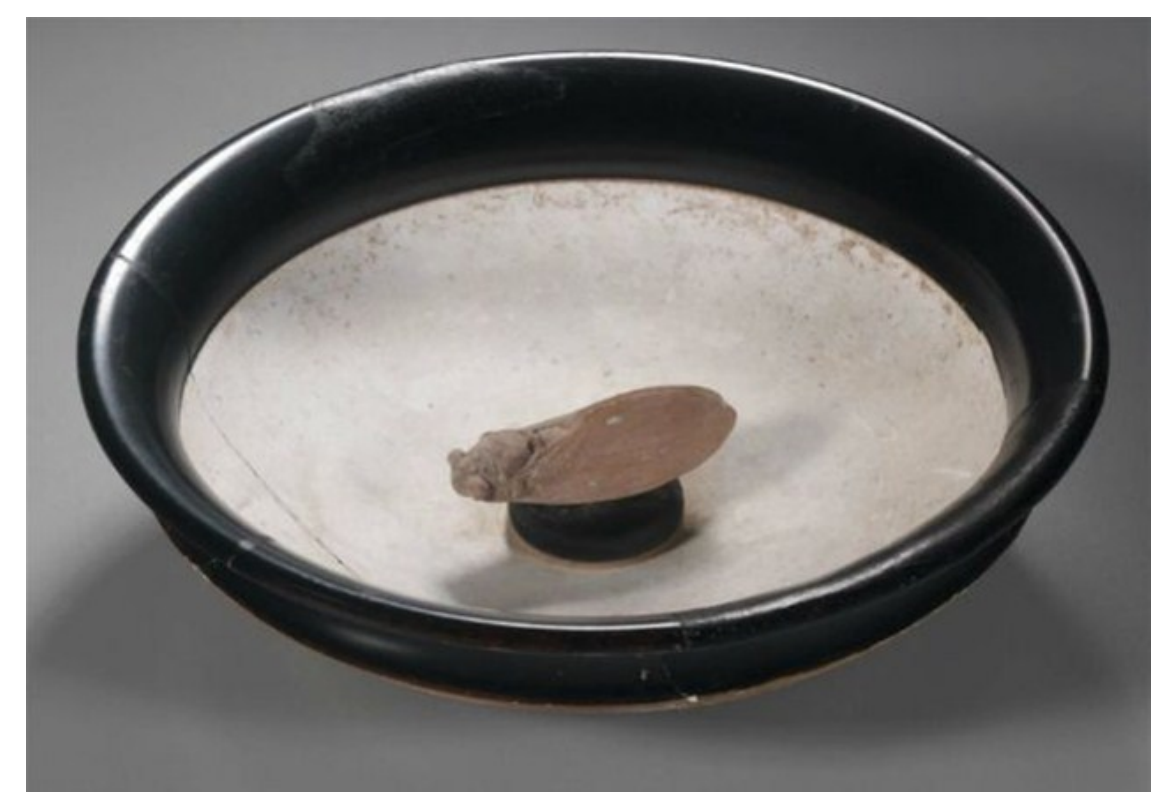

Interior

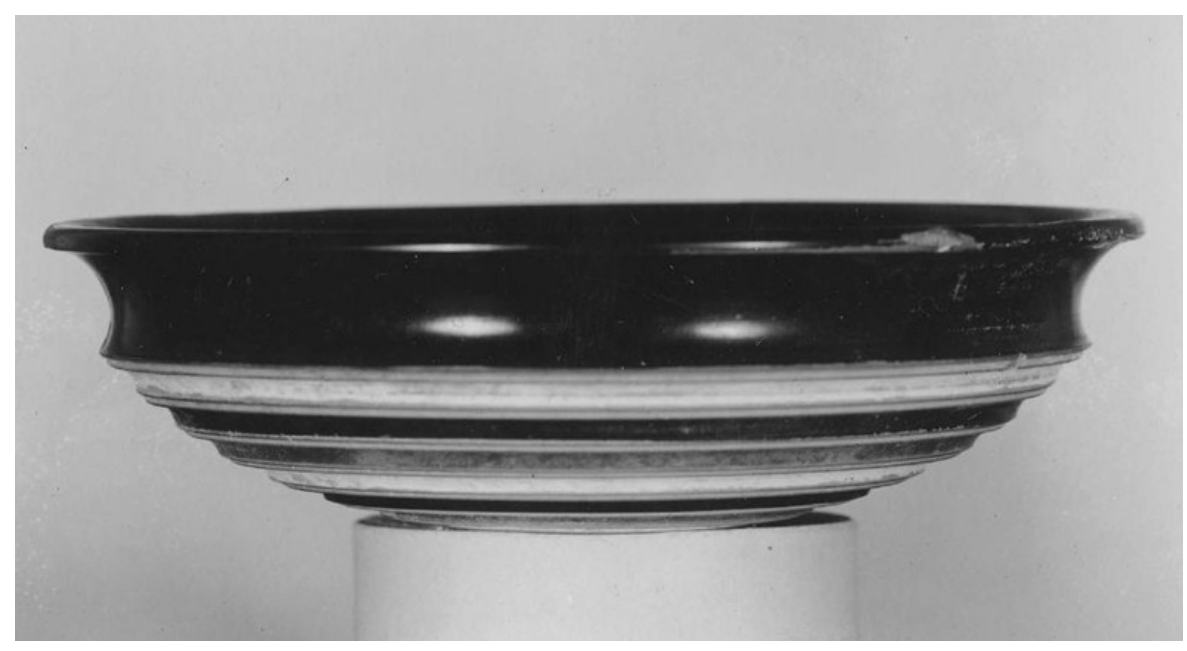

Exterior

Figure 82

Attic White-ground Libation Bowl

MFA 98.886

Greek, Early Classical Period, c. 460

Height: $4.7 \mathrm{~cm}$ (1 7/8 in.); diameter: $16.5 \mathrm{~cm}$ (6 1/2 in.)

Signed by Sotades as Potter

Museum of Fine Arts, Boston Database

http://www.mfa.org/collections/object/libation-bowl-phiale-154000

(accessed 7/20/12) 


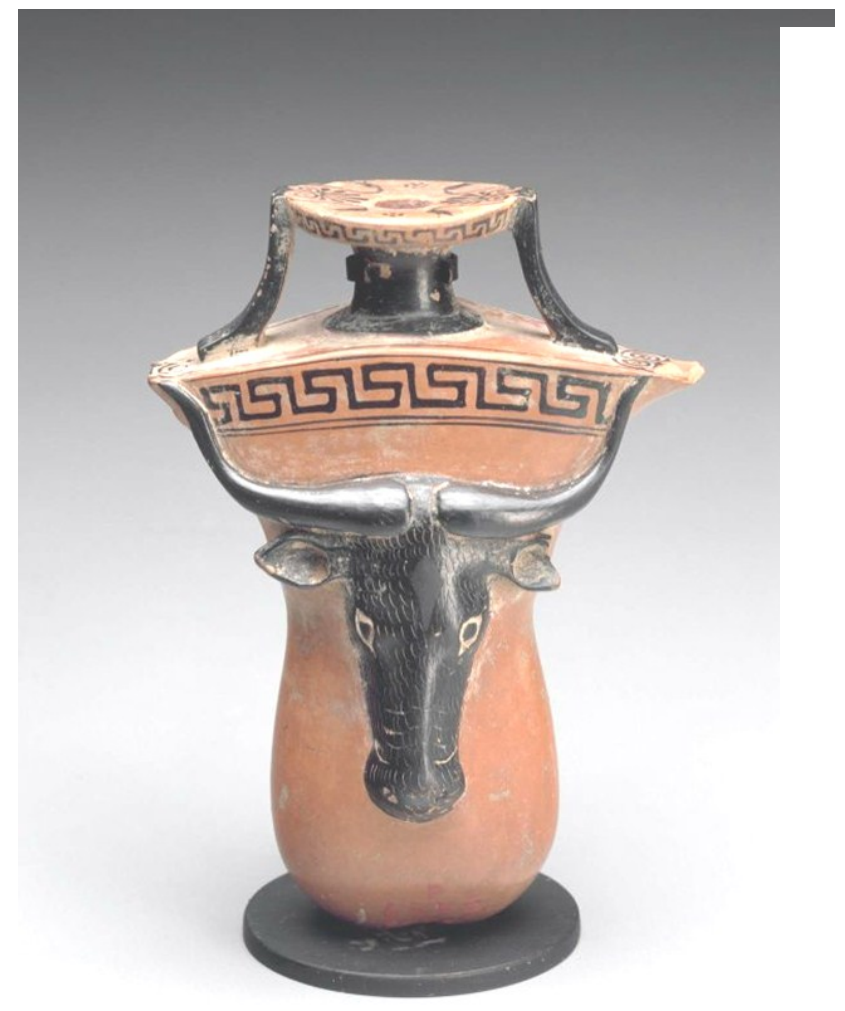

Side A

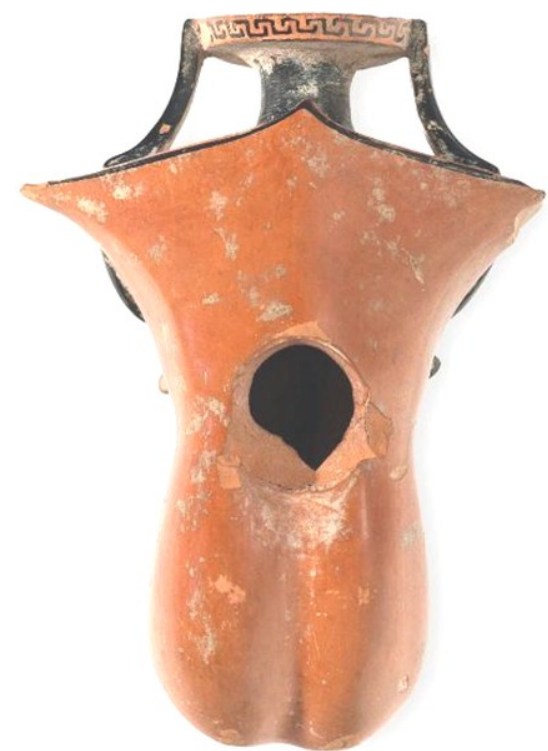

Side B

\section{$\underline{\text { Figure } 83}$}

Attic Black-figure Aryballos in the Shape of Male Genitals with a Bull's Head in Relief MFA 95.55

Greek, Late Archaic Period, c. 520-510

$11.2 \mathrm{~cm}$ (4 7/16 in.)

Museum of Fine Arts, Boston Database

http:/www.mfa.org/collections/object/oil-flask-aryballos-in-the-shape-of-male-genitalswith-a-bull-s-head-in-relief-153565

(accessed 7/20/12) 


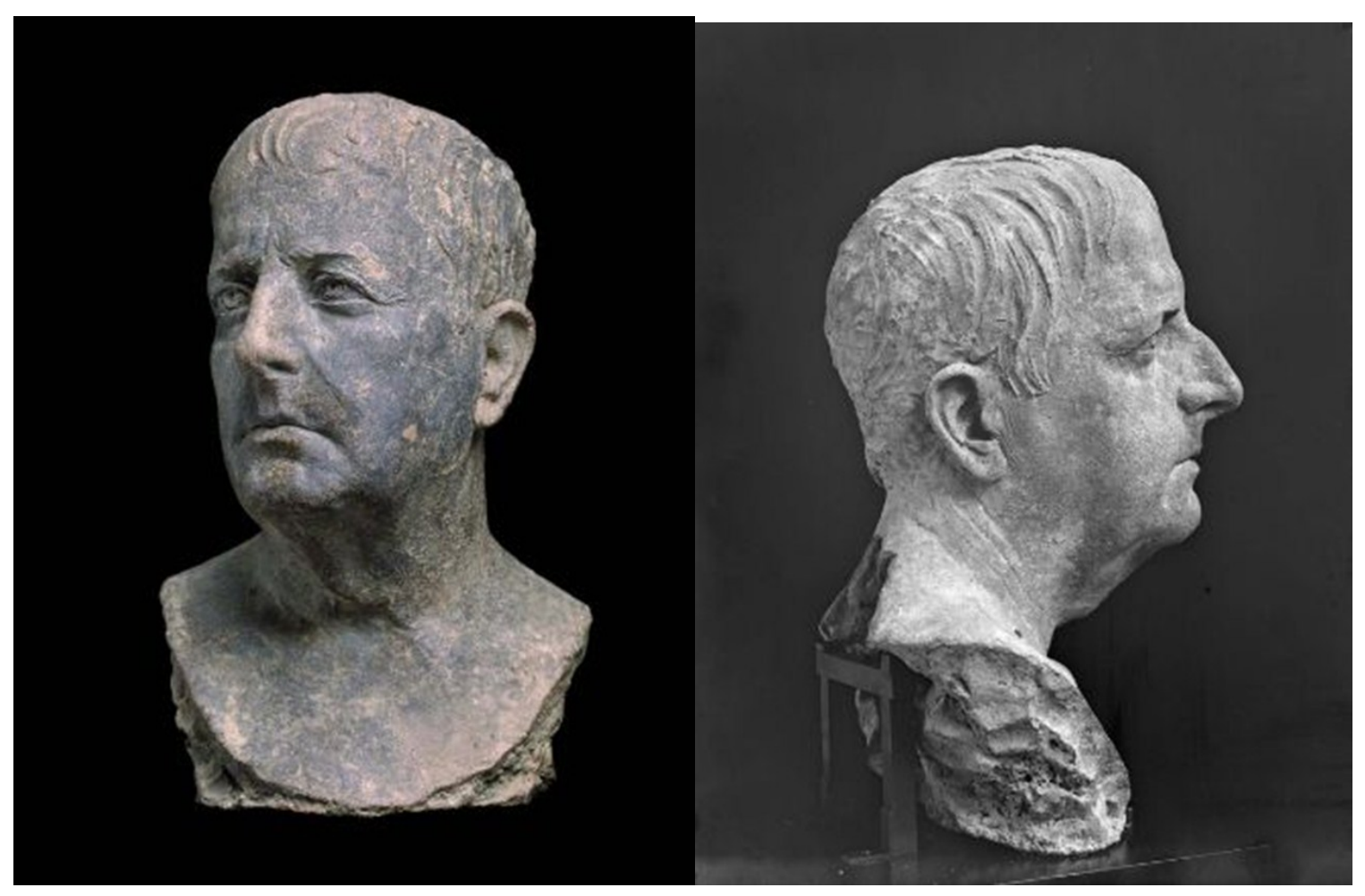

\section{Figure 84}

Terracotta Bust of a Man

MFA 01.8008

Roman, Late Republican Period, c. 50.

Height: 35.7 (14 1/16) in.); depth: $18 \mathrm{~cm}$ (7 1/16 in.)

http://www.mfa.org/collections/object/bust-of-a-man-155696

(accessed 9/22/12) 


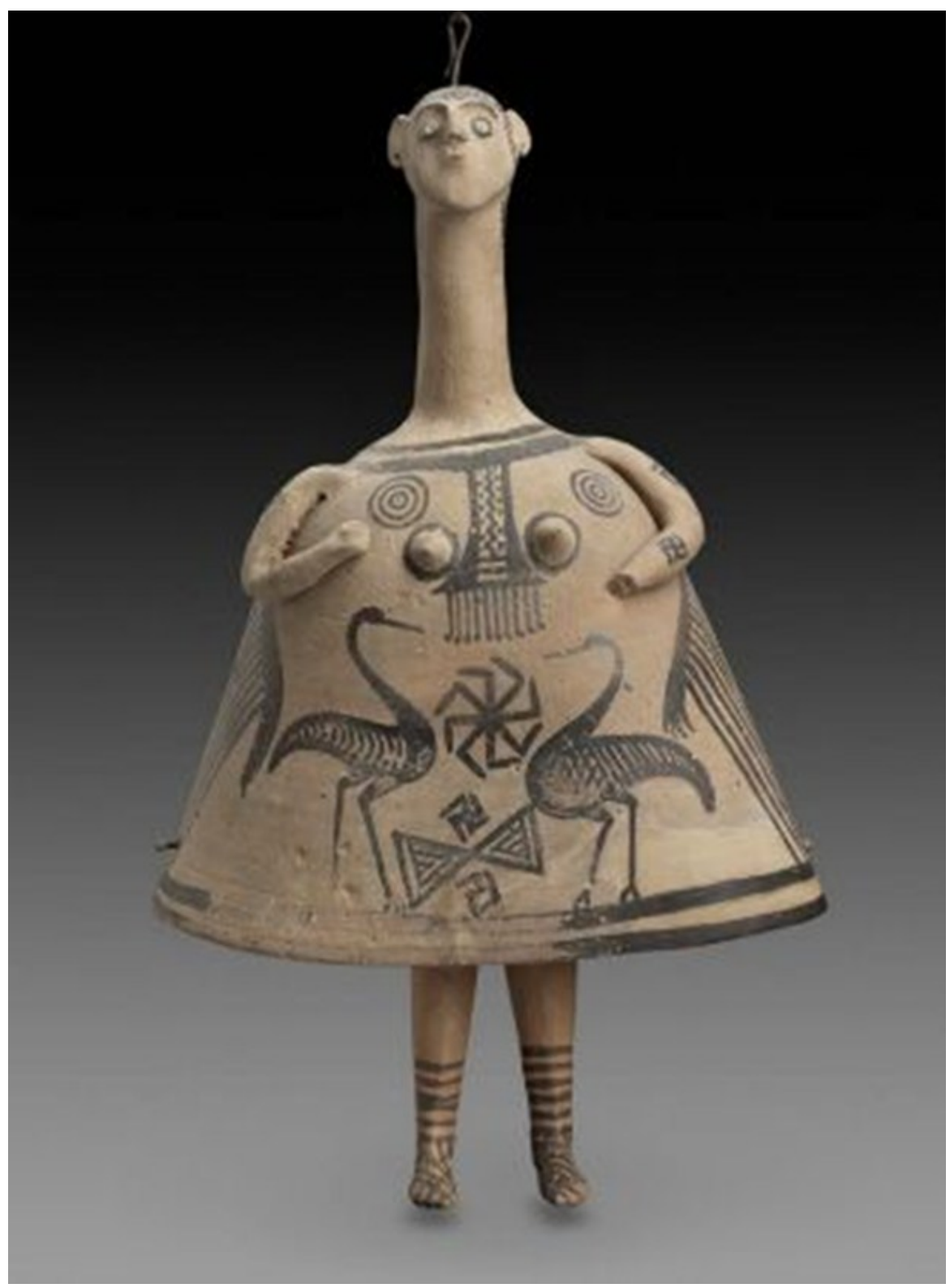

Figure 85

Terracotta Boeotian Bell-shaped Figurine MFA 98.891

Greek, Late Geometric or Early Orientalizing Period, c. 720-690.

Height: $30 \mathrm{~cm}$ (11 13/16 in.)

Museum of Fine Arts, Boston Database

http://www.mfa.org/collections/object/bell-shaped-female-figurine-151610

(accessed 7/20/12) 


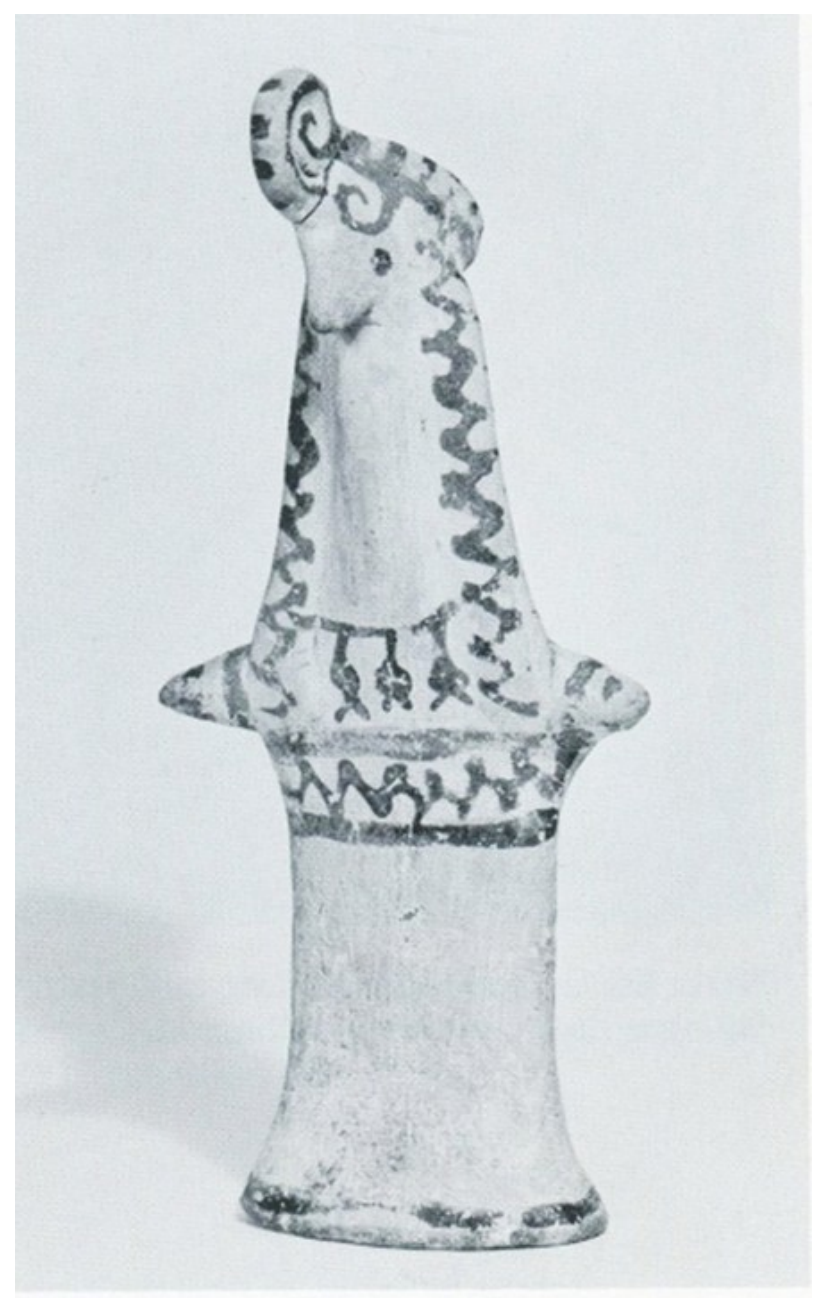

\section{Figure 86}

Standing Idol with Birdlike Head

From Boeotia

BCMA 1923.29

c. 650-600 B.C.E.

Height: 0.143 m; Width of bottom: 0.047

Bowdoin College Art Museum

Kevin Herbert

Ancient Art in Bowdoin College:

A Descriptive Catalogue of the Warren and Other Collections (1964) 


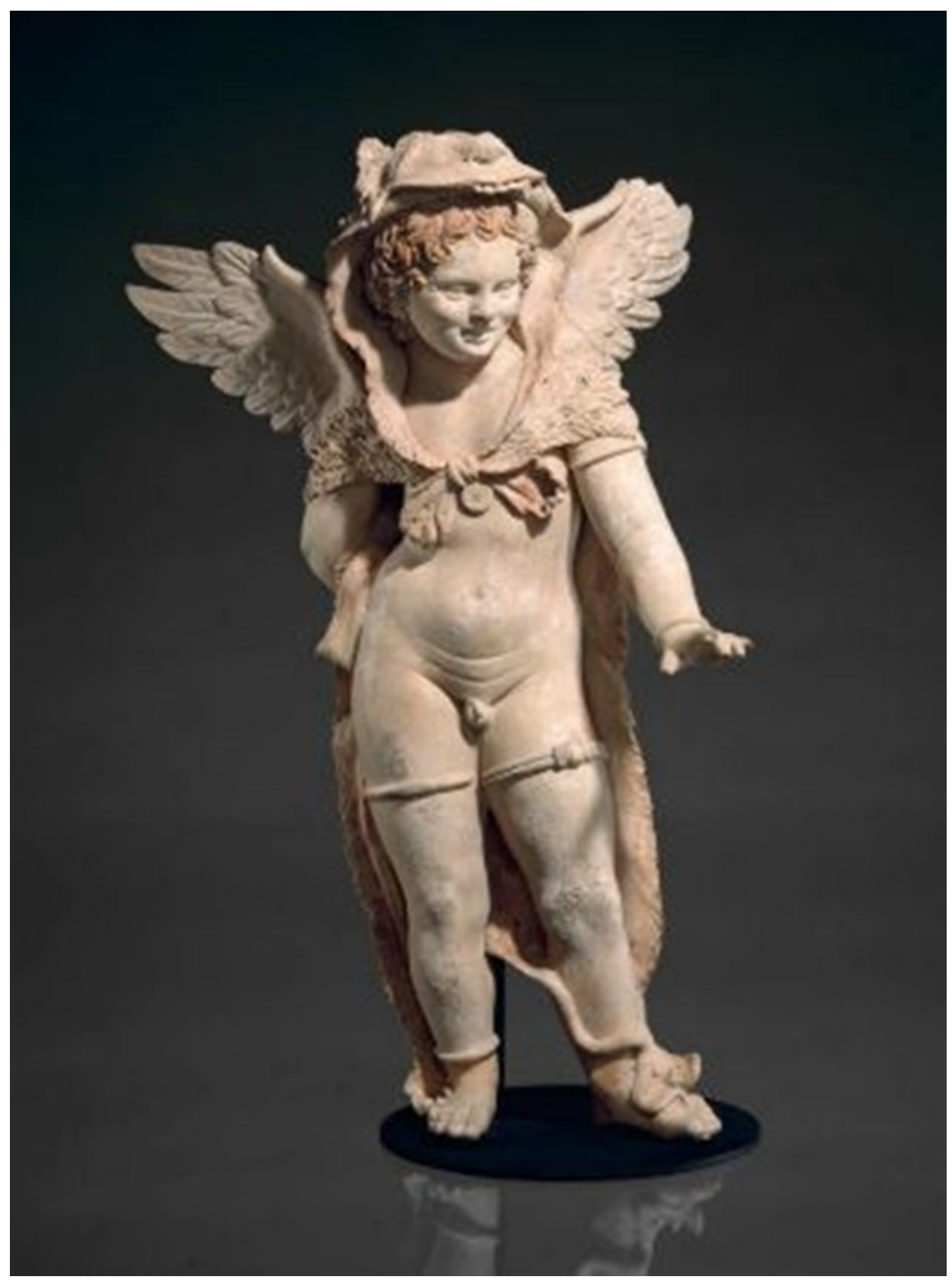

Figure 87

Terracotta Statuette of Eros Wearing the Lion Skin of Herakles MFA 00.321

Greek, East Greek, Hellenistic Period, First Century B.C.E.

Height: $40 \mathrm{~cm}$ (15 3/4 in.)

Museum of Fine Arts, Boston Database

http://www.mfa.org/collections/object/statuette-of-eros-wearing-the-lionskin-ofherakles-152112

(accessed 7/20/12) 


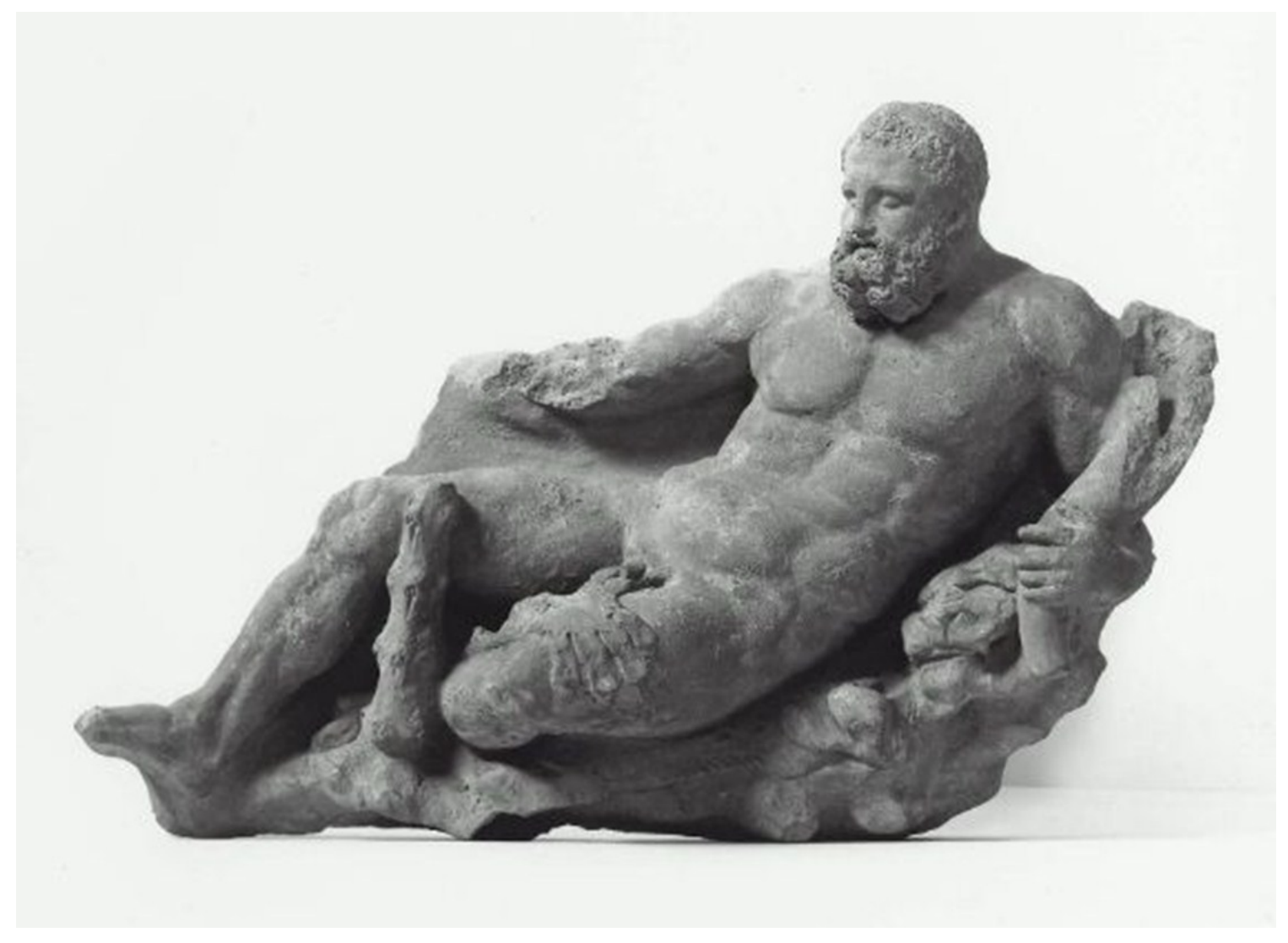

$\underline{\text { Figure } 88}$

Terracotta Relief of Herakles Reclining MFA 01.7967

Greek, South Italian, Hellenistic Period, c. late Second Century B.C.E.

Height: $30.4 \mathrm{~cm}$ (11 15/16 in.); width: $50.8 \mathrm{~cm}$ (20 in.)

Museum of Fine Arts, Boston Database

http://www.mfa.org/collections/object/relief-of-herakles-reclining-152643

(accessed 7/20/12) 


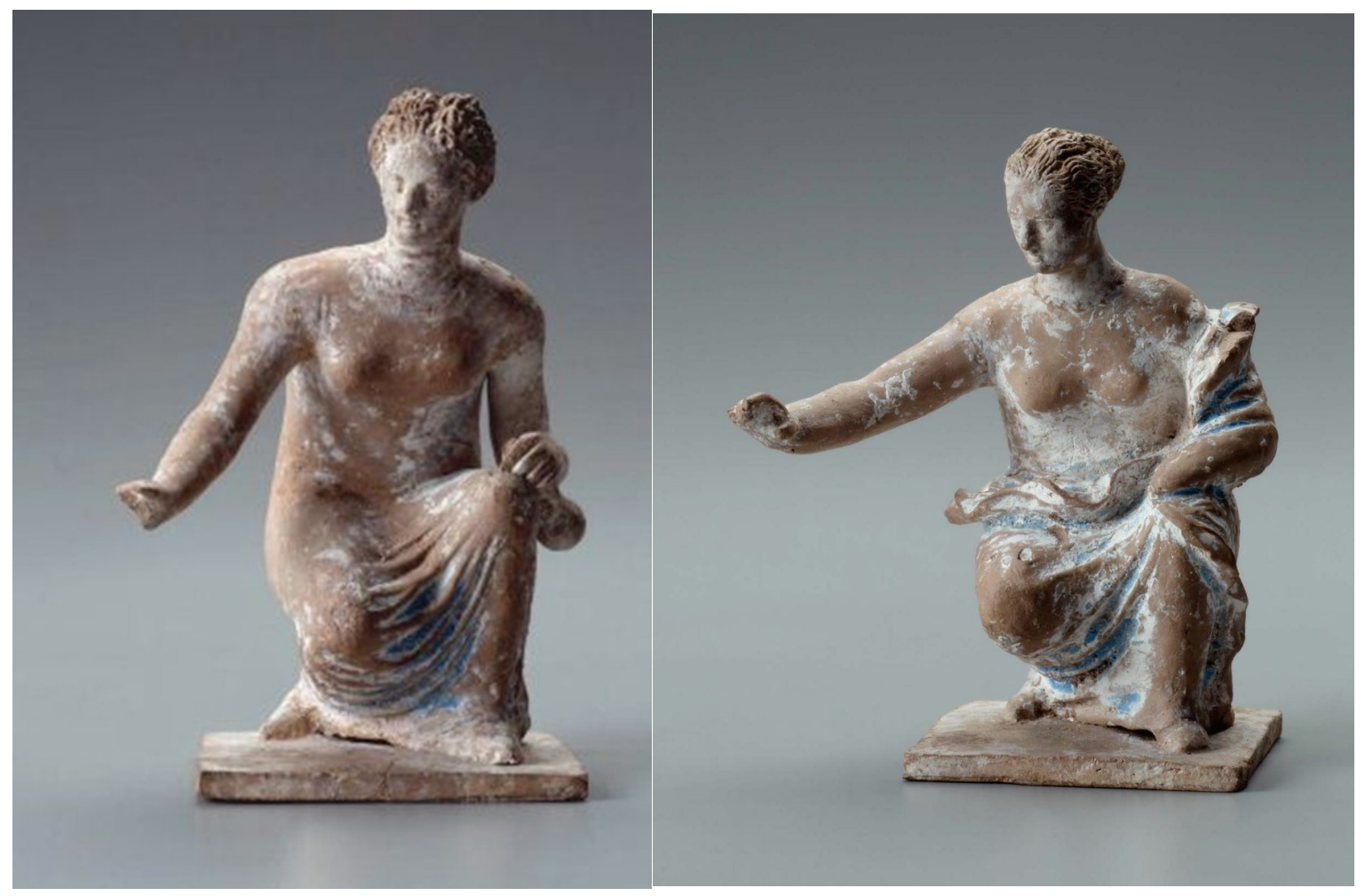

$\underline{\text { Figure } 89}$

Terracotta Figurine of a Girl

Playing Knucklebones

MFA 01.7799

Greek, Late Classical or

Early Hellenistic Period,

Fourth Century B.C.E.

Height: $12.3 \mathrm{~cm}$ (4 13/16 in.)

Museum of Fine Arts, Boston Database

http://www.mfa.org/collections/object/

figurine-of-a-girl-playing-knucklebones-

151769

(accessed 7/20/12)
Terracotta Figurine of a Girl

Playing Knucklebones MFA 01.7798

Greek, Late Classical or

Early Hellenistic Period,

Fourth Century B.C.E.

Height: $11.8 \mathrm{~cm}$ (4 5/8 in.)

Museum of Fine Arts, Boston Database

http://www.mfa.org/collections/object/

figurine-of-a-girl-playing-knucklebones

$-151768$

(accessed 7/20/12) 


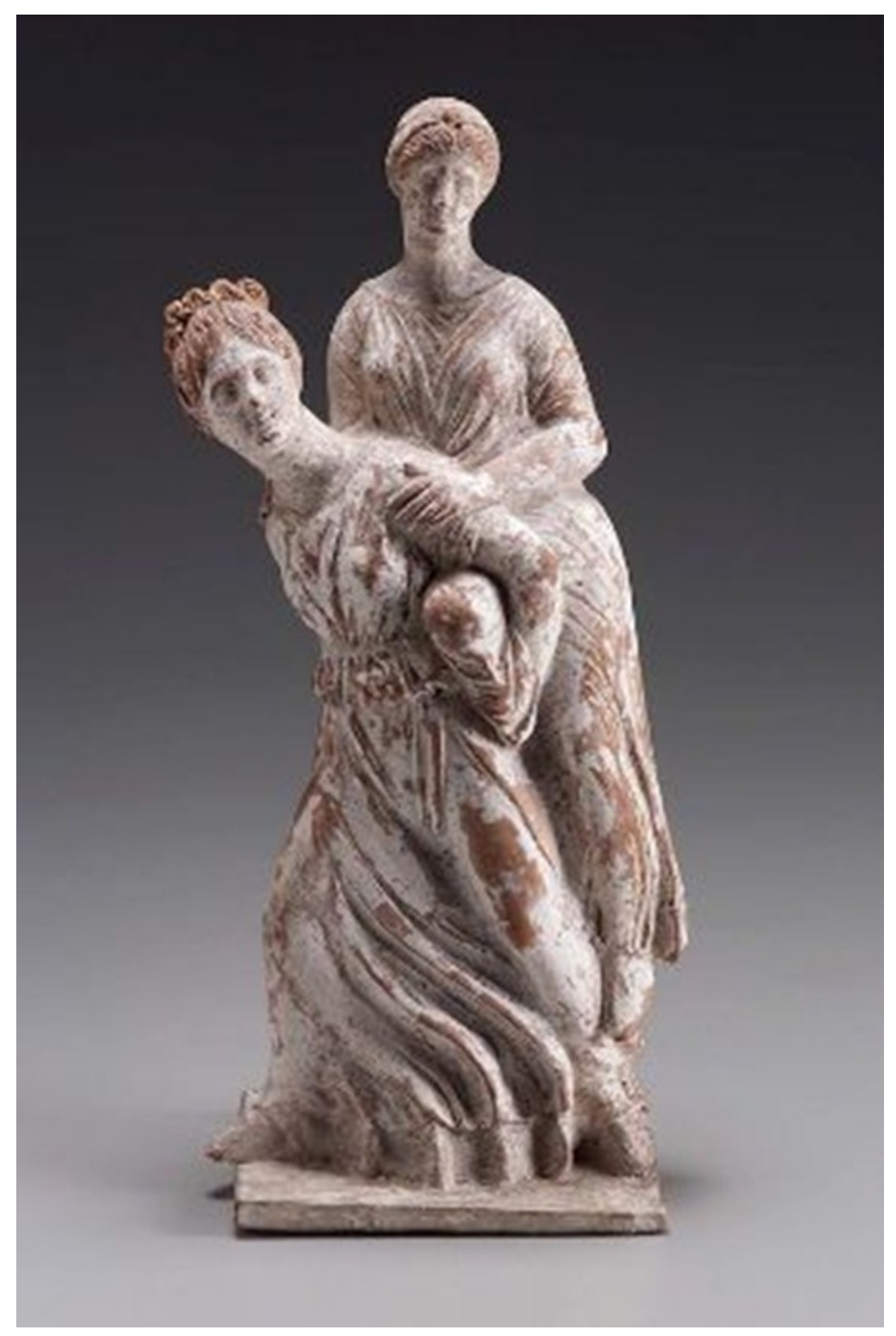

Figure 90

Terracotta Women Playing

MFA 03.894

Greek, Early Hellenistic Period, c. 300 B.C.E

$24.8 \mathrm{~cm}$ (9 3/4 in.)

Museum of Fine Arts, Boston Database

http:/www.mfa.org/collections/object/women-playing-151843

(accessed 7/20/12) 


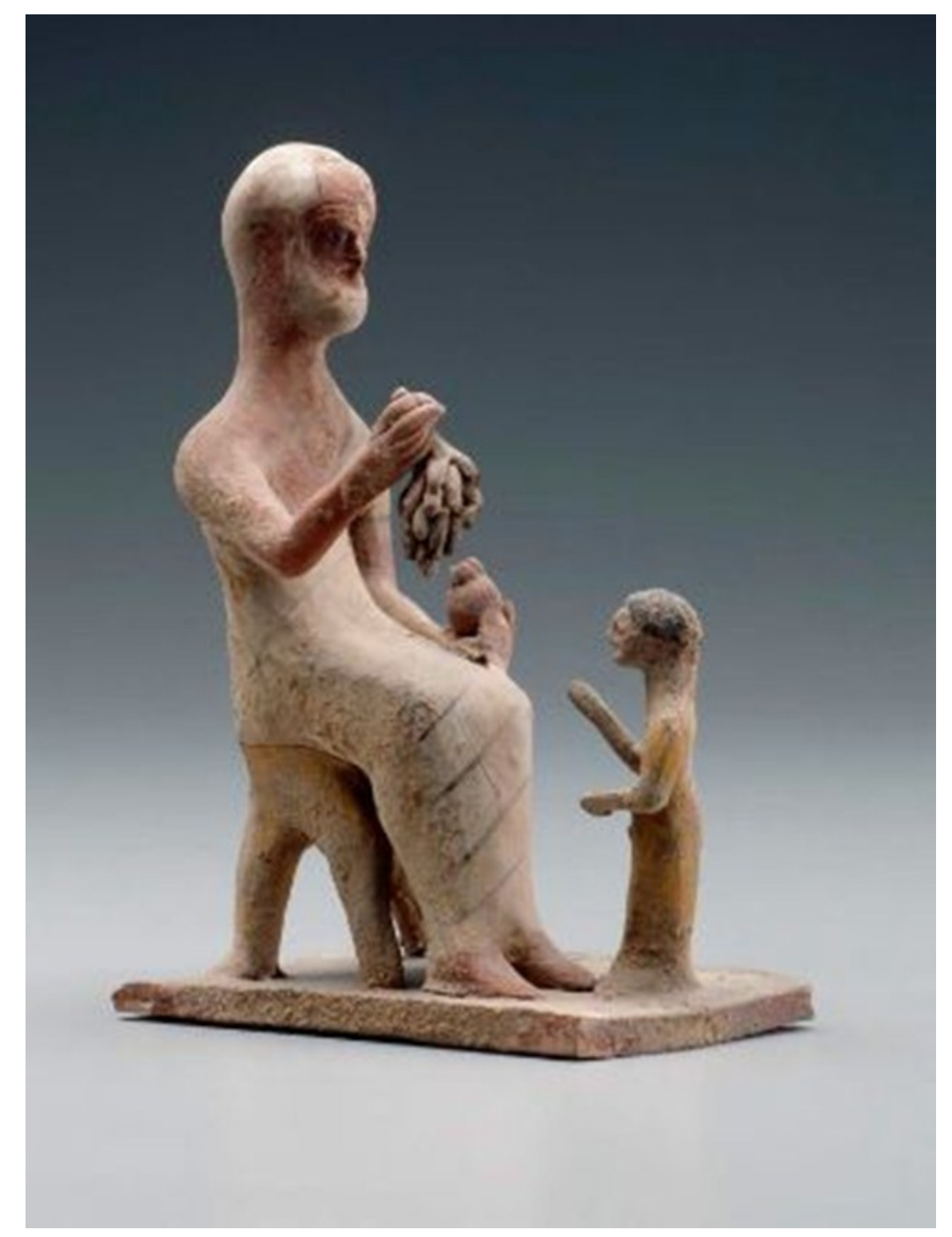

Figure 91

Terracotta Statuette of an Old Man Offering Grapes to a Girl MFA 97.350

Greek, Archaic Period, First Quarter of Fifth Century

Height: $11 \mathrm{~cm}(45 / 16$ in.)

Museum of Fine Arts, Boston Database

http://www.mfa.org/collections/object/statuette-of-an-old-man-offering-grapes-to-a-girl $-151719$

(accessed 7/20/12) 


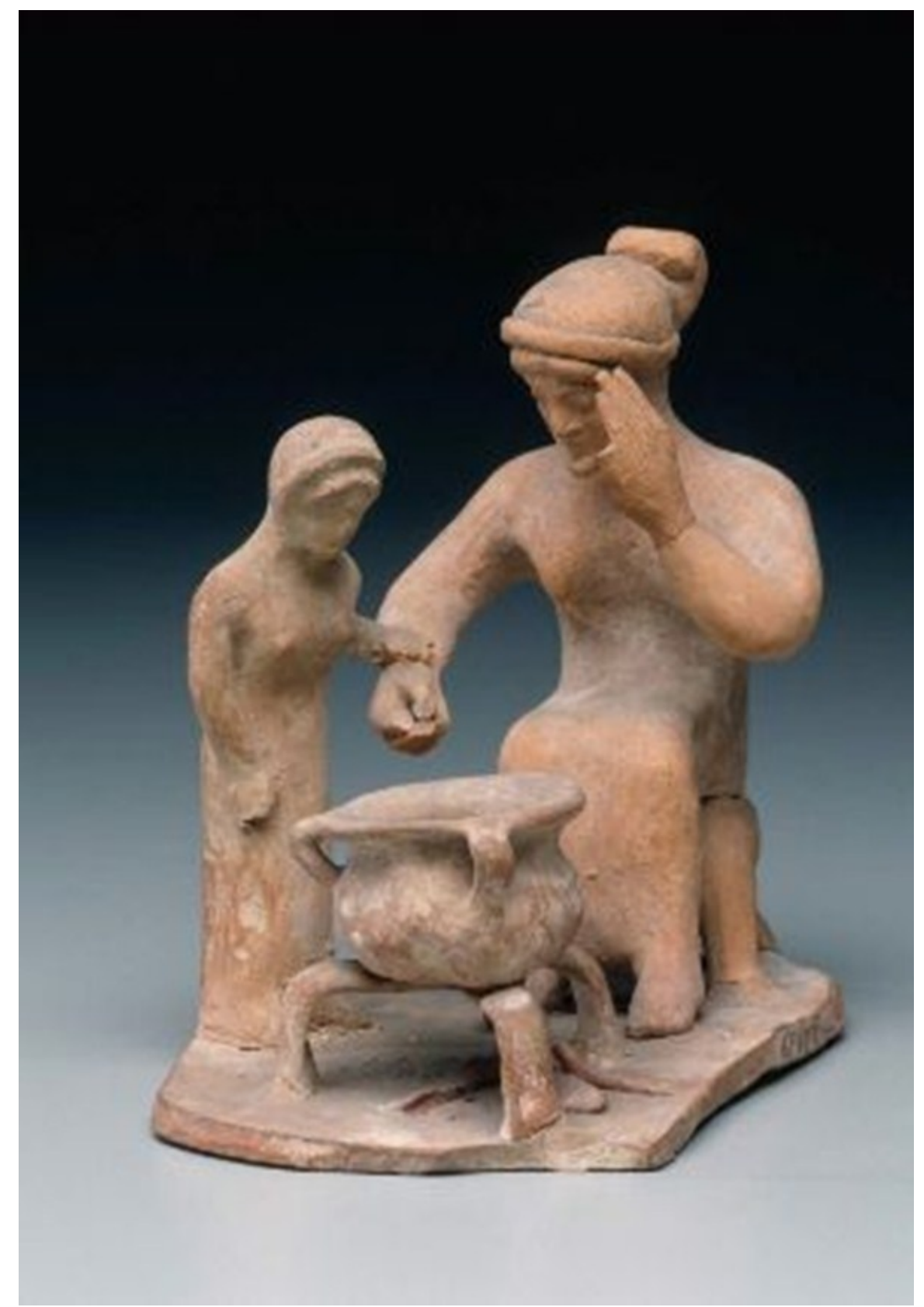

Figure 92

Terracotta Figurine of Woman Cooking, Watched by a Girl MFA 01.7788

Greek, Archaic Period, 500-475

Height: 10.7 cm (4 3/16 in.)

Museum of Fine Arts, Boston Database

http://www.mfa.org/collections/object/woman-cooking-watched-by-a-girl-151733 (accessed 7/20/12) 


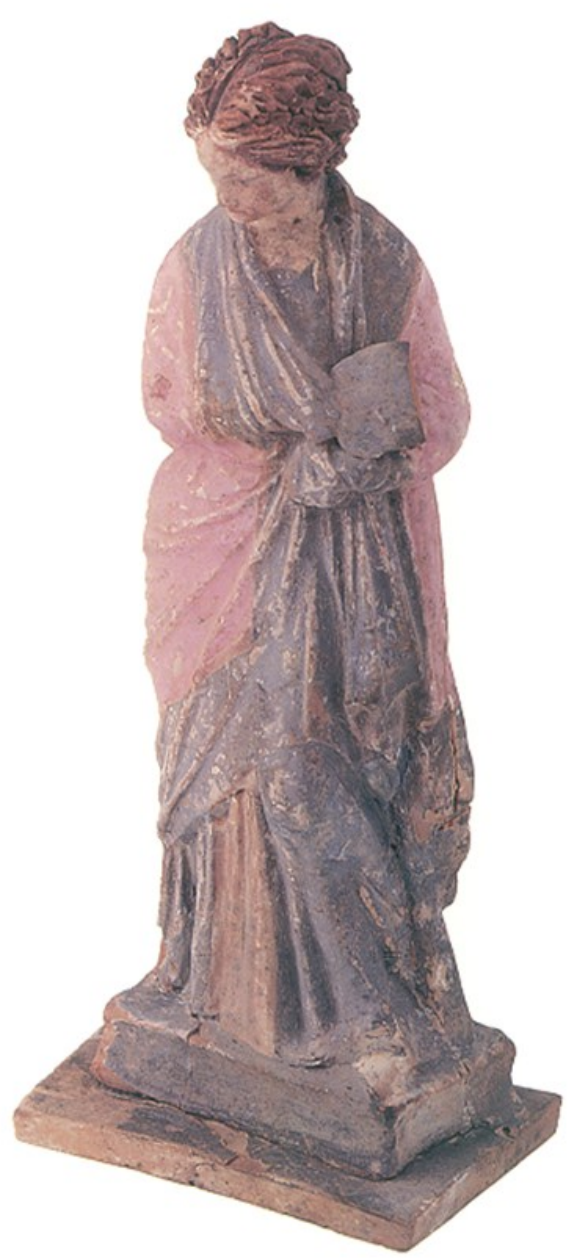

Figure 93

Terracotta Standing Woman

(Tanagra type)

BCMA 1915.12.1

Boeotia, c. Third Century

$75 / 8 \times 2 \frac{1 / 4}{4}$ inches

Bowdoin College Museum of Art

James A. Higginbotham and

Katherine M. Westley

Ars Antiqua: Treasures from the Ancient Mediterranean World at

Bowdoin College

(2005)

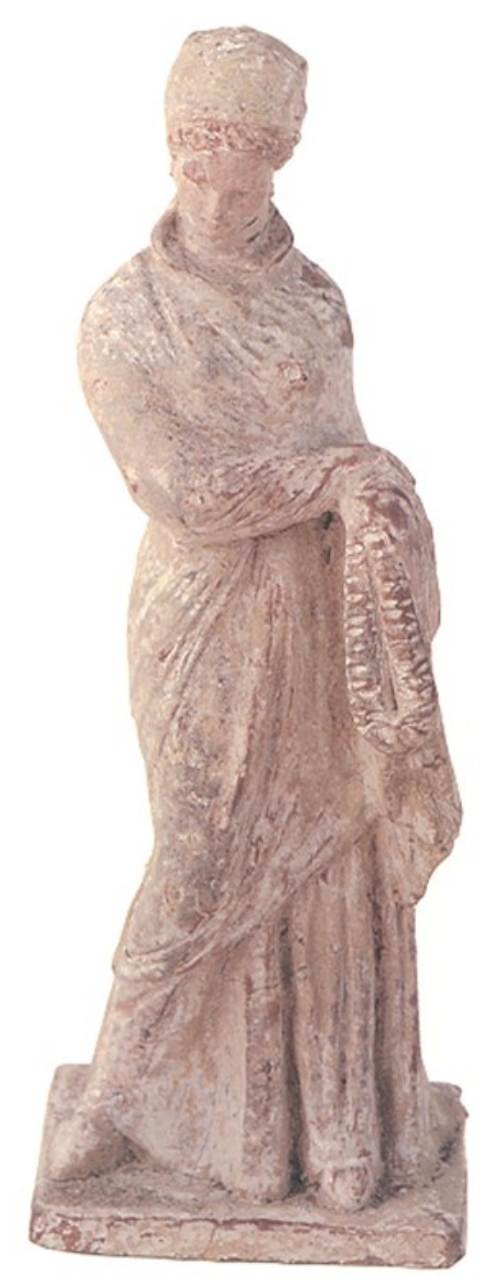

Terracotta Standing Woman

(Tanagra type)

BCMA 1908.10

Boeotia, c. Third Century

$81 / 16 \times 25 / 8$ inches

Bowdoin College Museum of Art

James A. Higginbotham and Katherine

M. Westley

Ars Antiqua: Treasures from the

Ancient Mediterranean World at

Bowdoin College (2005) 


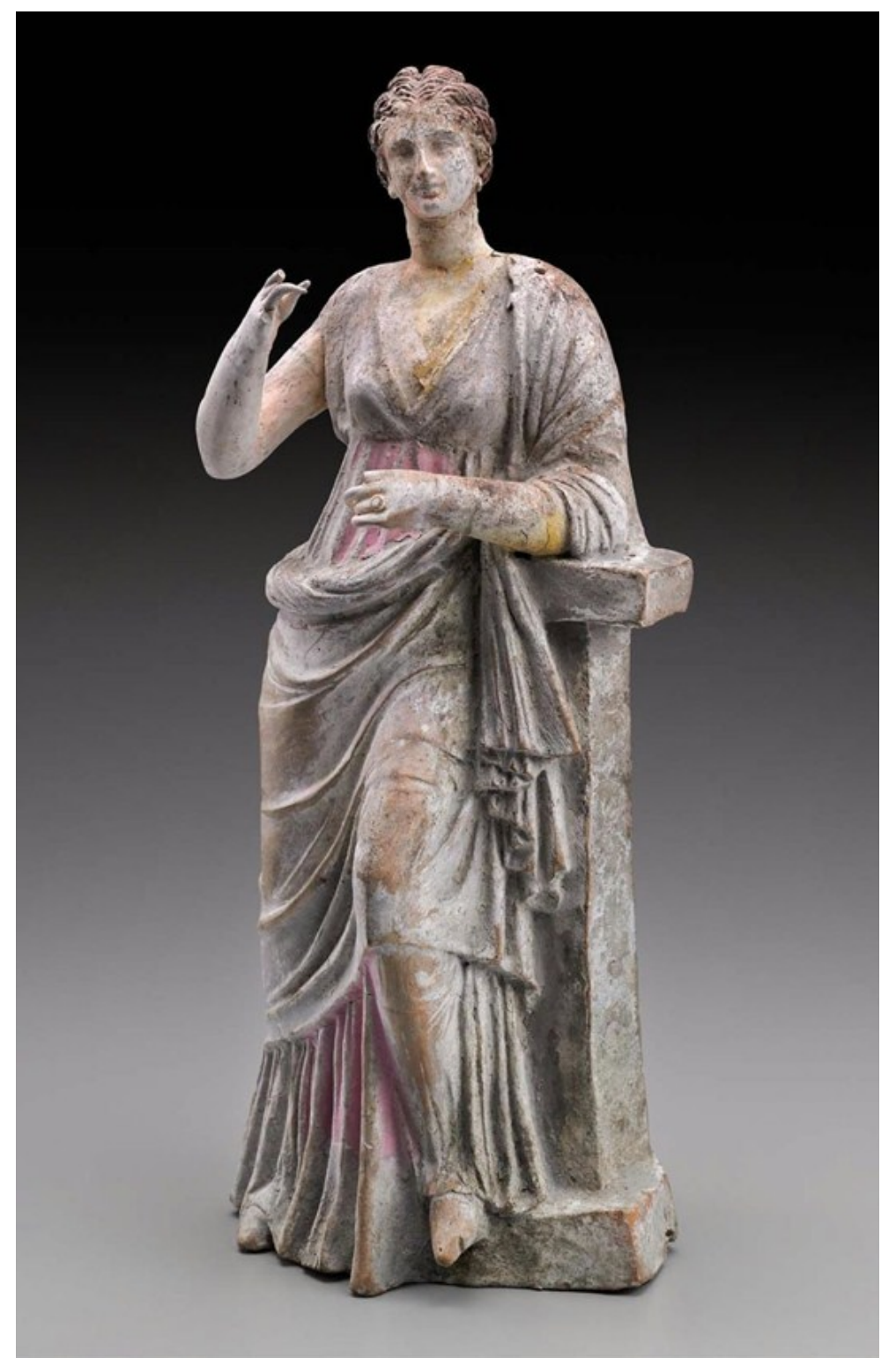

Figure 94

Terracotta Statuette of Aphrodite or a Muse Leaning on a Pillar MFA 98.893

Greek, Hellenistic Period, 300-250

Height: $39.4 \mathrm{~cm}$ (15 1/2 in.)

Museum of Fine Arts, Boston Database

http://www.mfa.org/collections/object/statuette-of-aphrodite-or-a-muse-leaning-on-apillar-151712

(accessed 7/20/12) 


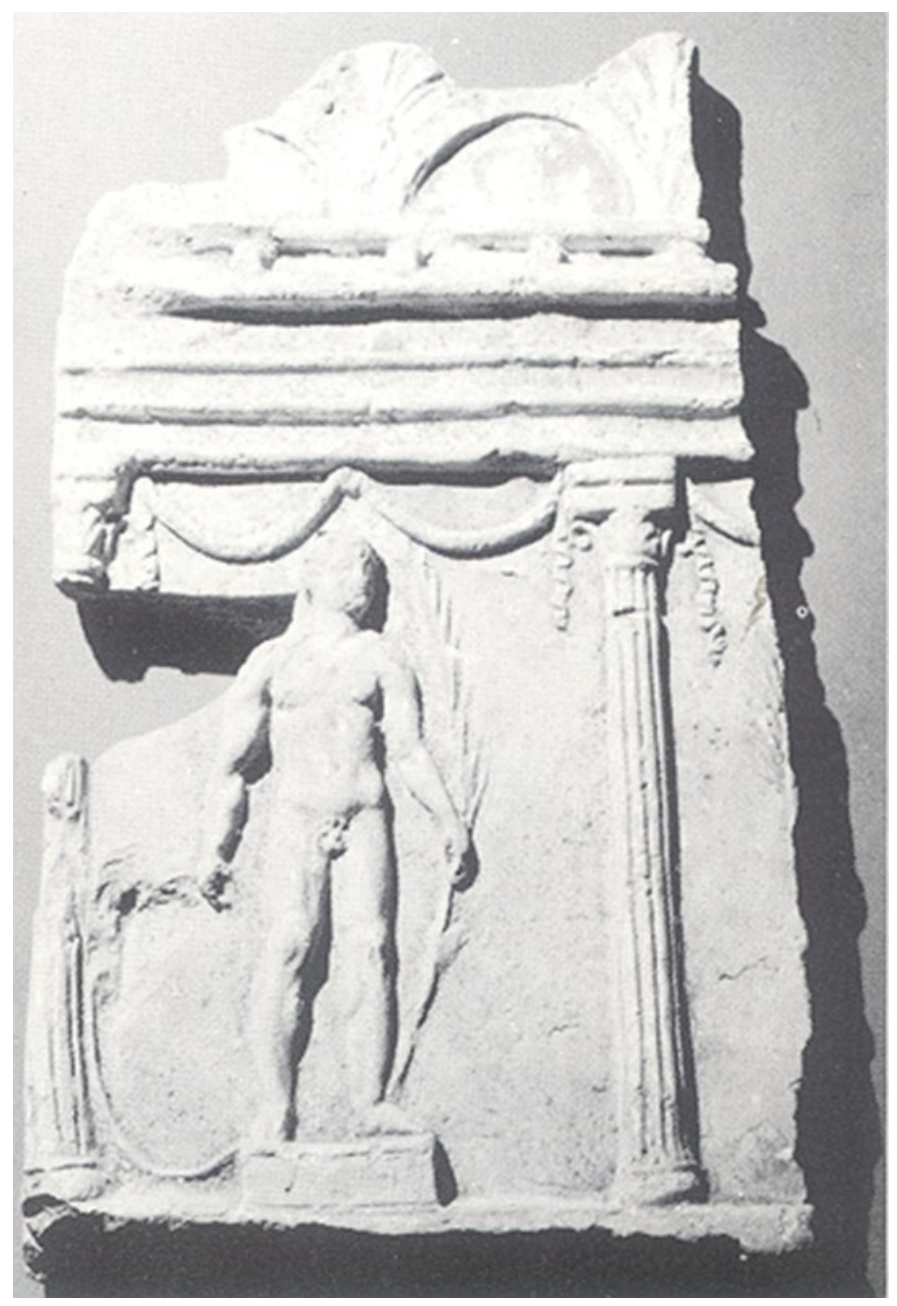

Figure 95

Terracotta Relief Depicting a Palaistra Scene

BCMA 1927.24.1-2

Roman, Imperial Period, Second Century C.E.

Height $0.345 \mathrm{~m}$; width: 0.210; thickness $0.035 \mathrm{~m}$

Bowdoin College Art Museum

Kevin Herbert

Ancient Art in Bowdoin College:

A Descriptive Catalogue of the Warren and Other Collections (1964) 


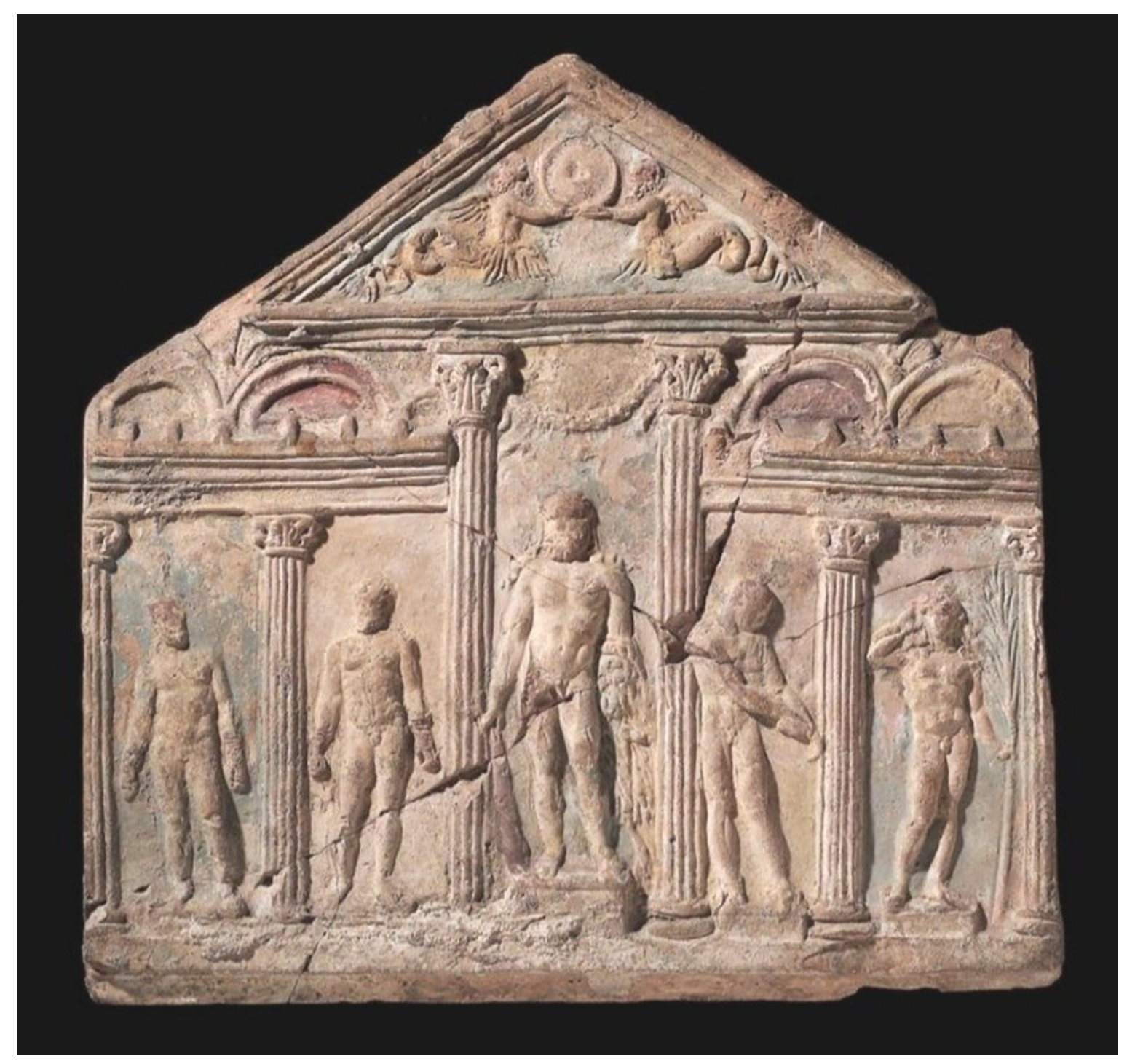

Figure 96

Terracotta Relief Depicting a Palaistra Scene MFA 03.883

Roman, Imperial Period, First Century C.E. $40.1 \times 40 \mathrm{~cm}(1513 / 16 \times 153 / 4 \mathrm{in})$

Museum of Fine Arts, Boston Database

http://www.mfa.org/collections/object/relief-depicting-a-palaistra-scene-181410 (accessed 7/20/12) 


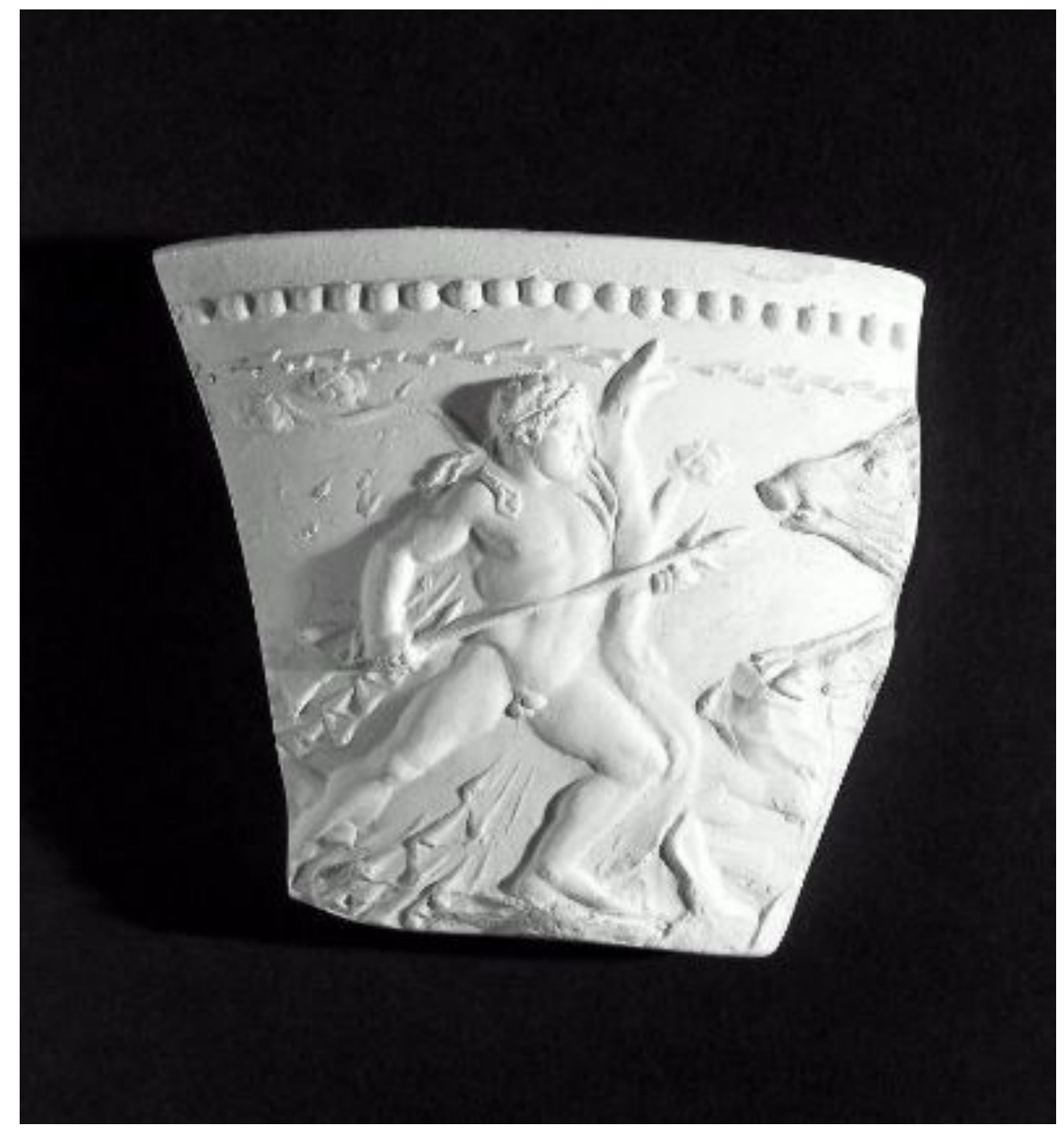

Figure 97

Impression of a Terracotta Fragment of Mold for an Arretine bowl with a Youth Attacking a Boar

MFA 98.853

Roman

Height x length: 7.4 × $9 \mathrm{~cm}(2$ 15/16 x 3 9/16 in.)

Museum of Fine Arts, Boston Database

http:/www.mfa.org/collections/object/fragment-of-mold-for-bowl-with-youthattacking-a-boar-186741

(accessed 7/20/12) 


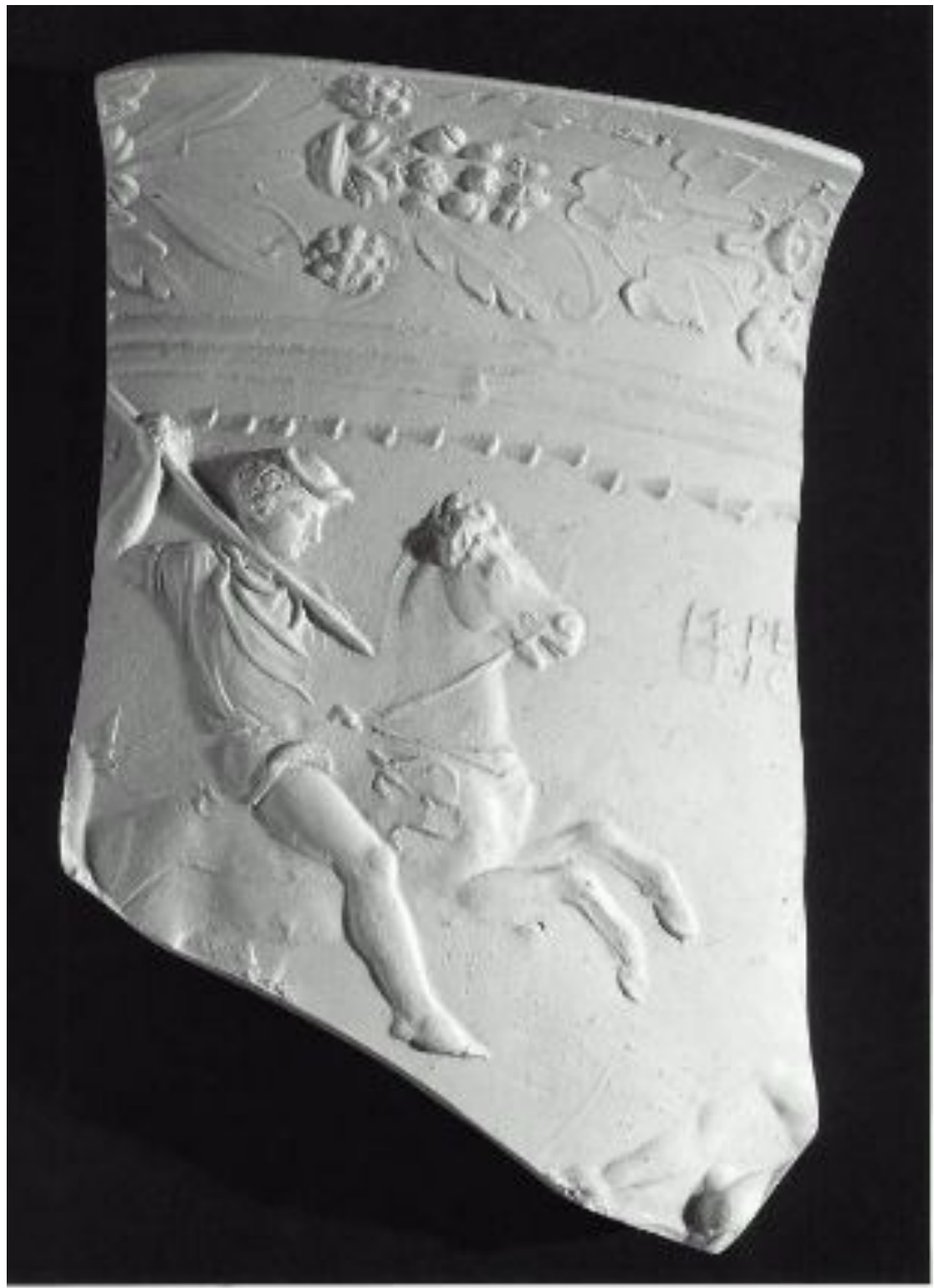

$\underline{\text { Figure } 98}$

Impression of Terracotta Fragment of Mold for an Arretine Bowl with a Hunter on Horseback

MFA 98.854

Roman

Height x length: $12 \times 9 \mathrm{~cm}(43 / 4 \times 3$ 9/16 in.)

http://www.mfa.org/collections/object/fragment-of-mold-for-bowl-with-hunter-onhorseback-186742

(accessed 7/20/12) 


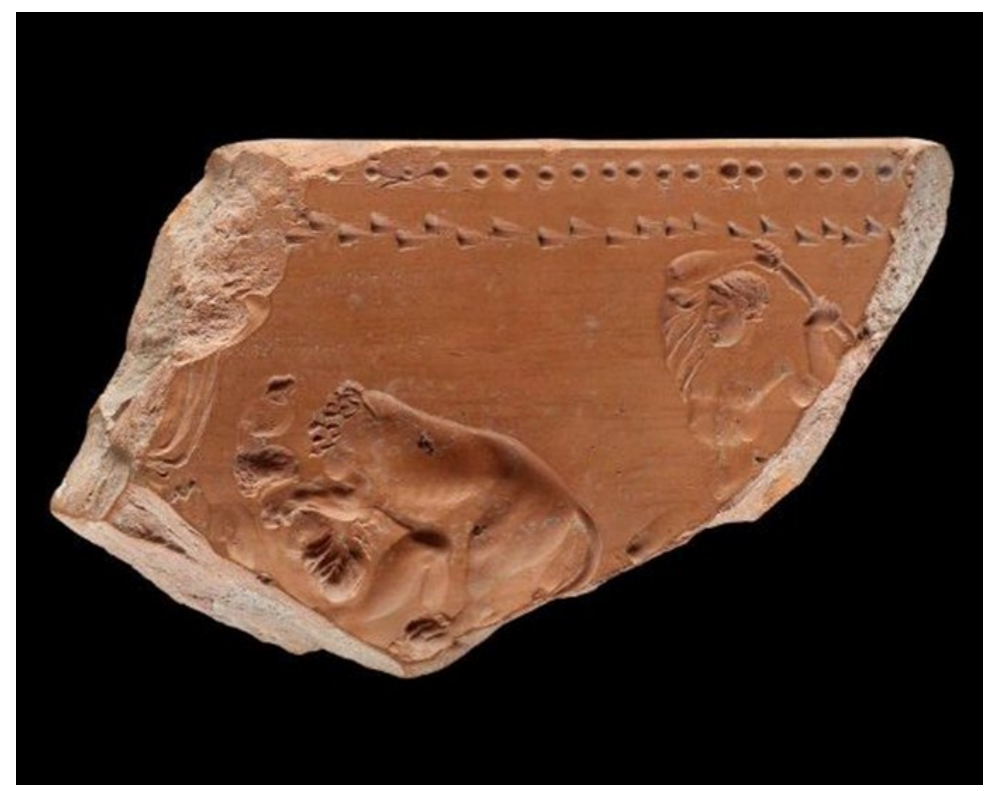

Mold

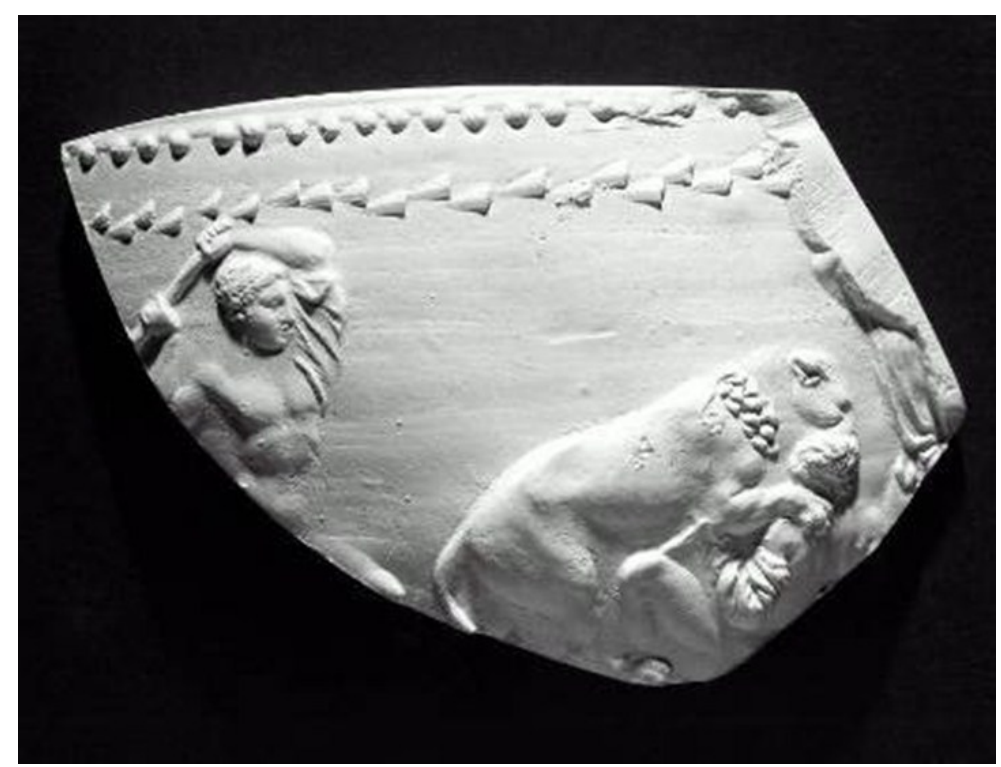

Impression

$\underline{\text { Figure } 99}$

Terracotta Fragment of Mold for an Arretine Bowl with a Youth Attacking a Lion MFA 98.882

Roman

Height x length: 7.6 x $12 \mathrm{~cm}(3 \times 43 / 4$ in.)

Museum of Fine Arts, Boston Database

http://www.mfa.org/collections/object/fragment-of-mold-for-bowl-with-youth-attacking -a-lion-186740 (accessed 7/20/12) 


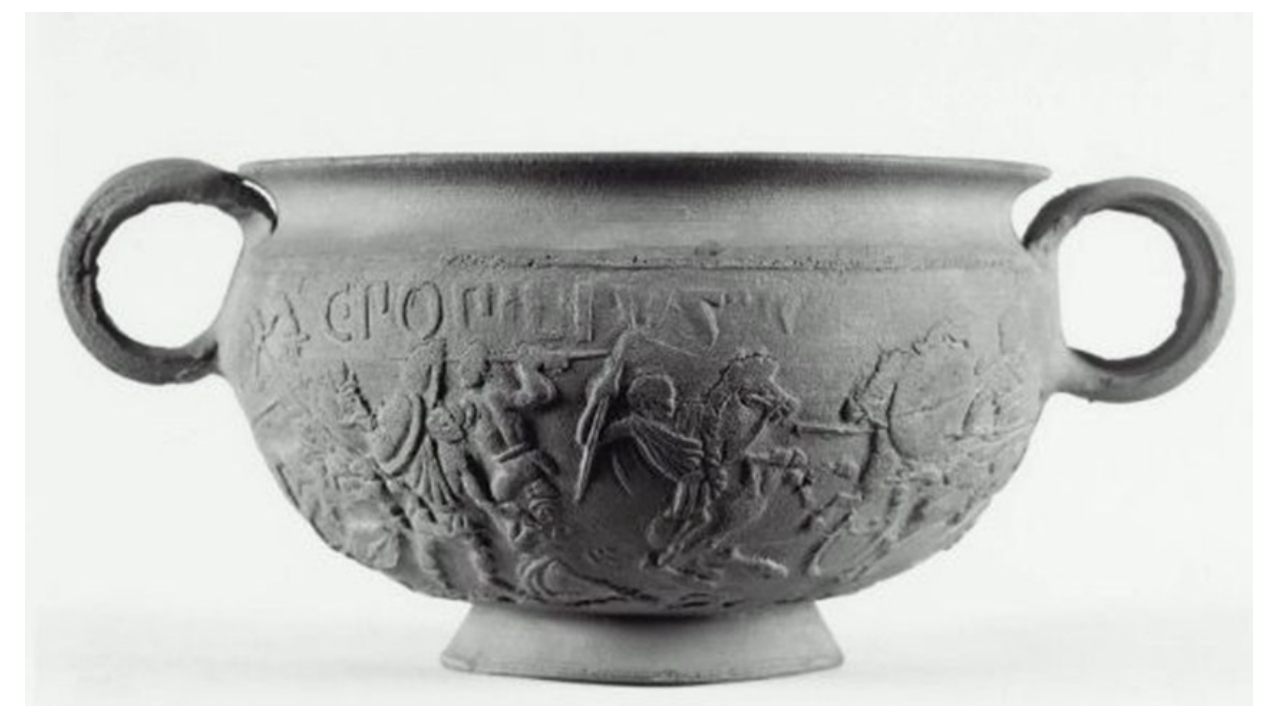

Exterior

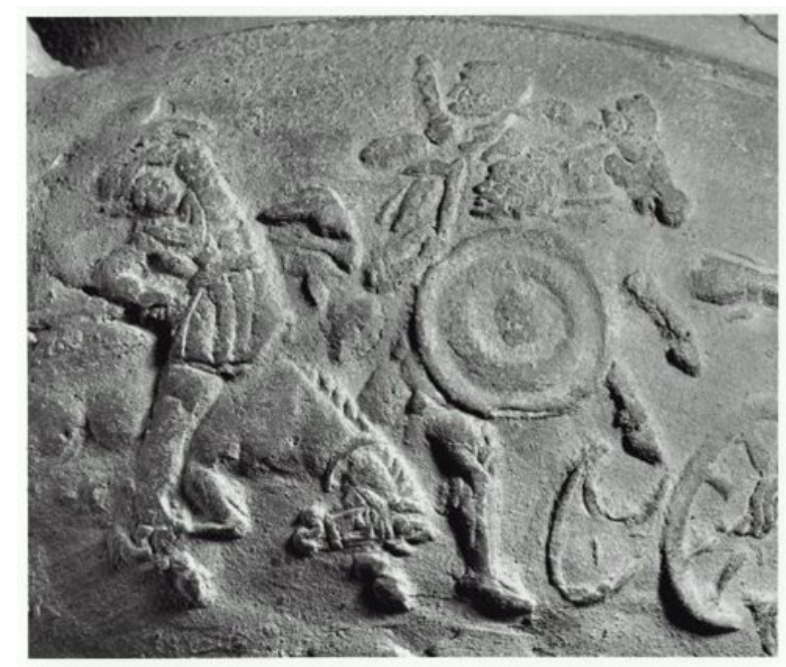

Detail

$\underline{\text { Figure } 100}$

\section{Italo-Megarian Relief Ware MFA 99.542}

Roman, Republican Period, c. 110-80

Height: 7.3 cm (2 7/8 in.); diameter: $11.6 \mathrm{~cm}$ (4 9/16 in.) signed by Caius Popilius

Museum of Fine Arts, Boston Database

http://www.mfa.org/collections/object/early-relief-ware-two-handled-cup-scyphus-orcantharus-154499

(accessed 7/20/12) 


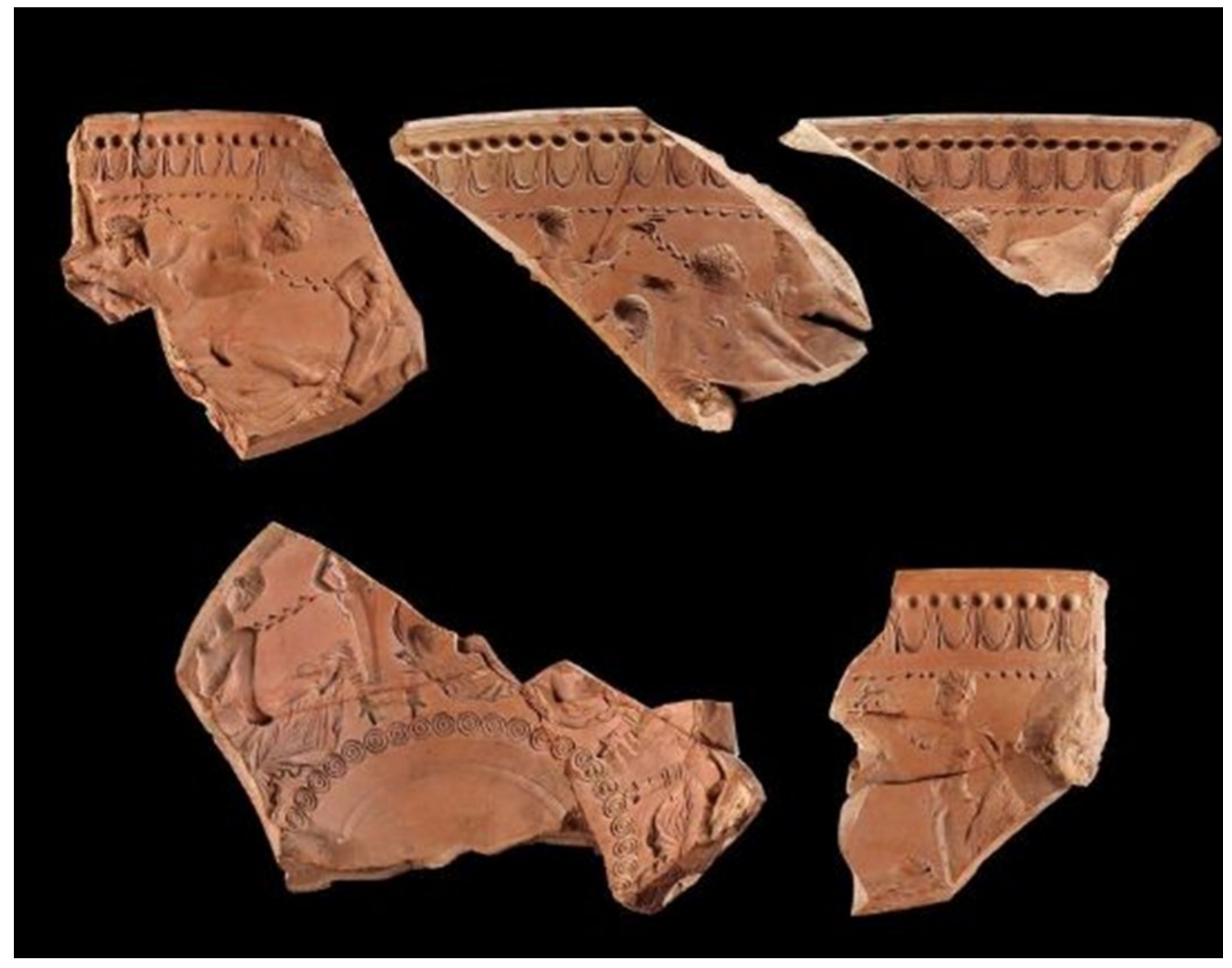

$\underline{\text { Figure } 101}$

Terracotta Mold Fragments for an Arretine Bowl

Res.O8.33c

Roman, Augustan Period, Late First Century B.C. E.

Height x diameter: 10 x $19 \mathrm{~cm}(3$ 15/16 x 7 1/2 in.)

Museum of Fine Arts, Boston Database

http://www.mfa.org/collections/object/mold-for-arretine-bowl-277503

(accessed 7/20/12) 


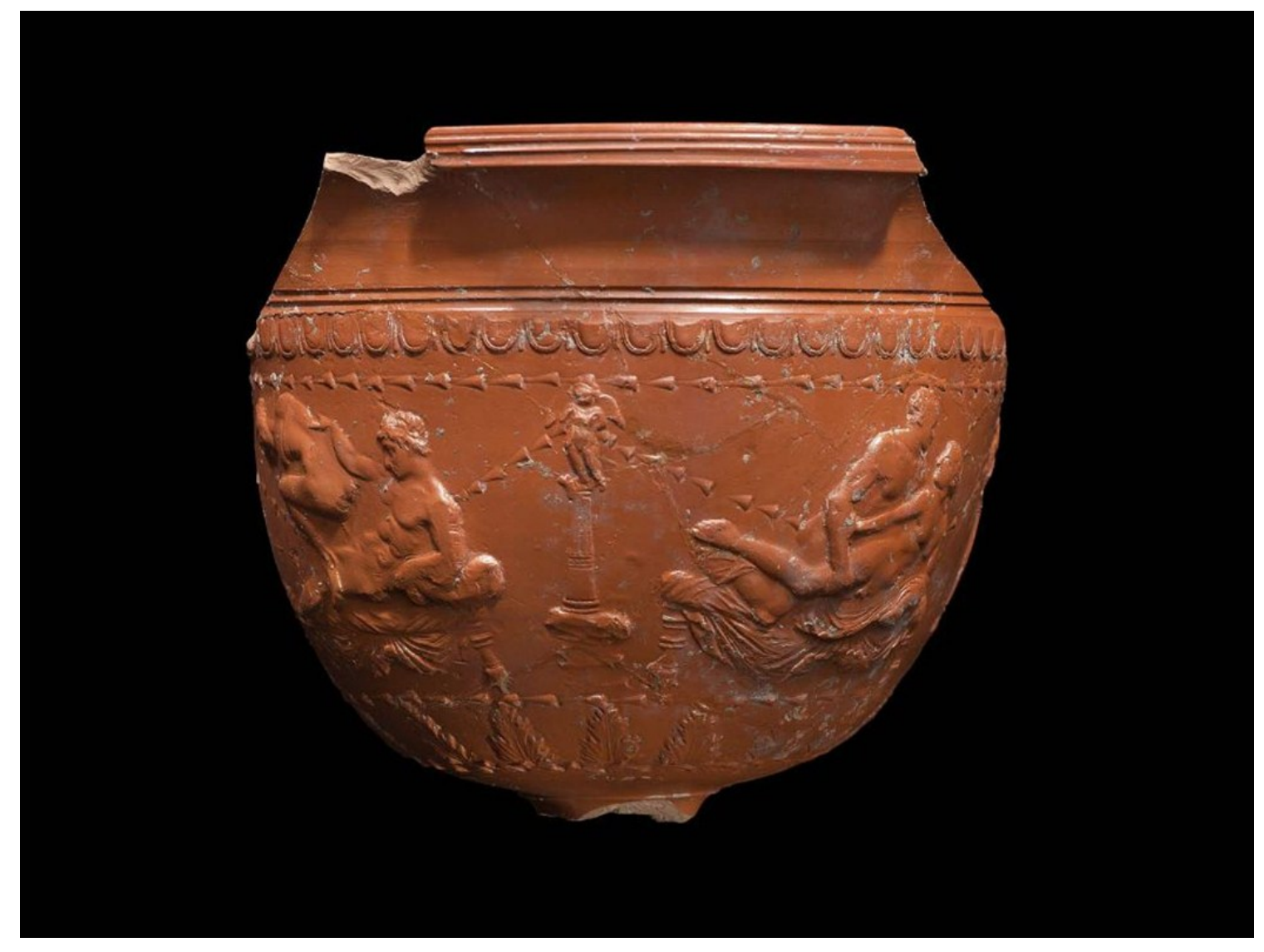

Figure 102

Fragmentary Terracotta Bowl with Cupid on a Column between Couples in Coitus MFA 13.109

Roman, Early Imperial period, Late First Century B.C.E. Height x diameter: 14 x $10.6 \mathrm{~cm}$ (5 1/2 x 4 3/16 in.)

Museum of Fine Arts, Boston Database

http://www.mfa.org/collections/object/fragmentary-bowl-with-cupid-on-a-columnbetween-couples-making-love-226939

(accessed 9/22/12) 

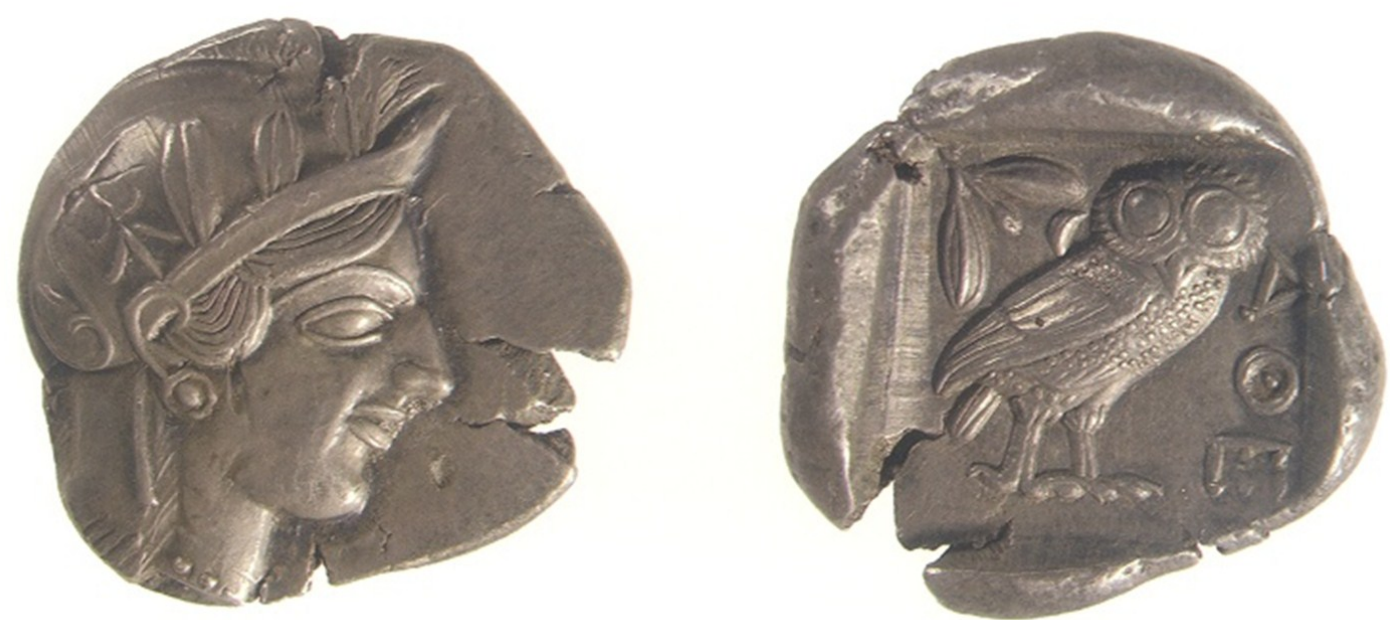

Silver Tetradrachm of Athens

Obverse: Head of Athena, facing right; Reverse: Owl, facing right

BCMA 1920.8.55

Greek, c. 514-407

Diameter: 1 inch

Bowdoin College Art Museum

James A. Higginbotham and Katherine M. Westley

Ars Antiqua: Treasures from the Ancient Mediterranean World at Bowdoin College

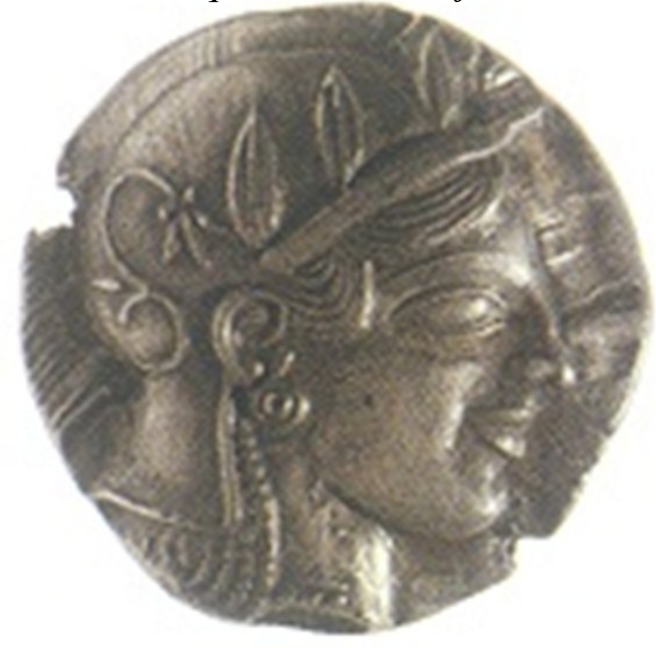

(2005)

Silver Tetradrachm of Athens

Obverse: Head of Athena, facing right; Reverse: Owl, facing right

RISD 13.1493

Greek c. 460-4340 .

Diameter: $15 / 16$ in

Rhode Island School of Design Art Museum

Selected Works, Museum of Art, Rhode Island School of Design.

(2008)

$\underline{\text { Figure } 103}$ 

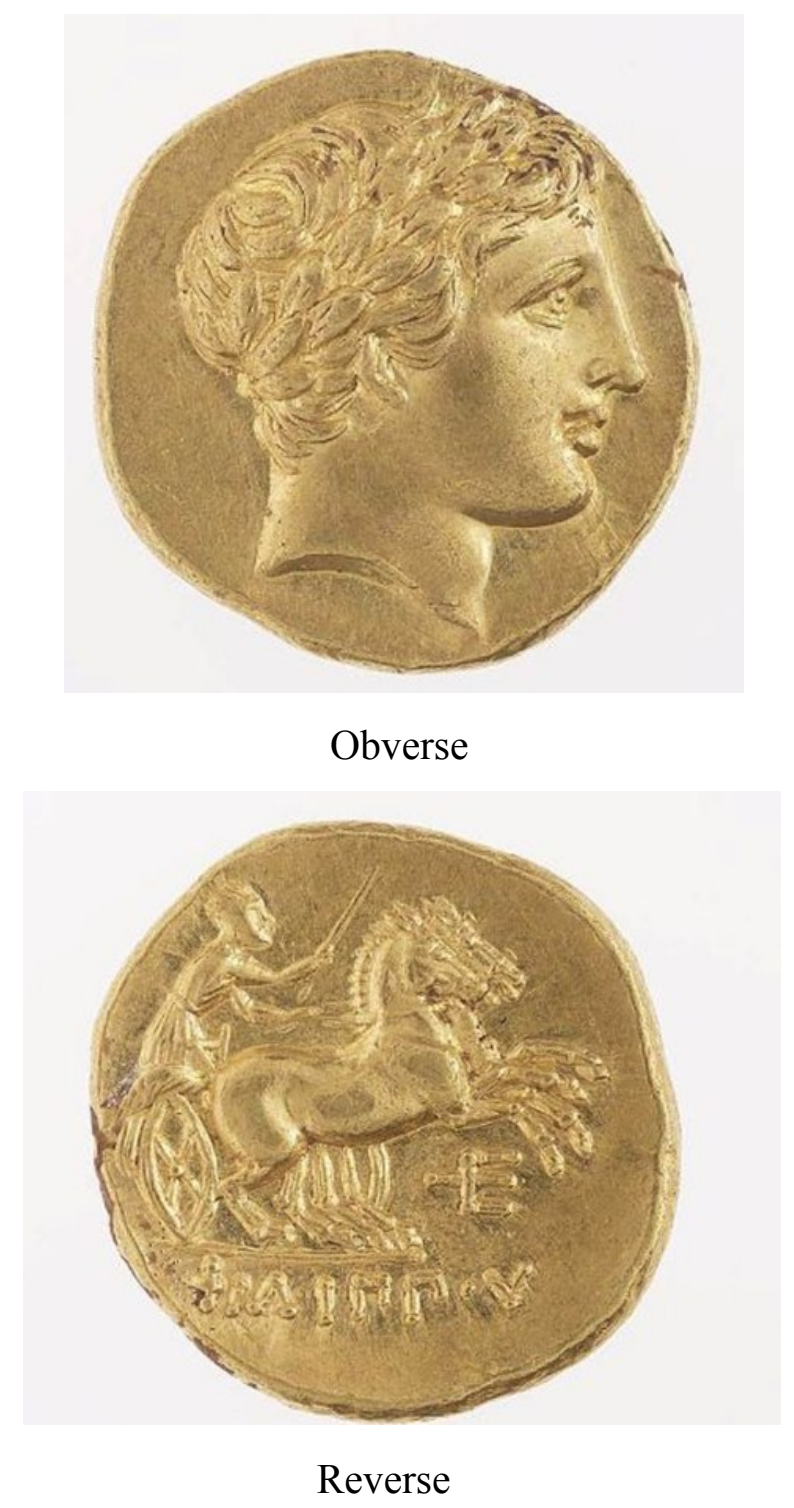

$\underline{\text { Figure } 104}$

Gold Stater of the Kingdom of Macedonia Struck under Philip II Obverse: Head of Apollo, facing right; Reverse: Biga, galloping right MFA 00.164

Greek, Late Classical Period, 359-336

Diameter: $19 \mathrm{~mm}$. Weight: $8.62 \mathrm{gm}$

Museum of Fine Arts, Boston Database

http://www.mfa.org/collections/object/stater-of-kingdom-of-macedonia-with-head-ofapollo-1295

(accessed 7/22/12) 

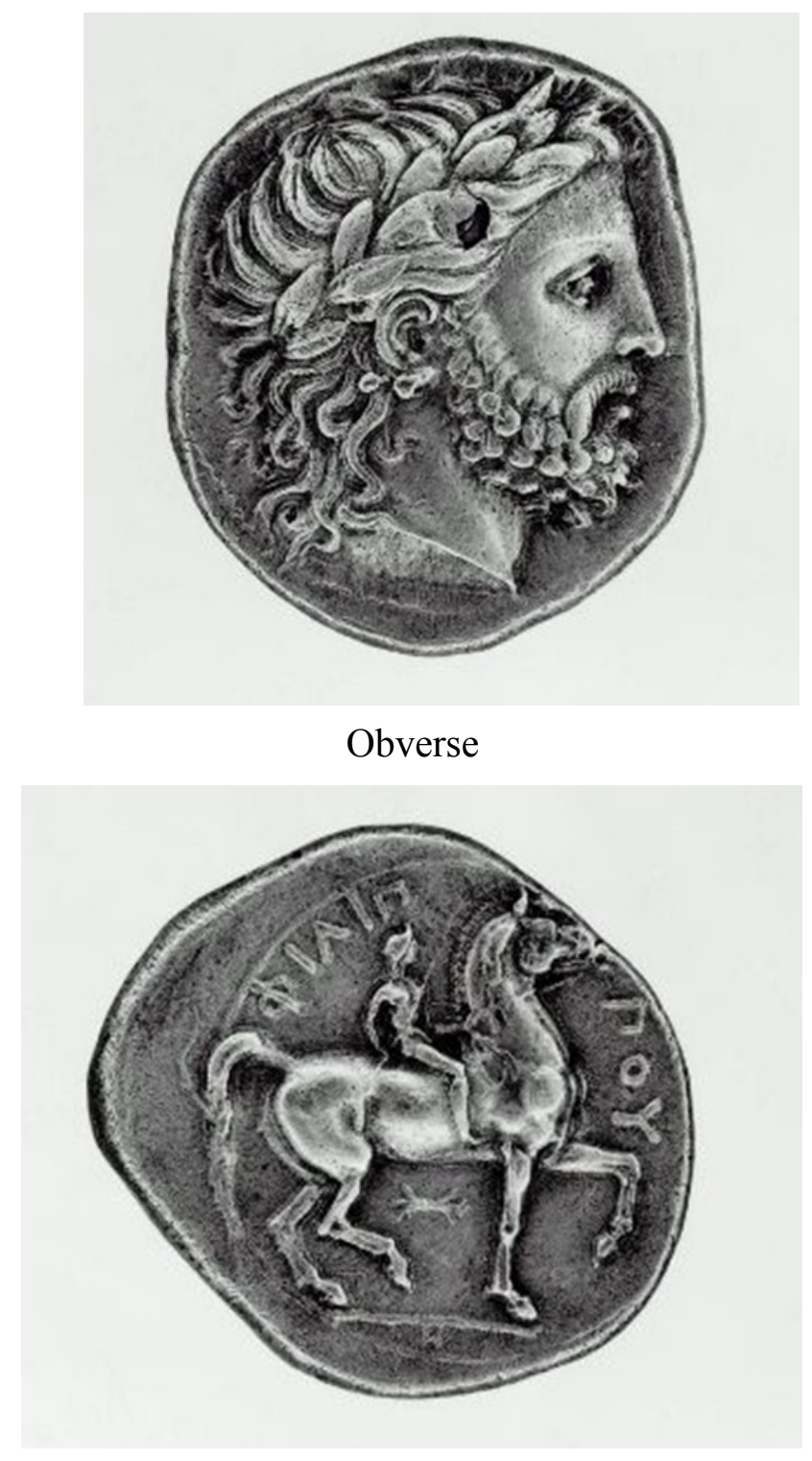

Reverse

$\underline{\text { Figure } 105}$

Silver Tetradrachm of Kingdom of Macedonia struck under Philip II Obverse: Head of Zeus, facing right; Reverse: Boy riding horse to right MFA 00.166

Greek, Late Classical Period, 359-336

Diameter: $26 \mathrm{~mm}$. Weight: $14.36 \mathrm{gm}$

Museum of Fine Arts, Boston Database

http:/www.mfa.org/collections/object/tetradrachm-of-kingdom-of-macedonia-with-head -of-zeus-struck-under-philip-ii-1297

(accessed 7/22/12) 

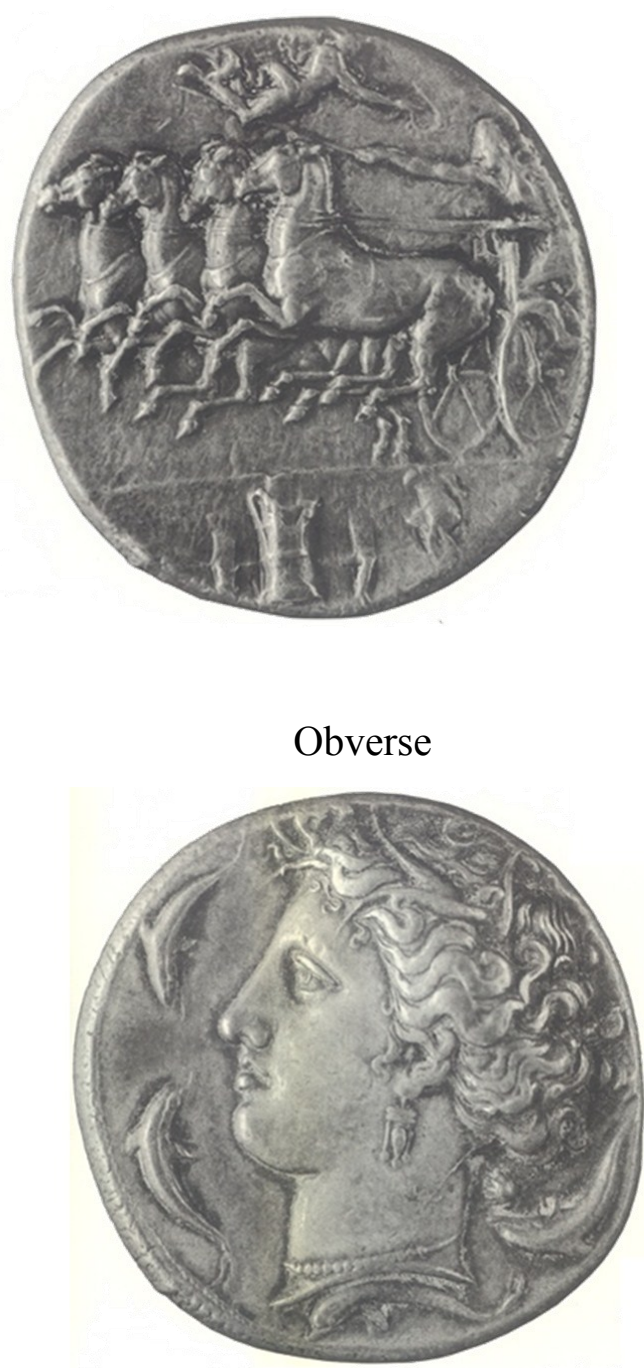

Reverse

Figure 106

Silver Decadrachm of Syracuse

Obverse: Quadriga, galloping left,, flying Nike; Reverse: Head of Arethusa, dolphins BCMA 1914.6.1

Greek, Classical Period, 412-410

Diameter: $17 / 16$ inches

Bowdoin College Art Museum

James A. Higginbotham and Katherine M. Westley

Ars Antiqua: Treasures from the Ancient Mediterranean World at Bowdoin College (2005) 


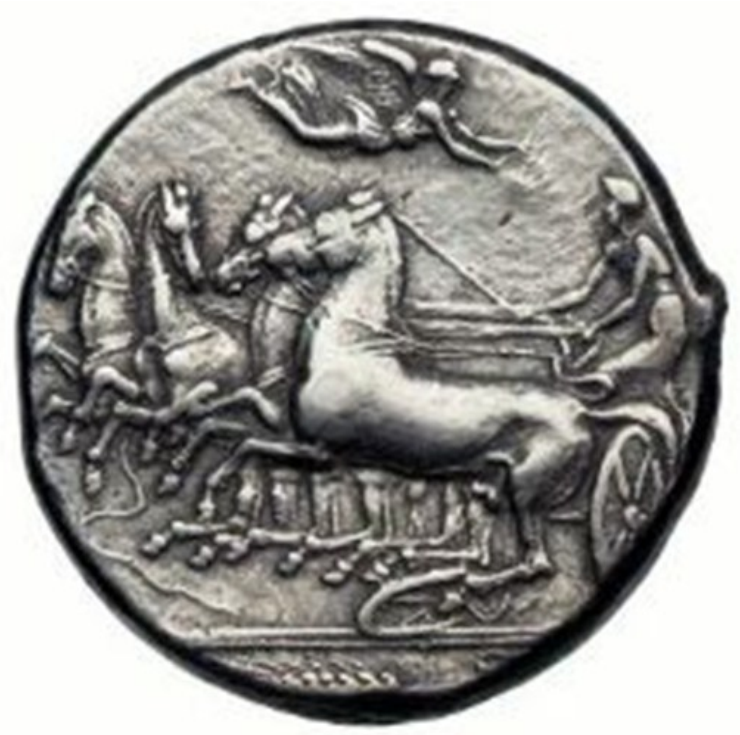

Obverse

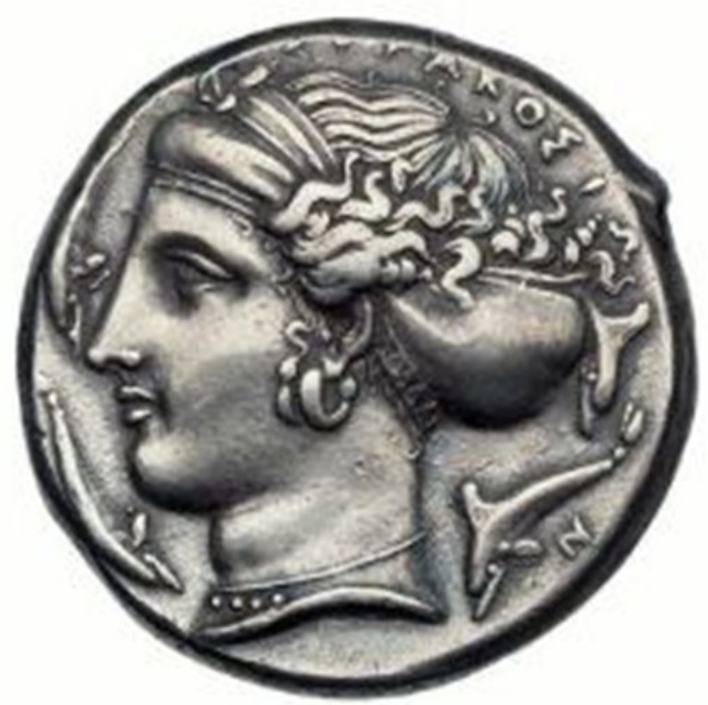

Reverse

$\underline{\text { Figure } 107}$

Silver Tetradrachm of Syracuse

Obverse: Quadriga, galloping left, flying Nike; Reverse: Head of Arethusa, dolphins MFA 04.556

Greek, Classical Period, 413-410

Diameter: 26 mm. Weight: 17.23 gm.Museum of Fine Arts, Boston Database http://www.mfa.org/collections/object/tetradrachm-of-syracuse-with-quadriga-1128 


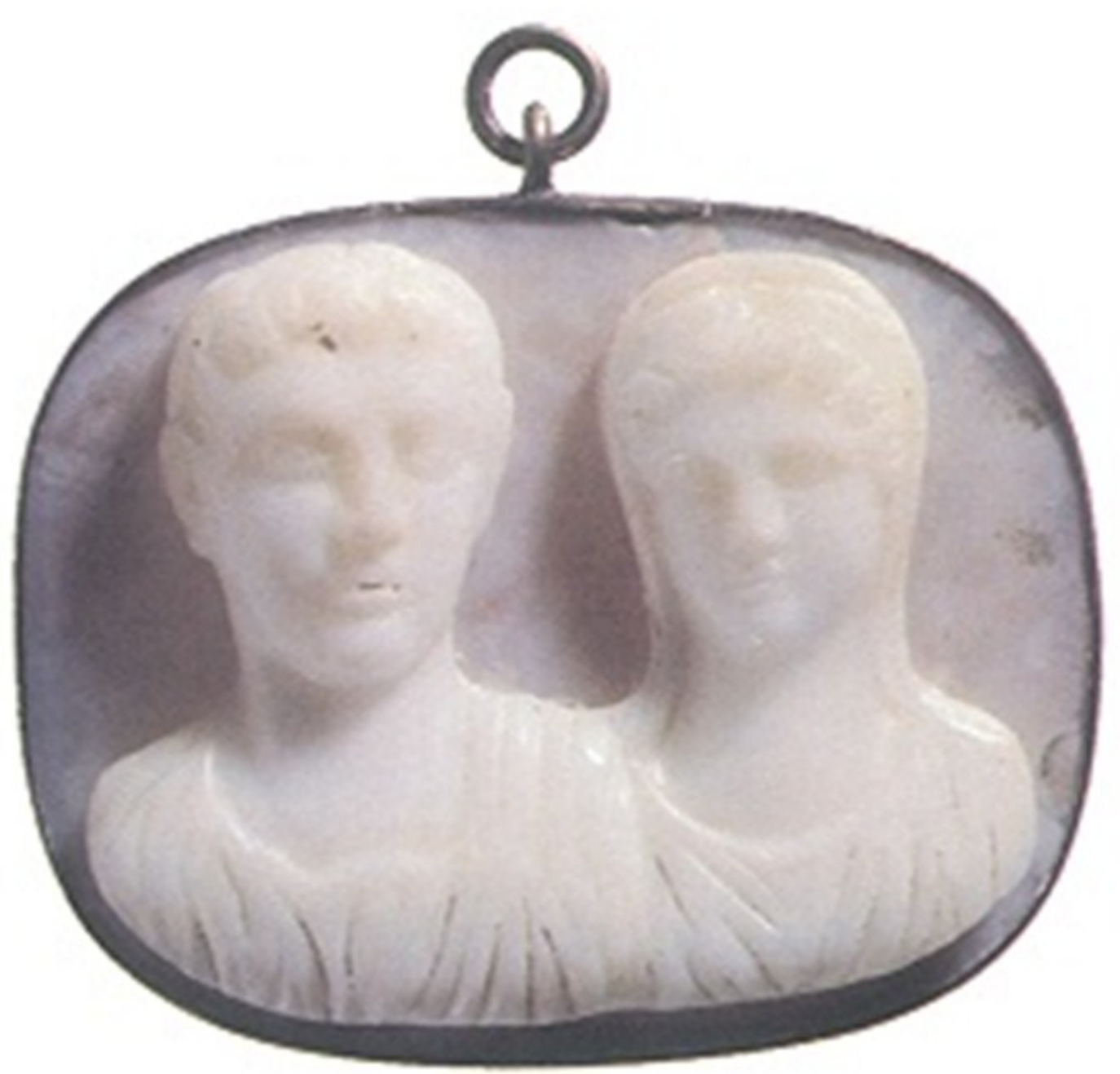

$\underline{\text { Figure } 108}$

Cameo of a Man and Woman

BCMA 1915.1

Roman, First Century B.C.E.

Layered chalcedony

$111 / 16 \times 15 / 16$ inches

Bowdoin College Museum of Art

James A. Higginbotham and Katherine M. Westley

Ars Antiqua: Treasures from the Ancient Mediterranean World at Bowdoin College (2005) 


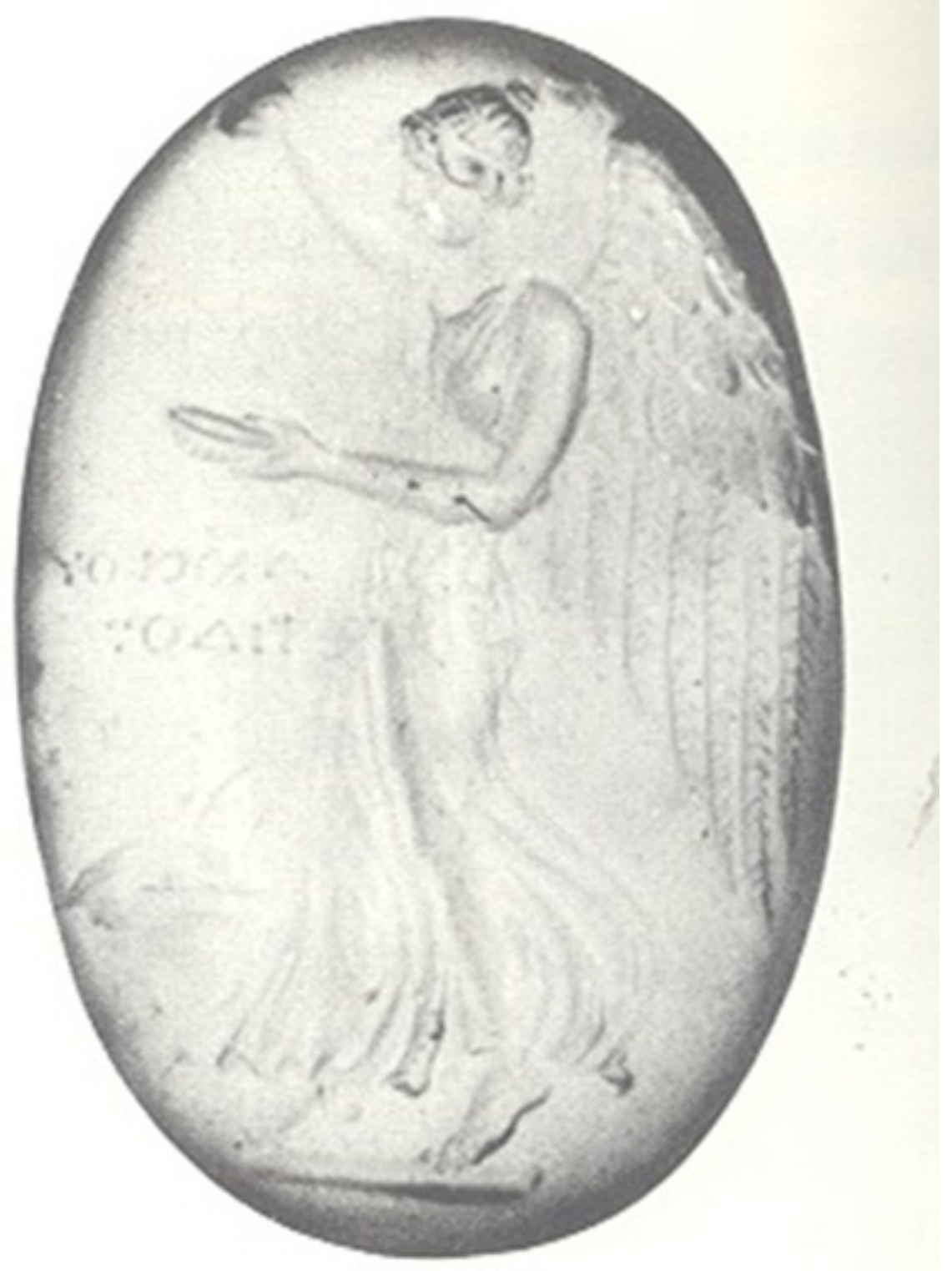

$\underline{\text { Figure } 109}$

\author{
Winged Victory \\ Greek 40-30 B.C.E. or Nineteenth-Century Forgery \\ RISD 25.094 \\ oval intaglio \\ Signed by Dioskourides \\ $1.88 \times 1.2 \mathrm{~cm}$
}

Rhode Island School of Design Art Museum

Tony Hackens, Catalogue of Classical Collection: Classical Jewelry (1976) 


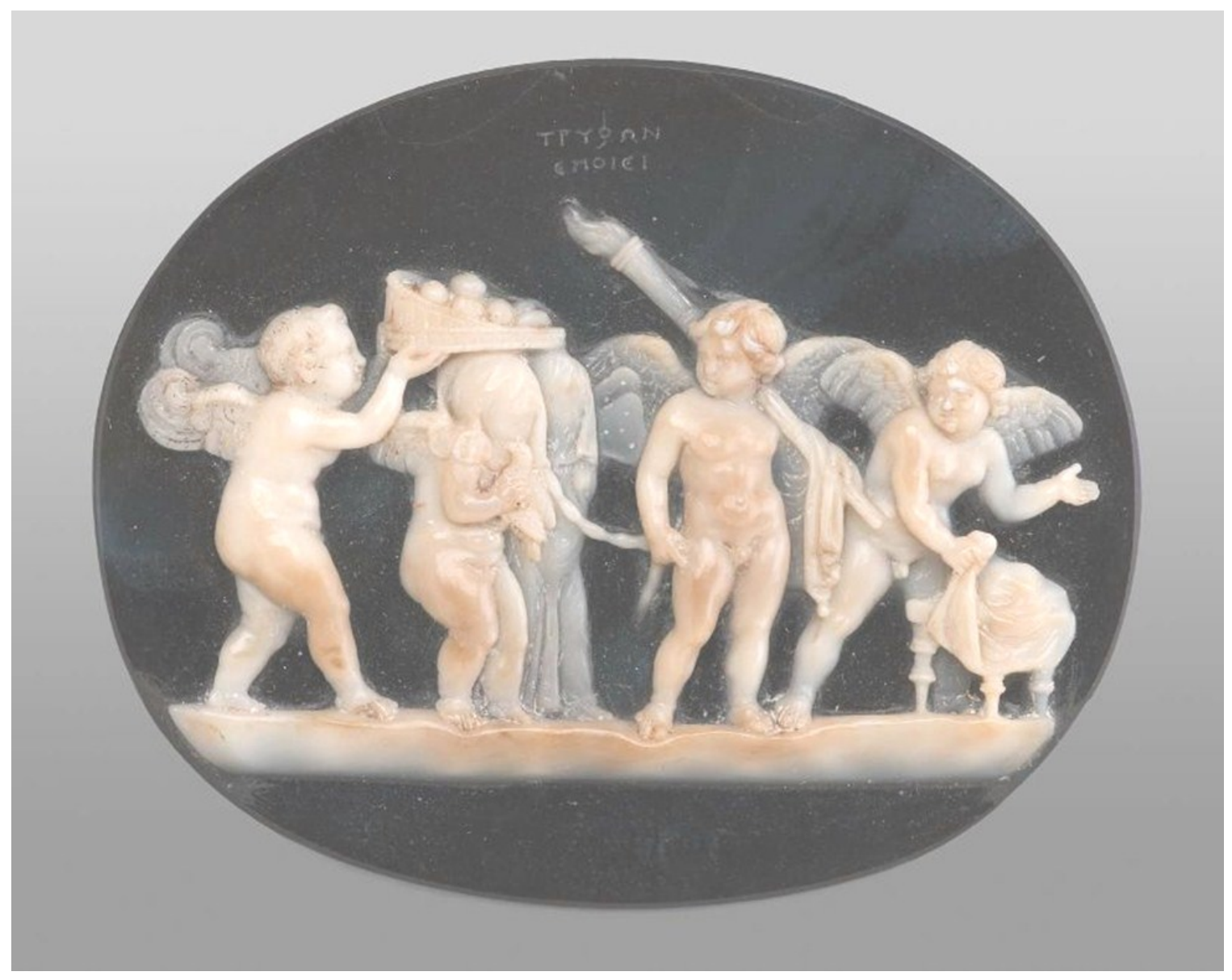

$\underline{\text { Figure } 110}$

Cameo with the Wedding of Cupid and Psyche

MFA 99.101

Roman, Late Republican or Early Imperial Period, Mid-to Late First Century B.C.E. Layered onyx

$4.5 \times 3.7 \times 0.6 \mathrm{~cm}(13 / 4 \times 17 / 16 \times 1 / 4$ in.)

Signed by Tryphon

Museum of Fine Arts, Boston Database

http://www.mfa.org/collections/object/cameo-with-the-wedding-of-cupid-and-psyche-or -an-initiation-rite-155692

(accessed 7/22/12) 


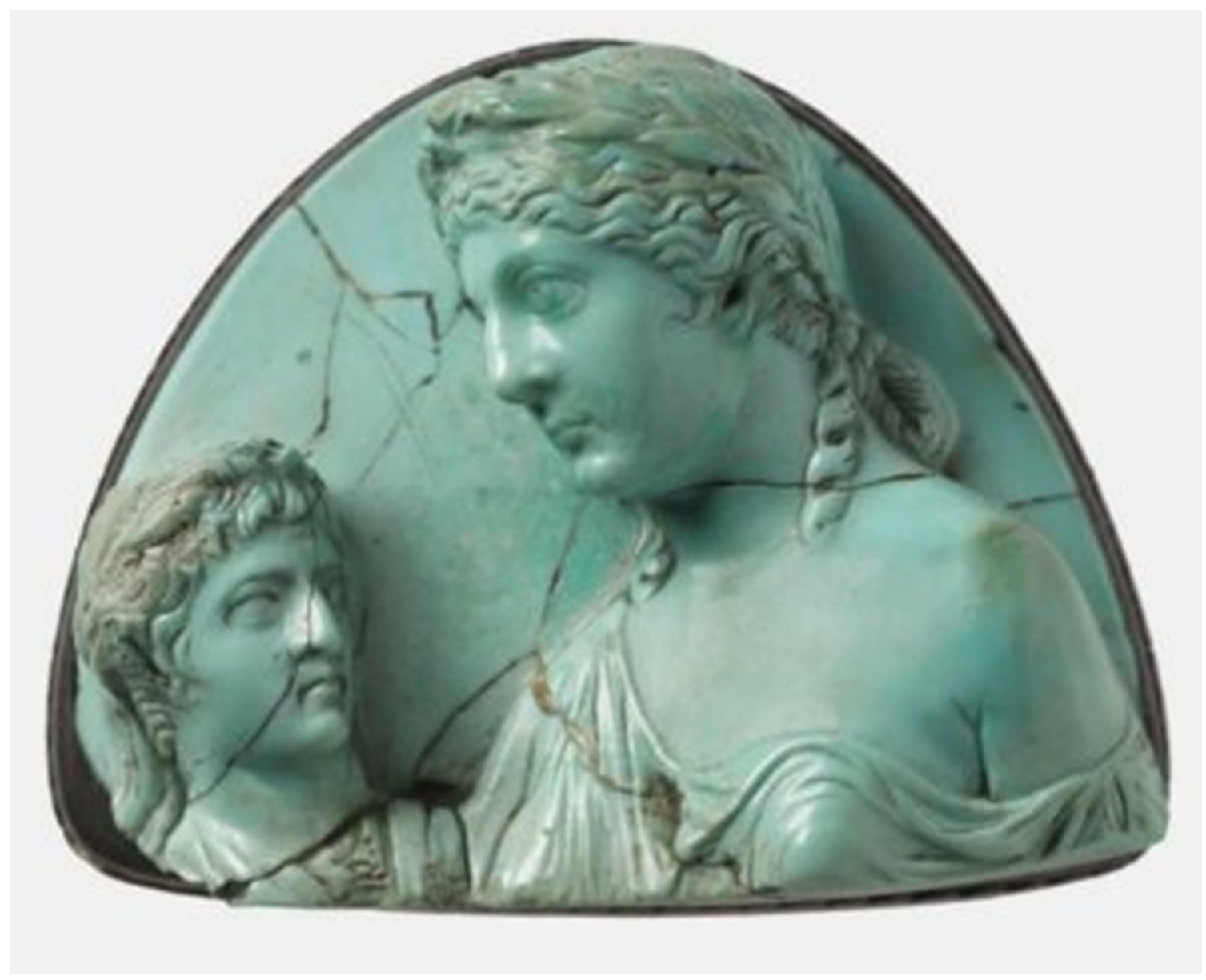

\section{$\underline{\text { Figure } 111}$}

Cameo with Livia Holding a Bust of Augustus (?)

MFA 99.109

Roman, Imperial Period, 14-37 C.E.

Turquoise

Height $x$ length: $3.1 \times 3.8 \mathrm{~cm}(11 / 4 \times 11 / 2$ in. $)$

Museum of Fine Arts, Boston Database

http://www.mfa.org/collections/object/cameo-with-livia-holding-a-bust-of-augustus155690

(accessed 7/22/12) 


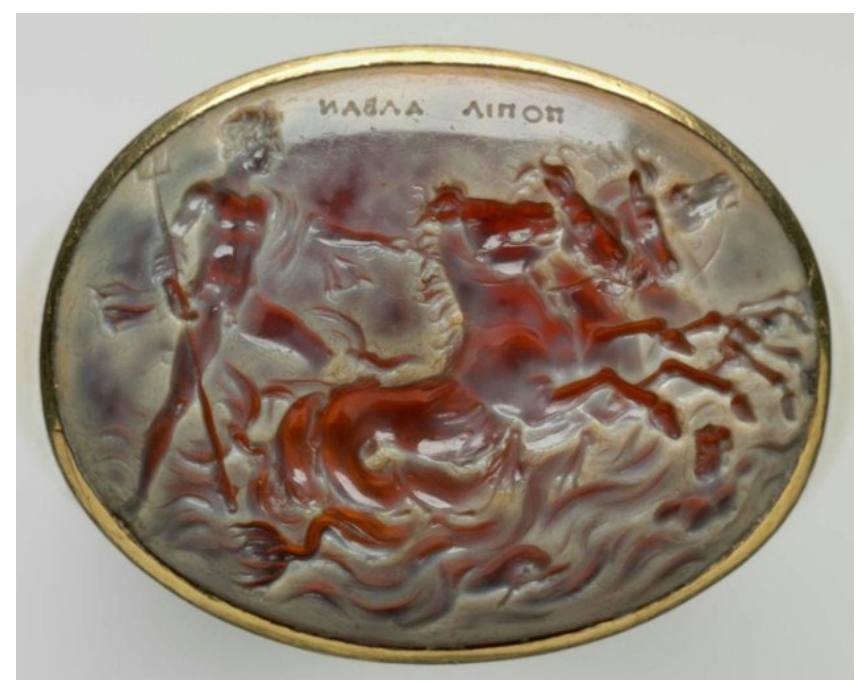

Exterior

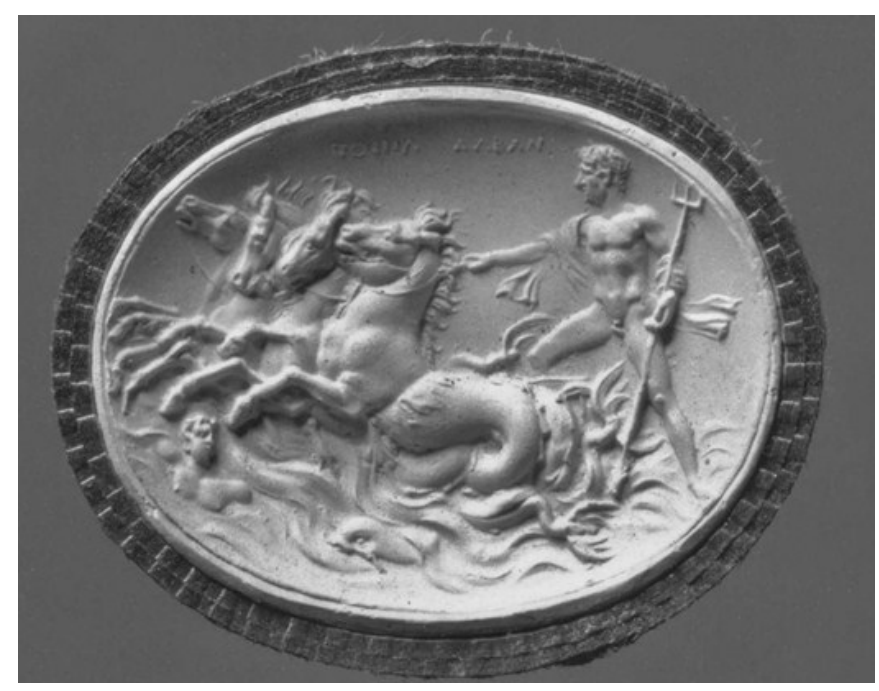

Impression

\section{$\underline{\text { Figure } 112}$}

Intaglio with Octavian (?) as Neptune

MFA 27.733

Roman, Early Imperial Period, about 31-27 B.C.E. Length: $2.1 \mathrm{~cm}$ (13/16 in.)

Sard, intaglio

Inscribed in Greek: POPIL ALBAN (Popilius Albanus )

Museum of Fine Arts, Boston Database

http://www.mfa.org/collections/object/intaglio-with-octavian-as-neptune-242574 


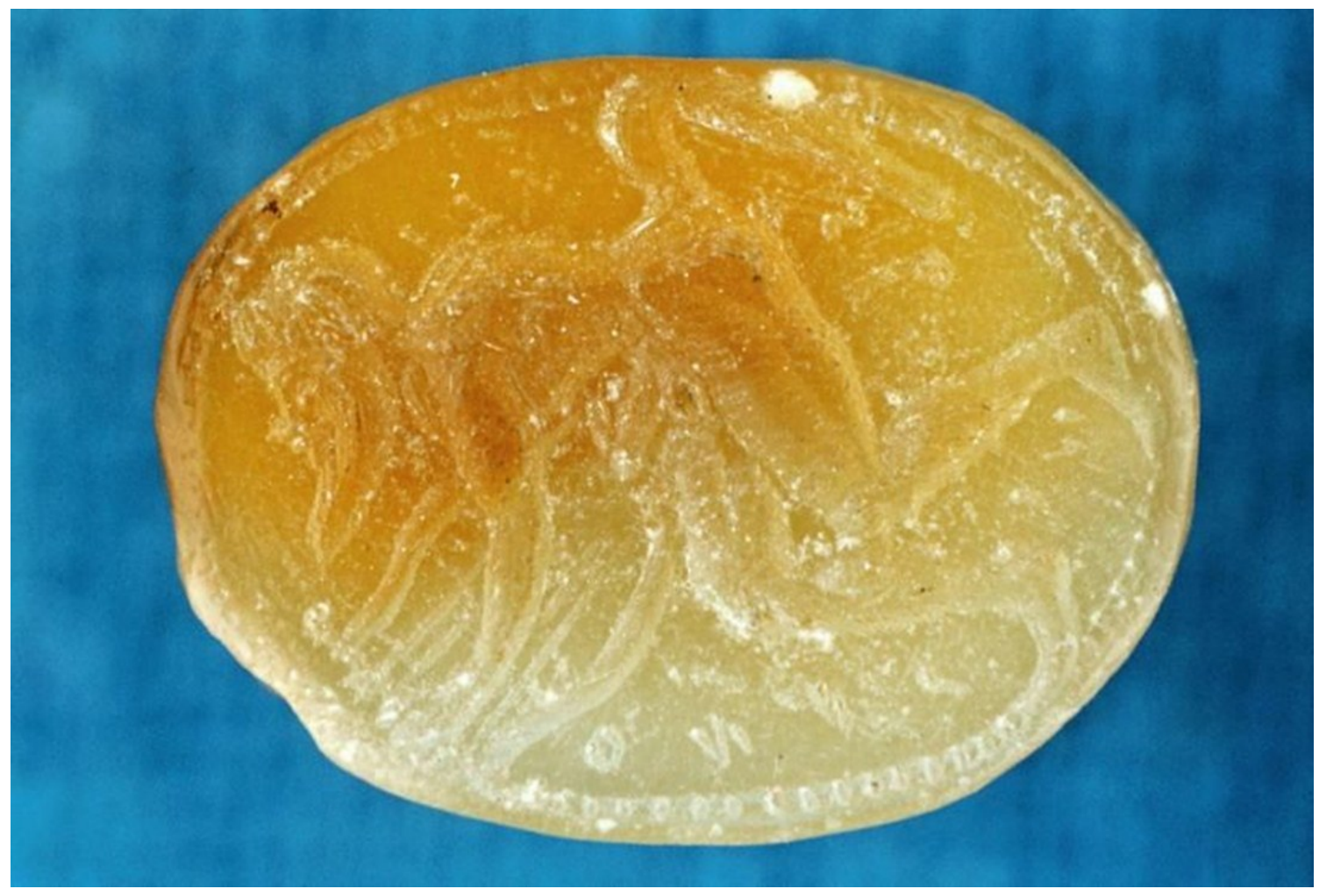

$\underline{\text { Figure } 113}$

Scarab with Satyr Tuning a Lyre MFA 27.673

Greek, Archaic Period, 525-500

Length: $1.6 \mathrm{~cm}(5 / 8$ in.)

Steatite

Signed by Onesimos

Museum of Fine Arts, Boston Database

http://www.mfa.org/collections/object/scarab-with-a-satyr-tuning-his-lyre-242480

(accessed 7/22/12) 


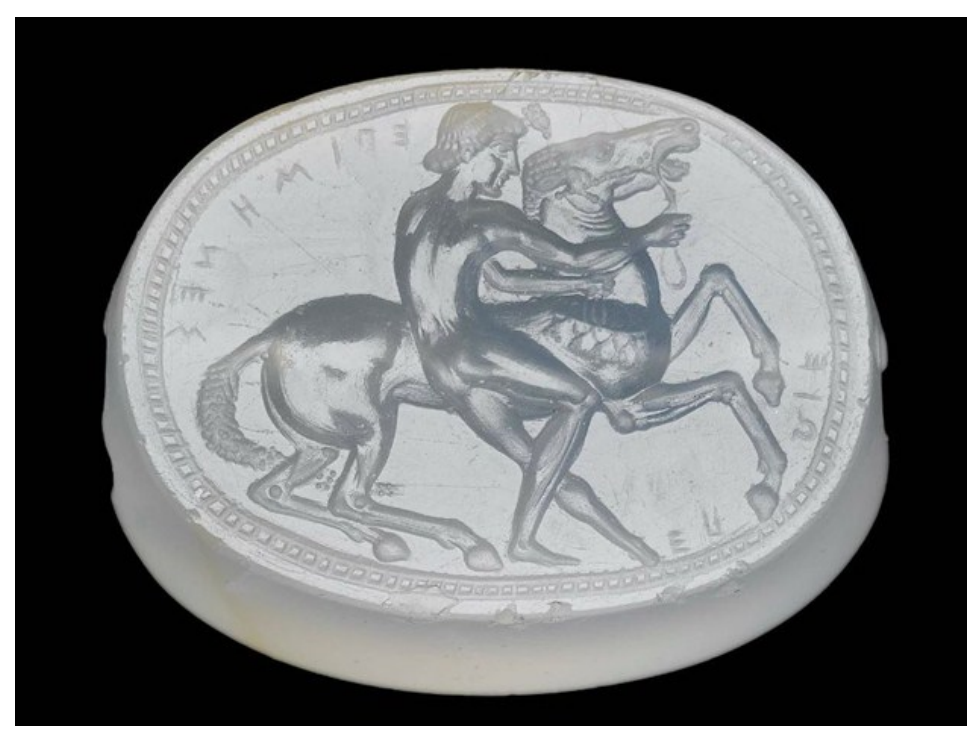

exterior

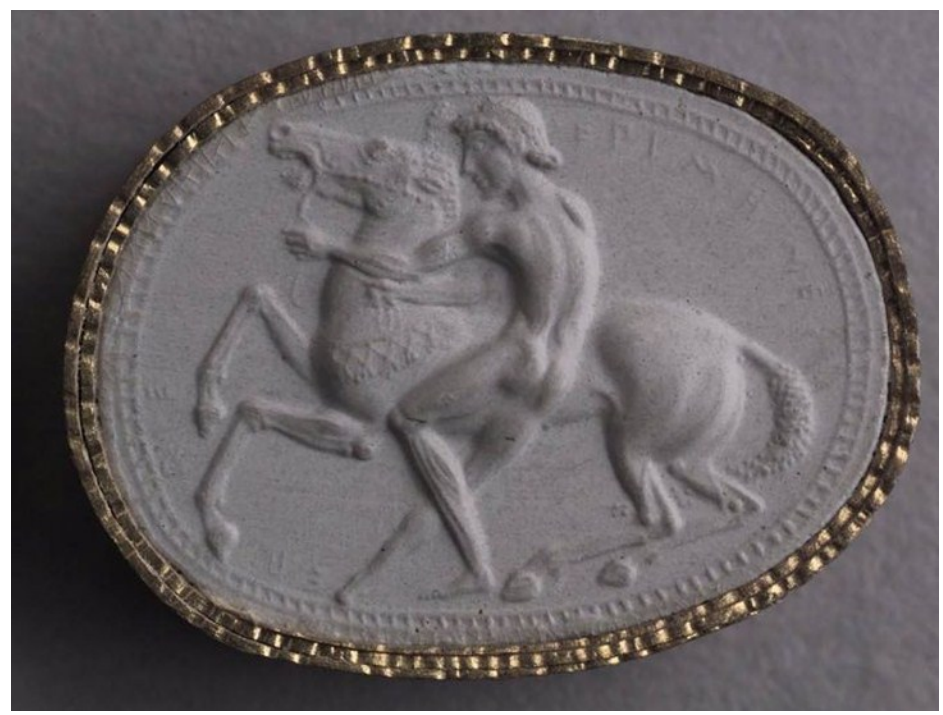

Impression

\section{$\underline{\text { Figure } 114}$}

Scaraboid Gem with a Nude Youth and a Horse

MFA 27.677

Greek, Late Archaic Period, about 500

Width x height: $1.6 \times 1.1 \mathrm{~cm}(5 / 8 \times 7 / 16$ in. $)$

Chalcedony

Signed by Epimenes

Museum of Fine Arts, Boston Database

http://www.mfa.org/collections/object/scaraboid-gem-with-a-nude-youth-and-a-horse-

242484

(accessed 7/22/12) 


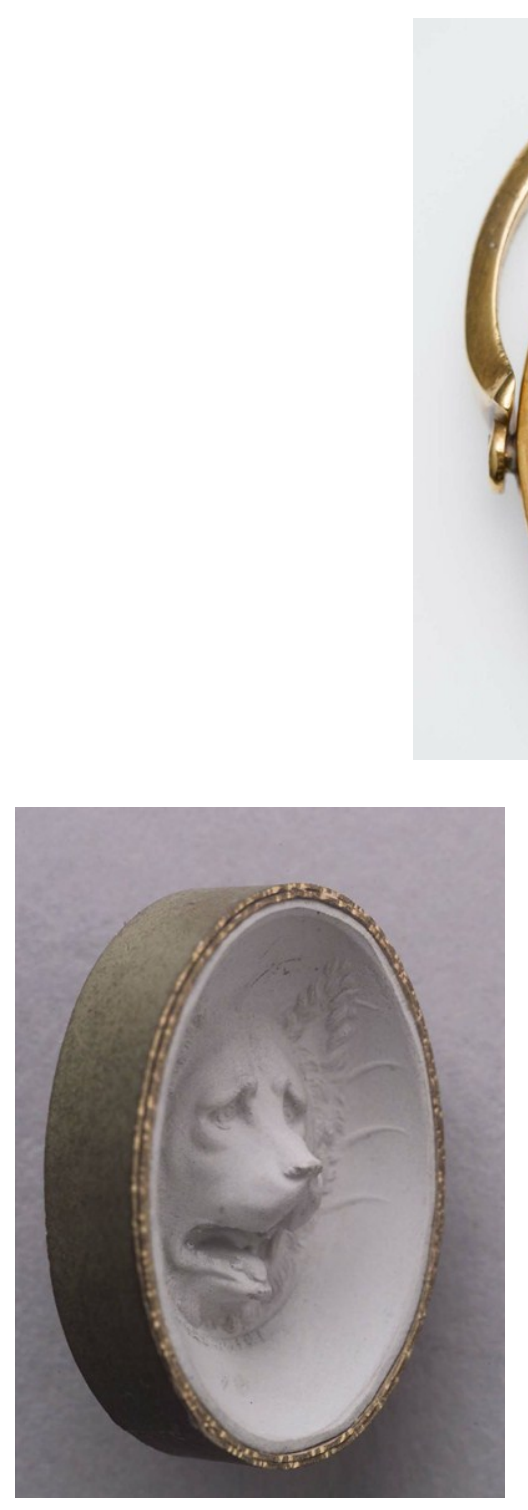

Plaster impression

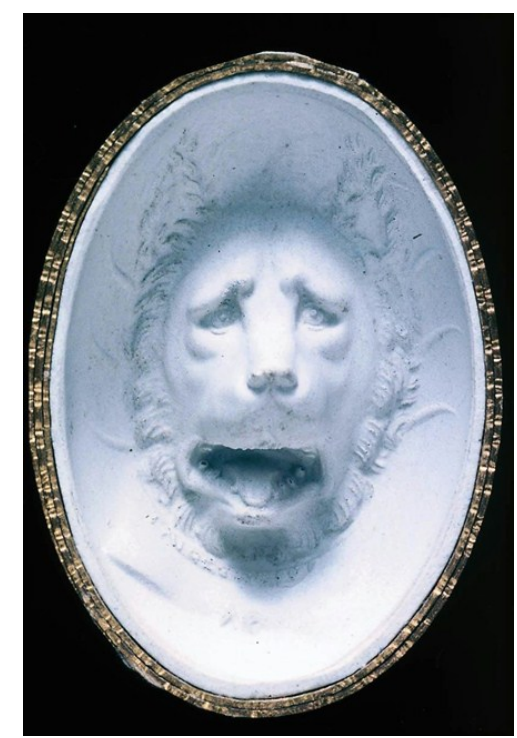

Plaster impression

\section{Figure 115}

Oval Gem with the Head of Sirius (the Dog Star)

MFA 27.734

Roman, Republican or Early Imperial Period, 1st century B.C.E.

Overall: 2.1 x $1.5 \mathrm{~cm}(13 / 16 \times 9 / 16$ in.)

Garnet

Signed by Epimenes

Museum of Fine Arts, Boston Database

http://www.mfa.org/collections/object/oval-gem-with-the-head-of-sirius-the-dog-star242575

(accessed 7/22/12) 

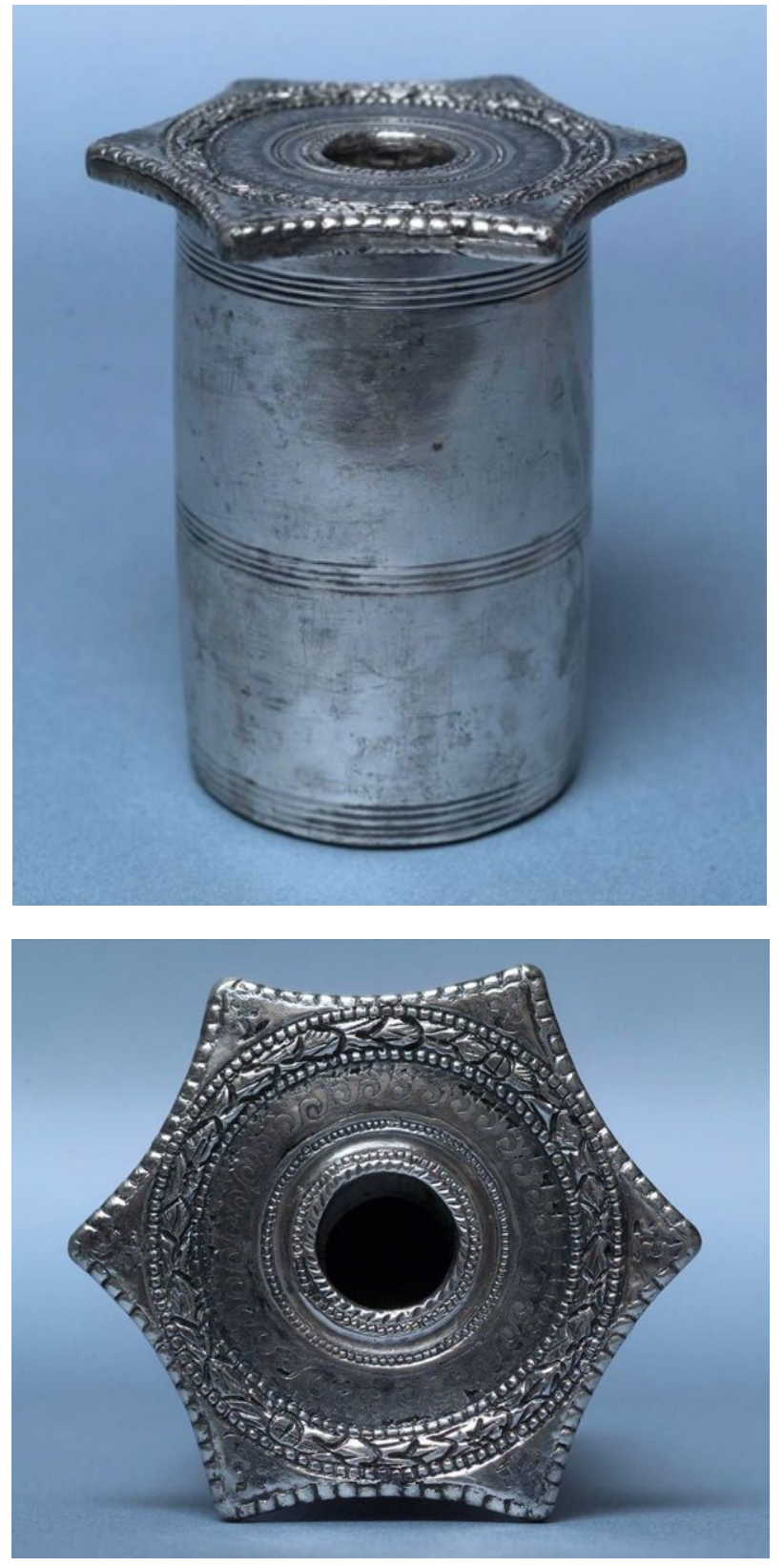

$\underline{\text { Figure } 116}$

Inkwell

MFA 01.8189

Roman

Legacy dimension: $0.073 \mathrm{H}$

Silver

Museum of Fine Arts, Boston Database

http://www.mfa.org/collections/object/inkstand-180737

(accessed 7/22/12) 


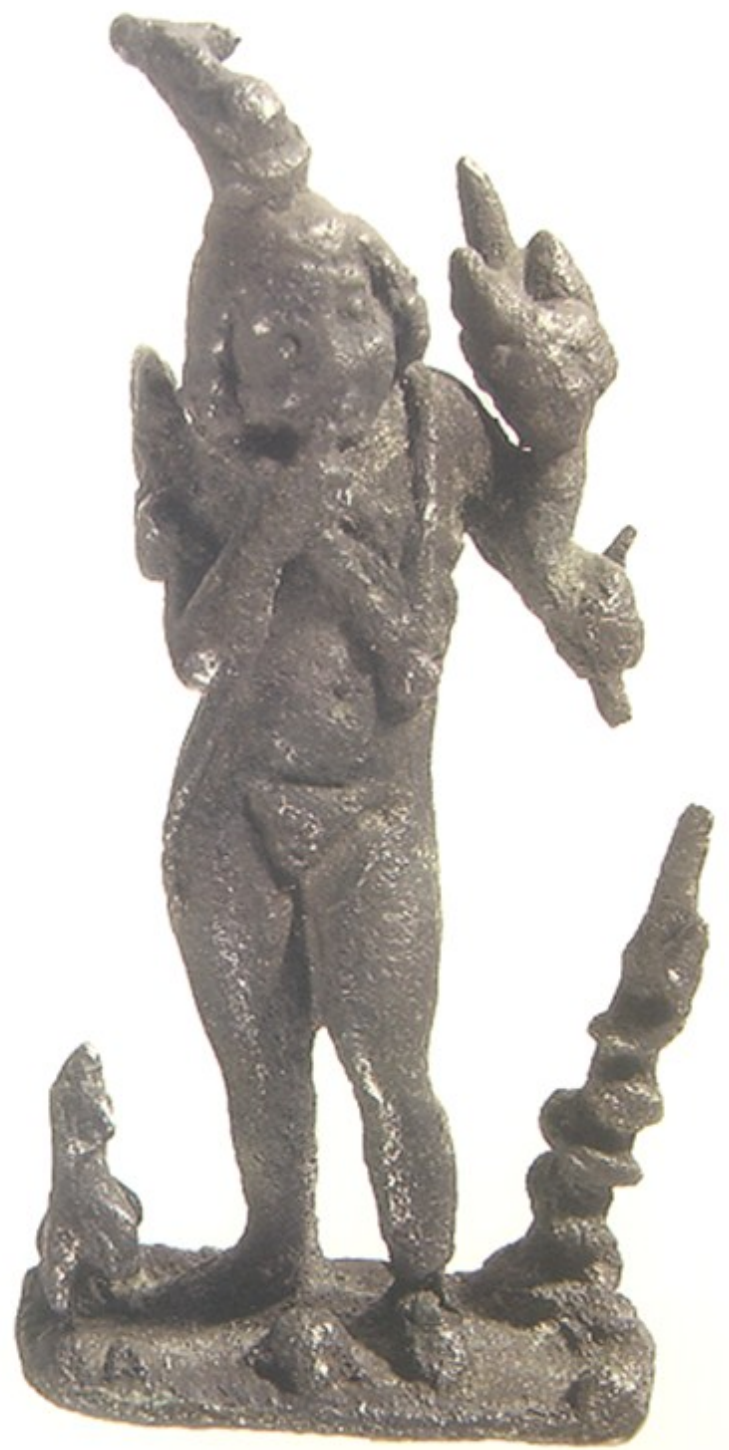

Figure 117

Silver Statuette of Harpocrates

BCMA 1915.52

Greek, Hellenistic, Second to First Century B.C.E.

$13 / 16$ inches

Bowdoin College Museum of Art

James A. Higginbotham and Katherine M. Westley

Ars Antiqua: Treasures from the Ancient Mediterranean World at Bowdoin College

(2005) 

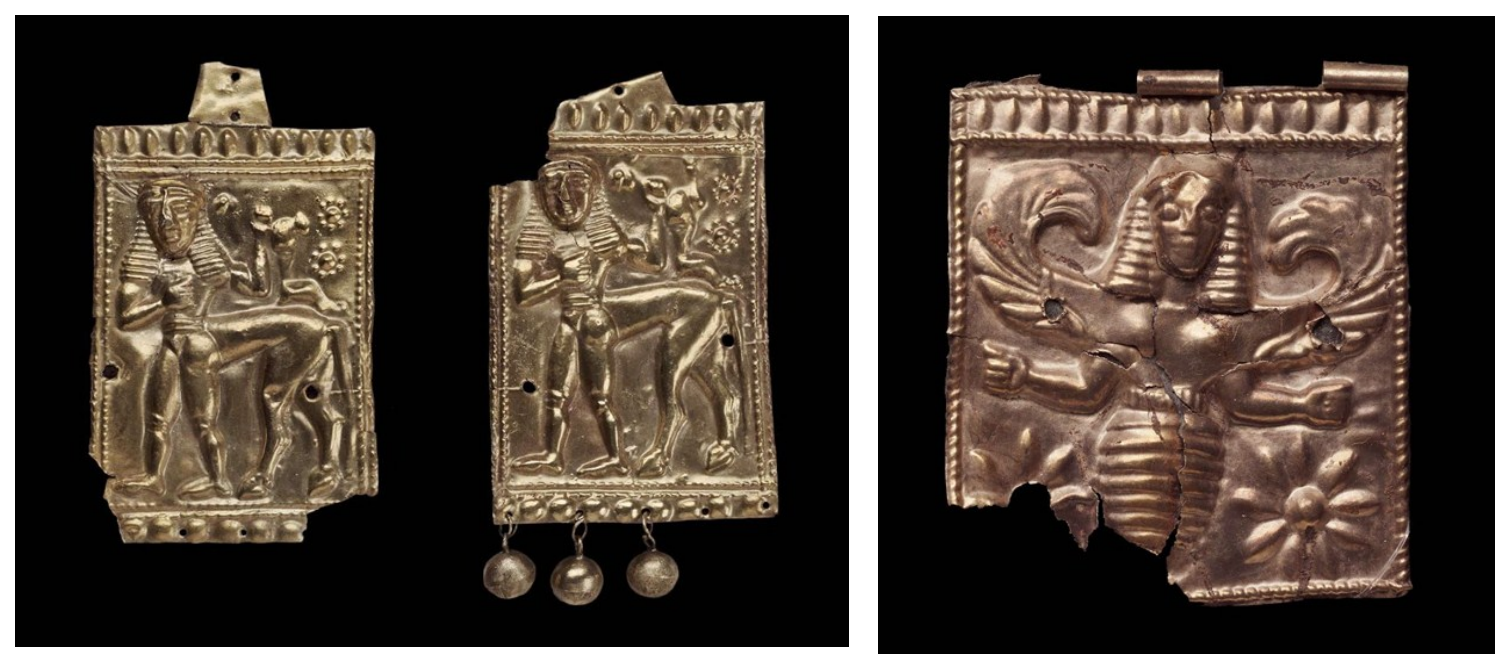

$\underline{\text { Figure } 118}$

Plaques with Centaur Holding a Rabbit MFA 99.386

Greek, East Greek, Orientalizing Period, 660-640

Height x width: 6.3 x $3.4 \mathrm{~cm}(21 / 2 \times 1$ $5 / 16$ in.) Electrum

Museum of Fine Arts, Boston Database http://www.mfa.org/collections/object/ plaque-with-a-centaur-holding-a-rabbit187274

(accessed 7/22/12)
Plaque with a Bee Woman MFA 99.397

Greek, East Greek, Orientalizing Period, 660-640

Height: $3 \mathrm{~cm}$ (1 3/16 in.); width: $2.7 \mathrm{~cm}$ (1 $1 / 16$ in.) Electrum

Museum of Fine Arts, Boston Database http:/www.mfa.org/collections/object/ plaque-with-a-bee-woman-187282 (accessed 7/22/12) 


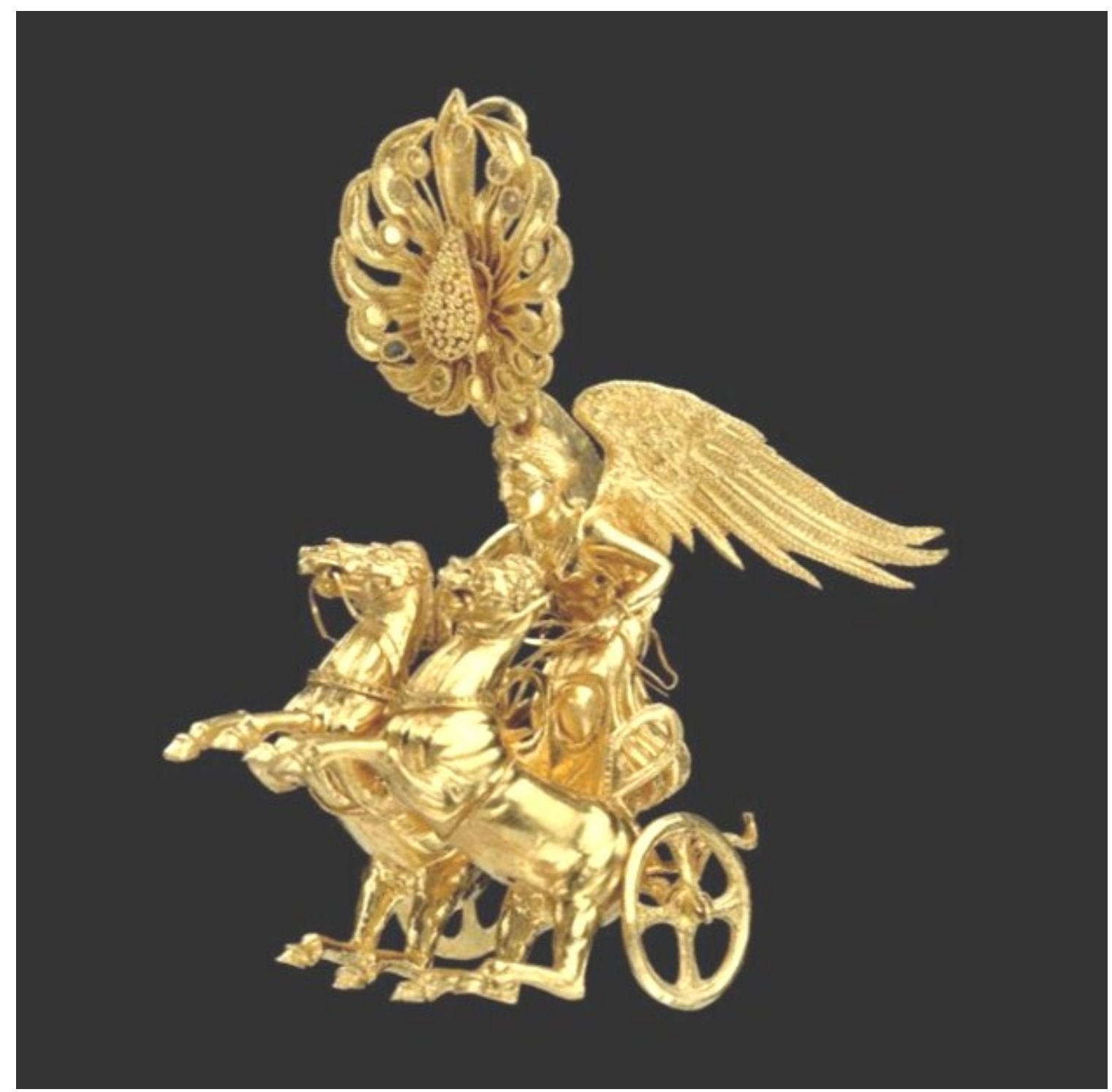

$\underline{\text { Figure } 119}$

Earring with Nike Driving a Two-horse Chariot MFA 98.788

Greek, Northern Greek, Late Classical or Early Hellenistic Period, c. 350-325

Height: $5 \mathrm{~cm}$ (1 15/16 in.)

Gold

Museum of Fine Arts, Boston Database

http://www.mfa.org/collections/object/earring-with-nike-driving-a-two-horse-chariot155707

(accessed 7/22/12) 

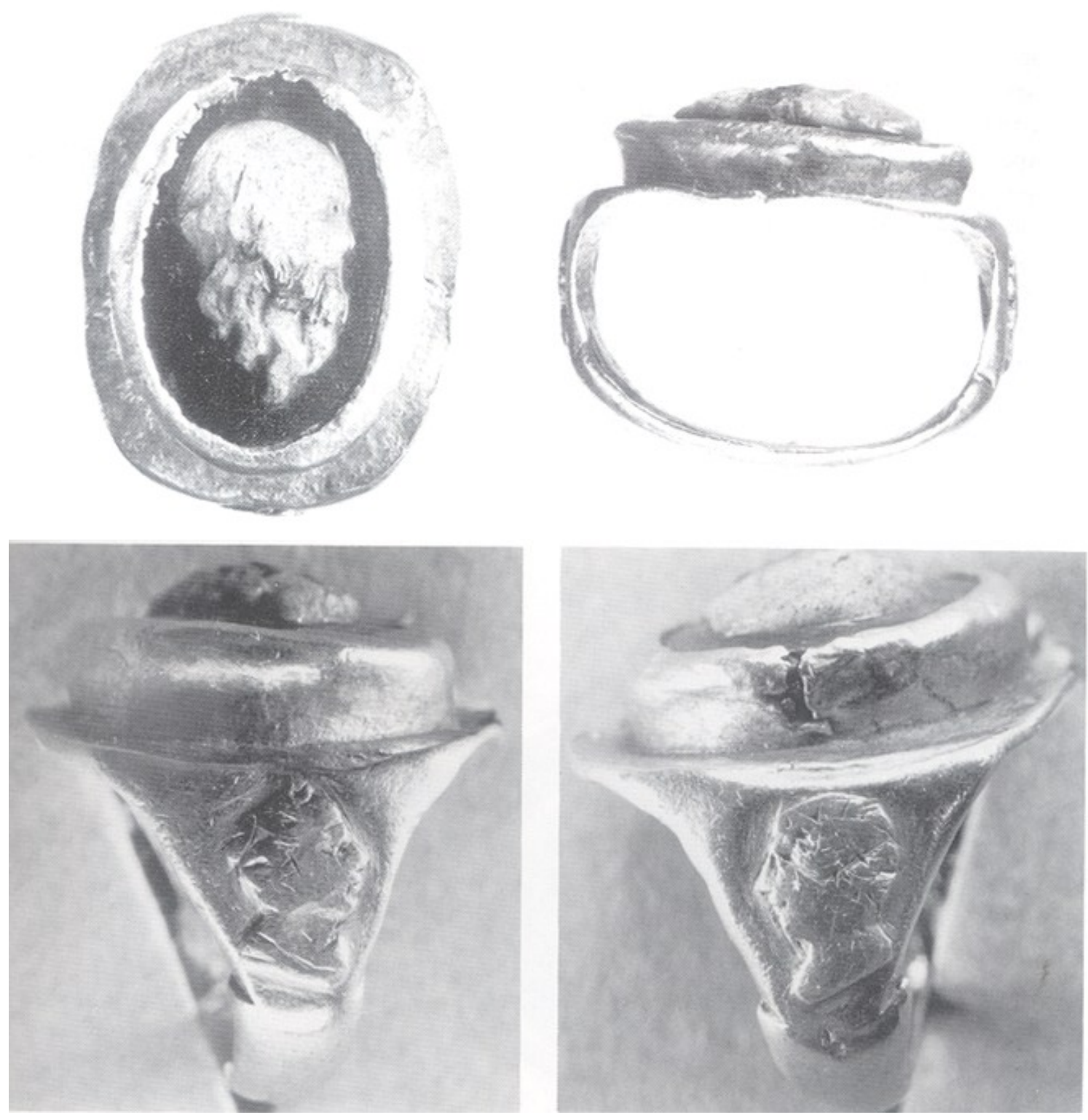

$\underline{\text { Figure } 120}$

Cameo Ring with a Mask of Silenus

BCMA 1923.114

Roman, First-Second Century C.E.

$13 / 16$ in $\times 9 / 16$ in $(2.1 \mathrm{~cm} \times 1.5 \mathrm{~cm})$

Cameo, gold, sardonyx

Bowdoin College Museum of Art

Tony Hackens, Gold: Jewelry: Craft, Style, and Meaning

from Mycenae to Constantinople (1983) 

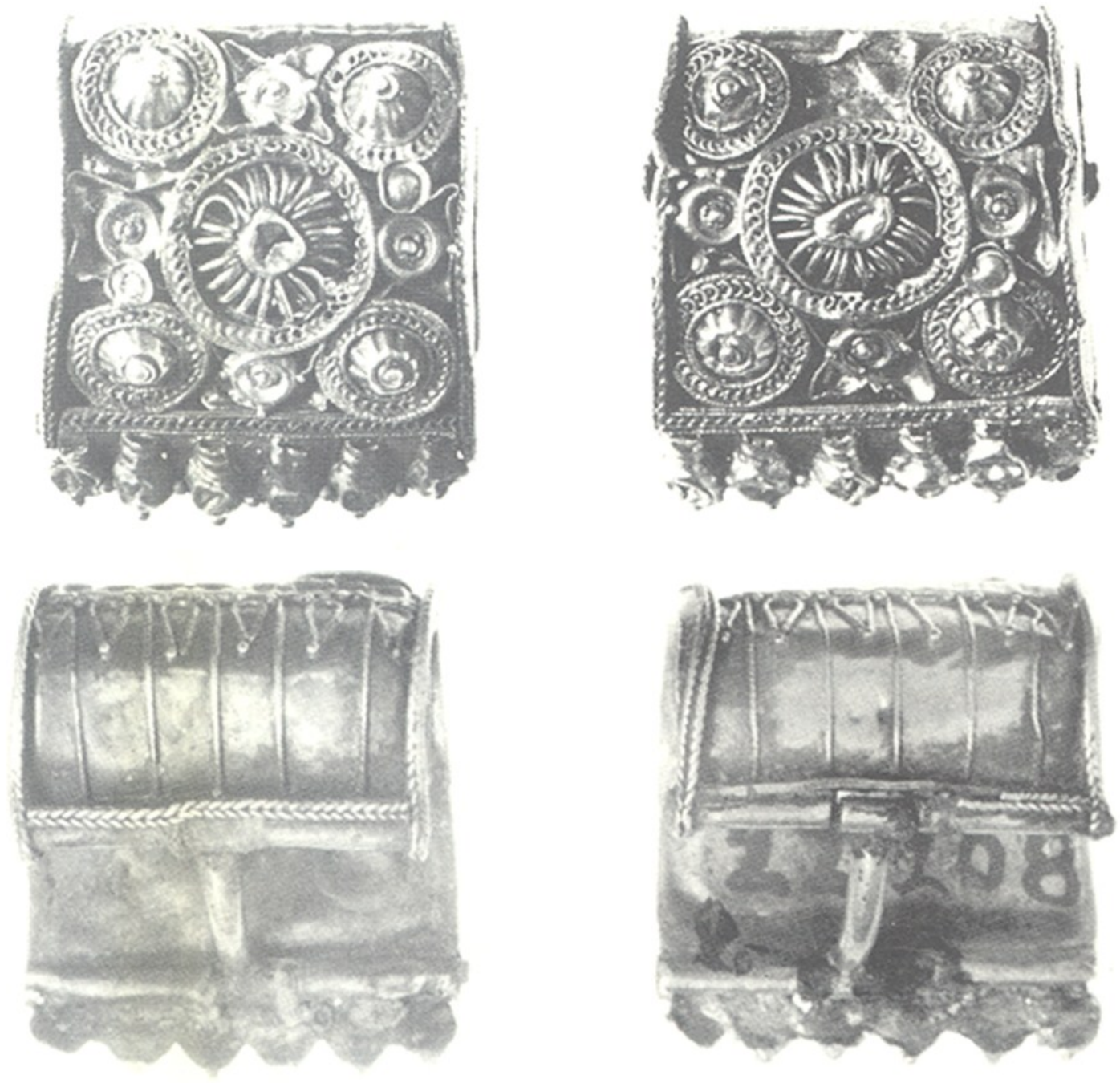

A: front and back

B: front and back

Figure 121

Pair of Etruscan Earrings

RISD 22.208a, b Gold

Height: $4 \mathrm{~cm}$ (1 15/16 inches)

Rhode Island School of Design Art Museum

Tony Hackens, Gold Jewelry: Craft, Style, and Meaning

from Mycenae to Constantinople (1983) 


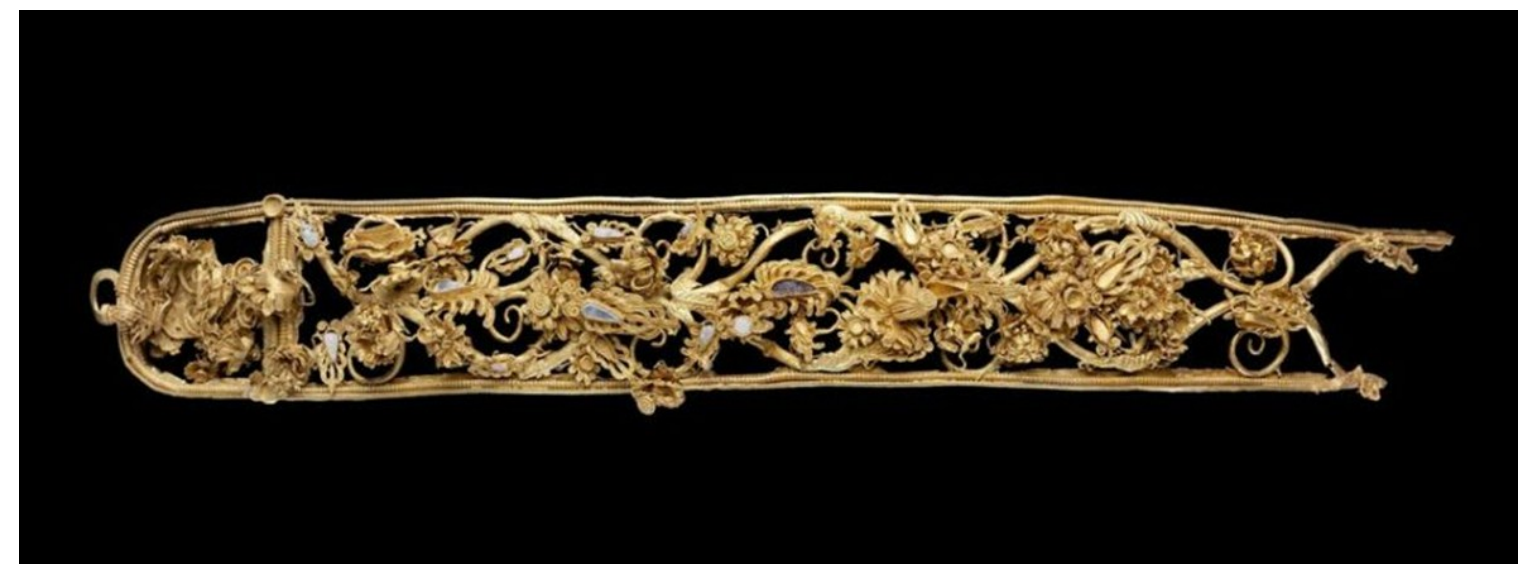

$\underline{\text { Figure } 122}$

Vine-trellis Diadem

MFA 98.798

Greek, Hellenistic Period, about 310-198

$2.5 \times 18.5 \mathrm{~cm}(1 \times 75 / 16$ in. $)$

Gold with glass and carnelian

Museum of Fine Arts, Boston Database

http://www.mfa.org/collections/object/vine-trellis-diadem-186436

(accessed 7/22/12) 

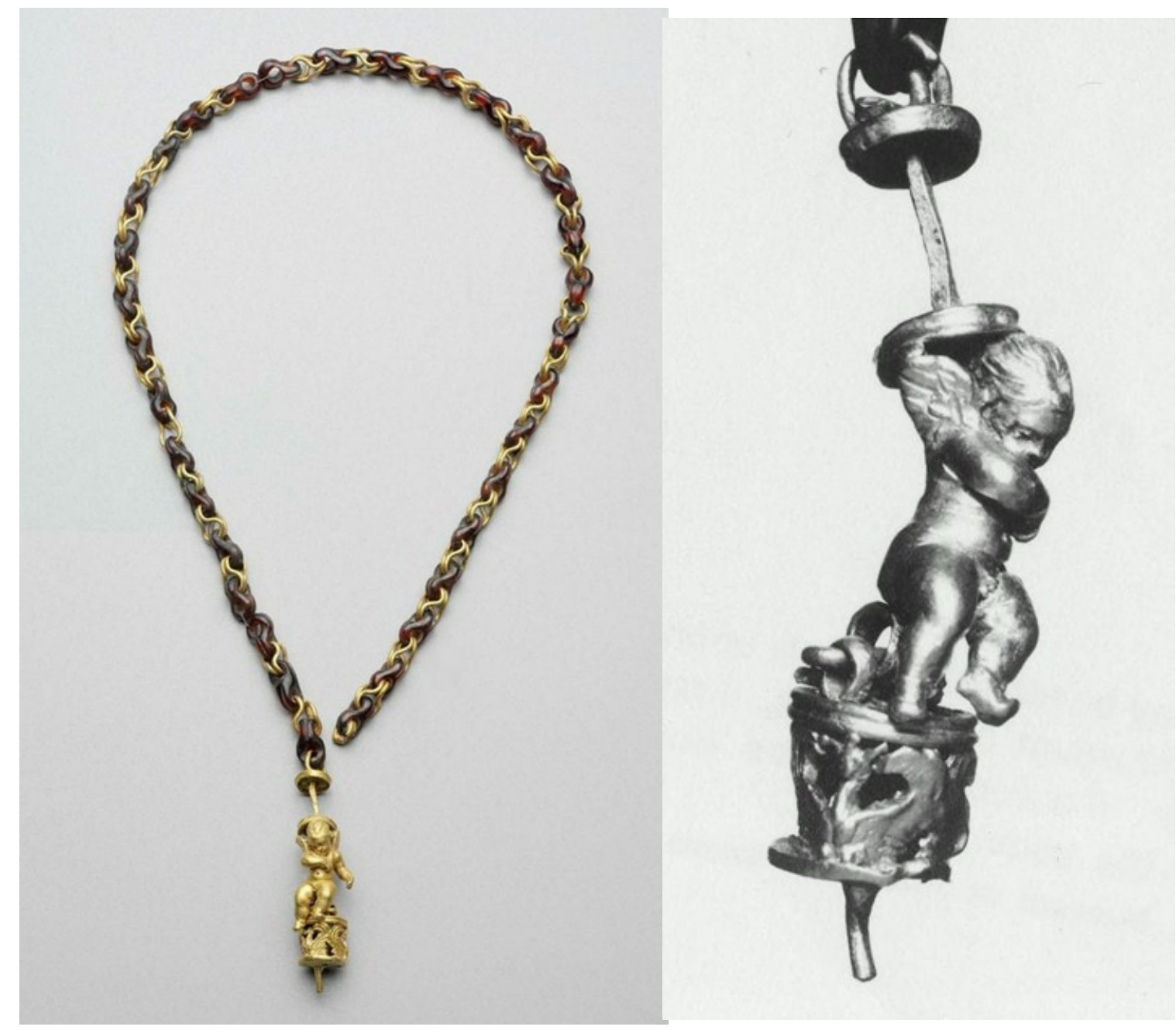

detail: pendant

\section{$\underline{\text { Figure } 123}$}

Necklace with Pendant Eros

MFA 98.798

Greek, Hellenistic Period, about 310-198 B.C.

Length of necklace: $32 \mathrm{~cm}$. (12 5/8 in.) Height of Eros: $2 \mathrm{~cm}$. (13/16 in.)

Gold and garnet

Museum of Fine Arts, Boston Database

http://www.mfa.org/collections/object/necklace-with-pendant-eros-186441

(accessed 7/22/12) 

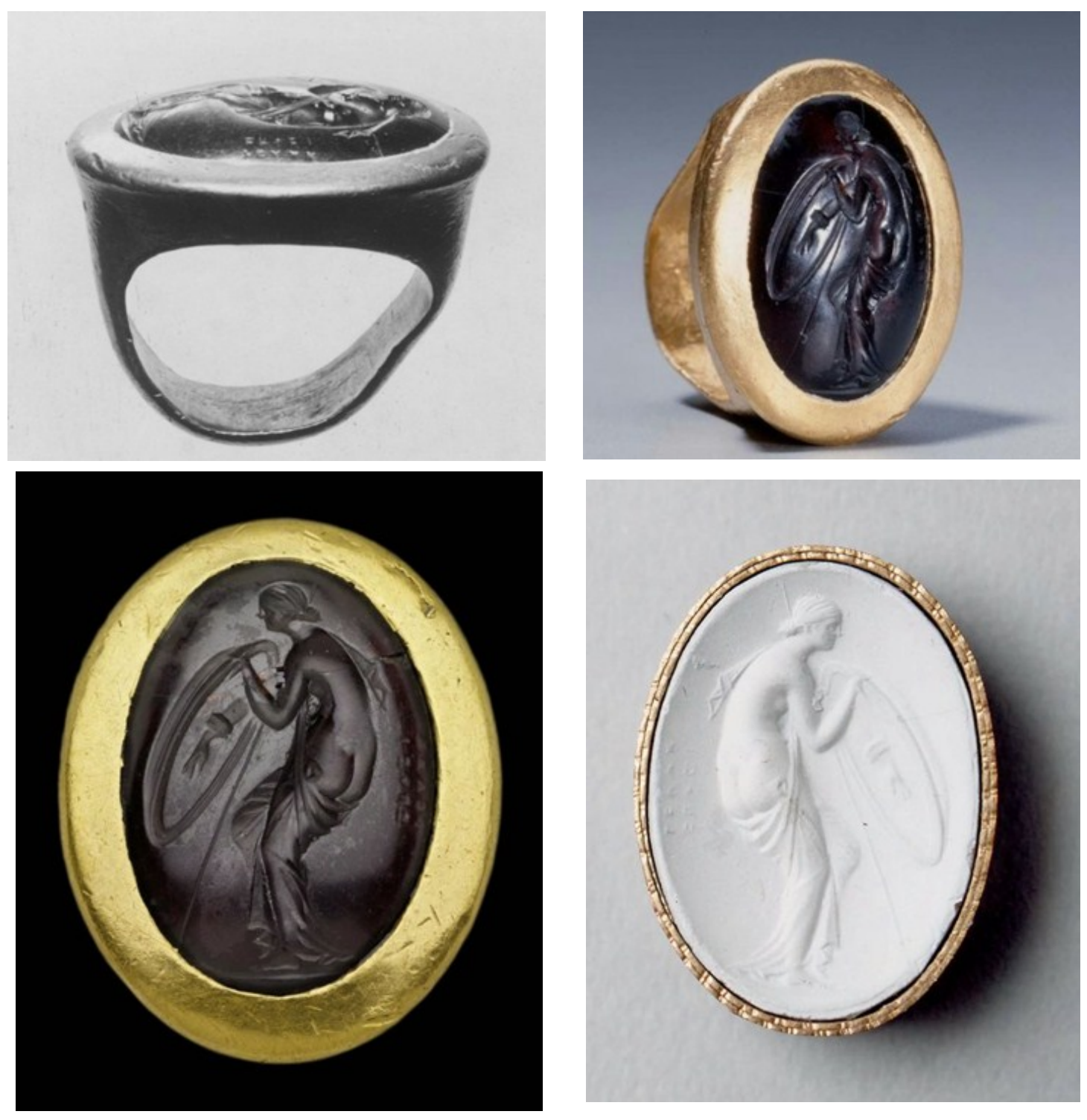

Impression

Figure 124

Ring with Aphrodite Taking-up Arms MFA 21.1213

Greek, Hellenistic Period, Late 3rd century

Length x width: $2.9 \times 2.4 \mathrm{~cm}(11 / 8 \times 15 / 16$ in.)

Gold and Garnet

Signed by Gelon

Museum of Fine Arts, Boston Database

http://www.mfa.org/collections/object/ring-with-aphrodite-taking-up-arms-238217 (accessed 7/22/12) 


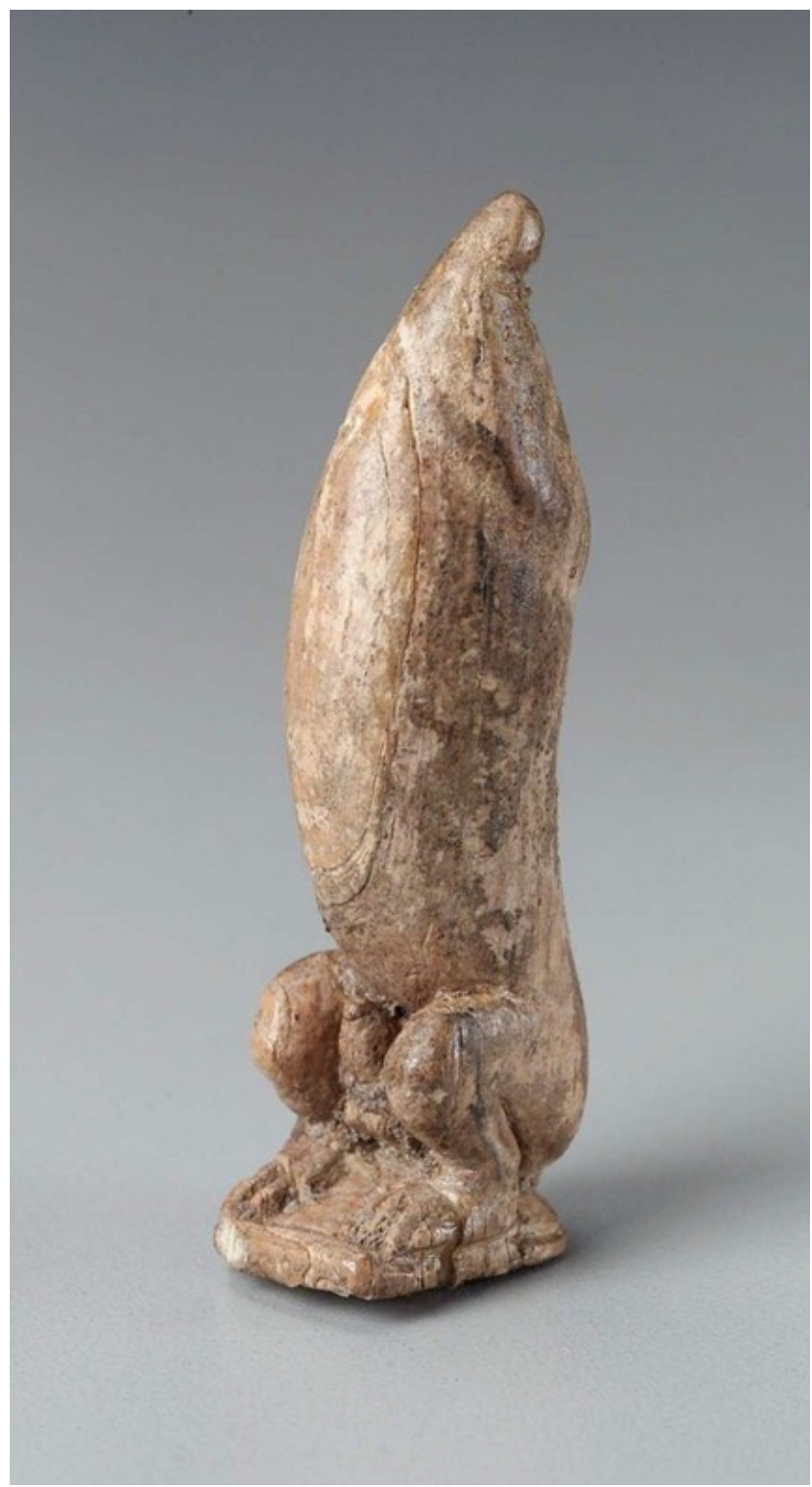

$\underline{\text { Figure } 125}$

Phallus on Two Legs

Res.08.35d

Greco-Roman?

$5 \mathrm{~cm}(1 \mathrm{15} / 16$ in.)

Ivory

Museum of Fine Arts, Boston Database

http://www.mfa.org/collections/object/ivory-277556

(accessed 7/22/12) 


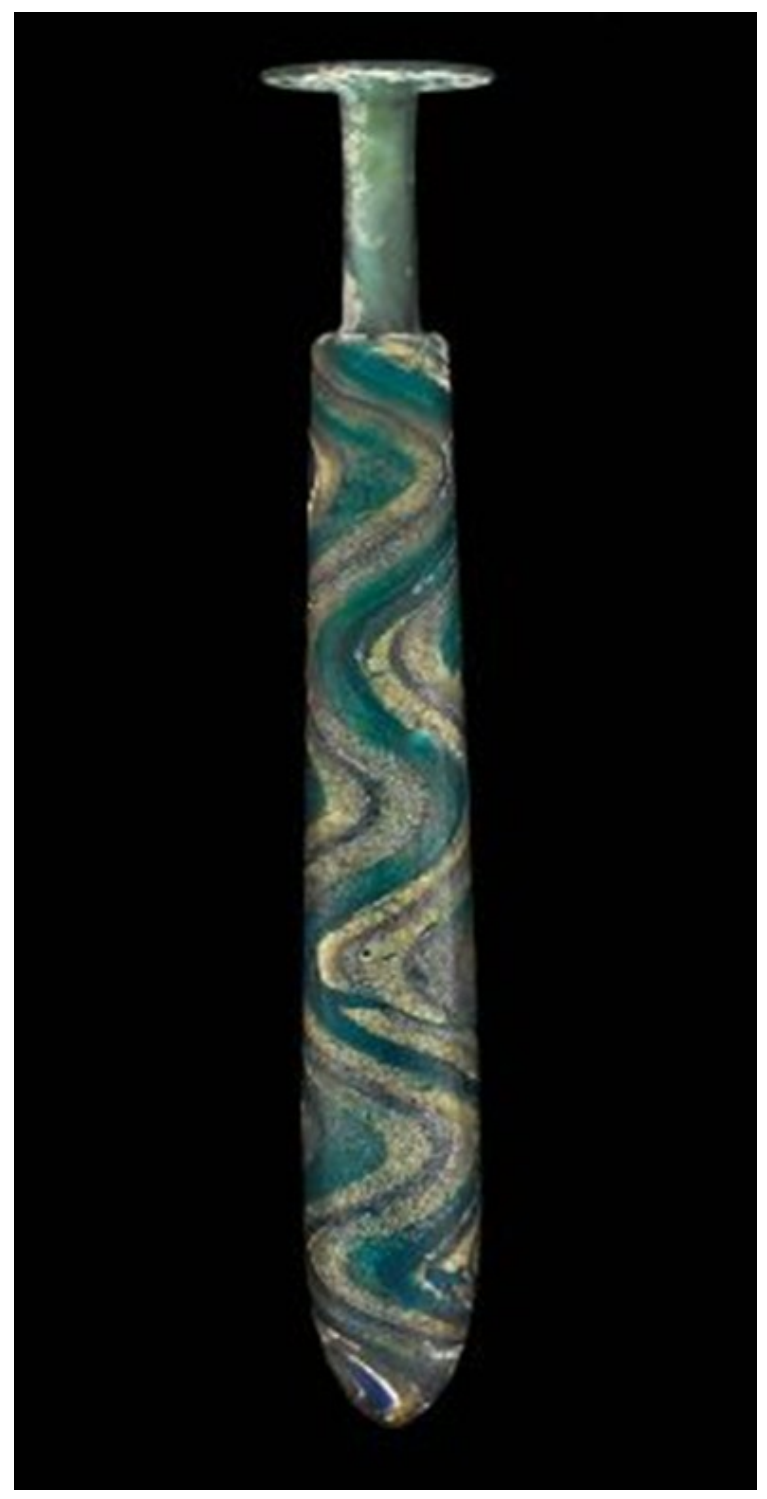

$\underline{\text { Figure } 126}$

Alabastron

MFA 98.938

Greek, Hellenistic Period, First Century B.C.E.

Height: $17.9 \mathrm{~cm}$ ( 7 1/16 in.)

Glass, cast, with gold-band mosaic

Museum of Fine Arts, Boston Database

http://www.mfa.org/collections/object/oil-flask-alabastron-154801

(accessed 7/22/12) 


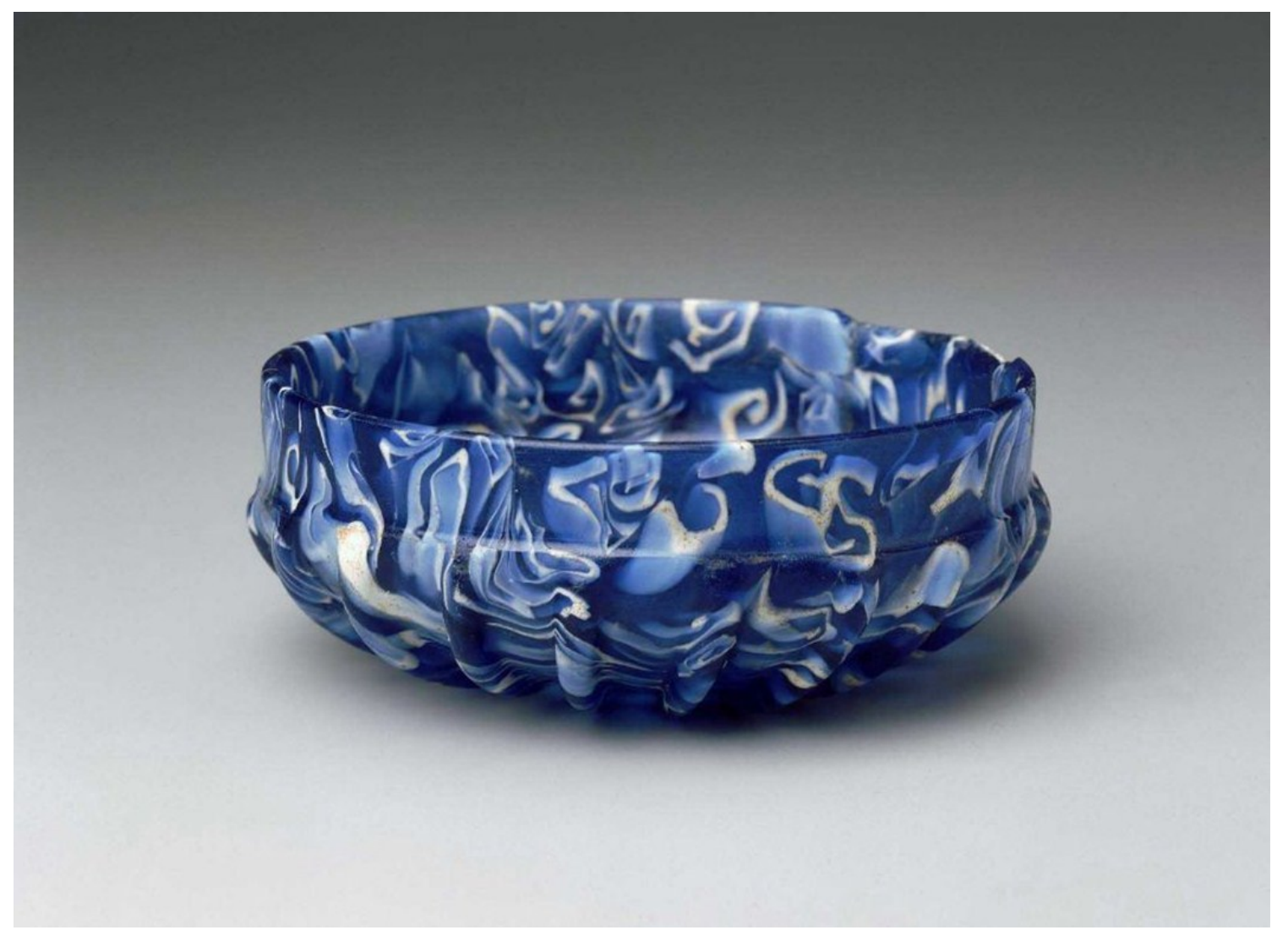

$\underline{\text { Figure } 127}$

Ribbed Bowl

MFA 99.442

Roman, Late Republican or Imperial Period,

Late First Century B.C.E.-First Century C.E.

Height: $4.4 \mathrm{~cm}$ (1 3/4 in.)

Mosaic glass

Museum of Fine Arts, Boston Database

http://www.mfa.org/collections/object/ribbed-bowl-154808

(accessed 7/22/12) 


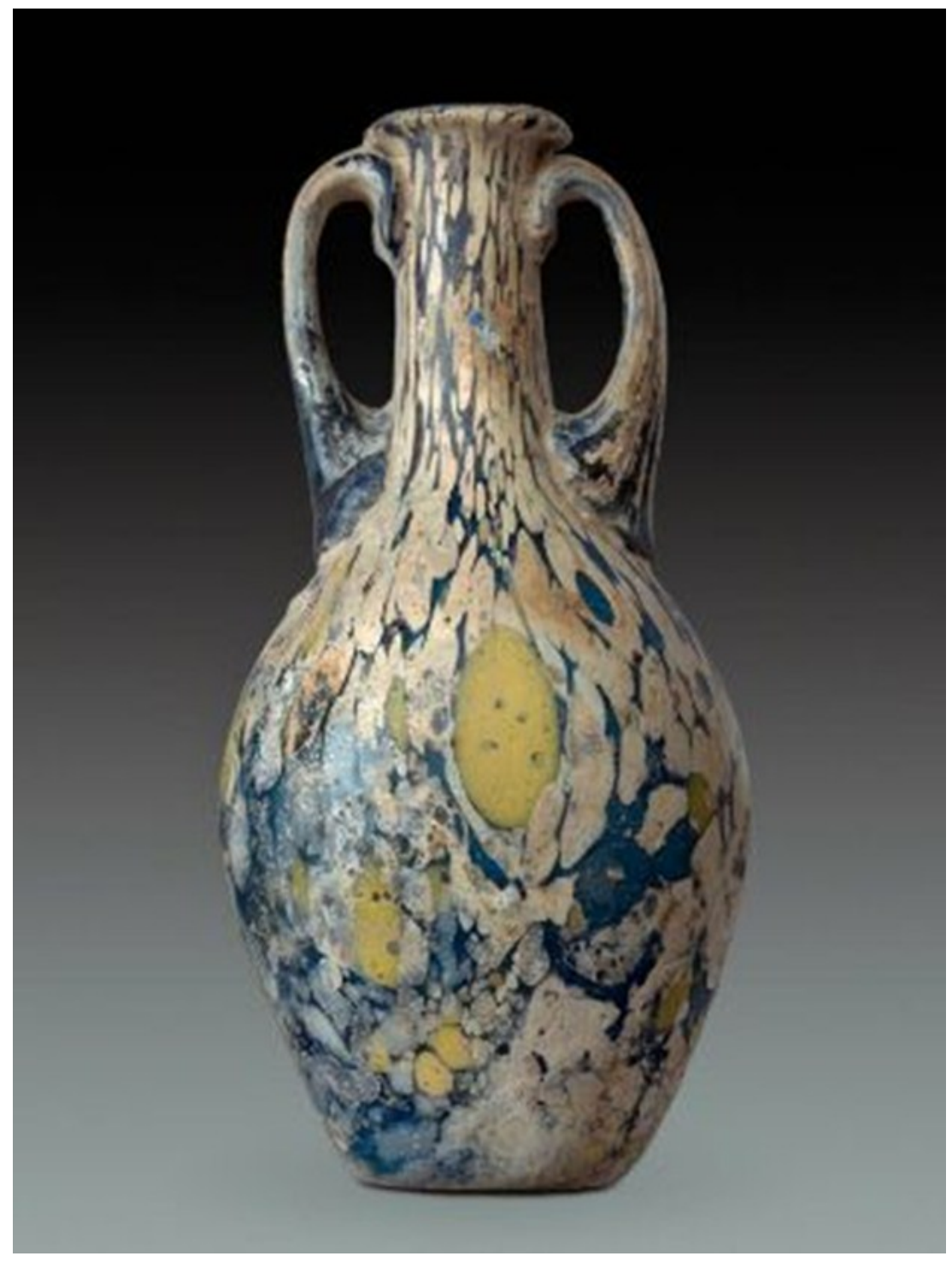

$\underline{\text { Figure } 128}$

Bottle with Two Handles

MFA 01.8225

Roman, Imperial Period, First Century C.E.

Height: $13.3 \mathrm{~cm}$ (5 1/4 in.)

Glass, free-blown, with applied handles; decorated with the "splash" technique

Museum of Fine Arts, Boston Database

http://www.mfa.org/collections/object/bottle-with-two-handles-156519

(accessed 7/22/12) 


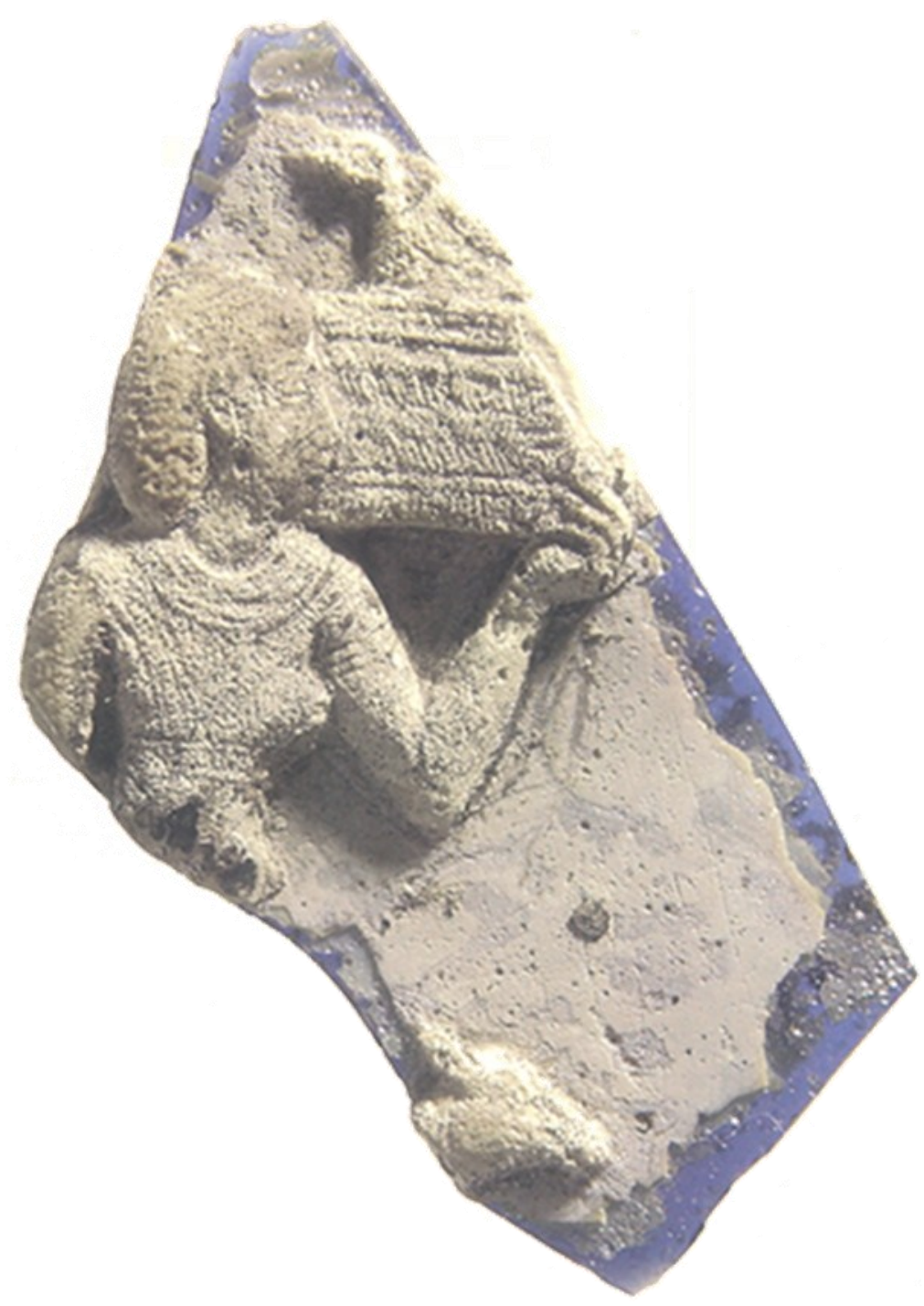

$\underline{\text { Figure } 129}$

Plaque with Priestess Figure

BCMA 1915.58

Hellenistic Period, Second-First Century

$2 / 3 / 16 \times 19 / 16$ in

Cameo glass

Bowdoin College Museum of Art

James A. Higginbotham and Katherine M. Westley

Ars Antiqua: Treasures from the Ancient Mediterranean World at Bowdoin College

(2005) 


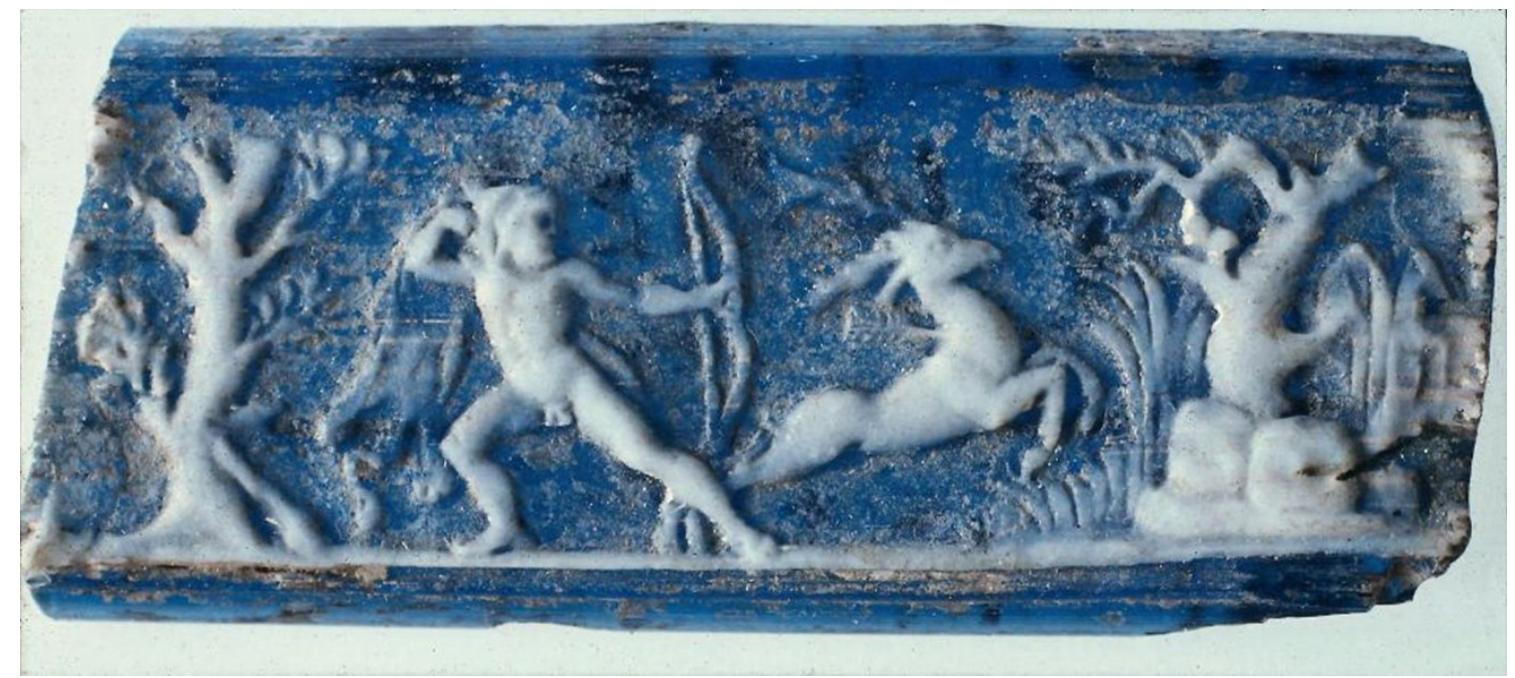

Figure 130

Plaque with Herakles and the Keryneian Stag

MFA 13.212

Roman, Imperial Period, Probably First Century C.E.

Height x length: 4.7 x $2 \mathrm{~cm}$ (1 7/8 x 13/16 in.)

Cameo Glass

Museum of Fine Arts, Boston Database

http://www.mfa.org/collections/object/plaque-fragment-with-herakles-154828

(accessed 7/22/12) 


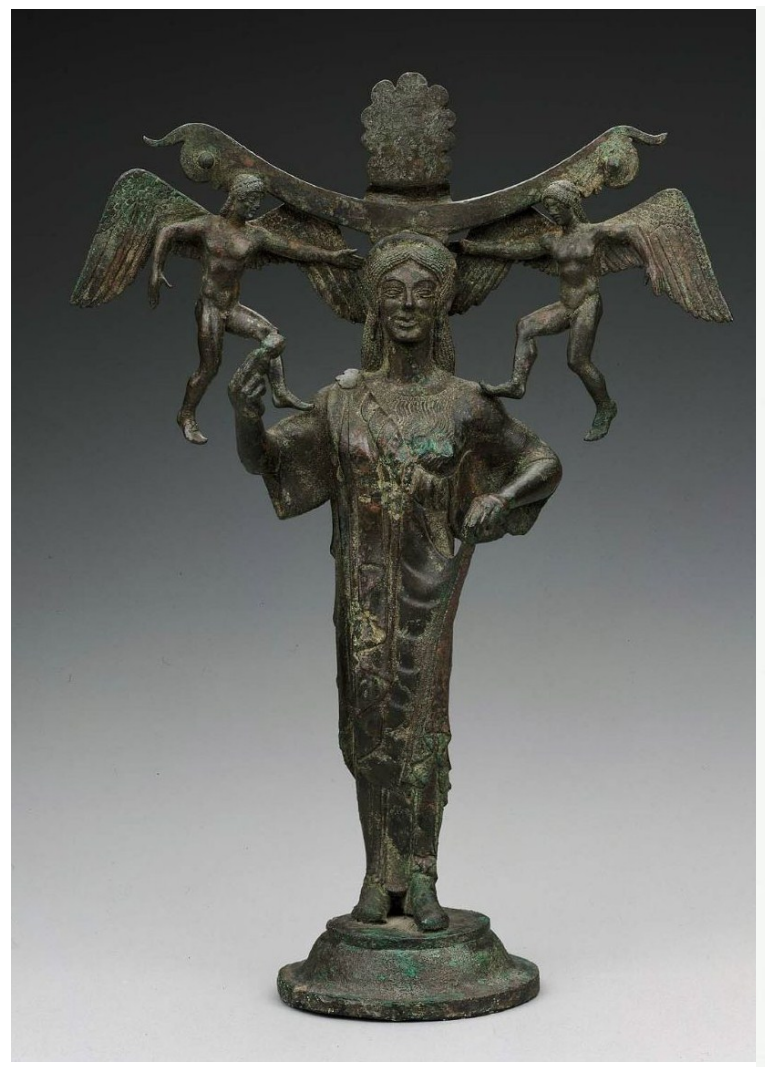

Front

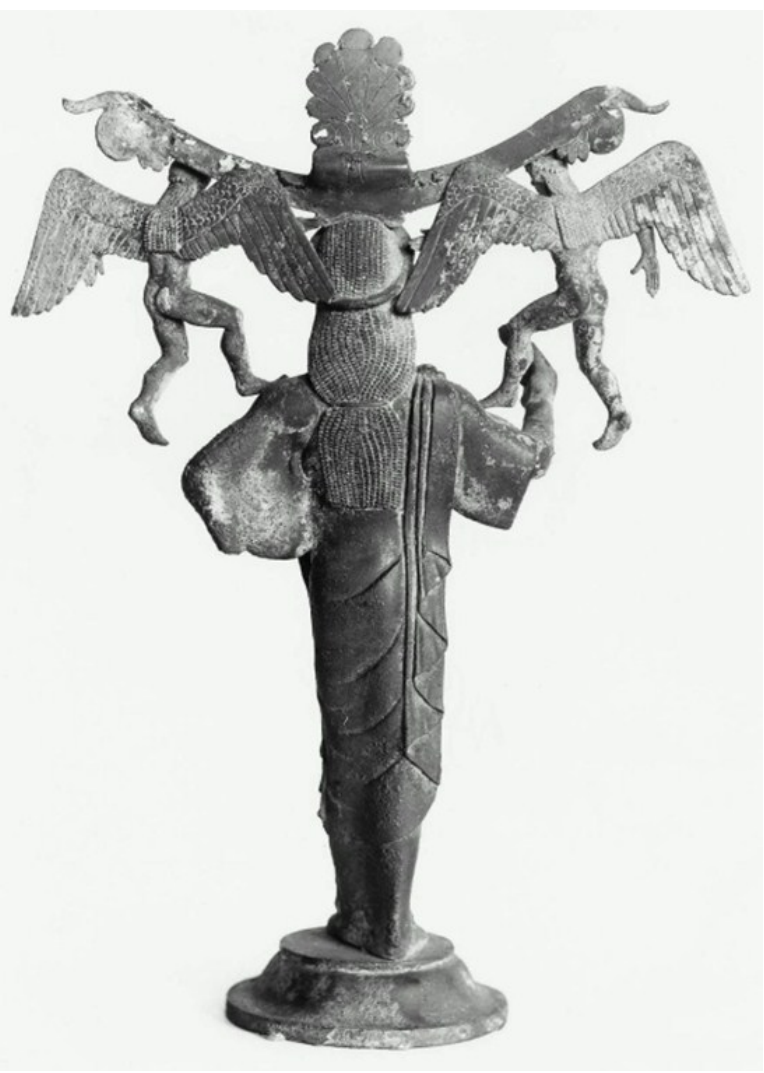

Back

Figure 131

Mirror stand with Aphrodite and Erotes

MFA 04.7

Greek, Archaic Period, c. 500

Height: $25.6 \mathrm{~cm}(101 / 16$ in.)

Bronze

Museum of Fine Arts, Boston Database

hhttp://www.mfa.org/collections/object/mirror-stand-with-aphrodite-and-erotes-117

(accessed 7/22/12) 


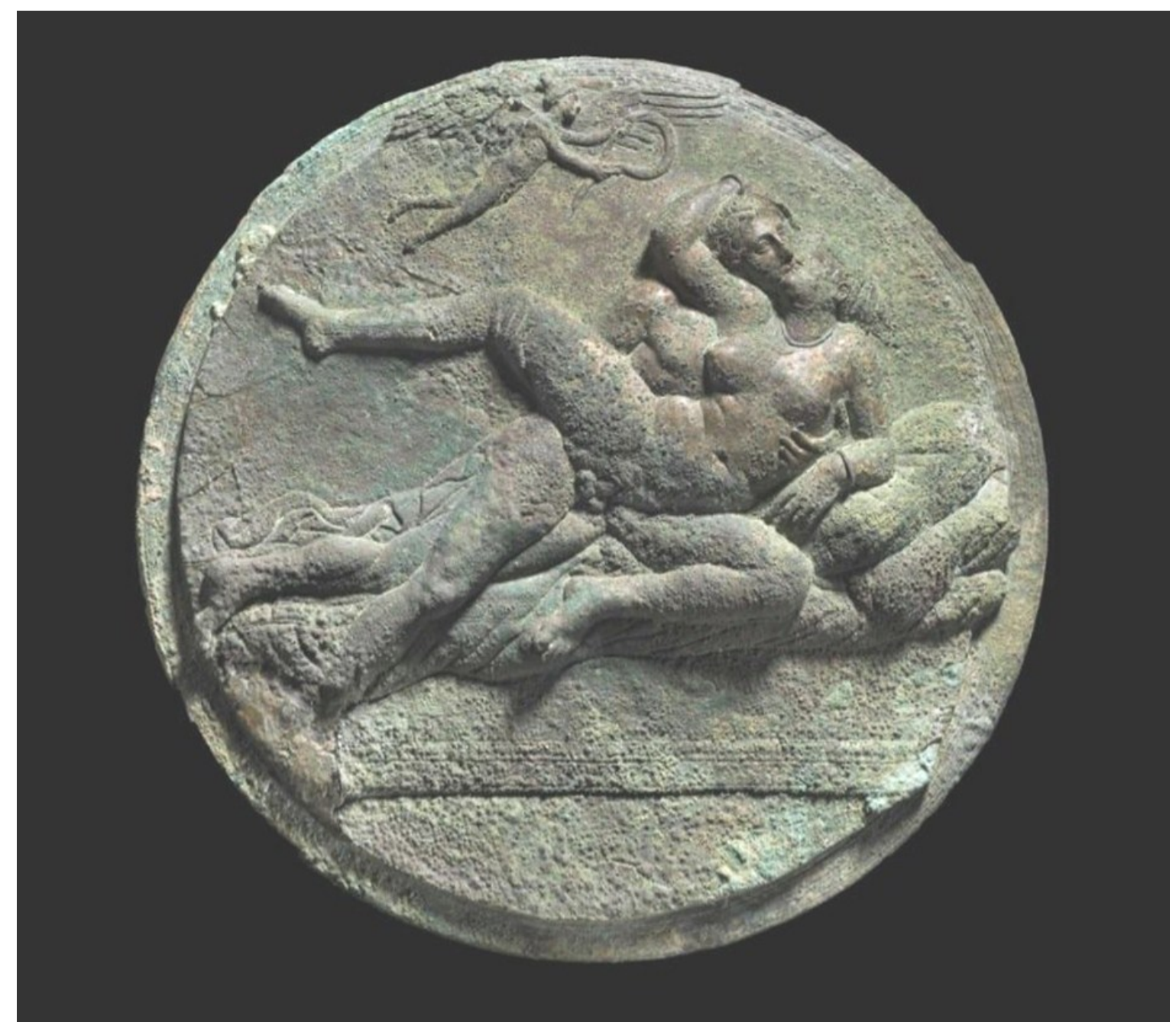

$\underline{\text { Figure } 132}$

Mirror Cover with Eros and Erotic Scene (symplegma)

RES.08.32c. 2

Greek, Late Classical or Early Hellenistic Period, c. 340-320

Diameter: $17.5 \mathrm{~cm}$ (6 7/8 in.)

Bronze

Museum of Fine Arts, Boston Database

http://www.mfa.org/collections/object/mirror-cover-with-eros-and-erotic-scene-

symplegma-375249

(accessed 7/22/12) 


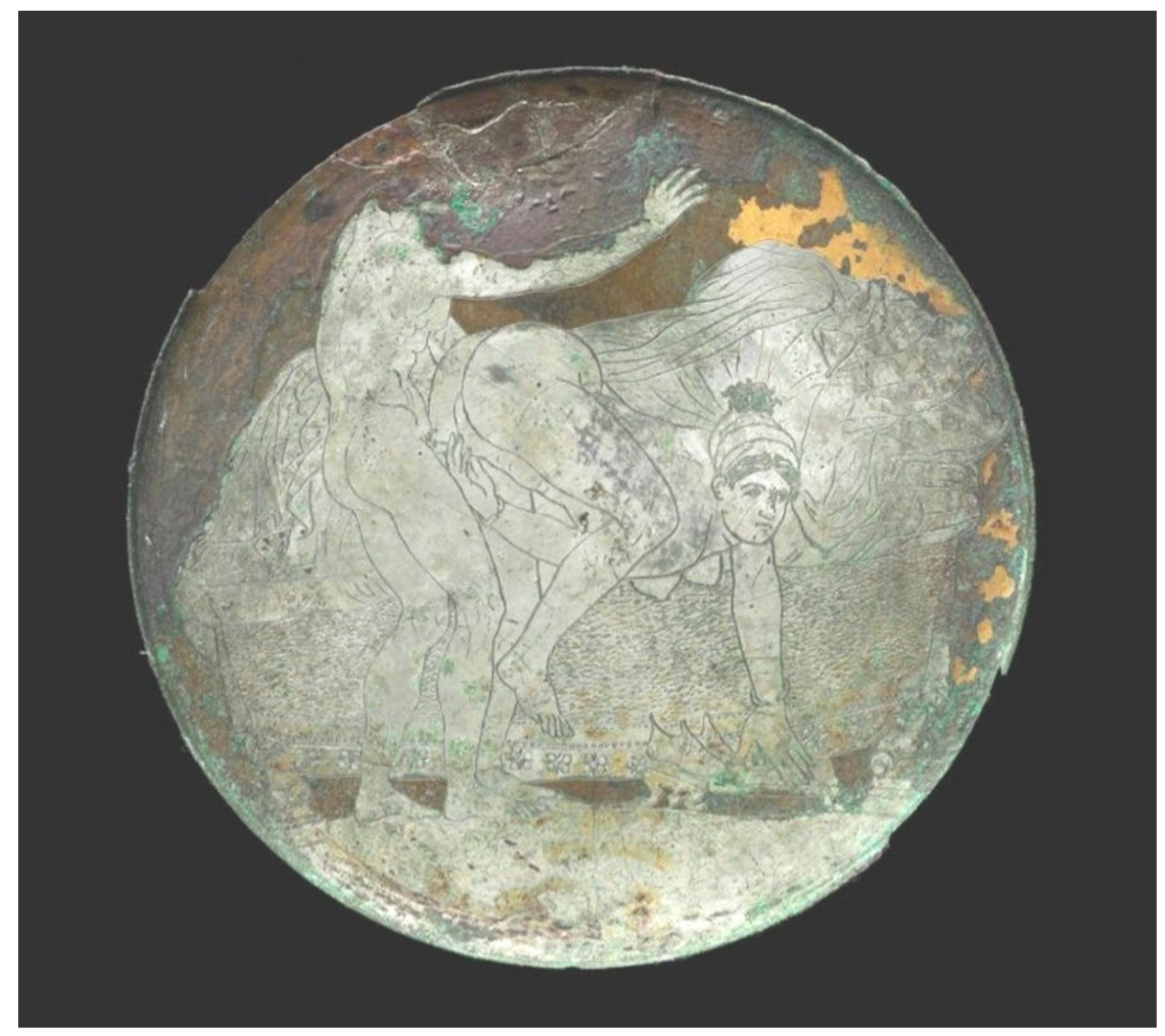

Figure 133

Inside of Mirror Cover: Erotic Scene (symplegma)

RES. $08.32 \mathrm{c} .1$

Greek, Late Classical or Early Hellenistic Period, c. 340-320

Diameter: $17.5 \mathrm{~cm}(67 / 8$ in.)

Bronze and silvered bronze

Museum of Fine Arts, Boston Database

http://www.mfa.org/collections/object/mirror-cover-with-eros-and-erotic-scene-

symplegma-375249

(accessed 7/22/12) 

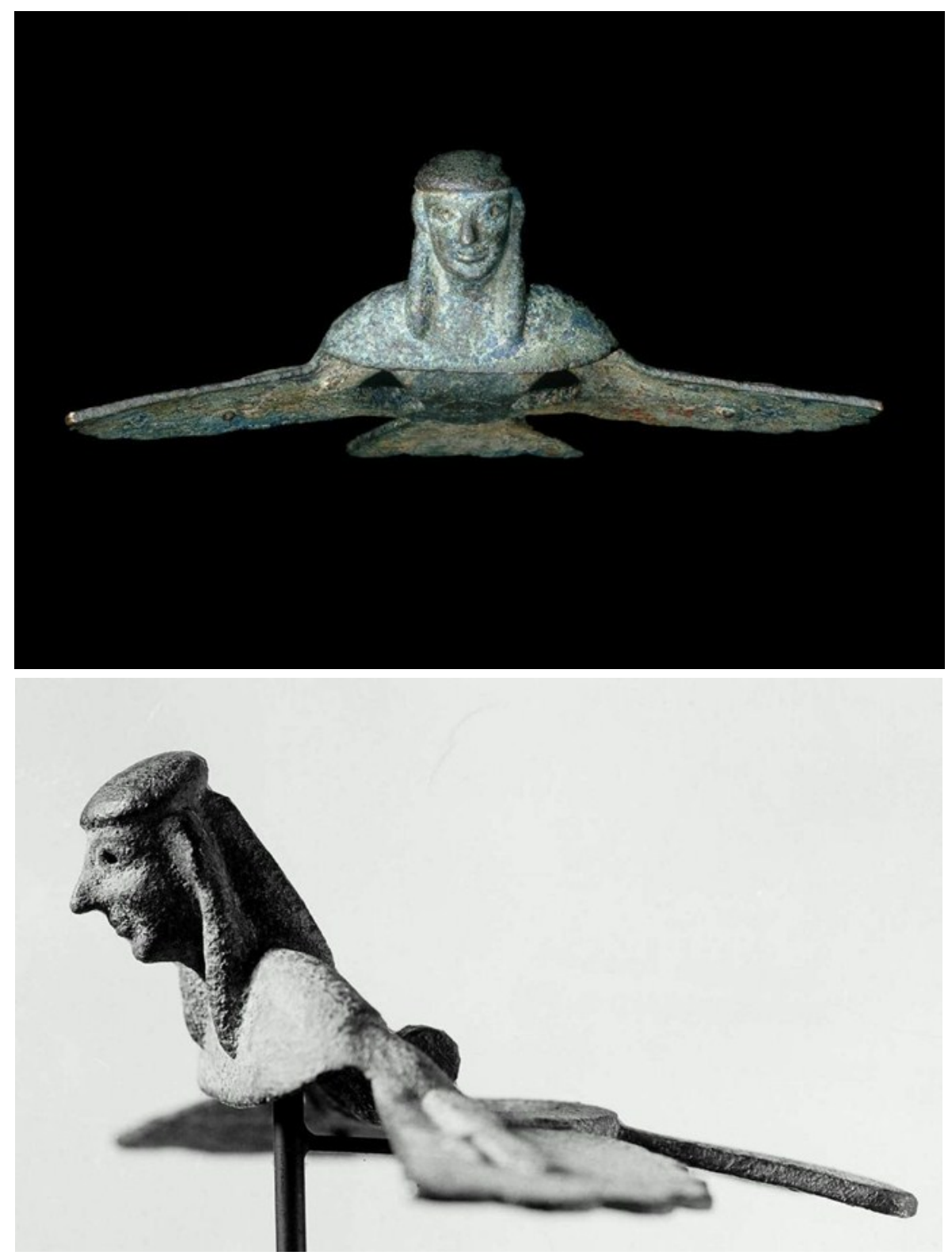

Figure 134

Siren from the Rim of a Lebes

MFA 99.458

Greek, Orientalizing Period, Mid-Seventh Century

Height: $5.2 \mathrm{~cm}$ (2 1/2 in.); width: $20.5 \mathrm{~cm}$ (8 1/16 in.); depth: $13.5 \mathrm{~cm}$ (5 5/16 in.) Bronze

Museum of Fine Arts, Boston Database

http://www.mfa.org/collections/object/siren-from-the-rim-of-a-lebes-153041

(accessed 7/22/12) 


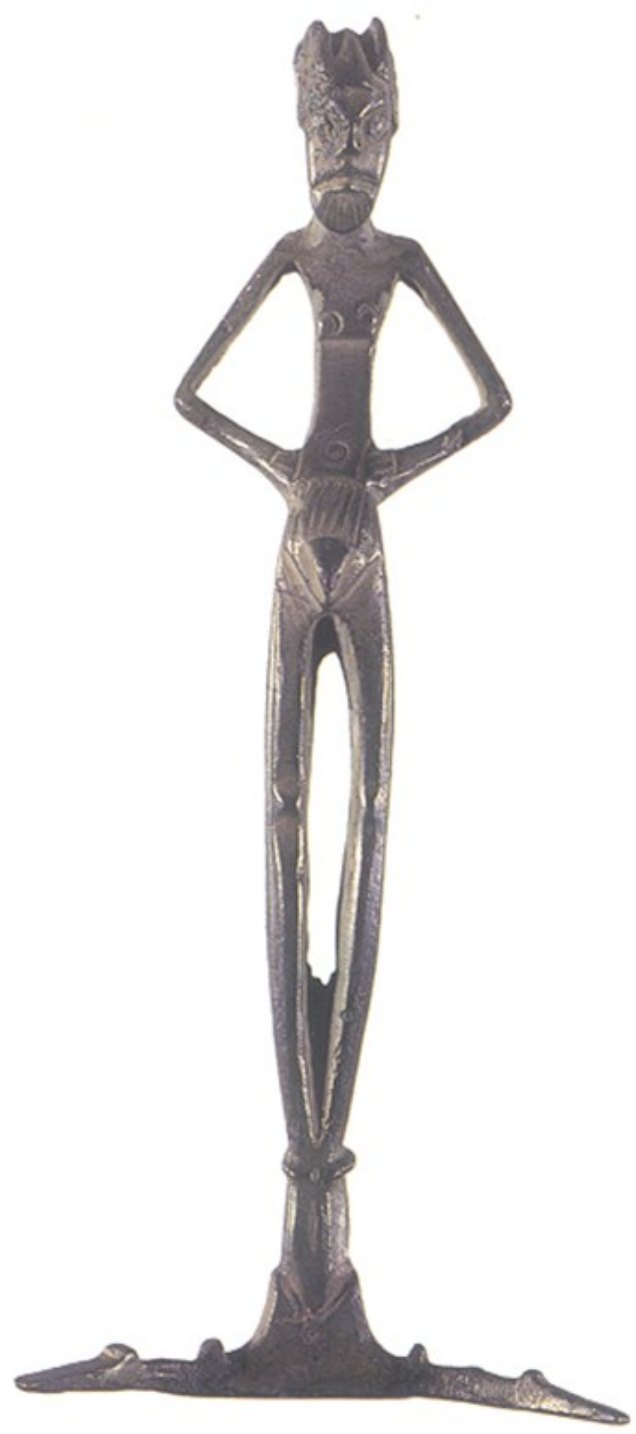

$\underline{\text { Figure } 135}$
Vessel Attachment: Priapus Figure
BCMA 1915.37
Roman , First Century B.C.E 4 5/16 x 1 7/; x 13/16 inches
Bronze

Bowdoin College Museum of Art

James A. Higginbotham and Katherine M. Westley

Ars Antiqua: Treasures from the Ancient Mediterranean World at Bowdoin College (2005) 


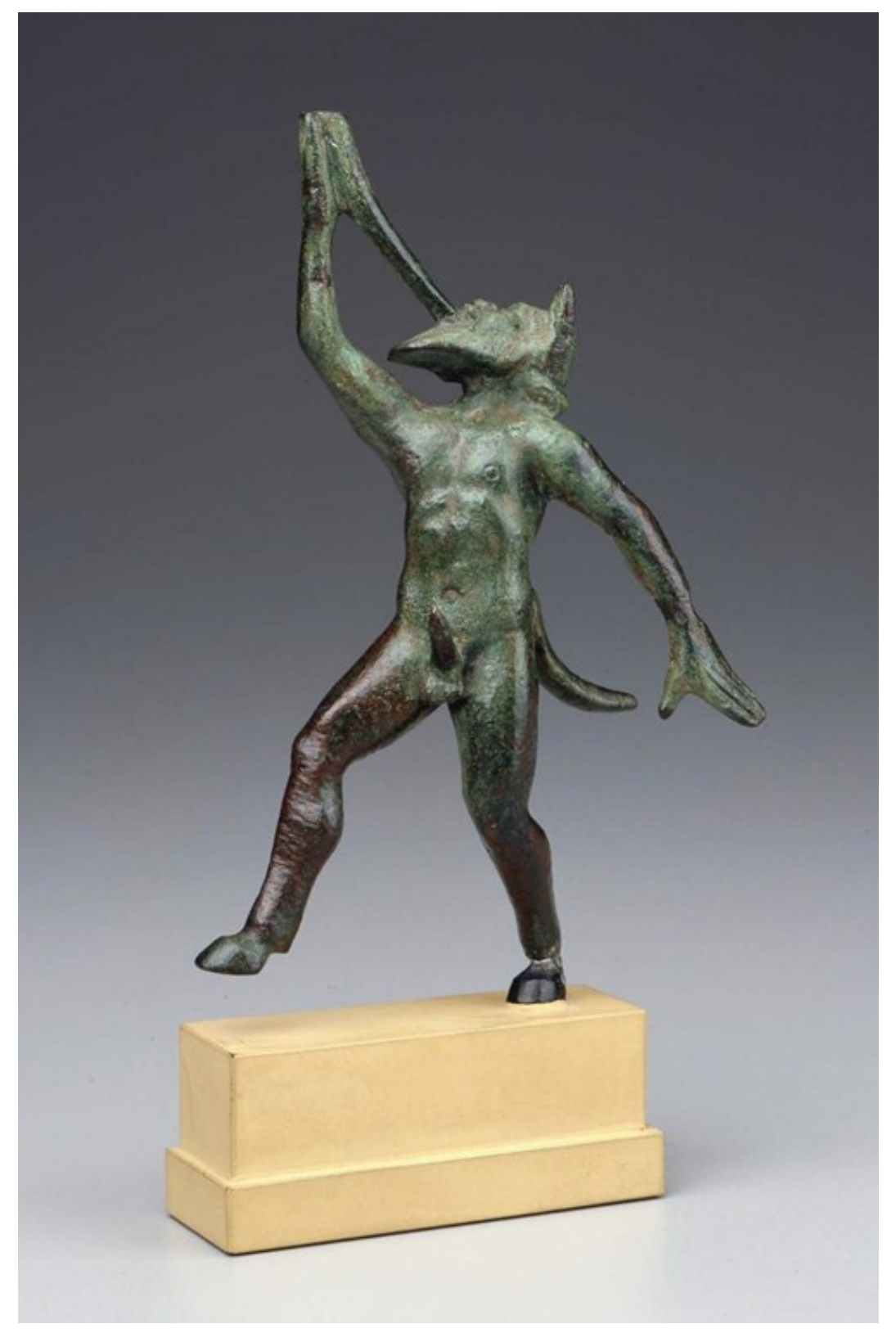

$\underline{\text { Figure } 136}$

\author{
Silenus \\ MFA 13.112
}

Italic, Etruscan, Classical, c. 450

Height: $13 \mathrm{~cm}(51 / 8$ in.)

Bronze

Museum of Fine Arts, Boston Database

http://www.mfa.org/collections/object/siren-from-the-rim-of-a-lebes-153041

(accessed 7/22/12) 


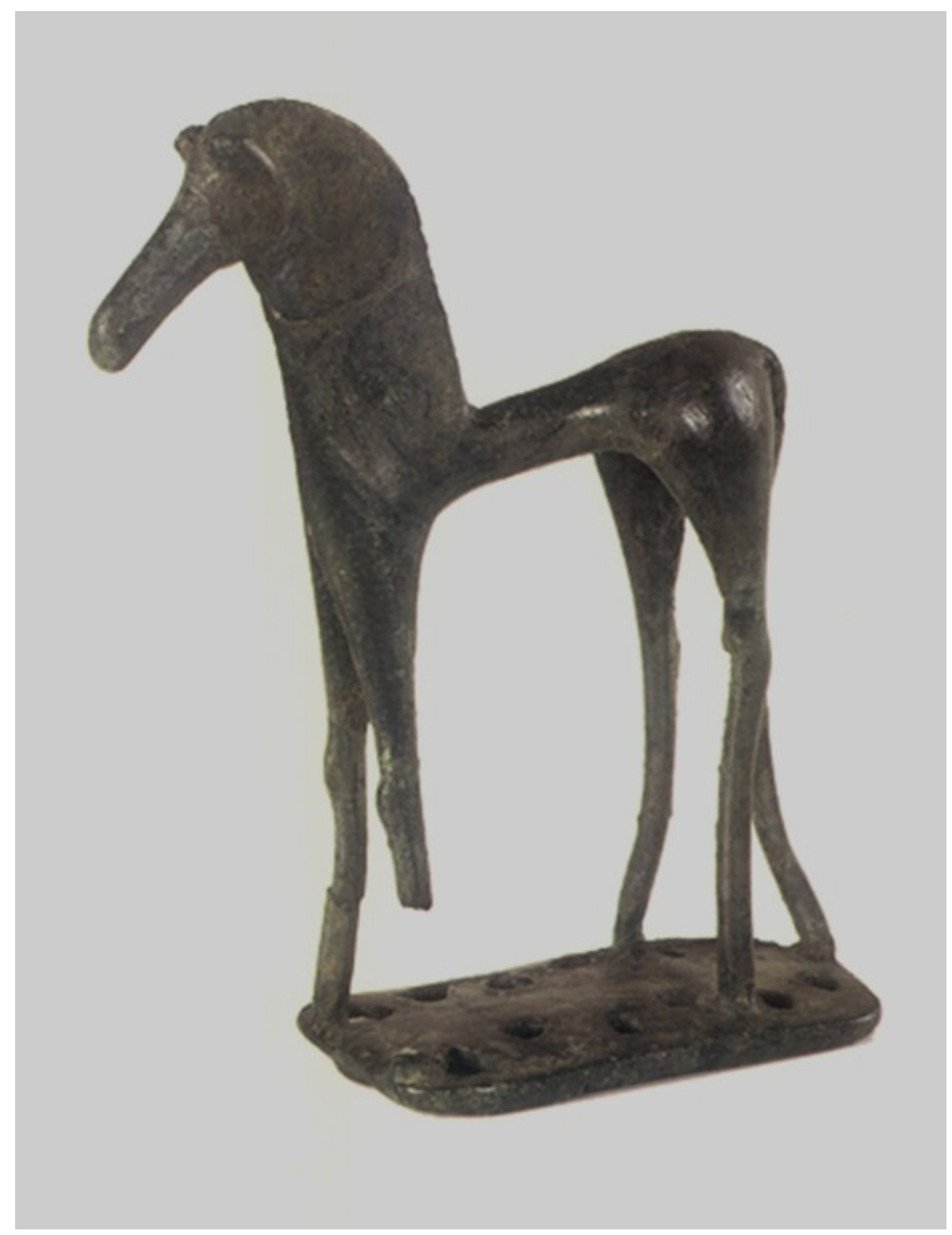

Figure 137

Statuette of Horse

BCMA 1927.14

Greek, c. 725

3 13/16 x $37 / 16 \times 13 / 16$ inches

Bronze

Bowdoin College Museum of Art

James A. Higginbotham and Katherine M. Westley

Ars Antiqua: Treasures from the Ancient Mediterranean World at Bowdoin College (2005) 


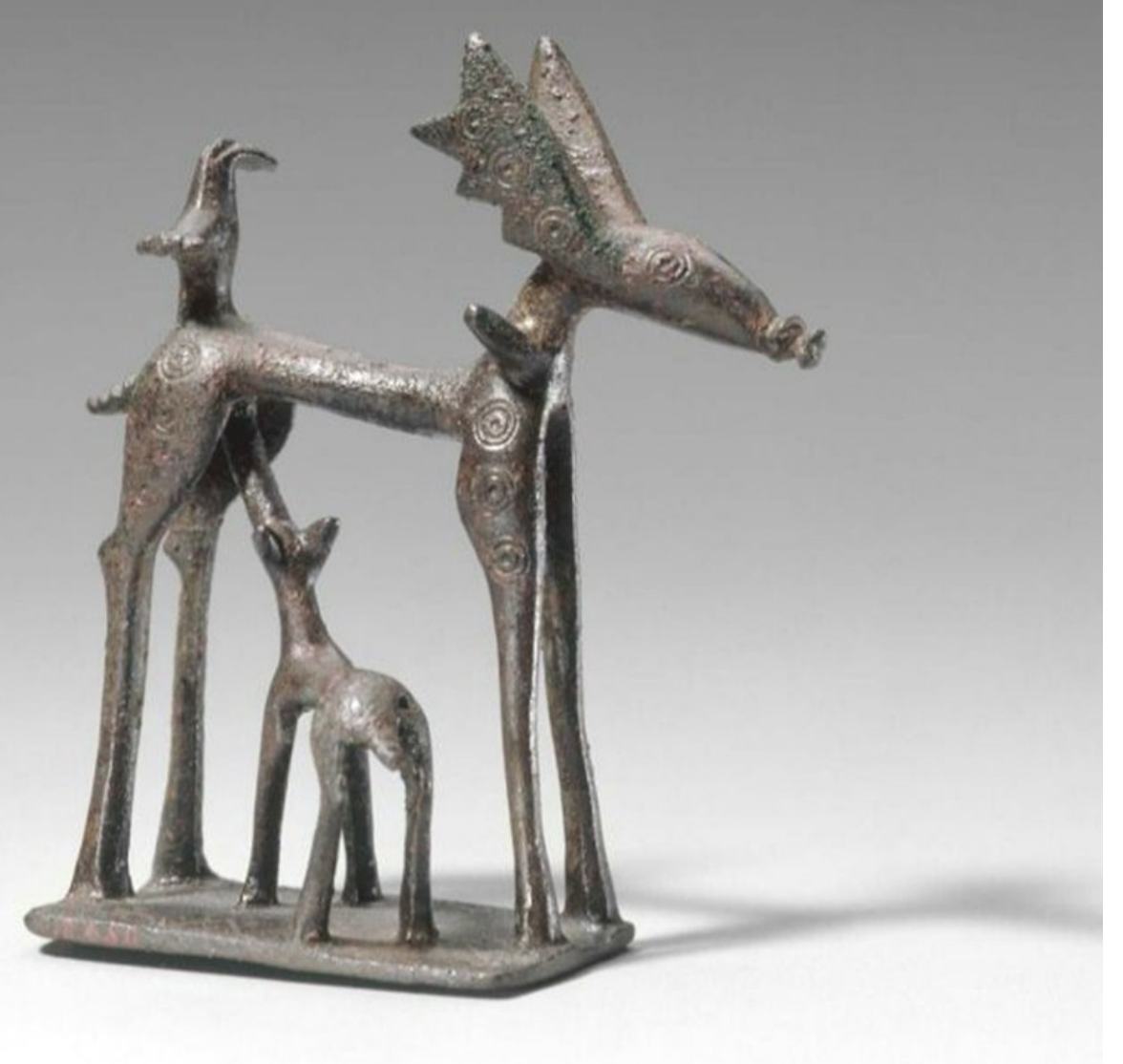

$\underline{\text { Figure } 138}$

Statuette of a Deer Nursing her Fawn MFA 98.650

Greek, Geometric Period, Eighth Century

Height: $7.2 \mathrm{~cm}$ (2 13/16 in.); depth: $4.2 \mathrm{~cm}$ (1 5/8 in.)

Bronze

Museum of Fine Arts, Boston Database

http://www.mfa.org/collections/object/statuette-of-a-deer-nursing-her-fawn-152647 (accessed 7/22/12) 


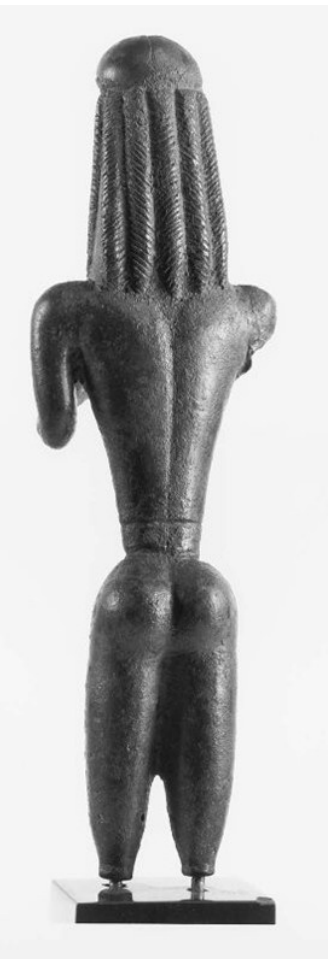

Back

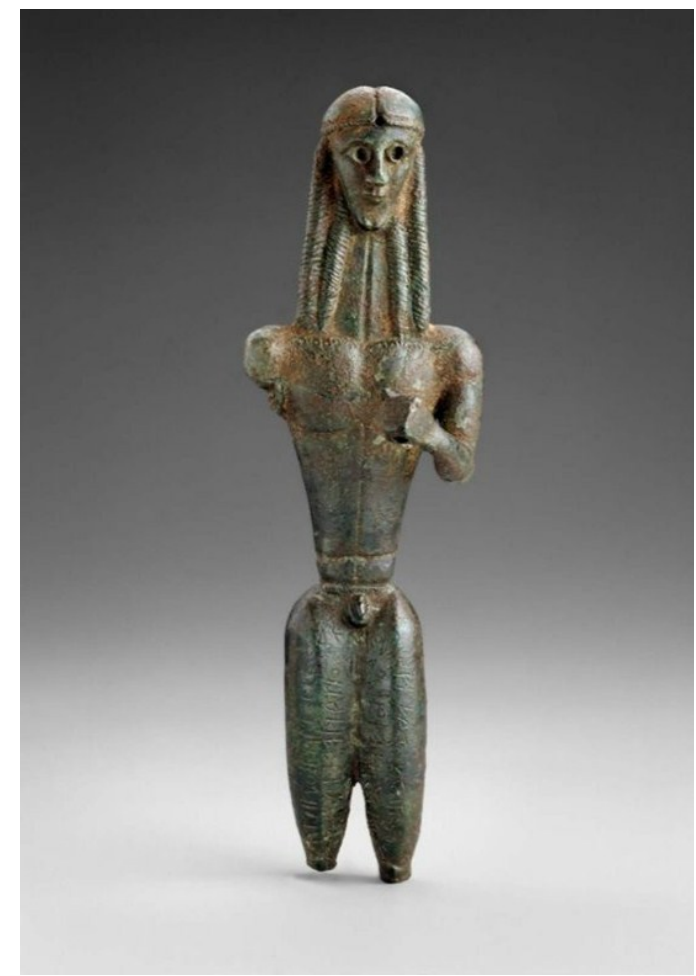

Front

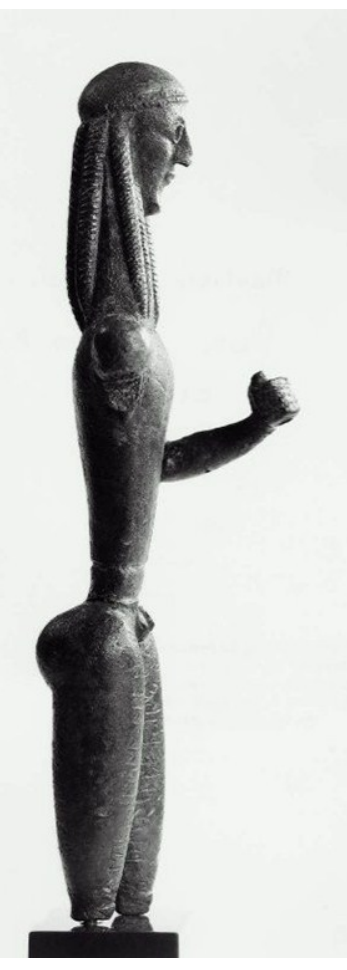

Side

Figure 139

Statuette: Mantiklos "Apollo"

MFA 03.997

Greek, Late Geometric or Early Orientalizing Period, c.700-675

Height: $20.3 \mathrm{~cm}$ (8 in.)

Bronze

Museum of Fine Arts, Boston Database

http://www.mfa.org/collections/object/mantiklos-apollo-152660

(accessed 7/22/12) 

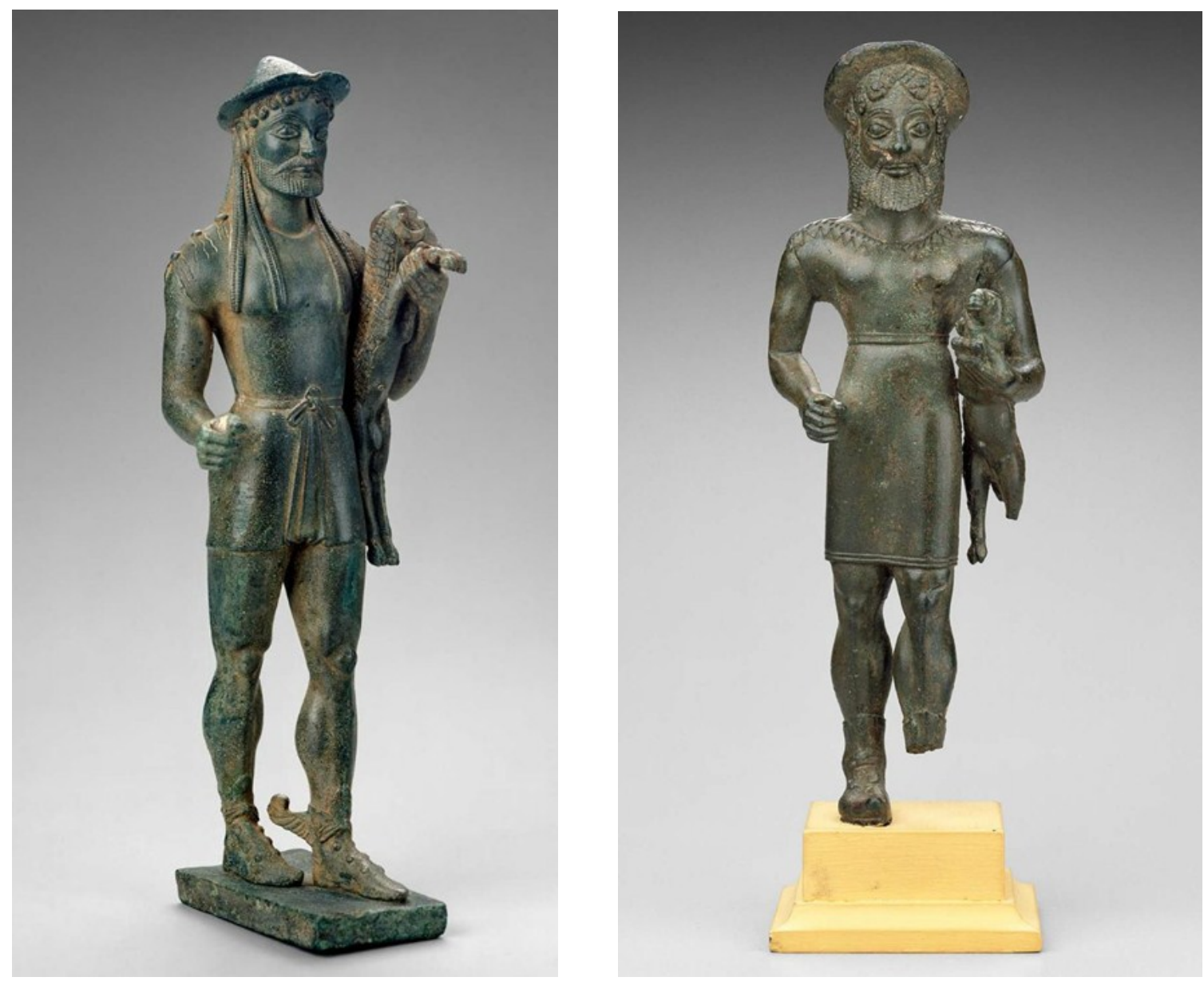

\section{Figure 140}

Statuette of Hermes Kriophoros MFA 99.489

Greek, Late Archaic Period c. 500-490

Height: $25 \mathrm{~cm}$ (9 13/16 in.)

Bronze( 8 in.)

Bronze

Museum of Fine Arts, Boston

Database

http://www.mfa.org/collections/ object/hermes-kriophoros-rambearer-152668 (accessed 7/22/12)
Statuette of Hermes Kriophoros MFA 04.6

Greek, Archaic Period

c. $520-510$

Height: $16.7 \mathrm{~cm}$ (6 9/16 in.)

Bronze

Museum of Fine Arts, Boston

Database

http://www.mfa.org/collections/

object/hermes-kriophoros-theram-bearer-152667

(accessed 7/22/12) 


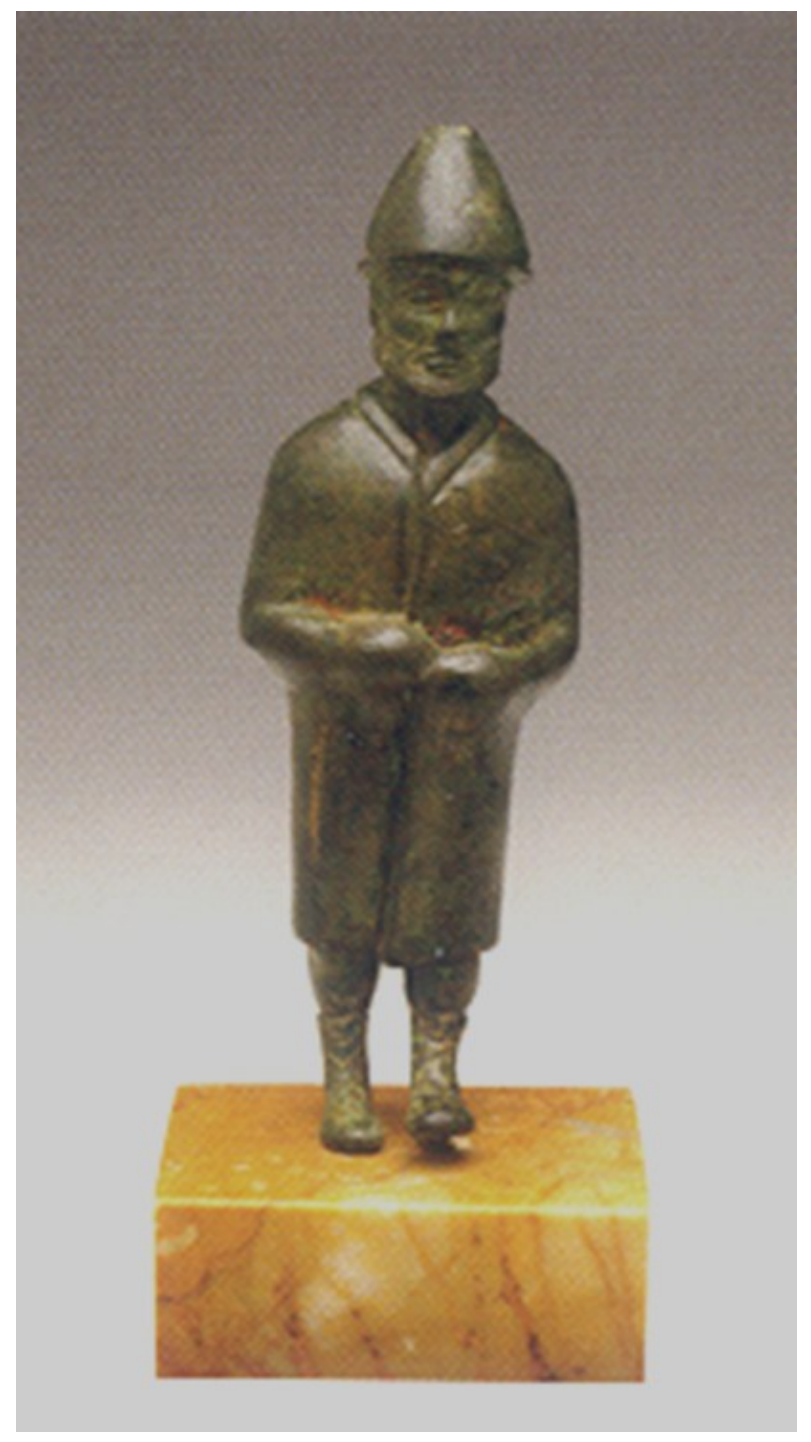

Figure 141

$$
\begin{gathered}
\text { Man in a Cloak } \\
\text { RISD 20.056 } \\
\text { c. } 520-500
\end{gathered}
$$

Height: 4 1/8; Width at elbows $13 / 8$;

Bronze

Rhode Island School of Design Art Museum

Selected Works, Museum of Art, Rhode Island School of Design

(2008) 


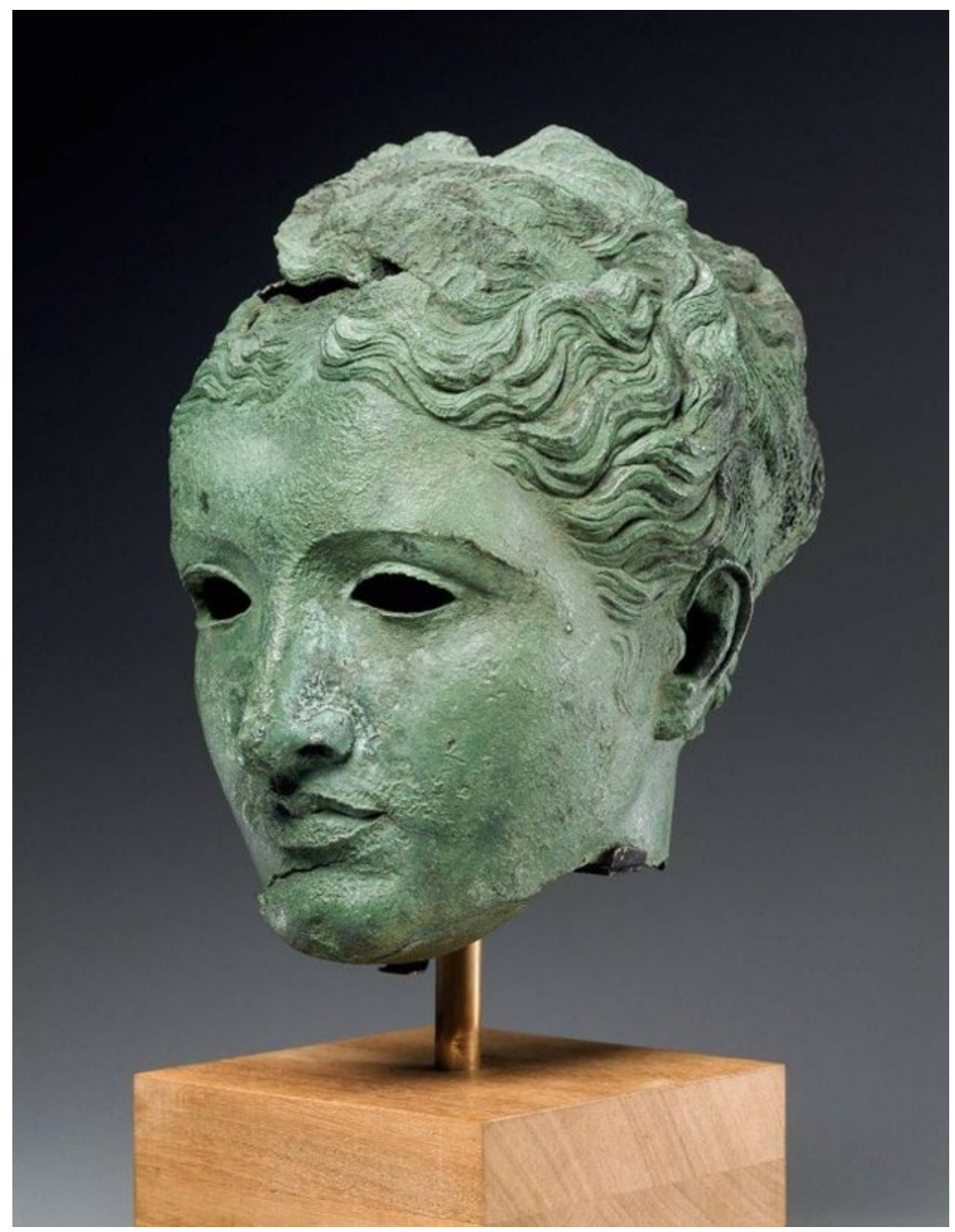

$\underline{\text { Figure } 142}$

Head of a Goddess or Queen

MFA 97.712

Greek, Ptolemaic, Hellenistic Period, c. 300-270 B.C.E.

Height: $25.5 \mathrm{~cm}$ (10 1/16 in.)

Bronze

Museum of Fine Arts, Boston Database

http://www.mfa.org/collections/object/head-of-a-goddess-or-queen-152722

(accessed 7/22/12) 


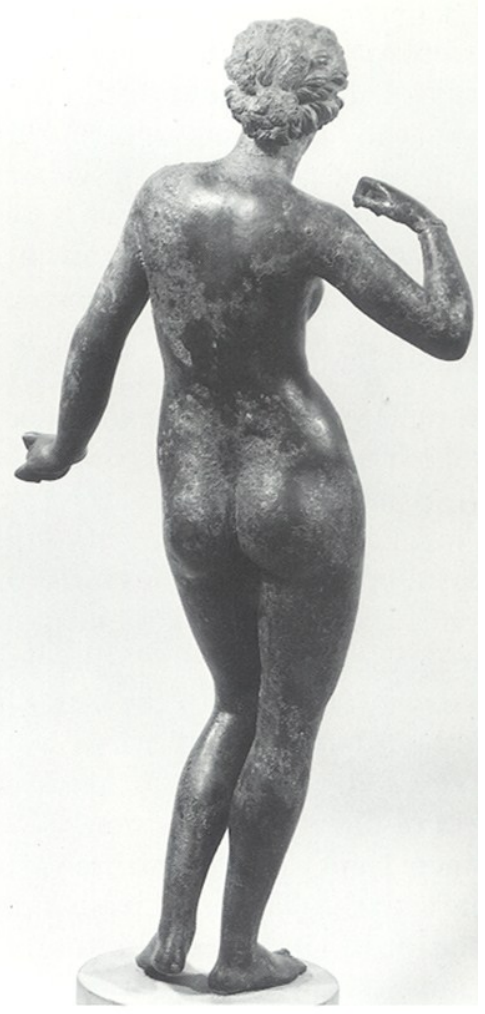

Back

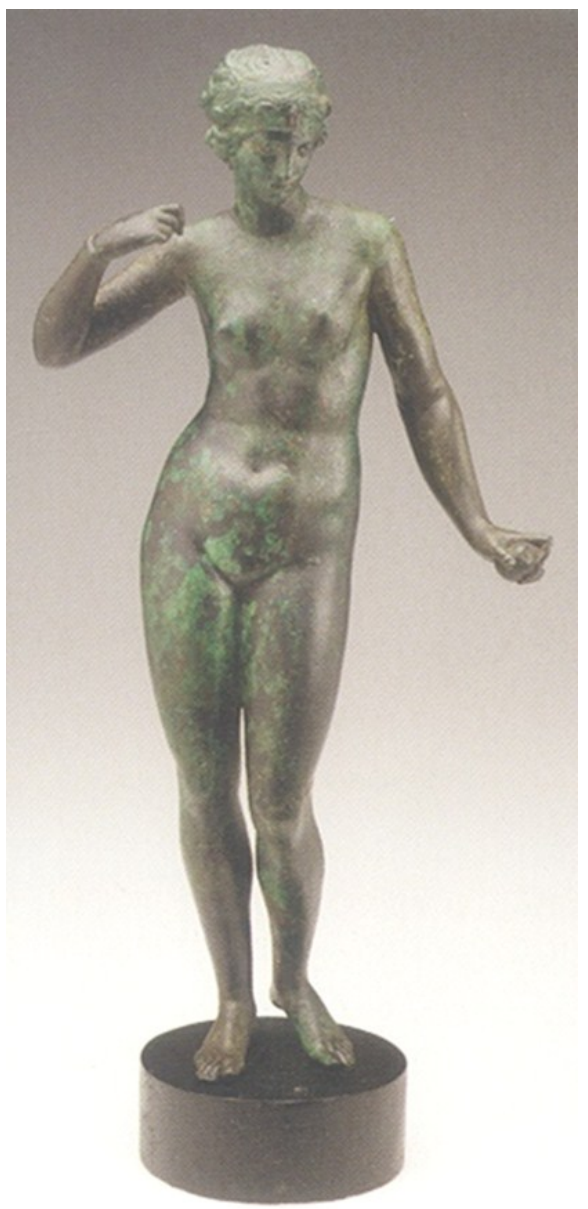

Center

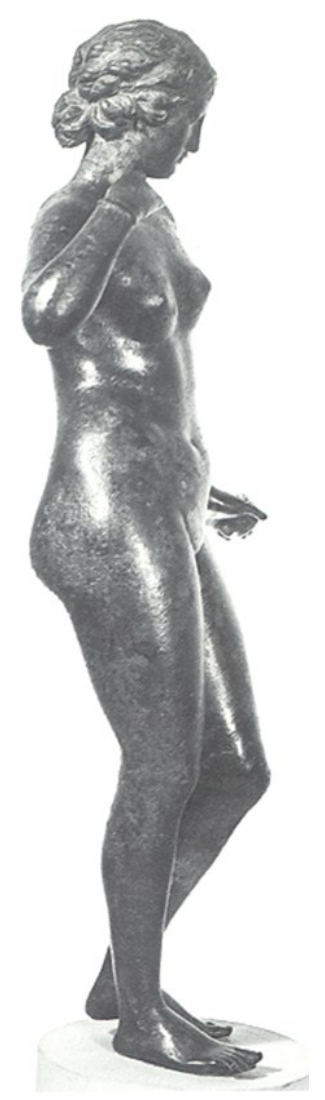

Side

$\underline{\text { Figure } 143}$

Aphrodite

Greek, Hellenistic Period, 323-31 B.C.E.

Height: 47 (18 5/8 ); Maximum width 24 (9 7/16)

Bronze

Rhode Island School of Design Art Museum

Center:

Selected Works, Museum of Art, Rhode Island School of Design. (2008)

Back and Side :

Arielle P. Koszloff and David GordonMitten

Gods Delight: The Human Figure in Classical Bronze (1988) 


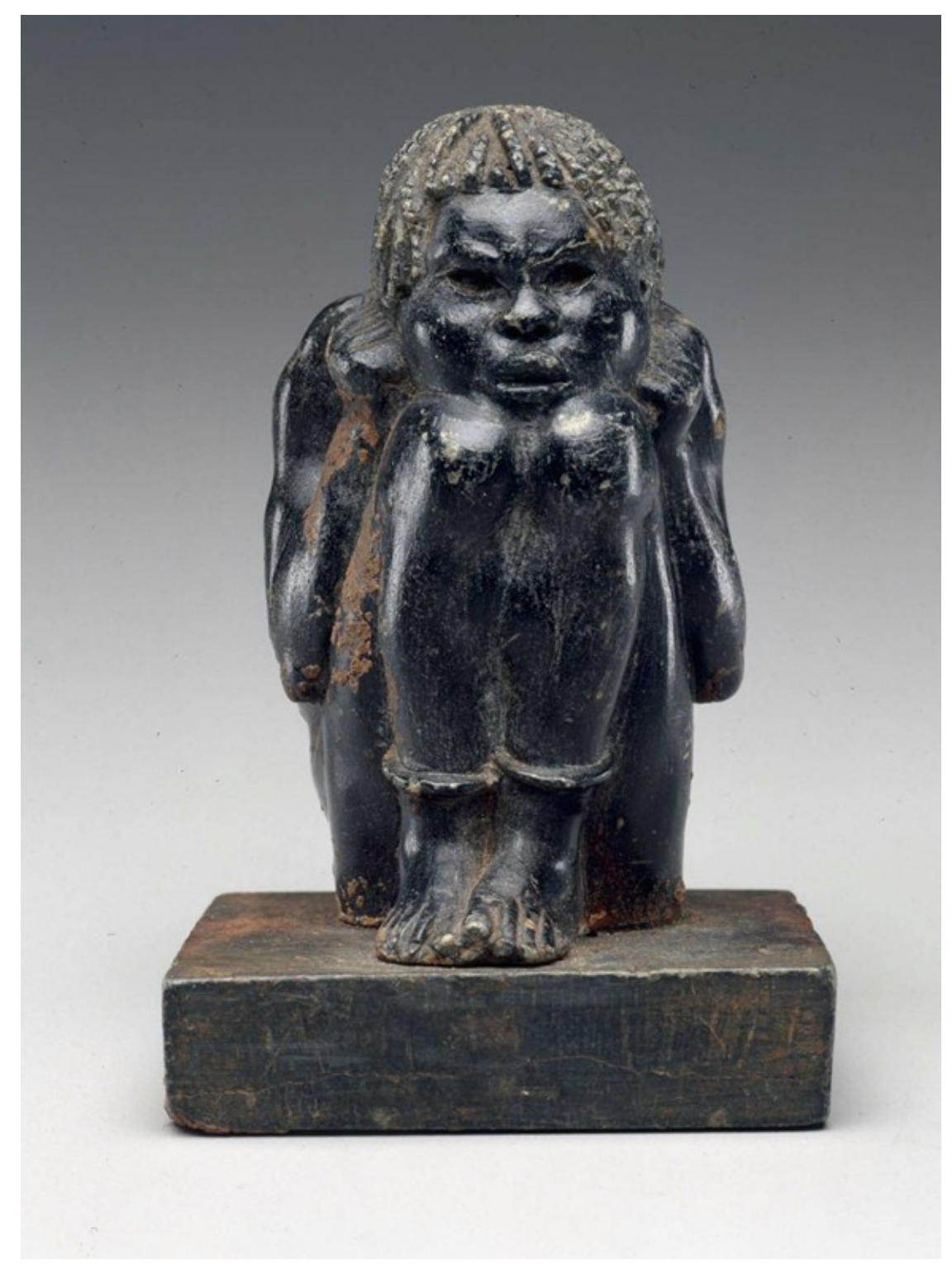

$\underline{\text { Figure } 144}$

\author{
Seated African Youth \\ MFA 01.8210 \\ Greek or Roman, Hellenistic or Imperial Period, \\ First Century B.C.E. or First Century C.E. \\ Black Steatite \\ Height (with plinth): $9.3 \mathrm{~cm}$ (3 11/16 in.) \\ Museum of Fine Arts, Boston Database \\ http://www.mfa.org/collections/object/figure-of-a-seated-african-youth-151115
}

(accessed 7/22/12) 


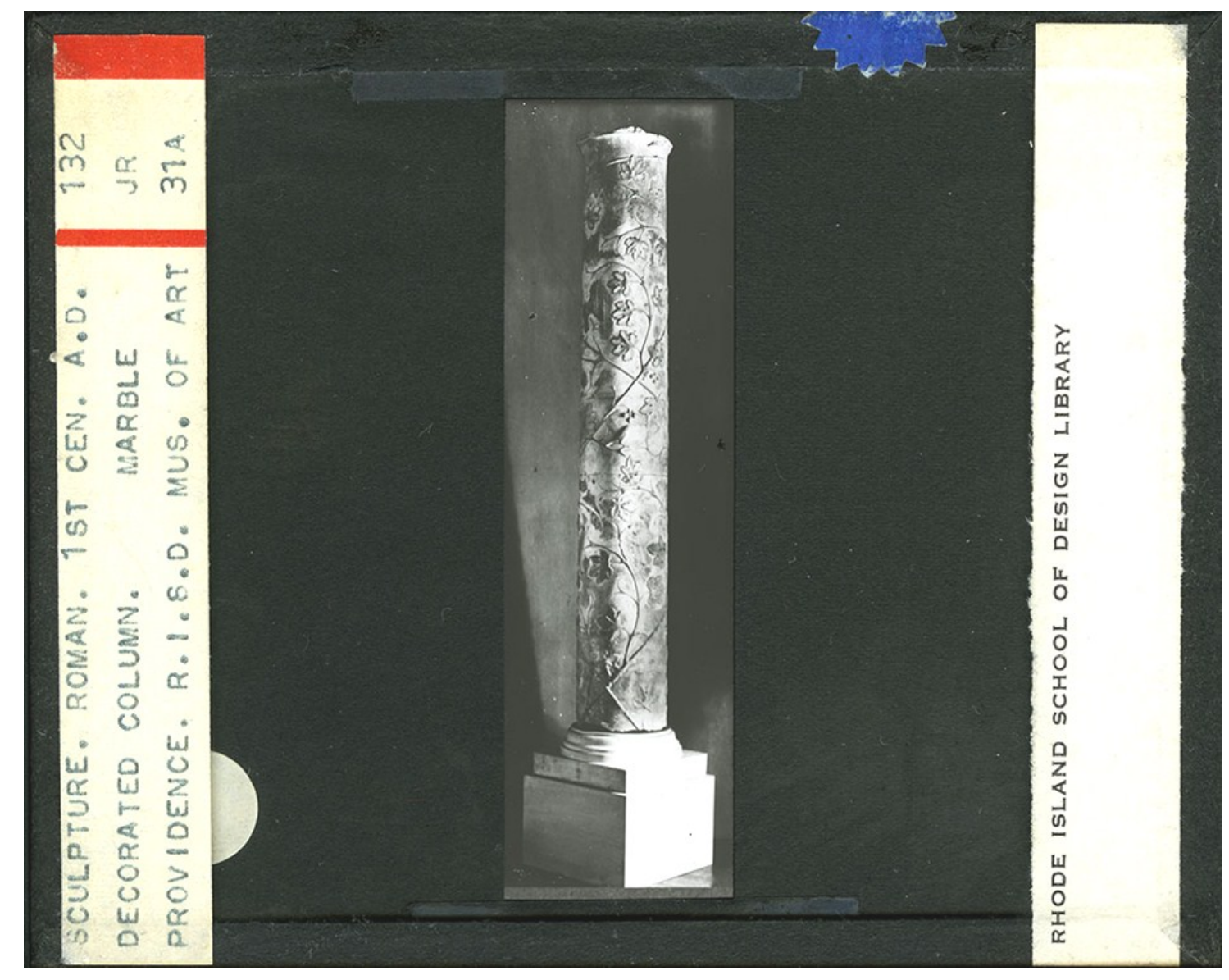

Figure 145

Lantern Slide: Marble Column with Vine Motif

RISD 26.156

RISD Visual Resources 


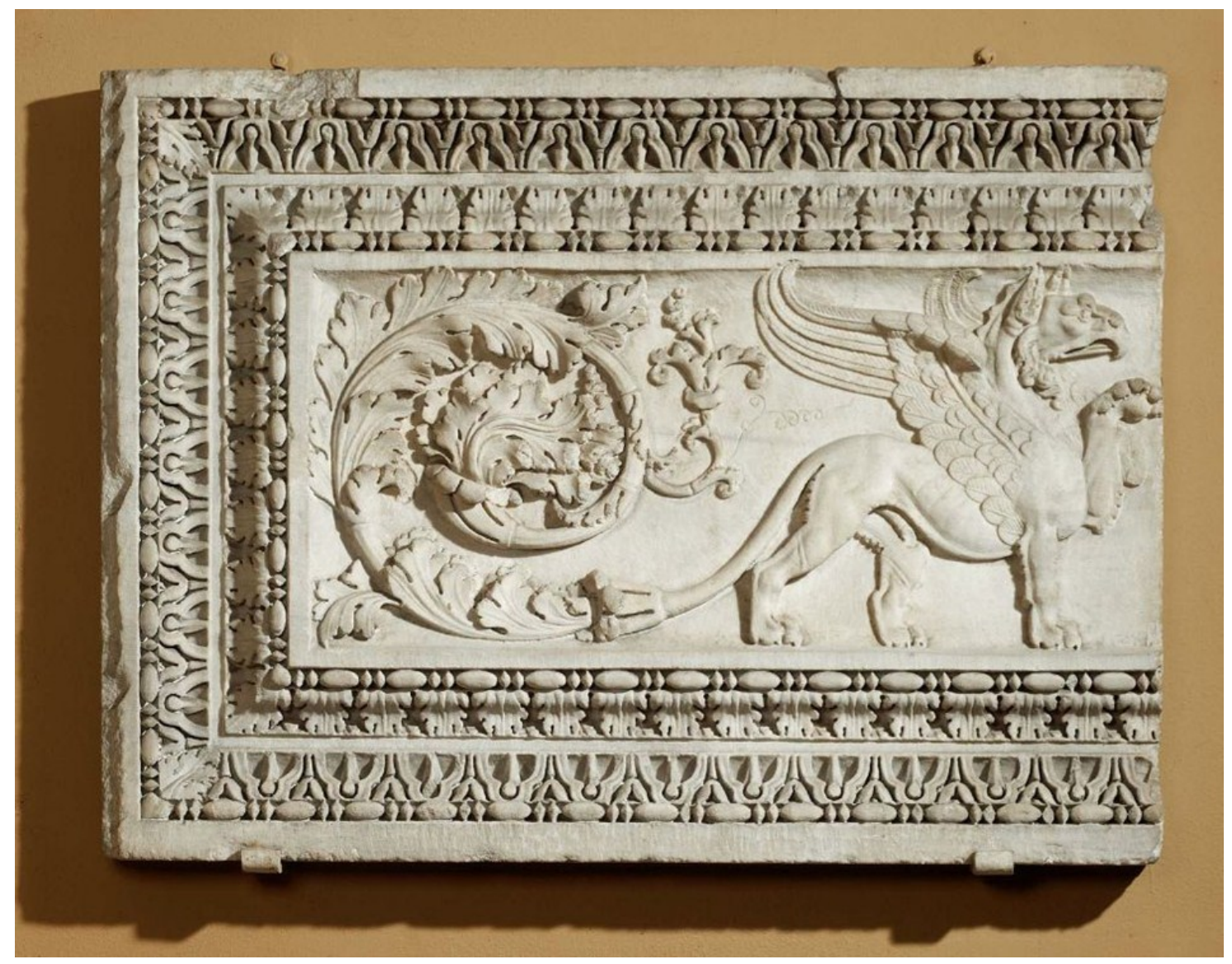

$\underline{\text { Figure } 146}$

Architectural Panel with Griffin MFA 03.747

Roman, Imperial Period, c.175-200 C.E.

Marble

Height x length: 104 x 139.2 cm (40 15/16 x 54 13/16 in.)

Museum of Fine Arts, Boston Database

http://www.mfa.org/collections/object/architectural-panel-with-a-griffin-151301

(accessed 7/22/12) 


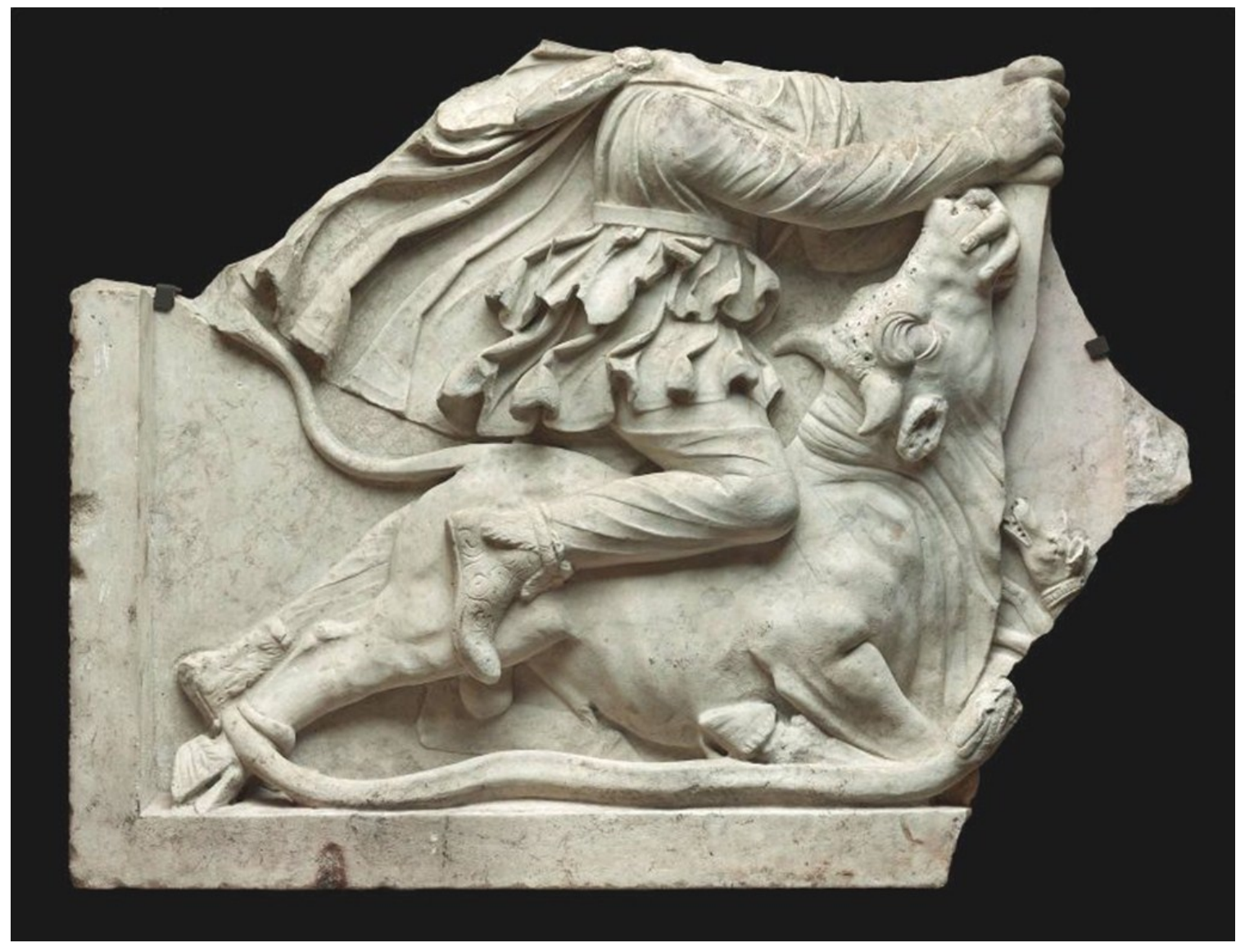

$\underline{\text { Figure } 147}$

Relief of Mithras Slaying the Bull

(Mithras Tauroctonos)

MFA 92.2692

Roman, Imperial Period, c. 125-175 C.E.

Marble

$65 \times 85 \mathrm{~cm}(259 / 16 \times 337 / 16$ in. $)$

http:/www.mfa.org/collections/object/relief-of-mithras-slaying-the-bull-mithrastauroctonos-151238

(accessed 7/22/12) 


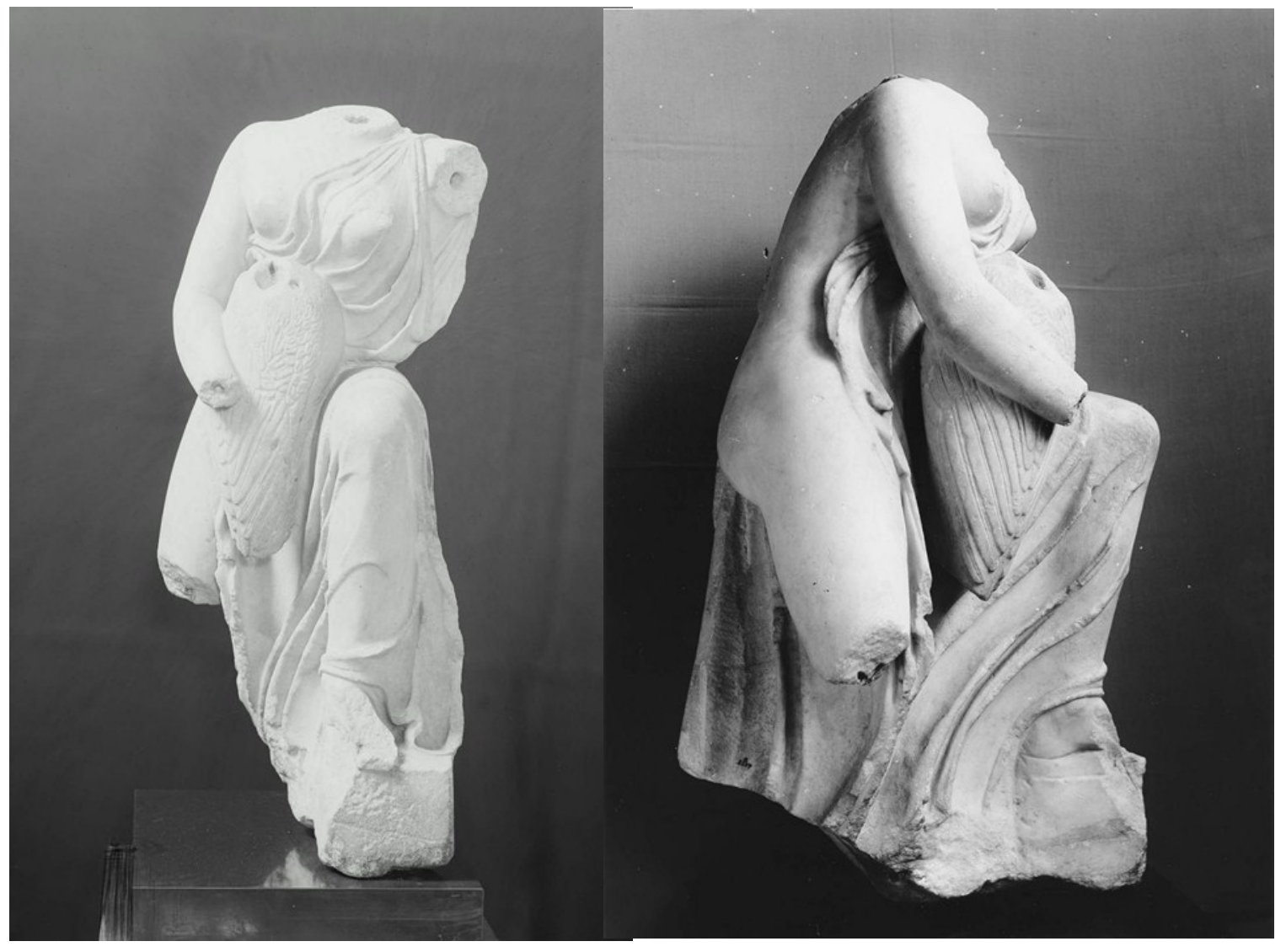

$\underline{\text { Figure } 148}$

Leda and the Swan

MFA 04.14

Greek, Classical Period, Late Fifth Century B.C.E.

Overall: 88.5 × 53 × $31 \mathrm{~cm}(3413 / 16$ × $207 / 8 \times 123 / 16$ in.)

Marble

Museum of Fine Arts, Boston Database

http://www.mfa.org/collections/object/leda-and-the-swan-151040

(accessed 7/22/12) 


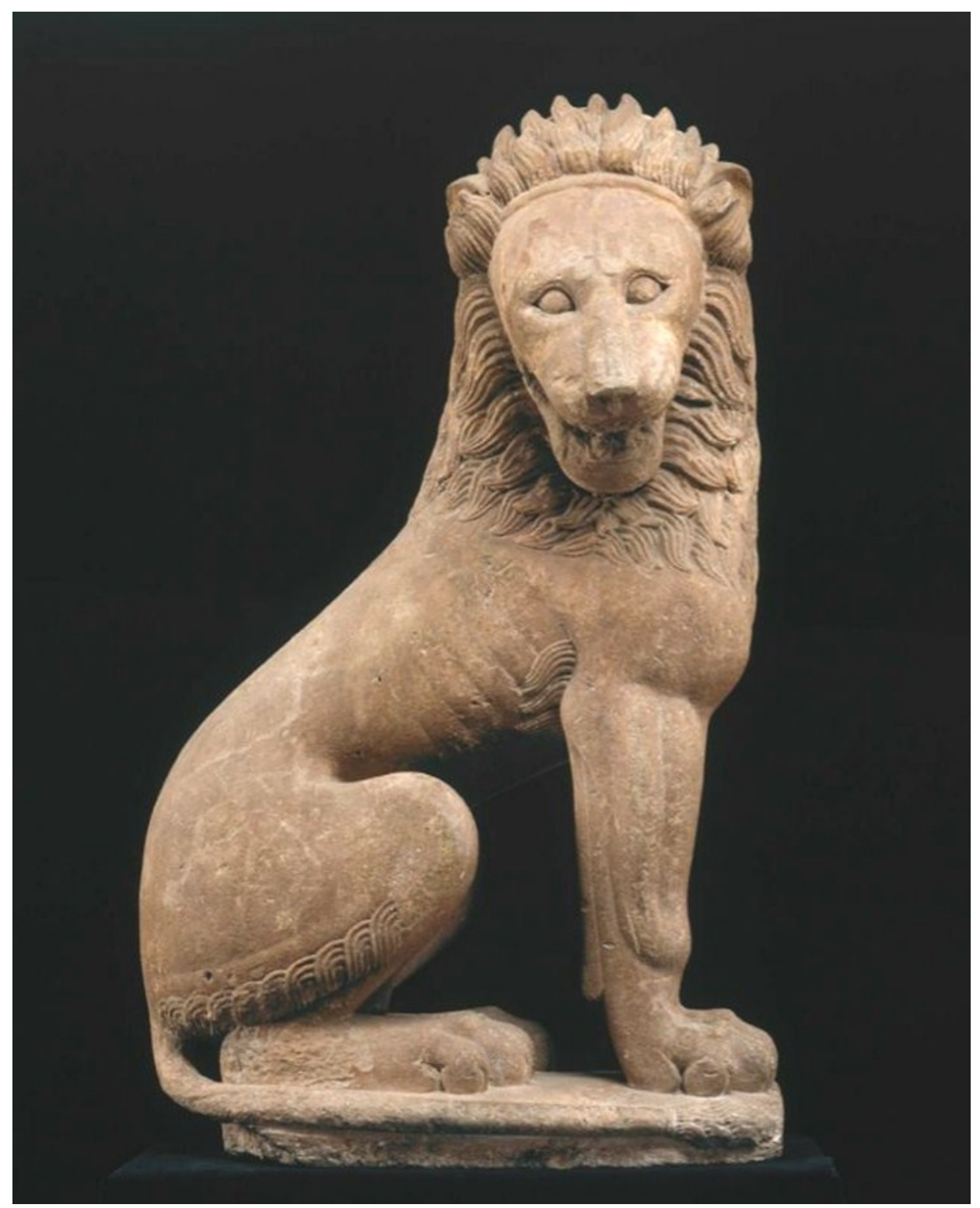

$\underline{\text { Figure } 149}$

Greek Lion

MFA 97.289

Limestone

Greek, Archaic Period, c. 550

Overall: 95.3 × 58 × 38 cm (37 1/2 x 22 13/16 x 14 15/16 in.)

http://www.mfa.org/collections/object/lion-151017

(accessed 9/23/12) 


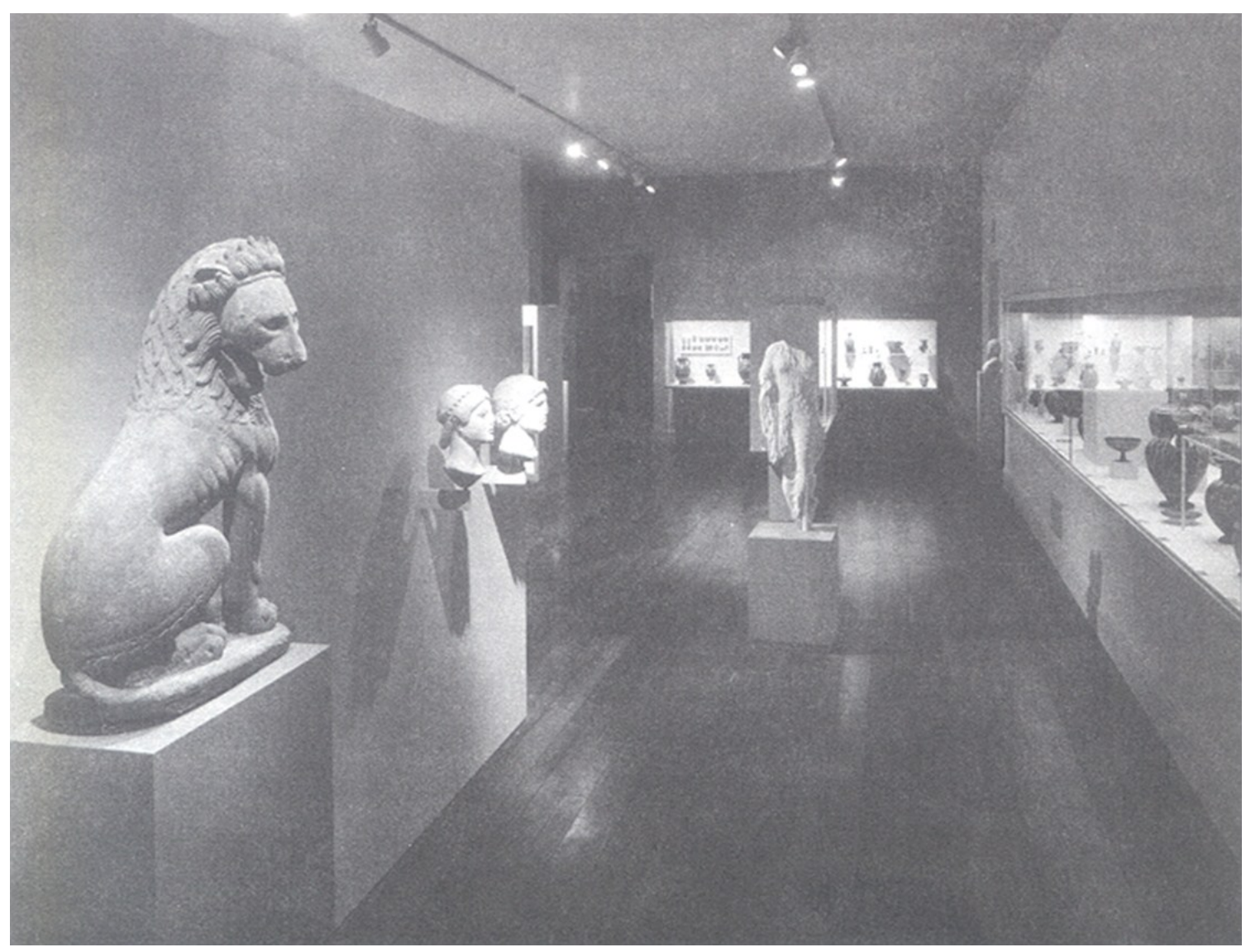

$\underline{\text { Figure } 150}$

Greek Lion (MFA 97.289) in the MFA Classical Gallery Walter Muir Whitehall, Museum of Fine Arts: A Centennial History, Volume II (1970) 


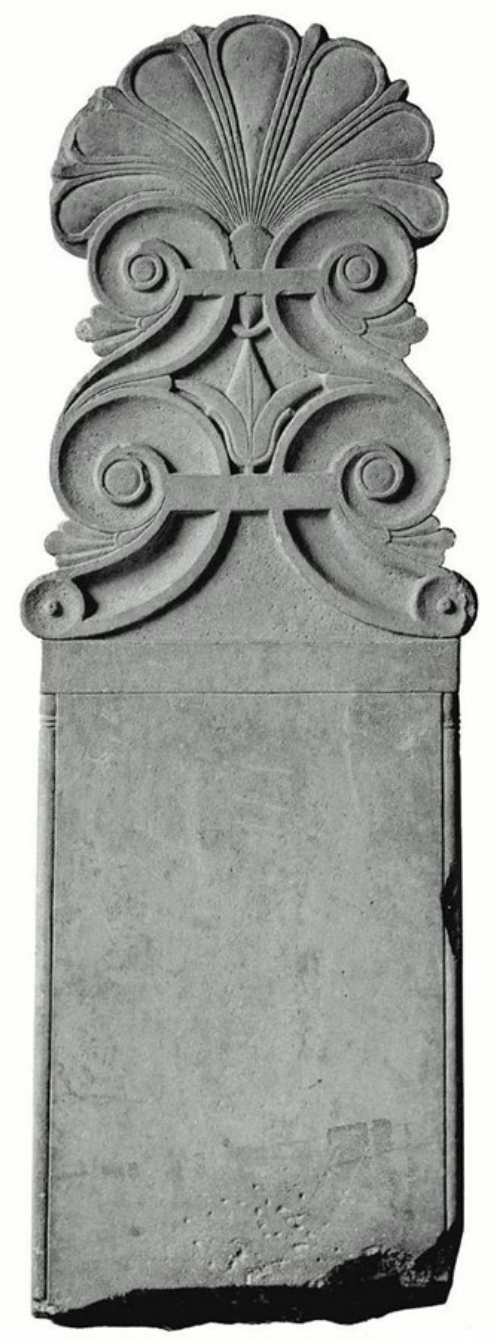

Figure 151

Top and shaft of a Grave Stele MFA 03.753

Greek, Archaic Period, c. 550-500

Height: $131 \mathrm{~cm}$ (51 9/16 in.) Marble

Museum of Fine Arts, Boston Database

http://www.mfa.org/collections/object/top-and-shaft-of-a-grave-stele-151026

(accessed 7/22/12) 


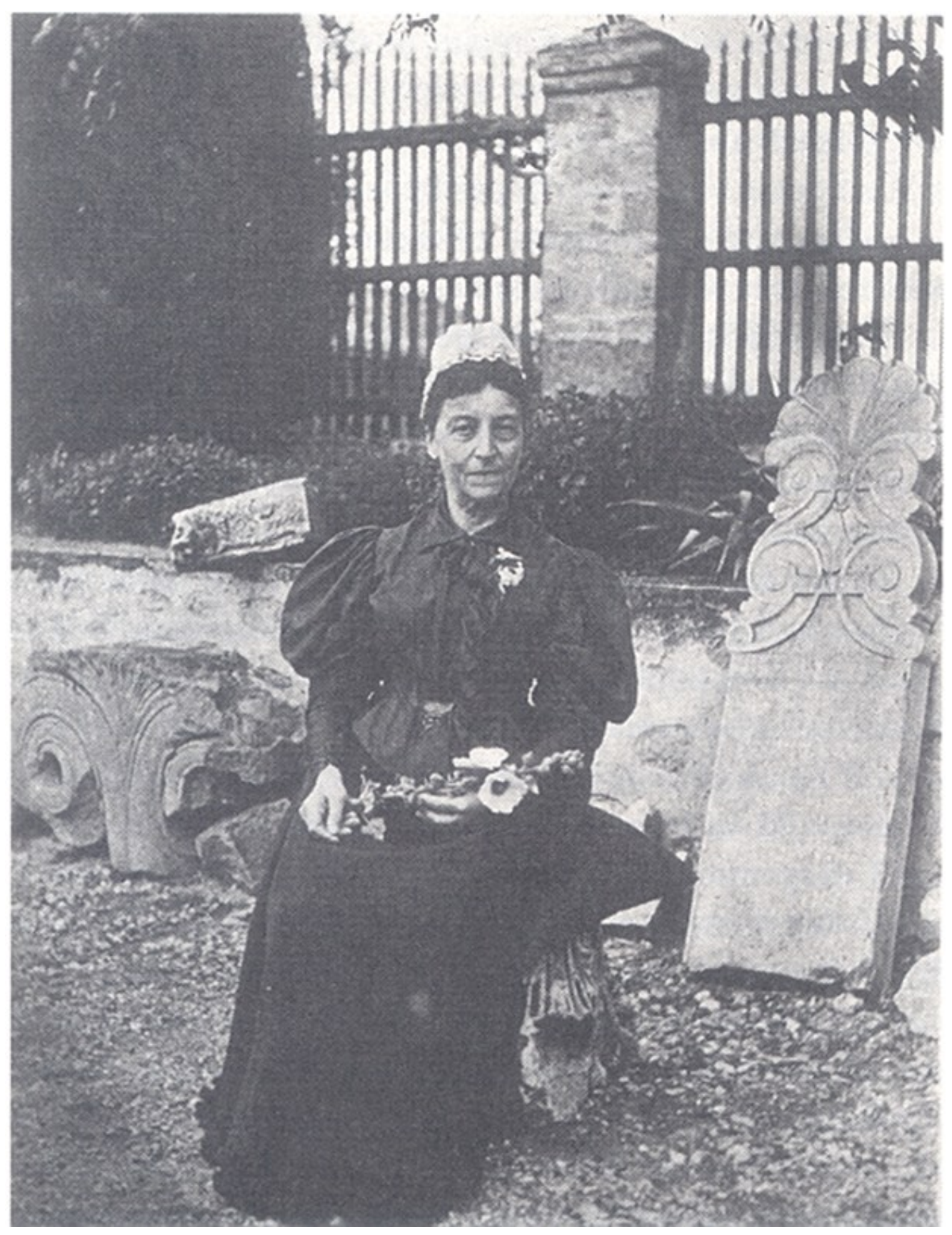

$\underline{\text { Figure } 152}$

Top and shaft of a Grave Stele (MFA 03.753)

Thymbra Farm, Frank Calvert's Estate at Batak in the Troad Susan Heuck Allen

Finding the Walls of Troy: Frank Calvert and Heinrich Schliemann at Hisarlik (1999) 


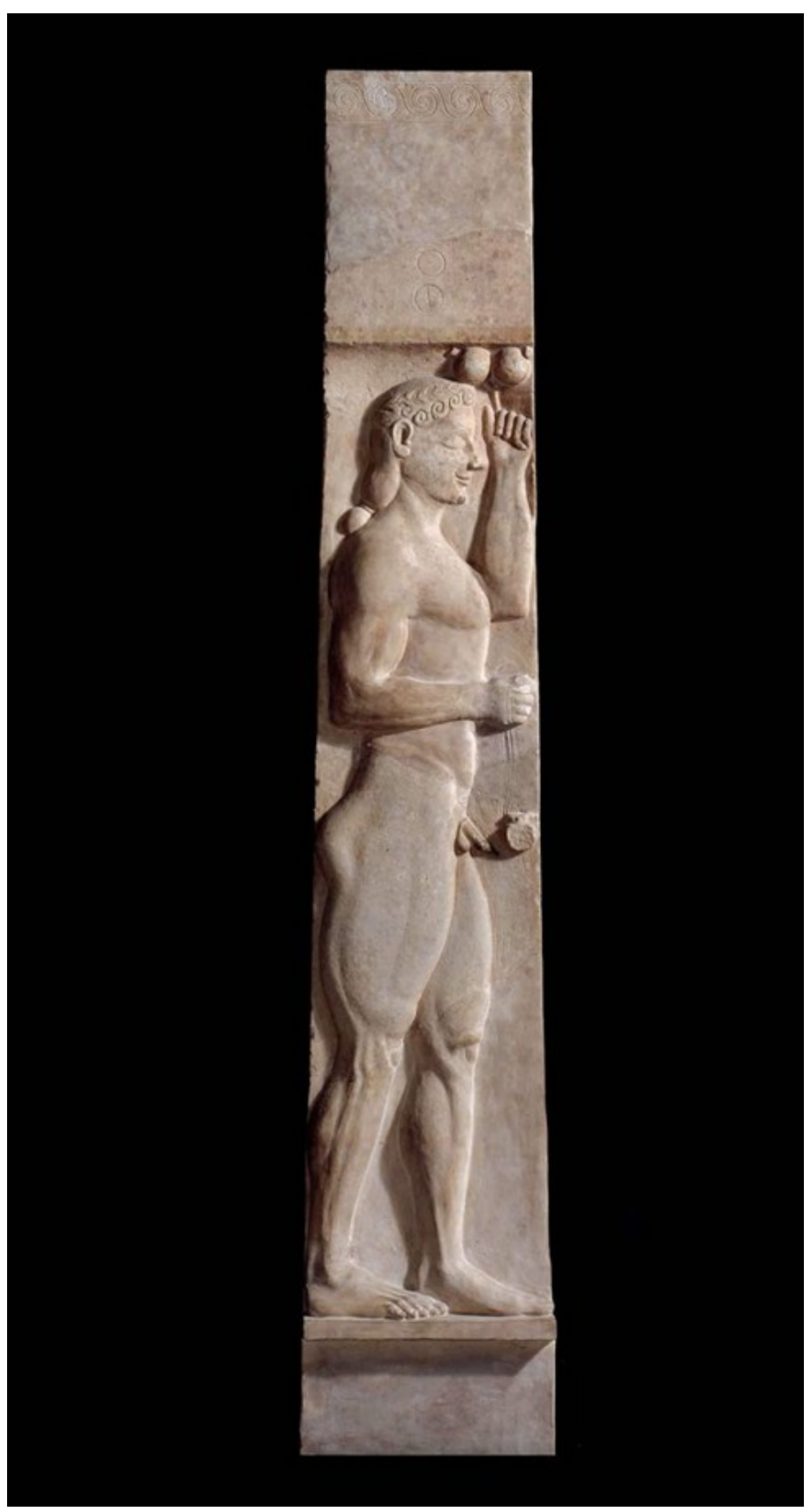

$\underline{\text { Figure } 153}$

Funerary Monument for an Athlete MFA 08.288

Greek, Archaic Period, c. 550-500

Height: $131 \mathrm{~cm}$ (51 9/16 in.) Marble

Museum of Fine Arts, Boston Database

http://www.mfa.org/collections/object/funerary-monument-for-an-athlete-151018

(accessed 7/22/12) 

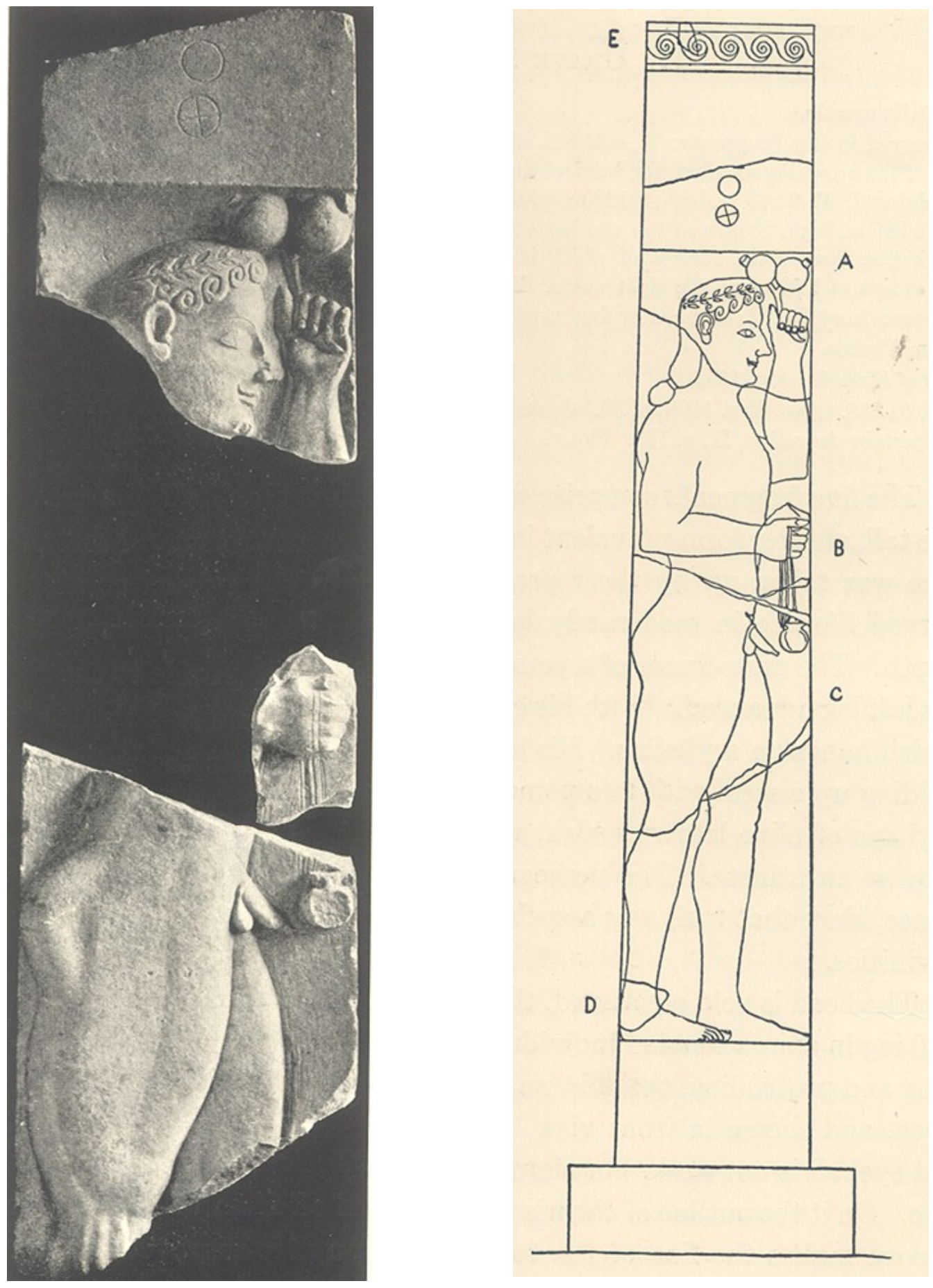

Figure 154

Funerary Monument for an Athlete Fragments of MFA 08.288 and Proposed Reconstruction

L. D. Caskey and the Museum of Fine Arts, Boston

Catalogue of Greek and Roman Sculpture (1925) 


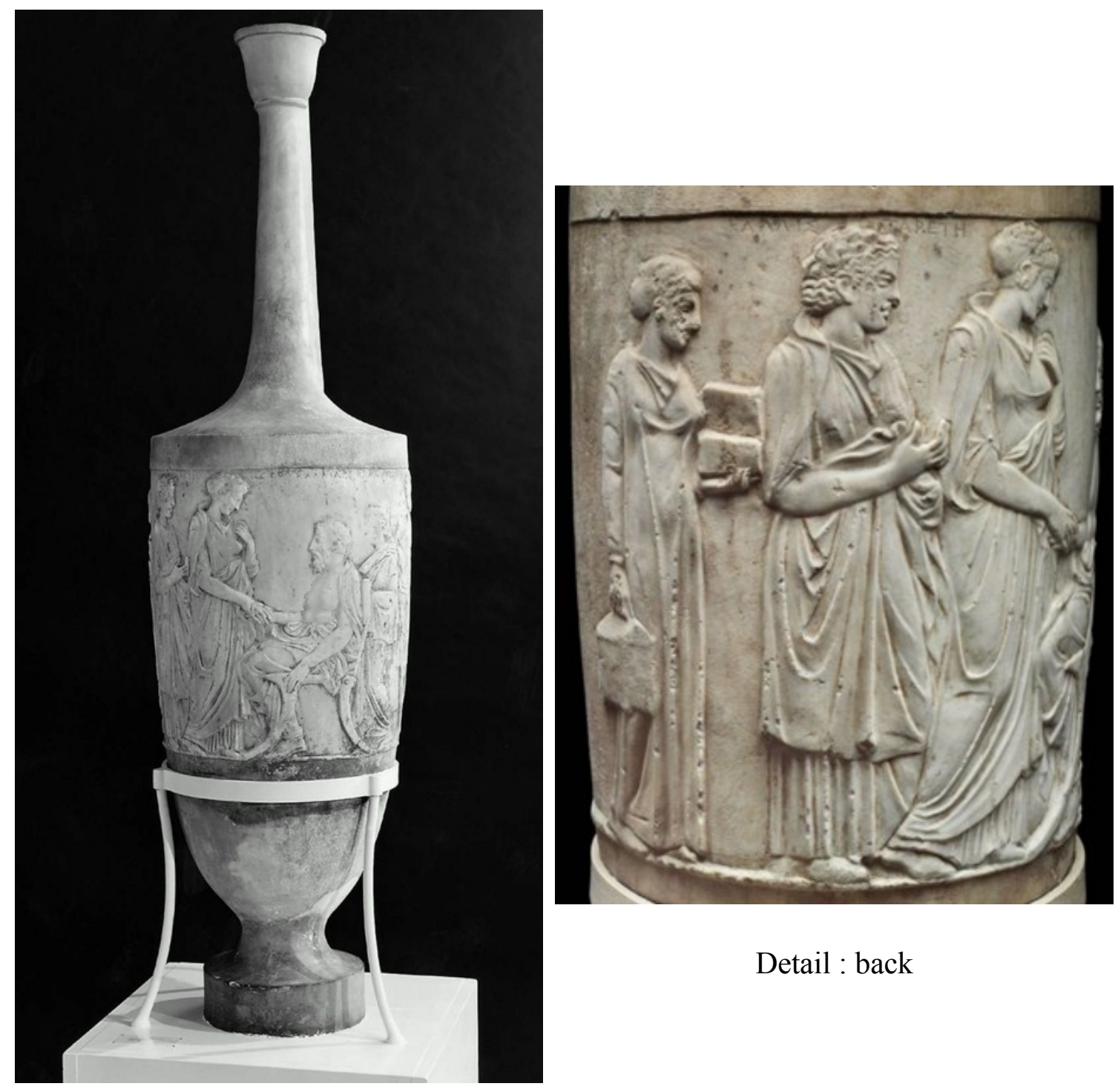

\section{Figure 155}

Fragmentary Oil Flask (Lekythos) Serving as a Grave Monument MFA 96.700

Greek, Classical Period, c. 390-380

Overall: 110 x $48 \mathrm{~cm}, 600 \mathrm{~kg}$ (43 5/16 x $187 / 8$ in.)

Marble

Museum of Fine Arts, Boston Database

http://www.mfa.org/collections/object/fragmentary-oil-flask-lekythos-serving-as-a-grave -monument-151077

(accessed 7/22/12) 


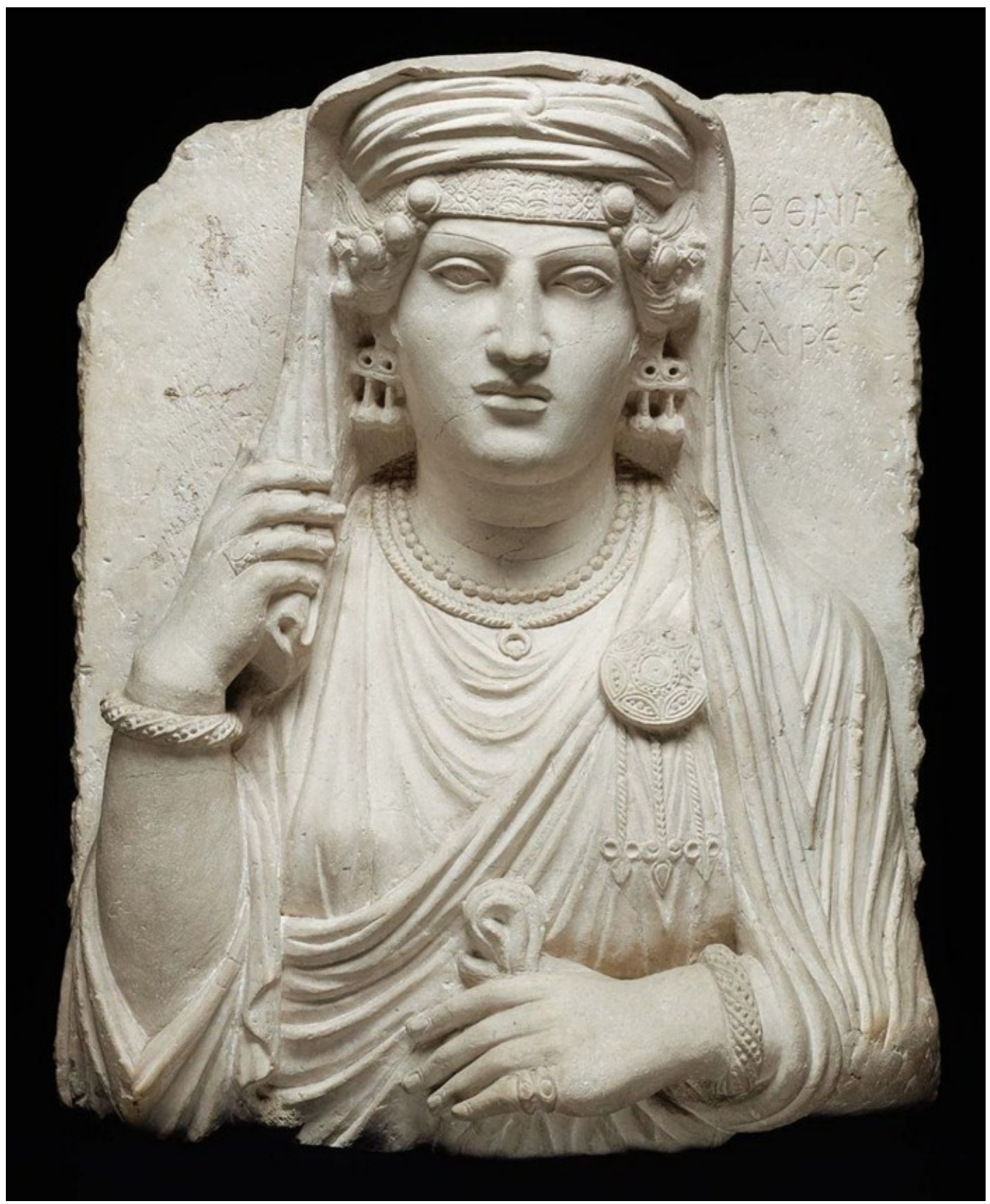

$\underline{\text { Figure } 156}$

Funerary Monument of Aththaia, Daughter of Malchos

MFA 22.659

Palmyrene, Imperial Period, 150-200 C.E.

Height: $55 \mathrm{~cm}$ (21 5/8 in.); width: $42 \mathrm{~cm}$ (16 9/16 in.) Limestone

Museum of Fine Arts, Boston Database

http://www.mfa.org/collections/object/funerary-monument-of-aththaia-daughter-ofmalchos- 151395

(accessed 7/22/12) 


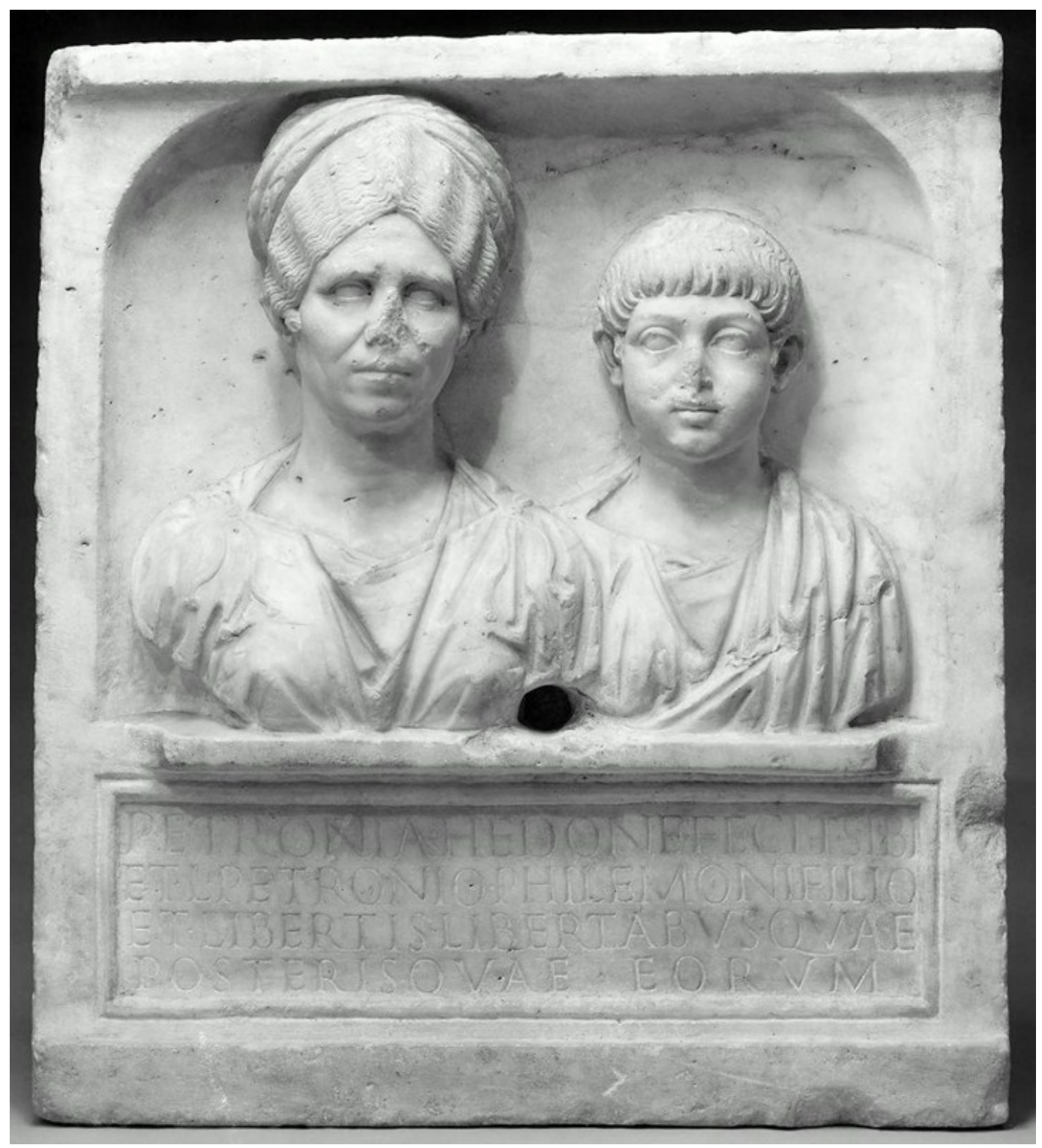

$\underline{\text { Figure } 157}$

Funerary Relief of Petronia Hedone and her Son, Lucius Petronius Philemon MFA 99.348

Roman, Imperial Period, c.110-120 C.E.

Height $x$ width $x$ depth at bottom: 56.5 x $49.5 \mathrm{~cm}$ x 8.9 (22 1/4 x $191 / 2$ x $31 / 2$ in.)

Marble

Museum of Fine Arts, Boston Database

http:/www.mfa.org/collections/object/tomb-relief-of-petronia-hedone-and-her-sonlucius-petronius-philemon-151349

(accessed 7/22/12) 


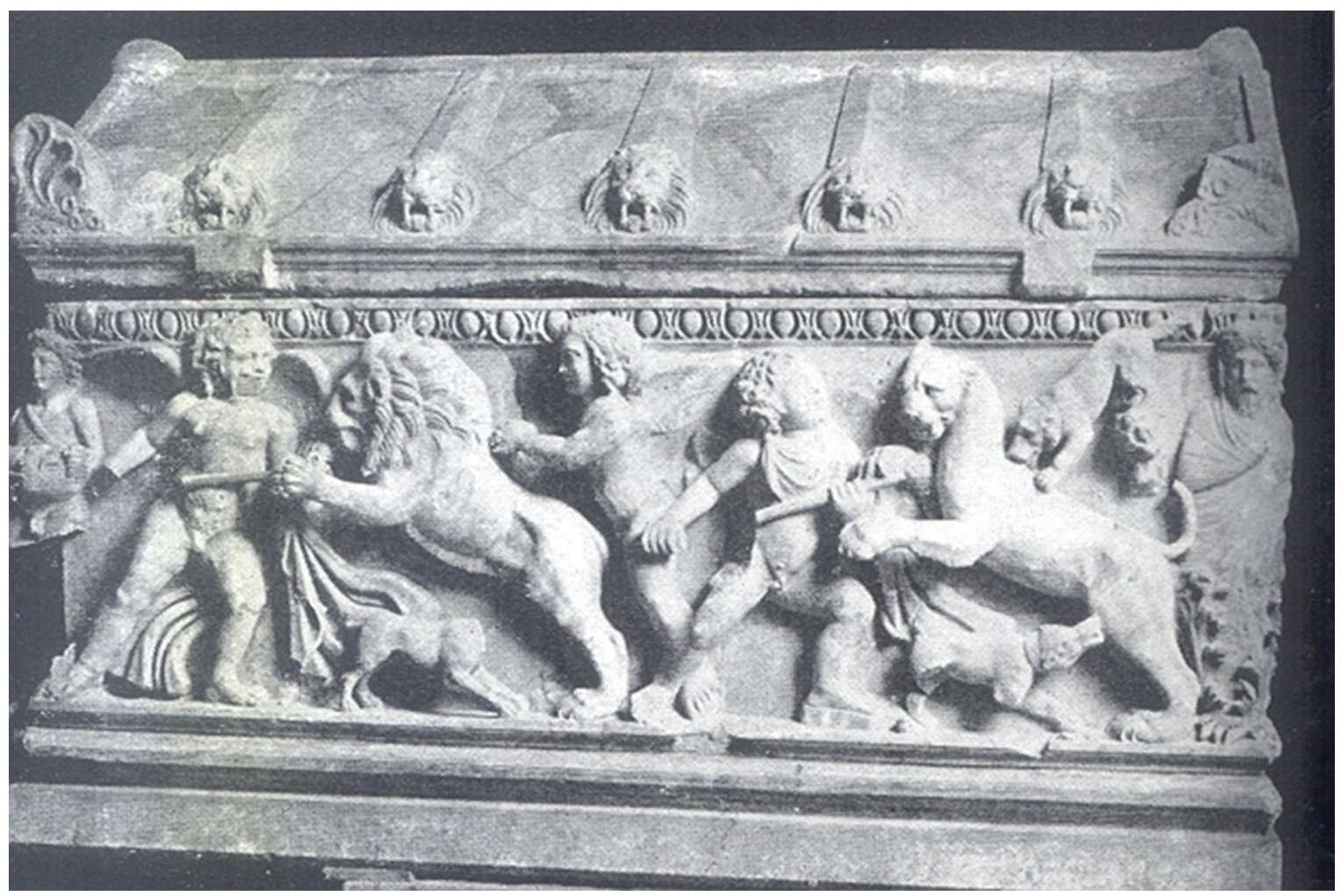

Figure 158

Pamphylian Sarcophagus

RISD 21.074

Back Side: Hunt Scene

Island School of Design Art Museum

A. W. Lawrence, Classical Sculpture (1929) 


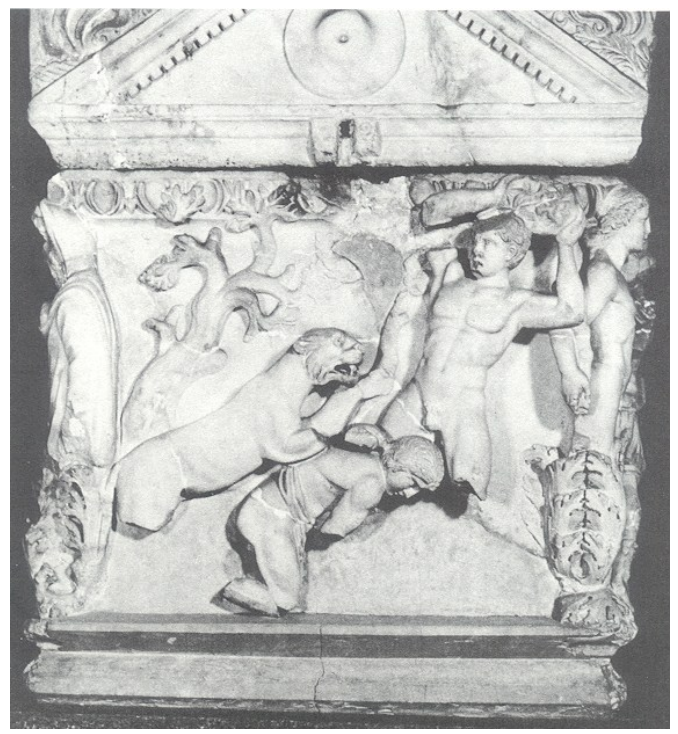

Left

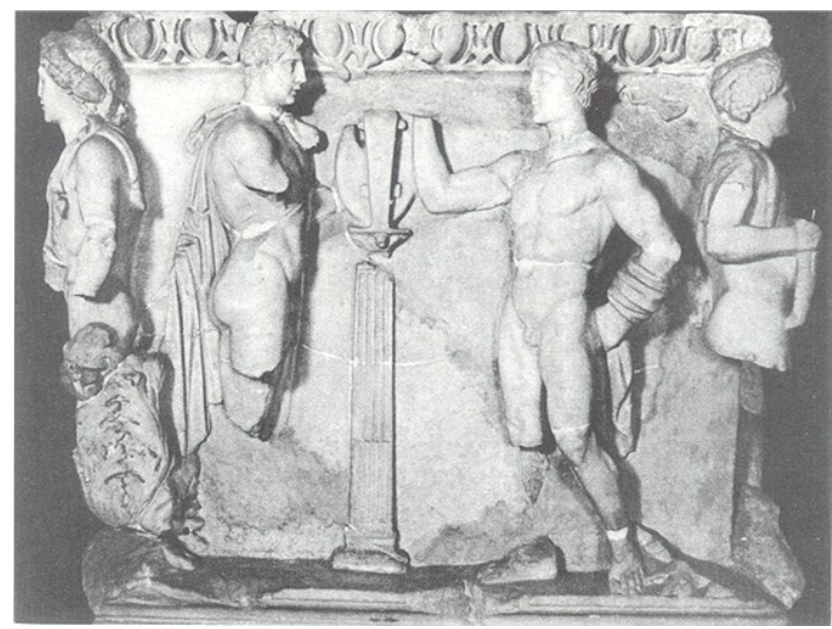

Right

$\underline{\text { Figure } 159}$

Pamphylian Sarcophagus

RISD 21.074

Ends

Island School of Design Art Museum

A. W. Lawrence, Classical Sculpture (1929) 

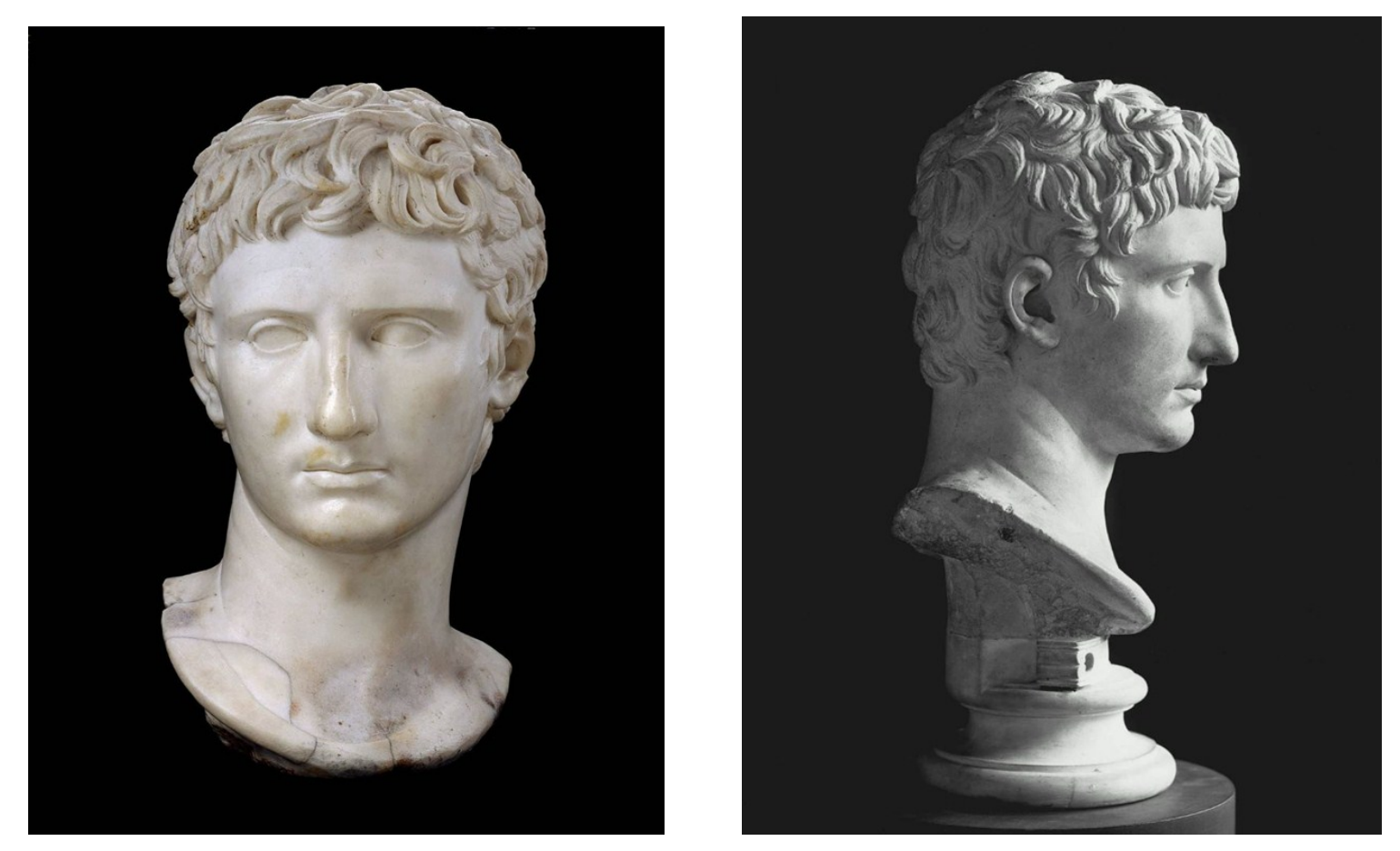

$\underline{\text { Figure } 160}$

Augustus

MFA 99.344

Roman, Imperial Period, First or Second Century C.E.

Height: $43.3 \mathrm{~cm}$ (17 1/16 in.); length (of face): $20 \mathrm{~cm}$ (7 7/8 in.)

Marble

Museum of Fine Arts, Boston Database

http://www.mfa.org/collections/object/augustus-151325

(accessed 7/22/12) 


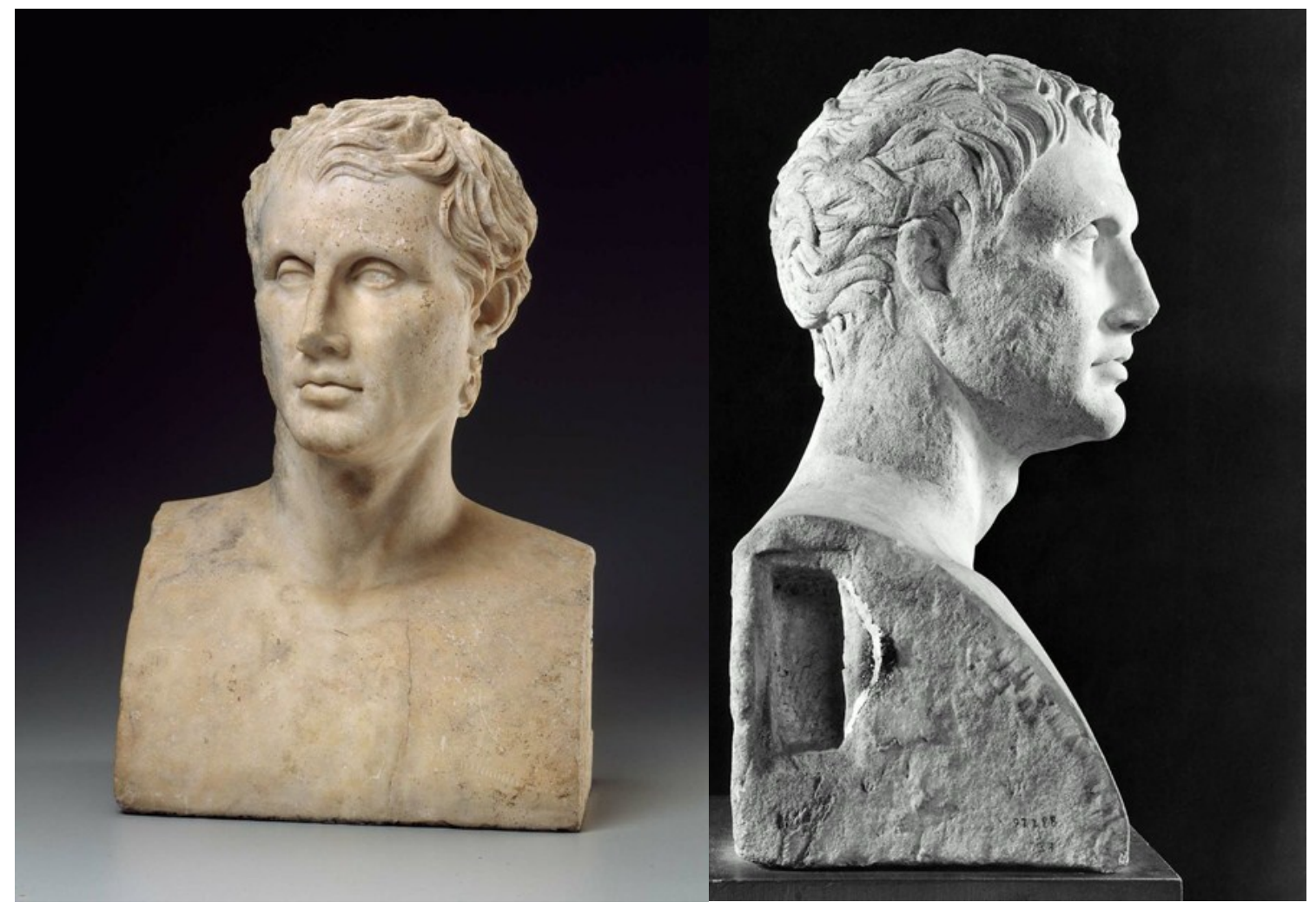

$\underline{\text { Figure } 161}$

Herm-bust of Menander

Roman, Imperial Period

Marble

Height: $51.5 \mathrm{~cm}$ ( 20 1/4 in.); length (of face): $19.6 \mathrm{~cm}$ (7 11/16 in.)

MFA 97.288

Museum of Fine Arts, Boston Database

http://www.mfa.org/collections/object/herm-bust-of-menander-151124

(accessed 7/22/12) 

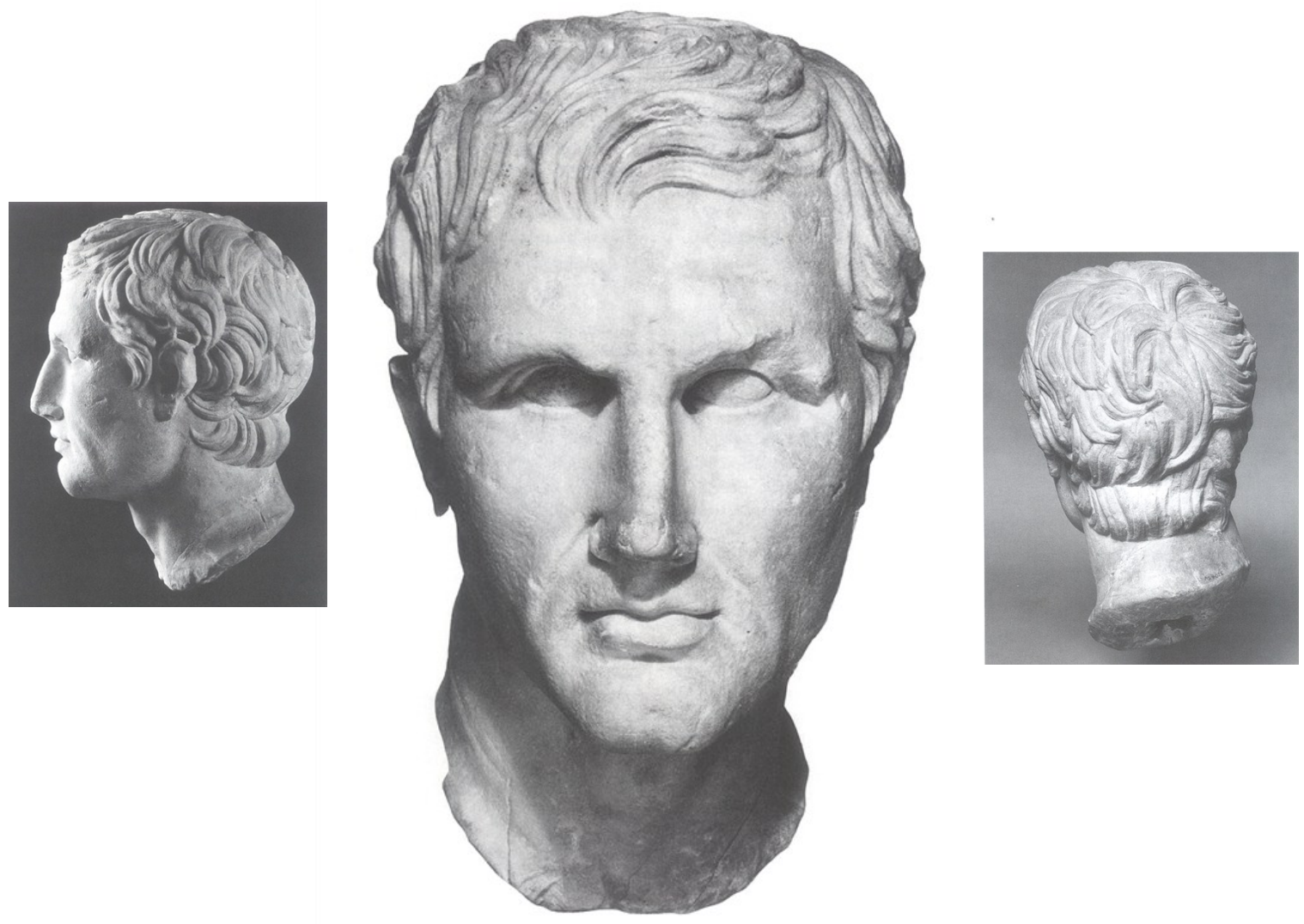

$\underline{\text { Figure } 162}$

Head of Menander

MS 4028

Roman, Imperial Period, Late First Century B.C.E. or Early First Century C.E.

H. 0.345; W. 0.21; Th. $0.27 \mathrm{~m}$

Marble

University of Pennsylvania Museum of Archaeology and Anthropology

Irene Bald Romano, Classical Sculpture (2006) 


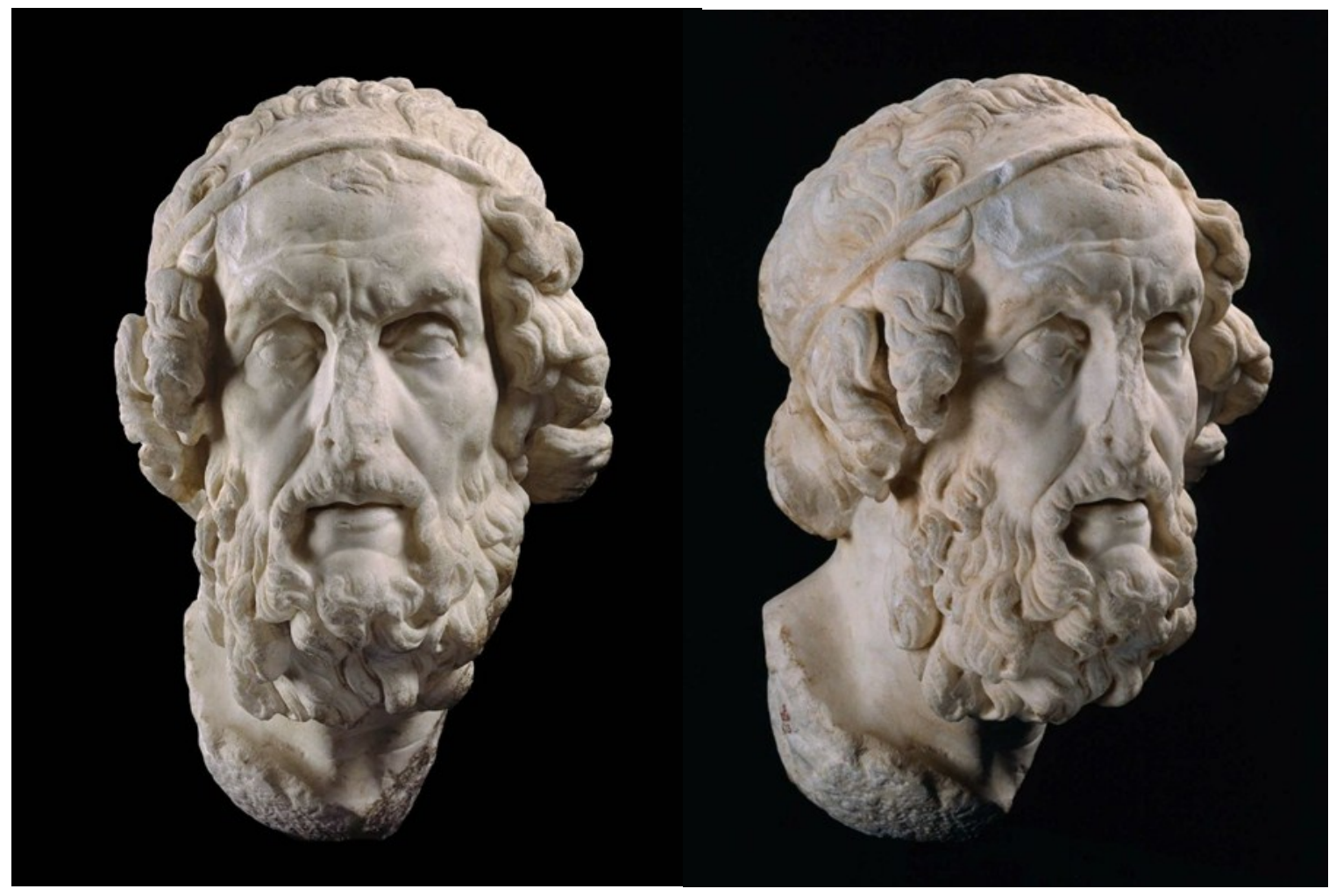

$\underline{\text { Figure } 163}$

Head of Homer

MFA 04.13

Roman: Late Republic /Early Imperial Marble

Height: $41 \mathrm{~cm}$ (16 1/8 in.); length (of face): $21 \mathrm{~cm}$ ( $81 / 4$ in.)

Museum of Fine Arts, Boston Database

http://www.mfa.org/collections/object/homer-151122

(accessed 7/22/12) 


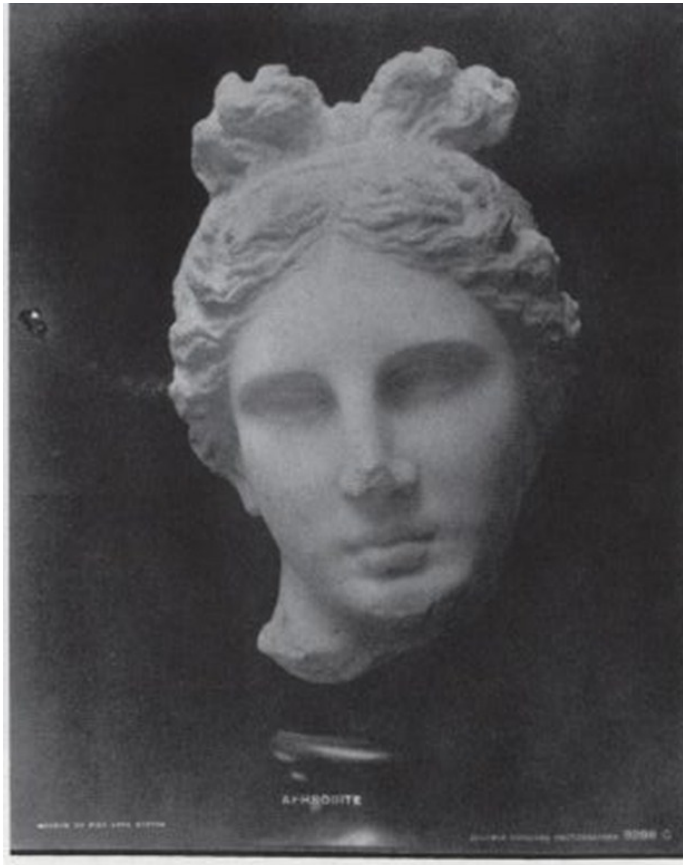

9 Baldwin Coolidge, Bartlett Aphrodite (courtesy: Museum of Fine Arts, Boston)

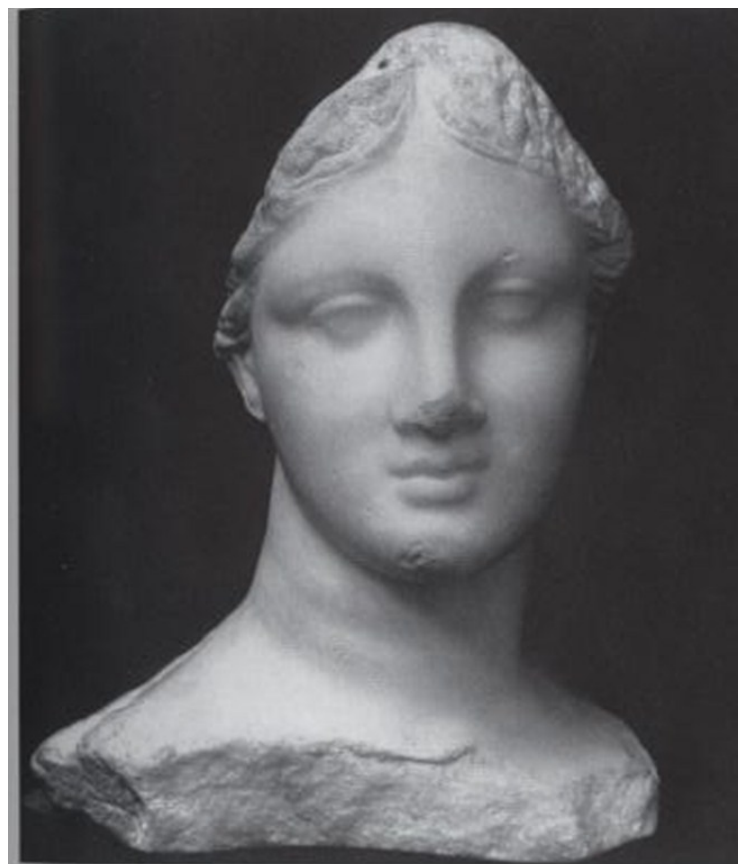

8 Edward J. Moore, Chios Girl, 1910 (courtesy: Museum of Fine Arts, Boston)

$\underline{\text { Figure } 164}$

\author{
Aphrodite ("The Bartlett Head") \\ MFA 03.743 \\ and \\ Head of Goddess ("The Chios Head") \\ MFA 10.70 \\ Mary Bergstein
}

"The Lonely Aphrodites: On the Documentary Photography of Sculpture" (1992) The Art Bulletin (74) 3. 


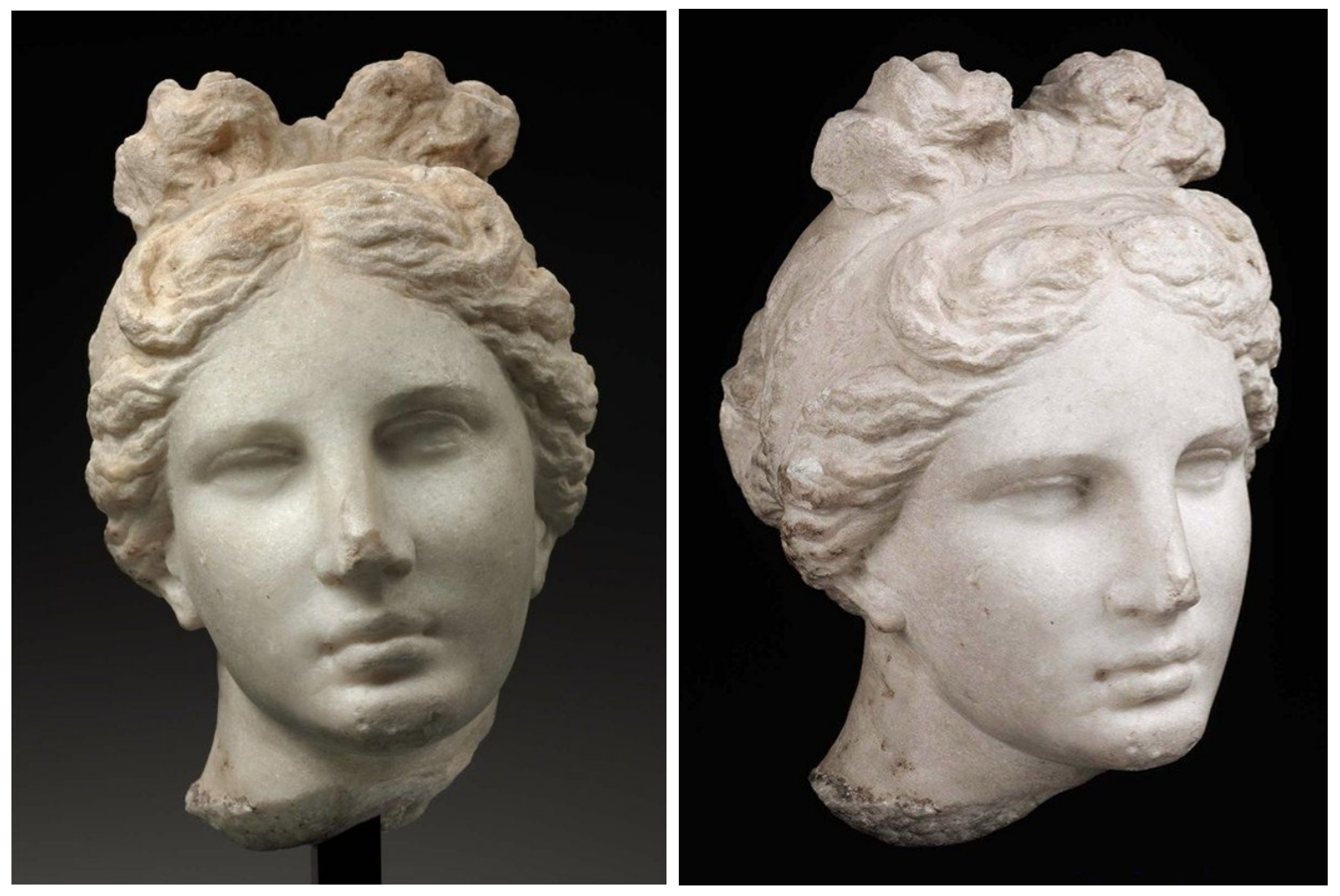

$\underline{\text { Figure } 165}$

Aphrodite ("The Bartlett Head")

MFA 03.743

Greek, Late Classical or Early Hellenistic Period, c. 330-300 B.C.E.

Overall (not including socle): 28.8 x 18.1 x $24.8 \mathrm{~cm}(115 / 16 \times 71 / 8 \times 93 / 4$ in.)

Marble

Museum of Fine Arts, Boston Database

http://www.mfa.org/collections/object/head-of-aphrodite-the-bartlett-head-151059

(accessed 7/22/12) 


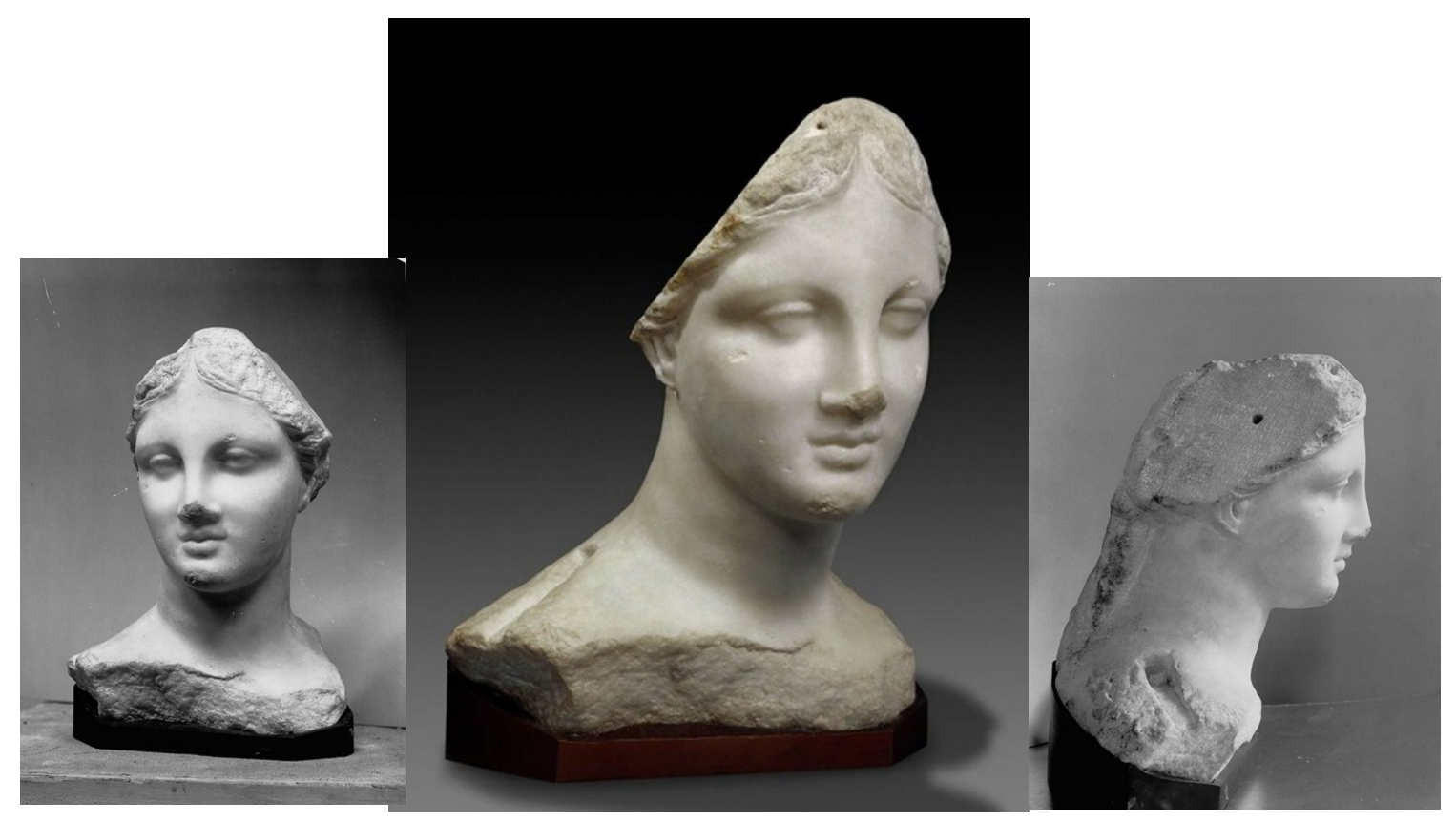

$\underline{\text { Figure } 166}$

Head of Goddess ("The Chios Head")

MFA 10.70

Greek, Late Classical or Early Hellenistic Period, c. 300 B.C.E.

Height: $36 \mathrm{~cm}(14$ 3/16)

Marble

Museum of Fine Arts, Boston Database

http://www.mfa.org/collections/object/head-of-a-goddess-the-chios-head-151060

(accessed 7/22/12) 


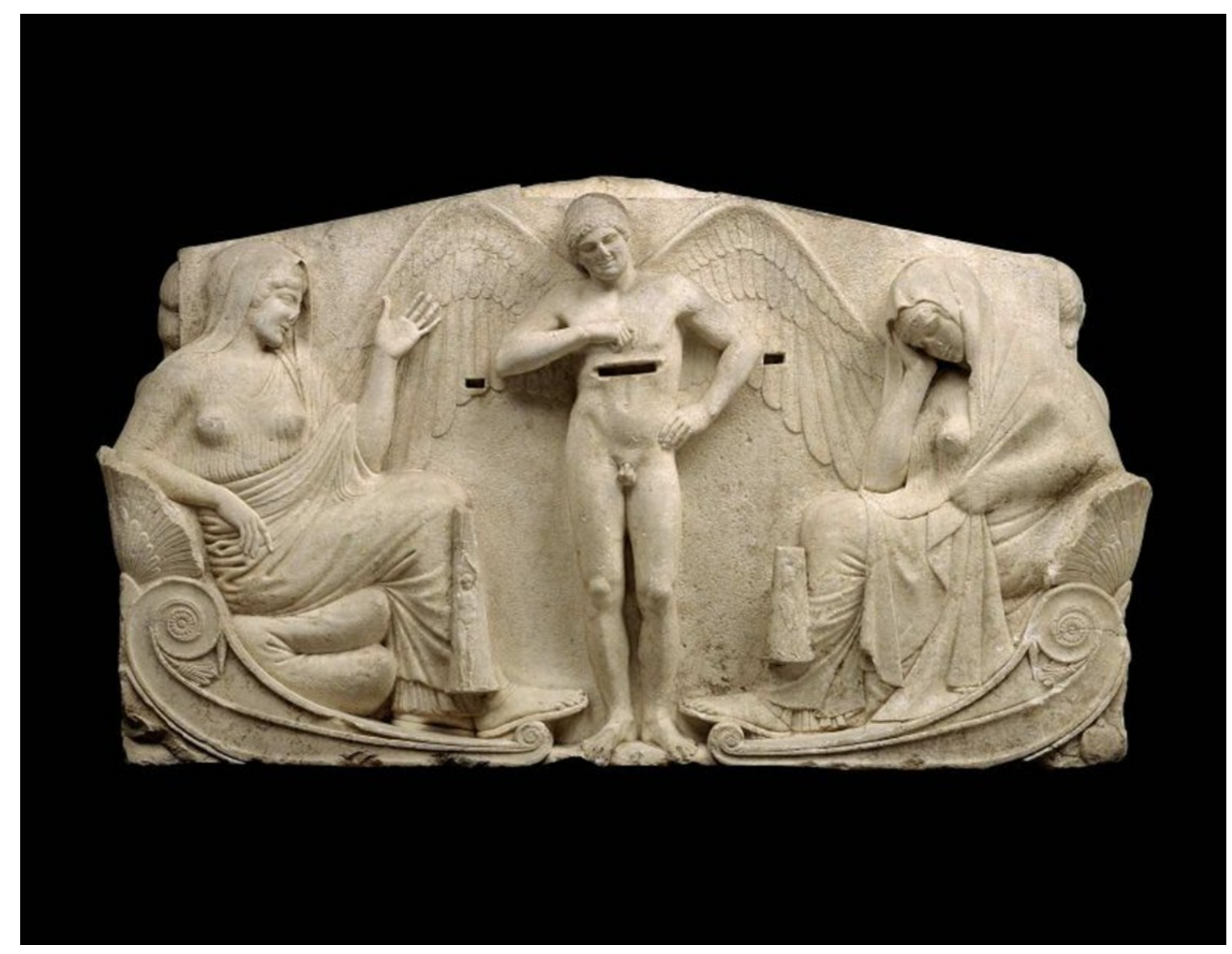

$\underline{\text { Figure } 167}$

Three-sided Relief

Back Panel

MFA 08.205

Greek, Classical Period, about 450-440

Overall: 82 x $161 \mathrm{~cm}(32$ 5/16 x 63 3/8 in.)

Marble

Museum of Fine Arts, Boston Database

http://www.mfa.org/collections/object/three-sided-relief-151033

(accessed 7/22/12) 


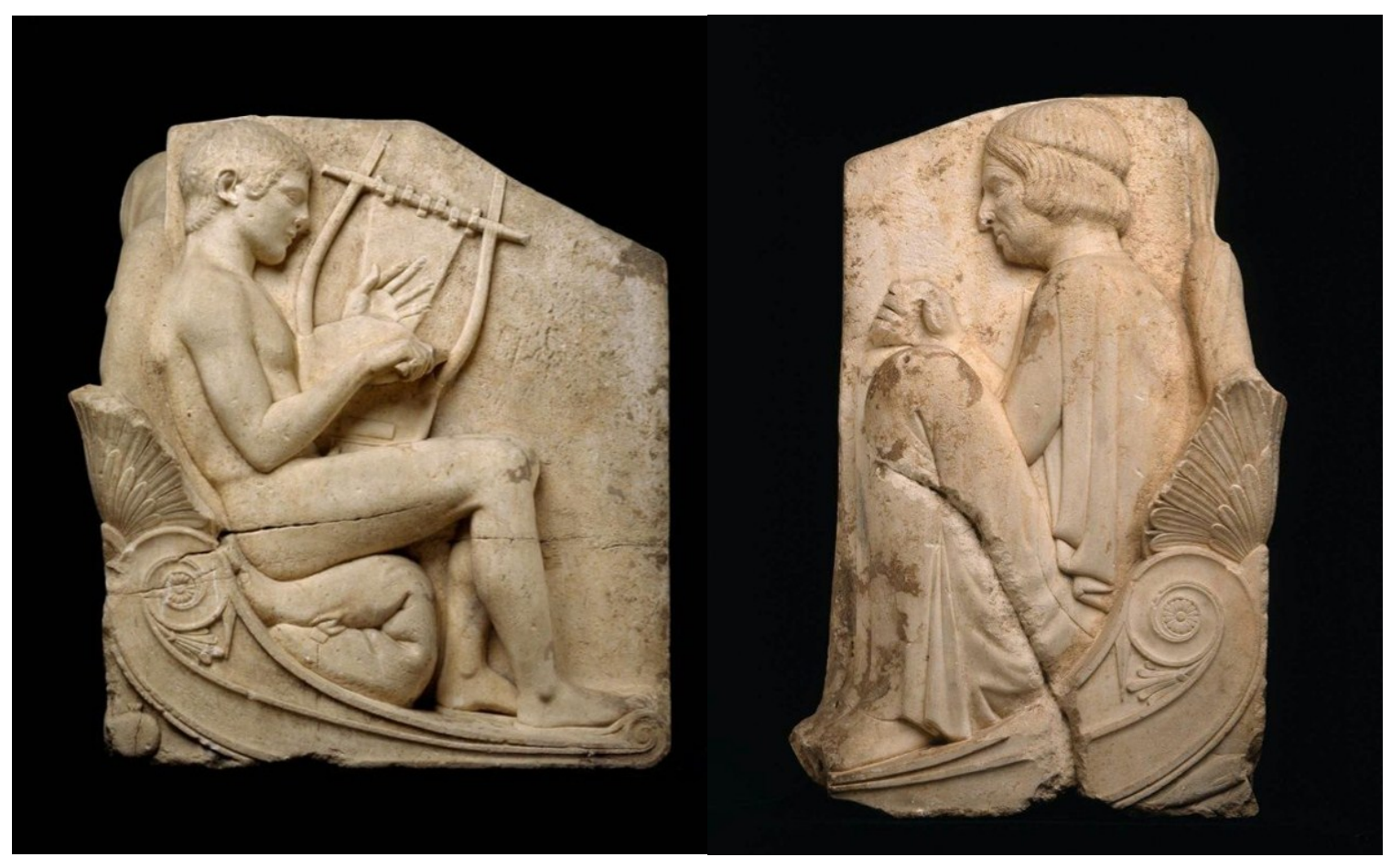

$\underline{\text { Figure } 168}$

Three-sided Relief

Side Panels

MFA 08.205

Greek, Classical Period, about 450-440

Overall: 82 x $161 \mathrm{~cm}(325 / 16 \times 633 / 8$ in. $)$

Marble

Museum of Fine Arts, Boston Database

http://www.mfa.org/collections/object/three-sided-relief-151033

(accessed 7/22/12) 


\section{CURRICULUM VITAE}

NAME: $\quad$ James Murley

ADDRESS: $\quad$ Professor of Art History and Humanities

Elizabethtown Community and Technical College

600 College Street Road

Elizabethtown, KY 42701

DOB: $\quad$ New Albany, IN - February 21, 1947

EDUCATION: $\quad$ B.A., English, magna cum laude

Bellarmine University

1965-69

M.A., English

Duke University

1970-71

M.A., Art History

University of Louisville

1997-2001

PH.D., Art History

University of Louisville

$2003-12$

AWARDS: $\quad$ University of Kentucky Alumni Association Great Teacher Award 1988

Fulbright Fellowship: American Academy, Rome:

Classical Summer Seminar, 2002

KCTCS Bell Program in Oxford: 2003

Fulbright Fellowship: American School of Classical Studies in Athens, Classical Summer Session, 2005

National Endowment for the Humanities Summer Institute Fellowship:

Models of Ancient Rome, 2006 